\title{
Little Cypress Creek Basin Archaeology: Six Late Caddo Period Cemeteries in Upshur County, Texas
}

Timothy K. Perttula

Heritage Research Center, Stephen F. Austin State University

Mark Walters

Heritage Research Center, Stephen F. Austin State University

Bo Nelson

Heritage Research Center, Stephen F. Austin State University

Follow this and additional works at: https://scholarworks.sfasu.edu/ita

Part of the American Material Culture Commons, Archaeological Anthropology Commons, Environmental Studies Commons, Other American Studies Commons, Other Arts and Humanities Commons, Other History of Art, Architecture, and Archaeology Commons, and the United States History Commons

Tell us how this article helped you.

This Article is brought to you for free and open access by the Center for Regional Heritage Research at SFA ScholarWorks. It has been accepted for inclusion in Index of Texas Archaeology: Open Access Gray Literature from the Lone Star State by an authorized editor of SFA ScholarWorks. For more information, please contact cdsscholarworks@sfasu.edu. 
Little Cypress Creek Basin Archaeology: Six Late Caddo Period Cemeteries in Upshur County, Texas

\section{Creative Commons License}

\section{(c) (1) \&}

This work is licensed under a Creative Commons Attribution-NonCommercial 4.0 International License 


\section{Little Cypress Creek Basin Archaeology: Six Late Caddo Period Cemeteries in Upshur County, Texas}

Timothy K. Perttula, Mark Walters, and Bo Nelson

Special Publication No. 22

Friends of Northeast Texas Archaeology

October 2012 
Special Publication No. 22

\author{
Editor, Timothy K. Perttula \\ 10101 Woodhaven Dr. \\ Austin, Texas 78753 \\ tkp4747@aol.com
}

\title{
Distribution, Bo Nelson, 344 CR 4154 \\ Pittsburg, Texas 75686 \\ RBoNelson@a)aol.com
}

\begin{abstract}
Cover arl:
Vessel 40, Burial 6 at the Herbert Taft cemetery (41UR320)
\end{abstract}

Friends of Northeast Texas Archaeology

Pittsburg and Austin 


\section{Table of Contents}

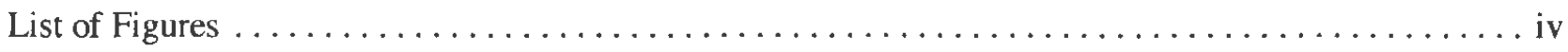

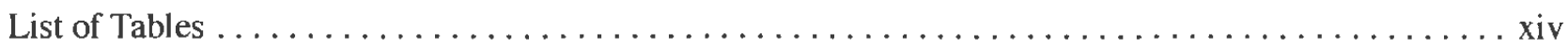

Acknowledgments $\ldots \ldots \ldots \ldots \ldots \ldots \ldots \ldots \ldots \ldots \ldots \ldots \ldots \ldots \ldots \ldots \ldots \ldots \ldots \ldots \ldots \ldots \ldots$

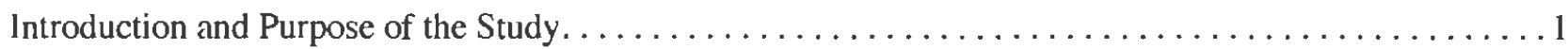

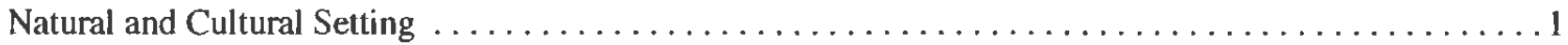

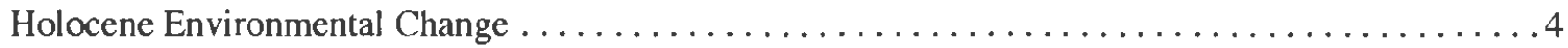

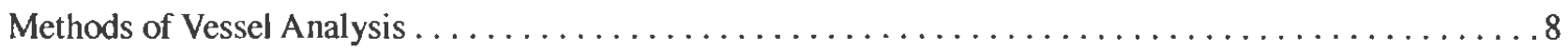

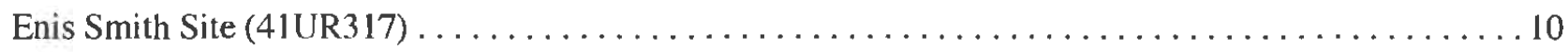

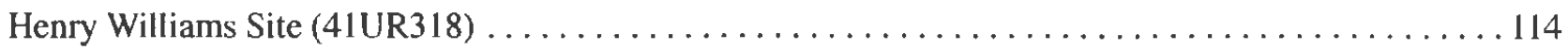

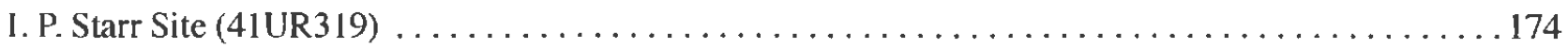

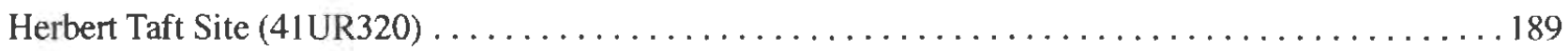

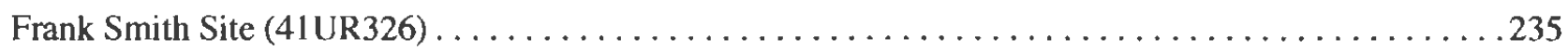

Frank Smith Refinery Site (4IUR327) . . . . . . . . . . . . . . . . . . . . . 309

Vessel Comparisons between Funerary Assemblages $\ldots \ldots \ldots \ldots \ldots \ldots \ldots \ldots \ldots \ldots \ldots \ldots \ldots$

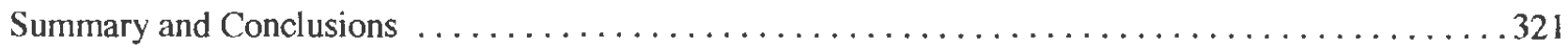

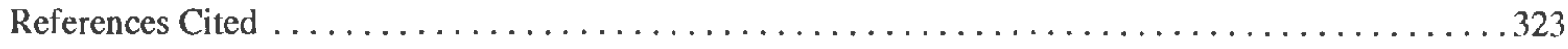




\section{List of Figures}

1. Location of the Littlc Cypress basin Late Caddo sites discussed in this report. . . . . . . . . . 2

2. The location of the Little Cypress Creek archaeological sites within the modern boundaries

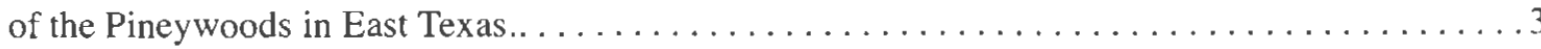

3. Tree-ring data between A.D. 997-165! from Big Cypress State Park . . . . . . . . . . . . 66

4. Defined varieties of Ripley Engraved and other engraved notifs on carinated bowls and compound bowls: a, var. McKinney; b, var. Gandy; c, var. Gals; d, var. Caldwell; e, var. Cash; f, var. Carpenter; g, var. Pilyrims; h, var. Williams; i, var. Reed; j, horizontal

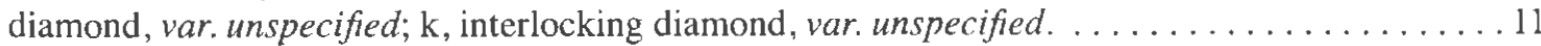

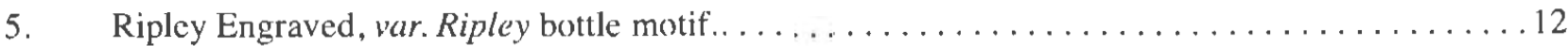

6. Wilder Engraved, var. Wilder bottle motifs, and var, unspecified motifs: a-c,

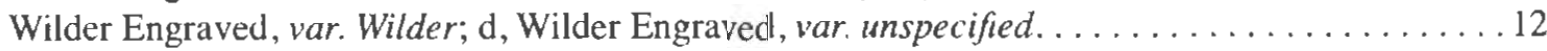

7. Turner Engraved and defined varieties: a-b, Turner Engraved, var. Turner; c-d,

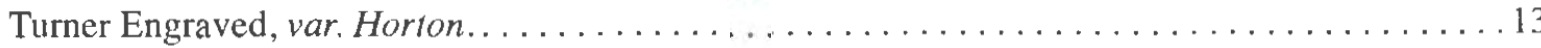

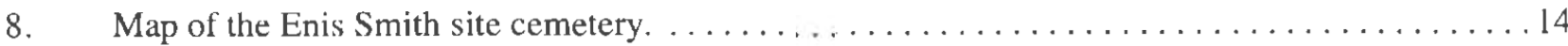

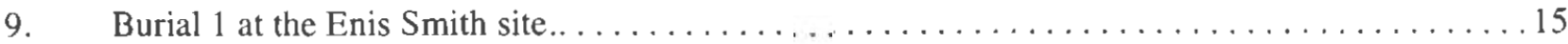

10. Ripley Engraved, var. Gandy carinated bowl, Enis Smith site, Burial 1, Vessel $1 \ldots \ldots \ldots \ldots \ldots$

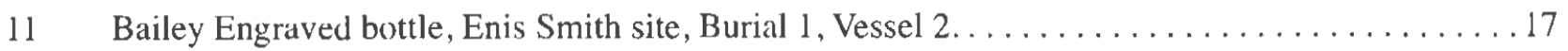

12. Ripley Engraved, var, unspecified carinated bowl, Enis Smith site, Burial 1, Vessel 3........ 18

13. Ripley Engraved, var. Gandy carinated bowl, Enis Smith site, Burial 1, Vessel 4............ 19

14. Taylor Engraved carinated bowl, Enis Smith site, Burial 1, Vessel 5.................20

15. Ripley Engraved, cf. var. Carpenter carinated bowl, Enis Smith site, Burial 1, Vessel 6.......21

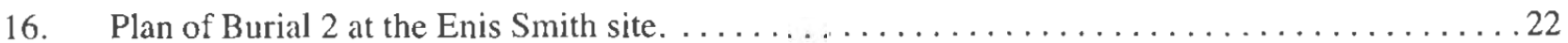

17. Riplcy Engraved, cf. var. Gandy carinated bowl, Enis Smith site, Burial 2, Vessel 7........23

18. Taylor Engraved carinated bowl, Enis Smith cemetcry, Burial 2, Vessel $8 \ldots \ldots \ldots \ldots \ldots 24$

19. Womack Engraved, var. Gum Creek carinated bowl, Enis Smith cemetery, Burial 2,

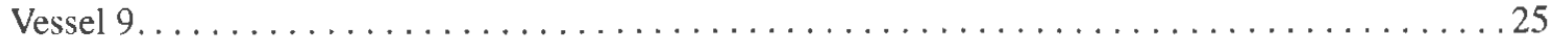

20. Bailey Engraved bottle, Enis Smith cemetery, Burial 2, Vessel $10 \ldots \ldots \ldots \ldots \ldots \ldots \ldots$

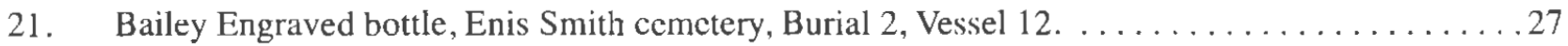

22. Ripley Engraved, var. Cash carinated bowl rim and body section, Enis Smith site, Burial 2, Vessel 13. . . . . . . . . . . . . . . . . . . . . . . . . . . . . . 28

23. Riplcy Engraved, cf. var. Gandy carinated bowl, Enis Smith cemetery, Burial 2, Vessel 14. . . . 29

24. Taylor Engraved carinated bowl, Enis Smith cemetery, Burial 2, Vessel 15. . . . . . . . . 30

25. Ripley Engraved, var. Galt carinated bowl, Enis Smith cemetery, Burial 2, Vessel $16 \ldots . . \ldots .31$

26. Ripley Engraved, cf. var. Cash carinated bowl, Enis Smith site, Burial 2, Vessel 17.........32 
Litlle Cypress Creek Basin Archaeology: Six Late Caddo Period Cemeteries in Upshur County, Texas

27. Harleton Appliqued jar, Enis Smith cemetery, Burial 2, Vessel 18.............. 33

28. Plan of Burial 3 at the Enis Smith site. . . . . . . . . . . . . .

29. Plain bowl, Enis Smith cemetery, Burial 3, Vessel 19....................... 35

30. Taylor Engraved carinated bowl, Enis Smith cemetery, Burial 3, Vessel 20........... 36

31. Wilder Engraved, var. unspecified bottle, Enis Smith cemetery, Burial 3, Vessel 21.........37

32. Cass Appliqued jar, Enis Smith cemetery, Burial 3, Vessel $22 \ldots \ldots \ldots \ldots \ldots \ldots \ldots \ldots \ldots$

33. Ripley Engraved, cf. var. Gandy carinated bowl, Enis Smith cemetery, Burial 3, Vessel 23.. . . . 39

34. Ripley Engraved, var. Galt compound bowl, Enis Smith cemetery, Burial 3, Vessel 24 . . . . . . 40

35. Harleton Appliqued jar, Enis Smith cemetery, Burial 3, Vessel $25 \ldots \ldots \ldots \ldots \ldots \ldots \ldots \ldots$

36. Ripley Engraved, var. Gandy bowl, Enis Smith cemetery, Burial 3, Vessel 26. . . . . . . . . .42

37. Taylor Engraved carinated bowl, Enis Smith cemetery, Burial 3 , Vessel 27 ............43

38. Taylor Engraved carinated bowl, Enis Smith cemetery, Burial 4, Vessel 28..........44

39. Taylor Engraved carinated bowl, Enis Smith cemetery, Burial 4, Vessel 29. . . . . . . . . . 45

40. Womack Engraved, var. Gum Creek carinated bowl, Enis Smith cemetery, Burial 4,

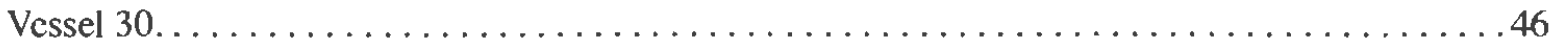

41. Engraved-punctated bowl, Enis Smith cemetery, Burial 5, Vessel $31 \ldots \ldots \ldots \ldots \ldots \ldots$

42. Taylor Engraved carinated bowl, Enis Smith cemetery, Burial 5, Vessel $32 \ldots \ldots \ldots \ldots$

43. Bailey Engraved bottle, Enis Smith cemetcry, Burial 5, Vessel $33 \ldots \ldots \ldots \ldots \ldots \ldots$

44. Ripley Engraved, var. McKinney carinated bowl, Enis Smith cemetery, Burial 5,

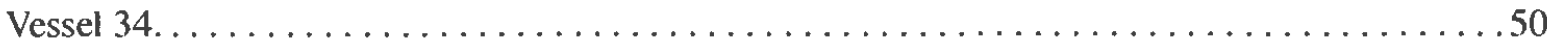

45. Harleton Appliqued jar, Enis Smith cemetery, Burial 5, Vessel $35 \ldots \ldots \ldots \ldots \ldots \ldots \ldots \ldots$

46. Ripley Engraved, cf. var. McKinney carinated bowl, Enis Smith cemetery, Burial 5,

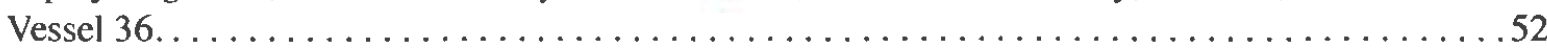

47. Ripley Engraved, var. McKinney carinated bowl, Enis Smith cemetery, Burial 5,

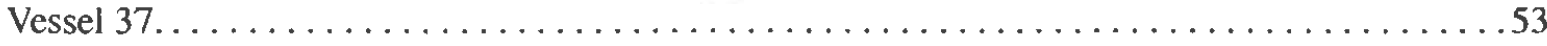

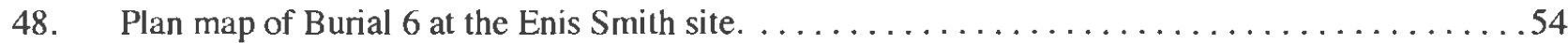

49. Ripley Engraved, var. unspecified carinated bowl, Enis Smith cemetery, Burial 6,

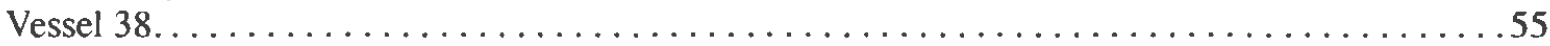

50. Womack Engraved, var. Gum Creek carinated bowl, Enis Smith cemetery, Burial 6,

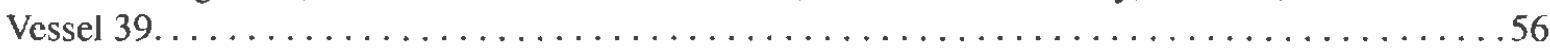

51. Turner Engraved, var. Turner compound bowl, Enis Smith cemetery, Burial 6,

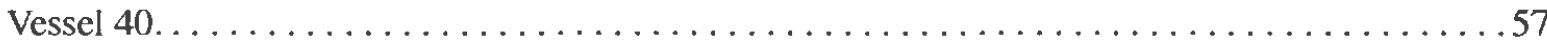

52. Plain bottle, Enis Smith cemetery, Burial 6, Vessel $41 \ldots \ldots \ldots \ldots \ldots \ldots \ldots \ldots \ldots \ldots \ldots$

53. Ripley Engraved, cf. var. McKinney carinated bowl, Enis Smith cemetery,

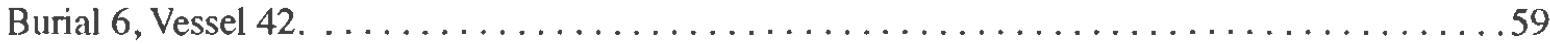

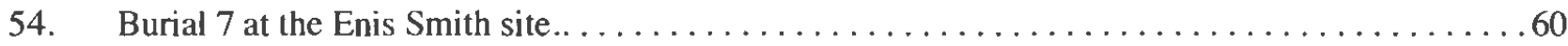


55. Ripley Engraved, cf. var. Gandy carinated bowl, Enis Smith cemetery, Burial 7, Vessel 43.....61

56. Engraved carinated bowl, Enis Smith cemetery, Burial 7, Vessel $44 \ldots \ldots \ldots \ldots \ldots \ldots \ldots \ldots$

57. Wilder Engraved, var. Wilder bottle, Enis Smith cemetery, Burial 7, Vessel 45 . . . . . . . 66

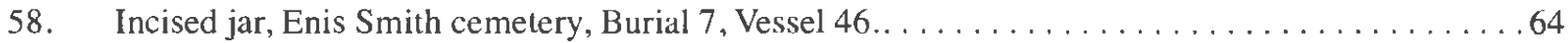

59. Ripley Engraved, cf. var. Gandy carinated bowl, Enis Smith cemetcry, Burial 7, Vessel 47.....65

60. Ripley Engraved, var. McKinney carinated bowl, Enis Smith cemetery, Burial 7, Vessel 48. . . .66

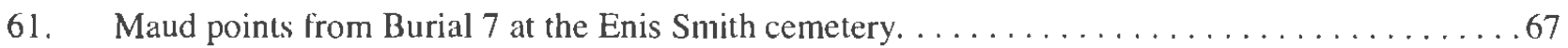

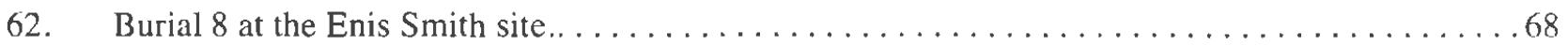

63. Ripley Engraved, var. Williams compound bowl, Enis Smith cemetcry, Burial 8, Vessel 52.. . . .69

64. Harleton Appliqued jar, Enis Smith cemetery, Burial 8, Vessel $53 \ldots \ldots \ldots \ldots \ldots \ldots \ldots \ldots$

65. Taylor Engraved carinated bowl, Enis Smith cemetery, Burial 8, Vessel 54 . . . . . . . . . . 71

66. Punctated-appliqued jar, Enis Smith cemetery, Burial 8, Vessel $55 \ldots \ldots \ldots \ldots \ldots \ldots \ldots \ldots$

67. Ripley Engraved, var. Williams carinated bowl, Enis Smith cemetcry, Burial 8, Vessel 56... . . 73

68. cf. Mockingbird Punctated jar, Enis Smith cemetery, Burial 8, Vessel 58 . . . . . . . . . . 74

69. Talco and Maud arrow points from Burial 8 at the Enis Smith cemetery. . . . . . . . . . .75

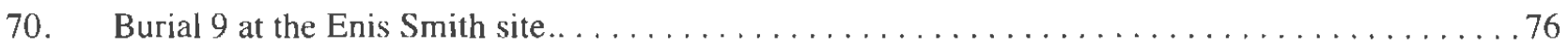

71. La Rue Neck Banded jar, Enis Smith cemetery, Burial 9, Vessel 59 . . . . . . . . . . . . 77

72. Wilder Engraved, var. Wilder boule, Enis Smith cemetery, Burial 9, Vessel $60 \ldots \ldots \ldots \ldots \ldots 78$

73. Cass Appliqued jar, Enis Smith cemetery, Burial 9, Vessel $61 \ldots \ldots \ldots \ldots \ldots \ldots \ldots \ldots \ldots$

74. Ripley Engraved, cf. var. Gandy carinated bowl, Enis Smith cemetery, Burial 9, Vessel 62... . . 80

75. Ripley Engraved, cf. var. Gandy carinated bowl, Enis Smith cemetery, Burial 9, Vessel 63... . . 81

76. Harleton Appliqued jar, Enis Smith centetery, Burial 9, Vessel $64 \ldots \ldots \ldots \ldots \ldots$

77. Ripley Engraved, var. McKinney carinated bowl, Enis Smith cemetery, Burial 9, Vessel 65. . . . 83

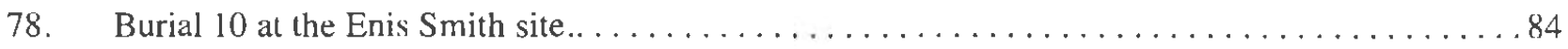

79. Ripley Engraved, var. unspecified carinated bowl, Enis Smith cemetery, Burial 10, Vessel 66.. . . 85

80. Ripley Engraved, var. Galt compound bowl, Enis Smith cemetery, Burial 10, Vessel $67 \ldots . . . .86$

81. Ripley Engraved, var. Galt carinated bowl, Enis Smith cemetery, Burial 10, Vessel $68 \ldots \ldots$. . . . .87

82. Ripley Engraved, cf. var. Gandy carinated bowl, Enis Smith cemctery, Burial 10, Vessel 69... . .88

83. cf. Pease Brushed-Incised jar, Enis Smith cemetery, Burial 10, Vessel 70. . . . . . . . . . . .89

84. Ripley Engraved, cf. var. Gandy carinated bowl, rim and body section, Enis Smith

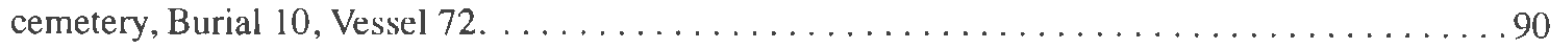

85. Riplcy Engraved, var. Galt carinated bowl, Enis Smith cemetery, Burial 10, Vessel 74. . . . . . .91

86. Engraved-punctated bottle, Enis Smith cemetery, Burial 10, Vessel $75 \ldots \ldots \ldots \ldots \ldots \ldots 2$ 


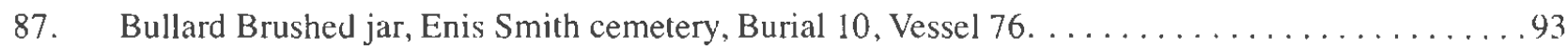

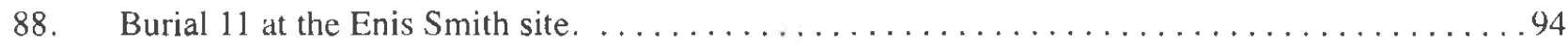

89. Ripley Engraved, cf. var. Gandy carinated bowl, Enis Smith cemetery, Burial 11, Vessel 78... .95

90. Ripley Engraved, var, unspecified carinated bowl, Enis Smith cemetery, Burial 11, Vessel 79... .96

91. Ripley Engraved, cf. var. Gandy carinated bowl, Enis Smith cemetery, Burial 11, Vessel 80. . . .997

92. Ripley Engraved, var. McKinney carinated bowl, Enis Smith cemetery, Burial 11, Vessel 81 . . .98

93. Bullard Brushed jar, Enis Smith cemetery, Burial 11, Vessel $82 \ldots \ldots \ldots \ldots \ldots \ldots \ldots . \ldots 99$

94. Ripley Engraved, var. McKinney carinated bowl, Enis Smith cemetery, Burial 11, Vessel 83. . . 100

95. Harleton Appliqued jar, Enis Smith cemetery, Burial 11, Vessel $84 \ldots \ldots \ldots \ldots \ldots \ldots$. . . . . 101

96. Ripley Engraved, var. unspecified bottle, Enis Smith cemetery, Burial 11, Vesse1 $85 \ldots . \ldots \ldots 102$

97. Engraved carinated bowl, Enis Smith cemetery, Burial 11, Vessel 86. . . . . . . . . . . . . 103

98. Ripley Engraved, cf. var. Gandy carinated bowl, Enis Smith cemetery, Burial 11, Vessel 87. . . 104

99. Ripley Engraved, var. McKinney carinated bowl, Enis Smith cemetery, Burial 11, Vessel 88. . . 105

100. Ripley Engraved, var. McKinney carinated bowl, Enis Smith cemetery, Burial 11, Vesscl 89. . . 106

101. Harleton Appliqued jar, Enis Smith cemetery, Burial 11, Vessel $90 \ldots \ldots \ldots \ldots \ldots \ldots$

102. Engraved carinated bowl, Enis Smith cemetery, Burial 12, Vessel 91 . . . . . . . . . . . . 109

103. Brushed-incised jar, Enis Smith cemetery, Burial 12, Vessel 92 . . . . . . . . . . . . 110

104. Ripley Engraved, var. Cash compound bowl, Enis Smith cemetery, Burial 12, Vessel 93 . . . . 111

105. Riplcy Engraved, cf. var. Gandy carinated bowl, Enis Smith cemetery, Burial 12, Vessel 94... . 112

106. Harleton Appliqued jar, Enis Smith cemetery, Burial 12, Vessel 95............... 113

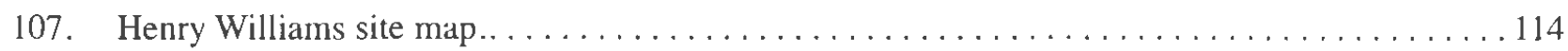

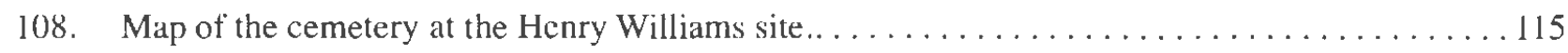

109. Ripley Engraved, cf. var. Gandy carinated bowl, Henry Williams cemetery, Burial 1,

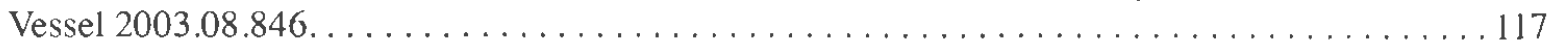

110. Riplcy Engraved, var. Galt carinated bowl, rim and body section, Henry Williams cemctery, Burial 2, Vessel 2003.08.1041 . . . . . . . . . . . . . . . . . . . . . . . . 118

111. Plain carinated bowl, Henry Williams site, Burial 2, Vessel 2003.08.844 . . . . . . . . . . 119

112. Engraved carinated bowl, Henry Williams cemetery, Burial 11, Vessel 2003.08.959 . . . . . 122

113. Taylor Engraved bottle, Henry Williams cemctery, Burial 11, Vessel 2003.08.964... . . . . 123

114. Taylor Engraved bottle, Henry Williams cemetery, Burial 11, Vesscl 2003.08.961 . . . . . . . 124

115. Ripley Engraved, cf. var. Gandy carinated bowl, Henry Williams cemetery, Burial 18.

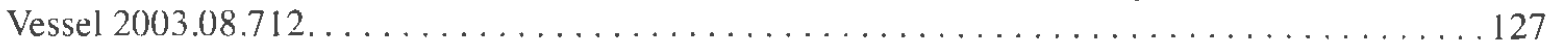

116. Ripley Engraved, var. Gandy carinated bowl, Henry Williams cemetery, Burial 19, Vessel

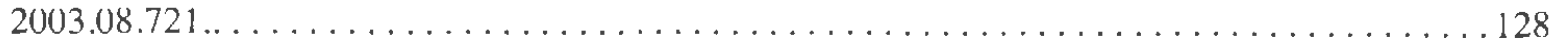


Little Cypress Creek Basin Archaeology: Six Late Caddo Period Cemeteries in Upshur County, Texas

118. Harleton Appliqued jar, Henry Williams cemetery, Burial 22, Vessel 2003.08.957......... 132

119. Ripley Engraved, cf. var. Gandy carinated bowl, Henry Williams cemetery,

Burial 22, Vessel 2003.08.1048. . . . . . . . . . . . . . . . . . . . . . . . . . 133

120. Ripley Engraved, var. Gandy carinated bowl, Henry Williams cemetery, Burial 22,

Vessel 2003.08.1044. . . . . . . . . . . . . . . . . . . . . . . . . . . . . . . . . . . . . . . . . . 134

121. Ripley Engraved, var. unspecified carinated bowl, Henry Williams cemetery, Burial 22,

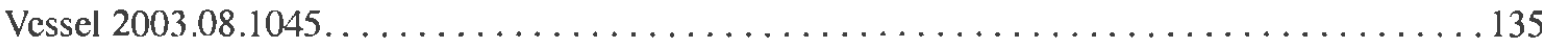

122. Ripley Engraved, var. Cash compound bowl, Henry Williams cemetery, Burial 27,

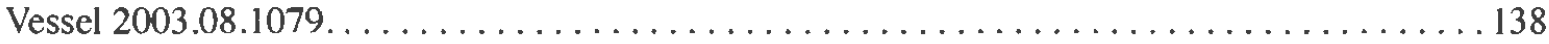

123. Ripley Engraved, var. Galt compound bowl, Henry Williams cemetery, Burial 27,

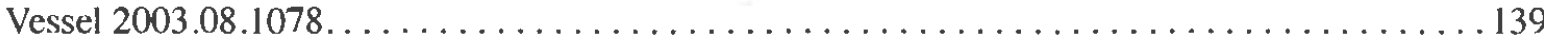

124. Ripley Engraved, var. Gandy carinated bowl, Henry Williams cemetery, Burial 30,

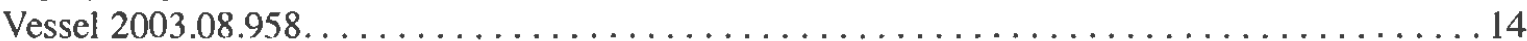

125. Conjoined Ripley Engraved-Wilder Engraved carinated bowls and bottle, Henry

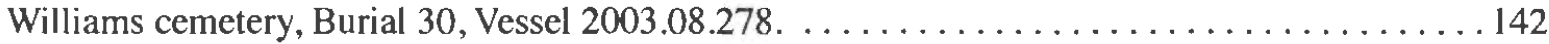

126. Ripley Engraved, var. Galt compound bowl, Henry Williams cemetery, Burial 32,

Vessel 2003,08.1964: a-b, circle element and scroll fill zone. . . . . . . . . . . . . . . 144

127. Ripley Engraved, cf. var. Gandy carinated bowl, Henry Williams cemetery, Burial 32,

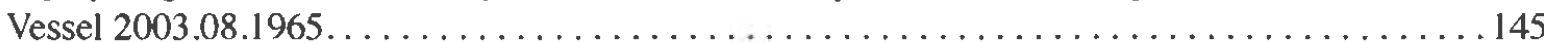

128. Pease Brushed-Incised jar, Henry Williams cemetery, Burial 36, Vessel 2003.08.1040 . . . . . 147

129. Harleton Appliqued jar, Henry Williams cemetery, Vessel $2003.08 .1303 \ldots \ldots \ldots \ldots \ldots \ldots . .148$

130. Plain bowl, Henry Williams cemetery, Vessel $2003.08 .1304 \ldots \ldots \ldots \ldots \ldots \ldots \ldots \ldots \ldots$

131. Ripley Engraved, var. unspecified compound bowl, Henry Williams cemetery, Vessel

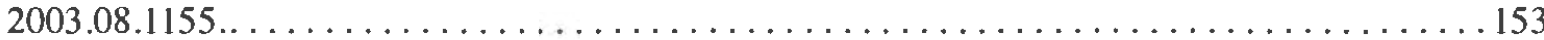

132. Ripley Engraved, cf. var. Gandy carinated bowl, Henry Williams cemetery, Vessel

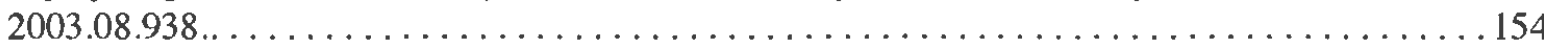

133. Ripley Engraved, cf. var. Gandy carinated bowl, Henry Williams cemetery, Vessel

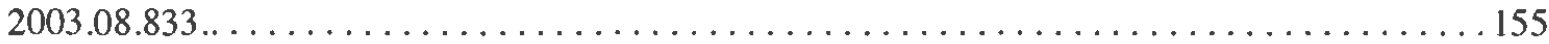

134. Ripley Engraved, var. Gandy carinated bowl, Henry Williams cemetery, Vessel

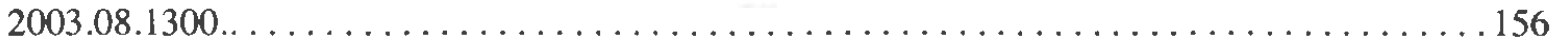

135. Brushed-Incised jar sherds, Henry Williams cemetery, Vessel 2003.08.1305 . . . . . . . . . 157

136. Ripley Engraved, var. Gandy carinated bowl, Henry Williams cemetery, Vesscl 2003.08 .939 . . . . . . . . . . . . . . . . . . . . . . . . . . . . . . . . . . . . . . . . . 159

137. Engraved-punctated bottle, Henry Williams cemetery, Vessel $2003.08 .940 \ldots \ldots \ldots \ldots \ldots 160$

138. Ripley Engraved, var. Gandy carinated bowl, Henry Williams cemetery, Vessel

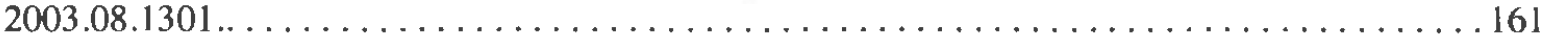

139. Karnack Brushed-Incised jar sherds, Henry Williams cemetery, Vessel 2003.08.1157 . . . . . 162 
Little Cypress Creek Basin Archaeology: Six Late Caddo Period Cemeteries in Upshur County, Texas

140. Tumer Engraved, var, unspecified compound bowl, Henry Williams cemetery,

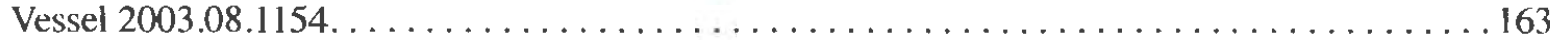

141. Ripley Engraved, cf. var. Gandy earinated bowl, Henry Williams cemetery, Vessel

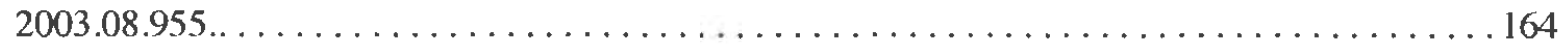

142. Pease Brushed-Incised jar, Henry Williams cemetery, Vessel $2003.08 .952 \ldots \ldots \ldots \ldots \ldots$

143. Miniature engraved carinated bowl, Henry Williams cemetery, Vessel 2003.08.0035 . . . . . . 166

144. Ripley Engraved, var. Galt compound bowl, Henry Williams cemetery, Vessel 2003.08.950. . . 167

145. Wilder Engraved, var. unspecified bottle, Henry Williams cemetery, Vessel 2003.08.0951 . . . 168

146. Ripley Engraved, cf. var. Cash carinated bowl, Henry Williams cemetery, Vessel 2003.08.971 .. . 169

147. Taylor Engraved carinated bowl, Henry Williams cemetery, Vessel 2003.08.953 . . . . . . . . 170

148. Taylor Engraved bowl, Henry Williams cemetery, Vessel 2003.08.954... . . . . . . . . . 171

149. Elbow pipe sherds from the Henry Williams cemetery: a, stem sherd; b, plain bowl sherd. . . . 172

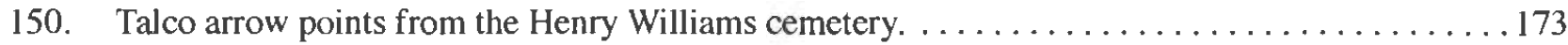

151. Jasper stone bead, Henry Williams cemetery. . . . . . . . . . . . . . . . . 174

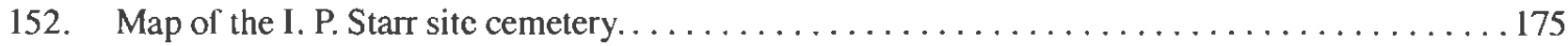

153. Bullard Brushed jar sherds, 1. P. Starr cemetery, Burial 4, Vessel 2003.08.1047 . . . . . . . . . 176

154. cf. Taylor Engraved compound bowl, I. P. Starr cemetery, Burial 5, Vessel 2003.08.1956. . . . . 177

156. Ripley Engraved, var. Cash compound bowl, I. P. Starr cemetery, Vessel 2003.08.582 . . . . . 180

157. Ripley Engraved, var. Galt compound bowl, Vessel $3 \ldots \ldots \ldots \ldots \ldots \ldots \ldots \ldots \ldots \ldots \ldots$

158. Taylor Engraved carinated bow1, I. P. Starr cemetery, Vessel $4 \ldots \ldots \ldots \ldots \ldots \ldots \ldots \ldots \ldots$

159. Taylor Engraved carinated bowl, I. P. Starr cemetery, Vessel $5 \ldots \ldots \ldots \ldots \ldots \ldots \ldots \ldots$

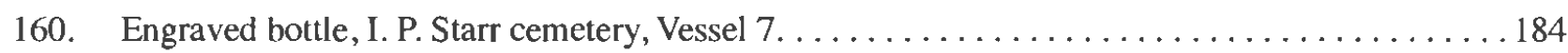

161. Ripley Engraved, var. Caldwell carinated bowl, I. P. Starr cemetery, Vessel 8. . . . . . . . 185

162. Pease Brushed-Incised jar, I. P. Starr cemetery, Vessel $9 \ldots \ldots \ldots \ldots \ldots \ldots \ldots \ldots \ldots \ldots \ldots$

163. cf. Hodges Engraved carinated bowl, I. P. Starr cemetery, Vessel 2003.08.1049 . . . . . . . . . . . 187

164. Ripley Engraved, var. Gandy carinated bowl, I. P. Starr cemetery, Vessel 2003.08.1048. . . . . . 188

165. Map of the Herbert Taft site cemetery.. . . . . . . . . . . . . . . . . . . . . 189

166. Burial 1 at the Herbert Taft site.. . . . . . . . . . . . . . . . . . . . . . . . 190

167. Red-slipped Simms Engraved deep bowl, Herbert Taft cemetery, Burial 1, Vessel 1. . . . . . . 191

168. Ripley Engraved, var. McKinney carinated bowl, Herbert Taft cemetery, Burial 1, Vessel 2. . . 192

169. Plain bottle, Herbert Taft cemetery, Burial 1, Vessel $3 \ldots \ldots \ldots \ldots \ldots \ldots \ldots \ldots \ldots \ldots \ldots$

170. Harleton Appliqued jar, Herbert Taft cemetery, Burial 1, Vessel 4.. . . . . . . . . . . . . . . 194

171. Taylor Engraved conjoined vessel, Herbert Taft cemetery, Burial 1, Vessel 5... . . . . . . . . 195

172. Ripley Engraved, cf. var. Gandy carinated bowl, Herbert Taft cemetery, Burial 1, Vessel 6... . . 196 
Little Cypress Creek Basin Archaeology: Six Late Caddo Period Cemeteries in Upshur County, Texas

173. Ripley Engraved, var. McKinney carinated bowl, Herbert Taft cemetery, Burial 1, Vessel 7. . . 197

174. Ripley Engraved, var. McKinney carinated bowl, Herbert Taft cemctery, Burial 1, Vessel 8. . . . 198

175. Ripley Engraved, var. Carpenter compound bowl sherds, Herbert Taft cemetery, Burial 1,

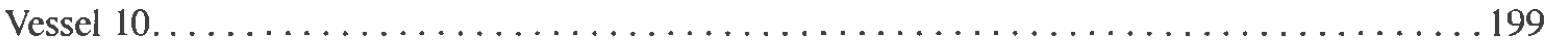

176. Long-stemmed elbow pipe from Burial 1 at the Herbert Taft cemetery . . . . . . . . . ...200

177. Burial 2 at the Herbert Taft site... . . . . . . . . . . . . . . . . . . . . . . . . . . 200

178. Engraved bottle, Herbert Taft cemetery, Burial 2, Vessel $11 \ldots \ldots \ldots \ldots \ldots \ldots \ldots \ldots \ldots$

179. Ripley Engraved, var. Carpenter carinated bowl, Herbert Taft cemetery, Burial 2, Vessel 12. . . 202

180. Engraved compound bowl, Herbert Taft cemetery, Burial 2, Vessel $13 \ldots \ldots \ldots \ldots \ldots \ldots$

181. Ripley Engraved, var. Caldwell carinated bowl, Herbert Taft cemetery, Burial 2, Vessel 14. . . 204

182. Bullard Brushed jar, Herbert Taft cemetery, Burial 2, Vessel $15 \ldots \ldots \ldots \ldots \ldots \ldots \ldots \ldots$

183. Turner Engraved, var. Turner compound bowl, Herbert Taft cemetery, Burial 2, Vessel 16. . . . 206

184. Ripley Engraved, var. Gandy carinated bowl, Herbert Taft cemetery, Burial 2, Vessel 17. . . . . 207

185. Wilder Engraved, var. Wilder jar, Herbert Taft cemetery, Burial 3, Vessel 19...........208

186. Wilder Engraved, var. unspecified bottle, Herbert Taft cemetery, Burial 3, Vessel 20. . . . . . . 209

187. Taylor Engraved carinated bowl, Herbert Taft cemetery, Burial 3, Vessel $21 \ldots \ldots \ldots \ldots \ldots$

188. Ripley Engraved, cf. var. Gandy carinated bowl, Herbert Taft cemetery, Burial 3, Vessel 22... . 211

189. Wilder Engraved, var. Wilder jar, Herbert Taft cemetery, Burial 3, Vessel 23. . . . . . . . 212

190. Turner Engraved, var. Horton compound bowl, Herbert Taft cemetery, Burial 3, Vessel 24. . . . 213

191. Ripley Engraved, var. Galt carinated bowl, Herbert Taft cemetery, Burial 3, Vessel 25 . . . . . 214

192. Ripley Engraved, var. Caldwell compound bowl, Herbert Taft cemetery, Burial 3, Vessel 26. . . 215

193. Ripley Engraved, var. Galt carinated bowl, Herbert Taft cemetery, Burial 3, Vessel 27. . . . . 216

194. Cass Appliqued jar, Herbert Taft cemetery, Burial 3, Vessel 29. . . . . . . . . . . . . . 217

195. Cass Appliqued jar, Herbert Taft ccmetery, Burial 3, Vessel $30 \ldots \ldots \ldots \ldots \ldots \ldots \ldots \ldots$

196. Ripley Engraved, var. McKinney carinated bowl, Herbert Taft cemetery, Burial 4, Vessel 32 . . 219

197. Turner Engraved, var. Tirner compound bowl, Herbert Taft cemetery, Burial 4, Vessel 33. . . . 220

198. Taylor Engraved carinated bowl, Herbert Taft cemetery, Burial 4, Vessel 2003.08.956. . . . . . 222

199. Ripley Engraved, var. McKinney carinated bowl, Herbert Taft cemetery, Burial 5, Vessel 35. . . 223

200. Ripley Engraved, var. McKinney carinated bowl, Herbert Taft cemetery, Burial 5, Vessel

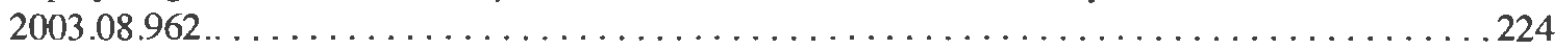

201. Talco point from Burial 5 at the Herbert Taft cemetery. . . . . . . . . . . . . . . 225

202. Bailey Engraved bottle, Herbert Taft cemetery, Burial 6, Vessel $37 \ldots \ldots \ldots \ldots \ldots \ldots \ldots$

203. Taylor Engraved carinated bowl, Herbert Taft cemetery, Burial 6, Vessel 38. . . . . . . . . 227

204. Simms Engraved carinated bowl, hubcap variety, Herbert Taft cemetery, Burial 6, Vessel $39 \ldots 228$ 
205. cf. Taylor Engraved conjoined vessel, Herbert Taft cemetery, Burial 6, Vessel 40. . . . . . . . 229

206. Simms Engraved, hubcap variety, Herbert Taft cemetery, Burial 6, Vessel $41 \ldots \ldots \ldots \ldots . .230$

207. Taylor Engraved carinated bowl, Herbert Taft cemetery, Burial 6, Vesscl $42 \ldots \ldots \ldots \ldots$. . . . 231

208. Ripley Engraved, var. McKinney carinated bowl, Herbert Taft cemetery, Burial 6, Vcssel 43 . . . 232

209. Taylor Engraved deep bowl, Herbert Taft cemetery, Burial 6, Vessel 44 . . . . . . . . . . . 233

211. Plan map of the Caddo cernetery at the Frank Smith site... . . . . . . . . . . . . . . . 235

212. Ripley Engraved, var. McKinney carinated bowl, Frank Smith cemetery, Burial 1, Vessel 1. . . 236

213. Karnack Brushed-Incised jar, Frank Smith cemetery, Burial 1, Vessel 2. . . . . . . . . . . 237

214. cf. Bullard Brushed jar sherds, Frank Smith cemetcry, Burial 1 , Vessel $3 \ldots \ldots \ldots \ldots \ldots \ldots$

215. Bullard Brushed jar, Frank Smith cemetery, Burial 3, Vessel 5. . . . . . . . . . . . . . . . . 239

216. Ripley Engraved, var. unspecified bottle, Frank Smith cemetery, Burial 3, Vessel 6... . . . . . . 240

217. Red-slipped engraved carinated bowl, Frank Smith cemetery, Burial 3, Vessel 7.... . . . . . . 241

218. Harleton Appliqued jar, Frank Smith cemetery, Burial 3, Vessel 8. . . . . . . . . . . . . 242

219. cf. Taylor Engraved carinated bowl, Frank Smith cemetery, Burial 3, Vessel 61.. . . . . . . . 243

220. Ripley Engraved, var. McKinney carinated bowl, Frank Smith cemetery, Burial 4, Vessel 57. . . 244

221. cf. Taylor Engraved bottle, Frank Smith cemetery, Burial 4, Vessel 58. . . . . . . . . . . . . 245

222. Plain jar, Frank Smith cemetery, Burial 4, Vessel $59 \ldots \ldots \ldots \ldots \ldots \ldots \ldots \ldots \ldots \ldots \ldots \ldots . \ldots \ldots$

223. Ripley Engraved, cf. var. Gandy carinated bowl, Frank Smith cemetery, Burial 4, Vcssel 60.. . . . 247

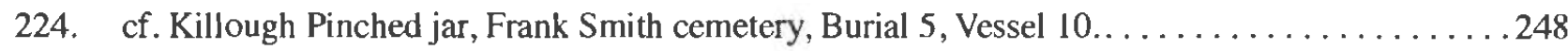

225. Taylor Engraved jar, Frank Smith cemetery, Burial 5, Vessel 11 . . . . . . . . . . . . . . . . . 249

226. Ripley Engraved, var. unspecified carinated bowl, Frank Smith cemetery, Burial 5, Vessel 12.. . 250

227. Harleton Appliqued jar, Frank Smith cemetery, Burial 5, Vessel $13 \ldots \ldots \ldots \ldots \ldots \ldots \ldots \ldots$

228. Ripley Engraved, var. McKinney carinated bowl, Frank Smith cemetery, Burial 5, Vesscl 13 A. . . . . . . . . . . . . . . . . . . . . . . . . . . . . . . . 252

229. Womack Engraved, var. Gum Creek carinated bowl, Frank Smith cemetery, Burial 5,

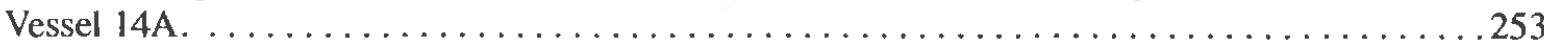

230. Ripley Engraved, var. Galt carinated bowl, Frank Smith cemetery, Burial 5, Vessel 14B.. . . . 254

231. Wilder Engraved, var. unspecified bottle, Frank Smith cemetery, Burial 5, Vessel 15.......255

232. Ripley Engraved, cf. var. McKinney carinated bowl, Frank Smith cemetery, Burial 6,

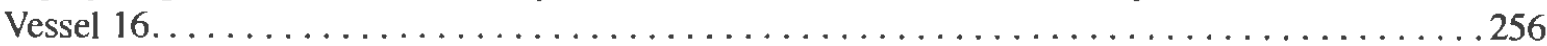

233. Ripley Engraved, var. McKinney carinated bowl, Frank Smith cemetery, Burial 6, Vessel 17. . .257

234. Turner Engraved, var. Horton compound bowl, Frank Smith cemetery, Burial 6, Vessel 19.. . . 258

235. Harleton Appliqued jar, Frank Smith cemetery, Burial 6, Vessel 20. . . . . . . . . . . . . . 259

236. Ripley Engraved, cf. var. Gandy carinated bowl, Frank Smith cemetery, Burial 7, Vessel 22. . . 260 
Lithle Cypress Creek Basin Archaeology: Six Late Caddo Period Cemeteries in Upshur County, Texas

237. Ripley Engraved, cf. var. Carpenter carinated bowl, Frank Smith cemetery, Burial 7 ,

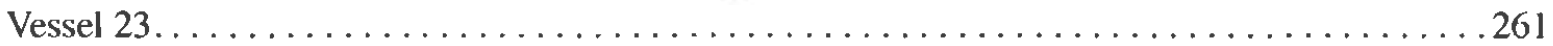

238. cf. Kamack Brushed-Incised jar, Frank Smith cemetery, Burial 7, Vesscl 24 . . . . . . . . . . 262

239. Harleton Appliqued jar, Frank Smith cemctery, Burial 7, Vessel 25 . . . . . . . . . . . 263

240. Ripley Engraved, var. McKinney carinated bowl, Frank Smith cemetery, Burial 7, Vessel 26. . .264

241. Ripley Engraved, var. Galt and Turner Engraved, var. unspecified hybrid compound

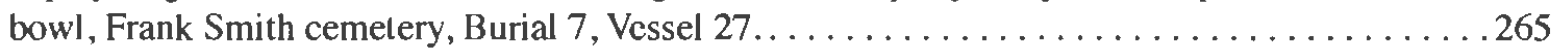

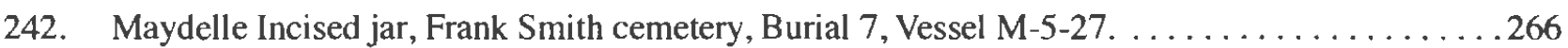

243. Ripley Engraved, var. McKinney carinated bowl, Frank Smith cemetery, Burial 8, Vessel 28. . . 267

244. Engraved bottle, Frank Smith cemetery, Burial 8, Vessel $2003.08 .1839 \ldots \ldots \ldots \ldots \ldots . \ldots 268$

245. Ripley Engraved, cf. var. Cash carinated bowl, Frank Smith cemetery, Burial 8, Vessel 30. . . . 269

247. Ripley Engraved, cf. var. Cash carinated bowl, Frank Smith cemetery, Burial 8, Vessel 32 . . . 271

248. Bailey Engraved bottle, Frank Smith cemetery, Burial 8, Vessel 33 . . . . . . . . . . . . . 272

249. Ripley Engraved, cf. var. Gandy carinated bowl, Frank Smith cemetery, Burial 8, Vessel 34.. . . 273

250. Harleton Appliqued jar, Frank Smith cemetery, Burial 9, Vessel 35 . . . . . . . . . . . 274

251. Ripley Engraved, var, unspecified or Taylor Engraved carinated bowl, Frank Smith

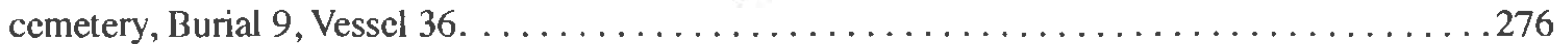

252. Ripley Engraved, var. unspecified carinated bowl, Frank Smith cemetery, Burial 9,

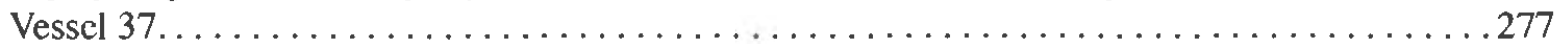

253. Ripley Engraved, cf. var. Caldwell or undefined variety of Womack Engraved carinated

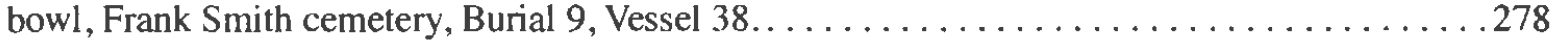

254. Taylor Engraved carinated bowl, Frank Smith cemetery, Burial 9, Vessel 39. . . . . . . . . . 279

255. Tubular pipe from Burial 9 at the Frank Smith cemetery: a, side view; b, top down vicw. . . . .280

256. Burial 10 at the Frank Smith site. . . . . . . . . . . . . . . . . . . . . .

257. Harleton Appliqued jar, Frank Smith cemetery, Burial 10, Vessel 40. . . . . . . . . . . 282

258. Ripley Engraved, var. McKinney carinated bowl, Frank Smith cemetery, Burial 10,

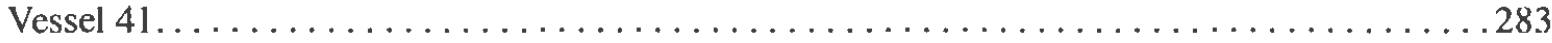

259. Pinched rattle carinated bowl, Frank Smith cemetery, Burial 10, Vessel $42 \ldots \ldots \ldots \ldots . . .284$

261. Pedestalled engraved bottle, Frank Smith cemetery, Burial 10, Vessel $44 \ldots \ldots \ldots \ldots \ldots \ldots 286$

262. Engraved-incised compound bowl, Frank Smith cemetery, Burial 10, Vessel 45 . . . . . . . 287

263. Ripley Engraved, cf. var. Gandy carinated bowl, Frank Smith cemetery, Burial 10,

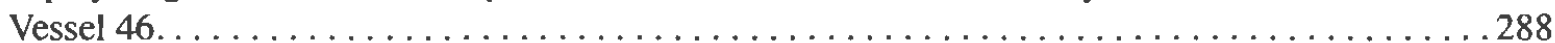

264. Engraved carinated bowl, Frank Smith cemetery, Burial 10, Vessel $47 \ldots \ldots \ldots \ldots . . \ldots \ldots . .289$

265. Karnack Brushed-Incised jar, Frank Smith cemetery, Burial 10, Vessel 2003.08.1016. . . . . . 290

266. Plain carinated bowl, Frank Smith cemetery, Burial 10, Vessel 48. . . . . . . . . . . 291 
266. Plain carinated bowl, Frank Smith cemetery, Burial 10, Vessel 48. . . . . . . . . . . . . 291

267. Engraved bottle, Frank Smith cemetery, Burial 10, Vessel $50 \ldots \ldots \ldots \ldots \ldots \ldots \ldots \ldots \ldots 2$

268. Ripley Engraved, var. unspecified carinated bowl, Frank Smith cemetery, Burial 11,

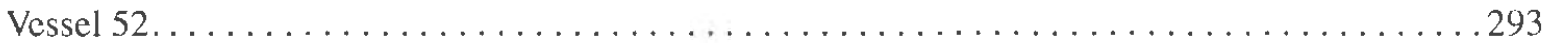

269. Wilder Engraved, var. Wilder bottle, Frank Smith cemetery, Burial 11, Vcssel 54 ... ......294

270. Cass Appliqued jar, Frank Smith cemetery, Burial 11 , Vessel 55 . . . . . . . . . . . . . . . . . . . 295

271. Ripley Engraved, var. unspecified carinated bowl, Frank Smith cemetery, Burial 11,

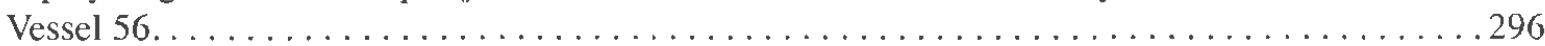

272. Riplcy Engraved, cf. var. McKinney carinated bowl, Frank Smith cemetery, Burial 12,

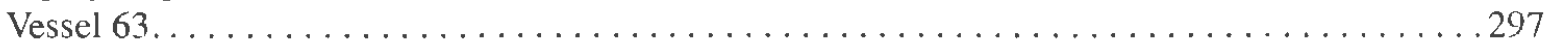

273. cf. Womack Engraved, var. Gum Creek or Turner Engraved, var. unspecified compound bowl, Frank Smith cemetery, Burial 12, Vessel 64. . . . . . . . . . . . . . . . . . . . . . 298

274. Maydelle Incised jar, Frank Smith cemetery, Burial 12, Vessel 65 . . . . . . . . . . . . . . . 299

275. Turner Engraved, var. Horton compound bowl, Frank Smith cemetery, Burial 12,

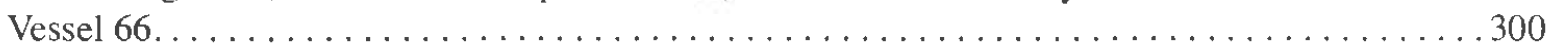

276. Plain carinated bowl, Frank Smitb cemetery, Burial 12, Vessel $67 \ldots \ldots \ldots \ldots \ldots \ldots \ldots$

277. Ripley Engraved, var. Caldwell compound bowl, Frank Smith cemetery, Burial 12,

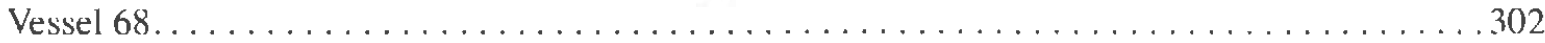

278. Engraved carinated bowl sherds, Frank Smith cemetery, Burial 12, Vessel 69. . . . . . . . 303

279. Wilder Engraved, var. unspecified olla, Frank Smith cemetery, Burial 13, Vessel 71 . ....... 304

280. Wilder Engraved, var. Wilder bottle, Frank Smith cemetery, Burial 13, Vessel 72. . . . . . . . 305

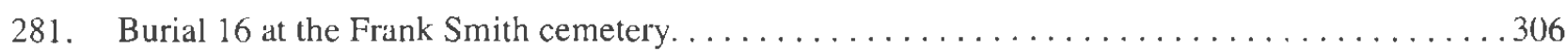

282. Wilder Engraved, var. unspecified olla, Frank Smith cemetery, Vessel 2003.08.670. . . . . . . 307

283. Pinched bowl, Frank Smith cemetery, Vessel $2003.08 .69 \ldots \ldots \ldots \ldots \ldots \ldots \ldots \ldots$

284. Plain carinated bowl, Frank Smith cemetery, Vessel 2003.08.490 . . . . . . . . . . . . . . . . . . 309

285. Hodges Engraved conjoined vessel, Frank Smith Refinery burial, Vessel 2003.08.1791 . . . . . 310

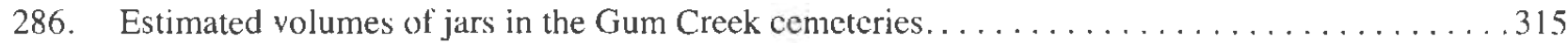

287. Estimated volumes of carinated bowls in the Gum Creek cemeteries. . . . . . . . . . . . . . 316

288. Estimated volumes of compound bowls in the Gum Creek cemeteries. . . . . . . . . . . 317 


\section{List of Tables}

1. Climatic Conditions based on the 1000 year dendrochronological record from Big Cypress State Park in northwestern Louisiana. The periods in bold and italics represent the periods in which the Little Cypress Creek sites were oecupied, based on ceramic

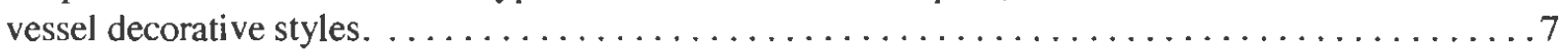

2. Maud points from Burial 7 at the Enis Smith site. . . . . . . . . . . . . . 67

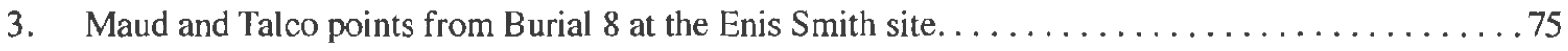

4. Funerary offerings from the Henry Williams site. $\ldots \ldots \ldots \ldots \ldots \ldots \ldots \ldots \ldots \ldots \ldots$

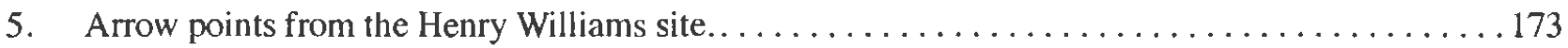

6. Funerary Offerings in Burials 1-6 at the I. P. Starr site. No information is available on

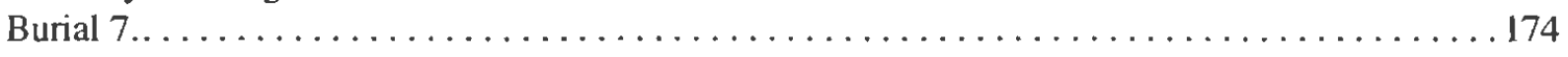

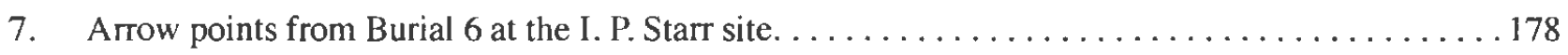

8. Fine ware and utility ware types and varieties identified in the Gum Creek/Little Cypress Creek cemetery sites.. . . . . . . . . . . . . . . . . . . . . . . 311

9. Relative frequency of fine ware types and varieties in the Gum Creek/Little Cypress

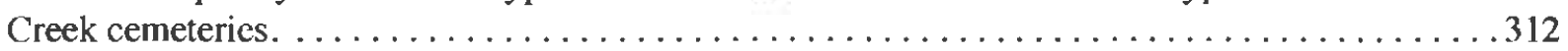

10. Temporal seriation of fine ware types and varieties................ 313

11. Vessel Forms by Ware and Site. . . . . . . . . . . . . . . . 314

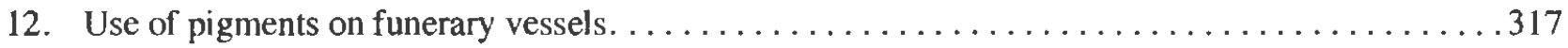

13. Special attributes of the vessels from the cemeteries in the Gum Creek cluster. ...........318

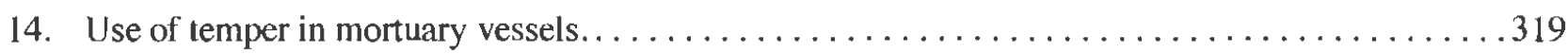


Little Cypress Creek Basin Archaeology: Six Late Caddo Period Cemeteries in Upshur County. Texas

\section{ACKNOWLEDGMENTS}

We appreciale the assistance provided by the Gregg Counly Historical Museum in completing this vessel documentation effort. In particular, Patti Haskins was key to the documentation work, both in sorting out inventory questions and in facilitating the logistics. We also want to thank Lance Trask for his work on various site maps, graphs, and burial plans included in the report. 


\section{Introduction and Purpose of the Study}

Our concern in this report is to present the archaeological findings from six Late Caddo (ca. A.D. 1450-1680) cemetery sites in the Little Cypress Creek basin in Upshur County, in East Texas. These are the Enis Smith (4IUR317), Henry Williams (41UR318), I. P. Starr (41UR319), Herbert Taft (4IUR320), Frank Smith (4IUR326), and Frank Smith Refinery (4IUR327) sites (Figure 1). There are two other large Late Caddo cemeteries in this same area that will also be discussed herein: Henry Spencer (4IUR315, Pcrttula et al. 2012) and the Sword site (4IUR8/208).

These sites represent a group of generally contemporaneous Caddo sites in the Little Cypress Creek basin of East Texas (Figure 1) that were apparently occupied as late as ca. A.D. 1670-1720. Perllula and Nelson (2007) grouped them under the rubric of the Gum Creek cluster. These sites may represent some of the very latest occupied Titus phase settlcments in the Cypress Creek basin.

The Gum Creck cluster Caddo sites were excavated by Buddy Calvin Jones in the 1950s and 1960s, but were never reported by him during his lifetime. After his dcath, his vessel collection and other artifacts were documented by Perttula (2006), with the able assistance of Bo Nelson and Bobby Gonzalez, and at that point it became clear that a certain number of excavated Caddo cemeteries in the Little Cypress Creek basin - the Gum Creek area specifically - had a distinctive artifact assemblage (especially in the form and decoration of certain vessels) that sometimes occurred in association with a few European trade goods (glass beads and a metal hawk bell). Caddo sites with European trade goods are otherwise very rare in the Big and Little Cypress Creek basins, and it seems likely that most of the aboriginal Caddo populations had vacated the area by the very end of the 17th century. Those few sites that are left, such as the Gum Creek cluster and various sites along Caney Creek and Stouts Creek in Wood and Hopkins counties, Texas, may hold crucial keys in understanding this rapid abandonment of an area of East Texas occupied by Caddo peoples for many centuries.

Beyond documenting the collections from these sites, which consist of 259 ceramic vessels, seven ceramic pipes/pipe sherds, 30 arrow points, and one stone bead, now held by the Gregg County Historical Museum in Longview, Texas, as fully as possible given the vagaries of the available notes and records, we will also discuss the contexts from which they were collected by Buddy Calvin Jones. In providing these sets of information, we hope to make available for the first time useful archaeological information on the post-A.D. 1450 Caddo archaeological record of this part of East Texas. This information may then be used in conjunction with what is already known about the Late Caddo period archaeology of the region-especially what is known about the mortuary practices and beliefs of Titus phase Caddo groups - to reach broader understandings of the lifeways of ancient Caddo societies and comnunities in the region.

\section{Natural and Cultural Setting}

The sites under study in this report are located along secondary streams that are tributary to Little Cypress Creek, in the modern Pineywoods in the eastern part of Upshur County, Texas. They are situated along the northern boundaries of the modern Pineywoods physiographic region of East Texas (see Diggs et al . 2006) and the southern boundary of the Post Oak Savannah (Figure 2). The majority of the Late Caddo sites discussed in this report are on Gum Creek, a southern-flowing tributary to Little Cypress Creek, while the others arc on Clear Creek, a northward-flowing tributary.

The Pineywoods cover large parts of East Texas, have medium-tall to tall broadleaf deciduous forests in more mesic habitats, and shortleaf and loblolly pines are common on upland fine sandy loam 


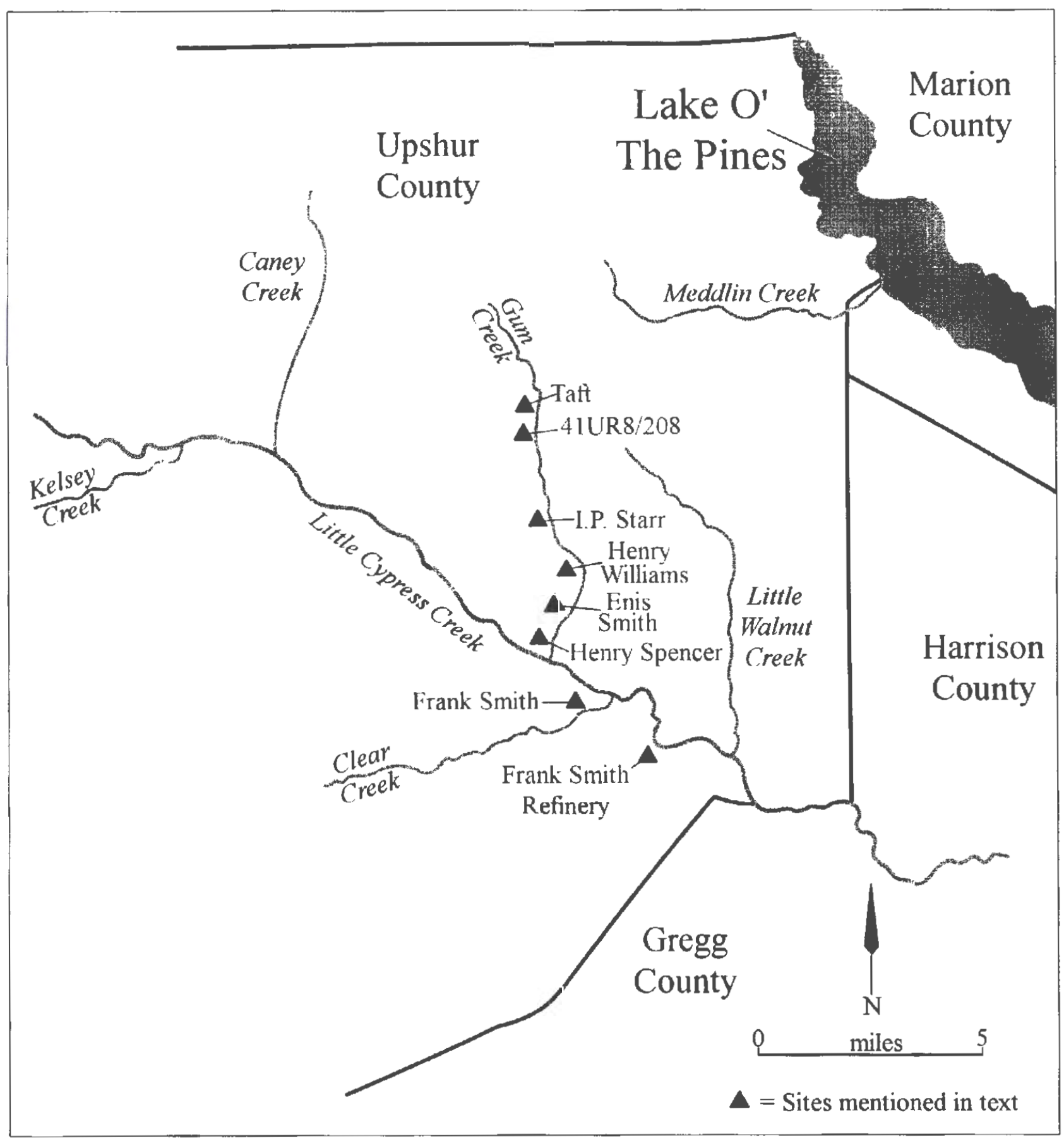

Figure 1. Location of the Little Cypress basin Late Caddo sites discussed in this report.

soils with adequate moisture. Small areas of tall grass prairie may be present in both communities throughout the region (e.g., Jordan 1981:Figure 4.1), and this may be particularly the case in more xeric sandy lands. Bottomland communities along the major river and creek drainages, such as Little Cypress Creek, contain a diverse hardwood and swamp forest (including cypress, tupelo, and sweet gum), with natural levees and alluvial terraces, point bar deposits, old stream channels, oxbow lakes, and backwater swamps. A less diverse bottomland hardwood community is present along the smaller creeks and their tributaries. 


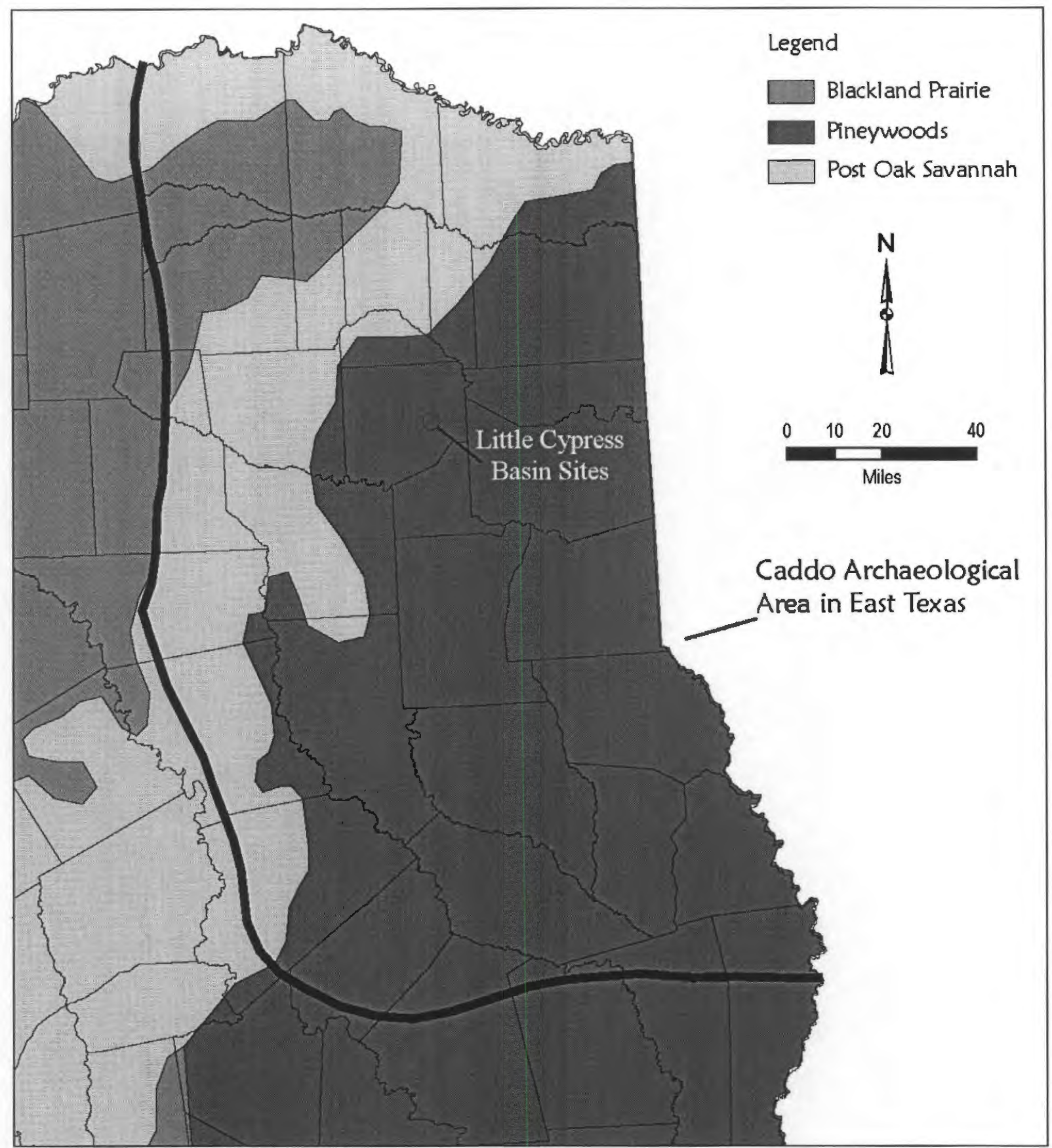

Figure 2. The location of the Little Cypress Creek archaeological sites within the modern boundaries of the Pineywoods in East Texas.

The Post Oak Savannah is a narrow southwest-northeast trending woodland that marks an ecotone between the more xeric Blackland Prairie to the west and south (Diggs et al. 2006:Figure 2) and the more mesic Pineywoods to the east. The woodlands in the Post Oak Savannah consist of broadleaf deciduous forests, primarily including several species of oak as well as hickory and pecan. Small areas of tall grass prairie were present in this physiographic province (see Diggs et al. 2006:Figure 5) that ran from the Colorado River on the west to near the Trinity River on the east. The closest prairie areas would have been ca. $30 \mathrm{~km}$ to the northwest in the White Oak Creek valley. Bottomland communities along the rivers and major tributaries in the Post Oak Savannah had a diverse hardwood and/or swamp forest, including 
cypress, sweet gum, and other hardwoods that tolcrant periodic flood waters, on natural levees and alluvial terraces, point bar deposits, old stream channels and oxbow lakes.

The climate of the East Texas region is humid, with a mean annual precipitation in modern times of at least $100-125 \mathrm{~cm}$ across the region as a whole. Periods of maximum rainfall occur in the spring and fall seasons. The growing season is about 260 days or more, with the last freeze occurring in March and the first freeze in late November. Droughts are also not uncommon in the modern era, and dendrochronological analyses of tree rings for the last 1000 years suggest there were numerous wet and dry spells during that time (Stahle and Cleaveland 1994, 1995), including several lengthy droughts.

Based on mid-19th century General Land Office records from various parts of East Texas, in the uplands in the Pineywoods, especially in settings with very deep and well-drained sandy soils, the overstory consisted of a mixture of pine and oaks, including blue oak, blackjack oak, post oak, and red oak. Some portion of these landform-soils settings (probably with deep sandy sediments) in the Pineywoods probably also had pure stands of pine. In the eastern and southern parts of the region, much of the steeply sloping uplands in the Pineywoods had pines or pine-oak overstories, as would southern and steeper upland slopes. However, northern and more gently sloping valley landforms appear to have been dominated by oaks.

In upland settings with thinner sandy sediments that are not as well-drained, the overstory in the Pineywoods probably consisted of a variety of oaks (post oak, red oak, blackjack oak, blue jack oak, and chinquapin oak) and hickory. Abundant nut mast would have been available in these upland habitats on an annual basis. On landforms with deep and well-drained loamy fine sand, such as more mesic lower valley slopes, toe slopes, and elevated alluvial landforms, the vegetational overstory in mid-19th century times across the region had red oak and post oak trees, along with other hardwoods that tolcrant periodic flooding.

\section{Holocene Environmental Change}

The climate in East Texas has changed dramatically over time, which has affected the biodiversity and carrying capacity of the region. This in turn likely influenced the adaptations of Native American groups like the Caddo and their ancestors that lived in this broad region, especially as the former became more dependent upon cultivated plants after ca. A.D. 1200-1300 (see Perttula 2008; Wilson 2012) and the latter more dependent on sources of water and arable soils in what is a risky and occasionally droughtprone environment.

Pollen data from Ferndale Bog (Holloway 1994) in the Ouachita Mountains of southeastern Oklahoma, and from several bogs in Central Texas (Bousman 1998), indicate that the Late Pleistocene climate (ca. 11,000-14,000 years ago) was cool and dry, and probably supported a grassland steppe. By 11,000 years ago, as the climate became warmer and wetter, oak woodlands or oak savanna habitats would likely have been present throughout much of eastern Texas (and north into Oklahoma). These woodlands were maintained for several thousand years: perhaps until 7500 years ago, although Bousman (1998: Figure 4) notes a period of open, grassland vegetation in Central Texas between 9500-8750 B.P. The Ferndale Bog pollen diagram (see Ferring 1994:Figure 4.5) also points to a more open and grassy setting, based on decreasing oak pollen and a lower pollen influx between ca. 8000-9200 years ago. Whether such a setting characterized East Texas at that time is not known.

Between ca. 7500-5000/4500 years ago, the Middle Holocene climate was quite warm and dry, and Ferring (1995:24) suggests this was a period of significant reduction in available biomass for Native 
American hunter-gatherers in the region. In the Ferndale Bog area of southeastern Oklahoma, the vegetation was an oak-hickory-pine woodland, while farther to the south and west in Central Texas, grasslands were dominant. Bousman's (1998:210) palynological analyses led him to conclude that the grass cover was greatest - and the climate the driest - between 5500-4500 B.P., while Ferring (1995:24) places the very dry and warm cpisode betwecn ca. $6500-5000$ B.P.

The Late Holocene period after ca. 4500 years ago appears to havc bccn onc of fluctuating climatesmoist or dry cycles - that were generally wetter than during the preceding Middle Holocene period, and more like modern climatic conditions. Ferring and Yates (1996:Figure 7.5) propose that there were wetter years between ca. 5000-2000 B.P. and after 1000 B.P., with a drier cycle between 1000-2000 years ago when grassier conditions prevailed, but detailed pollen analyses from cores in the upper Neches River basin have identified a significant xeric phase between 3000-4000 years ago, and there was an expansion of grassland vegetation from west to east in this part of East Texas (Albert 2011). With these fluctuating climatic and rainfall conditions, oak-hickory-pine woodlands were probably the principal vegetation in upland habitats in much of the East Texas lands (as they are today), with a well-developed riverine forest in floodplain settings.

Supporting the drier and warmer cycle in the middle portion of the Late Holocene, the Ferndale Bog pollen record indicates that the peak in pine pollen was between ca. 800-1800 B.P. (Holloway 1994:Table I.2), while Bousman (1998:207) notes one grass spike or peak in the Weakly Bog in Central Texas that dates about 1500-1600 years, with another between 400-500 B.P. Stable carbon and oxygen isotopes from mussel shells along Denton Creek in North Texas, however, point to a warm/dry peak at ca. 2850 B.P., and then again after 1500 B.P. (Brown 1998:164). Stable carbon isotope values from humatc samplcs in the Cooper Lake area of the upper Sulphur River basin in Northeast Texas have C4-enriched pcaks (i.e., higher C4 grasses in the biomass) around 2000 B.P. and 4000 B.P. (see Perttula 1999:Figurc 2-4).

For the last 1000 years or more, the broad period of relevance to thc Caddo archaeology of the region, dendrochronological records (from cypress trecs and $\operatorname{logs}$ ) are the most accurate and temporally sensitive data available on Late Holocenc cnvironmental change (e.g., Stahle 1996). Fortunately, recent dendrochronological rescarch in Texas, Arkansas, and Louisiana, as well as the Southeast and Midwest U.S., by Stahle and Cleaveland $(1988,1992,1993,1994,1995)$ and Benson et al. $(2007,2009)$ has compiled significant information on subtle but changing climatic and rainfall conditions and trends for the general Trans-Mississippi South region, of which East Texas is a part (see Schambach 2002:Figure 5.1).

Droughts are not uncommon in the region in modern times, and dendrochronological analysis suggests there were numerous wet and dry spells between ca. A.D. 1000-1700, just as there were between 5000-1000 years ago. Some of the worse droughts may have occurred around A.D. 1555, 1570, 1595, and 1670, and the period between A.D. 1549-1577 had been suggested to have had the worse droughts in the past 450 years (Stahle et al. 1985), at least in parts of the mid-continent. Another severe droughty period appears to have taken place between about A.D. 1440-1475.

More detailed dendrochronological analyses from bald cypress tree-ring chronologies on spring rainfall between A.D. 997-1988 from Big Cypress State Park in northwestern Louisiana indicate the wettest years were between A.D. 1053-1057, 1168-1176, 1178-1180, 1265-1268, 1323-1328, 1553$1555,1584-1586,1718-1719,1797-1800,1810-1812$, and 1866-1873 (Figurc 3 and Table 1). These weller years as a block of time would likely have been optimal growing years for prehistoric and early historic Caddo agricultural groups dispersed across a wooded landscape, assuming a correlation between crop production and spring precipitation valucs (cf. Anderson et al. 1995:265). Generally warmer and wetter conditions are optimal for increasing "the net yicld and predictability of the maize crop, raising 

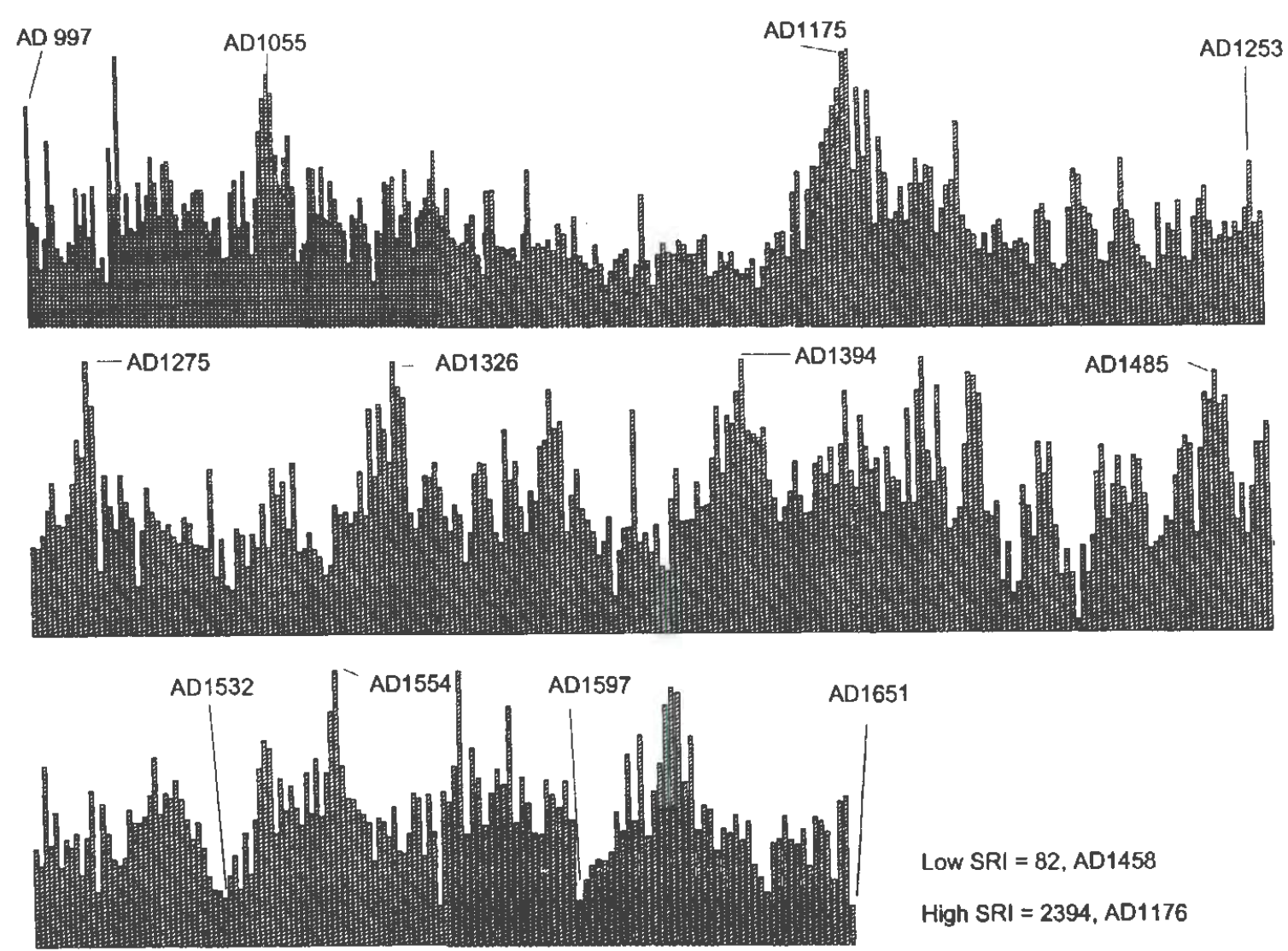

Figure 3. Tree-ring data between A.D. 997-1651 from Big Cypress State Park.

the economic potential of this resource relative to others" (Greenlece 2006:222). The wetter rainfall conditions would also likely have led to an increase in the extent of swamp and wetland habitats in the major stream basins, and a concomitant expansion in the carrying capacity of woodland plants and animals in the area.

Conversely, the driest years in prehistoric and early historic times in East Texas-between A.D. 1014-1016, 1215-1217, 1444-1447, 1455-1460, 1529-1533, 1653-1655, and 1697-1699-may well have led to stressed food supplies, as well as the ability of Caddo groups to produce sufficient and predictable food reserves from the cultivation of tropical cultigens, to maintain seed stock for future crops, and would have hindered the success of any maize harvests during these cxtended periods. The drier periods did not influence the character of Caddo settlement systems, which remained dispersed in character throughout the prehistoric and early historic periods, but it did influence their distribution across the landscape, as Caddo agricultural populations began to concentrate in the Pineywoods and along certain major streams (i.e., the Red, the lower Sulphur, the middle Sabine, and certain parts of the Neches-Angelina river basins).

The very dry years between A.D. 1444 and 1460 (see Table 1) corrclate well with the grass spike/drier episode noted by Bousman (1998) from the Weakly Bog pollen record. These more significant droughts probably also affected the constancy of flow in the numerous upland springs in the area, as well as the volume of flow in the major and minor stream basins. This in turn would have influenced the relative quantity of animal and plant foods in floodplain and upland forested habitats. The very droughty years between 1841-1846 correlate closely with the final abandonment of East Texas by the Caddo. Stahle and 
Table 1. Climatic Conditions based on the 1000 year dendrochronological record from Big Cypress State Park in northwestern Louisiana. The periods in bold and italics represent the periods in which the Little Cypress Creek sites were occupied, based on ceramic vessel decorative styles.

\begin{tabular}{|c|c|c|c|}
\hline $\begin{array}{l}\text { Drier Periods } \\
\text { (A.D.) }\end{array}$ & Mean tree-ring width & $\begin{array}{l}\text { Wetter periods } \\
\text { (A.D.) }\end{array}$ & $\begin{array}{l}\text { Mean tree- } \\
\text { Ring width }\end{array}$ \\
\hline $1014-1016$ & 462 & & \\
\hline \multirow[t]{3}{*}{$1044-1045$} & 568 & & \\
\hline & & $1053-1056$ & 1823 \\
\hline & & $1165-1180$ & 2005 \\
\hline $1215-1217$ & 520 & & \\
\hline \multirow[t]{2}{*}{$1233-1234$} & 512 & & \\
\hline & & $1265-1280$ & 1745 \\
\hline $1293-1294$ & 376 & & \\
\hline \multirow[t]{3}{*}{$1312-1313$} & 507 & & \\
\hline & & $1323-1328$ & 1803 \\
\hline & & 1357-1359 & 1577 \\
\hline \multirow[t]{4}{*}{$1378-1379$} & 463 & & \\
\hline & & 1391-1398 & 1554 \\
\hline & & $1428-1429$ & 1660 \\
\hline & & $1438-1440$ & 1610 \\
\hline $1446-1447$ & 285 & & \\
\hline $1455-1460$ & 380 & & \\
\hline \multirow[t]{2}{*}{$1472-1473$} & 556 & & \\
\hline & & $1483-1487$ & 1529 \\
\hline \multirow[t]{7}{*}{1529.1533} & 466 & & \\
\hline & & $1540-1541$ & 1571 \\
\hline & & $1553-1555$ & 1790 \\
\hline & & $1577-1578$ & 1975 \\
\hline & & $1580-1581$ & 1589 \\
\hline & & $1584-1586$ & 1675 \\
\hline & & $1610-1615$ & 1887 \\
\hline $1653-1655$ & 426 & & \\
\hline $1697-1699$ & 476 & & \\
\hline
\end{tabular}

Note: the driest years have mean standard tree-ring indices of less than 560 , while the welter years have standard treering indices greater than 1400 .

Cleaveland's (1988) drought reconstruction for North Texas indicates that three of the driest years between 1698-1980 occurred in $1855,1857,1859$, and 1855 was the driest year in that 282 year record.

For the period of wet and dry spells from ca. A.D. 1000-1650, the wetter years ( $>1400$ standard ring width indices [sri]) were more than two times as frequent as the driest and droughty ( $<560$ sri) years (see Perttula 1999:Figure 2-5). After ca. A.D. 1430, the wetter years occurred less often, some 55 percent less 
between A.D. 1600-1700 than in the ca. A.D. 1200-1400 pcriod. These very different paleoenvironmcntal conditions over long periods of time may have played an important role in East Texas in human adaptations. These conditions may also have influenced changes to the landscape brought about by significant erosion (and the transportation of sandy sediments), stream down-cutting, and the formation, prescrvation, or degradation of landforms that contain, or once contained, traces of human occupation.

Before the mid-14th century, Caddo groups lived during a period of relatively equitable and mesic climate and abundant precipitation, with only short-lived droughts in A.D. 1293-1294 and A.D. 13121313. During this time, particularly after 600 years ago, it is likely that Caddo farmers in the area created larger cleared areas through their horticultural practices, and also used deliberately-sct fires to open forest lands (cf. Wagner 2003:133-138). The next period of drought came in A.D. 1378-1379, but this was separated by years of regular rainfall and moderate temperatures, during a climatic era that ended in the mid-15th century A.D. (see Table 1), a time when some parts of East Texas were abandoned by the Caddo (see summary in Foster [2012]). During this time it was generally drier and colder, with much drier and colder climatic minima at ca. 500 and 300 years ago as identified by changes in reconstructed solar radiation (Bradley et al. 2003:Figure 6-13; Perttula and Nelson 2004:Figure 4). There were mesic (warmer and wetter) intervals particularly after 410 years ago (see Table 1), and the driest conditions during this period (and indeed over the last 1000 years ago) occurred between A.D. 1446-1460.

\section{Methods of Vessel Analysis}

To facilitate the vessel documentation project concerning the collcctions from these Little Cypress Creek basin cemetery sites, and aid in comparisons with other Caddo vessel documentation projects, we have established a documentation protocol to assist in the analysis of each of the vessels from the different sites. Each of the ceramic vessels in the collections is described and analyzed utilizing a consistent set of morphological, functional, and stylistic attributes modeled after the presentations in Cast et al. (2006); Gadus and Fields (1996); Gonzalez et al. (2005), Perttula et al. (1998, 2008, 2009a, 2009b, 2010a, 2010 b, 2011), Perttula (2011), and Perttula (2005, ed.). The purpose of the documentation is to thoroughly characterize the character of each of the ceramic vessels in the different Caddo collections. The sections that follow provide the completed vessel recordation forms for the Caddo vessels in the GCHM that can be confidently identificd as coming from the six Little Cypress Creek basin sires, as well as accompanying vessel photographic illustrations.

The following attributes were employed in the ceramic vessel study:

Non-plastics: Deliberate and indeterminate materials in the paste (Rice 1987:411), including a variety of tempers (grog or crushed sherds, bone, hematite, shell, quartz sands, etc.) and "particulate matter of some size." The grog, bone, and hematite non-plastics appear to have been deliberately added to the paste as tempers. The bone used for temper had been burned and calcined, then crushed, before it was added to the paste.

Yessel Form: The principal vessel form categories include open containers (bowls, carinated bowls, and compound bowls) and restricted containers, including jars and bottles of several shapes and sizes. As restricted containers, jars allow access by hand, but bottles do not (Brown 1996:335).

Additional form attributes that were recorded on each of the vessels (depending upon their completeness) include the rim profile (outflaring or everted, vertical or standing, and inverted), lip profile (rolled to the exterior, rounded, flat, or thinned), and base shape (flat or rounded). 
Core Colors: Observations on ceramic cross-section colors permit consideration of oxidation patterns (Teltser 1993:Figure 2A-H; Perttula 2005, ed.), and thus the conditions under which the vessel was fired and then cooled after firing. Comments are included for these attributes on the presence and location of fire-clouding, sooting or smudging from cooking usc (Skibo 1992), and the preservation and location of charred organic remains or residues.

Wall Thickness: Thickness was recorded in millimeters, using a vernier caliper, at the lip, along the rim, at several points along the body, and at the base when possible (only for the vessels that were not complete).

Interior and Exterior Surface Treatment: The primary methods of finishing the surface of the vessel include smoothing, burnishing, and polishing (Rice 1987:138), although polishing is generally rarely seen on burial vessels. Brushing is a popular method of roughening the surface (particularly the body) of large and small Middle Caddo (ca. A.D. 1200-1400) and Late Caddo (ca. A.D. 1400-1680) period cooking jars and other utility wares, as well as Historic Caddo sites (post-A.D. 1680) in certain parts of East Texas. Here it is considered a decorative treatment rather than solely a functional surface treatment (cf. Rice 1987:138), although not all Caddo ceramic analysts treat brushing as a decorative treatment (cf. Gadus ct al. 2006:31). In certain fine ware vessels, brushed bodies accompanied engraved rim panels. Smoothing creates "a finer and more regular surface... [and] has a matte rather than a lustrous finish" (Rice 1987:138). Burnishing, on the other hand, creates an irregular lustrous finish marked by parallel facets left by the burnishing tool (perhaps a pebble or bone). A polished surface treatment is marked by a uniform and highly lustrous surface finish, done when the vessel is dry, but without "the pronounced parallel facets produced by burnishing leather-hard clay" (Rice 1987:138).

The application of a hematite-rich clay slip (Ferring and Perttula 1987), either red or black after firing in an oxidizing or reducing (i.e., low-oxygen) environment, is another form of surface treatment noted in these vessel assemblages, albeit very rarely. The clay slip is more frequently applied on the vessel exterior than on the interior surface, and then was either burnished or polished after it was leather-hard or dry.

Height and Orifice Diameter: These attributes, measured in centimeters, were recorded with a ruler.

Diameter at Bottom of Rim and Base Diameter: Also recorded in centimeters using a ruler, these attributes permit characterization of the overall contour and shape of the vessel. With bottles, we also obtained measurements of their maximum body diameter.

Volume: Vessel volume in liters is normally determined by filling (to within $1 \mathrm{~mm}$ of the lip) the vessel with lentil seeds, then dumping the lentil seeds in containers of known volume. In estimating the volume of vessels with holes, the vessel was first filled with a cloth that conformed to vessel contours, then the lentil seeds were poured into the depression in the cloth to within $1 \mathrm{~mm}$ of the top of the lip. Then they were dumped into containers of known volume. In cases where the vessels were not (or could not) be reconstructed, but measurements of height and orifice diameter were obtained, volumes were estimated by comparison with known vessel volumes of specific forms (i.e., carinated bowl, jar, bottle, compound bowl, and bowl) in other documented Caddo vessel assemblages from the Big Cypress Creek basin (see Perttula et al. 1998, 2009a, 2009b, 2010a, 2010b, 2010c, 2010d). Vessels used in domestic contexts at Caddo sites tend to be generally much larger than those placed in burials with the deceased.

Decoration: Decorative techniques present in the vessel collections from sites in the Big Cypress basin of East Texas include engraving and excising, incising, punctating, pinching, lip notching, brushing, neck banding, and appliquéing. On certain vessels, primarily the utility wares, combinations of decorative 
techniques (i.e., brushed-punctated) created the decorative elements and motifs. Engraving and lip notching were done with a sharp tool when the vessel was either leather-hard, or after it was fired, while the other decorative techniques were executed with tools (incising and punctation), by adding strips of clay to the wet body (appliqué), by crimping the coils (ncck banding), using frayed sticks or grass stems (brushing) dragged across the body surface, or fingernails (certain forms of punctations and pinching), when the vessel was wet or still plastic. Excising is considered a form of engraved decoration, where the clay is deliberately and closely marked/scraped and carved away with a sharp tool, usually to create triangular elements (the pendant triangle or small tick marks), negative elements, or crescent-shaped elements or brackets that separate or serve to define scrolls (Suhm and Jelks 1962:Plate 64a-b, f).

A red clay film or wash was added to the surface (interior and/or exterior surfaces) of some vessels as a slip before they were fired. Another form of vessel decoration is the use of red (hematite or ochre) or white (kaolin clay) clay pigments that have been smeared, impressed, or rubbed into the cngraved lines of ccrtain vessels.

Type and Variety: The kinds of named ceramic types in these collections follow primarily the work of Suhm and Jelks (1962) and Thurmond (1990). In this report, we also employ a series of varieties of Ripley Engraved (Figure 4) that follow closely the engraved motifs illustrated by Thurmond (1990:Figure 6), and depend upon his ceramic vessel classifications of more than 740 Ripley Engraved carinated bowls and compound bowls in the Big Cypress Creek basin, as well as newly recognized varieties of Riplcy Engraved (Figure 5) and Wilder Engraved (Figure 6) bottles (see Perttula et al. 2010a, 2010b). Finally, we have recognized a new engraved typc (Turner Engraved) in the Titus phase vessel collections from several sites in the Big Cypress and Little Cypress Creek basins (Figure 7) (see Perttula et al. 2010a, 2010b, 2011), as well as varieties of Womack Engraved (Perttula and Nelson 2007).

In the sections that follow for each site, we first discuss the archaeological character of the vessels found in mortuary contexts. Then, at the conclusion of this study, the vessel data from the sites are employed to make comparisons of the kinds of decorative motifs and clements found on the different kinds of vessel forms, followed by assemblage-level considerations of vessel form, vessel size, use of temper, and firing conditions, as well as the use of pigments, from mortuary vessels of different ages and ceramic traditions in the Little Cypress Creek stream basin.

\section{Enis Smith Site (41UR317)}

A total of 12 Caddo burials were excavated by Buddy Calvin Jones (n.d.) at the Enis Smith site (Figure 8) in January and February 1958; three other burials had been excavated at the site by unknown parties. The burial pits are aligned gencrally east-west, with one burial (Burial 1 ) near the northern end of the landform, and the other 11 (in at least four rows) clustered 10-40 ft. to the south. The cemetery is on an elevated landform (270-280 fcet amsl) above the Gum Creek floodplain, and it is not far to the confluence of Gum Creek with Little Cypress Crcek. 

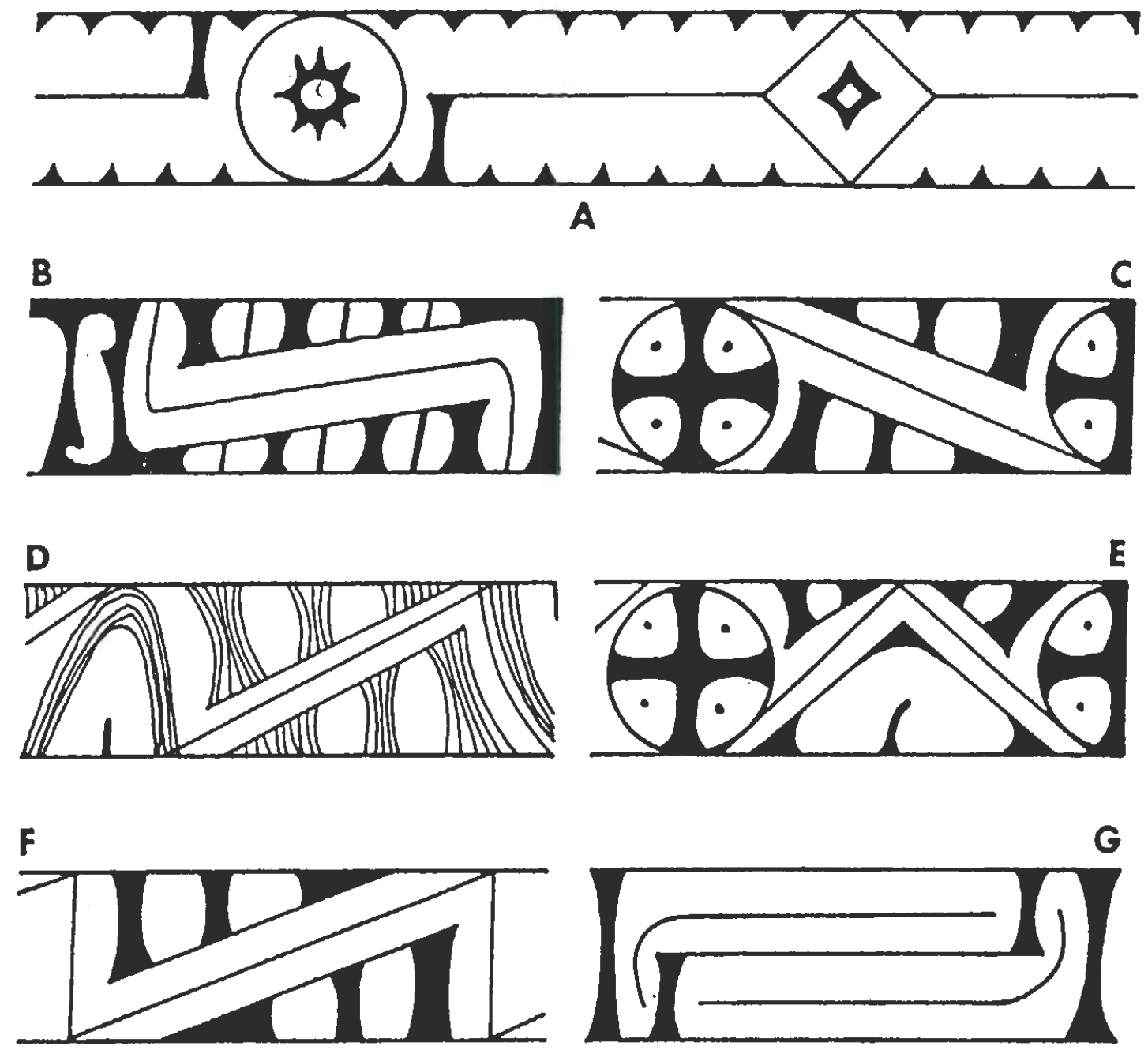

H

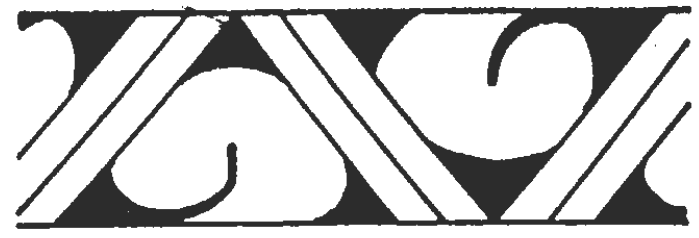

I
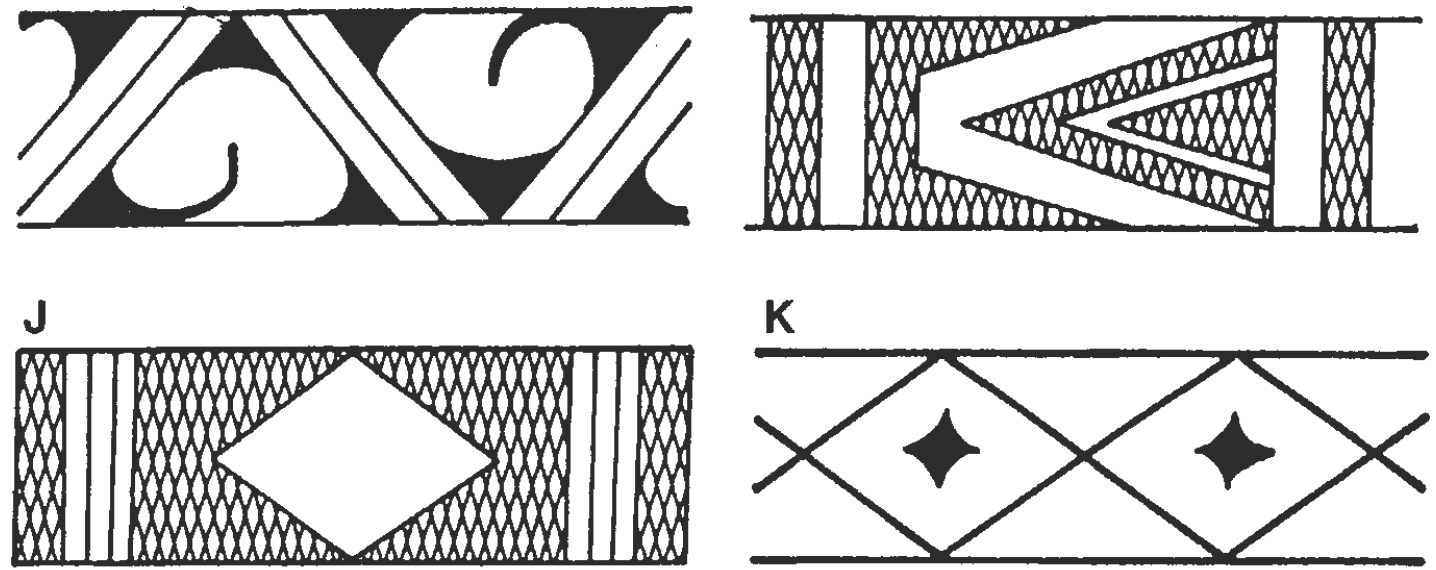

Figure 4. Defined varieties of Ripley Engraved and other engraved motifs on carinated bowls and compound bowls: a, var. McKinney; b, var. Gandy; c, var. Galt; d, var. Caldwell; e, var. Cash; f, var. Carpenter; g, var. Pilgrims; h, var. Williams; i, var. Reed; j, horizontal diamond, var. unspecified; $\mathrm{k}$, interlocking diamond, var. unspecified. 


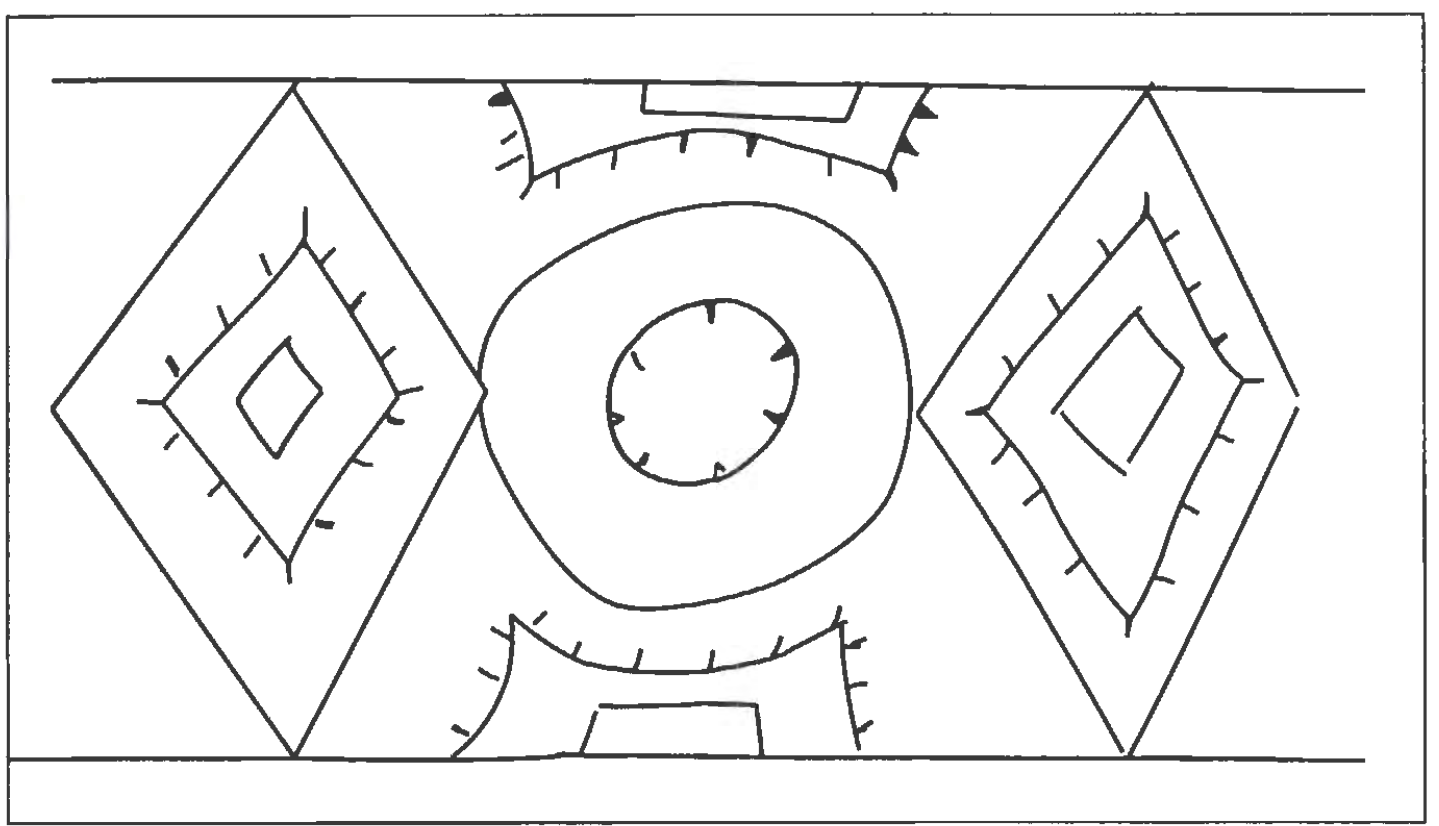

Figure 5. Ripley Engraved, var. Ripley bottle motif.
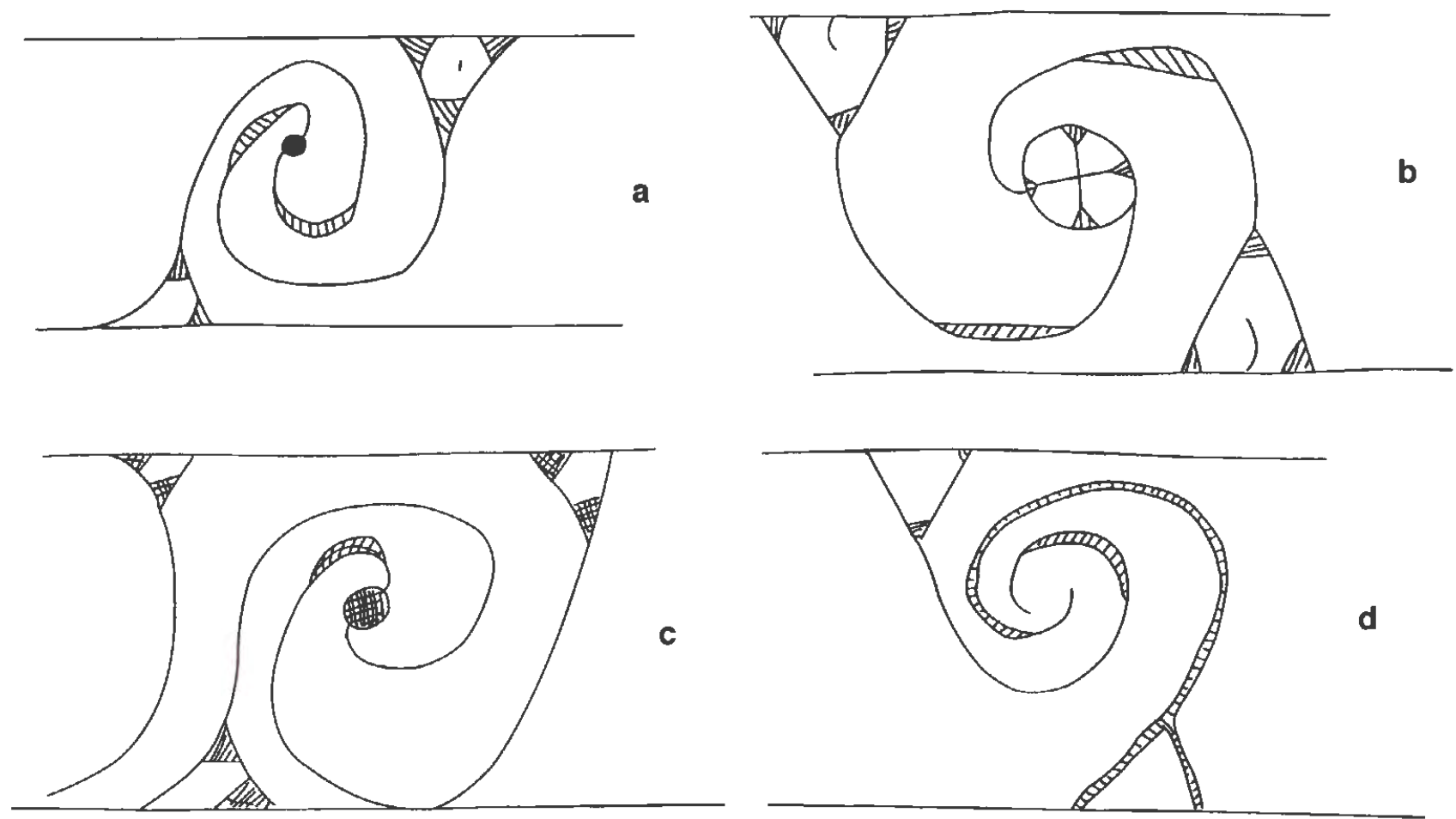

Figure 6. Wilder Engraved, var. Wilder bottle motifs, and var. unspecified motifs: a-c, Wilder Engraved, var. Wilder; d, Wilder Engraved, var. unspecified. 


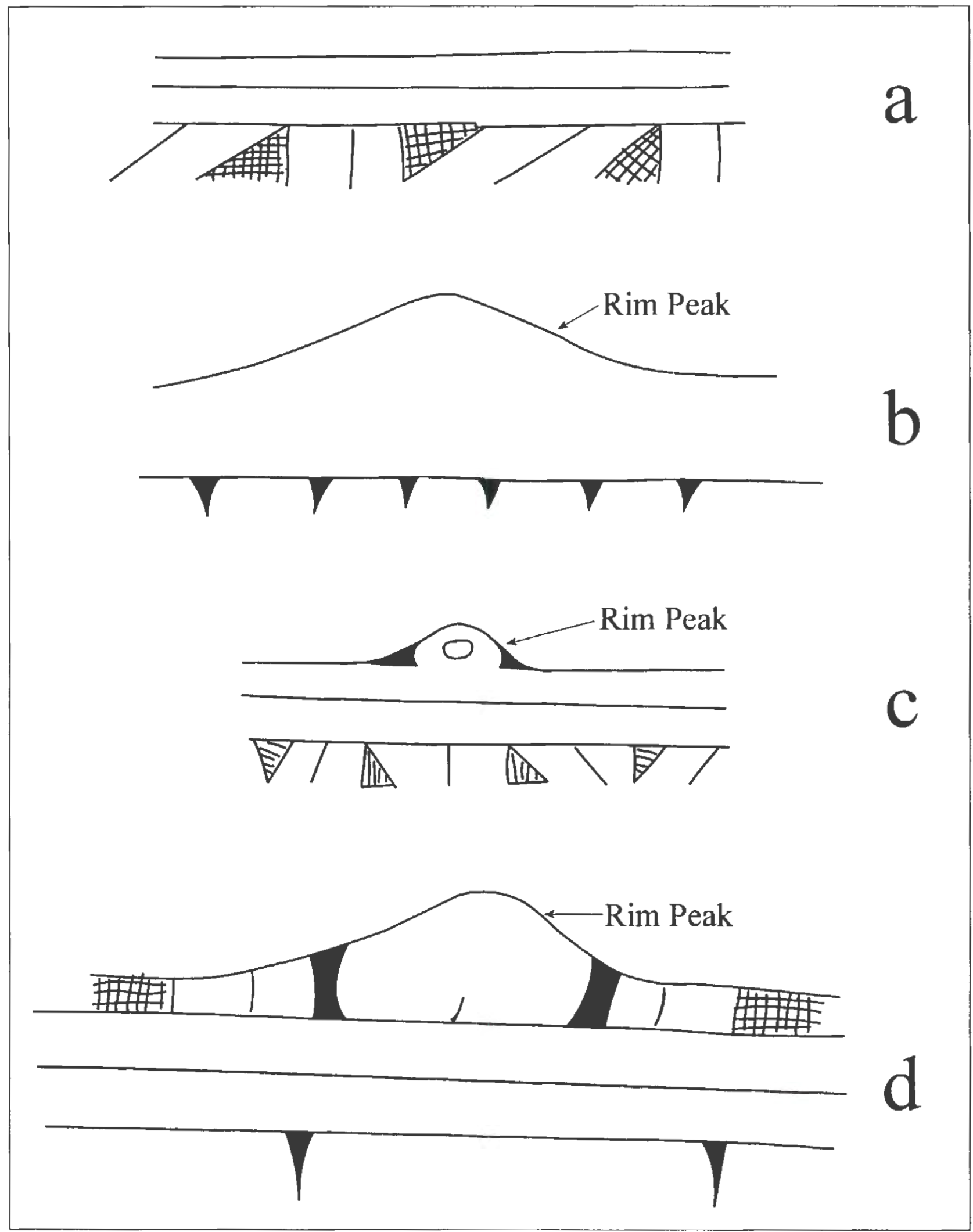

Figure 7. Turner Engraved and defined varieties: a-b, Turner Engraved, var. Turner; c-d, Turner Engraved, var. Horton. 


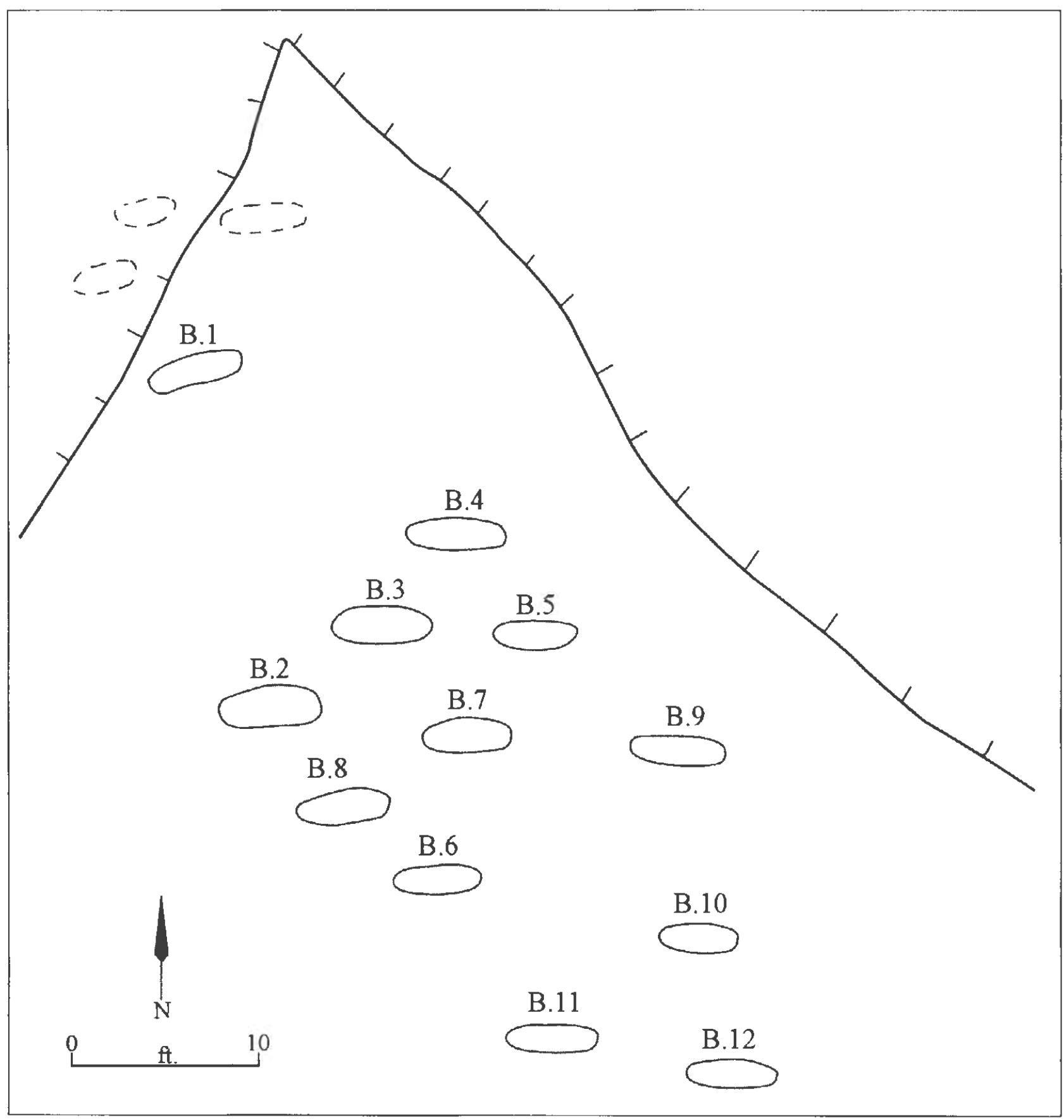

Figure 8. Map of the Enis Smith site cemetery. 


\section{Burial 1}

Burial 1 was in a $2.29 \times 0.92 \mathrm{~m}$ pit that extended to $0.76 \mathrm{~cm}$ bs (Figure 9). Jones' (n.d.) drawing indicates that the individual was buried with their head at the eastern end of the pit, facing west, with five ceramic vessels placed by the upper body and near the feet. The ceramic collection from this burial at the Gregg County Historical Museum, however, includes six vessels, namely one Bailey Engraved bottle and five engraved carinated bowls: Ripley Engraved $(n=4)$ and Taylor Engraved $(n=1)$.

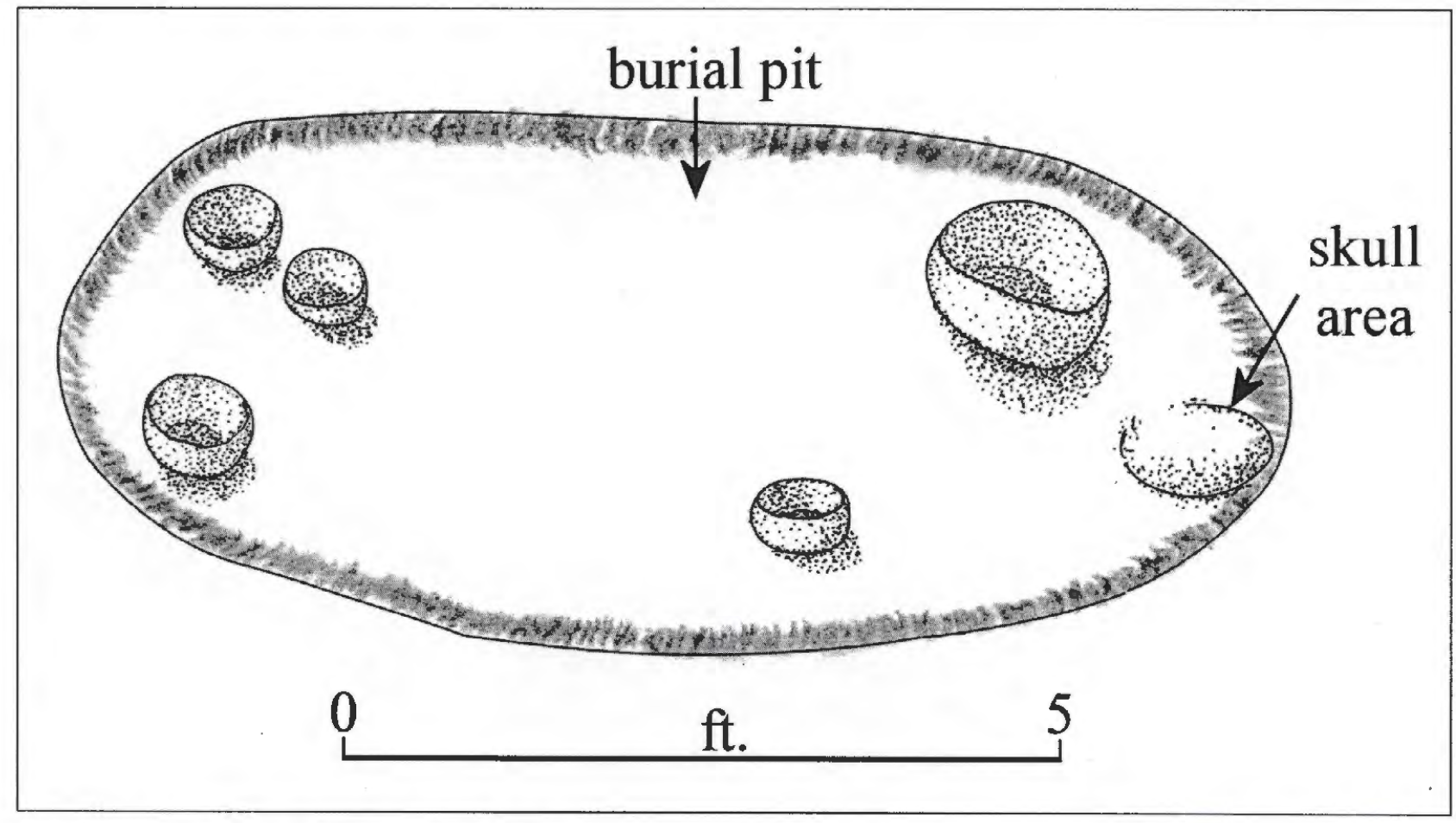

Figure 9. Burial 1 at the Enis Smith site.

VESSEL NO.: Burial 1, Vessel 1; 2003.08.326

NON-PLASTICS AND PASTE: grog and bone

VESSEL FORM: Carinated bowl

RIM AND LIP FORM: Direct rim and a rounded, exterior folded lip

CORE COLOR: $\mathrm{F}$ (fired in a reducing environment and cooled in the open air)

INTERIOR SURFACE COLOR: dark yellowish-brown; fire clouds on the rim and base

EXTERIOR SURFACE COLOR: dark yellowish-brown; fire clouds on the body and base

WALL THICKNESS (RIM, BODY, AND BASE IN MM): rim, $6.0 \mathrm{~mm}$

INTERIOR SURFACE TREATMENT: smoothed on the rim 
EXTERIOR SURFACE TREATMENT:

burnished

HEIGHT (IN CM): 7.5

ORIFICE DIAMETER (IN CM): 16.1

DIAMETER AT BOTTOM OF RIM OR NECK

(IN CM): 15.8

BASE DIAMETER (IN CM) AND SHAPE OF

BASE: 8.4

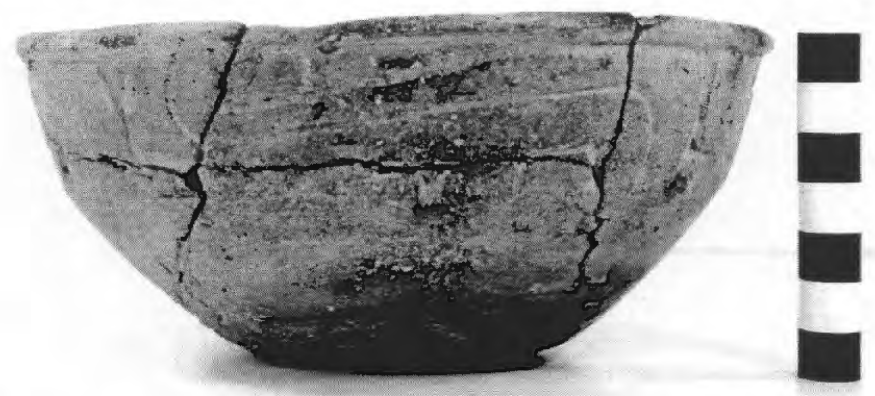

Figure 10. Ripley Engraved, var. Gandy carinated bowl, Enis Smith site, Burial 1, Vessel 1.

ESTIMATED VOLUME (IN LITERS): 0.72

DECORATION (INCLUDING MOTIF AND ELEMENTS WHEN APPARENT): The rim panel has an engraved scroll motif that is repeated four times around the vessel. The scrolls are divided by excised brackets. The upper and lower scroll fill zones have excised brackets and vertical excised lines (Figure 10).

There is also a single horizontal engraved line on the interior vessel surface at the carination.

PIGMENT USE AND LOCATION ON VESSEL: none

TYPE AND VARIETY [IF KNOWN]: Ripley Engraved, var. Gandy 
VESSEL NO.: Burial 1, Vessel 2; 2003.08.998

NON-PLASTICS AND PASTE: no non-plastics apparent

VESSEL FORM: Bottle with a flared neck (Figure 11)

RIM AND LIP FORM: Everted rim and a rounded lip

CORE COLOR: B (fired and cooled in a reducing environment)

INTERIOR SURFACE COLOR: very dark grayish-brown

EXTERIOR SURFACE COLOR: very dark grayish-brown

WALL THICKNESS (RIM, BODY, AND BASE IN MM): neck, $4.6 \mathrm{~mm}$

INTERIOR SURFACE TREATMENT: none

EXTERIOR SURFACE TREATMENT: burnished

HEIGHT (IN CM): II.7

ORIFICE DIAMETER (IN CM): 3.5

DIAMETER AT BOTTOM OF RIM OR NECK (IN CM): 4.3 ; maximum body diameter is $8.2 \mathrm{~cm}$

BASE DIAMETER (IN CM) AND SHAPE OF BASE: 4.1; circular and flat

ESTIMATED VOLUME (IN LITERS): 0.19

DECORATION (INCLUDING MOTIF AND ELEMENTS WHEN APPARENT): The vessel body has four panels of curvilinear engraved arcs, with each panel having 11 concentric curvilinear lines. Below the arcs of engraved lines are two broadly-spaced curvilinear engraved lines. Above the panels and below the base of the bottle neck are triangular and rectangular zones filled with small tool punctations (Figure 11).

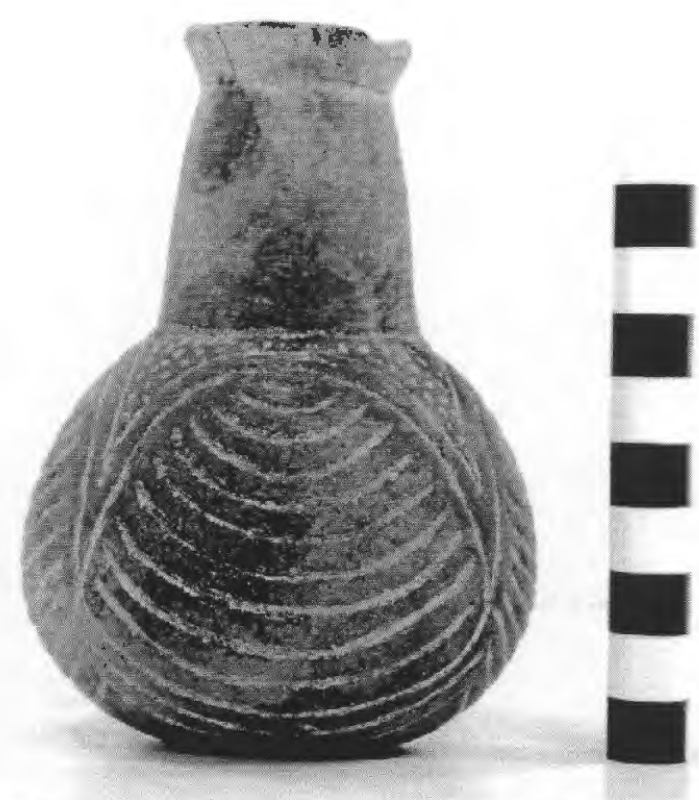

Figure 11. Bailey Engraved bottle, Enis Smith site, Burial 1, Vessel 2.

PIGMENT USE AND LOCATION ON VESSEL: none

TYPE AND VARIETY [IF KNOWN]: Bailey Engraved 
VESSEL NO.: Burial 1, Vessel 3; 2003.08.270

NON-PLASTICS AND PASTE: grog

VESSEL FORM: Carinated bowl

RIM AND LIP FORM: Direct rim and a rounded, exterior folded lip

CORE COLOR: N/A

INTERIOR SURFACE COLOR: dark yellowish-brown; fire clouds on the rim and base; organic residue on the rim

EXTERIOR SURFACE COLOR: dark yellowish-brown; organic residue on the rim and body

WALL THICKNESS (RIM, BODY, AND BASE IN MM): rim, 6.9 mm

INTERIOR SURFACE TREATMENT: smoothed on the rim

EXTERIOR SURFACE TREATMENT: burnished

HEIGHT (IN CM): 11.0

ORIFICE DIAMETER (IN CM): 21.9

DIAMETER AT BOTTOM OF RIM OR NECK (IN CM): $2 \mathrm{I} .4$

BASE DIAMETER (IN CM) AND SHAPE OF

BASE: 6.3 ; circular and flat

ESTIMATED VOLUME (IN LITERS): 1.44

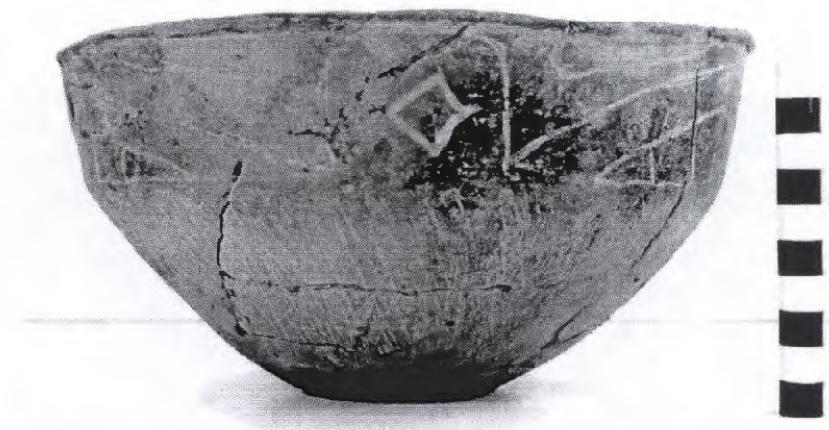

Figure 12. Ripley Engraved, var. unspecified carinated bowl, Enis Smith site, Burial 1, Vessel 3.

DECORATION (INCLUDING MOTIFAND ELEMENTS WHEN APPARENT): The rim panel has an engraved scroll motif repeated four times around the vessel, with two central elements: diamond in a circle (twice) and hatched brackets (twice). The upper scroll fill zones are plain, while the lower scroll fill zones have ovals and excised vertical lines; the ovals have a single dash within them (Figure 12).

The vessel body has vertical brushing marks, an unusual decorative treatment in Titus phase fine wares.

PIGMENT USE AND LOCATION ON VESSEL: none

TYPE AND VARIETY [IF KNOWN]: Ripley Engraved, var. unspecified 
VESSEL NO.: Burial 1, Vessel 4; 2003.08.772

NON-PLASTICS AND PASTE: grog and bone

VESSEL FORM: Carinated bowl

RIM AND LIP FORM: Direct rim and a rounded, exterior folded lip

CORE COLOR: $\mathrm{F}$ (fired in a reducing environment and cooled in the open air)

INTERIOR SURFACE COLOR: reddish-brown; organic residue on the rim

EXTERIOR SURFACE COLOR: reddish-brown; thick organic residue on the lip, rim, and body (Figure I3)

WALL THICKNESS (RIM, BODY, AND BASE IN MM): rim, $6.2 \mathrm{~mm}$

INTERIOR SURFACE TREATMENT: smoothed on the rim

EXTERIOR SURFACE TREATMENT:

smoothed

HEIGHT (IN CM): 6.5

ORIFICE DIAMETER (IN CM): 16.1

DIAMETER AT BOTTOM OF RIM OR NECK (IN CM): 14.3

BASE DIAMETER (IN CM) AND SHAPE OF BASE: 6.6 ; circular and flat

ESTIMATED VOLUME (IN LITERS): 0.63

Figure 13. Ripley Engraved, var. Gandy carinated

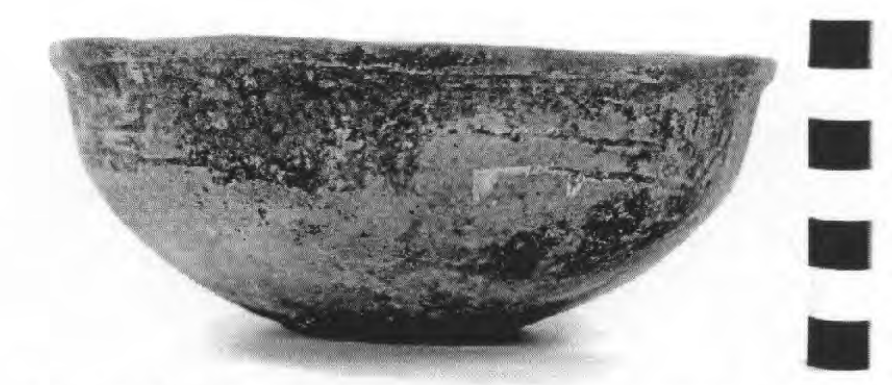
bowl, Enis Smith site, Burial 1, Vessel 4.

DECORATION (INCLUDING MOTIF AND ELEMENTS WHEN APPARENT): The rim panel has an engraved scroll motif repeated four times around the vessel. The scrolls are divided by brackets with a single interior diagonal engraved line. The upper and lower scroll fill zones include excised brackets and negative ovals (Figure I3).

There is also a single horizontal engraved line on the interior vessel surface at the carination.

PIGMENT USE AND LOCATION ON VESSEL: none

TYPE AND VARIETY [IF KNOWN]: Ripley Engraved, var. Gandy 
VESSEL NO.: Burial 1, Vessel 5; 2003.08.632

NON-PLASTICS AND PASTE: grog-organics

VESSEL FORM: Carinated bowl

RIM AND LIP FORM: Direct rim and a rounded, exterior folded lip

CORE COLOR: A (fired and cooled in an oxidizing environment)

INTERIOR SURFACE COLOR: reddish-brown

EXTERIOR SURFACE COLOR: reddishbrown

WALL THICKNESS (RIM, BODY, AND

BASE IN MM): rim, $6.9 \mathrm{~mm}$

INTERIOR SURFACE TREATMENT:

smoothed

EXTERIOR SURFACE TREATMENT:

burnished

HEIGHT (IN CM): 13.5

ORIFICE DIAMETER (IN CM): 28.9

Figure 14. Taylor Engraved carinated bowl, Enis Smith site, Burial 1, Vessel 5.

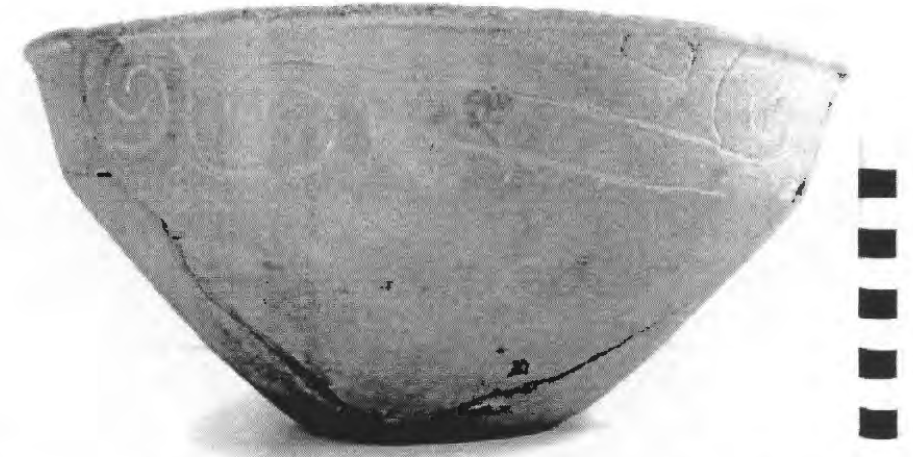

DIAMETER AT BOTTOM OF RIM OR NECK (IN CM): 27.6

BASE DIAMETER (IN CM) AND SHAPE OF BASE: 10.5

ESTIMATED VOLUME (IN LITERS): 3.5

DECORATION (INCLUDING MOTIFAND ELEMENTS WHEN APPARENT): The rim panel has an engraved scroll motif, repeated four times around the vessel, that has hooked arm elements at either end of the scroll (Figure 14). The scrolls are divided from each other by a single vertical engraved line with upper and lower excised triangles. The upper and lower scroll fill zones include hooked arms, excised triangles, and vertical to curvilinear engraved lines.

PIGMENT USE AND LOCATION ON VESSEL: none

TYPE AND VARIETY [IF KNOWN]: Taylor Engraved 
VESSEL NO.: Burial 1, Vessel 6; 2003.08.728

NON-PLASTICS AND PASTE: grog

VESSEL FORM: Carinated bowl

RIM AND LIP FORM: Direct rim and a rounded, exterior folded lip

CORE COLOR: $\mathrm{F}$ (fired in a reducing environment and cooled in the open air)

INTERIOR SURFACE COLOR: reddish-brown; fire clouds on the base

EXTERIOR SURFACE COLOR: reddish-brown; fire clouds on the body and base

WALL THICKNESS (RIM, BODY, AND BASE IN MM): rim, $8.2 \mathrm{~mm}$

INTERIOR SURFACE TREATMENT: smoothed on the rim

EXTERIOR SURFACE TREATMENT: smoothed

HEIGHT (IN CM): 12.5

ORIFICE DIAMETER (IN CM): 25.0

DIAMETER AT BOTTOM OF RIM OR NECK (IN CM): 25.4

BASE DIAMETER (IN CM) AND SHAPE OF BASE: 8.2 ; circular and flat

ESTIMATED VOLUME (IN LITERS): 1.88

DECORATION (INCLUDING MOTIF AND ELEMENTS WHEN APPARENT): The rim panel has an engraved and near continuous scroll motif that is repeated four times around the vessel. The scroll motifs are divided by single vertical engraved lines. The upper and lower scroll fill zones have cross-hatched triangles, negative ovals with a central dot, and short vertical engraved lines (Figure 15).

PIGMENT USE AND LOCATION ON

VESSEL: none

TYPE AND VARIETY [IF KNOWN]: Ripley Engraved, cf. var. Carpenter

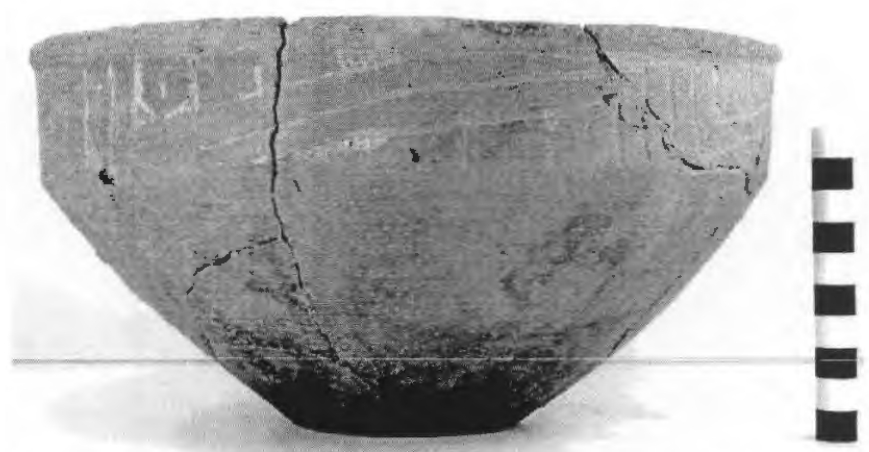

Figure 15. Ripley Engraved, cf. var. Carpenter carinated bowl, Enis Smith site, Burial 1, Vessel 6. 


\section{Burial 2}

Burial 2 is in the western part of the cemetery, in a row with Burials 7 and 9 . The burial pit was 2.44 $\mathrm{m}$ in length and $1.02 \mathrm{~m}$ in width; the pit extended to $1.22 \mathrm{~m}$ bs. Funerary offerings included 12 ceramic vessels, mainly clustered along what would have been the legs and feet of the deceased, except for two bottles near what would have been the head area (Figure 16). Several triangular arrow points were placed amongst the vessels at the lower end of the body. Based on Jones' (n.d.) burial drawing, the vessels in Burial 2 included two bottles, two jars, a large compound bowl, and a number of bowls/carinated bowls.

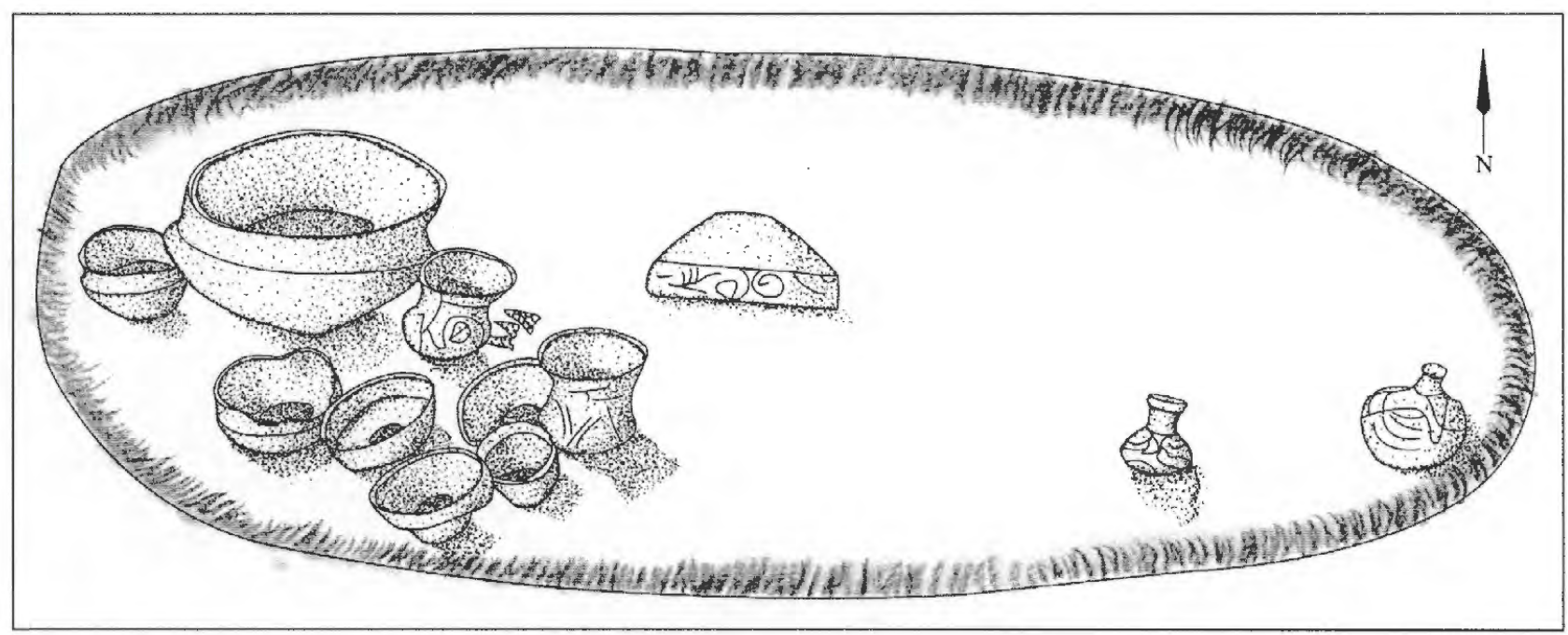

Figure 16. Plan of Burial 2 at the Enis Smith site.

Eleven of the 12 vessels from Burial 2 are present in the collections. These include two Bailey Engraved bottles, one Harleton Appliqued jar, and eight carinated bowls. These are represented by Ripley Engraved ( $\mathrm{n}=5$, cf. var. Gandy, var. Cash, var. Galt, and var. unspecified), Taylor Engraved ( $\mathrm{n}=2)$, and Womack Engraved $(n=1)$.

VESSEL NO.: Burial 2, Vessel 7; 2003.08.791

NON-PLASTICS AND PASTE: grog and bone

VESSEL FORM: Carinated bowl

RIM AND LIP FORM: Direct rim and a rounded, exterior folded lip

CORE COLOR: $\mathrm{G}$ (fired in a reducing environment and cooled in the open air)

INTERIOR SURFACE COLOR: grayish-brown; fire cloud on the base

EXTERIOR SURFACE COLOR: reddish-brown; fire clouds on the body and base

WALL THICKNESS (RIM, BODY, AND BASE IN MM): rim, 5.7 mm 
INTERIOR SURFACE TREATMENT: smoothed on the rim

EXTERIOR SURFACE TREATMENT: smoothed

HEIGHT (IN CM): 7.8

ORIFICE DIAMETER (IN CM): 14.4

DIAMETER AT BOTTOM OF RIM OR NECK (IN CM): 14.4

BASE DIAMETER (IN CM) AND SHAPE OF BASE: 6.5

ESTIMATED VOLUME (IN LITERS): 0.67

DECORATION (INCLUDING MOTIF AND ELEMENTS WHEN APPARENT): The rim panel has an engraved scroll motif repeated four times around the vessel. The scrolls are divided by vertical brackets that have two small projecting spur elements. The upper and lower scroll fill zones have vertical engraved lines (Figure 17).

PIGMENT USE AND LOCATION ON VESSEL: none

TYPE AND VARIETY [IF KNOWN]: Ripley Engraved, cf. var. Gandy

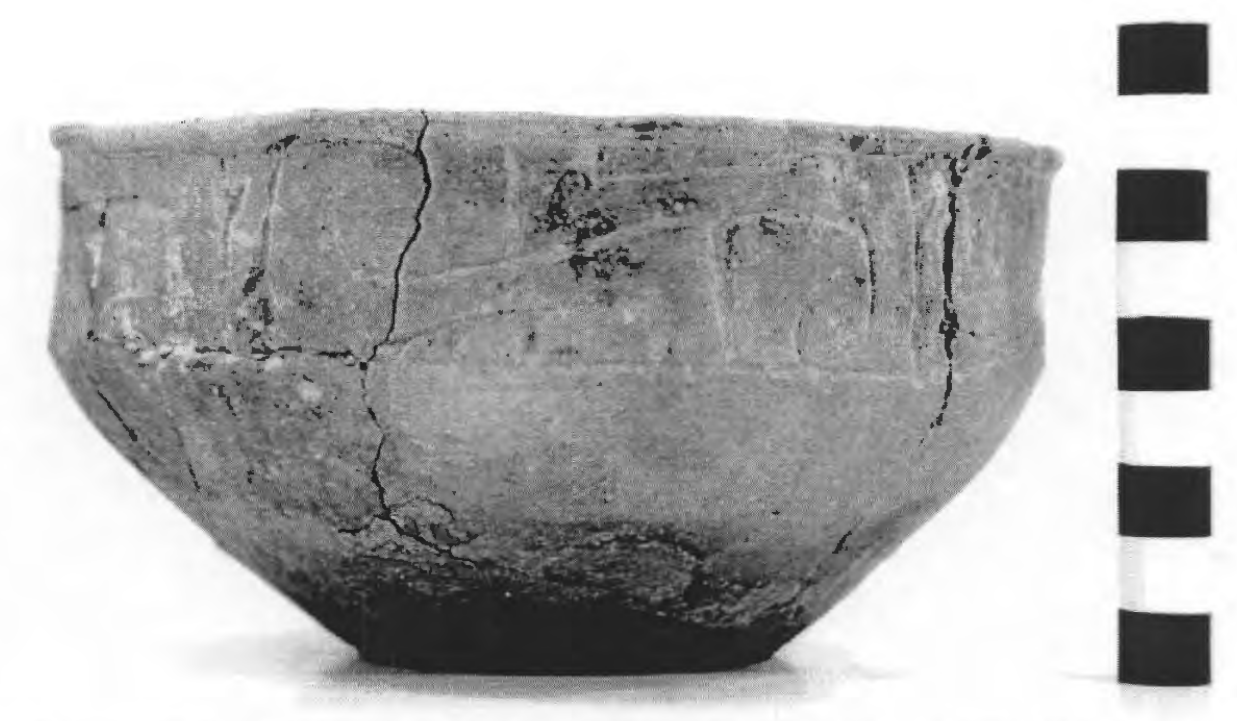

Figure 17. Ripley Engraved, cf. var. Gandy carinated bowl, Enis Smith site, Burial 2, Vessel 7. 
VESSEL NO.: Burial 2, Vessel 8; 2003.08.218

NON-PLASTICS AND PASTE: bone

VESSEL FORM: Carinated bowl

RIM AND LIP FORM: Direct rim and a rounded, exterior folded lip

CORE COLOR: $\mathrm{F}$ (fired in a reducing environment and cooled in the open air)

INTERIOR SURFACE COLOR: reddish-brown; fire cloud on the base

EXTERIOR SURFACE COLOR: reddish-brown; fire clouds on the body and base

WALL THICKNESS (RIM, BODY, AND BASE IN MM): rim, $6.1 \mathrm{~mm}$

INTERIOR SURFACE TREATMENT: smoothed

EXTERIOR SURFACE TREATMENT:

burnished

HEIGHT (IN CM): 6.5

ORIFICE DIAMETER (IN CM): 14.6

DIAMETER AT BOTTOM OF RIM OR

NECK (IN CM): 12.6

BASE DIAMETER (IN CM) AND

SHAPE OF BASE: 4.8

ESTIMATED VOLUME (IN LITERS): 0.57

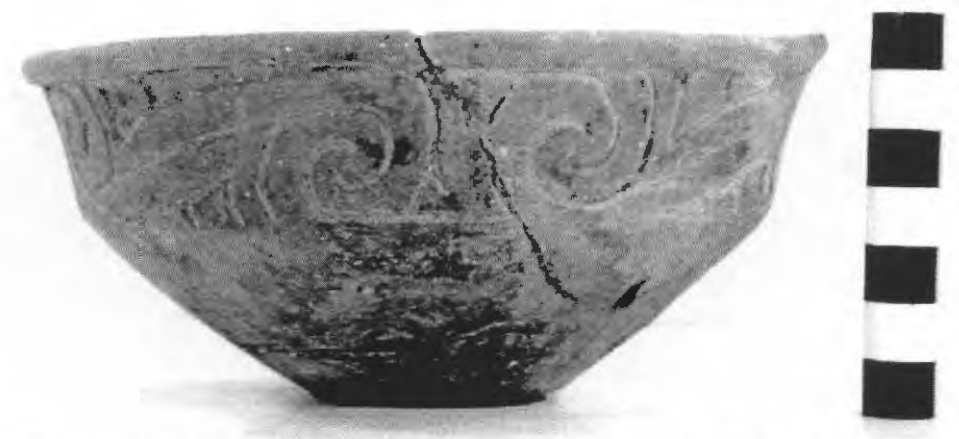

Figure 18. Taylor Engraved carinated bowl, Enis Smith cemetery, Burial 2, Vessel 8.

DECORATION (INCLUDING MOTIF AND ELEMENTS WHEN APPARENT): The rim panel has an engraved scroll motif, repeated four times around the vessel, that has hooked arm elements at either end of the scroll. The scrolls are divided from each other by vertical brackets with two projecting spurs. The upper and lower scroll fill zones include vertical to curvilinear engraved lines (Figure 18).

There is also a single horizontal engraved line on the interior vessel surface at the carination.

PIGMENT USE AND LOCATION ON VESSEL: red pigment in the engraved lines TYPE AND VARIETY [IF KNOWN]: Taylor Engraved 
VESSEL NO:: Burial 2, Vessel 9; 2003.08.1819

NON-PLASTICS AND PASTE: grog

VESSEL FORM: Carinated bowl

RIM AND LIP FORM: Inverted rim and rounded lip (Figure 19)

CORE COLOR: N/A

INTERIOR SURFACE COLOR: N/A (Reconstructed)

EXTERIOR SURFACE COLOR: N/A (Reconstructed)

WALL THICKNESS (RIM, BODY, AND BASE IN MM): rim, $5.6 \mathrm{~mm}$

INTERIOR SURFACE TREATMENT: N/A

EXTERIOR SURFACE TREATMENT: N/A

HEIGHT (IN CM): 7.4

ORIFICE DIAMETER (IN CM): 12.7

DIAMETER AT BOTTOM OF RIM OR NECK (IN CM): 16.2

BASE DIAMETER (IN CM) AND SHAPE OF BASE: 6.4 ; circular and flat

ESTIMATED VOLUME (IN LITERS): 0.56

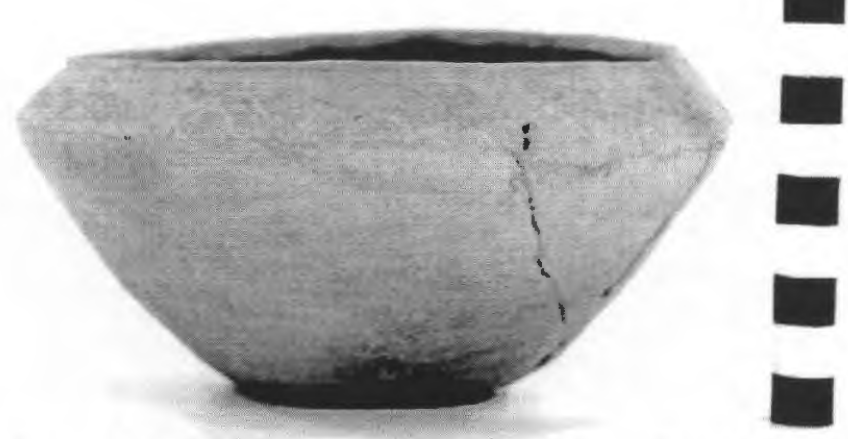

Figure 19. Womack Engraved, var. Gum Creek carinated bowl, Enis Smith cemetery, Burial 2, Vessel 9.

DECORATION (INCLUDING MOTIF AND ELEMENTS WHEN APPARENT): The rim panel has a continuous series of 14 engraved concentric semi-circles around the vessel (Figure 19).

PIGMENT USE AND LOCATION ON VESSEL: none

TYPE AND VARIETY [IF KNOWN]: Womack Engraved, var. Gum Creek 
VESSEL NO.: Burial 2, Vessel 10; 2003.08.750

NON-PLASTICS AND PASTE: grog and bone

VESSEL FORM: Bottle

RIM AND LIP FORM: N/A

CORE COLOR: B (fired and cooled in a reducing environment)

INTERIOR SURFACE COLOR: black

EXTERIOR SURFACE COLOR: black

WALL THICKNESS (RIM, BODY, AND BASE IN MM): neck, $7.2 \mathrm{~mm}$

INTERIOR SURFACE TREATMENT: none

EXTERIOR SURFACE TREATMENT: smoothed

HEIGHT (IN CM): 15.5+

ORIFICE DIAMETER (IN CM): 4.5

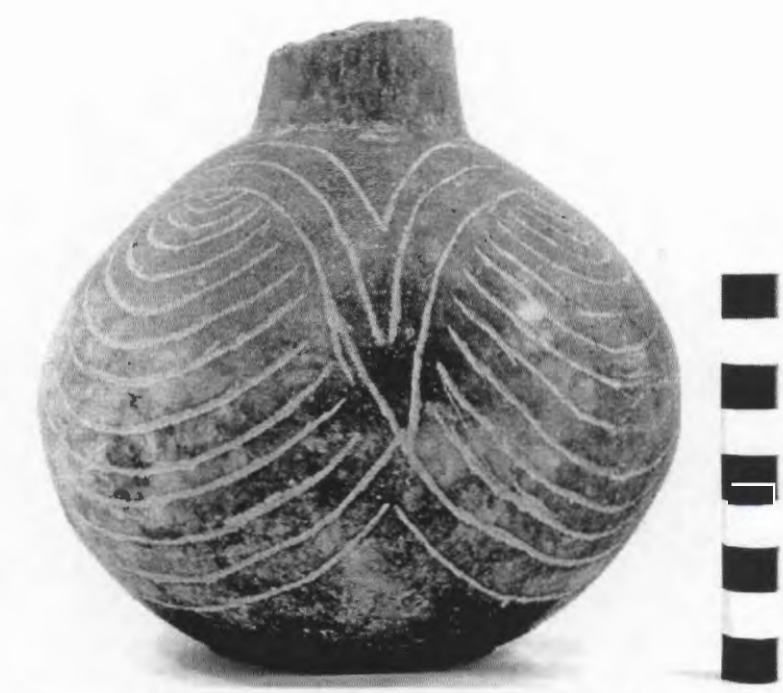

Figure 20. Bailey Engraved bottle, Enis Smith cemetery, Burial 2, Vessel 10.

DIAMETER AT BOTTOM OF RIM OR NECK (IN CM): 5.5

BASE DIAMETER (IN CM) AND SHAPE OF BASE: 7.7

ESTIMATED VOLUME (IN LITERS): 0.48+

DECORATION (INCLUDING MOTIF AND ELEMENTS WHEN APPARENT): The vessel body has four panels filled with II concentric engraved arcs (Figure 20). Unlike most Bailey Engraved bottles, there are no punctated-filled zones on this vessel.

PIGMENT USE AND LOCATION ON VESSEL: none

TYPE AND VARIETY [IF KNOWN]: cf. Bailey Engraved 
VESSEL NO.: Burial 2, Vessel 12; 2003.08.336

NON-PLASTICS AND PASTE: grog

VESSEL FORM: Bottle with a flaring lip

RIM AND LIP FORM: Everted rim and a rounded lip

CORE COLOR: B (fired and cooled in a reducing environment)

INTERIOR SURFACE COLOR: black

EXTERIOR SURFACE COLOR: black

WALL THICKNESS (RIM, BODY, AND BASE IN $\mathrm{MM})$ : rim, $6.3 \mathrm{~mm}$

INTERIOR SURFACE TREATMENT: none

EXTERIOR SURFACE TREATMENT: smoothed

HEIGHT (IN CM): 12.4

ORIFICE DIAMETER (IN CM): 3.8

DIAMETER AT BOTTOM OF RIM OR NECK (IN CM): 3.7

BASE DIAMETER (IN CM) AND SHAPE OF BASE: 5.0 ; circular and rounded

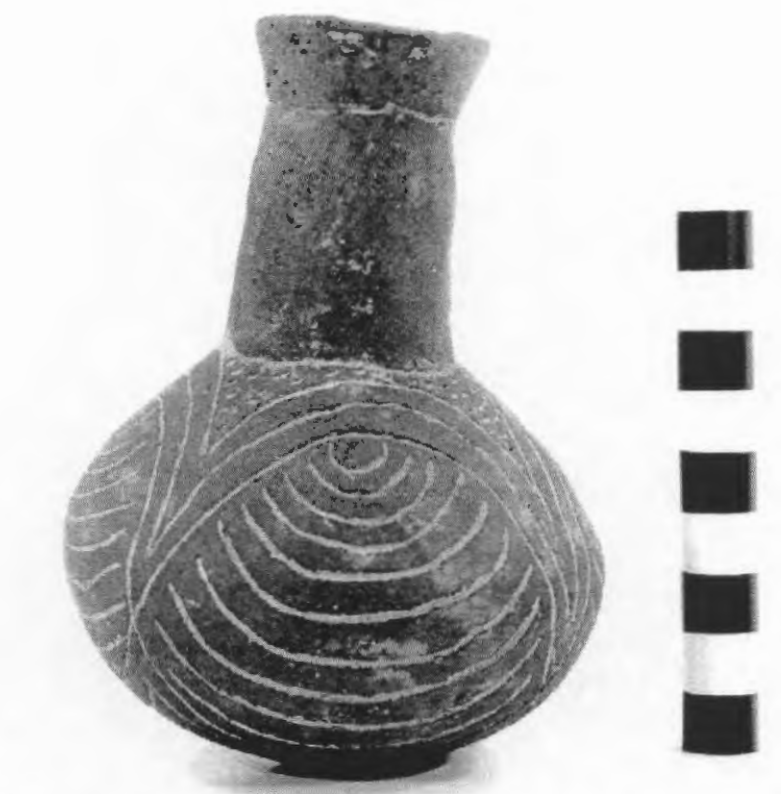

\section{ESTIMATED VOLUME (IN LITERS): 0.25}

Figure 21. Bailey Engraved bottle, Enis Smith cemetery, Burial 2, Vessel 12.

DECORATION (INCLUDING MOTIF AND ELEMENTS WHEN APPARENT): There is a single horizontal engraved line on the upper part of the bottle neck. The vessel body has four panels filled with 11 concentric engraved arcs. Above each panel is a continuous engraved zone filled with rows of tool punctations (Figure 21).

PIGMENT USE AND LOCATION ON VESSEL: none TYPE AND VARIETY [IF KNOWN]: Bailey Engraved 
VESSEL NO.: Burial 2, Vessel 13; 2003.08.1011

NON-PLASTICS AND PASTE: grog

VESSEL FORM: Carinated bowl

RIM AND LIP FORM: Direct rim and a rounded, exterior folded lip

CORE COLOR: $\mathrm{F}$ (fired in a reducing environment and cooled in the open air)

INTERIOR SURFACE COLOR: reddish-brown; fire clouds on the body

EXTERIOR SURFACE COLOR: reddish-brown; fire clouds on the rim and body

WALL THICKNESS (RIM, BODY, AND BASE IN MM): rim, $5.7 \mathrm{~mm}$; body, $6.2 \mathrm{~mm}$; base, $10.3 \mathrm{~mm}$

INTERIOR SURFACE TREATMENT: smoothed

EXTERIOR SURFACE TREATMENT: burnished

HEIGHT (IN CM): N/A

ORIFICE DIAMETER (IN CM): 29.0

DIAMETER AT BOTTOM OF RIM OR NECK (IN CM): 28.7

BASE DIAMETER (IN CM) AND SHAPE OF BASE:

8.4 ; circular and flat

ESTIMATED VOLUME (IN LITERS): N/A

DECORATION (INCLUDING MOTIF AND ELEMENTS

WHEN APPARENT): The rim panel has an engraved motif that features alternating circles inside circles (twice) and nested triangles (twice) along a scroll line. The circle element has a small inner circle with projecting lines or spurs (Figure 22). The nested triangles has a smaller triangle within that is filled with an oval-shaped element defined by hatched lines. Fill zones above and below the

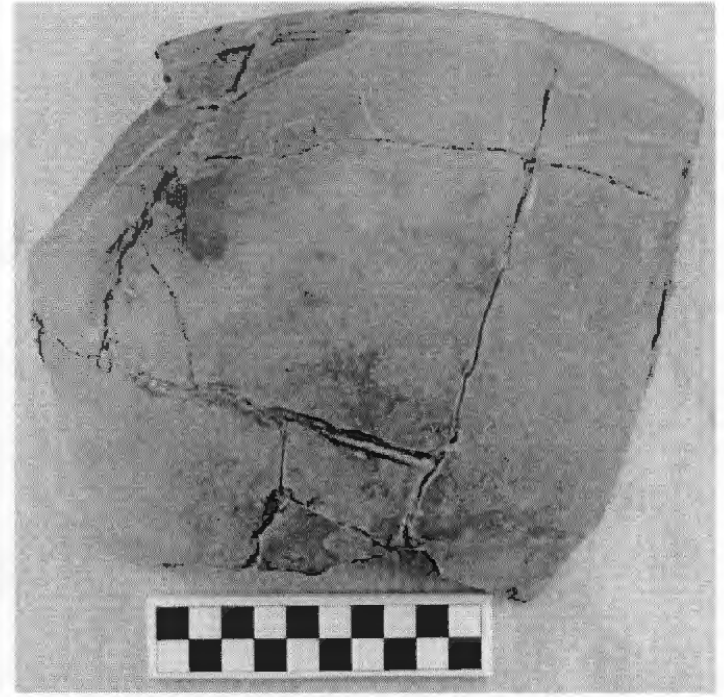

Figure 22. Ripley Engraved, var. Cash carinated bowl rim and body section, Enis Smith site, Burial 2, Vessel 13. scroll line have vertical engraved and excised lines.

PIGMENT USE AND LOCATION ON VESSEL: none

TYPE AND VARIETY [IF KNOWN]: Ripley Engraved, var. Cash 
VESSEL NO.: Burial 2, Vessel 14; 2003.08.614

NON-PLASTICS AND PASTE: grog

VESSEL FORM: Carinated bowl

RIM AND LIP FORM: Direct rim and a rounded lip

CORE COLOR: $\mathrm{F}$ (fired in a reducing environment and cooled in the open air)

INTERIOR SURFACE COLOR: yellowish-brown

EXTERIOR SURFACE COLOR: dark yellowish-brown; fire clouds on the body and base

WALL THICKNESS (RIM, BODY, AND BASE IN MM): rim, 5.6 mm

INTERIOR SURFACE TREATMENT: smoothed on the rim

EXTERIOR SURFACE TREATMENT: burnished

HEIGHT (IN CM): 11.3

ORIFICE DIAMETER (IN CM): 27.4

DIAMETER AT BOTTOM OF RIM OR NECK (IN $\mathrm{CM}): 26.6$

BASE DIAMETER (IN CM) AND SHAPE OF BASE: 9.0 ; circular and flat

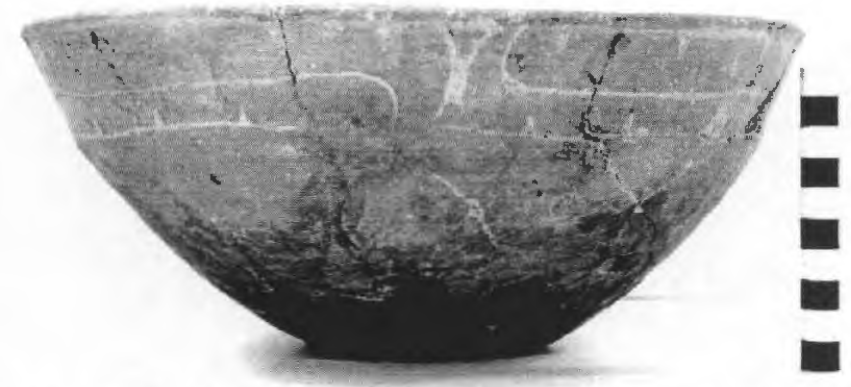

Figure 23. Ripley Engraved, cf. var. Gandy carinated bowl, Enis Smith cemetery, Burial 2, Vessel 14.

ESTIMATED VOLUME (IN LITERS): 1.86

DECORATION (INCLUDING MOTIF AND ELEMENTS WHEN APPARENT): The rim panel has a simple engraved scroll motif repeated four times around the vessel. The scrolls are divided by vertical brackets with excised central areas. Above and below the scrolls are small excised pendant triangles (Figure 23).

There is also a single horizontal engraved line on the interior vessel surface at the carination.

PIGMENT USE AND LOCATION ON VESSEL: none

TYPE AND VARIETY [IF KNOWN]: Ripley Engraved, cf. var. Gandy 
VESSEL NO.: Burial 2, Vessel 15; 2003.08.401

NON-PLASTICS AND PASTE: grog

VESSEL FORM: Carinated bowl

RIM AND LIP FORM: Direct rim and a rounded, exterior folded lip

CORE COLOR: $\mathrm{F}$ (fired in a reducing environment and cooled in the open air)

INTERIOR SURFACE COLOR: brown; fire clouds on the rim and base

EXTERIOR SURFACE COLOR: yellowishbrown; fire clouds on the rim, body, and base

WALL THICKNESS (RIM, BODY, AND BASE IN MM): rim, $6.5 \mathrm{~mm}$

INTERIOR SURFACE TREATMENT: smoothed on the rim

EXTERIOR SURFACE TREATMENT: burnished

HEIGHT (IN CM): 8.5

ORIFICE DIAMETER (IN CM): 16.0

Figure 24. Taylor Engraved carinated bowl, Enis

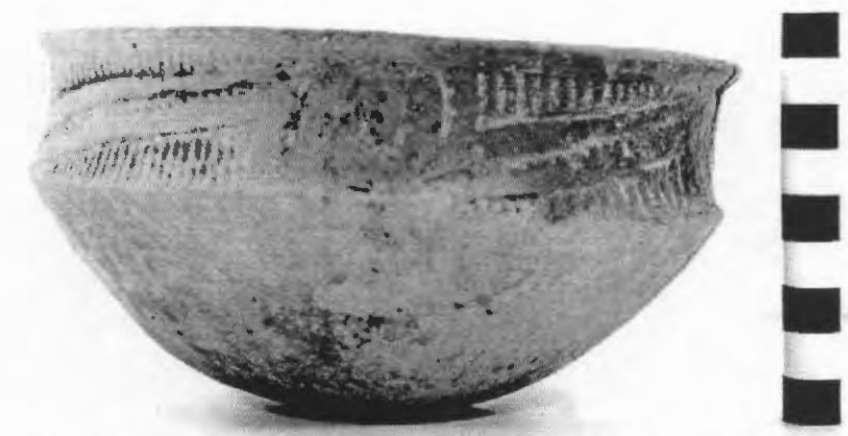

Smith cemetery, Burial 2, Vessel 15.

DIAMETER AT BOTTOM OF RIM OR NECK (IN CM): 16.8

BASE DIAMETER (IN CM) AND SHAPE OF BASE: 6.5; circular and rounded

ESTIMATED VOLUME (IN LITERS): 0.82

DECORATION (INCLUDING MOTIF AND ELEMENTS WHEN APPARENT): The rim panel has an engraved slanted scroll motif that is repeated four times around the vessel. The scrolls end in semi-circles and a distinctive spiral-shaped curvilinear line (i.e., joined hooked arms instead of a small gap between them, see Suhm and Jelks [1962:149]). The scrolls, semi-circles, and curvilinear lines all have small tick marks on them. The upper and lower scroll fill zones have short vertical to curvilinear engraved lines (Figure 24).

PIGMENT USE AND LOCATION ON VESSEL: red pigment in the engraved lines

TYPE AND VARIETY [IF KNOWN]: Taylor Engraved 
VESSEL NO.: Burial 2, Vessel 16; 2003.08.723

NON-PLASTICS AND PASTE: grog

VESSEL FORM: Carinated bowl

RIM AND LIP FORM: Direct rim and a rounded, exterior folded lip

CORE COLOR: $\mathrm{H}$ (fired in a reducing environment and cooled in the open air)

INTERIOR SURFACE COLOR: dark yellowish-brown; organic residue on the rim

EXTERIOR SURFACE COLOR: dark yellowish-brown; fire clouds on the body and base; thick resin-like organic residue on the rim and body

WALL THICKNESS (RIM, BODY, AND BASE IN MM): rim, 7.9 mm

INTERIOR SURFACE TREATMENT: smoothed

EXTERIOR SURFACE TREATMENT: burnished

HEIGHT (IN CM): 12.1

ORIFICE DIAMETER (IN CM): 25.6

DIAMETER AT BOTTOM OF RIM OR NECK (IN CM): 24.5

BASE DIAMETER (IN CM) AND SHAPE OF BASE: 7.0; circular and flat

ESTIMATED VOLUME (IN LITERS): 1.86

DECORATION (INCLUDING MOTIF AND ELEMENTS WHEN APPARENT): The rim panel has an engraved scroll and circle motif that is repeated four times around the vessel. Each central circle has a diamond element and spurs within it. The upper and lower scroll fill zones have negative ovals with a single inner dashed line or spur, excised brackets, excised triangles, and vertical engraved lines (Figure 25).

PIGMENT USE AND LOCATION ON VESSEL: none

TYPE AND VARIETY [IF KNOWN]: Ripley Engraved, var. Galt

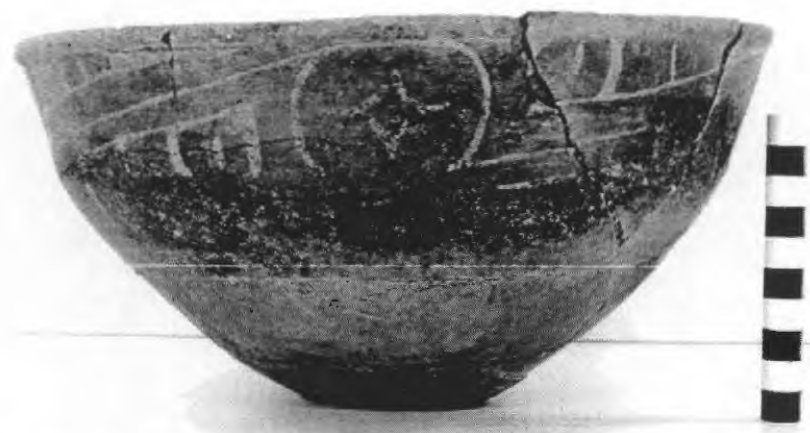

Figure 25. Ripley Engraved, var. Galt carinated bowl, Enis Smith cemetery, Burial 2, Vessel 16. 
VESSEL NO.: Burial 2, Vessel 17; 2003.08.704

NON-PLASTICS AND PASTE: grog; sandy paste

VESSEL FORM: Carinated bowl

RIM AND LIP FORM: Inverted rim and a rounded, exterior folded lip

CORE COLOR: $\mathrm{G}$ (fired in a reducing environment and cooled in the open air)

INTERIOR SURFACE COLOR: dark grayish-brown

EXTERIOR SURFACE COLOR: yellowish-brown; fire clouds on the rim, body, and base

WALL THICKNESS (RIM, BODY, AND BASE IN MM): rim, $10.0 \mathrm{~mm}$

INTERIOR SURFACE TREATMENT: smoothed on the rim

EXTERIOR SURFACE TREATMENT: burnished

HEIGHT (IN CM): 10.0

ORIFICE DIAMETER (IN CM): 19.8

DIAMETER AT BOTTOM OF RIM OR NECK (IN CM): 21.2

BASE DIAMETER (IN CM) AND SHAPE OF BASE: 7.0; circular and flat

ESTIMATED VOLUME (IN LITERS): 1.2

DECORATION (INCLUDING MOTIF AND ELEMENTS WHEN APPARENT): The rim panel has alternating engraved semi-circles and nested triangles that are each repeated around the vessel four times. Each semi-circle has an inner cross in circle element, while the nested triangles have two hatched corners and an oval-shaped element at its apex (Figure 26). There are oval and elongated triangular-shaped elements either above or below each nested triangle.

PIGMENT USE AND LOCATION ON

VESSEL: white pigment in the engraved lines

TYPE AND VARIETY [IF KNOWN]: Ripley Engraved, cf. var. Cash

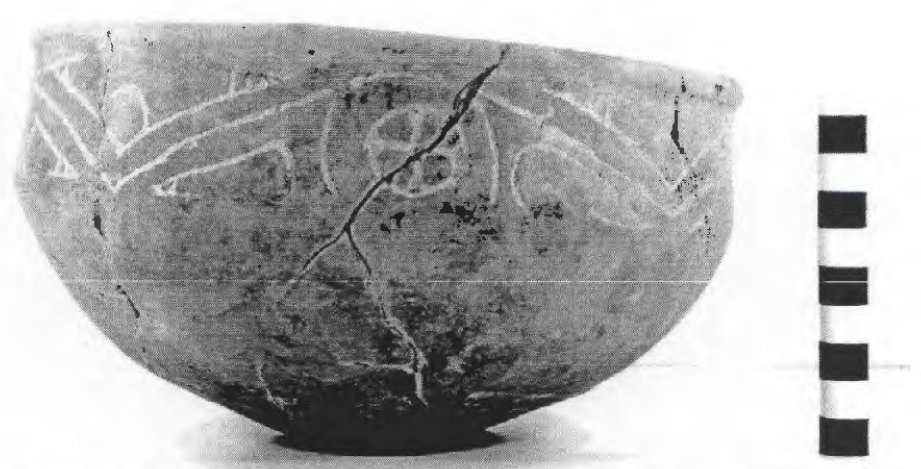

Figure 26. Ripley Engraved, cf. var. Cash carinated bowl, Enis Smith site, Burial 2, Vessel 17. 
VESSEL NO.: Burial 2, Vessel 18; 2003.08.188

NON-PLASTICS AND PASTE: grog; sandy paste

VESSEL FORM: Jar

RIM AND LIP FORM: Everted rim and rounded lip

CORE COLOR: N/A [reconstructed]

INTERIOR SURFACE COLOR: dark grayish-brown

EXTERIOR SURFACE COLOR: N/A; fire clouds on the base

WALL THICKNESS (RIM, BODY, AND BASE IN MM): rim, $7.8 \mathrm{~mm}$

INTERIOR SURFACE TREATMENT: smoothed

EXTERIOR SURFACE TREATMENT: N/A

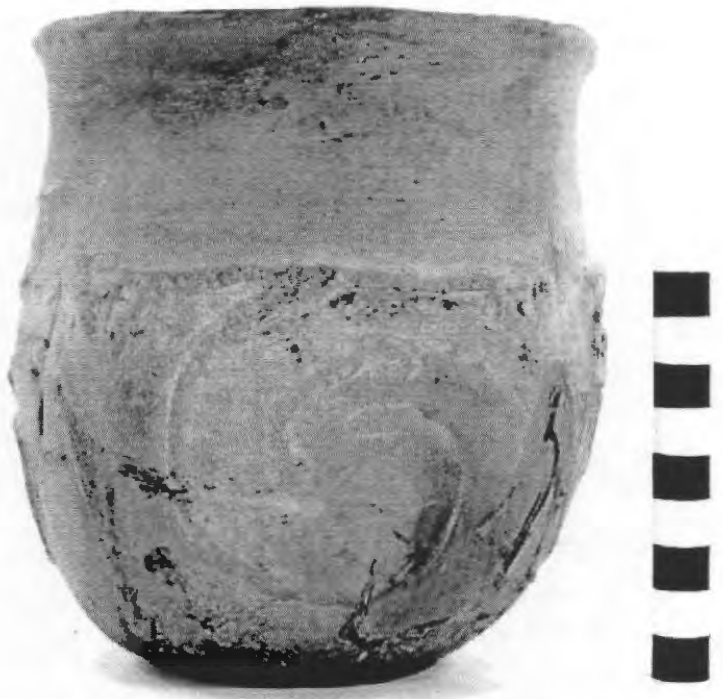

Figure 27. Harleton Appliqued jar, Enis Smith cemetery, Burial 2, Vessel 18.

HEIGHT (IN CM): 15.0

ORIFICE DIAMETER (IN CM): 13.0

DIAMETER AT BOTTOM OF RIM OR NECK (IN CM): 13.4

BASE DIAMETER (IN CM) AND SHAPE OF BASE: 7.5; circular and flat

ESTIMATED VOLUME (IN LITERS): 1.17

DECORATION (INCLUDING MOTIF AND ELEMENTS WHEN APPARENT): The rim has horizontal brushing marks. The vessel body has an appliqued fillet scroll repeated four times around the body; the scrolls end in a hooked arm element. There are four appliqued triangles on the upper body that separate the appliqued fillet scrolls (Figure 27).

PIGMENT USE AND LOCATION ON VESSEL: none

TYPE AND VARIETY [IF KNOWN]: Harleton Appliqued 


\section{Burial 3}

Burial 3 is a few feet northeast of Burial 2. The burial pit was $2.13 \mathrm{~m}$ in length, $1.17 \mathrm{~m}$ in width (Figure 28 ), and $0.83 \mathrm{~m}$ in depth. A number of ceramic vessels were placed as funerary offerings with the deceased, and they are clustered in what would have been the head and upper body areas.

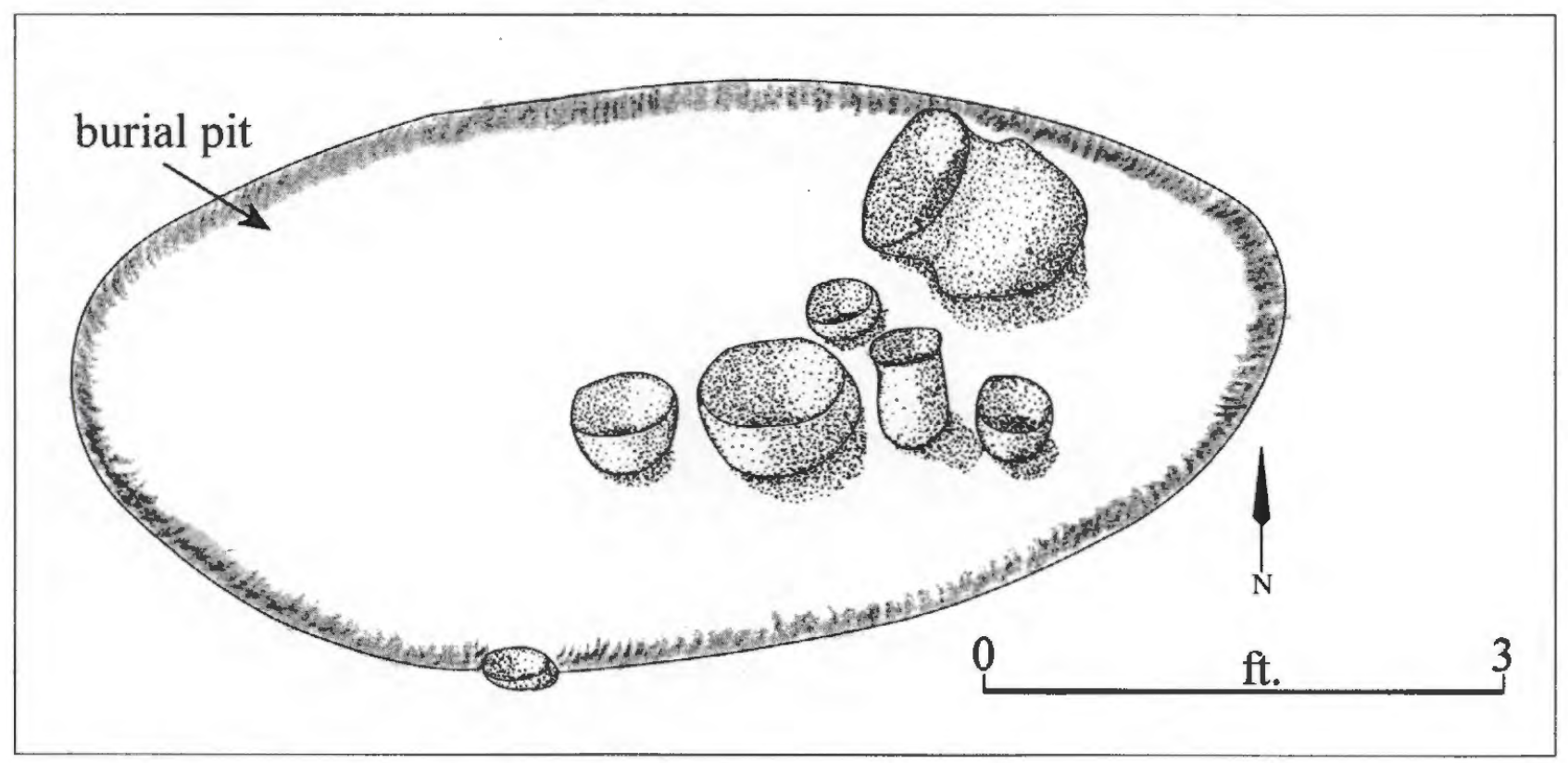

Figure 28. Plan of Burial 3 at the Enis Smith site.

Although the Jones (n.d.) burial drawing only depicted seven ceramic vessels in the grave, there are nine vessels that can be associated with Burial 3 in the collections. These include one Wilder Engraved bottle, two bowls (plain and a Ripley Engraved, var. Gandy), two jars (Cass Appliqued and Harleton Appliqued), one Ripley Engraved, var. Galt compound bowl, and three Taylor Engraved carinated bowls.

VESSEL NO.: Burial 3, Vessel 19; 2003.08.426

NON-PLASTICS AND PASTE: grog

VESSEL FORM: Bowl

RIM AND LIP FORM: Direct rim and a rounded, exterior folded lip

CORE COLOR: B (fired and cooled in a reducing environment)

INTERIOR SURFACE COLOR: dark grayish-brown

EXTERIOR SURFACE COLOR: dark grayish-brown; resin-like organic residue on the body 
WALL THICKNESS (RIM, BODY, AND BASE IN MM): rim, 5.2 mm

INTERIOR SURFACE TREATMENT: smoothed

EXTERIOR SURFACE TREATMENT: smoothed

HEIGHT (IN CM): 9.4

ORIFICE DIAMETER (IN CM): I8.3

DIAMETER AT BOTTOM OF RIM OR NECK (IN CM): N/A

BASE DIAMETER (IN CM) AND SHAPE OF BASE: 6.0; circular and rounded

ESTIMATED VOLUME (IN LITERS): 0.69

DECORATION (INCLUDING MOTIF AND ELEMENTS WHEN APPARENT): Plain (Figure 29)

PIGMENT USE AND LOCATION ON VESSEL: none

TYPE AND VARIETY [IF KNOWN]: Unidentified plain ware

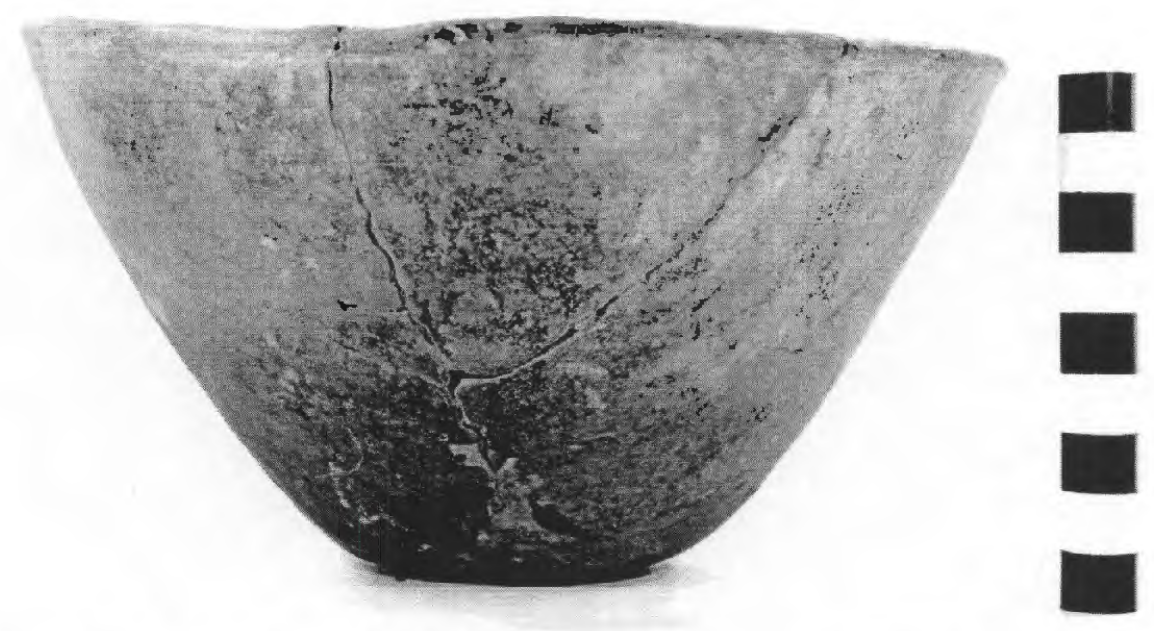

Figure 29. Plain bowl, Enis Smith cemetery, Burial 3, Vessel 19. 
VESSEL NO.: Burial 3, Vessel 20; 2003.08.61

NON-PLASTICS AND PASTE: grog

VESSEL FORM: Carinated bowl

RIM AND LIP FORM: Inverted rim and a rounded, exterior folded lip (Figure 30)

CORE COLOR: B (fired and cooled in a reducing environment)

INTERIOR SURFACE COLOR: dark grayish-brown

EXTERIOR SURFACE COLOR: dark grayish-brown; resin-like organic residue on the rim and body

WALL THICKNESS (RIM, BODY, AND BASE IN MM): rim, 6.6 mm

INTERIOR SURFACE TREATMENT: smoothed

EXTERIOR SURFACE TREATMENT:

smoothed

HEIGHT (IN CM): 6.4

ORIFICE DIAMETER (IN CM): 15.2

DIAMETER AT BOTTOM OF RIM OR

NECK (IN CM): I6.2

BASE DIAMETER (IN CM) AND SHAPE

OF BASE: 5.7 ; circular and rounded

ESTIMATED VOLUME (IN LITERS): 0.58

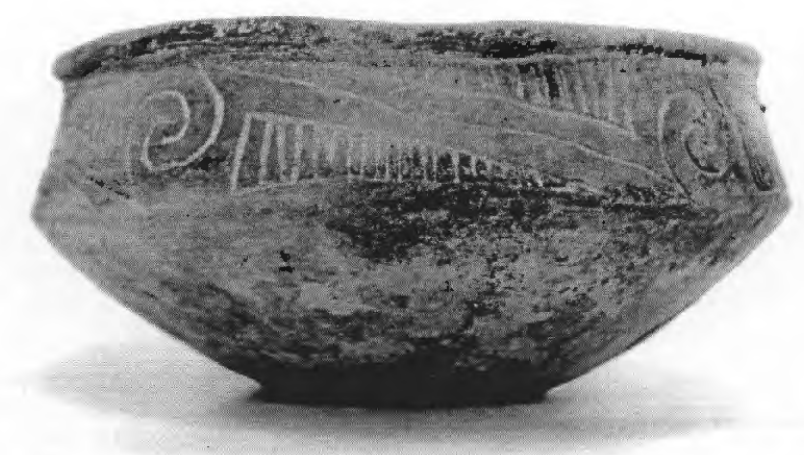

Figure 30. Taylor Engraved carinated bowl, Enis Smith cemetery, Burial 3, Vessel 20.

DECORATION (INCLUDING MOTIF AND ELEMENTS WHEN APPARENT): The rim panel has an engraved slanted scroll motif repeated four times around the vessel that ends in a hooked arm element. The upper and lower scroll fill zones are vertical hatched lines (Figure 30).

PIGMENT USE AND LOCATION ON VESSEL: white pigment in the engraved lines TYPE AND VARIETY [IF KNOWN]: Taylor Engraved 
VESSEL NO.: Burial 3, Vessel 21; 2003.08.419

NON-PLASTICS AND PASTE: grog and bone

VESSEL FORM: Bottle

RIM AND LIP FORM: Direct rim and a flat, exterior folded lip

CORE COLOR: N/A

INTERIOR SURFACE COLOR: N/A

EXTERIOR SURFACE COLOR: yellowish-brown (on the bottle neck) to dark grayish-brown

WALL THICKNESS (RIM, BODY, AND BASE IN MM): N/A

INTERIOR SURFACE TREATMENT: none

EXTERIOR SURFACE TREATMENT: smoothed

HEIGHT (IN CM): 18.0

ORIFICE DIAMETER (IN CM): 3.9

DIAMETER AT BOTTOM OF RIM OR NECK (IN CM): 4.4; maximum body diameter of $13.7 \mathrm{~cm}$

BASE DIAMETER (IN CM) AND SHAPE OF BASE: 7.5; circular and flat

ESTIMATED VOLUME (IN LITERS): 0.54

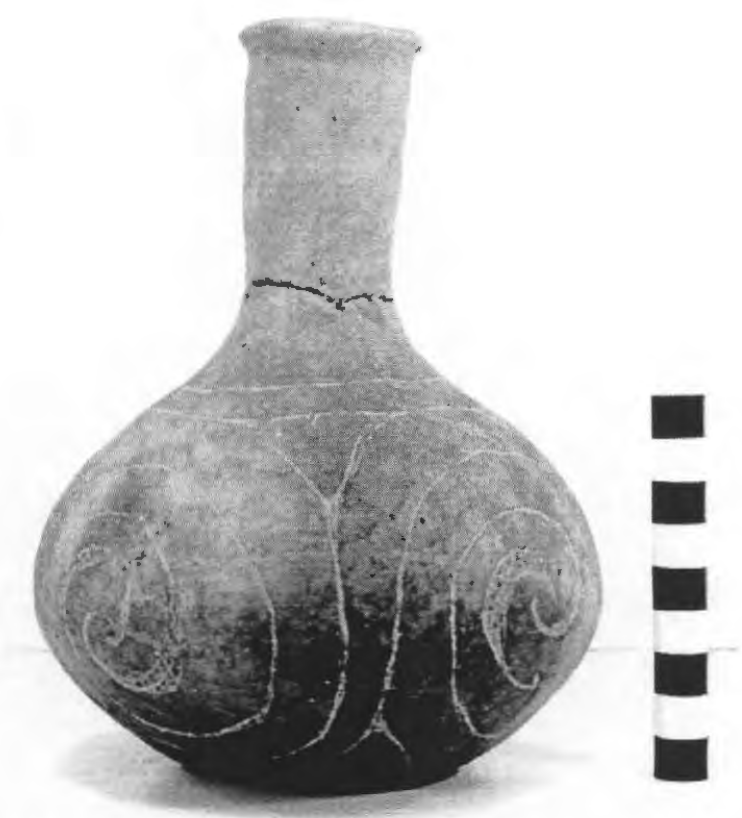

Figure 31. Wilder Engraved, var. unspecified bottle, Enis Smith cemetery, Burial 3, Vessel 21.

DECORATION (INCLUDING MOTIF AND ELEMENTS WHEN APPARENT): The upper vessel body has two widely-spaced horizontal engraved lines above a scroll motif that is repeated four times around the vessel. The scrolls have upper and lower arms that encircle each other, and end in hooked arms. As the two arms of the scroll pass the hooked arm area, the scrolls are widened with cross-hatching. The arms of the scrolls originate from the apex of upper and lower triangles (Figure 31). These triangles have excised corners, and the upper triangles have single inner tick marks or small excised pendant triangles.

PIGMENT USE AND LOCATION ON VESSEL: none

TYPE AND VARIETY [IF KNOWN]: Wilder Engraved, var. unspecified 
VESSEL NO.: Burial 3, Vessel 22; 2003.08.94

NON-PLASTICS AND PASTE: bone and grog

VESSEL FORM: Jar with short rim (Figure 32)

RIM AND LIP FORM: Everted rim and a rounded, exterior folded lip

CORE COLOR: $\mathrm{G}$ (fired in a reducing environment and cooled in the open air)

INTERIOR SURFACE COLOR: grayish-brown; fire clouds on the rim

EXTERIOR SURFACE COLOR: light grayish-brown; fire clouds on the rim and body

WALL THICKNESS (RIM, BODY, AND BASE IN

MM): body, $7.2 \mathrm{~mm}$

INTERIOR SURFACE TREATMENT: smoothed

EXTERIOR SURFACE TREATMENT: none

HEIGHT (IN CM): 5.3

ORIFICE DIAMETER (IN CM): 7.5

DIAMETER AT BOTTOM OF RIM OR NECK (IN CM): 7.4

BASE DIAMETER (IN CM) AND SHAPE OF BASE:

5.2; circular and flat

ESTIMATED VOLUME (IN LITERS): 0.24

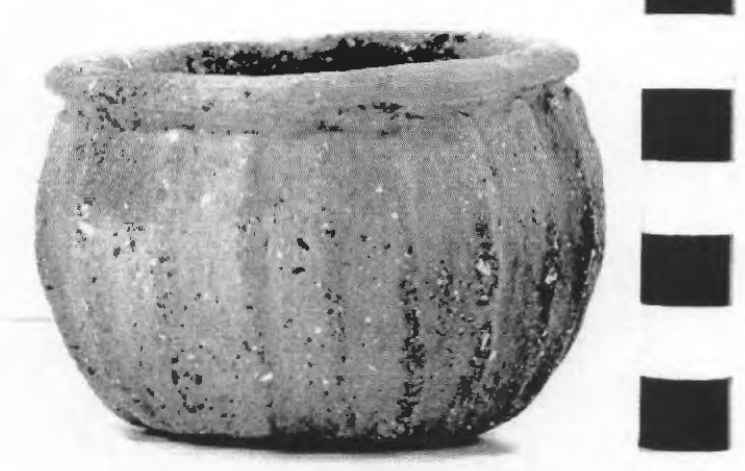

Figure 32. Cass Appliqued jar, Enis Smith cemetery, Burial 3, Vessel 22.

DECORATION (INCLUDING MOTIF AND ELEMENTS WHEN APPARENT): The rim and body of the vessel have 18 vertical appliqued fillets that extend to the vessel base. There are faint vertical brushing marks between each of the appliqued fillets (Figure 32).

PIGMENT USE AND LOCATION ON VESSEL: none

TYPE AND VARIETY [IF KNOWN]: Cass Appliqued 
VESSEL NO.: Burial 3, Vessel 23; 2003.08.565

NON-PLASTICS AND PASTE: grog

VESSEL FORM: Carinated bowl

RIM AND LIP FORM: Direct rim and a rounded, exterior folded lip

CORE COLOR: $\mathrm{F}$ (fired in a reducing environment and cooled in the open air)

INTERIOR SURFACE COLOR: reddish-brown; fire cloud on the base

EXTERIOR SURFACE COLOR: reddish-brown; fire clouds on the body and base

WALL THICKNESS (RIM, BODY, AND BASE IN MM): rim, $7.0 \mathrm{~mm}$

INTERIOR SURFACE TREATMENT: smoothed

EXTERIOR SURFACE TREATMENT: smoothed

HEIGHT (IN CM): 12.7

ORIFICE DIAMETER (IN CM): 27.0

DIAMETER AT BOTTOM OF RIM OR NECK (IN CM): 24.5

BASE DIAMETER (IN CM) AND SHAPE OF

BASE: 8.5 ; circular and flat

ESTIMATED VOLUME (IN LITERS): 2.1

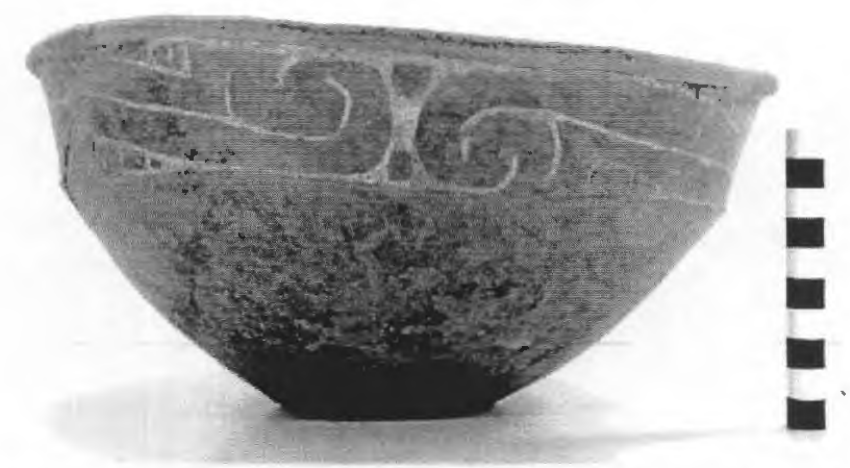

Figure 33. Ripley Engraved, cf. var. Gandy carinated bowl, Enis Smith cemetery, Burial 3, Vessel 23.

DECORATION (INCLUDING MOTIF AND ELEMENTS WHEN APPARENT): The rim panel has an engraved scroll motif repeated four times around the vessel; each scroll ends in upper and lower hooked arms. The scrolls are divided by excised brackets with two negative oval elements. The upper and lower scroll fill zones include excised triangles and brackets as well as a negative oval with a single central excised dot (Figure 33).

PIGMENT USE AND LOCATION ON VESSEL: white pigment in the engraved lines TYPE AND VARIETY [IF KNOWN]: Ripley Engraved, cf. var. Gandy 
VESSEL NO.: Burial 3, Vessel 24; 2003.08.795

NON-PLASTICS AND PASTE: grog

VESSEL FORM: Compound bowl

RIM AND LIP FORM: Everted rim and a rounded lip

CORE COLOR: $\mathrm{F}$ (fired in a reducing environment and cooled in the open air)

INTERIOR SURFACE COLOR: yellowish-brown

EXTERIOR SURFACE COLOR: yellowish-brown; fire clouds on the rim and body

WALL THICKNESS (RIM, BODY, AND BASE IN $\mathrm{MM})$ : rim, $8.3 \mathrm{~mm}$

INTERIOR SURFACE TREATMENT: smoothed

EXTERIOR SURFACE TREATMENT: smoothed

HEIGHT (IN CM): 27.8

ORIFICE DIAMETER (IN CM): 28.2

DIAMETER AT BOTTOM OF RIM OR NECK (IN CM): 28.5

BASE DIAMETER (IN CM) AND SHAPE OF

BASE: 10.0; circular and flat

ESTIMATED VOLUME (IN LITERS): 6.3

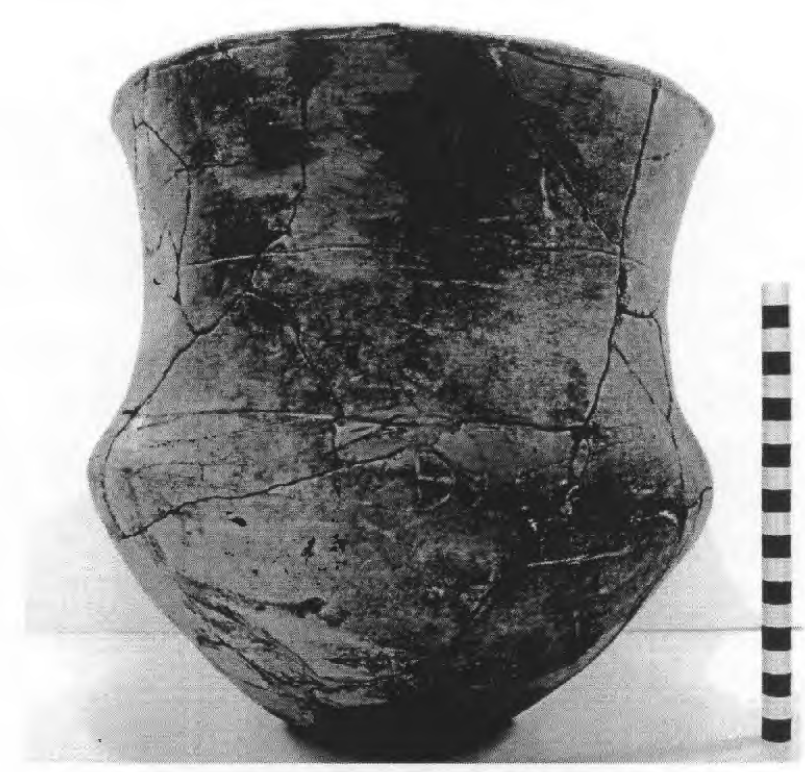

Figure 34. Ripley Engraved, var. Galt compound bowl, Enis Smith cemetery, Burial 3, Vessel 24.

DECORATION (INCLUDING MOTIF AND ELEMENTS WHEN APPARENT): The upper rim panel has three widely-spaced horizontal engraved lines. The lower rim panel has an engraved scroll and circle motif repeated four times around the vessel. Each circle has a smaller inner cross in circle element (Figure 34). The upper and lower scroll fill zones have vertical and curvilinear engraved lines.

PIGMENT USE AND LOCATION ON VESSEL: red pigment in the engraved lines TYPE AND VARIETY [IF KNOWN]: Ripley Engraved, var. Galt 
VESSEL NO.: Burial 3, Vessel 25; 2003.08.465

NON-PLASTICS AND PASTE: grog

VESSEL FORM: Jar

RIM AND LIP FORM: Everted rim and a rounded, exterior folded lip

CORE COLOR: $\mathrm{G}$ (fired in a reducing environment and cooled in the open air)

INTERIOR SURFACE COLOR: grayish-brown; fire clouds on the rim and base

EXTERIOR SURFACE COLOR: yellowish-brown; fire clouds on the rim and base; organic residue on the rim and base

WALL THICKNESS (RIM, BODY, AND BASE IN MM): rim, $6.1 \mathrm{~mm}$

INTERIOR SURFACE TREATMENT: smoothed

EXTERIOR SURFACE TREATMENT: smoothed

HEIGHT (IN CM): 16.9

ORIFICE DIAMETER (IN CM): 16.1

DIAMETER AT BOTTOM OF RIM OR NECK (IN CM): 13.6

BASE DIAMETER (IN CM) AND SHAPE OF BASE: 8.5 ; circular and flat

ESTIMATED VOLUME (IN LITERS): 2.45

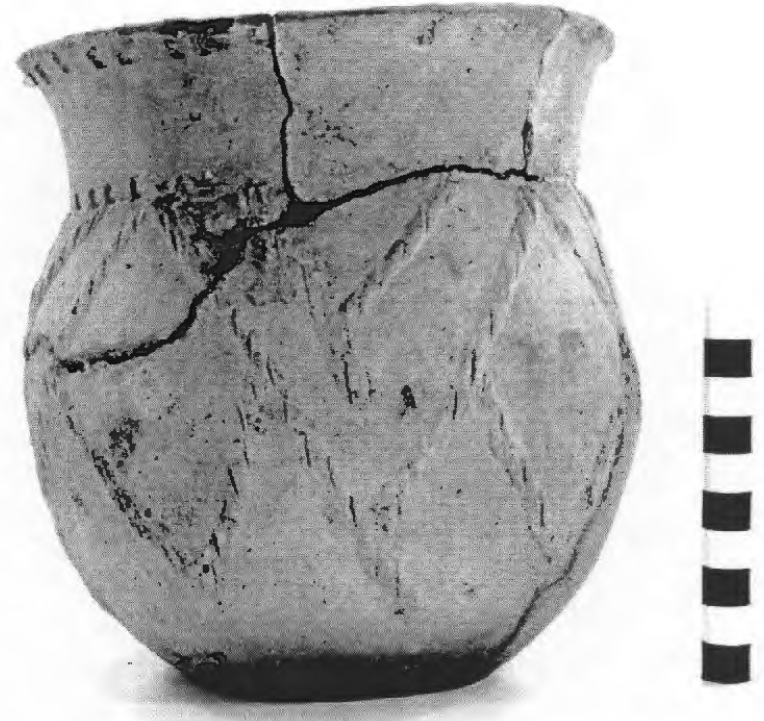

Figure 35. Harleton Appliqued jar, Enis Smith cemetery, Burial 3, Vessel 25.

DECORATION (INCLUDING MOTIF AND ELEMENTS WHEN APPARENT): The rim has two horizontal rows of tool punctates, one below the lip and the other at the rim-body juncture. The vessel body has an appliqued fillet diamond motif repeated four times around the body. Each diamond has a large appliqued node at its center, and the diamonds are connected by diagonal opposed appliqued fillets (Figure 35). The diamond elements are separated by appliqued fillet triangles.

PIGMENT USE AND LOCATION ON VESSEL: none

TYPE AND VARIETY [IF KNOWN]: Harleton Appliqued 
VESSEL NO.: Burial 3, Vessel 26; 2003.08.483

NON-PLASTICS AND PASTE: grog

VESSEL FORM: Miniature deep bowl (Figure 36)

RIM AND LIP FORM: Direct rim and rounded lip

CORE COLOR: B (fired and cooled in a reducing environment)

INTERIOR SURFACE COLOR: dark grayish-brown

EXTERIOR SURFACE COLOR: dark grayish-brown

WALL THICKNESS (RIM, BODY, AND BASE IN MM): rim, $5.6 \mathrm{~mm}$

INTERIOR SURFACE TREATMENT: smoothed

EXTERIOR SURFACE TREATMENT: smoothed

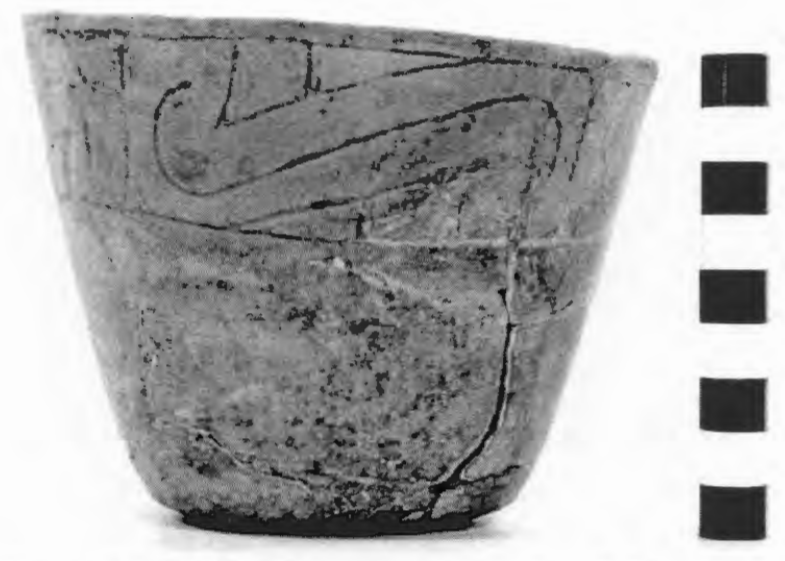

Figure 36. Ripley Engraved, var. Gandy bowl, Enis Smith cemetery, Burial 3, Vessel 26.

HEIGHT (IN CM): 9.7

ORIFICE DIAMETER (IN CM): 12.4

DIAMETER AT BOTTOM OF RIM OR NECK (IN CM): N/A

BASE DIAMETER (IN CM) AND SHAPE OF BASE: 6.9; circular and flat

ESTIMATED VOLUME (IN LITERS): 0.96

DECORATION (INCLUDING MOTIF AND ELEMENTS WHEN APPARENT): The rim panel has an engraved scroll motif repeated four times around the vessel. The scrolls are divided by hatched and excised vertical brackets. The upper and lower scroll fill zones have curvilinear and vertical engraved lines (Figure 36).

PIGMENT USE AND LOCATION ON VESSEL: none

TYPE AND VARIETY [IF KNOWN]: Ripley Engraved, var. Gandy 
VESSEL NO.: Burial 3, Vessel 27; 2003.08.727

NON-PLASTICS AND PASTE: grog

VESSEL FORM: Carinated bowl

RIM AND LIP FORM: Direct rim and rounded, exterior folded lip

CORE COLOR: $\mathrm{G}$ (fired in a reducing environment and cooled in the open air)

INTERIOR SURFACE COLOR: grayish-brown; fire clouds on the body and base

EXTERIOR SURFACE COLOR: reddish-brown; fire cloud on the base

WALL THICKNESS (RIM, BODY, AND BASE IN MM): rim, $6.6 \mathrm{~mm}$

INTERIOR SURFACE TREATMENT: smoothed

EXTERIOR SURFACE TREATMENT: smoothed

HEIGHT (IN CM): 10.4

ORIFICE DIAMETER (IN CM): 24.2

DIAMETER AT BOTTOM OF RIM OR NECK

(IN CM): 22.8

BASE DIAMETER (IN CM) AND SHAPE OF BASE: 8.1 ; circular and flat

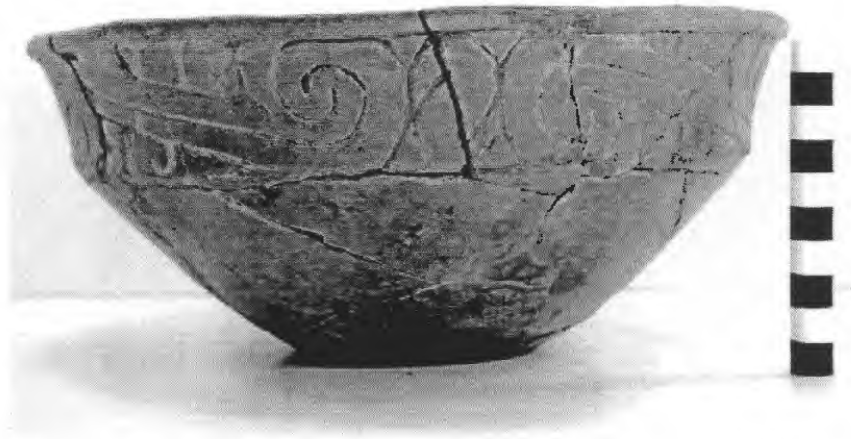

Figure 37. Taylor Engraved carinated bowl, Enis Smith cemetery, Burial 3, Vessel 27.

ESTIMATED VOLUME (IN LITERS): 1.51

DECORATION (INCLUDING MOTIF AND ELEMENTS WHEN APPARENT): The rim panel has an engraved slanted scroll motif, repeated four times around the vessel, that ends in upper and lower hooked arm elements. The scrolls are divided by either vertical brackets with inner spur-like projections or by two sets of vertical engraved lines that originate in upper and lower open triangles (Figure 37). The scroll fill zones have vertical and curvilinear engraved lines.

PIGMENT USE AND LOCATION ON VESSEL: red pigment in the engraved lines TYPE AND VARIETY [IF KNOWN]: Taylor Engraved 


\section{Burial 4}

The only information available concerning Burial 4 at the Enis Smith is its location on the cemetery map (see Figure 8). Burial 4 is the northernmost burial in the southern cluster of 11 burials. There are three ceramic vessels in the collections from Burial 4: two Taylor Engraved carinated bowls and one Womack Engraved, var. Gum Creek carinated bowl.

VESSEL NO.: Burial 4, Vessel 28; 2003.08.323

NON-PLASTICS AND PASTE: grog

VESSEL FORM: Carinated bowl

RIM AND LIP FORM: Direct rim and rounded lip

CORE COLOR: $\mathrm{F}$ (fired in a reducing environment and cooled in the open air)

INTERIOR SURFACE COLOR: dark yellowish-brown; fire clouds on the rim

EXTERIOR SURFACE COLOR: dark yellowish-brown; fire clouds on the rim, body, and base

WALL THICKNESS (RIM, BODY, AND BASE IN MM): rim, 9.4 mm

INTERIOR SURFACE TREATMENT: smoothed

EXTERIOR SURFACE TREATMENT: burnished

HEIGHT (IN CM): 10.0

ORIFICE DIAMETER (IN CM): 22.4

DIAMETER AT BOTTOM OF RIM OR NECK (IN

CM): 20.6

BASE DIAMETER (IN CM) AND SHAPE OF

BASE: 7.9; circular and flat

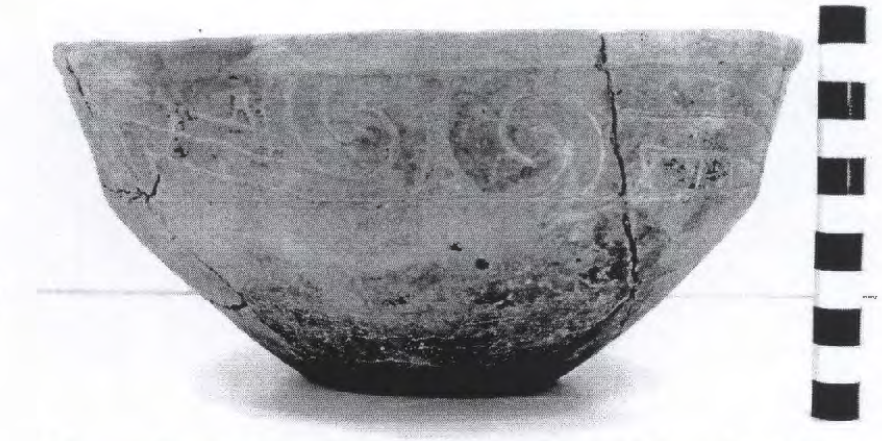

Figure 38. Taylor Engraved carinated bowl, Enis Smith cemetery, Burial 4, Vessel 28.

ESTIMATED VOLUME (IN LITERS): 1.34

DECORATION (INCLUDING MOTIF AND ELEMENTS WHEN APPARENT): The rim panel has an engraved slanted scroll motif, repeated four times around the vessel, that ends in upper and lower hooked arm elements. The scrolls are divided by vertical brackets with horizontal hatched or cross-hatched lines along its center (Figure 38). The scroll fill zones have vertical and curvilinear engraved lines, negative ovals, and excised triangles.

PIGMENT USE AND LOCATION ON VESSEL: none

TYPE AND VARIETY [IF KNOWN]: Taylor Engraved 
VESSEL NO.: Burial 4, Vessel 29; 2003.08.0725

NON-PLASTICS AND PASTE: grog; fine sandy paste

VESSEL FORM: Carinated bowl

RIM AND LIP FORM: Direct rim and rounded lip

CORE COLOR: $\mathrm{H}$ (fired in a reducing environment and cooled in the open air)

INTERIOR SURFACE COLOR: yellowish-brown; fire clouds on the rim, body, and base

EXTERIOR SURFACE COLOR: dark grayish-brown

WALL THICKNESS (RIM, BODY, AND BASE IN MM): rim, $8.6 \mathrm{~mm}$

INTERIOR SURFACE TREATMENT: smoothed

EXTERIOR SURFACE TREATMENT: smoothed

HEIGHT (IN CM): I3.0

ORIFICE DIAMETER (IN CM): 26.2

DIAMETER AT BOTTOM OF RIM OR NECK (IN CM): 23.5

BASE DIAMETER (IN CM) AND SHAPE OF BASE: 9.0; circular and flat

ESTIMATED VOLUME (IN LITERS): 2.04

DECORATION (INCLUDING MOTIF AND ELEMENTS WHEN APPARENT): The rim panel has an engraved slanted scroll motif, repeated four times around the vessel, that ends in upper and lower hooked arm elements. The scrolls are divided by vertical brackets with two inner spur-like projections (Figure 39). The scroll fill zones have vertical and curvilinear engraved lines.

PIGMENT USE AND LOCATION ON VESSEL: none

TYPE AND VARIETY [IF KNOWN]: Taylor Engraved

There was also a mass of gray clay pigment (2003.08.1175) inside Vessel 29, Burial 4.

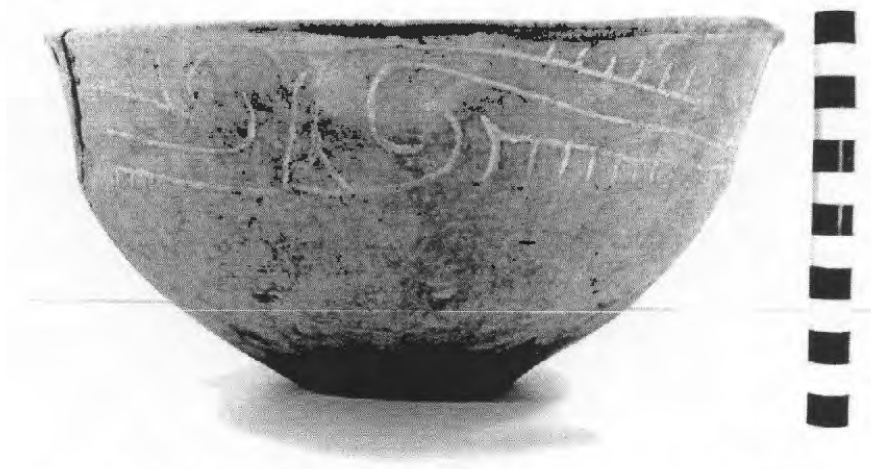

Figure 39. Taylor Engraved carinated bowl, Enis Smith cemetery, Burial 4, Vessel 29. 
VESSEL NO.: Burial 4, Vessel 30; 2003.08.319

NON-PLASTICS AND PASTE: grog

VESSEL FORM: Carinated bowl

RIM AND LIP FORM: Inverted rim and a rounded lip (Figure 40)

CORE COLOR: G (fired in a reducing environment and cooled in the open air)

INTERIOR SURFACE COLOR: grayish-brown

EXTERIOR SURFACE COLOR: yellowish-brown; fire clouds on the rim and body

WALL THICKNESS (RIM, BODY, AND BASE IN MM): rim, $5.6 \mathrm{~mm}$

INTERIOR SURFACE TREATMENT: smoothed

EXTERIOR SURFACE TREATMENT: burnished

HEIGHT (IN CM): 15.6

ORIFICE DIAMETER (IN CM): 25.0

DIAMETER AT BOTTOM OF RIM OR NECK (IN CM): 28.5

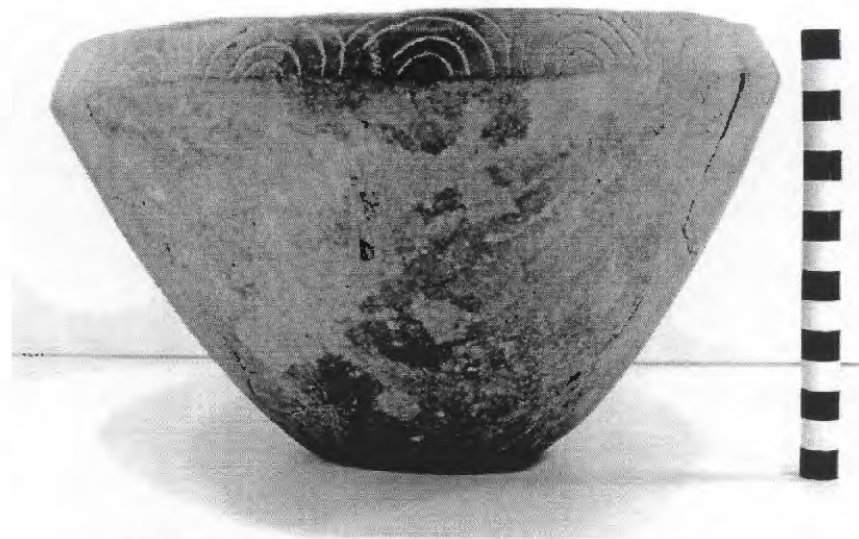

Figure 40. Womack Engraved, var. Gum Creek carinated bowl, Enis Smith cemetery, Burial 4, Vessel 30.

BASE DIAMETER (IN CM) AND SHAPE OF BASE: 8.5; circular and flat

ESTIMATED VOLUME (IN LITERS): 3.51

DECORATION (INCLUDING MOTIF AND ELEMENTS WHEN APPARENT): The rim panel has 18 continuous engraved concentric semi-circles. Each semi-circle consists of four concentric semi-circles, with the smallest semi-circle at the vessel carination (Figure 40).

PIGMENT USE AND LOCATION ON VESSEL: none

TYPE AND VARIETY [IF KNOWN]: Womack Engraved, var. Gum Creek 


\section{Burial 5}

There is no specific information available about Burial 5, except that it was located a few feet east of Burial 3 and a few feet southeast of Burial 4 (see Figure 8). There are seven vessels in the collections from Burial 5 at the Enis Smith site. They include a Bailey Engraved bottle, an engraved-punctated bowl of undetermined type, a Harleton Appliqued jar, and four carinated bowls (one Taylor Engraved and three Ripley Engraved, var. McKinney vessels).

VESSEL NO.: Burial 5, Vessel 31; 2003.08.106

NON-PLASTICS AND PASTE: grog

VESSEL FORM: Bowl

RIM AND LIP FORM: Direct rim and a rounded lip

CORE COLOR: B (fired and cooled in a reducing environment)

INTERIOR SURFACE COLOR: very dark grayish-brown

EXTERIOR SURFACE COLOR: very dark grayish-brown

WALL THICKNESS (RIM, BODY, AND BASE IN MM): rim, $6.6 \mathrm{~mm}$

INTERIOR SURFACE TREATMENT: smoothed

EXTERIOR SURFACE TREATMENT: smoothed

HEIGHT (IN CM): 6.5

ORIFICE DIAMETER (IN CM): 13.1

DIAMETER AT BOTTOM OF RIM OR NECK (IN CM): N/A

BASE DIAMETER (IN CM) AND SHAPE OF BASE: 6.8

ESTIMATED VOLUME (IN LITERS): 0.34

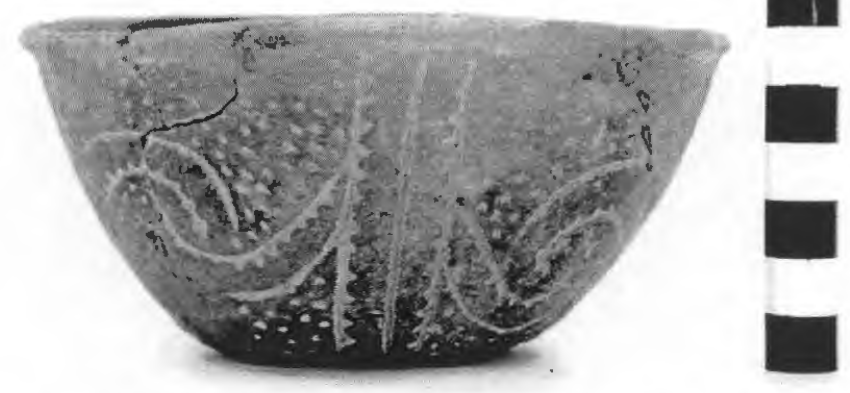

Figure 41. Engraved-punctated bowl, Enis Smith cemetery, Burial 5, Vessel 31.

DECORATION (INCLUDING MOTIF AND ELEMENTS WHEN APPARENT): The vessel has four engraved panels that are divided by vertical columns with inward-pointing tick marks. The panels each have an engraved hook arm element with tick marks and surrounding curvilinear engraved lines. The upper and Iower zones in the panel are filled with small tool punctations (Figure 41).

PIGMENT USE AND LOCATION ON VESSEL: red pigment in engraved lines

TYPEAND VARIETY [IF KNOWN]: Unidentified fine ware, possible unspecified variety of Taylor Engraved 
VESSEL NO:: Burial 5, Vessel 32; 2003.08.427

NON-PLASTICS AND PASTE: grog

VESSEL FORM: Carinated bowl

RIM AND LIP FORM: Inverted rim and a rounded, exterior folded lip (Figure 42)

CORE COLOR: B (fired and cooled in a reducing environment)

INTERIOR SURFACE COLOR: dark grayish-brown

EXTERIOR SURFACE COLOR: dark grayish-brown; fire clouds on the body; organic residue on the rim and body

WALL THICKNESS (RIM, BODY, AND BASE IN MM): rim, 6.7 mm

INTERIOR SURFACE TREATMENT: smoothed on the rim

EXTERIOR SURFACE TREATMENT: smoothed

HEIGHT (IN CM): 10.0

ORIFICE DIAMETER (IN CM): 15.0

DIAMETER AT BOTTOM OF RIM OR NECK (IN CM): 14.8

BASE DIAMETER (IN CM) AND SHAPE OF

BASE: 7.0; circular and rounded

ESTIMATED VOLUME (IN LITERS): 0.90

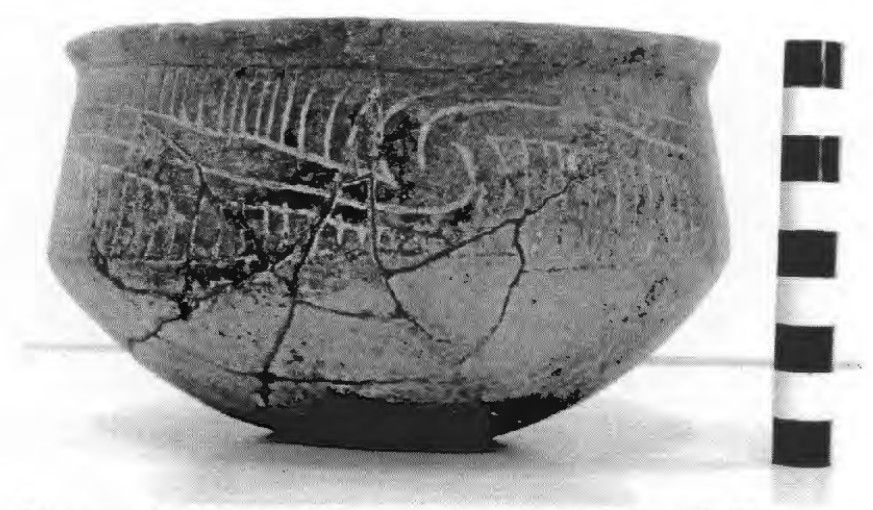

Figure 42. Taylor Engraved carinated bowl, Enis Smith cemetery, Burial 5, Vessel 32.

DECORATION (INCLUDING MOTIF AND ELEMENTS WHEN APPARENT): The rim paneI has an engraved slanted scroll motif that is repeated four times around the vessel. Each scroll ends in a hooked arm element. The upper and lower scroll fill zones are continuous around the vessel, and have vertical to curvilinear engraved lines (Figure 42).

PIGMENT USE AND LOCATION ON VESSEL: none

TYPE AND VARIETY [IF KNOWN]: Taylor Engraved 
VESSEL NO.: Burial 5, Vessel 33; 2003.08.418

NON-PLASTICS AND PASTE: grog, bone, and hematite

VESSEL FORM: Bottle with a short neck

RIM AND LIP FORM: Direct rim and a rounded lip

CORE COLOR: G (fired in a reducing environment and cooled in the open air)

INTERIOR SURFACE COLOR: dark grayish-brown

EXTERIOR SURFACE COLOR: reddish-brown; fire clouds on the neck, body, and base

WALL THICKNESS (RIM, BODY, AND BASE IN $\mathrm{MM}$ ): rim, $7.6 \mathrm{~mm}$

INTERIOR SURFACE TREATMENT: none

EXTERIOR SURFACE TREATMENT: smoothed

HEIGHT (IN CM): 16.2

ORIFICE DIAMETER (IN CM): 4.5

DIAMETER AT BOTTOM OF RIM OR NECK (IN

$\mathrm{CM}$ ): 5.3 ; maximum body diameter of $13.7 \mathrm{~cm}$

BASE DIAMETER (IN CM) AND SHAPE OF BASE: 7.0; circular and rounded

ESTIMATED VOLUME (IN LITERS): 0.45

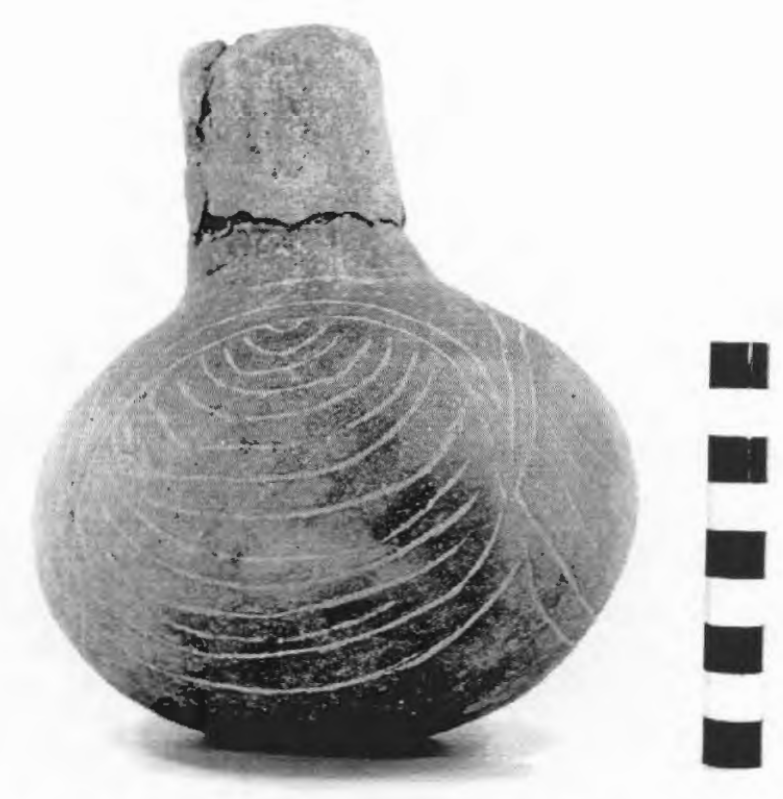

Figure 43. Bailey Engraved bottle, Enis Smith cemetery, Burial 5, Vessel 33.

DECORATION (INCLUDING MOTIF AND ELEMENTS WHEN APPARENT): The vessel body is divided into four conjoined panels with 11 sets of concentric engraved arcs. Above the engraved arcs, and below the base of the bottle neck, is a continuous engraved zone filled with small tool punctations (Figure 43).

PIGMENT USE AND LOCATION ON VESSEL: none

TYPE AND VARIETY [IF KNOWN]: Bailey Engraved 
VESSEL NO.: Burial 5, Vessel 34; 2003.08.715

NON-PLASTICS AND PASTE: grog

VESSEL FORM: Carinated bowl

RIM AND LIP FORM: Direct rim and rounded lip

CORE COLOR: $\mathrm{F}$ (fired in a reducing environment and cooled in the open air)

INTERIOR SURFACE COLOR: strong brown; fire clouds on the rim

EXTERIOR SURFACE COLOR: strong brown; fire clouds on the rim, body, and base

WALL THICKNESS (RIM, BODY, AND BASE IN MM): rim, $8.9 \mathrm{~mm}$

INTERIOR SURFACE TREATMENT: smoothed

EXTERIOR SURFACE TREATMENT:

smoothed

HEIGHT (IN CM): 11.5

ORIFICE DIAMETER (IN CM): 27.7

DIAMETER AT BOTTOM OF RIM OR NECK (IN CM): 25.3

BASE DIAMETER (IN CM) AND SHAPE OF BASE: 9.0 ; flat and circular

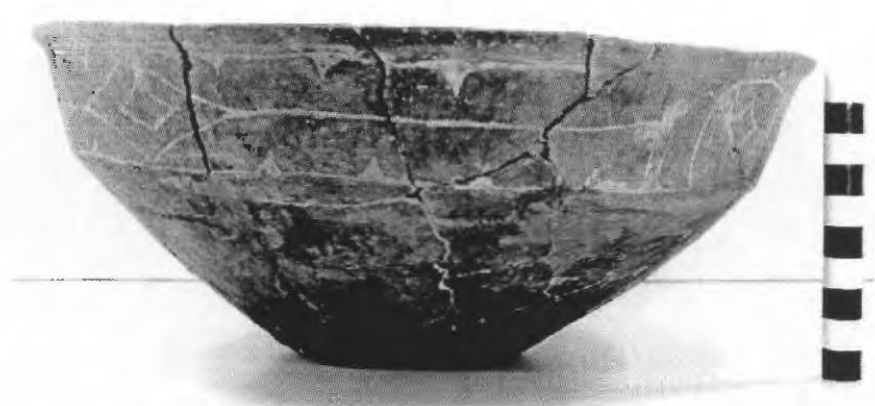

Figure 44. Ripley Engraved, var. McKinney carinated bowl, Enis Smith cemetery, Burial 5, Vessel 34.

ESTIMATED VOLUME (IN LITERS): 1.91

DECORATION (INCLUDING MOTIF AND ELEMENTS WHEN APPARENT): The rim panel has engraved central circle and nested diamond elements that alternate twice around the vessel. The central circle has a small inner diamond, as does the nested diamond element. The nested diamond is the central part in short horizontal scrolls, and each scroll ends in upper and lower excised brackets (Figure 44). Above and below each of the scrolls are small excised pendant triangles.

PIGMENT USE AND LOCATION ON VESSEL: white pigment in the engraved lines

TYPE AND VARIETY [IF KNOWN]: Ripley Engraved, var. McKinney 
VESSEL NO.: Burial 5, Vessel 35; 2003.08.1753

NON-PLASTICS AND PASTE: grog and hematite

VESSEL FORM: Jar with four rim peaks (Figure 45)

RIM AND LIP FORM: Everted rim and rounded lip

CORE COLOR: G (fired in a reducing environment and cooled in the open air)

INTERIOR SURFACE COLOR: dark grayish-brown

EXTERIOR SURFACE COLOR: yellowish-brown; fire clouds on the rim, body, and base

WALL THICKNESS (RIM, BODY, AND BASE IN MM): rim, $8.4 \mathrm{~mm}$

INTERIOR SURFACE TREATMENT: smoothed on the rim

EXTERIOR SURFACE TREATMENT: none

HEIGHT (IN CM): 14.4

ORIFICE DIAMETER (IN CM): 15.1

DIAMETER AT BOTTOM OF RIM OR NECK (IN CM): 12.2

BASE DIAMETER (IN CM) AND SHAPE OF BASE: 7.1

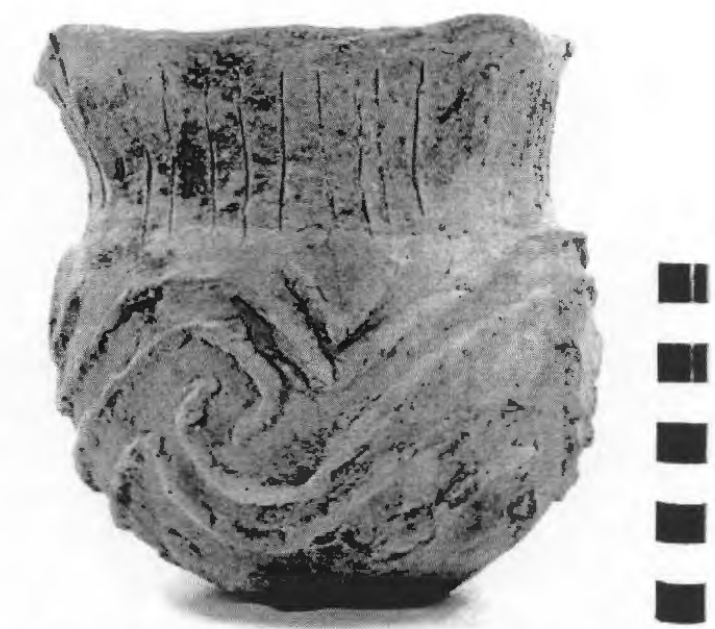

Figure 45. Harleton Appliqued jar, Enis Smith cemetery, Burial 5, Vessel 35.

ESTIMATED VOLUME (IN LITERS): 1.30

DECORATION (INCLUDING MOTIF AND ELEMENTS WHEN APPARENT): The rim is decorated with vertical incised lines, except under the rim peaks, where there are four vertical appliqued ridges under each peak. The vessel body has an appliqued ridge scroll and hooked arm motif repeated four times around the vessel. There are upper and lower V-shaped appliqued elements on either side of the appliqued scrolls (Figure 45).

PIGMENT USE AND LOCATION ON VESSEL: none

TYPE AND VARIETY [IF KNOWN]: Harleton Appliqued 
VESSEL NO.: Burial 5, Vessel 36; 2003.08.219

NON-PLASTICS AND PASTE: grog

VESSEL FORM: Carinated bowl

RIM AND LIP FORM: Direct rim and rounded lip

CORE COLOR: $F$ (fired in a reducing environment and cooled in the open air)

INTERIOR SURFACE COLOR: yellowish-brown; fire clouds on the body and base

EXTERIOR SURFACE COLOR: yellowish-brown; fire clouds on the body and base

WALL THICKNESS (RIM, BODY, AND BASE IN

MM): rim, $5.4 \mathrm{~mm}$

INTERIOR SURFACE TREATMENT: smoothed

EXTERIOR SURFACE TREATMENT: smoothed

HEIGHT (IN CM): 5.3

ORIFICE DIAMETER (IN CM): 13.8

DIAMETER AT BOTTOM OF RIM OR NECK (IN CM): 12.5

BASE DIAMETER (IN CM) AND SHAPE OF BASE: 5.4; circular and rounded

ESTIMATED VOLUME (IN LITERS): 0.44

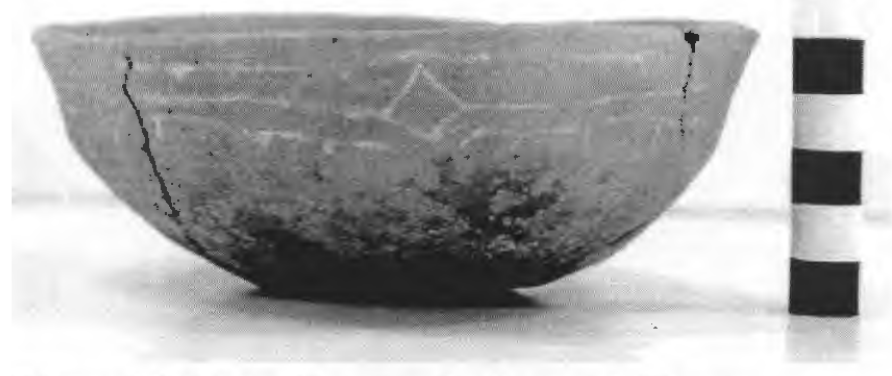

Figure 46. Ripley Engraved, cf. var. McKinney carinated bowl, Enis Smith cemetery, Burial 5, VesseI 36.

DECORATION (INCLUDING MOTIF AND ELEMENTS WHEN APPARENT): The rim panel has an engraved motif that features alternating nested diamonds (twice) and circle within circle (twice) elements. The nested diamond element is the central feature in a series of four separate curvilinear scrolls. Above the scrolls are small excised pendant triangles, while below the scrolls are curvilinear engraved lines with excised pendant triangles (Figure 46).

PIGMENT USEAND LOCATION ON VESSEL: white pigment in engraved lines

TYPE AND VARIETY [IF KNOWN]: Ripley Engraved, cf. var. McKinney 
VESSEL NO.: Burial 5, Vessel 37; 2003.08.568

NON-PLASTICS AND PASTE: grog, bone, and organics

VESSEL FORM: Carinated bowl

RIM AND LIP FORM: Direct rim and rounded lip

CORE COLOR: $\mathrm{G}$ (fired in a reducing environment and cooled in the open air)

INTERIOR SURFACE COLOR: dark grayish-brown; resin-like organic residue on the rim

EXTERIOR SURFACE COLOR: dark reddish-brown; thick organic residue on the rim and body (Figure 47)

WALL THICKNESS (RIM, BODY, AND BASE IN MM): rim, $7.6 \mathrm{~mm}$

INTERIOR SURFACE TREATMENT: smoothed

EXTERIOR SURFACE TREATMENT: burnished

HEIGHT (IN CM): 11.4

ORIFICE DIAMETER (IN CM): 22.2

DIAMETER AT BOTTOM OF RIM OR NECK (IN CM): 18.8

\section{BASE DIAMETER (IN CM) AND SHAPE OF}

BASE: 8.8; flat and circular

ESTIMATED VOLUME (IN LITERS): 1.52

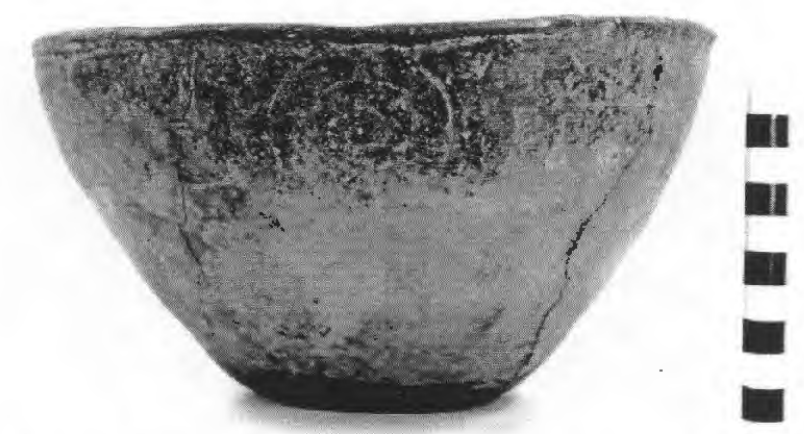

Figure 47. Ripley Engraved, var. McKinney carinated bowl, Enis Smith cemetery, Burial 5, Vessel 37.

DECORATION (INCLUDING MOTIF AND ELEMENTS WHEN APPARENT): The rim panel has a motif repeated four times that features central engraved circles and nested diamonds (Figure 47). The central circles have two inner circles, one of which has excised pendant triangles on it. The nested diamond elements have inner diamonds; the corners of the larger nested diamond have small excised triangles.

The nested diamond element is the central part of a horizontal scroll that has upper and lower excised vertical brackets. There are rows of excised pendant triangles both above and below the horizontal scroll line.

There is also a single horizontal engraved line on the interior vessel surface at the carination.

PIGMENT USE AND LOCATION ON VESSEL: none

TYPE AND VARIETY [IF KNOWN]: Ripley Engraved, var. McKinney 


\section{Burial 6}

Burial 6 is situated in the southern part of the cemetery, a few feet south of Burial 8 (see Figure 8). The burial pit was $2.44 \mathrm{~m}$ in length, $1.22 \mathrm{~m}$ in width (Figure 48), and the depth was $1.05 \mathrm{~m}$.

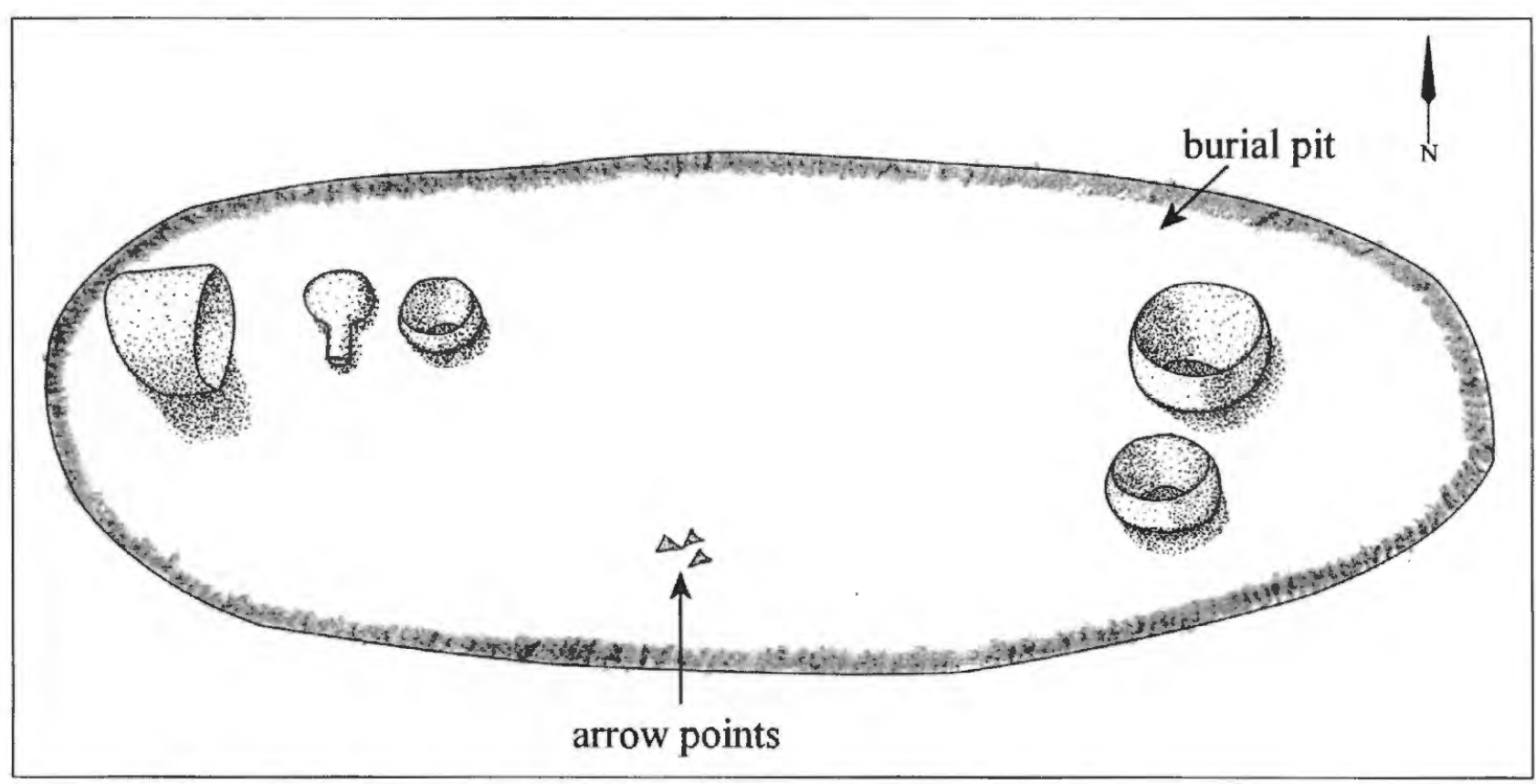

Figure 48. Plan map of Burial 6 at the Enis Smith site.

Associated funerary offerings in the burial include five ceramic vessels and three triangular arrow points. The latter were placed in the area of the left hand, while two vessels (carinated bowls) were by the head area, and the other three vessels (a carinated bowl, bottle, and compound bowl) were by what would have been the right leg and feet (see Figure 48). The vessels are a plain bottle, a Turner Engraved, var. Turner compound bowl, and three carinated bowls: Ripley Engraved, var. unspecified, Ripley Engraved, var. McKinney, and Womack Engraved, var. Gum Creek.

VESSEL NO.: Burial 6, Vessel 38; 2003.08.220

NON-PLASTICS AND PASTE: grog

VESSEL FORM: Carinated bowl

RIM AND LIP FORM: Inverted rim and a rounded lip (Figure 49)

CORE COLOR: $\mathrm{F}$ (fired in a reducing environment and cooled in the open air)

INTERIOR SURFACE COLOR: reddish-brown

EXTERIOR SURFACE COLOR: reddish-brown 
WALL THICKNESS (RIM, BODY, AND BASE IN MM): rim, 7.5 mm

INTERIOR SURFACE TREATMENT: none

EXTERIOR SURFACE TREATMENT: smoothed

HEIGHT (IN CM): 4.8

ORIFICE DIAMETER (IN CM): 9.0

DIAMETER AT BOTTOM OF RIM OR NECK (IN CM): 11.4

BASE DIAMETER (IN CM) AND SHAPE OF BASE: 5.3; circular and rounded

ESTIMATED VOLUME (IN LITERS): 0.26

DECORATION (INCLUDING MOTIF AND ELEMENTS WHEN APPARENT): The rim panel has four rectangular engraved zones with upper and lower large excised pendant triangles. The zones are separated by vertical excised brackets with an inner negative S-shaped element (Figure 49).

PIGMENT USE AND LOCATION ON VESSEL: none

TYPE AND VARIETY [IF KNOWN]: Ripley Engraved, var. unspecified

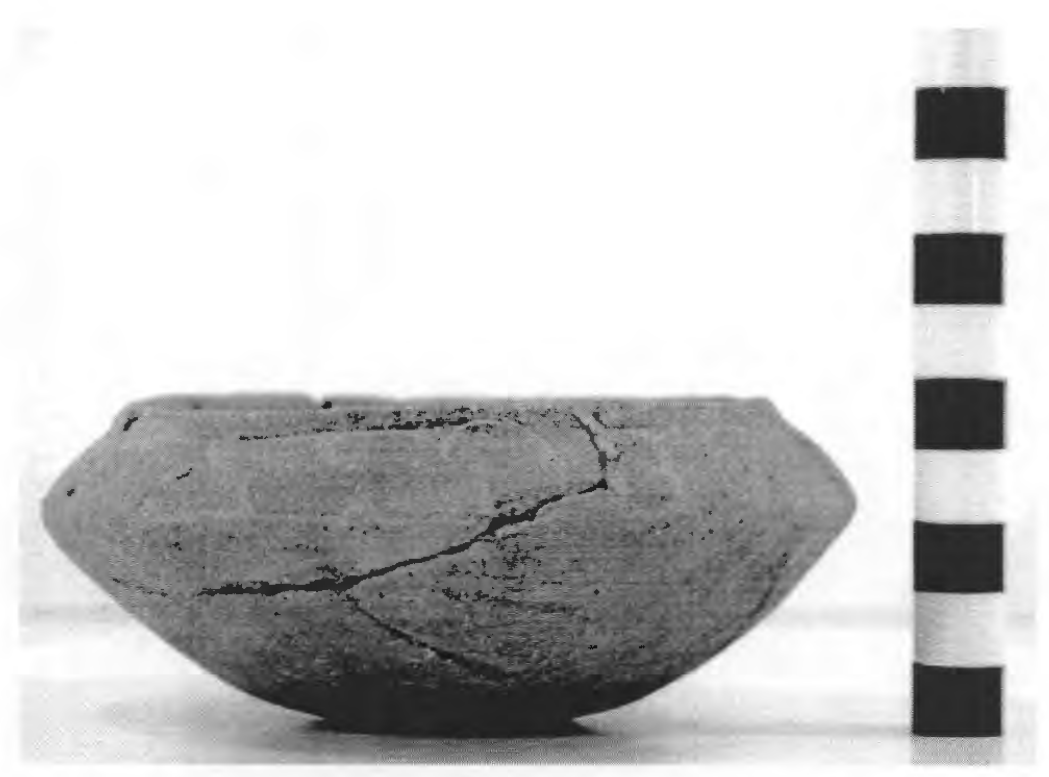

Figure 49. Ripley Engraved, var. unspecified carinated bowl, Enis Smith cemetery, Burial 6, Vessel 38. 
VESSEL NO.: Burial 6, Vessel 39; 2003.08.242

NON-PLASTICS AND PASTE: grog and finely crushed bone

VESSEL FORM: Carinated bowl

RIM AND LIP FORM: Inverted rim and rounded lip (Figure 50)

CORE COLOR: $\mathrm{F}$ (fired in a reducing environment and cooled in the open air)

INTERIOR SURFACE COLOR: yellowish-brown

EXTERIOR SURFACE COLOR: yellowishbrown

WALL THICKNESS (RIM, BODY, AND BASE IN MM): rim, $6.2 \mathrm{~mm}$

INTERIOR SURFACE TREATMENT:

smoothed

EXTERIOR SURFACE TREATMENT:

burnished

HEIGHT (IN CM): 16.5

ORIFICE DIAMETER (IN CM): 24.0

DIAMETER AT BOTTOM OF RIM OR NECK

(IN CM): 24.2

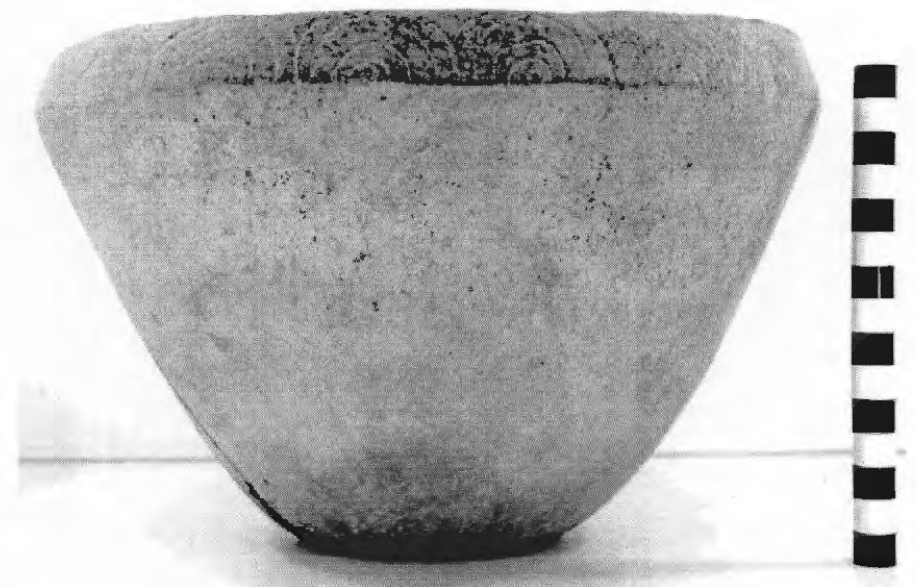

Figure 50. Womack Engraved, var. Gum Creek carinated bowl, Enis Smith cemetery, Burial 6, Vessel 39.

BASE DIAMETER (IN CM) AND SHAPE OF BASE: 9.3

ESTIMATED VOLUME (IN LITERS): 3.56

DECORATION (INCLUDING MOTIF AND ELEMENTS WHEN APPARENT): The rim panel has a continuous series of 18 engraved concentric semi-circles. Each semi-circle has four concentric semi-circular lines within it (Figure 50).

PIGMENT USE AND LOCATION ON VESSEL: none

TYPE AND VARIETY [IF KNOWN]: Womack Engraved, var. Gum Creek 
VESSEL NO.: Burial 6, Vessel 40; 2003.08.0015

NON-PLASTICS AND PASTE: grog and hematite

VESSEL FORM: Compound bowl with scalloped lip (Figure 51)

RIM AND LIP FORM: Everted rim and rounded lip

CORE COLOR: B (fired and cooled in a reducing environment)

INTERIOR SURFACE COLOR: black

EXTERIOR SURFACE COLOR: dark grayish-brown; fire clouds

WALL THICKNESS (RIM, BODY, AND BASE IN MM): rim, $5.8 \mathrm{~mm}$

INTERIOR SURFACE TREATMENT:

smoothed

EXTERIOR SURFACE TREATMENT:

burnished

HEIGHT (IN CM): 8.0

ORIFICE DIAMETER (IN CM): 17.2

DIAMETER AT BOTTOM OF RIM OR NECK

(IN CM): 14.6

BASE DIAMETER (IN CM) AND SHAPE OF BASE: 6.5

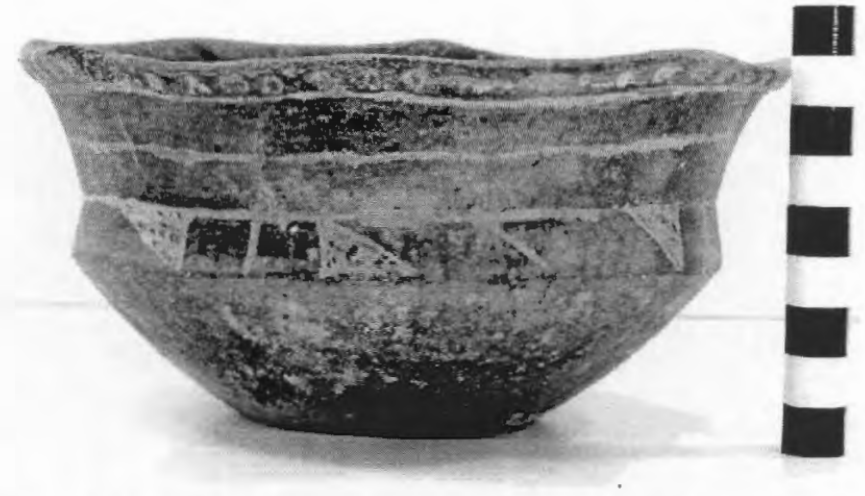

Figure 51. Turner Engraved, var. Turner compound bowl, Enis Smith cemetery, Burial 6, Vessel 40.

ESTIMATED VOLUME (IN LITERS): 1.10

DECORATION (INCLUDING MOTIF AND ELEMENTS WHEN APPARENT): The upper rim panel has three widely-spaced horizontal engraved lines. There is also a row of excised punctations on the side of the lip. The narrow lower rim panel has a series of eight large excised and cross-hatched triangles that are separated from each other by short vertical or diagonal engraved lines (Figure 51).

PIGMENT USE AND LOCATION ON VESSEL: none

TYPE AND VARIETY [IF KNOWN]: Turner Engraved, var. Turner 
VESSEL NO.: Burial 6, Vessel 41; 2003.08.0030

NON-PLASTICS AND PASTE: grog

VESSEL FORM: Bottle with a short neck

RIM AND LIP FORM: Direct rim and a rounded lip

CORE COLOR: $\mathrm{F}$ (fired in a reducing environment and cooled in the open air)

INTERIOR SURFACE COLOR: reddish-brown

EXTERIOR SURFACE COLOR: reddish-brown; fire clouds on the rim, body, and base

WALL THICKNESS (RIM, BODY, AND BASE IN MM): rim, $5.9 \mathrm{~mm}$

INTERIOR SURFACE TREATMENT: none

EXTERIOR SURFACE TREATMENT: smoothed

HEIGHT (IN CM): 14.3

ORIFICE DIAMETER (IN CM): 4.8

DIAMETER AT BOTTOM OF RIM OR NECK (IN CM): 4.7

BASE DIAMETER (IN CM) AND SHAPE OF BASE: 6.5

ESTIMATED VOLUME (IN LITERS): 0.37

DECORATION (INCLUDING MOTIF AND ELEMENTS WHEN APPARENT): Plain (Figure 52)

PIGMENT USE AND LOCATION ON VESSEL: none

TYPE AND VARIETY [IF KNOWN]: Unidentified plain ware

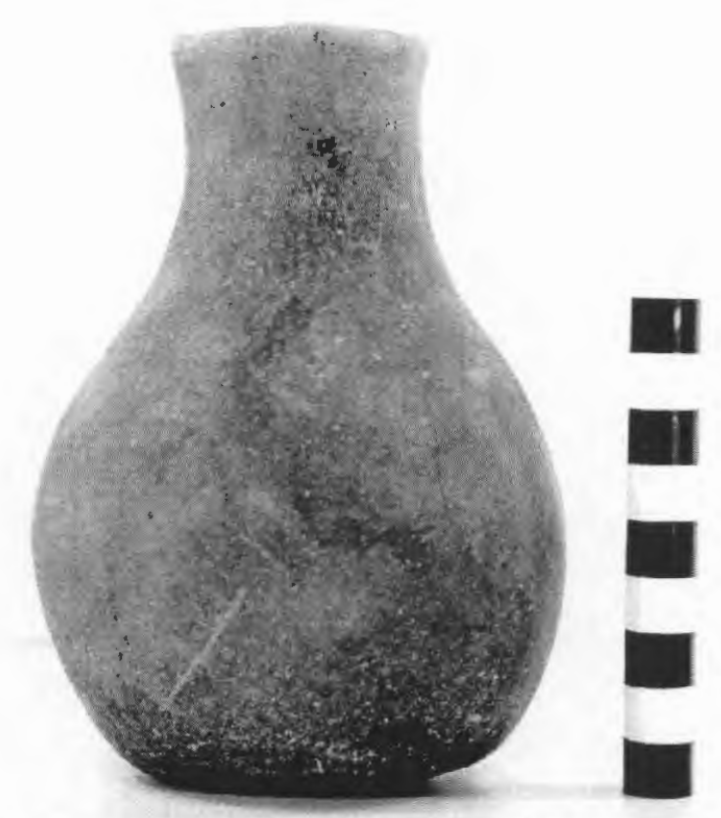

Figure 52. Plain bottle, Enis Smith cemetery, Burial 6, Vessel 41. 
VESSEL NO.: Burial 6, Vessel 42; 2003.08.1856

NON-PLASTICS AND PASTE: grog

VESSEL FORM: Carinated bowl

RIM AND LIP FORM: Direct rim and rounded lip

CORE COLOR: $\mathrm{F}$ (fired in a reducing environment and cooled in the open air)

INTERIOR SURFACE COLOR: reddish-brown

EXTERIOR SURFACE COLOR: reddish-brown; fire clouds on the body and base; organic residue on the body

WALL THICKNESS (RIM, BODY, AND BASE IN MM): rim, $6.7 \mathrm{~mm}$

INTERIOR SURFACE TREATMENT: smoothed

EXTERIOR SURFACE TREATMENT:

burnished

HEIGHT (IN CM): 9.6

ORIFICE DIAMETER (IN CM): 21.5

DIAMETER AT BOTTOM OF RIM OR NECK (IN CM): 21.0

BASE DIAMETER (IN CM) AND SHAPE OF BASE: 8.3; circular and flat

ESTIMATED VOLUME (IN LITERS): 1.24

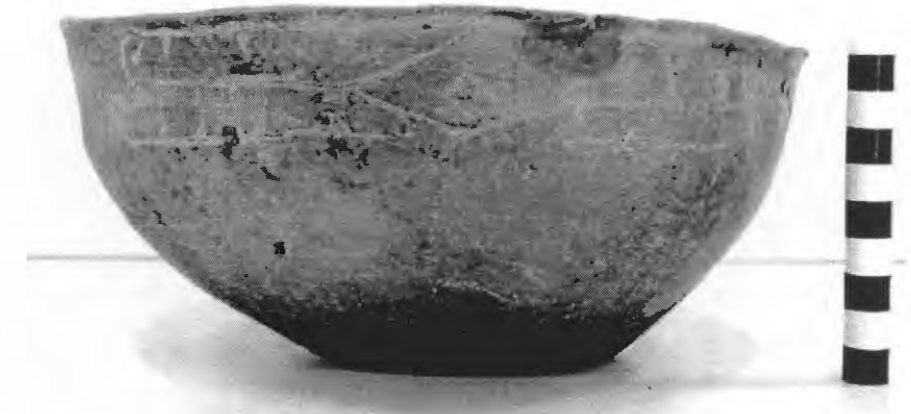

Figure 53. Ripley Engraved, cf. var. McKinney carinated bowl, Enis Smith cemetery, Burial 6, Vessel 42.

DECORATION (INCLUDING MOTIF AND ELEMENTS WHEN APPARENT): The rim panel has three engraved nested diamond and one hatched bracket elements around the vessel. The nested diamond element has a smaller diamond within it; the element is also the central part of a horizontal scroll that ends in a hooked arm element (Figure 53). Above and below the scrolls are excised pendant triangles. The hatched bracket divides two of the nested diamond-horizontal scrolls.

PIGMENT USE AND LOCATION ON VESSEL: red pigment in the engraved lines

TYPE AND VARIETY [IF KNOWN]: Ripley Engraved, cf. var. McKinney 


\section{Burial 7}

Burial 7 at the Enis Smith cemetery is in the central east-west row, with Burials 2 and 9 (see Figure 8). The burial pit was $2.79 \mathrm{~m}$ in length, $1.02 \mathrm{~m}$ width, and its depth was $0.99 \mathrm{~m}$ (Figure 54).

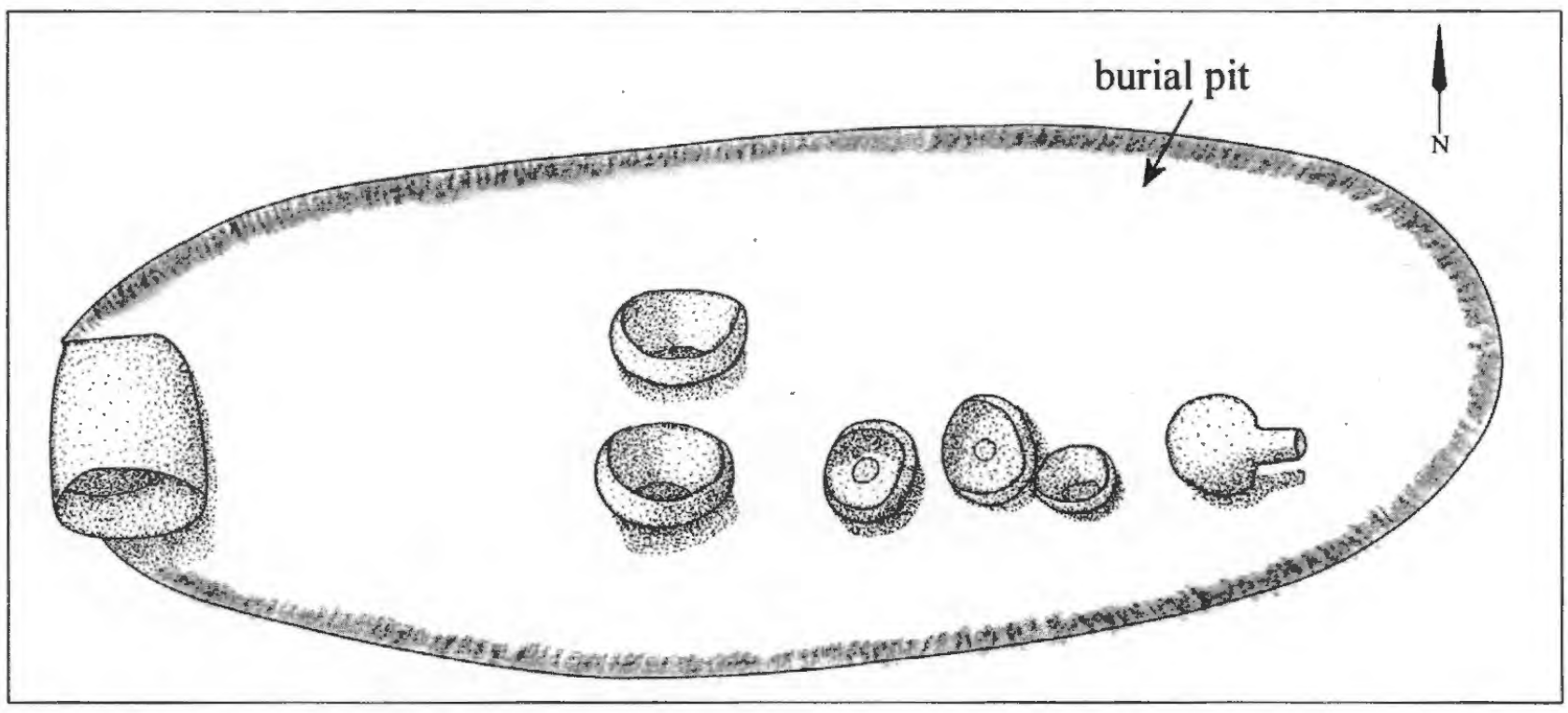

Figure 54. Burial 7 at the Enis Smith site.

There were seven ceramie vessels placed in the grave as associated funerary offerings, as well as eight Maud arrow points. This included a bottle near the head area, carinated bowls along the left side of the body, and a large jar at the feet. One of the carinated bowls was placed near what would have been the upper right leg; the Maud points (although not illustrated on Figure 54) were in a cache/quiver next to this vessel.

The six vessels from Burial 7 in the collection include one bottle, four carinated bowls, and a jar. The bottle is a Wilder Engraved, var. Wilder type, while the jar has an incised decoration on both rim and body. All four of the carinated bowls are classified as Ripley Engraved, including cf. var. Gandy $(\mathrm{n}=2)$, cf. var. Carpenter, and var. McKinney vessels.

VESSEL NO.: Burial 7, Vessel 43; 2003.08.474

NON-PLASTICS AND PASTE: grog and bone

VESSEL FORM: Carinated bowl

RIM AND LIP FORM: Direct rim and rounded, exterior folded lip

CORE COLOR: $F$ (fired in a reducing environment and cooled in the open air)

INTERIOR SURFACE COLOR: yellowish-brown; fire clouds on the rim and base 
EXTERIOR SURFACE COLOR: yellowish-brown; fire clouds on the rim and base

WALL THICKNESS (RIM, BODY, AND BASE IN MM): rim, $7.0 \mathrm{~mm}$

INTERIOR SURFACE TREATMENT: smoothed

EXTERIOR SURFACE TREATMENT: smoothed

HEIGHT (IN CM): 8.0

ORIFICE DIAMETER (IN CM): 17.5

DIAMETER AT BOTTOM OF RIM OR NECK (IN CM): I6.3

BASE DIAMETER (IN CM) AND SHAPE OF BASE: 6.1

ESTIMATED VOLUME (IN LITERS): 0.84

DECORATION (INCLUDING MOTIF AND ELEMENTS WHEN APPARENT): The rim panel has an engraved scroll motif repeated four times around the vessel. Above and below each scroll are small excised pendant triangles. The scrolls are divided by vertical brackets with hatched or excised zones in the central part of the bracket (Figure 55).

PIGMENT USE AND LOCATION ON VESSEL: none

TYPE AND VARIETY [IF KNOWN]: Ripley Engraved, cf. var. Gandy

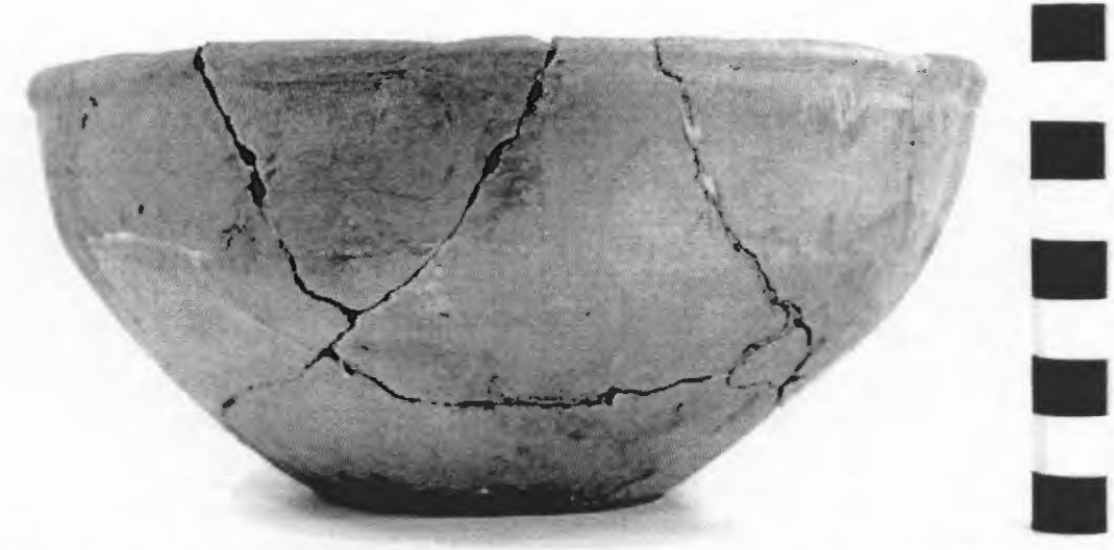

Figure 55. Ripley Engraved, cf. var. Gandy carinated bowl, Enis Smith cemetery, Burial 7, Vessel 43. 
VESSEL NO.: Burial 7, Vessel 44

NON-PLASTICS AND PASTE: grog and bone

VESSEL FORM: Carinated bowl

RIM AND LIP FORM: Direct rim and rounded lip

CORE COLOR: $\mathrm{G}$ (fired in a reducing environment and cooled in the open air)

INTERIOR SURFACE COLOR: dark grayish-brown

EXTERIOR SURFACE COLOR: reddish-brown; fire clouds on the rim, body, and base

WALL THICKNESS (RIM, BODY, AND BASE IN MM): rim, 7.2 mm

INTERIOR SURFACE TREATMENT: smoothed on the rim

EXTERIOR SURFACE TREATMENT: burnished

HEIGHT (IN CM): 9.0

ORIFICE DIAMETER (IN CM): 21.4

DIAMETER AT BOTTOM OF RIM OR NECK

(IN CM): 20.4

BASE DIAMETER (IN CM) AND SHAPE OF

BASE: 8.0 ; circular and flat

ESTIMATED VOLUME (IN LITERS): 1.16

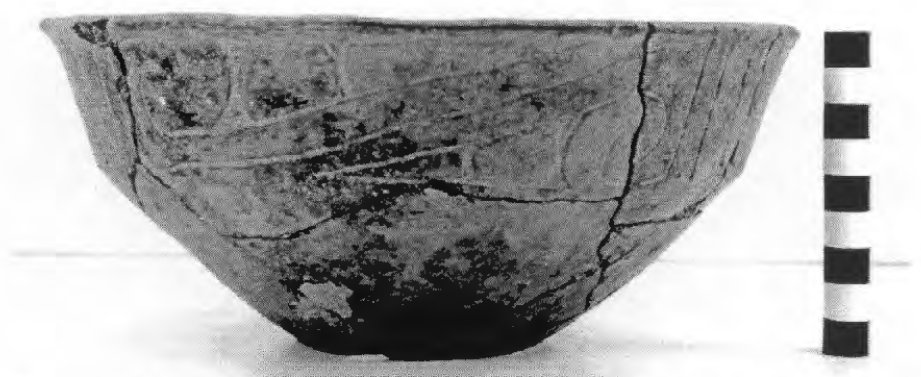

Figure 56. Engraved carinated bowl, Enis Smith cemetery, Burial 7, Vessel 44.

DECORATION (INCLUDING MOTIF AND ELEMENTS WHEN APPARENT): The rim panel has a nearcontinuous and slanting scroll motif repeated four times around the vessel. The scrolls end in upper and lower hooked arm elements. The scroll fill zones have vertical excised lines. The scrolls are divided by sets of two vertical engraved lines (Figure 56).

PIGMENT USE AND LOCATION ON VESSEL: red pigment in the engraved lines

TYPE AND VARIETY [IF KNOWN]: Taylor Engraved or Ripley Engraved, cf. var. Carpenter 
VESSEL NO.: Burial 7, Vessel 45; 2003.08.361

NON-PLASTICS AND PASTE: grog

VESSEL FORM: Bottle

RIM AND LIP FORM: Direct rim and rounded lip

CORE COLOR: $\mathrm{H}$ (fired in a reducing environment and cooled in the open air)

INTERIOR SURFACE COLOR: yellowish-brown

EXTERIOR SURFACE COLOR: dark grayish-brown to black

WALL THICKNESS (RIM, BODY, AND BASE IN MM): rim, $3.8 \mathrm{~mm}$

INTERIOR SURFACE TREATMENT: none

EXTERIOR SURFACE TREATMENT: burnished

HEIGHT (IN CM): 18.5

ORIFICE DIAMETER (IN CM): 4.5

DIAMETER AT BOTTOM OF RIM OR NECK (IN CM): 4.9; maximum body diameter is $13.1 \mathrm{~cm}$

BASE DIAMETER (IN CM) AND SHAPE OF BASE: 9.7

ESTIMATED VOLUME (IN LITERS): 0.72

DECORATION (INCLUDING MOTIF AND ELEMENTS WHEN APPARENT): The top and bottom of the vessel body have two or three horizontal engraved lines. The body panel has an engraved scroll motif repeated four times around the bottle. The scrolls have upper and lower arms that encircle each other before meeting at a small hatched circle. As the scroll arms pass by the small central circle, they are widened by hatched and cross-hatched areas (Figure 57). The scroll arms originate from large upper and lower triangles that have hatched corners and either short engraved dashes or dots.

PIGMENT USE AND LOCATION ON VESSEL: red pigment in engraved lines

TYPE AND VARIETY [IF KNOWN]: Wilder Engraved, var. Wilder

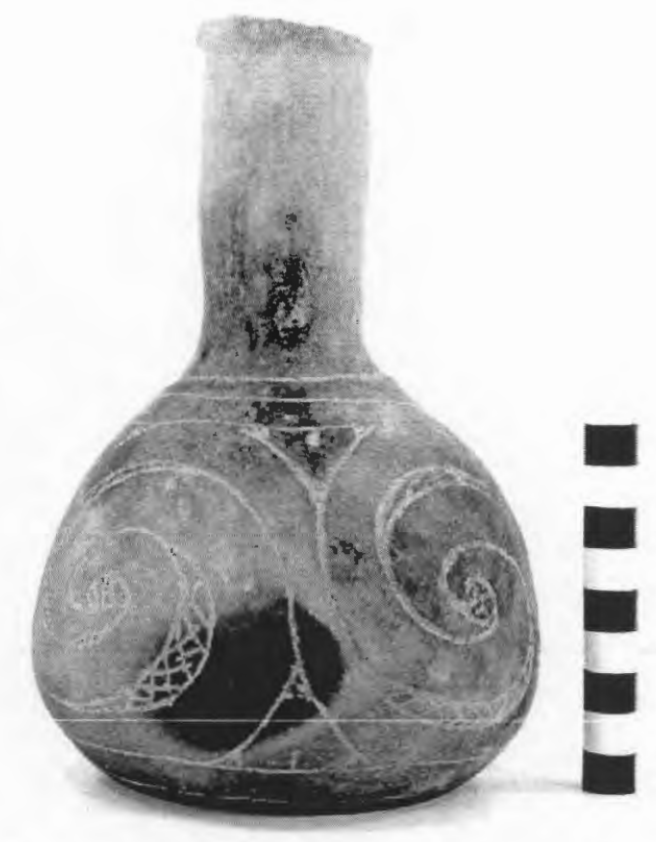

Figure 57. Wilder Engraved, var. Wilder bottle, Enis Smith cemetery, Burial 7, Vessel 45. 
VESSEL NO.: Burial 7, Vessel 46; 2003.08.16

NON-PLASTICS AND PASTE: grog

VESSEL FORM: Jar

RIM AND LIP FORM: Everted rim and a rounded, exterior folded lip

CORE COLOR: $F$ (fired in a reducing environment and cooled in the open air)

INTERIOR SURFACE COLOR: yellowish-brown; fire clouds on the base

EXTERIOR SURFACE COLOR: yellowish-brown; fire clouds on the rim and body; organic residue on the rim

WALL THICKNESS (RIM, BODY, AND BASE IN MM): rim, $7.4 \mathrm{~mm}$

INTERIOR SURFACE TREATMENT: smoothed

EXTERIOR SURFACE TREATMENT: none

HEIGHT (IN CM): 28.0

ORIFICE DIAMETER (IN CM): 24.5

DIAMETER AT BOTTOM OF RIM OR NECK (IN CM): 24.2

BASE DIAMETER (IN CM) AND SHAPE OF BASE: 6.5; circular and flat

ESTIMATED VOLUME (IN LITERS): 8.9

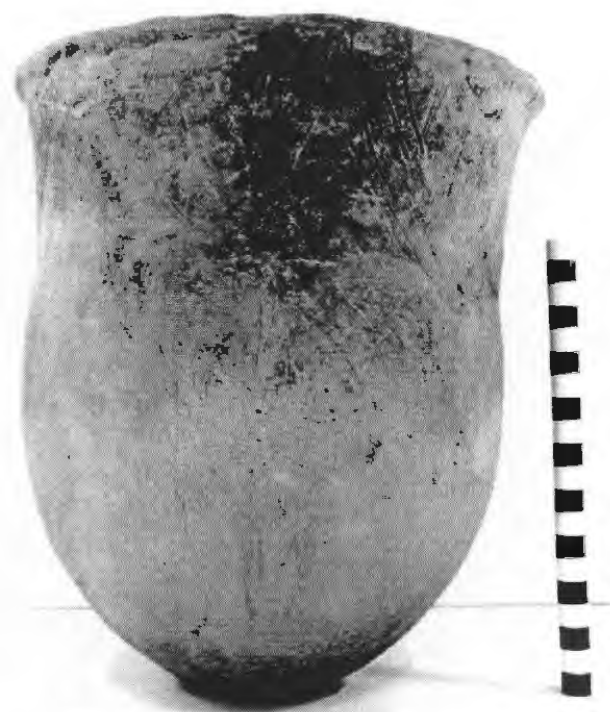

Figure 58. Incised jar, Enis Smith cemetery, Burial 7, Vessel 46.

DECORATION (INCLUDING MOTIF AND ELEMENTS WHEN APPARENT): Cross-hatched incised lines on the rim and diagonal opposed and diagonal incised lines on the vessel body (Figure 58).

PIGMENT USE AND LOCATION ON VESSEL: none

TYPE AND VARIETY [IF KNOWN]: Unidentified utility ware 
VESSEL NO.: Burial 7, Vessel 47; 2003.08.865

NON-PLASTICS AND PASTE: grog; sandy paste

VESSEL FORM: Carinated bowl

RIM AND LIP FORM: Direct rim and rounded, exterior folded lip

CORE COLOR: $\mathrm{F}$ (fired in a reducing environment and cooled in the open air)

INTERIOR SURFACE COLOR: yellowish-brown

EXTERIOR SURFACE COLOR: yellowish-brown; fire clouds on the rim and body

WALL THICKNESS (RIM, BODY, AND BASE IN MM): rim, $7.3 \mathrm{~mm}$; body, $7.0 \mathrm{~mm}$; base, $10.2 \mathrm{~mm}$ INTERIOR SURFACE TREATMENT: smoothed

EXTERIOR SURFACE TREATMENT: smoothed

HEIGHT (IN CM): 13.0

ORIFICE DIAMETER (IN CM): 30.0

DIAMETER AT BOTTOM OF RIM OR NECK (IN CM): 29.8

BASE DIAMETER (IN CM) AND SHAPE OF BASE: 8.2

ESTIMATED VOLUME (IN LITERS): 2.34

DECORATION (INCLUDING MOTIF AND ELEMENTS WHEN APPARENT): The rim panel has an engraved scroll motif repeated four times around the vessel. Each scroll is divided from the other by vertical brackets. Above and below each scroll are small excised pendant triangles (Figure $59)$.

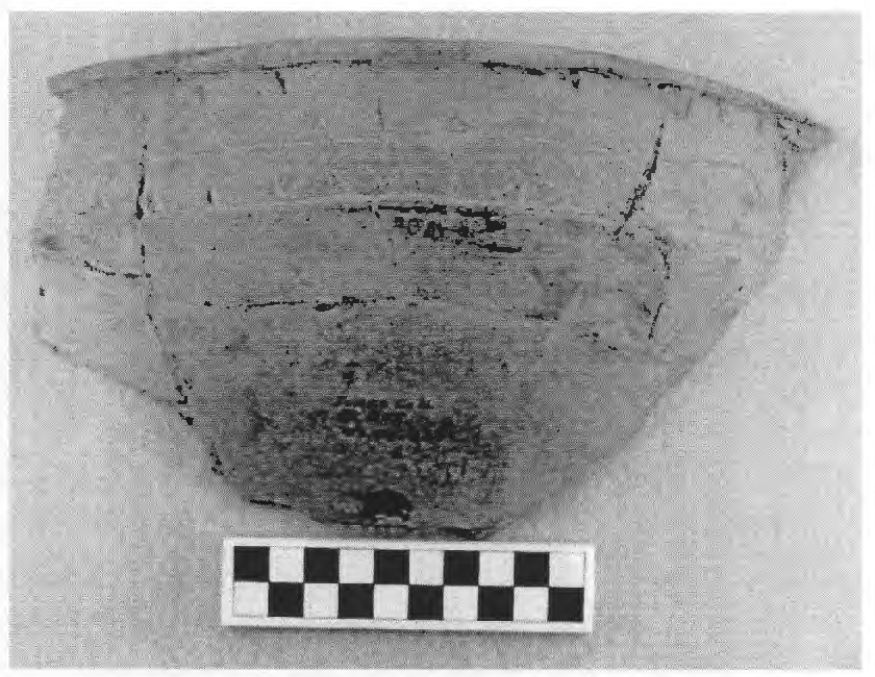

Figure 59. Ripley Engraved, cf. var. Gandy carinated bowl rim and body section, Enis Smith cemetery, Burial 7, Vessel 47.

PIGMENT USE AND LOCATION ON VESSEL: none

TYPE AND VARIETY [IF KNOWN]: Ripley Engraved, cf. var. Gandy 
VESSEL NO.: Burial 7, Vessel 48; 2003.08.346

NON-PLASTICS AND PASTE: grog

VESSEL FORM: Carinated bowl

RIM AND LIP FORM: Direct rim and a rounded, exterior folded lip

CORE COLOR: $\mathrm{F}$ (fired in a reducing environment and cooled in the open air)

INTERIOR SURFACE COLOR: dark yellowish-brown; fire cloud on the base

EXTERIOR SURFACE COLOR: dark yellowish-brown; fire clouds on the body

WALL THICKNESS (RIM, BODY, AND BASE IN MM): rim, $8.1 \mathrm{~mm}$

INTERIOR SURFACE TREATMENT: smoothed on the rim

EXTERIOR SURFACE TREATMENT:

smoothed

HEIGHT (IN CM): 13.0

ORIFICE DIAMETER (IN CM): 27.0

DIAMETER AT BOTTOM OF RIM OR NECK

(IN CM): 26.8

BASE DIAMETER (IN CM) AND SHAPE OF BASE: 9.0

ESTIMATED VOLUME (IN LITERS): 2.1

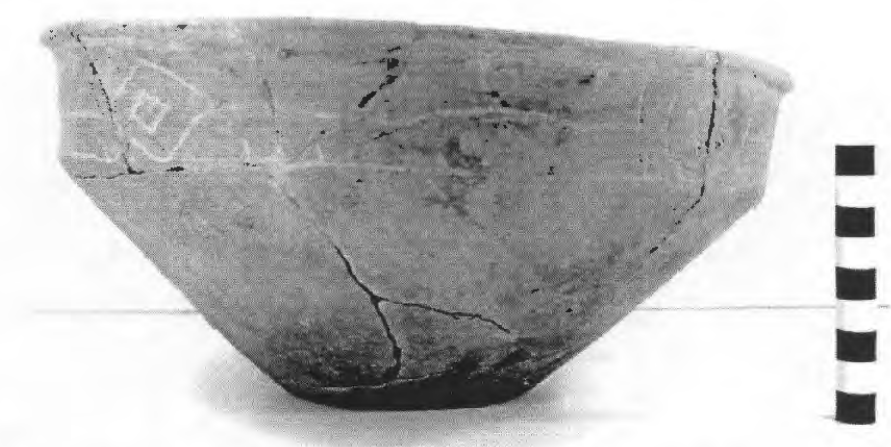

Figure 60. Ripley Engraved, var. McKinney carinated bowl, Enis Smith cemetery, Burial 7, Vessel 48.

DECORATION (INCLUDING MOTIFAND ELEMENTS WHEN APPARENT): The rim panel has two engraved circle within circle elements that alternate with two nested diamonds; the nested diamonds have a smaller diamond within them (Figure 60). The inner circle in the circle in circle element has a continuous series of small tick marks.

The nested diamond element is the central feature of horizontal scrolls that extend, but do not touch, the circle in circle elements. Above and below each of the scrolls are small excised pendant triangles.

There is also a single horizontal engraved line on the interior vessel surface at the carination.

PIGMENT USE AND LOCATION ON VESSEL: none

TYPE AND VARIETY [IF KNOWN]: Ripley Engraved, var. McKinney 
Eight bifacially chipped Maud arrow points (2003.08.903) were placed with the deceased in Burial 7 (Table 2), probably in a quiver of arrows. The points were made from a local quartzite that was occasionally heat-treated to improve its knappability. The points ranged from 21.7-26.0 mm in length, 11.2-13.0 $\mathrm{mm}$ in width, and 1.5-3.6 mm in thickness, and all have concave bases, several with short basal "ears," and serrated blades (Figure 61).

Table 2. Maud points from Burial 7 at the Enis Smith site.

\begin{tabular}{llllllll}
\hline No. & Raw Material & Heat-treated & $\begin{array}{l}\text { L } \\
(\mathrm{mm})\end{array}$ & $\begin{array}{l}\text { W } \\
(\mathrm{mm})\end{array}$ & $\begin{array}{l}\text { Th } \\
(\mathrm{mm})\end{array}$ & Serrated & Comments \\
\hline 38 & quartzite & - & 21.7 & 13.0 & 2.8 & + & cortex on one ear \\
39 & quartzite & + & 22.1 & 13.0 & 2.8 & + & \\
40 & quartzite & - & 25.0 & 12.0 & 2.7 & + & \\
41 & quartzite & - & 25.9 & 13.0 & 3.6 & + & \\
42 & quartzite & - & 26.0 & 11.7 & 1.5 & + & \\
43 & quartzite & - & $23.1+$ & 11.2 & 2.8 & + & \\
44 & quartzite & + & $17.0+$ & 11.7 & 2.6 & + & \\
45 & quartzite & + & 23.0 & 12.4 & 3.0 & + & \\
\hline
\end{tabular}

$+=$ presence

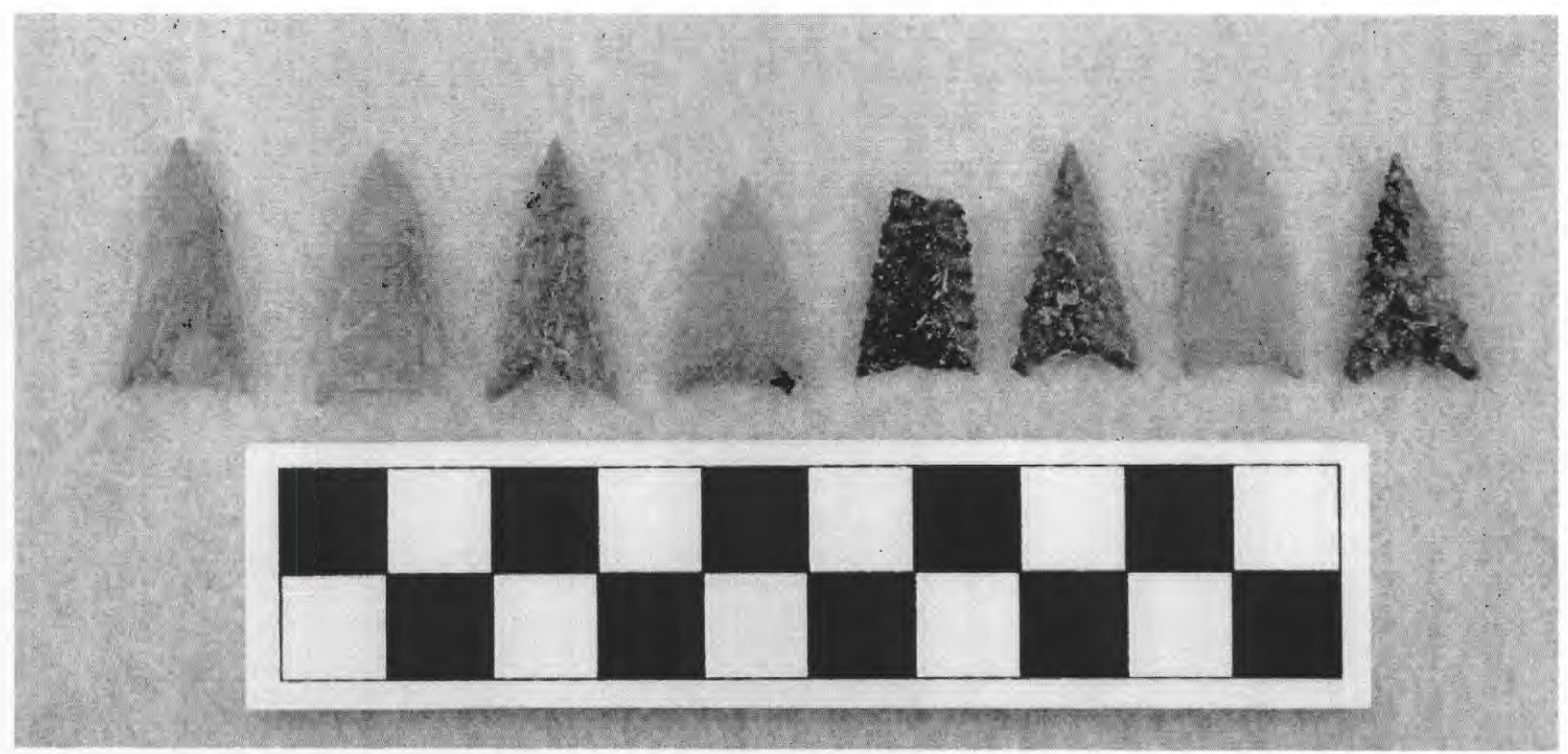

Figure 61. Maud points from Burial 7 at the Enis Smith cemetery. 


\section{Burial 8}

This burial is located along the western part of the cemetery, but in its own row (see Figure 8). The burial pit was $2.23 \mathrm{~m}$ in length, $1.12 \mathrm{~m}$ in width, and extended to a maximum depth of $0.89 \mathrm{~m}$ (Figure 62). Two post holes were identified at the head of the burial pit, and these may have been burial marker posts

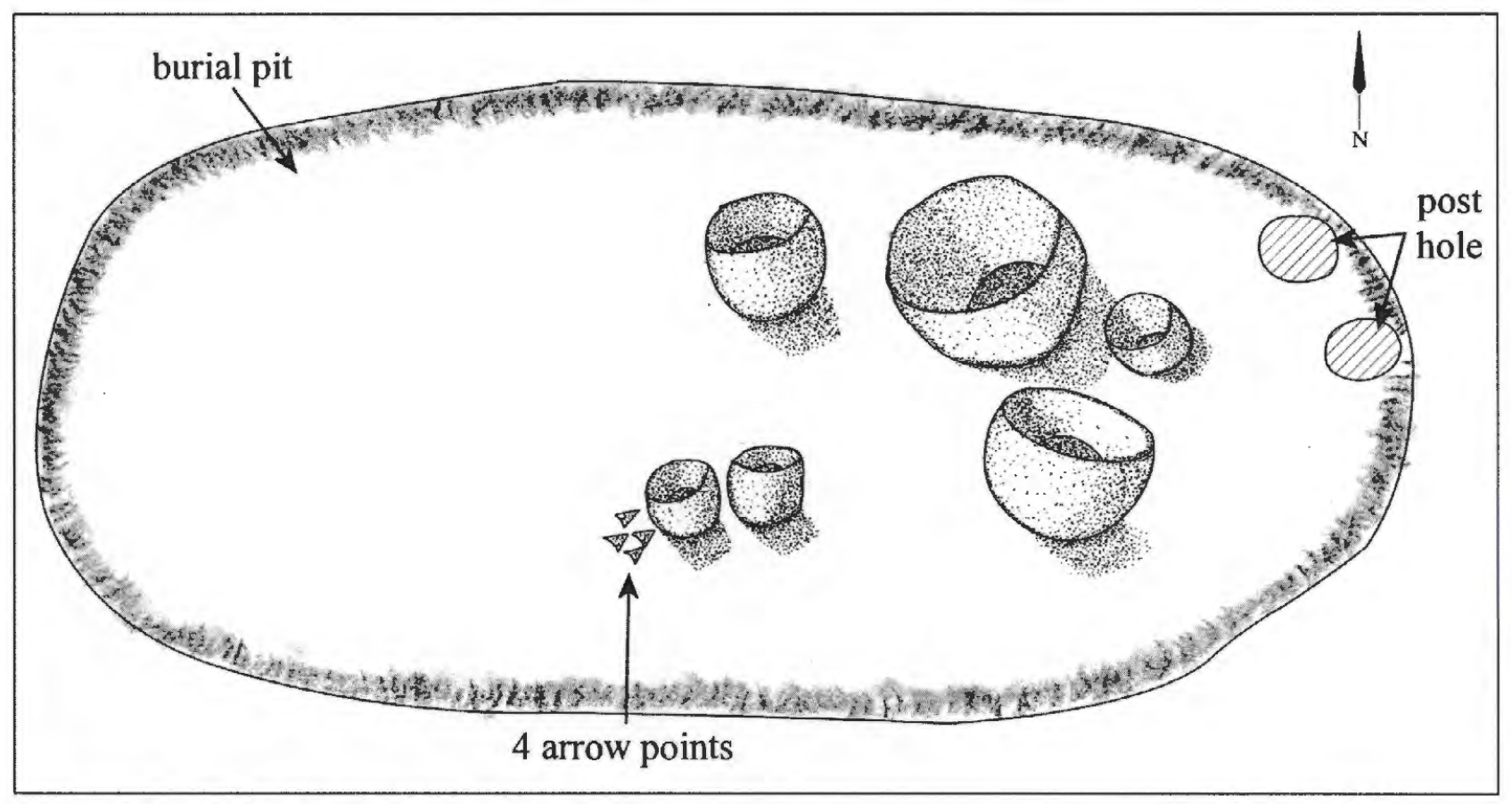

Figure 62. Burial 8 at the Enis Smith site.

Funerary offerings included a number of ceramic vessels and a quiver/cache of triangular arrow points. The vessels were clustered in what would have been the upper body and waist area of the deceased, and the arrow points may have been placed by the left hand (see Figure 62). The vessels in the collection include three jars (Harleton Appliqued, cf. Mockingbird Punctated, and a punctated-appliqued vessel), two carinated bowls (Taylor Engraved and Ripley Engraved, var. Williams), and a Ripley Engraved, var. Williams compound bowl.

VESSEL NO:: Burial 8, Vessel 52; 2003.08.978

NON-PLASTICS AND PASTE: grog

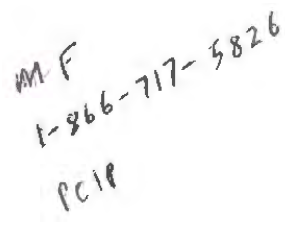

VESSEL FORM: Compound bowl

RIM AND LIP FORM: Everted rim and rounded lip

CORE COLOR: $\mathrm{F}$ (fired in a reducing environment and cooled in the open air)

INTERIOR SURFACE COLOR: brown 
EXTERIOR SURFACE COLOR: brown

WALL THICKNESS (RIM, BODY, AND BASE IN MM): rim, 9.2 mm

INTERIOR SURFACE TREATMENT: smoothed

EXTERIOR SURFACE TREATMENT: burnished

HEIGHT (IN CM): 22.0

ORIFICE DIAMETER (IN CM): 33.0

DIAMETER AT BOTTOM OF RIM OR NECK (IN CM): 30.2

BASE DIAMETER (IN CM) AND SHAPE OF BASE: 9.5; circular and flat

ESTIMATED VOLUME (IN LITERS): 5.8

DECORATION (INCLUDING MOTIF AND ELEMENTS WHEN APPARENT): The upper rim panel has two widely-spaced horizontal engraved lines. The lower rim panel has two sets of alternate nested triangles, separated from each other by sets of three vertical engraved lines. Each alternate nested triangle has a small circle and dot element within the smallest of the triangles within the nested set of triangles (Figure 63).

PIGMENT USE AND LOCATION ON VESSEL: none

TYPE AND VARIETY [IF KNOWN]: Ripley Engraved, var. Williams

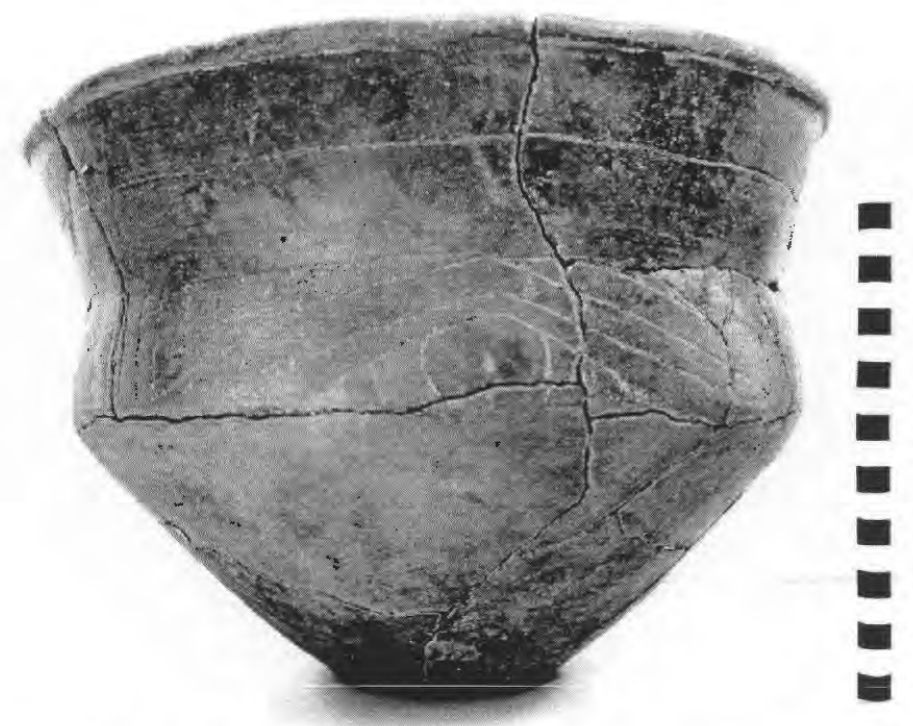

Figure 63. Ripley Engraved, var. Williams compound bowl, Enis Smith cemetery, Burial 8, Vessel 52. 
VESSEL NO.: Burial 8, Vessel 53; 2003.08.1760

NON-PLASTICS AND PASTE: grog

VESSEL FORM: Jar with a short rim

RIM AND LIP FORM: Everted rim and rounded lip

CORE COLOR: $\mathrm{G}$ (fired in a reducing environment and cooled in the open air)

INTERIOR SURFACE COLOR: black

EXTERIOR SURFACE COLOR: yellowish-brown; fire clouds on rim, body, and base

WALL THICKNESS (RIM, BODY, AND BASE IN MM): rim, $5.1 \mathrm{~mm}$

INTERIOR SURFACE TREATMENT: smoothed

EXTERIOR SURFACE TREATMENT: none

HEIGHT (IN CM): 23.0

ORIFICE DIAMETER (IN CM): 16.9

DIAMETER AT BOTTOM OF RIM OR NECK (IN CM): I6.2

BASE DIAMETER (IN CM) AND SHAPE OF BASE: 8.0; circular and flat

ESTIMATED VOLUME (IN LITERS): 3.5

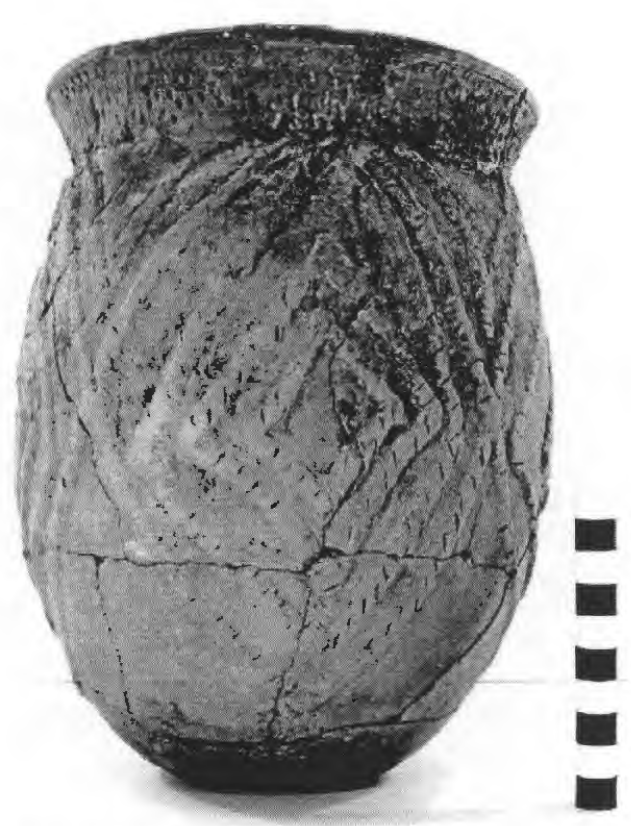

Figure 64. Harleton Appliqued jar, Enis Smith cemetery, Burial 8, Vessel 53.

DECORATION (INCLUDING MOTIF AND ELEMENTS WHEN APPARENT): The rim has five closelyspaced horizontal rows of tool punctations. The vessel body has four appliqued fillet triangular panels and cross-hatched appliqued fillets. The triangular panels are filled with appliqued nested diamonds (Figure 64).

PIGMENT USE AND LOCATION ON VESSEL: none

TYPE AND VARIETY [IF KNOWN]: Harleton Appliqued 
VESSEL NO.: Burial 8, Vessel 54; 2003.08.111

NON-PLASTICS AND PASTE: grog; sandy paste

VESSEL FORM: Carinated bowl

RIM AND LIP FORM: Direct rim and a rounded, exterior folded lip

CORE COLOR: $\mathrm{F}$ (fired in a reducing environment and cooled in the open air)

INTERIOR SURFACE COLOR: yellowish-brown; fire clouds on the base

EXTERIOR SURFACE COLOR: dark reddish-

brown; fire clouds on the rim, body, and base

WALL THICKNESS (RIM, BODY, AND

BASE IN MM): rim, $5.4 \mathrm{~mm}$

INTERIOR SURFACE TREATMENT:

smoothed

EXTERIOR SURFACE TREATMENT:

burnished

HEIGHT (IN CM): 7.3

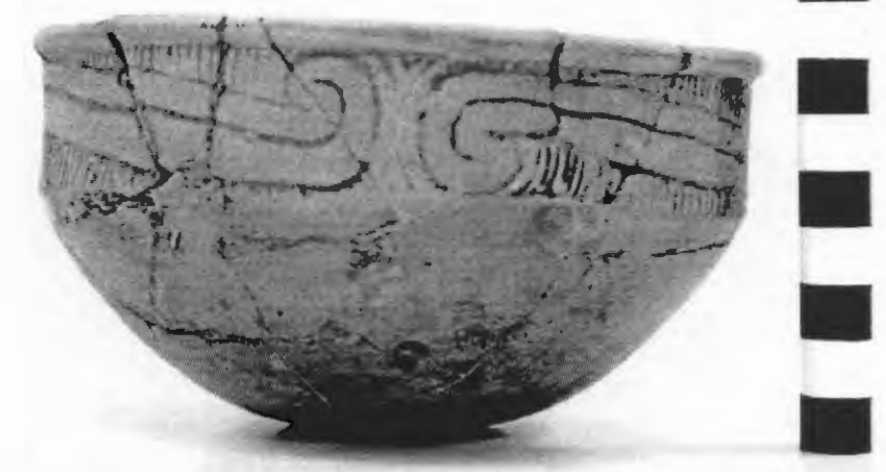

Figure 65. Taylor Engraved carinated bowl, Enis Smith

ORIFICE DIAMETER (IN CM): 13.2 cemetery, Burial 8, Vessel 54.

DIAMETER AT BOTTOM OF RIM OR NECK (IN CM): 13.6

BASE DIAMETER (IN CM) AND SHAPE OF BASE: 5.5; circular and rounded

ESTIMATED VOLUME (IN LITERS): 0.58

DECORATION (INCLUDING MOTIF AND ELEMENTS WHEN APPARENT): The rim panel has an engraved scroll motif repeated four times around the vessel. The scrolls end in a hooked arm element, the larger and outer hooked arm with small tick marks. The scrolls are separated by a vertical engraved bracket with small upper and lower triangles (Figure 65).

PIGMENT USE AND LOCATION ON VESSEL: red pigment in engraved lines

TYPE AND VARIETY [IF KNOWN]: Taylor Engraved 
VESSEL NO.: Burial 8, Vessel 55; 2003.08.12

NON-PLASTICS AND PASTE: grog

VESSEL FORM: Jar

RIM AND LIP FORM: Everted rim and a rounded, exterior folded lip

CORE COLOR: $\mathrm{F}$ (fired in a reducing environment and cooled in the open air)

INTERIOR SURFACE COLOR: yellowish-brown; fire clouds on the base

EXTERIOR SURFACE COLOR: yellowish-brown; fire clouds on the rim and body; thick organic residue in a band below the rim-body juncture and on the rim itself

WALL THICKNESS (RIM, BODY, AND BASE IN $\mathrm{MM})$ : rim, $5.6 \mathrm{~mm}$

INTERIOR SURFACE TREATMENT: smoothed

EXTERIOR SURFACE TREATMENT: smoothed on the body

HEIGHT (IN CM): 9.0

ORIFICE DIAMETER (IN CM): 8.7

DIAMETER AT BOTTOM OF RIM OR NECK (IN CM): 7.2

BASE DIAMETER (IN CM) AND SHAPE OF BASE: 6.0

ESTIMATED VOLUME (IN LITERS): 0.47

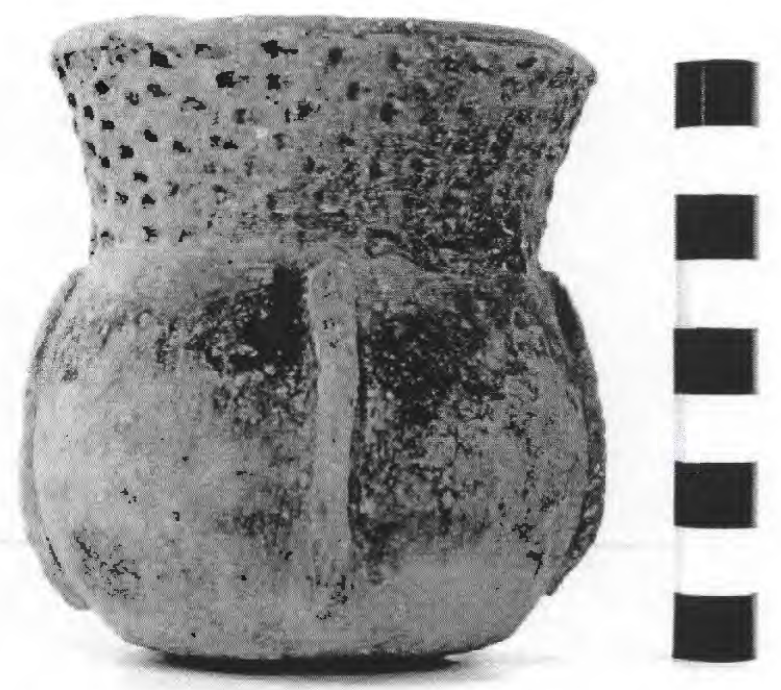

Figure 66. Punctated-appliqued jar, Enis Smith cemetery, Burial 8, Vessel 55.

DECORATION (INCLUDING MOTIF AND ELEMENTS WHEN APPARENT): There are seven rows of large tool punctations on the vessel rim. The vessel body has four broad vertical appliqued ridges that run from the rim-body juncture to $1.0 \mathrm{~cm}$ above the base (Figure 66).

PIGMENT USE AND LOCATION ON VESSEL: none

TYPE AND VARIETY [IF KNOWN]: Unidentified utility ware 
VESSEL NO.: Burial 8, Vessel 56; 2003.08.1771

NON-PLASTICS AND PASTE: grog and bone

VESSEL FORM: Carinated bowl

RIM AND LIP FORM: Inverted rim and a rounded, exterior folded lip

CORE COLOR: $\mathrm{G}$ (fired in a reducing environment and cooled in the open air)

INTERIOR SURFACE COLOR: dark grayish-brown

EXTERIOR SURFACE COLOR: dark reddish-brown; fire clouds on the body and base

WALL THICKNESS (RIM, BODY, AND BASE IN MM): rim, $7.0 \mathrm{~mm}$

INTERIOR SURFACE TREATMENT: smoothed on the rim

EXTERIOR SURFACE TREATMENT: smoothed

HEIGHT (IN CM): 8.4

ORIFICE DIAMETER (IN CM): 12.5

DIAMETER AT BOTTOM OF RIM OR NECK (IN CM): I3.1

BASE DIAMETER (IN CM) AND SHAPE OF BASE: 5.0; circular and flat

ESTIMATED VOLUME (IN LITERS): 0.63

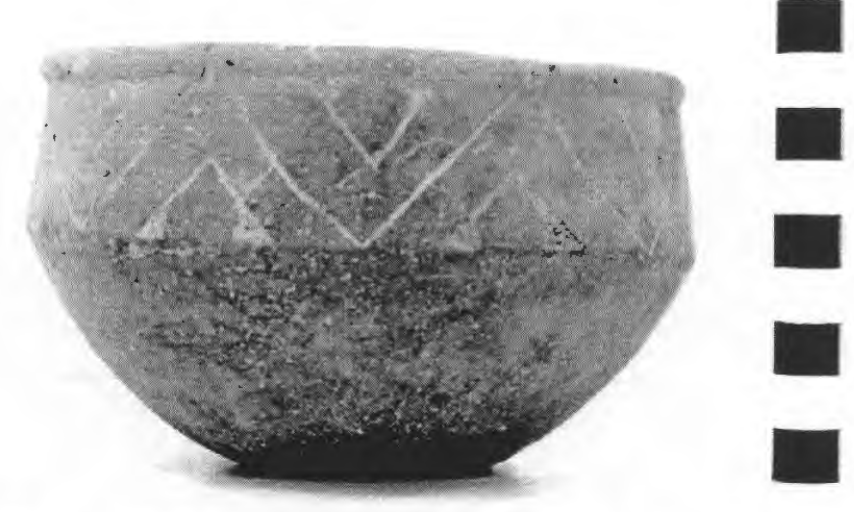

Figure 67. Ripley Engraved, var. Williams carinated bowl, Enis Smith cemetery, Burial 8, Vessel 56.

DECORATION (INCLUDING MOTIF AND ELEMENTS WHEN APPARENT): The rim panel has seven upper and seven lower engraved alternate nested triangles. Each of the nested triangles has a single smaller triangle within it, and these smaller triangles are plain or have negative ovals in them formed by excising each of the corners of the triangles (Figure 67).

PIGMENT USE AND LOCATION ON VESSEL: none

TYPE AND VARIETY [IF KNOWN]: Ripley Engraved, var. Williams 
VESSEL NO.: Burial 8, Vessel 58; 2003.08.480

NON-PLASTICS AND PASTE: grog

VESSEL FORM: Jar

RIM AND LIP FORM: Everted rim and a rounded lip

CORE COLOR: $\mathrm{G}$ (fired in a reducing environment and cooled in the open air)

INTERIOR SURFACE COLOR: black

EXTERIOR SURFACE COLOR: yellowish-brown; fire clouds on the rim and body; organic residue on the rim and body

WALL THICKNESS (RIM, BODY, AND BASE IN MM): rim, 6.4 mm

INTERIOR SURFACE TREATMENT: smoothed

EXTERIOR SURFACE TREATMENT: none

HEIGHT (IN CM): I6.0

ORIFICE DIAMETER (IN CM): 14.6

DIAMETER AT BOTTOM OF RIM OR NECK (IN CM): I4.2

BASE DIAMETER (IN CM) AND SHAPE OF BASE: 7.0

ESTIMATED VOLUME (IN LITERS): 1.4

DECORATION (INCLUDING MOTIF AND ELEMENTS WHEN APPARENT): The rim is decorated with two rows of tool punctations. One row is under the lip and the other is at the rim-body junction (Figure 68).

PIGMENT USE AND LOCATION ON VESSEL: none

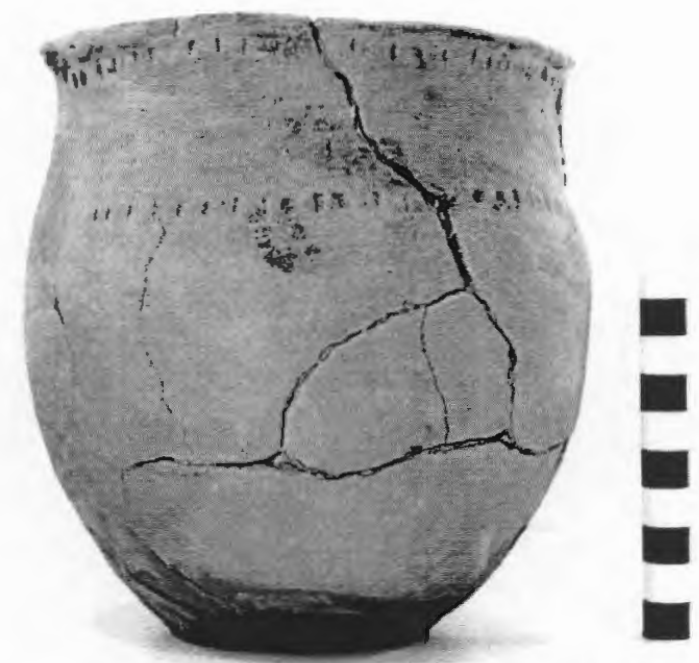

Figure 68. cf. Mockingbird Punctated jar, Enis Smith cemetery, Burial 8, Vessel 58.

TYPE AND VARIETY [IF KNOWN]: cf. Mockingbird Punctated

Six Maud and Talco arrow points were among the funerary objects in Burial 8 (Table 3). They were probably in a quiver of arrow points (see Figure 62). All the points are made from a heat-treated local quartzite, and are bifacially chipped to completion; one of the Talco points has a serrated blade (Figure 69e). 
Table 3. Maud and Talco points from Burial 8 at the Enis Smith site.

\begin{tabular}{lllcccc}
\hline No. & Type & $\begin{array}{l}\text { Raw Material- } \\
\text { Heat-treated }\end{array}$ & $\begin{array}{c}\mathrm{L} \\
(\mathrm{mm})\end{array}$ & $\begin{array}{c}\text { W } \\
(\mathrm{mm})\end{array}$ & $\begin{array}{c}\text { Th } \\
(\mathrm{mm})\end{array}$ & Serrated \\
\hline 46 & Talco & QTZ-HT & 30.3 & 9.9 & 2.3 & - \\
47 & Talco & QTZ-HT & 27.5 & 11.0 & 2.7 & - \\
48 & Talco & QTZ-HT & 25.9 & 10.5 & 1.9 & + \\
49 & Maud & QTZ-HT & 22.9 & 13.0 & 2.8 & - \\
50 & Talco & QTZ-HT & 28.5 & 11.0 & 2.8 & - \\
51 & Maud & QTZ-HT & 21.2 & 12.0 & 2.3 & - \\
\hline
\end{tabular}

QTZ=quartzite; $\mathrm{HT}=$ heat-treated

The Talco points are longer, wider, and thinner triangular tools than are the Maud points (Figure 69ab, e-f). The Talco points range from 25.9-30.3 mm in length, 9.9-11.0 mm in width, and 1.9-2.8 $\mathrm{mm}$ in thickness; one of the Talco points has noticeable concave blade margins (Figure 69a). The Maud points in Burial 8 are 21.2-22.9 $\mathrm{mm}$ in length, $12.0-13.0 \mathrm{~mm}$ in width, and range from 2.3-2.8 $\mathrm{mm}$ thick (Figure $69 \mathrm{c}-\mathrm{d})$.

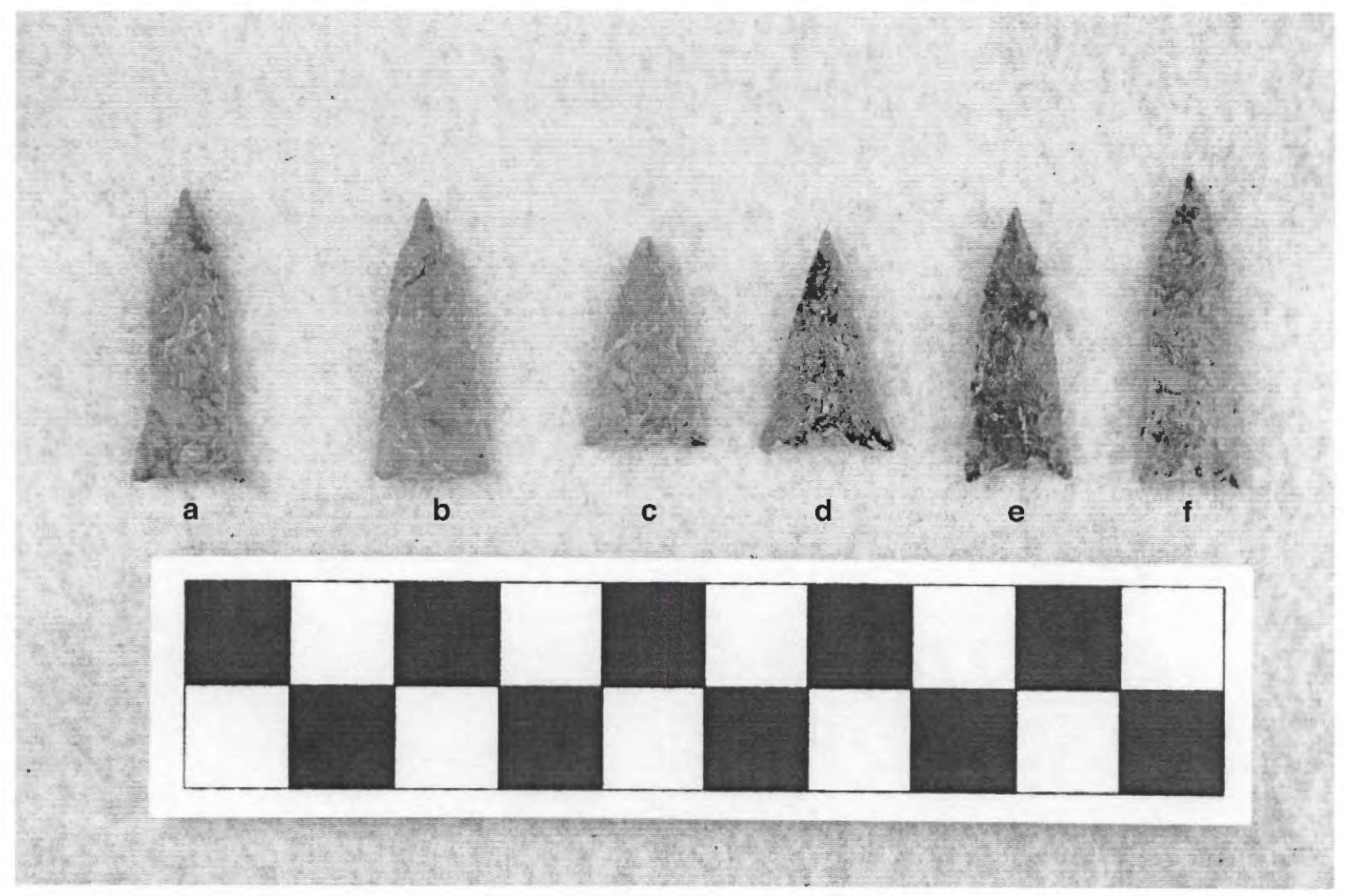

Figure 69. Talco and Maud arrow points from Burial 8 at the Enis Smith cemetery. 


\section{Burial 9}

Burial 9 is the easternmost burial in the central row (Burials 2, 7, and 9) at the cemetery. Jones (n.d.) provided no details on the size or depth of the burial, but did note that a number of ceramic vessels were included as funerary offerings (Figure 70).

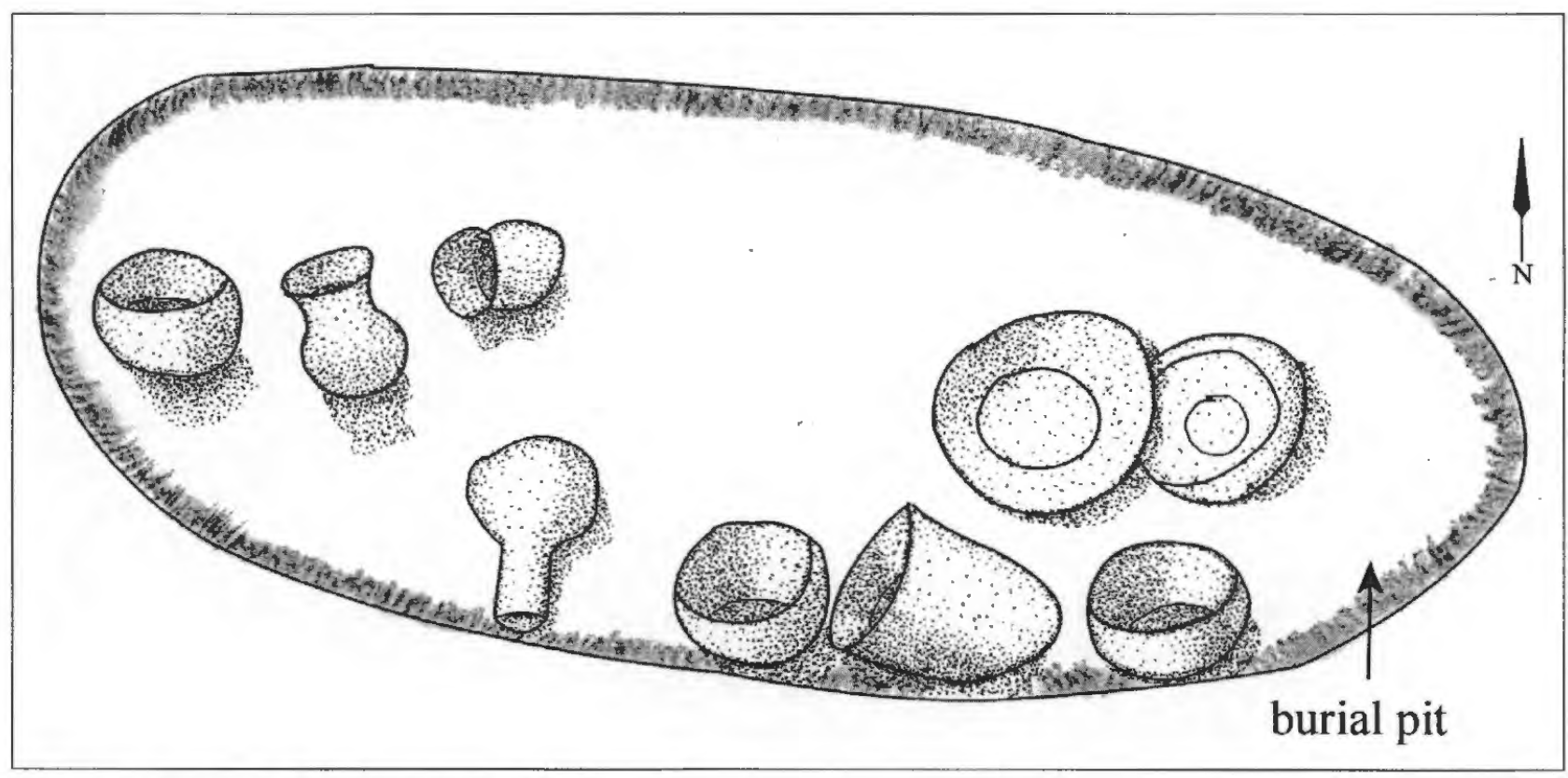

Figure 70. Burial 9 at the Enis Smith site.

The vessels were apparently placed near the head area, along the left side of the upper and lower body (including a bottle), and in the feet area. Seven of the vessels identified from Burial 9 are in the collections. They include La Rue Neck Banded, Cass Appliqued, and Harleton Appliqued jars; a Wilder Engraved, var. Wilder bottle; and three carinated bowls: Ripley Engraved, cf. var. Gandy $(\mathrm{n}=2)$ and Ripley Engraved, cf. var. McKinney.

VESSEL NO.: Burial 9, Vessel 59; 2003.08.309

NON-PLASTICS AND PASTE: grog and bone

VESSEL FORM: Jar

RIM AND LIP FORM: Direct rim and a rounded, exterior folded lip

CORE COLOR: G (fired in a reducing environment and cooled in the open air)

INTERIOR SURFACE COLOR: dark grayish-brown; organic residue on the rim

EXTERIOR SURFACE COLOR: yellowish-brown; fire clouds on the body; organic residue on the rim and body 
WALL THICKNESS (RIM, BODY, AND BASE IN MM): rim, 8.1 mm

INTERIOR SURFACE TREATMENT: smoothed

EXTERIOR SURFACE TREATMENT: none

HEIGHT (IN CM): 29.4

ORIFICE DIAMETER (IN CM): 24.8

DIAMETER AT BOTTOM OF RIM OR NECK (IN CM): 20.6

BASE DIAMETER (IN CM) AND SHAPE OF BASE: 9.8; circular and flat

ESTIMATED VOLUME (IN LITERS): 9.5

DECORATION (INCLUDING MOTIF AND ELEMENTS WHEN APPARENT): The rim has seven rows of horizontal neck bands. The vessel body is decorated with vertical brushing marks that extend from the rim-body juncture to $3.5 \mathrm{~cm}$ above the vessel base (Figure 71).

PIGMENT USE AND LOCATION ON VESSEL: none

TYPE AND VARIETY [IF KNOWN]: La Rue Neck Banded

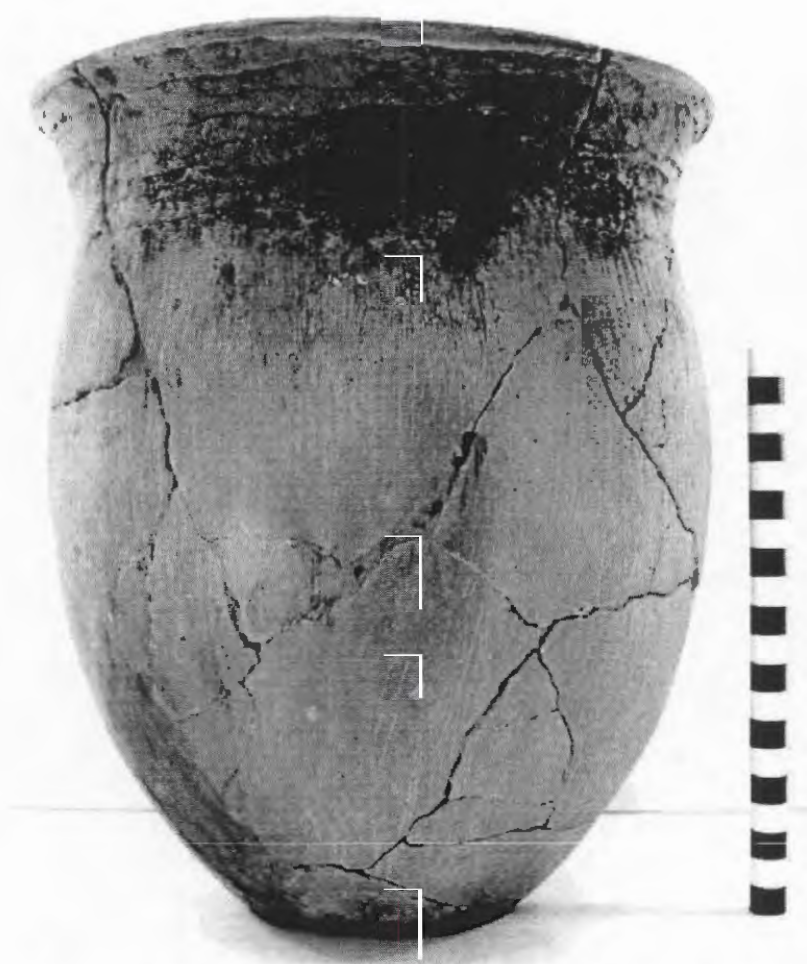

Figure 71. La Rue Neck Banded jar, Enis Smith cemetery, Burial 9, Vessel 59. 
VESSEL NO.: Burial 9, Vessel 60; 2003.08.364

NON-PLASTICS AND PASTE: grog and bone

VESSEL FORM: Bottle

RIM AND LIP FORM: N/A

CORE COLOR: B (fired and cooled in a reducing environment)

INTERIOR SURFACE COLOR: black

EXTERIOR SURFACE COLOR: black

WALL THICKNESS (RIM, BODY, AND BASE IN MM): rim, $4.8 \mathrm{~mm}$

INTERIOR SURFACE TREATMENT: none

EXTERIOR SURFACE TREATMENT: burnished

HEIGHT (IN CM): 20.6

ORIFICE DIAMETER (IN CM): 4.8

DIAMETER AT BOTTOM OF RIM OR NECK (IN CM):

6.2 ; maximum body diameter is $15.0 \mathrm{~cm}$

BASE DIAMETER (IN CM) AND SHAPE OF BASE: 8.0 ;

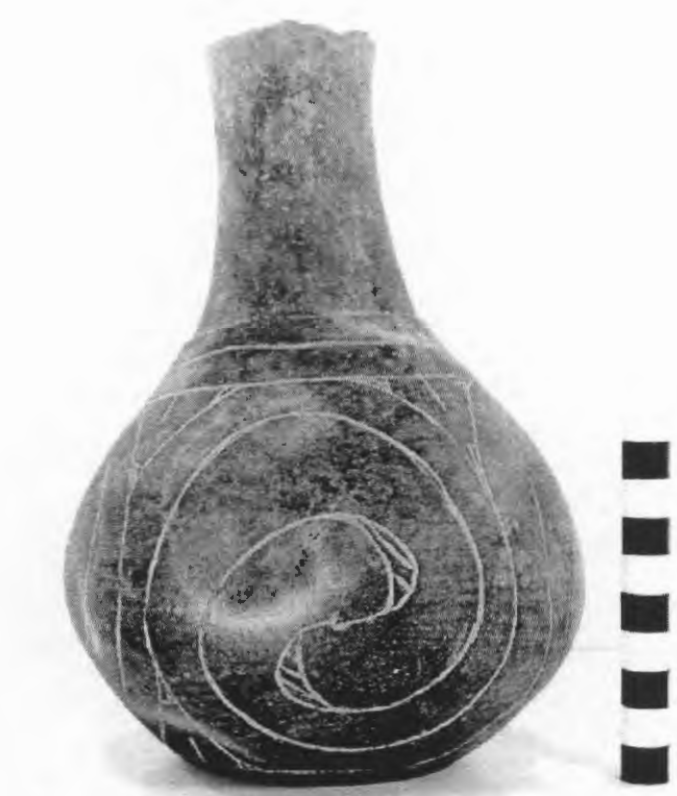

Figure 72. Wilder Engraved, var. Wilder bottle, Enis Smith cemetery, Burial 9 , Vessel 60.

circular and flat

\section{ESTIMATED VOLUME (IN LITERS): 0.66}

DECORATION (INCLUDING MOTIF AND ELEMENTS WHEN APPARENT): The vessel body, defined at the top by two horizontal engraved lines and by one horizontal engraved line at the bottom, has an engraved scroll motif repeated four times around the vessel. The motif consists of two arms of a scroll that encircle each other and meet at a central excised circle. The scrolls have a wider hatched area where the arms pass near the central excised circle (Figure 72).

The scroll arms originate from the apex of large engraved pendant triangles at the top and bottom of the body. The triangles have excised corners and a central slash mark (Figure 72).

PIGMENT USE AND LOCATION ON VESSEL: red pigment in engraved lines

TYPE AND VARIETY [IF KNOWN]: Wilder Engraved, var. Wilder 
VESSEL NO.: Burial 9, Vessel 61; 2003.08.1847

NON-PLASTICS AND PASTE: grog and hematite

VESSEL FORM: Jar with a short rim

RIM AND LIP FORM: Everted rim and a rounded, exterior folded lip

CORE COLOR: A (fired and cooled in an oxidizing environment)

INTERIOR SURFACE COLOR: yellowish-brown

EXTERIOR SURFACE COLOR: yellowish-brown; fire clouds on the body and base

WALL THICKNESS (RIM, BODY, AND BASE IN $\mathrm{MM}$ ): rim, $7.0 \mathrm{~mm}$

INTERIOR SURFACE TREATMENT: smoothed

EXTERIOR SURFACE TREATMENT: none

HEIGHT (IN CM): 15.6

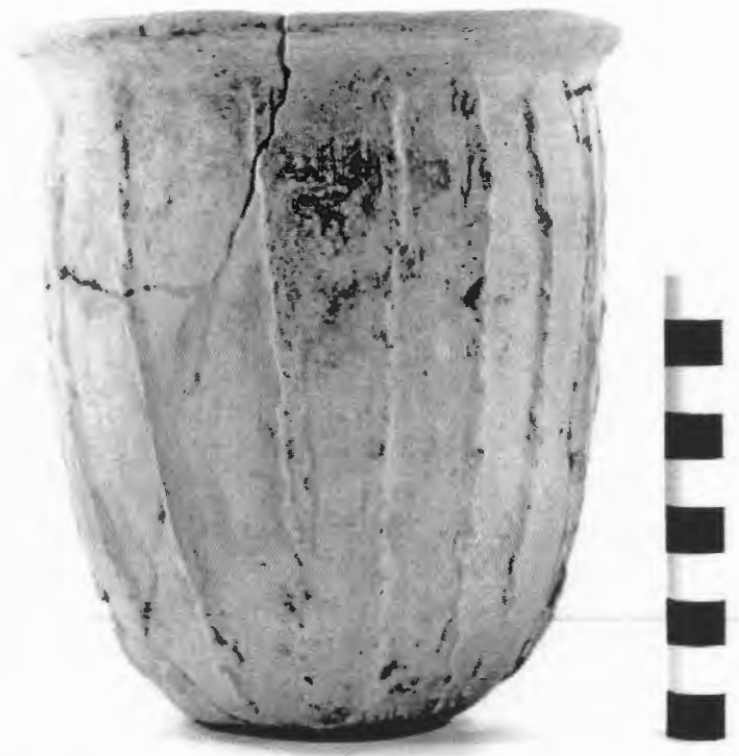

Figure 73. Cass Appliqued jar, Enis Smith cemetery, Burial 9, Vessel 61.

ORIFICE DIAMETER (IN CM): 13.5

DIAMETER AT BOTTOM OF RIM OR NECK (IN CM): 13.0

BASE DIAMETER (IN CM) AND SHAPE OF BASE: 6.8; circular and flat

ESTIMATED VOLUME (IN LITERS): 1.26

DECORATION (INCLUDING MOTIF AND ELEMENTS WHEN APPARENT): The rim of the vessel is plain, but the vessel body has 14 vertical appliqued fillets that extend from the rim-body juncture to the base (Figure 73).

PIGMENT USE AND LOCATION ON VESSEL: none

TYPE AND VARIETY [IF KNOWN]: Cass Appliqued 
VESSEL NO.: Burial 9, Vessel 62; 2003.08.726

NON-PLASTICS AND PASTE: grog; sandy paste

VESSEL FORM: Carinated bowl

RIM AND LIP FORM: Direct rim and a rounded, exterior folded lip

CORE COLOR: $\mathrm{F}$ (fired in a reducing environment and cooled in the open air)

INTERIOR SURFACE COLOR: dark yellowish-brown

EXTERIOR SURFACE COLOR: reddish-brown; fire clouds on the rim and body

WALL THICKNESS (RIM, BODY, AND BASE IN MM): rim, 7.2 mm

INTERIOR SURFACE TREATMENT: smoothed

EXTERIOR SURFACE TREATMENT: smoothed

HEIGHT (IN CM): 12.9

ORIFICE DIAMETER (IN CM): 29.0

DIAMETER AT BOTTOM OF RIM OR NECK (IN CM): 27.5

BASE DIAMETER (IN CM) AND SHAPE OF

BASE: 7.5; circular and flat

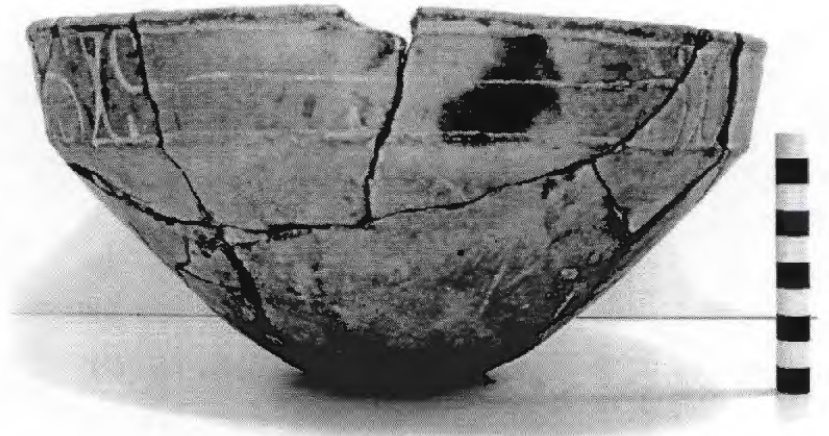

Figure 74. Ripley Engraved, cf. var. Gandy carinated bowl, Enis Smith cemetery, Burial 9, Vessel 62.

ESTIMATED VOLUME (IN LITERS): 2.24

DECORATION (INCLUDING MOTIF AND ELEMENTS WHEN APPARENT): The rim panel has an engraved scroll motif repeated four times around the vessel. The horizontal scrolls are divided by vertical engraved brackets (with a central excised zone). Above and below each of the scrolls are a few small and widely spread excised pendant triangles (Figure 74).

PIGMENT USE AND LOCATION ON VESSEL: white pigment in the engraved lines TYPE AND VARIETY [IF KNOWN]: Ripley Engraved, cf. var. Gandy 
VESSEL NO.: Burial 9, Vessel 63; 2003.08.986

NON-PLASTICS AND PASTE: grog

VESSEL FORM: Carinated bowl

RIM AND LIP FORM: Everted rim and a rounded, exterior folded lip

CORE COLOR: F (fired in a reducing environment and cooled in the open air)

INTERIOR SURFACE COLOR: yellowish-brown

EXTERIOR SURFACE COLOR: yellowish-brown; fire clouds on the rim, body, and base

WALL THICKNESS (RIM, BODY, AND BASE IN MM): rim, $5.6 \mathrm{~mm}$

INTERIOR SURFACE TREATMENT: smoothed

EXTERIOR SURFACE TREATMENT:

smoothed

HEIGHT (IN CM): 8.3

ORIFICE DIAMETER (IN CM): 19.7

DIAMETER AT BOTTOM OF RIM OR NECK (IN CM): 18.1

BASE DIAMETER (IN CM) AND SHAPE OF BASE: 6.7 ; circular and flat

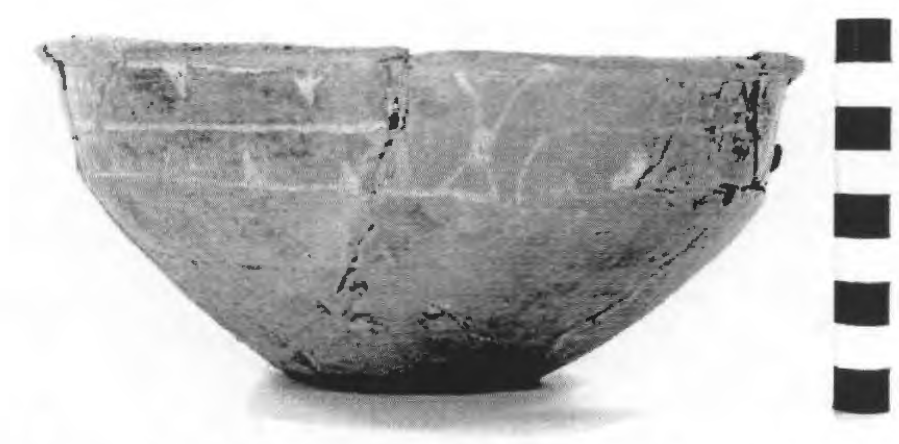

Figure 75. Ripley Engraved, cf. var. Gandy carinated bowl, Enis Smith cemetery, Burial 9, Vessel 63.

ESTIMATED VOLUME (IN LITERS): 0.98

DECORATION (INCLUDING MOTIF AND ELEMENTS WHEN APPARENT): The rim panel has an engraved scroll motif repeated four times around the vessel. The horizontal scrolls are divided by vertical engraved brackets (with a central excised zone). Above and below each of the scrolls are large excised pendant triangles (Figure 75).

There is also a single horizontal engraved line on the interior vessel surface at the carination point.

PIGMENT USE AND LOCATION ON VESSEL: none

TYPE AND VARIETY [IF KNOWN]: Ripley Engraved, cf. var. Gandy 
VESSEL NO.: Burial 9, Vessel 64; 2003.08.292

NON-PLASTICS AND PASTE: grog and bone

VESSEL FORM: Jar with a short rim

RIM AND LIP FORM: Direct rim and a rounded, exterior folded lip

CORE COLOR: $\mathrm{H}$ (fired in a reducing environment and cooled in the open air)

INTERIOR SURFACE COLOR: yellowish-brown

EXTERIOR SURFACE COLOR: grayish-brown with fire clouds on the upper body and rim

WALL THICKNESS (RIM, BODY, AND BASE IN MM): rim, $7.0 \mathrm{~mm}$

INTERIOR SURFACE TREATMENT: smoothed

EXTERIOR SURFACE TREATMENT: none

HEIGHT (IN CM): 16.6

ORIFICE DIAMETER (IN CM): 10.8

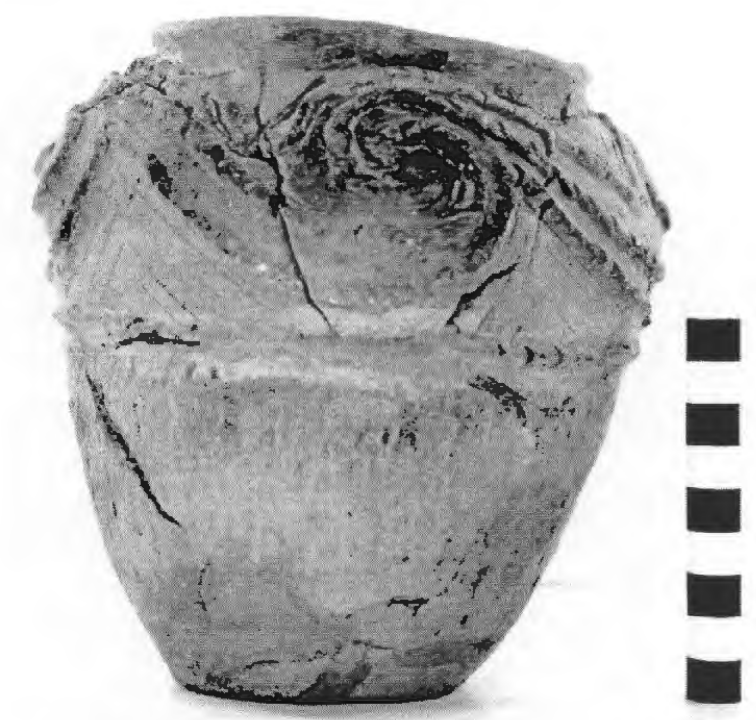

Figure 76. Harleton Appliqued jar, Enis Smith cemetery, Burial 9, Vessel 64.

DIAMETER AT BOTTOM OF RIM OR NECK (IN CM): 10.3

BASE DIAMETER (IN CM) AND SHAPE OF BASE: 7.0; circular and flat

ESTIMATED VOLUME (IN LITERS): 1.61

DECORATION (INCLUDING MOTIF AND ELEMENTS WHEN APPARENT): The rim of the vessel has an appliqued fillet scroll motif that is repeated four times around the vessel. The scrolls end in hooked arm appliqued fillet elements. Appliqued fillet scroll fill zones have large diagonal opposed incised triangles (Figure 76).

The vessel body is defined by two closely-spaced single horizontal appliqued fillets at the rim-body juncture. There are four large appliqued nodes on the body, placed underneath each of the hooked arm elements on the rim. The remainder of the body has vertical rows of linear tool punctations that extend from just below the rim-body juncture to within $4 \mathrm{~cm}$ of the vessel base (Figure 76).

PIGMENT USE AND LOCATION ON VESSEL: none

TYPE AND VARIETY [IF KNOWN]: Harleton Appliqued 
VESSEL NO.: Burial 9, Vessel 65; 2003.08.1808

NON-PLASTICS AND PASTE: grog and bone

VESSEL FORM: Carinated bowl

RIM AND LIP FORM: Direct rim and a rounded, exterior folded lip

CORE COLOR: $\mathrm{F}$ (fired in a reducing environment and cooled in the open air)

INTERIOR SURFACE COLOR: grayish-brown

EXTERIOR SURFACE COLOR: grayish-brown with fire clouds on the rim, body, and base

WALL THICKNESS (RIM, BODY, AND BASE IN MM): rim, $5.4 \mathrm{~mm}$

INTERIOR SURFACE TREATMENT: smoothed

EXTERIOR SURFACE TREATMENT: smoothed

HEIGHT (IN CM): 8.6

ORIFICE DIAMETER (IN CM): 18.5

DIAMETER AT BOTTOM OF RIM OR NECK (IN CM): 17.3

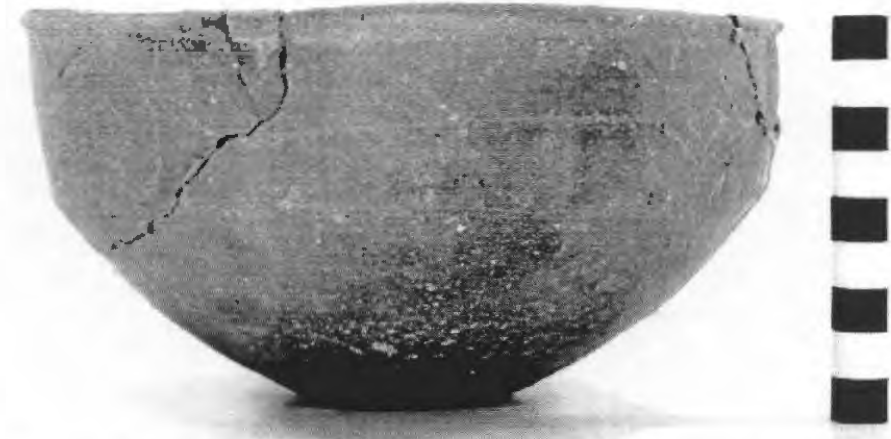

Figure 77. Ripley Engraved, var. McKinney carinated bowl, Enis Smith cemetery, Burial 9, Vessel 65.

BASE DIAMETER (IN CM) AND SHAPE OF BASE: 6.0; circular and flat

ESTIMATED VOLUME (IN LITERS): 0.95

DECORATION (INCLUDING MOTIF AND ELEMENTS WHEN APPARENT): The rim panel features alternating circle in circle and diamond within diamond elements that are each repeated two times. The diamond within diamond element is the central feature in a horizontal scroll motif that is also repeated four times; the scrolls do not connect with the circle and circle elements. Above and below each of the scrolls are small excised pendant triangles (Figure 77).

There is also a single horizontal engraved line on the interior vessel surface at the carination point.

PIGMENT USE AND LOCATION ON VESSEL: white pigment in engraved lines on exterior surface TYPE AND VARIETY [IF KNOWN]: Ripley Engraved, var. McKinney 


\section{Burial 10}

This burial is situated in the southern part of the Enis Smith cemetery, a few feet north and northeast of Burials 11 and 12 (see Figure 8). The burial pit was a maximum of $1.22 \mathrm{~m}$ in width, and had a number of ceramic vessels placed in the grave as funerary offerings (Figure 78); information on the length or depth of the burial was not provided by Jones (n.d.).

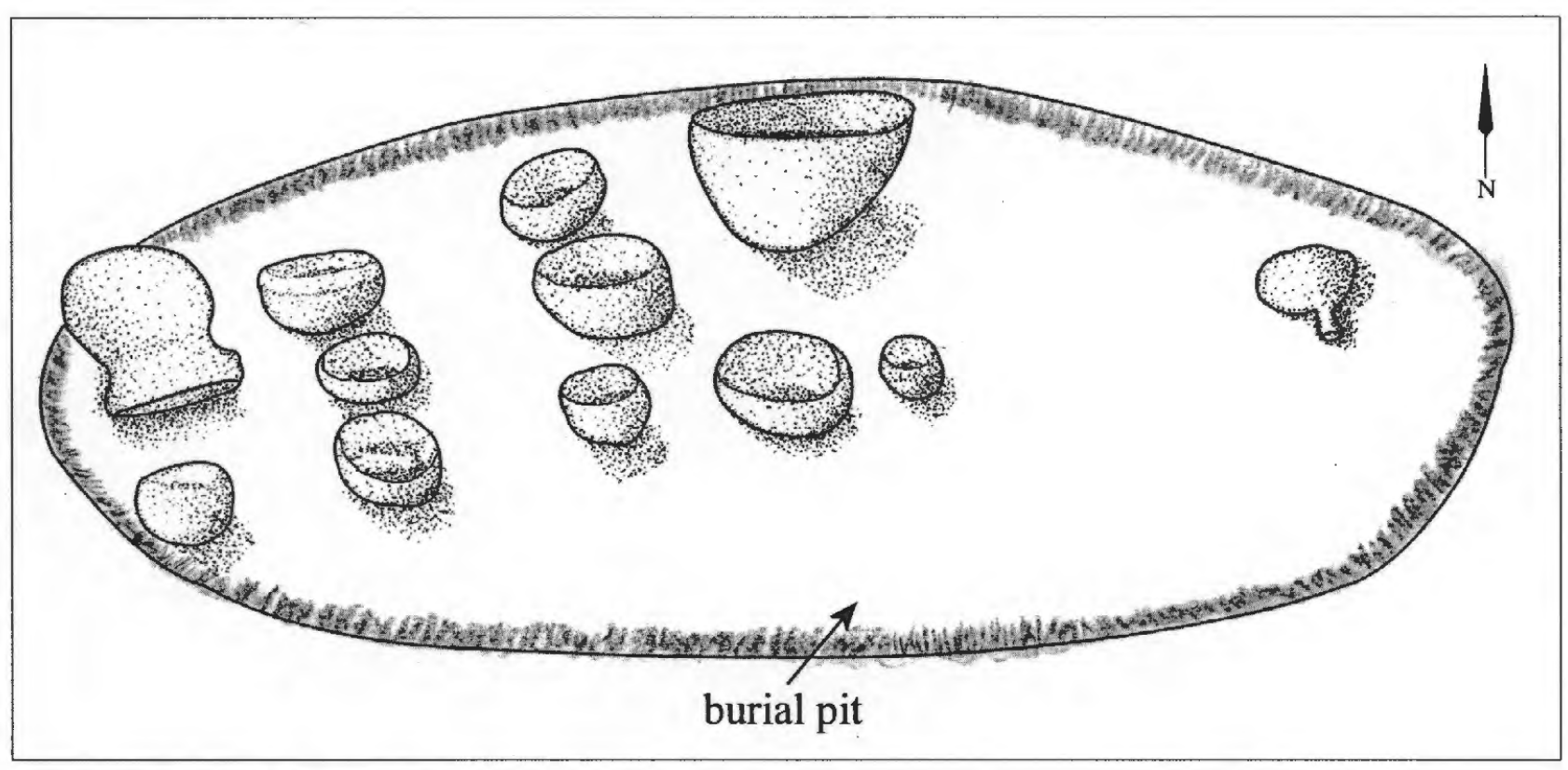

Figure 78. Burial 10 at the Enis Smith site.

A bottle had been placed near what would have been the head area of the deceased, and the other vessels appear to have been placed along the lower body and feet areas. The vessels in the collection include an engraved-punctated bottle, two jars (Bullard Brushed and cf. Pease Brushed-Incised), a Ripley Engraved, var. Galt compound bowl, and five carinated bowls. These are Ripley Engraved, var. unspecified $(\mathrm{n}=1)$, Ripley Engraved, var. Galt $(\mathrm{n}=2)$, and Ripley Engraved, cf. var. Gandy $(\mathrm{n}=2)$.

VESSEL NO.: Burial 10, Vessel 66; 2003.08.224

NON-PLASTICS AND PASTE: grog and bone

VESSEL FORM: Carinated bowl

RIM AND LIP FORM: Direct rim and rounded, exterior folded lip

CORE COLOR: $\mathrm{F}$ (fired in a reducing environment and cooled in the open air)

INTERIOR SURFACE COLOR: yellowish-brown; fire cloud on the base

EXTERIOR SURFACE COLOR: yellowish-brown; fire clouds on the body and base 
WALL THICKNESS (RIM, BODY, AND BASE IN MM): rim, 4.9 mm

INTERIOR SURFACE TREATMENT: smoothed

EXTERIOR SURFACE TREATMENT: smoothed

HEIGHT (IN CM): 7.3

ORIFICE DIAMETER (IN CM): 16.1

DIAMETER AT BOTTOM OF RIM OR NECK (IN CM): I4.8

BASE DIAMETER (IN CM) AND SHAPE OF BASE: 6.4; circular and flat

ESTIMATED VOLUME (IN LITERS): 0.71

DECORATION (INCLUDING MOTIF AND ELEMENTS WHEN APPARENT): The rim panel has a horizontal scroll motif repeated twice around the vessel. The scroll motif features two engraved diamonds (Figure 79). The scrolls are divided by vertical brackets with excised central areas. Above and below each of the scrolls are a few excised pendant triangles, short vertical lines, one excised bracket, and two semicircular elements with vertical lines, small excised triangles and rectangles, and one negative oval.

There is also a horizontal engraved line on the vessel interior surface at the carination point.

PIGMENT USE AND LOCATION ON VESSEL: none

TYPE AND VARIETY [IF KNOWN]: Ripley Engraved, var. unspecified

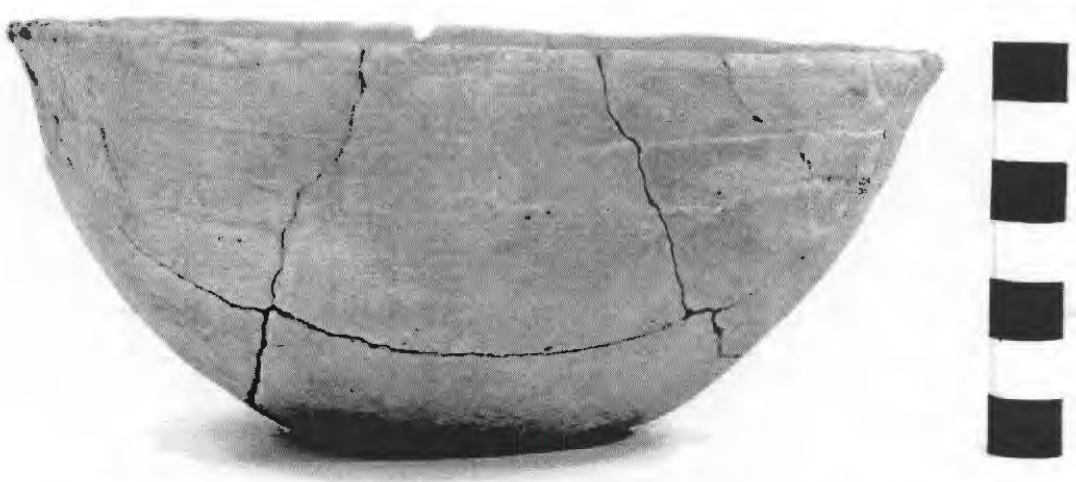

Figure 79. Ripley Engraved, var. unspecified carinated bowl, Enis Smith cemetery, Burial 10, Vessel 66. 
VESSEL NO.: Burial 10, Vessel 67; 2003.08.487

NON-PLASTICS AND PASTE: grog

VESSEL FORM: Compound bowl

RIM AND LIP FORM: Everted rim and a rounded, exterior folded lip

CORE COLOR: F (fired in a reducing environment and cooled in the open air)

INTERIOR SURFACE COLOR: yellowish-brown; fire clouds on the body and base

EXTERIOR SURFACE COLOR: yellowish-brown; fire clouds on the rim and body

WALL THICKNESS (RIM, BODY, AND BASE IN

$\mathrm{MM})$ : rim, $7.2 \mathrm{~mm}$

INTERIOR SURFACE TREATMENT: smoothed

EXTERIOR SURFACE TREATMENT: smoothed

HEIGHT (IN CM): 25.3

ORIFICE DIAMETER (IN CM): 35.4

DIAMETER AT BOTTOM OF RIM OR NECK (IN

CM): 31.2

BASE DIAMETER (IN CM) AND SHAPE OF

BASE: 7.6; circular and flat

ESTIMATED VOLUME (IN LITERS): 7.2

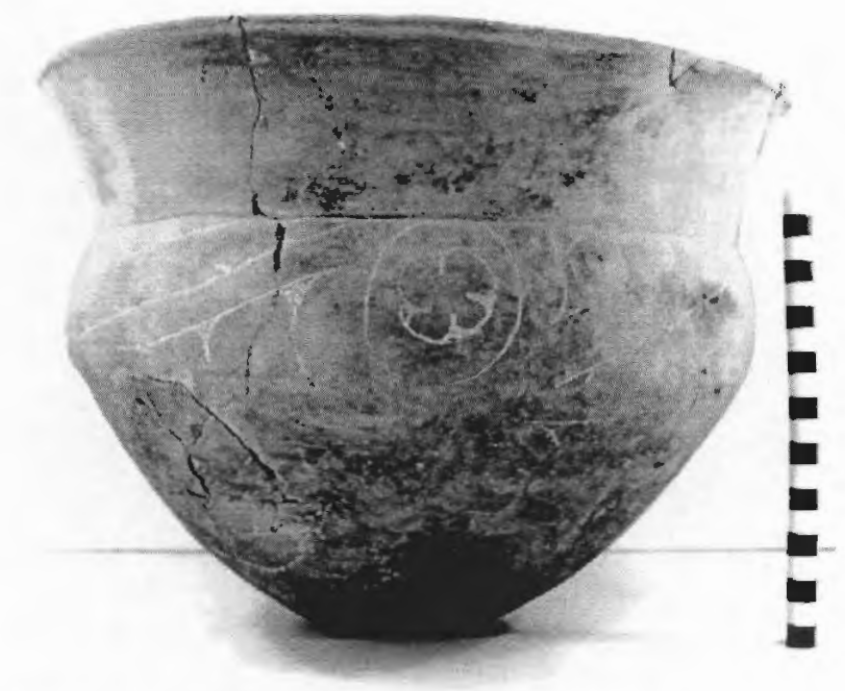

Figure 80. Ripley Engraved, var. Galt compound bowl, Enis Smith cemetery, Burial 10, Vessel 67.

DECORATION (INCLUDING MOTIF AND ELEMENTS WHEN APPARENT): The upper rim panel is plain. The lower rim panel has an engraved scroll and circle motif repeated four times around the vessel. The central circles are circles within circles, and the inner circle has four excised pendant triangles that form the shape of peyote "buttons." The scroll center line has spurs on one side, while the upper and lower scroll fill zones have negative ovals formed by excised brackets and vertical lines (Figure 80).

PIGMENT USE AND LOCATION ON VESSEL: white pigment in the engraved lines TYPE AND VARIETY [IF KNOWN]: Ripley Engraved, var. Galt 
VESSEL NO.: Burial 10, Vessel 68; 2003.08.409

NON-PLASTICS AND PASTE: grog and hematite

VESSEL FORM: Carinated bowl

RIM AND LIP FORM: Everted rim and a rounded, exterior folded lip

CORE COLOR: A (fired and cooled in an oxidizing environment)

INTERIOR SURFACE COLOR: reddish-brown

EXTERIOR SURFACE COLOR: reddish-brown

WALL THICKNESS (RIM, BODY, AND BASE IN MM): rim, $4.3 \mathrm{~mm}$

INTERIOR SURFACE TREATMENT: smoothed

EXTERIOR SURFACE TREATMENT: burnished

HEIGHT (IN CM): 3.4

ORIFICE DIAMETER (IN CM): 10.8

DIAMETER AT BOTTOM OF RIM OR NECK (IN CM): 8.5

BASE DIAMETER (IN CM) AND SHAPE OF BASE: 5.6 ; circular and flat

ESTIMATED VOLUME (IN LITERS): 0.22

DECORATION (INCLUDING MOTIF AND ELEMENTS WHEN APPARENT): The rim panel has an engraved scroll and circle motif repeated four times around the vessel. Each of the circles has an equal-arm cross within it. The scroll fill zones have a single negative oval formed by excised brackets and triangles (Figure 81).

PIGMENT USE AND LOCATION ON VESSEL: none

TYPE AND VARIETY [IF KNOWN]: Ripley Engraved, var. Galt

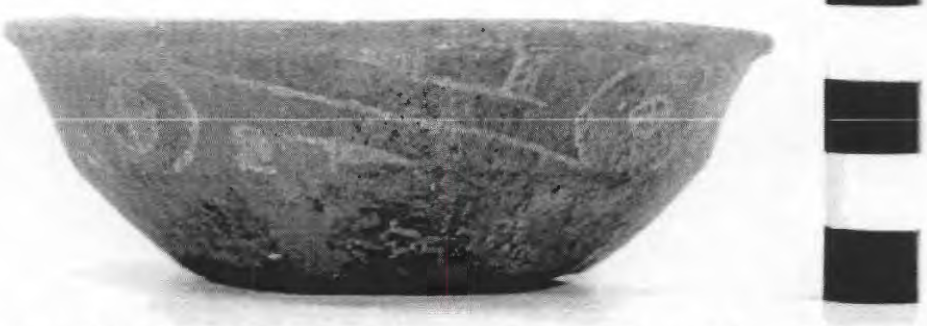

Figure 81. Ripley Engraved, var. Galt carinated bowl, Enis Smith cemetery, Burial 10, Vessel 68. 
VESSEL NO.: Burial 10, Vessel 69; 2003.08.567

NON-PLASTICS AND PASTE: grog and hematite; sandy paste

VESSEL FORM: Carinated bowl

RIM AND LIP FORM: Direct rim and a rounded, exterior folded lip

CORE COLOR: $F$ (fired in a reducing environment and cooled in the open air)

INTERIOR SURFACE COLOR: reddish-brown; fire clouds on lower body and base

EXTERIOR SURFACE COLOR: reddish-brown; fire clouds on the body and base

WALL THICKNESS (RIM, BODY, AND BASE IN MM): rim, $5.6 \mathrm{~mm}$

INTERIOR SURFACE TREATMENT: smoothed

EXTERIOR SURFACE TREATMENT: burnished

HEIGHT (IN CM): 7.7

ORIFICE DIAMETER (IN CM): 19.8

DIAMETER AT BOTTOM OF RIM OR NECK (IN CM): 18.0

BASE DIAMETER (IN CM) AND SHAPE OF BASE: 7.4; circular and flat

ESTIMATED VOLUME (IN LITERS): 0.9I

DECORATION (INCLUDING MOTIF AND ELEMENTS WHEN APPARENT): The rim panel has an engraved scroll motif repeated four times around the vessel. The horizontal scrolls are divided by vertical engraved brackets (with a central excised zone). Above and below each of the scrolls are excised pendant triangles (Figure 82).

PIGMENT USE AND LOCATION ON VESSEL: white pigment in the engraved lines

TYPE AND VARIETY [IF KNOWN]: Ripley Engraved, cf. var. Gandy

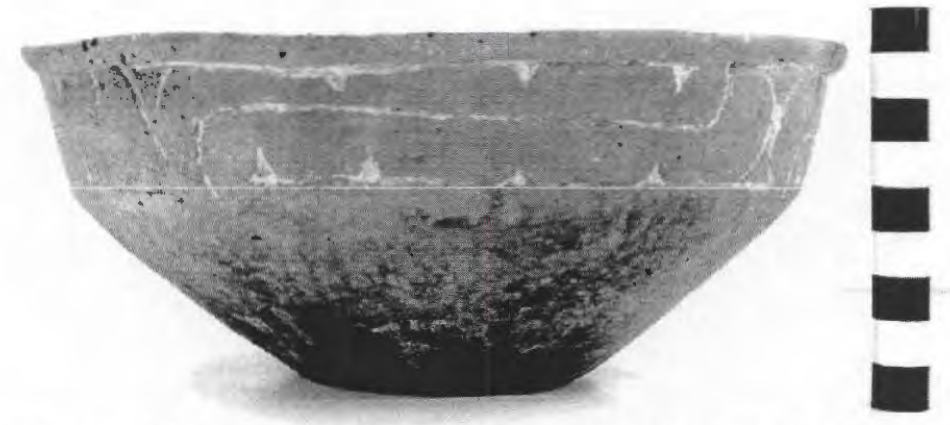

Figure 82. Ripley Engraved, cf. var. Gandy carinated bowl, Enis Smith cemetery, Burial 10, Vessel 69. 
VESSEL NO.: Burial 10, Vessel 70; 2003.08.796

NON-PLASTICS AND PASTE: grog and hematite

VESSEL FORM: Jar

RIM AND LIP FORM: Everted rim and rounded, exterior folded lip

CORE COLOR: $\mathrm{G}$ (fired in a reducing environment and cooled in the open air)

INTERIOR SURFACE COLOR: dark grayish-brown

EXTERIOR SURFACE COLOR: yellowish-brown; fire clouds on the body and base; organic residue on the rim and body

WALL THICKNESS (RIM, BODY, AND BASE IN MM): rim, $5.2 \mathrm{~mm}$

INTERIOR SURFACE TREATMENT: smoothed

EXTERIOR SURFACE TREATMENT: none

HEIGHT (IN CM): 14.5

ORIFICE DIAMETER (IN CM): 13.0

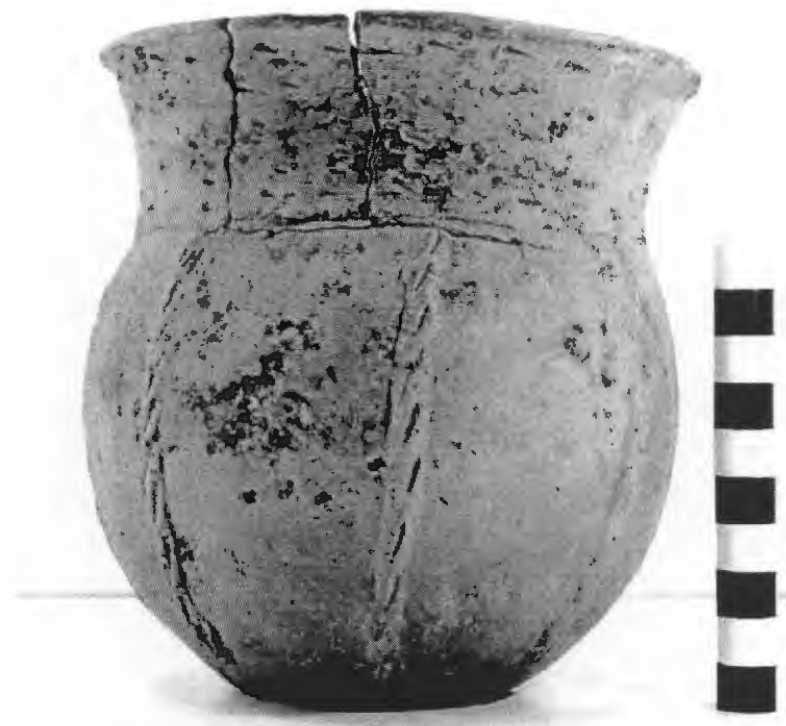

Figure 83. cf. Pease Brushed-Incised jar, Enis Smith cemetery, Burial 10, Vessel 70.

DIAMETER AT BOTTOM OF RIM OR NECK (IN CM): 11.1

BASE DIAMETER (IN CM) AND SHAPE OF BASE: 6.2; circular and flat

ESTIMATED VOLUME (IN LITERS): 1.1

DECORATION (INCLUDING MOTIF AND ELEMENTS WHEN APPARENT): The rim is decorated with horizontal brushing marks as well as four horizontal tool punctated rows pushed through the brushing. The vessel body has eight rows of vertical appliqued fillets that extend from the rim-body juncture to $2.0 \mathrm{~cm}$ above the base. The panels created by the fillets are plain (Figure 83).

PIGMENT USE AND LOCATION ON VESSEL: none

TYPE AND VARIETY [IF KNOWN]: cf. Pease Brushed-Incised 
VESSEL NO.: Burial 10, Vessel 72; 2003.08.494

NON-PLASTICS AND PASTE: grog and hematite

VESSEL FORM: Carinated bowl

RIM AND LIP FORM: Direct rim and a rounded, exterior folded lip

CORE COLOR: $\mathrm{F}$ (fired in a reducing environment and cooled in the open air)

INTERIOR SURFACE COLOR: yellowish-brown

EXTERIOR SURFACE COLOR: yellowish-brown;

fire clouds on the rim

WALL THICKNESS (RIM, BODY, AND BASE IN

$\mathrm{MM}$ ): rim, $5.8 \mathrm{~mm}$; body, $6.2 \mathrm{~mm}$; base, $8.1 \mathrm{~mm}$

INTERIOR SURFACE TREATMENT: smoothed

EXTERIOR SURFACE TREATMENT: smoothed

HEIGHT (IN CM): 16.8

ORIFICE DIAMETER (IN CM): 27.0

DIAMETER AT BOTTOM OF RIM OR NECK (IN CM): 24.0

BASE DIAMETER (IN CM) AND SHAPE OF

BASE: 8.7 ; circular and flat

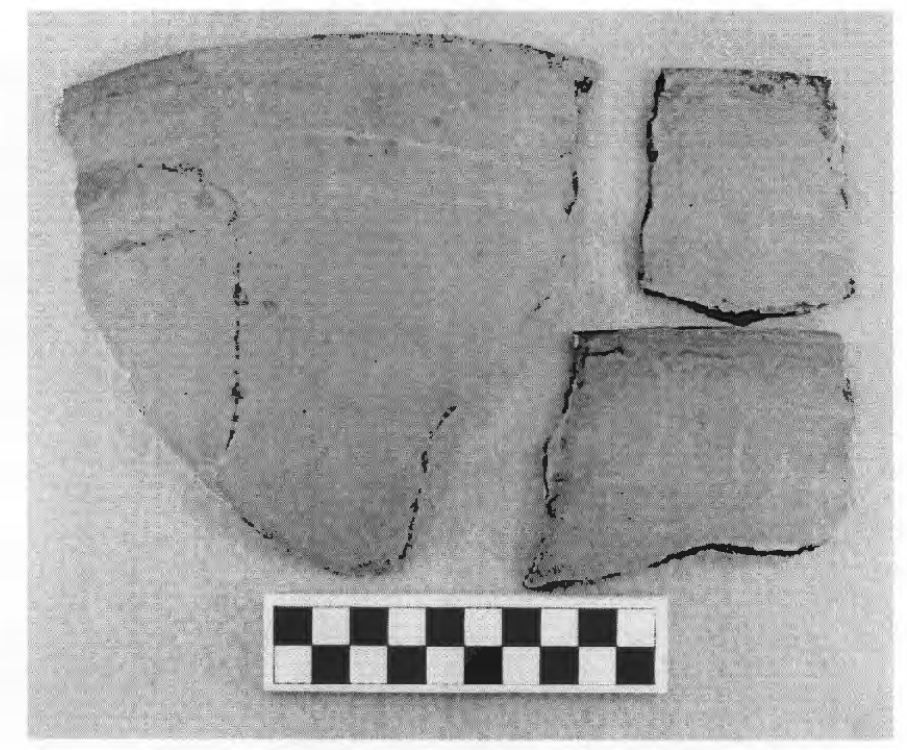

BASE: 8.7; circular and flat

ESTIMATED VOLUME (IN LITERS): 4.1

Figure 84. Ripley Engraved, cf. var. Gandy carinated bowl rim and body section, Enis Smith cemetery, Burial 10, Vessel 72.

DECORATION (INCLUDING MOTIF AND ELEMENTS WHEN APPARENT): The rim panel has an engraved scroll motif repeated four times around the vessel. The scrolls are divided by four hatched brackets. There are rows of excised pendant triangles both above and below the scroll elements (Figure 84).

There also is a single horizontal engraved line on the interior vessel surface at the carination.

PIGMENT USE AND LOCATION ON VESSEL: none

TYPE AND VARIETY [IF KNOWN]: Ripley Engraved, cf. var. Gandy 
VESSEL NO.: Burial 10, Vessel 74

NON-PLASTICS AND PASTE: grog, hematite, and bone

VESSEL FORM: Carinated bowl

RIM AND LIP FORM: Direct rim and a rounded, exterior folded lip

CORE COLOR: F (fired in a reducing environment and cooled in the open air)

INTERIOR SURFACE COLOR: reddish-brown

EXTERIOR SURFACE COLOR: reddish-brown; fire clouds on the rim and body

WALL THICKNESS (RIM, BODY, AND

BASE IN MM): rim, $7.4 \mathrm{~mm}$

INTERIOR SURFACE TREATMENT:

smoothed

EXTERIOR SURFACE TREATMENT:

smoothed

HEIGHT (IN CM): 13.7

ORIFICE DIAMETER (IN CM): 25.8

DIAMETER AT BOTTOM OF RIM OR

NECK (IN CM): 22.8

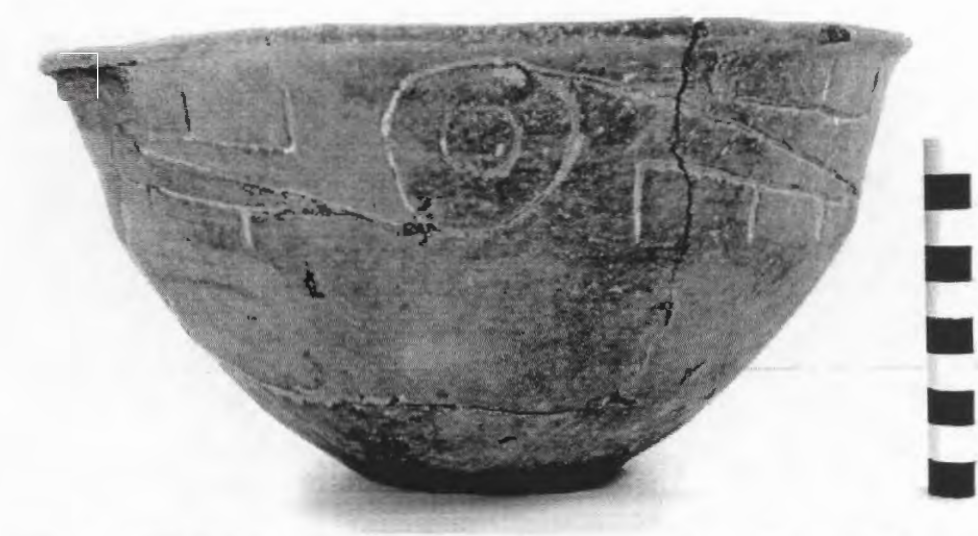

Figure 85. Ripley Engraved, var. Galt carinated bowl, Enis Smith cemetery, Burial 10, Vessel 74.

BASE DIAMETER (IN CM) AND SHAPE OF BASE: 8.9; circular and flat

ESTIMATED VOLUME (IN LITERS): 3.2

DECORATION (INCLUDING MOTIF AND ELEMENTS WHEN APPARENT): The rim has an engraved scroll and circle motif repeated four times around the vessel. The circles have an inner circle, while the scroll fill zones have vertical engraved and excised lines. The upper and lower part of the scroll itself end in excised triangles that touch the outer central circles (Figure 85).

PIGMENT USE AND LOCATION ON VESSEL: white pigment in the engraved lines

TYPE AND VARIETY [IF KNOWN]: Ripley Engraved, var. Galt 
VESSEL NO.: Burial 10, Vessel 75; 2003.08 .93

NON-PLASTICS AND PASTE: grog; sandy paste

VESSEL FORM: Bottle with a flaring neck

RIM AND LIP FORM: Everted rim and a rounded lip

CORE COLOR: $\mathrm{B}$ (fired and cooled in a reducing environment)

INTERIOR SURFACE COLOR: dark grayish-brown

EXTERIOR SURFACE COLOR: dark grayish-brown

WALL THICKNESS (RIM, BODY, AND BASE IN MM):

rim, $4.7 \mathrm{~mm}$

INTERIOR SURFACE TREATMENT: none

EXTERIOR SURFACE TREATMENT: smoothed

HEIGHT (IN CM): 13.9

ORIFICE DIAMETER (IN CM): 3.8

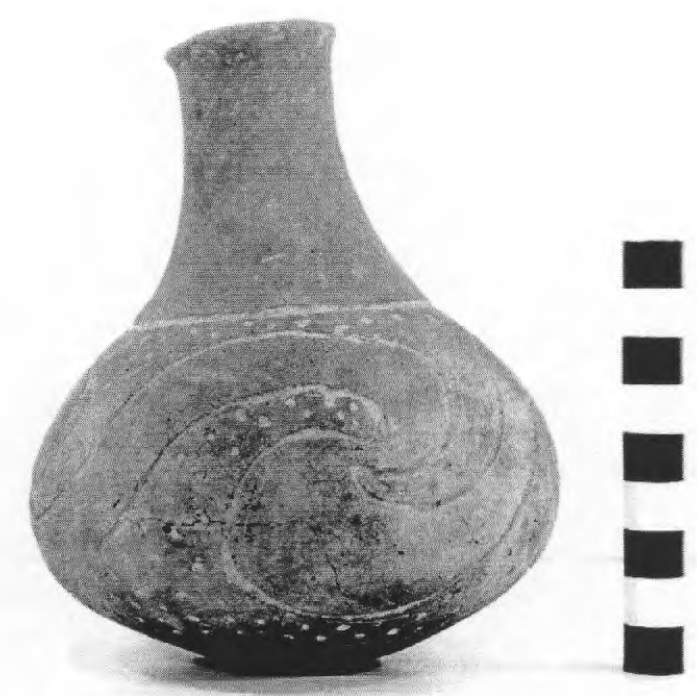

Figure 86. Engraved-punctated bottle, Enis Smith cemetery, Burial 10, Vessel 75.

DIAMETER AT BOTTOM OF RIM OR NECK (IN CM): 6.7 ; maximum body diameter is $11.0 \mathrm{~cm}$

BASE DIAMETER (IN CM) AND SHAPE OF BASE: 4.3; circular and rounded

ESTIMATED VOLUME (IN LITERS): 0.24

DECORATION (INCLUDING MOTIF AND ELEMENTS WHEN APPARENT): The bottle body has hooked arm engraved scrolls that are filled with tool punctations (Figure 86). The hooked arm scrolls, similar to several Johns Engraved vessels (see Turner 1978:Figure 31d-e), are repeated four times around the vessel.

PIGMENT USE AND LOCATION ON VESSEL: none

TYPEAND VARIETY [IF KNOWN]: Unidentified fine ware, possibly Johns Engraved 
VESSEL NO.: Burial 10, Vessel 76; 2003.08.438

NON-PLASTICS AND PASTE: grog; sandy paste

VESSEL FORM: Jar

RIM AND LIP FORM: Everted rim and a rounded, exterior folded lip

CORE COLOR: $\mathrm{G}$ (fired in a reducing environment and cooled in the open air)

INTERIOR SURFACE COLOR: dark grayish-brown

EXTERIOR SURFACE COLOR: reddish-brown; fire clouds on the rim and upper body

WALL THICKNESS (RIM, BODY, AND BASE IN MM): rim, $6.8 \mathrm{~mm}$

INTERIOR SURFACE TREATMENT: smoothed

EXTERIOR SURFACE TREATMENT: smoothed on the lower body

HEIGHT (IN CM): 24.4

ORIFICE DIAMETER (IN CM): 22.3

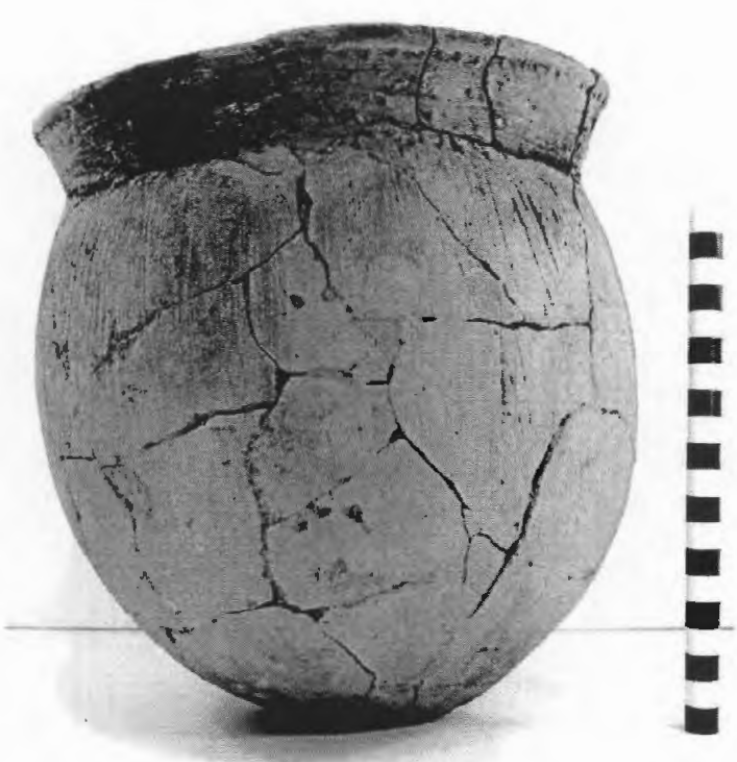

Figure 87. Bullard Brushed jar, Enis Smith cemetery, Burial 10, Vessel 76.

DIAMETER AT BOTTOM OF RIM OR NECK (IN CM): 19.3

BASE DIAMETER (IN CM) AND SHAPE OF BASE: 7.5; circular and flat

ESTIMATED VOLUME (IN LITERS): 7.1

DECORATION (INCLUDING MOTIF AND ELEMENTS WHEN APPARENT): The rim has horizontal brushing marks, as well as four horizontal rows of tool punctations that have been pushed through the brushing. The vessel body has vertical brushing marks that extend from the rim-body juncture to $4.5 \mathrm{~cm}$ above the base (Figure 87).

PIGMENT USE AND LOCATION ON VESSEL: none

TYPE AND VARIETY [IF KNOWN]: Bullard Brushed 


\section{Burial 11}

Burial 11 is in the southern part of the Enis Smith cemetery, a few feet west of Burial 12 (see Figure 8 ). The burial pit was $3.10 \mathrm{~m}$ in length, $0.84 \mathrm{~m}$ in width, and reached a depth of $1.04 \mathrm{~m}$, extending into the clay B-horizon (Figure 88).

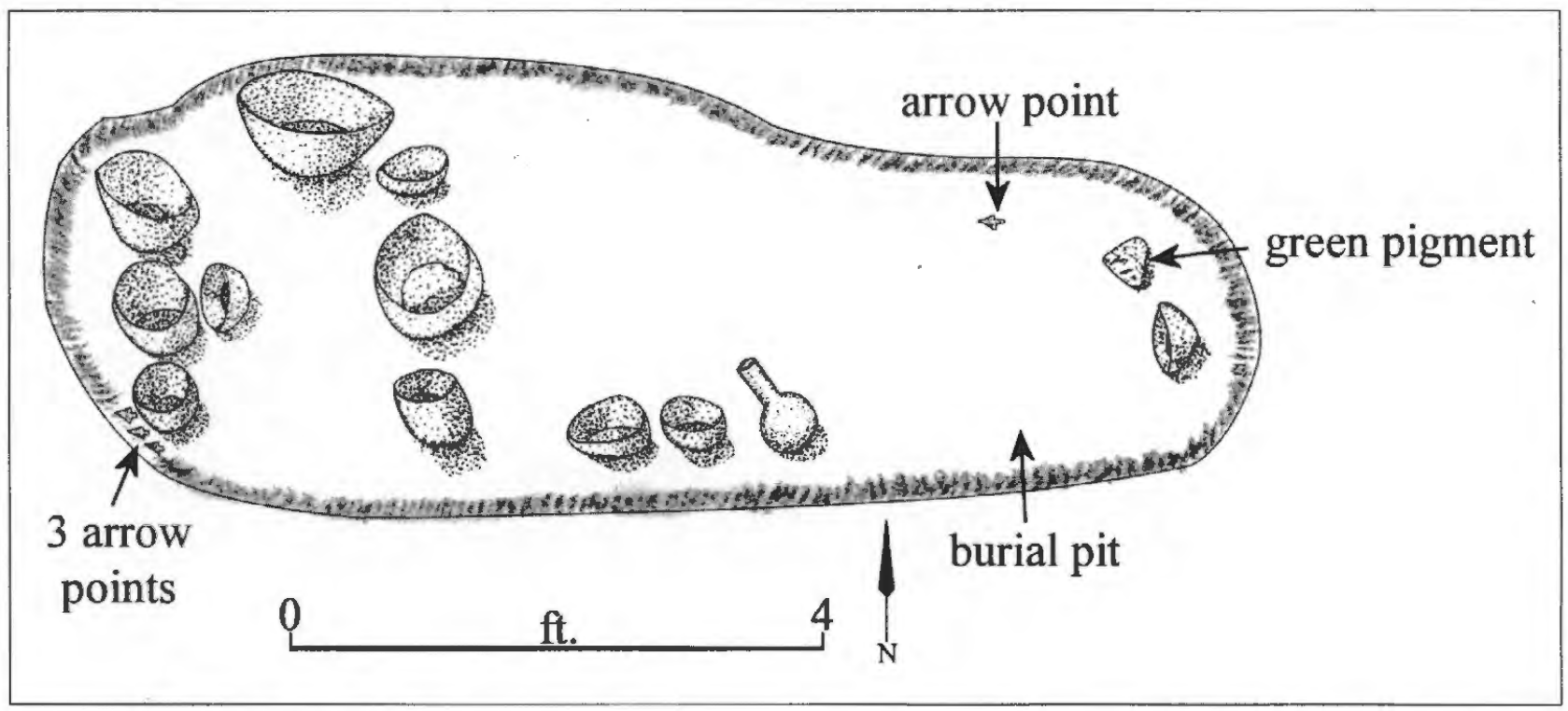

Figure 88. Burial 11 at the Enis Smith site.

According to Jones (n.d.), the burial had several kinds of funerary offerings, including a green glauconitic clay pigment mass near what would have been the head area, four arrow points (of unknown type), and 12 ceramic vessels. The vessels were placed along what would have been the left side of the body, as well as the lower part of the right leg, and by the feet (see Figure 88).

The collection from this burial includes 13 vessels, one more than depicted on Jones' burial map. There is one unidentified engraved bottle, three jars (two Harleton Appliqued and one Bullard Brushed vessels), and nine carinated bowls. These have been identified as Ripley Engraved, cf. var. Gandy $(\mathrm{n}=3)$, Ripley Engraved, var. McKinney ( $\mathrm{n}=4)$, Ripley Engraved, var. unspecified $(\mathrm{n}=1)$, and an unidentified engraved type $(n=1)$. 
VESSEL NO.: Burial 11, Vessel 78; 2003.08.1803

NON-PLASTICS AND PASTE: grog and bone; sandy paste

VESSEL FORM: Carinated bowl

RIM AND LIP FORM: Direct rim and a rounded lip

CORE COLOR: A (fired and cooled in an oxidizing environment)

INTERIOR SURFACE COLOR: reddish-brown

EXTERIOR SURFACE COLOR: reddish-brown; fire clouds on the body and base

WALL THICKNESS (RIM, BODY, AND BASE

IN MM): rim, $8.4 \mathrm{~mm}$

INTERIOR SURFACE TREATMENT:

smoothed on the rim

EXTERIOR SURFACE TREATMENT:

smoothed

HEIGHT (IN CM): 9.2

ORIFICE DIAMETER (IN CM): 18.5

DIAMETER AT BOTTOM OF RIM OR NECK

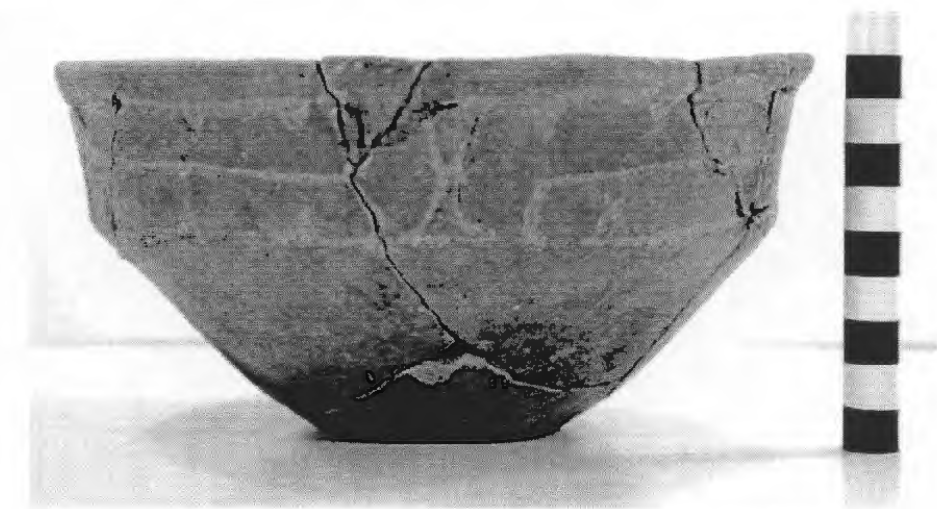

Figure 89. Ripley Engraved, cf. var. Gandy carinated bowl, Enis Smith cemetery, Burial 11, Vessel 78.

(IN CM): 18.2

BASE DIAMETER (IN CM) AND SHAPE OF BASE: 6.5 ; circular and flat

ESTIMATED VOLUME (IN LITERS): 1.0

DECORATION (INCLUDING MOTIF AND ELEMENTS WHEN APPARENT): The rim panel has an engraved scroll motif repeated four times around the vessel. The scrolls are divided by vertical brackets with a single interior diagonal engraved line. Above and below each of the scrolls are sets of large excised pendant triangles (Figure 89).

PIGMENT USE AND LOCATION ON VESSEL: none

TYPE AND VARIETY [IF KNOWN]: Ripley Engraved, cf. var. Gandy 
VESSEL NO:: Burial 11, Vessel 79; 2003.08.1772

NON-PLASTICS AND PASTE: grog

VESSEL FORM: Carinated bowl

RIM AND LIP FORM: Direct rim and a rounded, exterior folded lip

CORE COLOR: N/A

INTERIOR SURFACE COLOR: N/A

EXTERIOR SURFACE COLOR: N/A

WALL THICKNESS (RIM, BODY, AND

BASE IN MM): rim, $5.6 \mathrm{~mm}$

INTERIOR SURFACE TREATMENT: N/A

EXTERIOR SURFACE TREATMENT: N/A

HEIGHT (IN CM): 6.1

ORIFICE DIAMETER (IN CM): 12.5

DIAMETER AT BOTTOM OF RIM OR

NECK (IN CM): I1.4

BASE DIAMETER (IN CM) AND SHAPE

OF BASE: 5.7

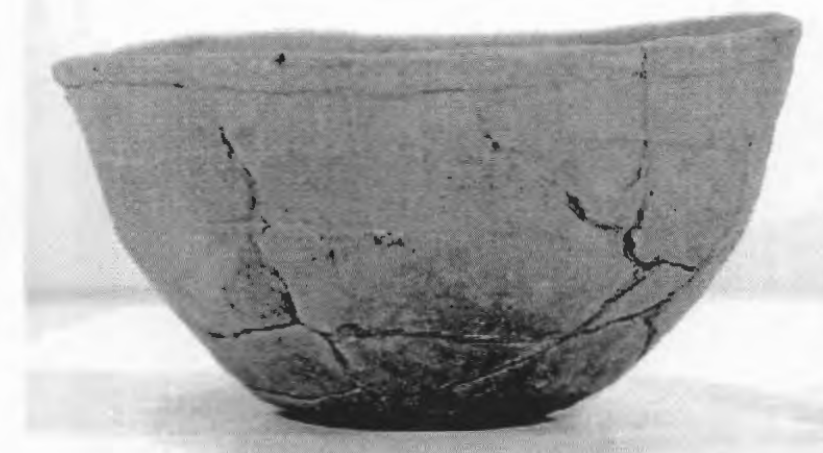

Figure 90. Ripley Engraved, var. unspecified carinated bowl, Enis Smith cemetery, Burial 11, Vessel 79.

ESTIMATED VOLUME (IN LITERS): 0.46

DECORATION (INCLUDING MOTIFAND ELEMENTS WHEN APPARENT): The rim panel has four sets of engraved rectangles, the bottom side of which has small excised pendant triangles. The rectangles also have small engraved pendant triangles. Within each of the larger rectangles are smaller rectangles with hatched or cross-hatched vertical sides (Figure 90).

PIGMENT USE AND LOCATION ON VESSEL: none

TYPE AND VARIETY [IF KNOWN]: Ripley Engraved, var. unspecified 
VESSEL NO.: Burial 11, Vessel 80; 2003.08.227

NON-PLASTICS AND PASTE: grog

VESSEL FORM: Carinated bowl

RIM AND LIP FORM: Direct rim and rounded, exterior folded lip

CORE COLOR: $\mathrm{F}$ (fired in a reducing environment and cooled in the open air)

INTERIOR SURFACE COLOR: reddish-brown; fire clouds on the rim, body, and base

EXTERIOR SURFACE COLOR: reddishbrown; fire clouds on the rim, body, and base

WALL THICKNESS (RIM, BODY, AND BASE IN MM): rim, $6.2 \mathrm{~mm}$

INTERIOR SURFACE TREATMENT: smoothed

EXTERIOR SURFACE TREATMENT: burnished

HEIGHT (IN CM): 7.1

ORIFICE DIAMETER (IN CM): 16.5

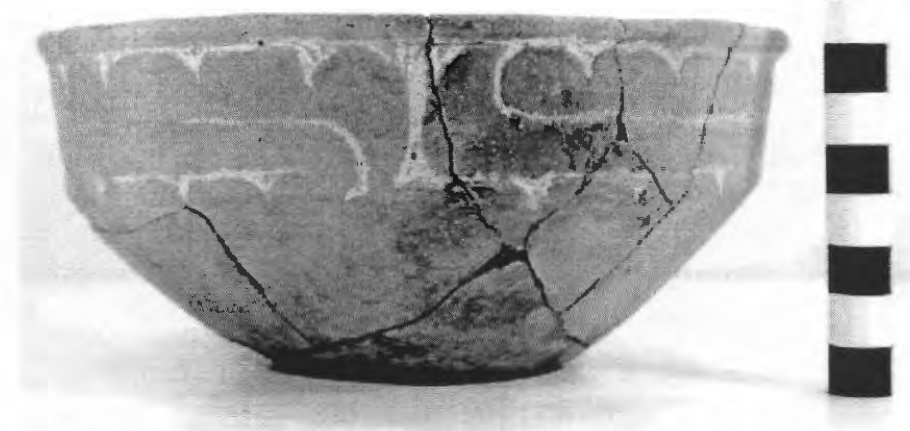

Figure 91. Ripley Engraved, cf. var. Gandy carinated bowl, Enis Smith cemetery, Burial 11, Vessel 80.

DIAMETER AT BOTTOM OF RIM OR NECK (IN CM): 15.6

BASE DIAMETER (IN CM) AND SHAPE OF BASE: 6.9; circular and flat

ESTIMATED VOLUME (IN LITERS): 0.70

DECORATION (INCLUDING MOTIF AND ELEMENTS WHEN APPARENT): The rim panel has an engraved scroll motif repeated four times around the vessel. The scrolls are divided by excised brackets and vertical engraved lines with upper and lower excised triangles. Above and below each of the scrolls are single rows of excised pendant triangles (Figure 91).

PIGMENT USE AND LOCATION ON VESSEL: white pigment in the engraved lines TYPE AND VARIETY [IF KNOWN]: Ripley Engraved, cf. var. Gandy 
VESSEL NO.: Burial 11, Vessel 81; 2003.08.631

NON-PLASTICS AND PASTE: grog

VESSEL FORM: Carinated bowl

RIM AND LIP FORM: Direct rim and a rounded, exterior folded lip

CORE COLOR: $\mathrm{F}$ (fired in a reducing environment and cooled in the open air)

INTERIOR SURFACE COLOR: yellowish-brown; fire clouds

EXTERIOR SURFACE COLOR: yellowish-brown; fire clouds on the body and base

WALL THICKNESS (RIM, BODY, AND

BASE IN MM): rim, $7.5 \mathrm{~mm}$; body, $8.3 \mathrm{~mm}$;

base, $8.3 \mathrm{~mm}$

INTERIOR SURFACE TREATMENT:

smoothed

EXTERIOR SURFACE TREATMENT:

burnished

HEIGHT (IN CM): 13.3

ORIFICE DIAMETER (IN CM): 29.5

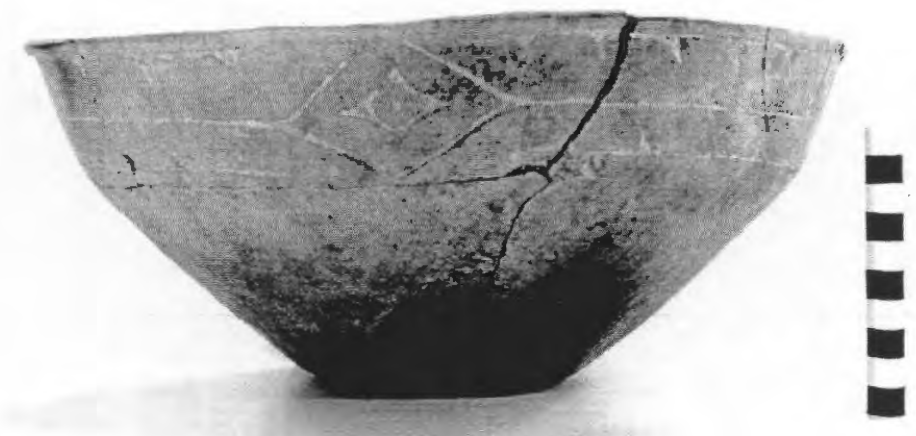

Figure 92. Ripley Engraved, var. McKinney carinated bowl, Enis Smith cemetery, Burial 11, Vessel 81.

DIAMETER AT BOTTOM OF RIM OR NECK (IN CM): 26.5

BASE DIAMETER (IN CM) AND SHAPE OF BASE: 10.2; circular and flat

ESTIMATED VOLUME (IN LITERS): 3.5

DECORATION (INCLUDING MOTIF AND ELEMENTS WHEN APPARENT): The rim panel has four alternating engraved circle and diamond elements. Each of these elements has an inner diamond with a negative circle formed by excised areas; the negative circles have a central excised dot (Figure 92). The engraved diamond elements are the central feature of horizontal scrolls that end in upper and lower excised brackets; the scrolls do not touch the central circles. Above and below each scroll are single rows of excised pendant triangles.

PIGMENT USE AND LOCATION ON VESSEL: white pigment in the engraved lines TYPE AND VARIETY [IF KNOWN]: Ripley Engraved, var. McKinney 
VESSEL NO.: Burial 11, Vessel 82; 2003.08.459

NON-PLASTICS AND PASTE: bone and hematite

VESSEL FORM: Jar

RIM AND LIP FORM: Everted rim and rounded lip

CORE COLOR: $\mathrm{G}$ (fired in a reducing environment and cooled in the open air)

INTERIOR SURFACE COLOR: dark grayish-brown

EXTERIOR SURFACE COLOR: yellowish-brown; fire clouds on the rim, body, and base; organic residue on the rim and body

WALL THICKNESS (RIM, BODY, AND BASE IN MM): rim, $6.9 \mathrm{~mm}$

INTERIOR SURFACE TREATMENT: smoothed

EXTERIOR SURFACE TREATMENT: smoothed on the lower body

HEIGHT (IN CM): 25.2

ORIFICE DIAMETER (IN CM): 23.9

DIAMETER AT BOTTOM OF RIM OR NECK (IN CM): 21.9

BASE DIAMETER (IN CM) AND SHAPE OF BASE: 8.6; circular and flat

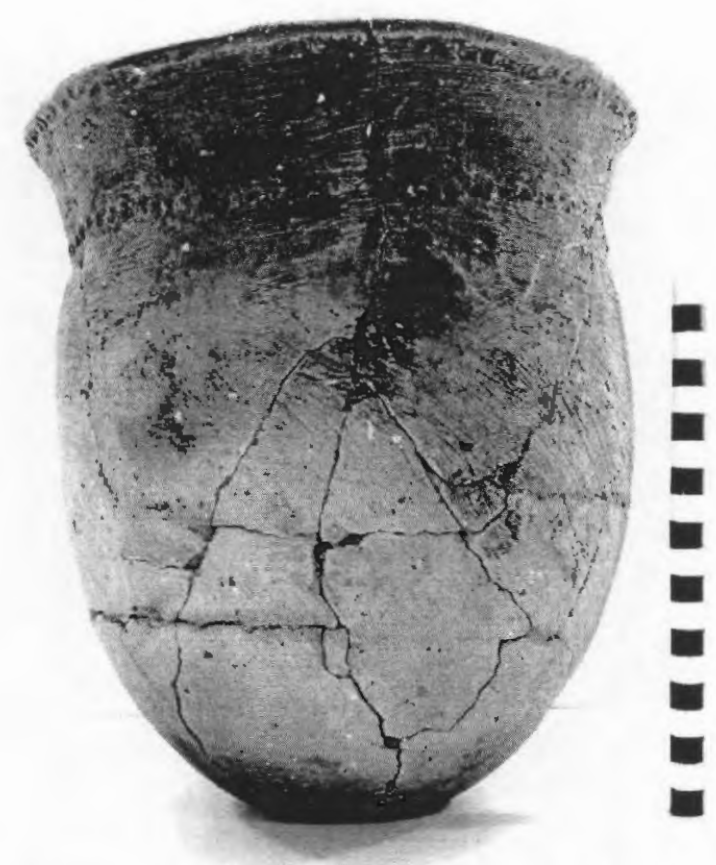

Figure 93. Bullard Brushed jar, Enis Smith cemetery, Burial 11, Vessel 82.

ESTIMATED VOLUME (IN LITERS): 7.8

DECORATION (INCLUDING MOTIF AND ELEMENTS WHEN APPARENT): The rim is decorated with horizontal brushing marks, as well as two rows of tool punctations. One row is under the lip and the other is at the rim-body juncture. The vessel body has diagonal and overlapping brushed marks from the rim-body juncture to within $8.0 \mathrm{~cm}$ of the base (Figure 93 ).

PIGMENT USE AND LOCATION ON VESSEL: none

TYPE AND VARIETY [IF KNOWN]: Bullard Brushed 
VESSEL NO.: Burial 11, Vessel 83; 2003.08.996

NON-PLASTICS AND PASTE: grog

VESSEL FORM: Carinated bowl

RIM AND LIP FORM: Direct rim and a rounded, exterior folded lip

CORE COLOR: $\mathrm{F}$ (fired in a reducing environment and cooled in the open air)

INTERIOR SURFACE COLOR: brown

EXTERIOR SURFACE COLOR: dark brown; fire clouds on the body and base

WALL THICKNESS (RIM, BODY, AND BASE IN MM): rim, $7.9 \mathrm{~mm}$

INTERIOR SURFACE TREATMENT: smoothed

EXTERIOR SURFACE TREATMENT:

burnished

HEIGHT (IN CM): 11.5

ORIFICE DIAMETER (IN CM): 30.0

DIAMETER AT BOTTOM OF RIM OR NECK (IN CM): 28.8

BASE DIAMETER (IN CM) AND SHAPE

OF BASE: 9.0; flat and circular

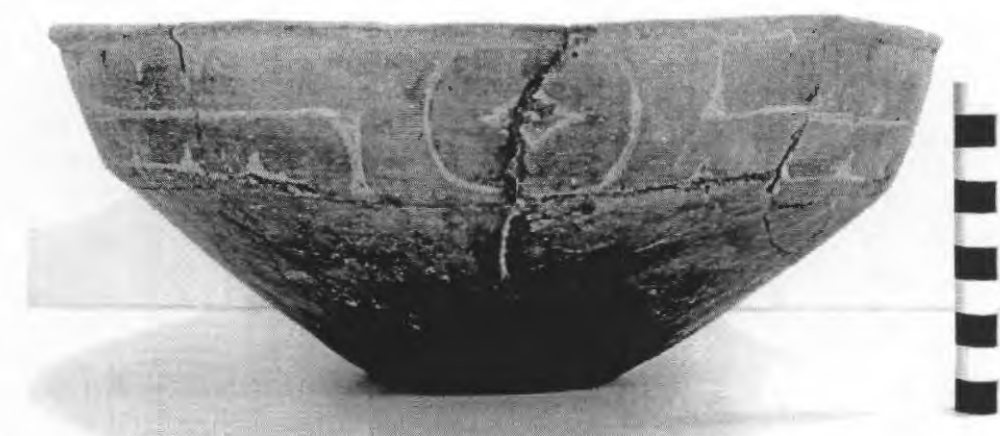

Figure 94. Ripley Engraved, var. McKinney carinated bowl, Enis Smith cemetery, Burial 11, Vessel 83.

\section{ESTIMATED VOLUME (IN LITERS): 2.1}

DECORATION (INCLUDING MOTIF AND ELEMENTS WHEN APPARENT): The rim panel has four alternating engraved circle and diamond elements. Each of these elements has an inner diamond; the inner diamond in the diamond element has a central excised dot. The engraved diamond elements are the central feature of horizontal scrolls that end in upper and lower excised brackets; the scrolls do not touch the central circles. Above and below each scroll are single rows of excised pendant triangles (Figure 94).

There is also a single horizontal engraved line on the interior vessel surface at the carination.

PIGMENT USE AND LOCATION ON VESSEL: none

TYPE AND VARIETY [IF KNOWN]: Ripley Engraved, var. McKinney 
VESSEL NO.: Burial 11, Vessel 84; 2003.08.97

NON-PLASTICS AND PASTE: grog and hematite

VESSEL FORM: Jar with four strap handles, four rim peaks, and a collared rim (Figure 95)

RIM AND LIP FORM: Everted rim and a rounded lip

CORE COLOR: $\mathrm{G}$ (fired in a reducing environment and cooled in the open air)

INTERIOR SURFACE COLOR: dark grayish-brown; organic residue on the rim

EXTERIOR SURFACE COLOR: yellowish-brown; organic residue on the rim

WALL THICKNESS (RIM, BODY, AND BASE IN MM): rim, $7.4 \mathrm{~mm}$

INTERIOR SURFACE TREATMENT: smoothed

EXTERIOR SURFACE TREATMENT: none

HEIGHT (IN CM): 13.5

ORIFICE DIAMETER (IN CM): 14.5

DIAMETER AT BOTTOM OF RIM OR NECK (IN CM): 11.5

BASE DIAMETER (IN CM) AND SHAPE OF BASE: 7.5; circular and flat

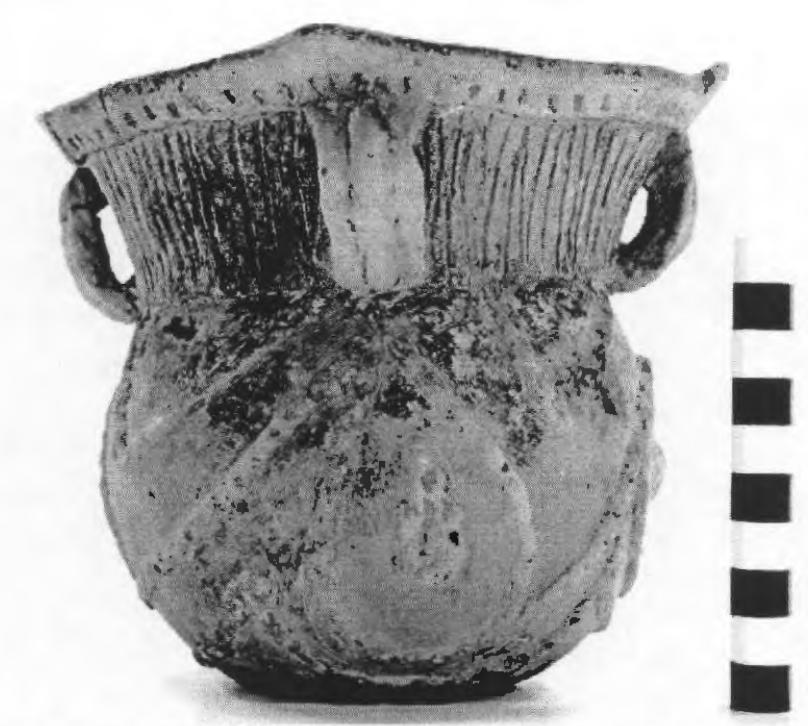

Figure 95. Harleton Appliqued jar, Enis Smith cemetery, Burial 11, Vessel 84.

ESTIMATED VOLUME (IN LITERS): 1.2

DECORATION (INCLUDING MOTIF AND ELEMENTS WHEN APPARENT): The vessel rim is decorated with two rows of tool punctations (under the lip and at the rim-body juncture) as well as closelyspaced vertical incised lines. The vessel body has an appliqued fillet scroll and circle motif that is repeated four times around the vessel. Each appliqued fillet circle has either a small oval or circular punctated appliqued node at its center. The upper and lower scroll fill zones are composed of appliqued fillet triangles and curvilinear appliqued fillet lines (Figure 95). The strap handles are decorated with three pinched ridges.

PIGMENT USE AND LOCATION ON VESSEL: none

TYPE AND VARIETY [IF KNOWN]: Harleton Appliqued 
VESSEL NO.: Burial 11, Vessel 85; 2003.08.198

NON-PLASTICS AND PASTE: grog, bone, and hematite

VESSEL FORM: Bottle with flaring neck

RIM AND LIP FORM: Everted rim and rounded lip

CORE COLOR: $\mathrm{G}$ (fired in a reducing environment and cooled in the open air)

INTERIOR SURFACE COLOR: dark grayish-brown

EXTERIOR SURFACE COLOR: reddish-brown; fire clouds on the rim, body, and base

WALL THICKNESS (RIM, BODY, AND BASE IN MM): rim, $5.4 \mathrm{~mm}$

INTERIOR SURFACE TREATMENT: none

EXTERIOR SURFACE TREATMENT: smoothed

HEIGHT (IN CM): 15.3

ORIFICE DIAMETER (IN CM): 4.4

DIAMETER AT BOTTOM OF RIM OR NECK (IN $\mathrm{CM}$ ): 5.0 ; maximum body diameter is $9.3 \mathrm{~cm}$

BASE DIAMETER (IN CM) AND SHAPE OF BASE: 6.5 ; circular and flat

ESTIMATED VOLUME (IN LITERS): 0.40

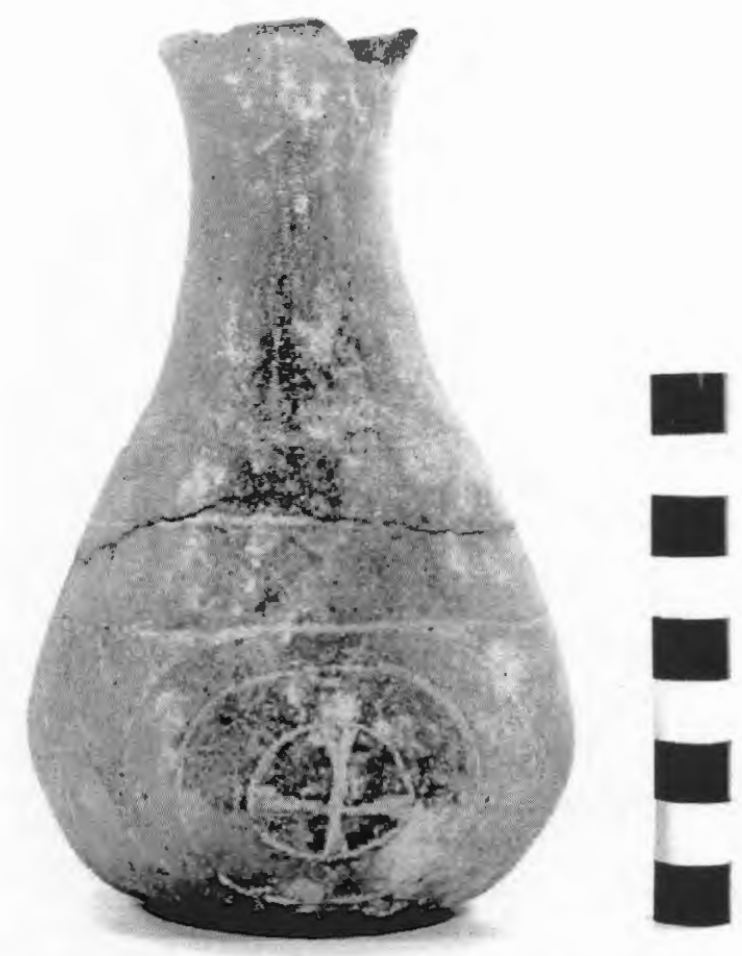

Figure 96. Ripley Engraved, var. unspecified bottle, Enis Smith cemetery, Burial 11, Vessel 85.

DECORATION (INCLUDING MOTIF AND ELEMENTS WHEN APPARENT): The vessel body has an engraved circle in circle element that is repeated four times around the vessel. Each circle has a small inner circle with crossed engraved lines. The circles are divided from each other by large pendant triangles that are nestled against the outer and largest circle (Figure 96). These triangles either have excised corners and a single spur element, or simply have the spur element.

PIGMENT USE AND LOCATION ON VESSEL: red pigment in the engraved lines

TYPE AND VARIETY [IF KNOWN]: Ripley Engraved, var. unspecified 
VESSEL NO.: Burial 11, Vessel 86; 2003.08.216

NON-PLASTICS AND PASTE: grog and bone

VESSEL FORM: Carinated bowl

RIM AND LIP FORM: Direct rim and a rounded, exterior folded lip

CORE COLOR: $\mathrm{G}$ (fired in a reducing environment and cooled in the open air)

INTERIOR SURFACE COLOR: dark grayish-brown

EXTERIOR SURFACE COLOR: reddish-brown; fire clouds on the body and base

WALL THICKNESS (RIM, BODY, AND BASE IN MM): rim, $6.3 \mathrm{~mm}$

INTERIOR SURFACE TREATMENT: none

EXTERIOR SURFACE TREATMENT: smoothed

HEIGHT (IN CM): 6.4

ORIFICE DIAMETER (IN CM): 14.5

DIAMETER AT BOTTOM OF RIM OR NECK (IN CM): 13.1

BASE DIAMETER (IN CM) AND SHAPE OF BASE: 7.0

ESTIMATED VOLUME (IN LITERS): 0.56

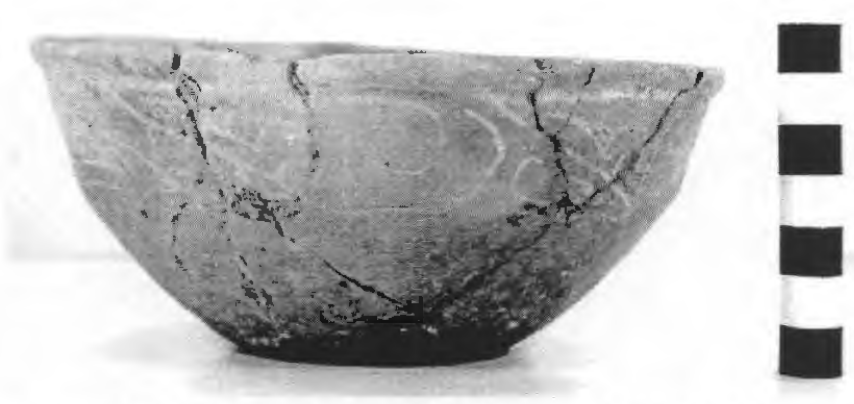

Figure 97. Engraved carinated bowl, Enis Smith cemetery, Burial 11, Vessel 86.

DECORATION (INCLUDING MOTIF AND ELEMENTS WHEN APPARENT): The rim panel has an eclectic mix of elements, including circle in circle (twice, and with crossed lines in the smaller inner circle), encircled scrolls (twice), as well as slanting scrolls. Between the circle in circle and encircled scrolls are a single slanting scroll and large excised triangles attached to hooked arms. Another slanted scroll has an upper scroll fill zone with short curvilinear lines; this scroll fill zone also ends in a hooked arm element (Figure 97).

PIGMENT USE AND LOCATION ON VESSEL: none

TYPE AND VARIETY [IF KNOWN]: Unidentified fine ware 
VESSEL NO.: Burial 11, Vessel 87; 2003.08.1820

NON-PLASTICS AND PASTE: grog

VESSEL FORM: Carinated bowl

RIM AND LIP FORM: Direct rim and rounded, exterior folded lip

CORE COLOR: $\mathrm{G}$ (fired in a reducing environment and cooled in the open air)

INTERIOR SURFACE COLOR: dark grayish-brown

EXTERIOR SURFACE COLOR: reddish-brown; fire clouds on the body

WALL THICKNESS (RIM, BODY, AND BASE IN MM): rim, 7.0 mm

INTERIOR SURFACE TREATMENT: smoothed

EXTERIOR SURFACE TREATMENT: burnished

HEIGHT (IN CM): 8.5

ORIFICE DIAMETER (IN CM): 15.8

DIAMETER AT BOTTOM OF RIM OR NECK

(IN CM): 16.2

BASE DIAMETER (IN CM) AND SHAPE OF BASE: 6.8

ESTIMATED VOLUME (IN LITERS): 0.81

DECORATION (INCLUDING MOTIF AND ELEMENTS WHEN APPARENT): The rim

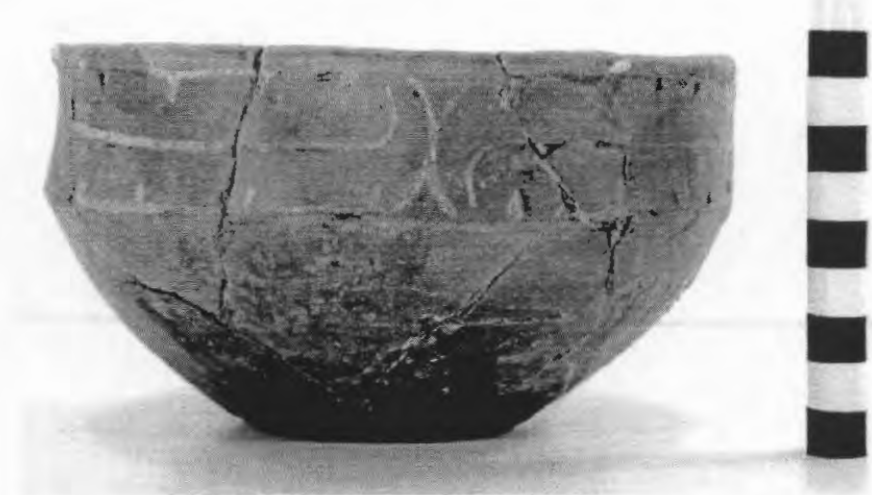

Figure 98. Ripley Engraved, cf. var. Gandy carinated bowl, Enis Smith cemetery, Burial 11, Vessel 87. panel has an engraved horizontal and curvilinear scroll motif repeated four times around the vessel. The scroll are divided by vertical engraved brackets. Above and below each of the scrolls are single rows of small excised pendant triangles (Figure 98).

PIGMENT USE AND LOCATION ON VESSEL: none

TYPE AND VARIETY [IF KNOWN]: Ripley Engraved, cf. var. Gandy 
VESSEL NO.: Burial 11, Vessel 88; 2003.08.1769

NON-PLASTICS AND PASTE: grog

VESSEL FORM: Carinated bowl

RIM AND LIP FORM: Direct rim and a rounded, exterior folded lip

CORE COLOR: $\mathrm{G}$ (fired in a reducing environment and cooled in the open air)

INTERIOR SURFACE COLOR: grayish-brown; organic residue on the rim

EXTERIOR SURFACE COLOR: yellowish-brown; fire clouds on the rim and body; resin-like organic residue on the rim and body

WALL THICKNESS (RIM, BODY, AND BASE IN MM): rim, $6.7 \mathrm{~mm}$; body, $8.2 \mathrm{~mm}$; base, $8.6 \mathrm{~mm}$

INTERIOR SURFACE TREATMENT: burnished

EXTERIOR SURFACE TREATMENT: smoothed

HEIGHT (IN CM): 11.6

ORIFICE DIAMETER (IN CM): 29.0

DIAMETER AT BOTTOM OF RIM OR

NECK (IN CM): 28.6

BASE DIAMETER (IN CM) AND SHAPE OF BASE: N/A

ESTIMATED VOLUME (IN LITERS): 2.0

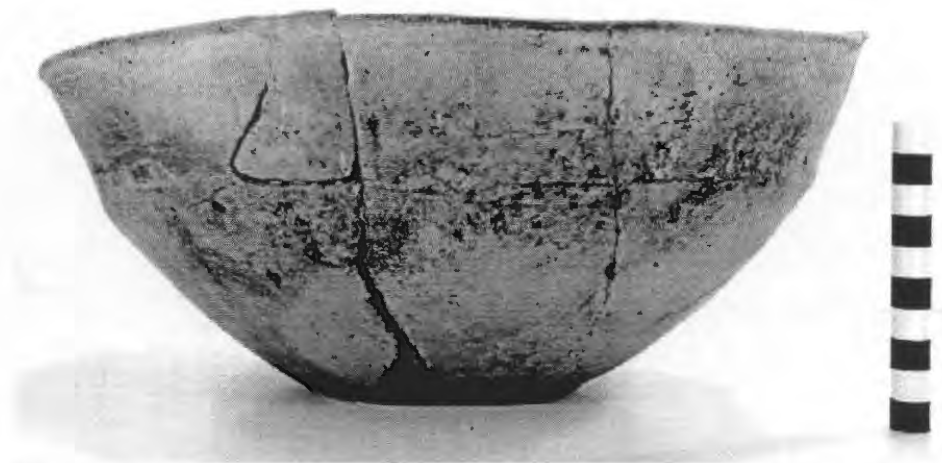

Figure 99. Ripley Engraved, var. McKinney carinated bowl, Enis Smith cemetery, Burial 11, Vessel 88.

DECORATION (INCLUDING MOTIF AND

ELEMENTS WHEN APPARENT): The rim panel has four alternating circle and diamond elements. The circle element has an inner circle, and the diamond element has an inner diamond. The diamond element is at the center of a horizontal scroll that is repeated four times around the vessel; the scroll does not extend to include the circle in circle element. The horizontal scrolls end at upper and lower cross-hatched dividers, and there are single rows of excised pendant triangles above and below each scroll (Figure 99).

There is also a single horizontal engraved line on the interior vessel surface at the carination.

PIGMENT USE AND LOCATION ON VESSEL: white pigment in the engraved lines

TYPE AND VARIETY [IF KNOWN]: Ripley Engraved, var. McKinney 
VESSEL NO.: Burial 11, Vessel 89; 2003.08.422

NON-PLASTICS AND PASTE: grog

VESSEL FORM: Carinated bowl

RIM AND LIP FORM: Direct rim and a rounded, exterior folded lip

CORE COLOR: $\mathrm{G}$ (fired in a reducing environment and cooled in the open air)

INTERIOR SURFACE COLOR: grayish-brown

EXTERIOR SURFACE COLOR: reddish-brown

WALL THICKNESS (RIM, BODY, AND BASE IN MM): rim, $6.0 \mathrm{~mm}$

INTERIOR SURFACE TREATMENT: smoothed

EXTERIOR SURFACE TREATMENT: smoothed

HEIGHT (IN CM): 9.5

ORIFICE DIAMETER (IN CM): 17.0

DIAMETER AT BOTTOM OF RIM OR NECK (IN CM): 17.5

BASE DIAMETER (IN CM) AND SHAPE OF

BASE: 7.5; circular and flat

ESTIMATED VOLUME (IN LITERS): 0.97

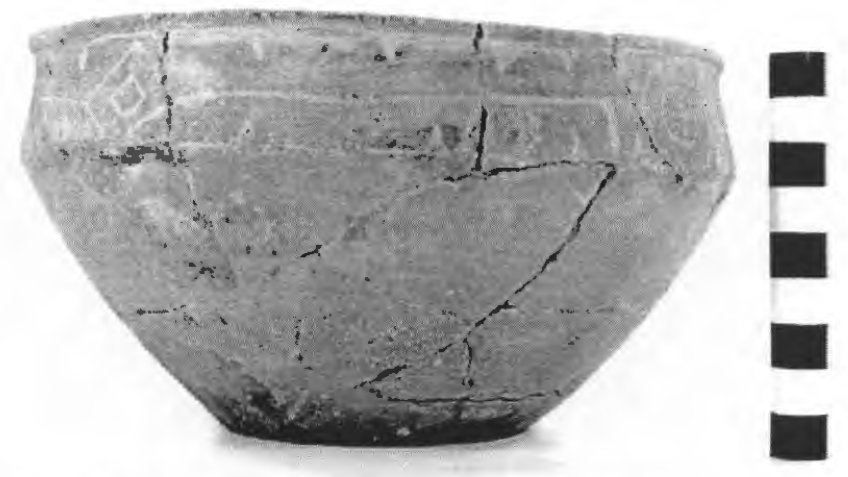

Figure 100. Ripley Engraved, var. McKinney carinated bowl, Enis Smith cemetery, Burial 11, Vessel 89.

DECORATION (INCLUDING MOTIF AND ELEMENTS WHEN APPARENT): The rim panel has four alternating circle and diamond elements. The circle element has an inner circle with crossed engraved lines, and the diamond element has an inner diamond. The diamond element is at the center of a horizontal scroll that is repeated four times around the vessel; the scroll does not extend to include the circle in circle element (Figure 100). The horizontal scrolls end at upper and lower excised dividers, and there are single rows of excised pendant triangles above and below each scroll.

PIGMENT USE AND LOCATION ON VESSEL: none

TYPE AND VARIETY [IF KNOWN]: Ripley Engraved, var. McKinney 
VESSEL NO.: Burial 11, Vessel 90; 2003.08.882

NON-PLASTICS AND PASTE: grog

VESSEL FORM: Jar

RIM AND LIP FORM: Everted rim and a rounded lip

CORE COLOR: B (fired and cooled in a reducing environment)

INTERIOR SURFACE COLOR: dark grayish-brown

EXTERIOR SURFACE COLOR: grayish-brown

WALL THICKNESS (RIM, BODY, AND BASE IN MM): rim, $6.6 \mathrm{~mm}$

INTERIOR SURFACE TREATMENT: smoothed

EXTERIOR SURFACE TREATMENT: none

HEIGHT (IN CM): 13.3

ORIFICE DIAMETER (IN CM): 12.6

DIAMETER AT BOTTOM OF RIM OR NECK (IN CM): 10.6

BASE DIAMETER (IN CM) AND SHAPE OF BASE:

7.7; circular and flat

ESTIMATED VOLUME (IN LITERS): 1.0

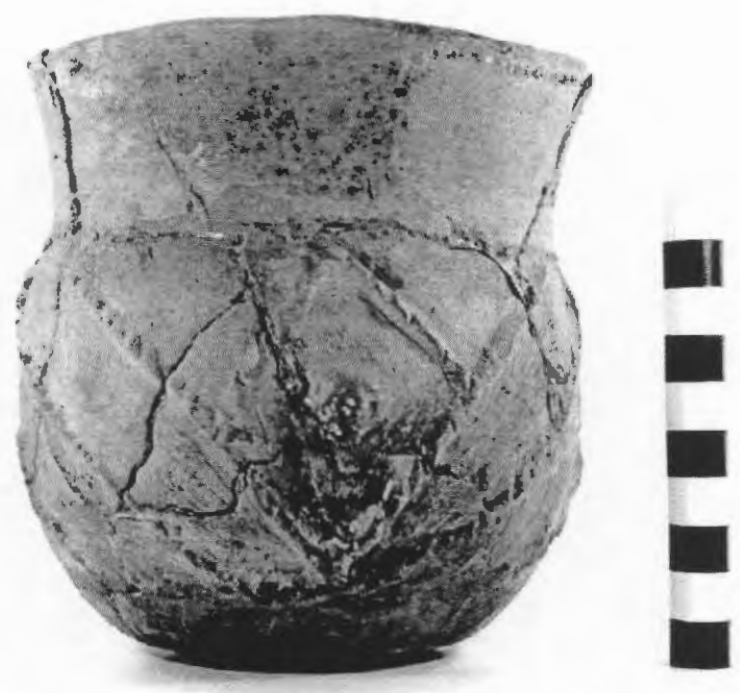

Figure 101. Harleton Appliqued jar, Enis Smith cemetery, Burial 11, Vessel 90.

DECORATION (INCLUDING MOTIF AND ELEMENTS WHEN APPARENT): The rim has horizontal brushing marks and two rows of tool punctations. The punctated rows are under the lip and at the rim-body juncture (Figure 101). The body decoration is an appliqued fillet scroll and nested diamond motif repeated two times around the vessel. Inside each appliqued diamond is a large appliqued node with punctations. The upper and lower scroll fill zones are appliqued fillet triangles. Finally, the space between the appliqued fillets is brushed.

PIGMENT USE AND LOCATION ON VESSEL: none

TYPE AND VARIETY [IF KNOWN]: Harleton Appliqued 


\section{Burial 12}

Burial 12 is the southernmost burial in the Enis Smith cemetery (see Figure 8). No other information is available about it other than that Jones (n.d.) indicated that 12 ceramic vessels were included in the grave as funerary offerings.

Only five of these vessels can be identified in the Buddy Jones collections from the site. They include a brushed-ineised jar and a Harleton Appliqued jar, a Ripley Engraved, var. Cash compound bowl, and two carinated bowls. One is a Taylor Engraved vessel, while the other is a Ripley Engraved, ef. var. Gandy vessel.

VESSEL NO.: Burial 12, Vessel 91; 2003.08.284

NON-PLASTICS AND PASTE: grog and hematite

VESSEL FORM: Carinated bowl

RIM AND LIP FORM: Direct rim and a rounded, exterior folded lip

CORE COLOR: $F$ (fired in a reducing environment and cooled in the open air)

INTERIOR SURFACE COLOR: yellowish-brown

EXTERIOR SURFACE COLOR: yellowish-brown; resin-like organic residue on the rim and body

WALLTHICKNESS (RIM, BODY,AND BASE IN MM): rim, 5.8 mm

INTERIOR SURFACE TREATMENT: smoothed

EXTERIOR SURFACE TREATMENT: smoothed

HEIGHT (IN CM): 13.6

ORIFICE DIAMETER (IN CM): 22.4

DIAMETER AT BOTTOM OF RIM OR NECK (IN CM): 20.7

BASE DIAMETER (IN CM) AND SHAPE OF BASE: 8.0; circular and flat

ESTIMATED VOLUME (IN LITERS): 2.7 
DECORATION (INCLUDING MOTIF AND ELEMENTS WHEN APPARENT): The rim panel has a curvilinear engraved scroll motif repeated four times around the vessel. Each of the scrolls ends in upper and lower hooked arm elements. The scrolls are divided from each other by vertical brackets with excised central areas (Figure 102). The upper and lower scroll fill zones have excised dividers and excised triangles, along with vertical engraved lines, forming a series of negative ovals.

PIGMENT USE AND LOCATION ON VESSEL: white pigment in the engraved lines

TYPE AND VARIETY [IF KNOWN]: Taylor Engraved or Ripley Engraved, cf. var. Gandy

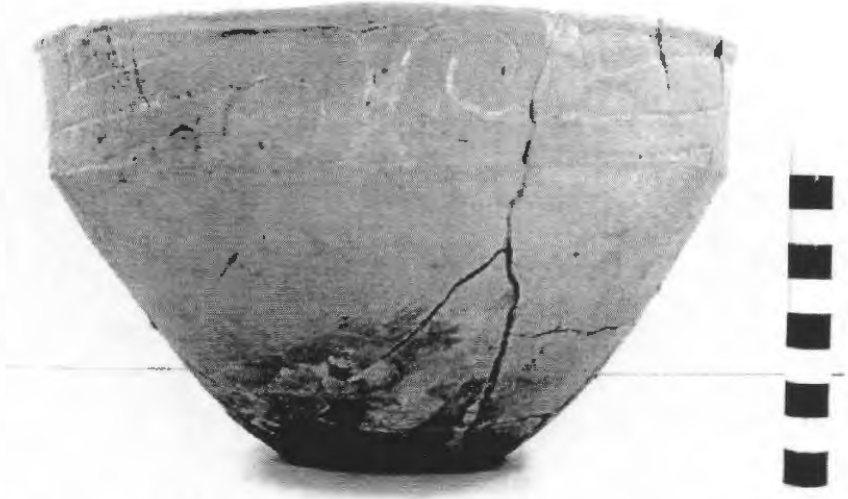

Figure 102. Engraved carinated bowl, Enis Smith cemetery, Burial 12, Vessel 91.

VESSEL NO.: Burial 12, Vessel 92; 2003.08.277

NON-PLASTICS AND PASTE: grog and bone

VESSEL FORM: Jar

RIM AND LIP FORM: Everted rim and rounded lip

CORE COLOR: $\mathrm{H}$ (fired in a reducing environment and cooled in the open air)

INTERIOR SURFACE COLOR: grayish-brown

EXTERIOR SURFACE COLOR: dark grayish-brown

WALL THICKNESS (RIM, BODY, AND BASE IN MM): rim, $10.0 \mathrm{~mm}$; body, $8.4 \mathrm{~mm}$

INTERIOR SURFACE TREATMENT: smoothed

EXTERIOR SURFACE TREATMENT: none

HEIGHT (IN CM): 36.1

ORIFICE DIAMETER (IN CM): 31.0

DIAMETER AT BOTTOM OF RIM OR NECK (IN CM): 29.0

BASE DIAMETER (IN CM) AND SHAPE OF BASE: 8.3

ESTIMATED VOLUME (IN LITERS): 14.5 
DECORATION (INCLUDING MOTIF AND ELEMENTS WHEN APPARENT): The vessel rim is decorated with vertical and diagonal brushed-incised lines. The vessel body has vertical brushed-incised lines (Figure 103).

PIGMENT USE AND LOCATION ON VESSEL: none

TYPE AND VARIETY [IF KNOWN]: Unidentified utility ware

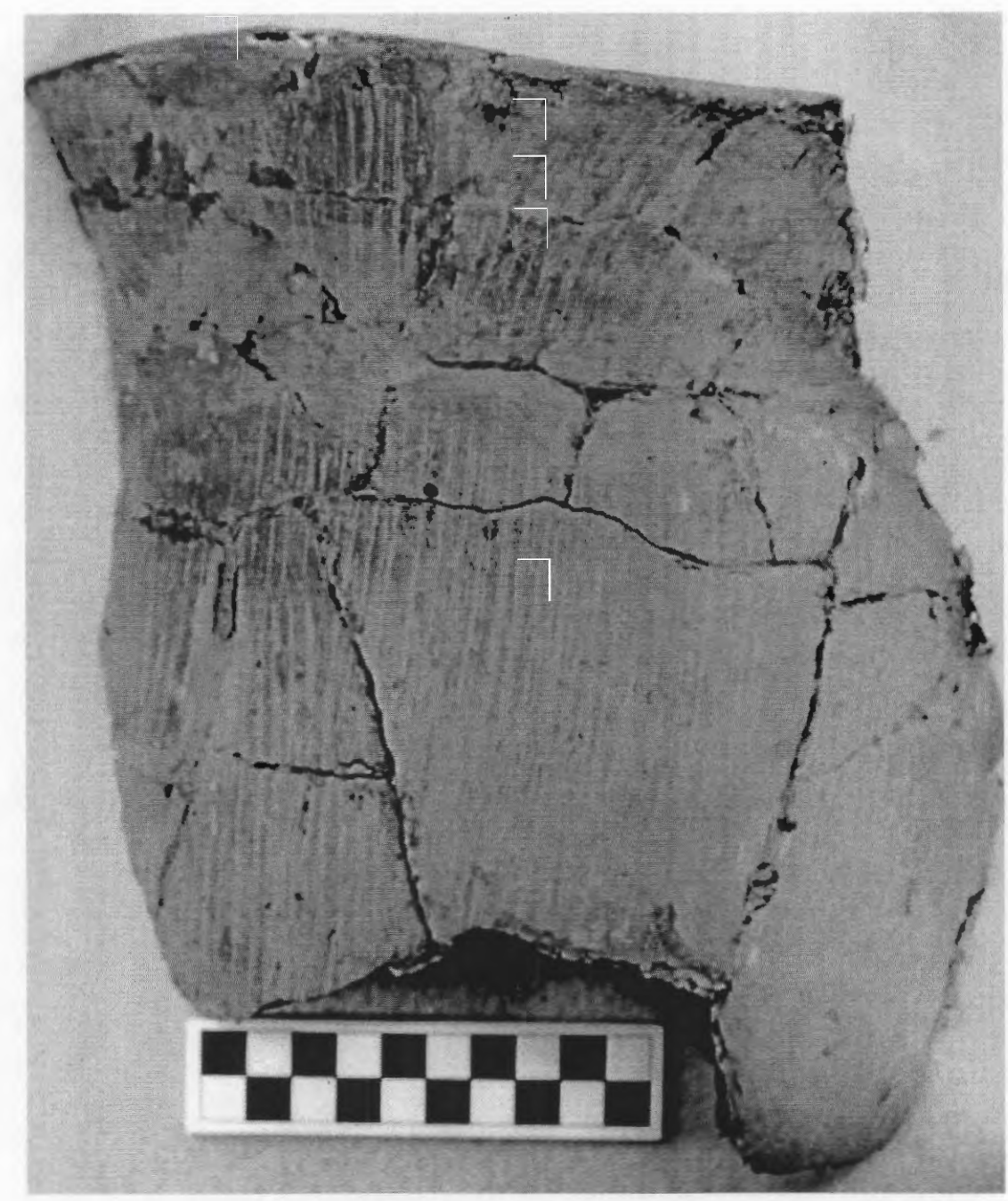

Figure 103. Brushed-incised jar, Enis Smith cemetery, Burial 12, Vessel 92. 
VESSEL NO.: Burial 12, Vessel 93; 2003.08.725

NON-PLASTICS AND PASTE: grog and bone

VESSEL FORM: Compound bowl

RIM AND LIP FORM: Direct rim and a rounded, exterior folded lip

CORE COLOR: $\mathrm{G}$ (fired in a reducing environment and cooled in the open air)

INTERIOR SURFACE COLOR: grayish-brown

EXTERIOR SURFACE COLOR: yellowish-brown; fire clouds on the rim and base

WALL THICKNESS (RIM, BODY, AND BASE IN MM): rim, 7.7 mm

INTERIOR SURFACE TREATMENT: smoothed

EXTERIOR SURFACE TREATMENT: smoothed

HEIGHT (IN CM): 20.2

ORIFICE DIAMETER (IN CM): 34.4

DIAMETER AT BOTTOM OF RIM OR NECK (IN CM): 31.2

BASE DIAMETER (IN CM) AND SHAPE OF BASE: 9.5 ; circular and flat

ESTIMATED VOLUME (IN LITERS): 5.6

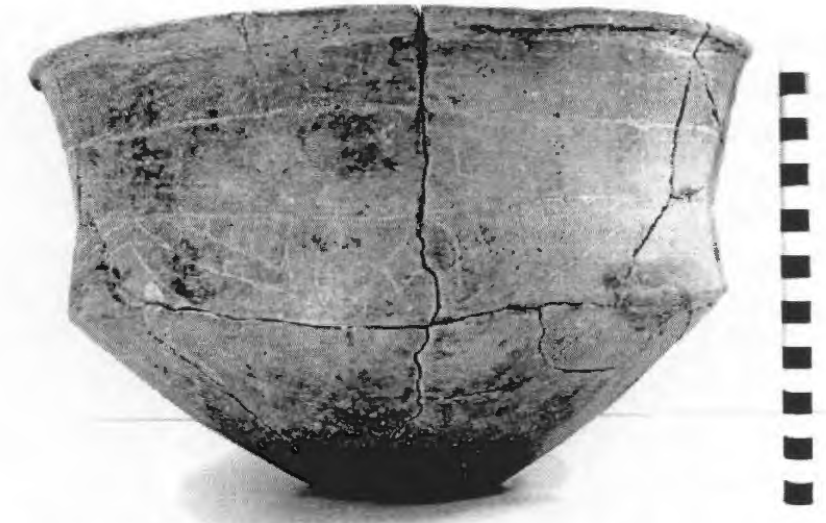

Figure 104. Ripley Engraved, var. Cash compound bowl, Enis Smith cemetery, Burial 12, Vessel 93.

DECORATION (INCLUDING MOTIF AND ELEMENTS WHEN APPARENT): The upper rim panel has three widely-spaced horizontal engraved lines. The lower rim panel has an engraved circle and nested triangle motif that is repeated four times around the vessel. The engraved circle element has an inner diamond, while each nested triangle has within it two excised corners and a large oval with a single central slash mark (Figure 104). The scroll fill zones above the nested triangles have a series of short diagonal engraved lines.

PIGMENT USE AND LOCATION ON VESSEL: white pigment in engraved lines

TYPE AND VARIETY [IF KNOWN]: Ripley Engraved, var. Cash 
VESSEL NO.: Burial 12, Vessel 94; 2003.08.617

NON-PLASTICS AND PASTE: grog

VESSEL FORM: Carinated bowl

RIM AND LIP FORM: Direct rim and a rounded, exterior folded lip

CORE COLOR: $\mathrm{F}$ (fired in a reducing environment and cooled in the open air)

INTERIOR SURFACE COLOR: reddish-brown

EXTERIOR SURFACE COLOR: reddish-brown

WALL THICKNESS (RIM, BODY, AND BASE IN MM): rim, $6.8 \mathrm{~mm}$

INTERIOR SURFACE TREATMENT: smoothed

EXTERIOR SURFACE TREATMENT: smoothed

HEIGHT (IN CM): 12.3

ORIFICE DIAMETER (IN CM): 23.0

DIAMETER AT BOTTOM OF RIM OR NECK

(IN CM): 21.2

BASE DIAMETER (IN CM) AND SHAPE OF

BASE: 7.0; circular and flat

ESTIMATED VOLUME (IN LITERS): 1.7

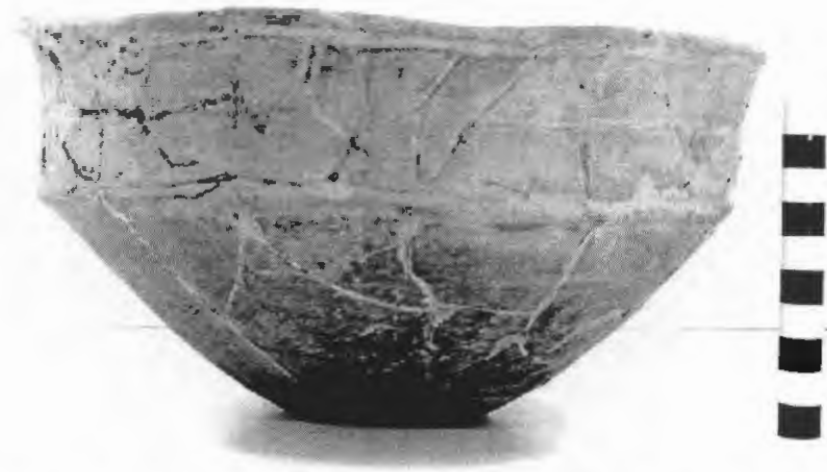

Figure 105. Ripley Engraved, cf. var. Gandy carinated bowl, Enis Smith cemetery, Burial 12, Vessel 94.

DECORATION (INCLUDING MOTIF AND ELEMENTS WHEN APPARENT): The rim panel has an horizontal engraved scroll motif repeated five times around the vessel. The scrolls are divided by vertical engraved brackets with a single central diagonal engraved line. Above and below each scroll are single rows of small excised pendant triangles (Figure 105).

PIGMENT USE AND LOCATION ON VESSEL: none

TYPE AND VARIETY [IF KNOWN]: Ripley Engraved, cf. var. Gandy 
VESSEL NO.: Burial 12, Vessel 95; 2003.08.328

NON-PLASTICS AND PASTE: grog and bone

VESSEL FORM: Jar

RIM AND LIP FORM: Direct rim and a rounded, exterior folded lip

CORE COLOR: $\mathrm{F}$ (fired in a reducing environment and cooled in the open air)

INTERIOR SURFACE COLOR: yellowish-brown

EXTERIOR SURFACE COLOR: yellowish-brown; fire clouds on the body and base

WALL THICKNESS (RIM, BODY, AND BASE IN MM): rim, $7.3 \mathrm{~mm}$

INTERIOR SURFACE TREATMENT: smoothed

EXTERIOR SURFACE TREATMENT: none

HEIGHT (IN CM): 14.3

ORIFICE DIAMETER (IN CM): 13.5

DIAMETER AT BOTTOM OF RIM OR NECK (IN CM): 12.0

BASE DIAMETER (IN CM) AND SHAPE OF BASE: 6.0; circular and flat

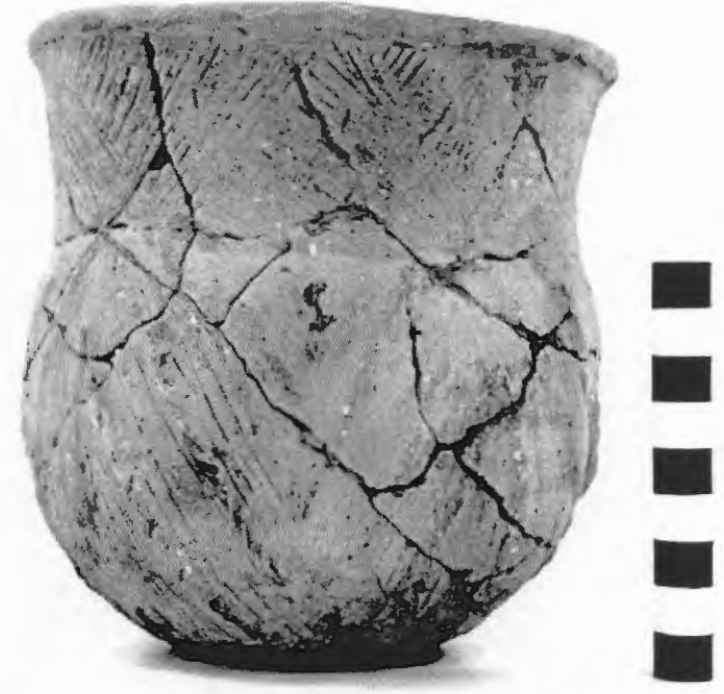

Figure 106. Harleton Appliqued jar, Enis Smith cemetery, Burial 12, Vessel 95.

ESTIMATED VOLUME (IN LITERS): 1.2

DECORATION (INCLUDING MOTIF AND ELEMENTS WHEN APPARENT): The rim has five incised triangles filled with diagonal incised lines that are pitched in opposing directions. The vessel body has four sets of appliqued fillet nested triangles that are filled with brushing marks pitched to follow the orientation of the appliqued fillets (Figure 106).

PIGMENT USE AND LOCATION ON VESSEL: none

TYPE AND VARIETY [IF KNOWN]: Harleton Appliqued 
114 Little Cypress Creek Basin Archaeology: Six Late Caddo Period Cemeteries in Upshur County, Texas

\section{Henry Williams Site (41UR318)}

The Henry Williams site is a Late Caddo habitation and cemetery locale situated north and west of Gum Creek (Figure 107). Buddy Jones excavated the cemetery in 1954 and 1955.

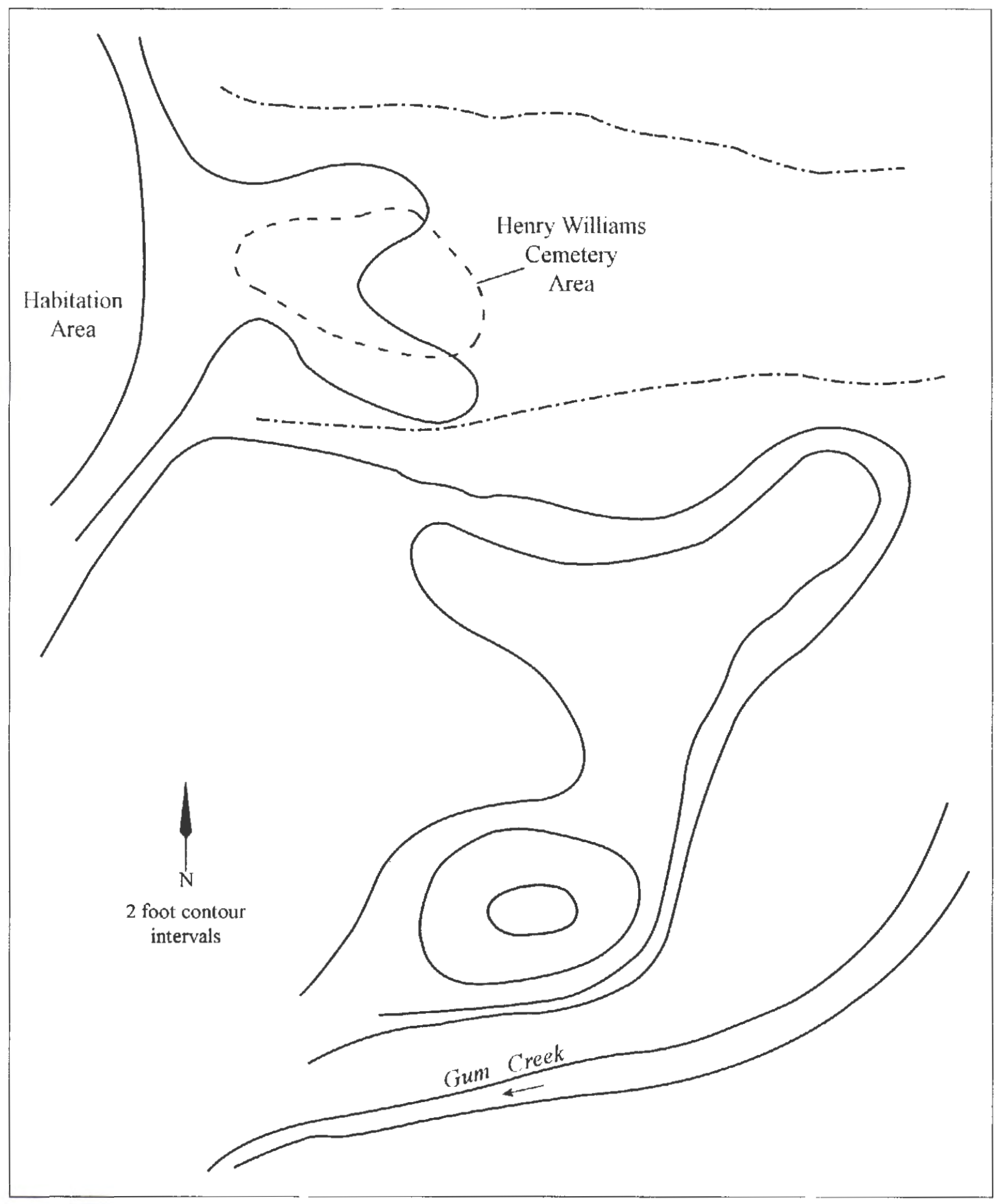

Figure 107. Henry Williams site map. 
The cemetery was situated in a cotton field, about $2.5 \mathrm{~m}$ above the Gum Creek floodplain on an alluvial terrace landform; several of the burials were found in a low-lying eroded area (with red clay exposed at the surface) in the edge of the floodplain itself (Figure 108). A total of 37 burials were excavated by Jones in the cemetery, in a number of east to northeast-oriented rows and clusters. Although no specific information was provided by Jones (n.d.), it is likely that all the burials represent single individuals placed in the graves in extended supine position, with the head facing towards the west. The deceased individuals were accompanied with several kinds of funerary offerings, primarily ceranic vessels $(54 \%)$ and arrow point caches/quivers (43\%) (Table 4). All of the burials had ceramic vessels, two burials had ceramic pipes, eight burials had arrow point caches, three burials had tools (celts or a large chipped biface), and two burials had clay pigments. Total numbers of funerary offerings ranged from 1-45 items, with a mean of 8.0 offerings per burial.

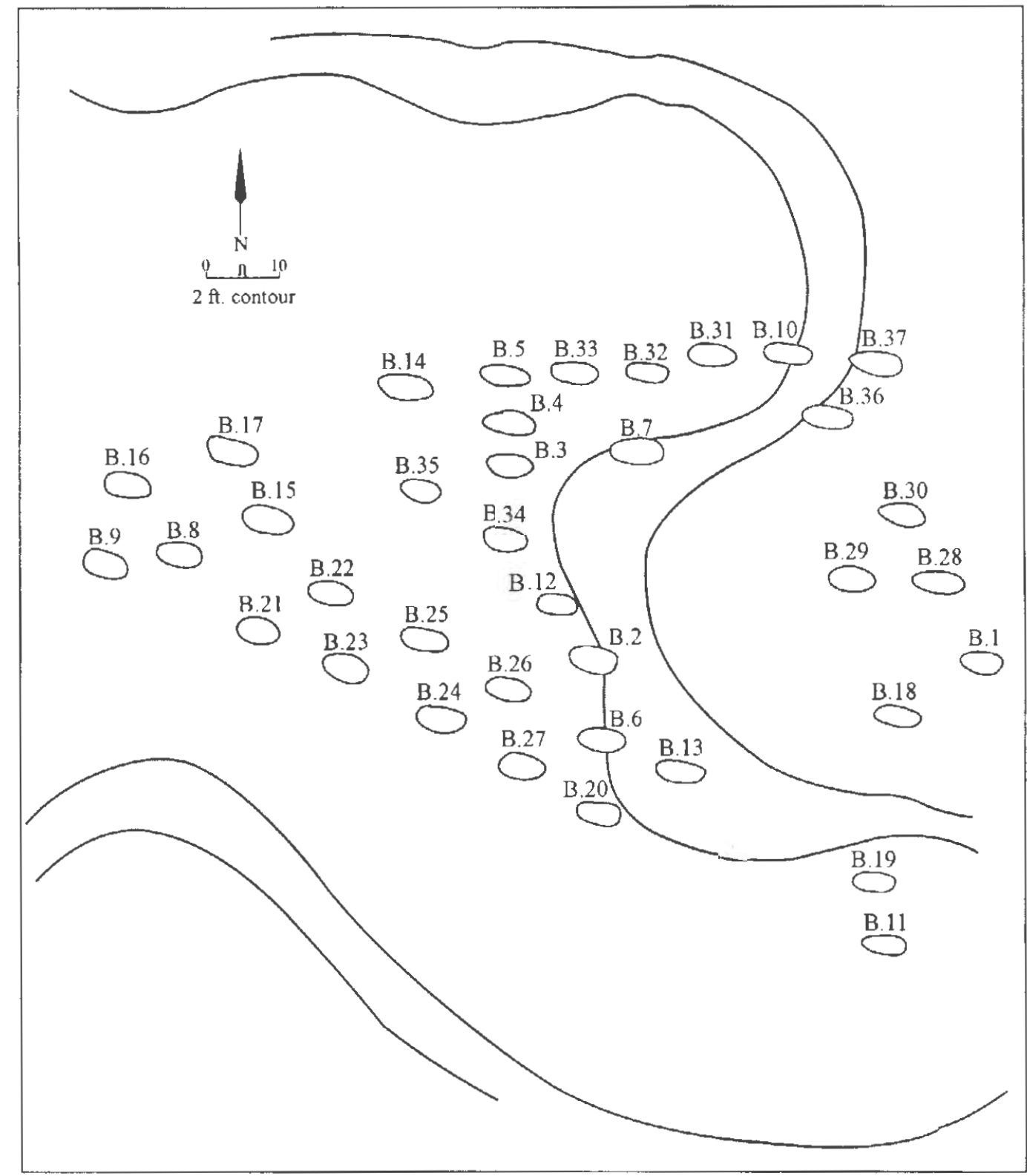

Figure 108. Map of the cemetery at the Henry Williams site. 
Table 4. Funerary offerings from the Henry Williams site.

\begin{tabular}{|c|c|c|c|c|c|c|}
\hline Burial No. & Vessels & Pipe & $\begin{array}{l}\text { Arrow } \\
\text { Points }\end{array}$ & Tools & Other+ & No. \\
\hline 1 & 1 & - & - & - & - & 1 \\
\hline 2 & 8 & - & - & 1 & - & 9 \\
\hline $3-5$ & 21 & - & 10 & - & - & 31 \\
\hline 6 & 17 & 1 & 26 & 1 & - & 45 \\
\hline 7 & 6 & - & 17 & - & 1 & 24 \\
\hline 8 & 5 & - & - & - & - & 5 \\
\hline 9 & 4 & - & - & - & - & 4 \\
\hline 10 & 4 & 1 & - & - & 1 & 6 \\
\hline 11 & 5 & - & - & 1 & - & 6 \\
\hline 13 & 1 & - & - & - & - & 1 \\
\hline 14 & 2 & - & - & - & - & 2 \\
\hline 15 & 6 & - & 5 & - & - & 11 \\
\hline 16 & 3 & - & - & - & - & 3 \\
\hline 17 & 2 & - & - & - & - & 2 \\
\hline 18 & 3 & - & - & $=$ & - & 3 \\
\hline 19 & 1 & - & - & - & - & 1 \\
\hline 20 & 4 & - & - & - & - & 4 \\
\hline 21 & 3 & - & - & - & - & 3 \\
\hline 22 & 4 & - & 16 & - & - & 20 \\
\hline 23 & 4 & - & - & - & - & 4 \\
\hline 24 & 5 & - & 8 & - & - & 13 \\
\hline 25 & 3 & - & - & - & - & 3 \\
\hline 26 & $*$ & - & - & - & - & * \\
\hline 27 & 4 & - & - & - & - & 4 \\
\hline 28 & 5 & - & - & - & - & 5 \\
\hline 29 & 4 & - & - & - & - & 4 \\
\hline 30 & 2 & - & 5 & - & - & 7 \\
\hline 31 & 4 & - & - & - & - & 4 \\
\hline 32 & 3 & - & 13 & - & - & 16 \\
\hline 33 & 2 & - & - & - & - & 2 \\
\hline 34 & $*$ & - & - & - & - & * \\
\hline 35 & 2 & - & - & - & - & 2 \\
\hline Totals & 138 & 2 & 110 & 3 & 2 & 255 \\
\hline
\end{tabular}

*unknown number of vessels

+Other=clay pigment 


\section{Burial 1}

Burial 1 is the easternmost of the 37 burials in the cemetery. It was uncovered at a depth of $30 \mathrm{~cm}$ bs. A single Ripley Engraved carinated bowl was the sole funerary offering.

VESSEL NO.: 2003.08.846

NON-PLASTICS AND PASTE: grog

VESSEL FORM: Carinated bowI

RIM AND LIP FORM: Direct rim and a rounded, exterior folded lip

CORE COLOR: $\mathrm{F}$ (fired in a reducing environment and cooled in the open air)

INTERIOR SURFACE COLOR: yellowish-brown; fire clouding on the rim

EXTERIOR SURFACE COLOR: dark yellowish-brown; fire clouds on the rim and body; charred organic residue on the rim and body

WALL THICKNESS (RIM, BODY, AND BASE IN MM): rim, $6.0 \mathrm{~mm}$; body, $6.8 \mathrm{~mm}$

INTERIOR SURFACE TREATMENT: smoothed

EXTERIOR SURFACE TREATMENT: smoothed

HEIGHT (IN CM): 10.2

ORIFICE DIAMETER (IN CM): 23.3

DIAMETER AT BOTTOM OF RIM OR NECK (IN CM): 21.5

BASE DIAMETER (IN CM) AND SHAPE OF BASE: 6.2 ; flat and circular

ESTIMATED VOLUME (IN LITERS): 1.4

DECORATION (INCLUDING MOTIF AND

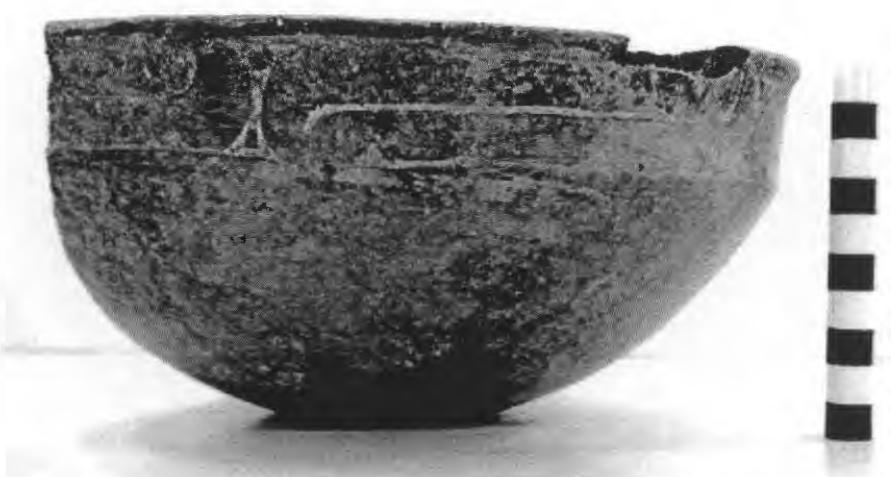

Figure 109. Ripley Engraved, cf. var. Gandy carinated bowl, Henry Williams cemetery, Burial 1, Vessel 2003.08.846. ELEMENTS WHEN APPARENT): The rim panel has engraved scrolls repeated four times around the vessel. The scrolls are divided by excised brackets or dividers with negative ovals or triangles. Above and below each of the scrolls are excised pendant triangles (Figure 109).

PIGMENT USE AND LOCATION ON VESSEL: white pigment in the engraved lines TYPE AND VARIETY [IF KNOWN]: Ripley Engraved, cf. var. Gandy 


\section{Burial 2}

This burial was $76 \mathrm{~cm}$ bs in depth. According to Jones, four ceramic vessels had been placed in the grave as funerary offerings, along with a large broken chert biface. Three of the vessels remain in the collection, a Ripley Engraved, var. Galt carinated bowl, a plain carinated bowl, and portions of a brushed jar.

VESSEL NO.: 2003.08.1041

NON-PLASTICS AND PASTE: grog

VESSEL FORM: Carinated bowl

RIM AND LIP FORM: Direct rim and a rounded, exterior folded lip

CORE COLOR: $\mathrm{F}$ (fired in a reducing environment and cooled in the open air)

INTERIOR SURFACE COLOR: reddish-brown

EXTERIOR SURFACE COLOR: reddish-brown; fire clouds on the rim and body

WALL THICKNESS (RIM, BODY, AND BASE IN MM): rim, $7.6 \mathrm{~mm}$; body, $7.0 \mathrm{~mm}$; base, $9.5 \mathrm{~mm}$

INTERIOR SURFACE TREATMENT: smoothed

EXTERIOR SURFACE TREATMENT: smoothed

HEIGHT (IN CM): 12.5

ORIFICE DIAMETER (IN CM): 31.0

DIAMETER AT BOTTOM OF RIM OR NECK (IN CM): 31.0

BASE DIAMETER (IN CM) AND SHAPE OF

BASE: 6.2; flat and circular

ESTIMATED VOLUME (IN LITERS): 2.3

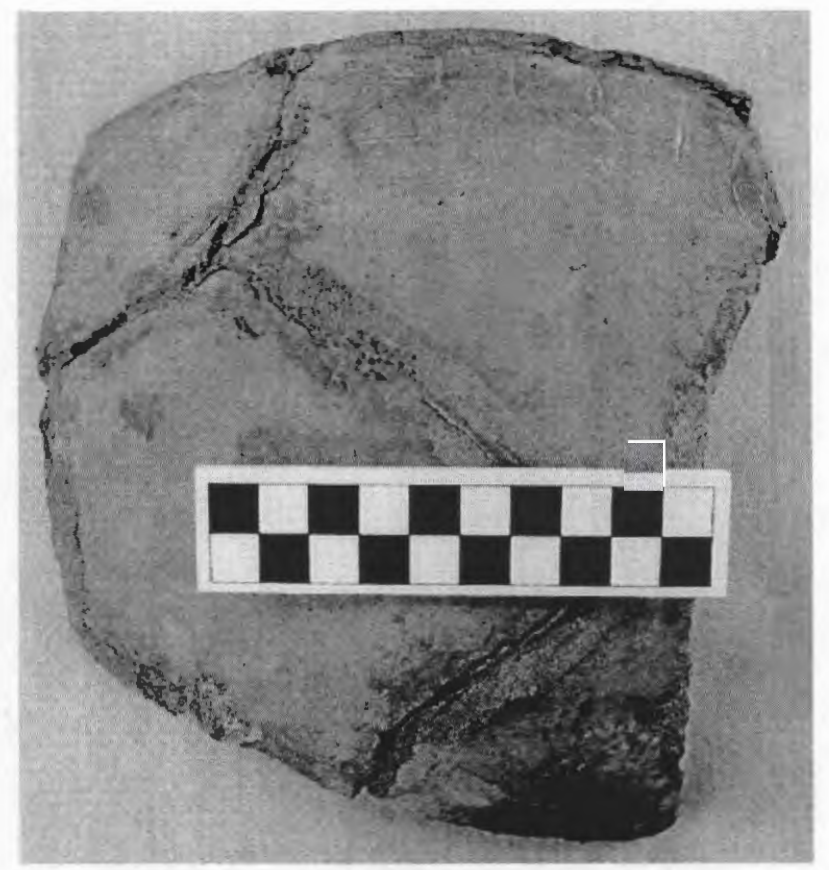

Figure 110. Ripley Engraved, var. Galt carinated bowl rim and body section, Henry Williams cemetery, Burial 2, Vessel 2003.08.1041.

DECORATION (INCLUDING MOTIF AND ELEMENTS WHEN APPARENT): The rim panel has an engraved scroll and circle motif probably repeated four times around the vessel. The upper and lower scroll fill zones have excised and cross-hatched triangular areas and negative ovals; the negative ovals have a single short vertical engraved line within them (Figure 110).

PIGMENT USE AND LOCATION ON VESSEL: none 
VESSEL NO.: 2003.08.844

NON-PLASTICS AND PASTE: grog and bone

VESSEL FORM: Carinated bowl

RIM AND LIP FORM: Direct rim and a rounded, exterior folded lip

CORE COLOR: $\mathrm{F}$ (fired in a reducing environment and cooled in the open air)

INTERIOR SURFACE COLOR: reddish-brown; organic residue on the rim

EXTERIOR SURFACE COLOR: reddish-brown; organic residue on the rim and body

WALL THICKNESS (RIM, BODY, AND BASE IN MM): rim, $7.3 \mathrm{~mm}$; body, $6.2 \mathrm{~mm}$; base, $8.6 \mathrm{~mm}$

INTERIOR SURFACE TREATMENT: none

EXTERIOR SURFACE TREATMENT: smoothed

HEIGHT (IN CM): 11.9

ORIFICE DIAMETER (IN CM): 20.0

DIAMETER AT BOTTOM OF RIM OR NECK (IN CM): 20.1

BASE DIAMETER (IN CM) AND SHAPE OF BASE: N/A

ESTIMATED VOLUME (IN LITERS): 1.4

DECORATION (INCLUDING MOTIF AND ELEMENTS WHEN APPARENT): Plain (Figure 111)

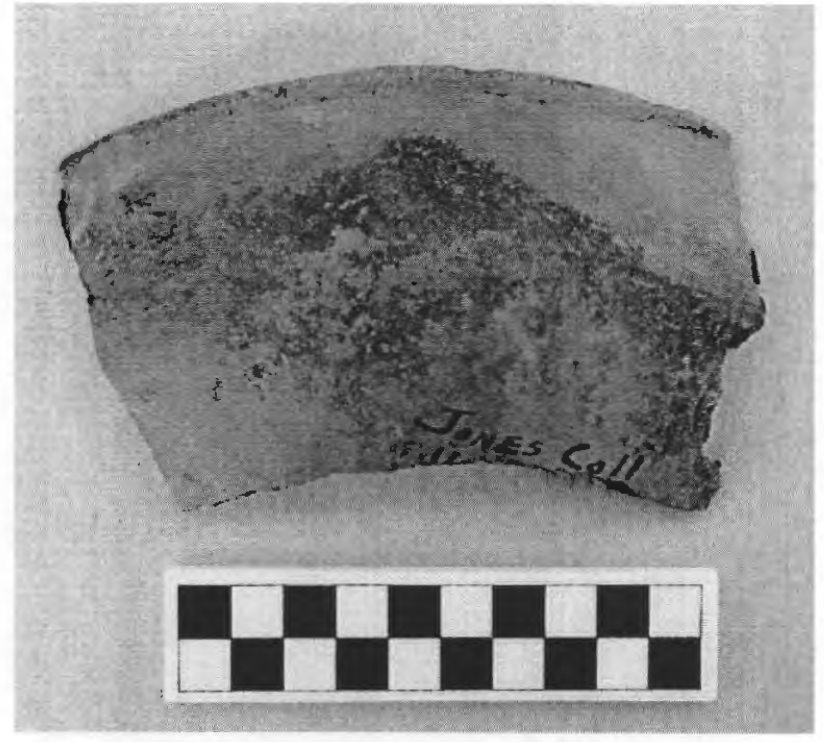

Figure 111. Plain carinated bowl, Henry Williams site, Burial 2, Vessel 2003.08.844.

PIGMENT USE AND LOCATION ON VESSEL: none

TYPE AND VARIETY [IF KNOWN]: Unidentified plain ware 
$120^{\circ}$ Little Cypress Creek Basin Archaeology: Six Late Caddo Period Cemeteries in Upshur County, Texas

VESSEL NO.: 2003.08.1046

NON-PLASTICS AND PASTE: grog

VESSEL FORM: Jar

RIM AND LIP FORM: N/A

CORE COLOR: $\mathrm{G}$ (fired in a reducing environment and cooled in the open air)

INTERIOR SURFACE COLOR: dark grayish-brown

EXTERIOR SURFACE COLOR: yellowish-brown; fire clouds on the body

WALL THICKNESS (RIM, BODY, AND BASE IN MM): body, 7.2 mm

INTERIOR SURFACE TREATMENT: none

EXTERIOR SURFACE TREATMENT: none

HEIGHT (IN CM): N/A

ORIFICE DIAMETER (IN CM): N/A

DIAMETER AT BOTTOM OF RIM OR NECK (IN CM): N/A

BASE DIAMETER (IN CM) AND SHAPE OF BASE: N/A

ESTIMATED VOLUME (IN LITERS): N/A

DECORATION (INCLUDING MOTIF AND ELEMENTS WHEN APPARENT): There are vertical brushing marks on body sherds that extend to within $2.0 \mathrm{~cm}$ of the base.

PIGMENT USE AND LOCATION ON VESSEL: none

TYPE AND VARIETY [IF KNOWN]: Unidentified utility ware 


\section{Burial 3, Burial 4, and Burial 5}

These three burials in the northern part of the ccmetery were described together by Jones in his notcs as being found at a depth of $46 \mathrm{~cm}$ bs. Between them, there were 21 ceramic vessels and 10 triangular arrow points placed in the burials as funerary offcrings; there was also a skull fragment. None of these funerary offerings have been identified in the Henry Williams site collection.

\section{Burial 6}

Burial 6, near the southern part of the cemetery, was in a deep pit $(1.36 \mathrm{~m})$. At the bottom of the burial pit was a $5 \mathrm{~cm}$ thick layer of blue-black alluvial clay. Associated funerary offerings included 17 ceramic vessels, including a "rare vase which might be called a lamp" (Jones n.d.), 26 triangular arrow points, one celt, and one ceramic pipe. The range and frcquency of funerary offerings suggests that Burial 6 was that of an important person, most likely an adult male (Perttula 2012:403-405).

\section{Burial 7}

Burial 7 was in the northern part of the cemetery. The burial pit was $36 \mathrm{~cm}$ decp, and there were skull and arm bone fragments. Associated funerary offerings included six ceramic vessels, 17 triangular arrow points, and a glauconitic green clay mass.

\section{Burial 8}

This burial is near the western end of the cemetery. It was in a deep pit ( $1.22 \mathrm{~m})$ that had fragments of human teeth. Funerary offerings included five ceramic vessels.

\section{Burial 9}

Burial 9 was the westernmost burial in the Henry Williams cemetery, being placed at the end of a row that included Burials $8,15,35,3$, and 7 (see Figure 108). It was also in a deep pit $(1.22 \mathrm{~m}$ ), and there were four ceramic vessels placed in the grave as funerary offerings.

\section{Burial 10}

Burial 10 was very shallow, only $20 \mathrm{~cm}$ bs, likely because of $20^{\text {th }}$ century erosion along the eastern terrace edge. The funerary offerings with this individual included four ceramic vessels, a decorated ceramic pipe, and a mass of green glauconitic clay.

\section{Burial 11}

Burial 11 is the southernmost burial in the cemetery, near Burial 19. It was in a shallow pit ( $20 \mathrm{~cm}$ bs), due most likely to modern erosion on the terrace. Funerary offerings included five vessels and a celt. The three vessels in the Buddy Jones collection that can be identified as being from Burial 11 include one Ripley Engraved, var. Pilgrims carinated bowl and two Taylor Engraved bottles. 
VESSEL NO:: 2003.08.959

NON-PLASTICS AND PASTE: grog

VESSEL FORM: Carinated bowl

RIM AND LIP FORM: Direct rim and rounded, exterior folded lip

CORE COLOR: B (fired and cooled in a reducing environment)

INTERIOR SURFACE COLOR: black

EXTERIOR SURFACE COLOR: grayish-brown

WALL THICKNESS (RIM, BODY, AND BASE IN MM): rim, 7.6 mm; body, $7.4 \mathrm{~mm}$

INTERIOR SURFACE TREATMENT:

smoothed

EXTERIOR SURFACE TREATMENT:

smoothed

HEIGHT (IN CM): 6.8

ORIFICE DIAMETER (IN CM): 15.0

DIAMETER AT BOTTOM OF RIM OR

NECK (IN CM): 15.2

BASE DIAMETER (IN CM) AND SHAPE OF BASE: N/A

ESTIMATED VOLUME (IN LITERS): 0.61

DECORATION (INCLUDING MOTIF AND ELEMENTS WHEN APPARENT):

The rim panel has horizontal engraved scrolls that end with hooked arm elements and have horizontal scroll fill elements that end in triangles. The scrolls are divided by negative S-shaped brackets or simple brackets (Figure 112). There is an interior horizontal engraved line at the carination.

PIGMENT USE AND LOCATION ON VESSEL: white pigment in engraved lines

TYPE AND VARIETY [IF KNOWN]: Unidentified fine ware, probably Ripley Engraved, var. Gandy 
VESSEL NO:: 2003.08.964

NON-PLASTICS AND PASTE: bone and grog

VESSEL FORM: Bottle

RIM AND LIP FORM: N/A

CORE COLOR: B (fired and cooled in a reducing environment)

INTERIOR SURFACE COLOR: black

EXTERIOR SURFACE COLOR: black

WALL THICKNESS (RIM, BODY, AND BASE IN MM): body, $7.0 \mathrm{~mm}$; base, $11.0 \mathrm{~mm}$

INTERIOR SURFACE TREATMENT: none

EXTERIOR SURFACE TREATMENT: smoothed

HEIGHT (IN CM): N/A

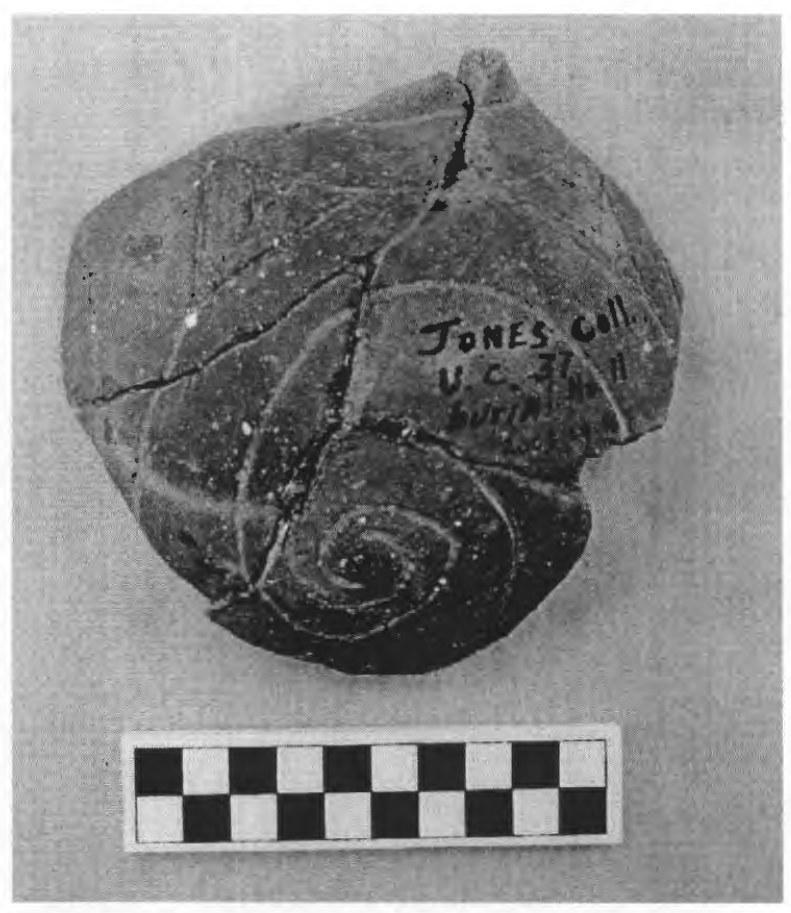

Figure 113. Taylor Engraved bottle, Henry Williams cemetery, Burial 11, Vessel 2003.08.964.

ORIFICE DIAMETER (IN CM): N/A

DIAMETER AT BOTTOM OF RIM OR NECK (IN CM): N/A

BASE DIAMETER (IN CM) AND SHAPE OF BASE: 7.0; flat and circular

ESTIMATED VOLUME (IN LITERS): N/A

DECORATION (INCLUDING MOTIF AND ELEMENTS WHEN APPARENT): The vessel body has four panels of concentric curvilinear engraved lines that end in a hooked arm element. The engraved lines in each panel begin from the apex of upper and lower triangular elements pendant from upper and lower horizontal engraved lines (Figure 113).

PIGMENT USE AND LOCATION ON VESSEL: none

TYPE AND VARIETY [IF KNOWN]: Taylor Engraved 
VESSEL NO.: 2003.08.961

NON-PLASTICS AND PASTE: grog

VESSEL FORM: Bottle

RIM AND LIP FORM: N/A

CORE COLOR: B (fired and cooled in a reducing environment)

INTERIOR SURFACE COLOR: dark grayish-brown

EXTERIOR SURFACE COLOR: dark grayish-brown

WALL THICKNESS (RIM, BODY, AND BASE IN MM): body, $5.7 \mathrm{~mm}$

INTERIOR SURFACE TREATMENT:

none

EXTERIOR SURFACE TREATMENT:

smoothed

HEIGHT (IN CM): N/A

ORIFICE DIAMETER (IN CM): N/A

DIAMETER AT BOTTOM OF RIM OR NECK (IN CM): N/A; $17.3 \mathrm{~cm}$ maximum body diameter

BASE DIAMETER (IN CM) AND SHAPE OF BASE: 9.0; flat and circular

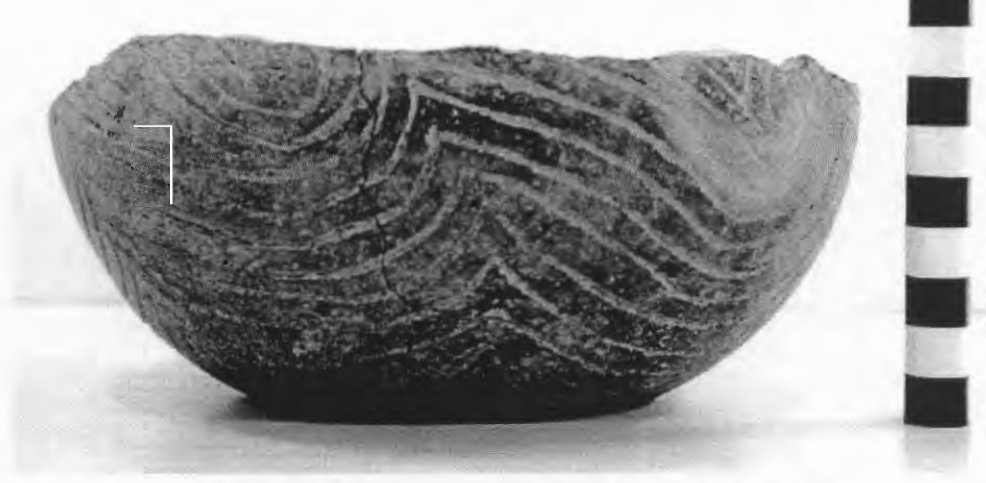

Figure 114. Taylor Engraved bottle, Henry Williams cemetery, Burial 11, Vessel 2003.08.961.

ESTIMATED VOLUME (IN LITERS): N/A

DECORATION (INCLUDING MOTIF AND ELEMENTS WHEN APPARENT): The body has four panels of curvilinear and arcing engraved lines that end in single hooked arm elements (Figure 114).

PIGMENT USE AND LOCATION ON VESSEL: none

TYPE AND VARIETY [IF KNOWN]: Taylor Engraved 


\section{Burial 12}

This burial is in the central part of the cemetery (see Figure 108). Unfortunately, no information was provided about the burial in Jones (n.d.).

\section{Burial 13}

Burial 13 was in a shallow and eroded part of the cemetery. The burial pit extended to only $10 \mathrm{~cm}$ bs. Funerary offerings included only one ceramic vessel.

\section{Burial 14}

This burjal is along the northernmost burial row in the cemetery, near Burial 5. The burial pit was 51 $\mathrm{cm}$ bs, and there were two funerary offerings, both ceramic vessels.

\section{Burial 15}

Burial 15 , in the western part of the cemetery, was in a $66 \mathrm{~cm}$ deep pit. Funerary offerings included six ceramic vessels and five triangular arrow points.

\section{Burial 16}

Burial 16 is a few feet west-northwest of Burial 15 (see Figure 108). It had a deep pit (1.22 m) like those documented for nearby Burials 8 and 9. Associated funerary offerings consisted of three ceramic vessels.

\section{Burial 17}

This burial is in the northwestern part of the cemetery, near Burials 15 and 16 . The burial pit was $1.12 \mathrm{~m}$ in depth. Associated funerary offerings included two ceramic vessels.

\section{Burial 18}

Burial 18 is in an eroded area in the Gum Creek floodplain, near the eastcrn end of the cemetery. The burial pit was only $20 \mathrm{~cm}$ bs; the fill contained a black ash. Associated funerary offerings consist of three ceramic vessels. The two vessels in the collection from Burial 18 are Ripley Engraved, cf. var. Gandy carinated bowls. 
VESSEL NO.: 2003.08.963

NON-PLASTICS AND PASTE: grog

VESSEL FORM: Carinated bowl

RIM AND LIP FORM: Direct rim and a rounded, exterior folded lip

C.ORE COLOR: F (fircd in a reducing environment and cooled in the open air)

INTERIOR SURFACE COLOR: yellowish-brown

EXTERIOR SURFACE COLOR: yellowish-brown

WALL THICKNESS (RIM, BODY, AND BASE IN MM): rim, $5.7 \mathrm{~mm}$; body, $7.5 \mathrm{~mm}$; base, $9.5 \mathrm{~mm}$

INTERIOR SURFACE TREATMENT: smoothed

EXTERIOR SURFACE TREATMENT: smoothed

HEIGHT (IN CM): 12.5

ORIFICE DIAMETER (IN CM): 22.0

DIAMETER AT BOTTOM OF RIM OR NECK (IN CM): 22.0

BASE DIAMETER (IN CM) AND SHAPE OF BASE: 6.5 ; flat and circular

ESTIMATED VOLUME (IN LITERS): 1.65

DECORATION (INCLUDING MOTIF AND ELEMENTS WHEN APPARENT): The rim paneI has an engraved scroll motif repeated four times around the vessel. Above and below the scrolls are excised pendant triangles.

PIGMENT USE AND LOCATION ON VESSEL: none

TYPE AND VARIETY [1F KNOWN]: Ripley Engraved, cf. var. Gandy 
VESSEL NO.: 2003.08.712

NON-PLASTICS AND PASTE: grog

VESSEL FORM: Carinated bowl

RIM AND LIP FORM: Direct rim and a rounded, exterior folded lip

CORE COLOR: B (fired and cooled in a reducing environment)

INTERIOR SURFACE COLOR: dark grayish-brown

EXTERIOR SURFACE COLOR: dark grayish-brown

WALL THICKNESS (RIM, BODY, AND BASE IN MM): rim, $6.0 \mathrm{~mm}$; body, $7.0 \mathrm{~mm}$; base, $11.3 \mathrm{~mm}$

INTERIOR SURFACE TREATMENT: smoothed

EXTERIOR SURFACE TREATMENT:

smoothed

HEIGHT (IN CM): 9.2

ORIFICE DIAMETER (IN CM): 18.0

DIAMETER AT BOTTOM OF RIM OR NECK (IN CM): 17.2

BASE DIAMETER (IN CM) AND SHAPE OF BASE: 6.8 ; flat and circular

ESTIMATED VOLUME (IN LITERS): 0.99

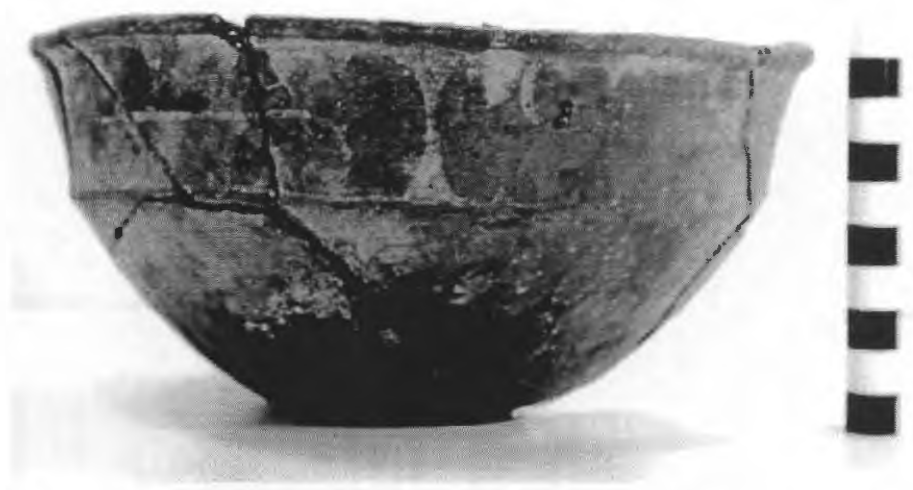

Figure 115. Ripley Engraved, cf. var. Gandy carinated bowl, Henry Williams cemetery, Burial 18, Vessel 2003.08.712.

DECORATION (INCLUDING MOTIF AND ELEMENTS WHEN APPARENT): The rim panel has engraved scrolls repeated four times around the vessel. The scrolls are divided by excised brackets. Above and below each of the scroll lines are excised pendant triangles (Figure 115). There is a single engraved horizontal line at the interior carination point.

PIGMENT USE AND LOCATION ON VESSEL: none

TYPE AND VARIETY [IF KNOWN]: Ripley Engraved, cf. var. Gandy 


\section{Burial 19}

Burial 19 in the Henry Williams cemetery is in an eroded area in the southernmost part, near Burial 11. The burial pit was only $10 \mathrm{~cm}$ in depth. According to Jones (n.d.), this burial only contained one broken vessel, but the collection contains one Ripley, var. Gandy carinated bowl as well as fragments of a Ripley Engraved, var. unspecified carinated bowl.

VESSEL NO:: 2003.08.721

NON-PLASTICS AND PASTE: grog

VESSEL FORM: Carinated bowl

RIM AND LIP FORM: Direct rim and rounded, exterior folded lip

CORE COLOR: $\mathrm{F}$ (fired in a reducing environment and cooled in the open air)

INTERIOR SURFACE COLOR: yellowish-brown; fire clouds on the base

EXTERIOR SURFACE COLOR: yellowish-brown; fire clouds on the rim, body, and base

WALL THICKNESS (RIM, BODY, AND

BASE IN MM): rim, $9.1 \mathrm{~mm}$; body, $8.0 \mathrm{~mm}$

INTERIOR SURFACE TREATMENT:

smoothed

EXTERIOR SURFACE TREATMENT:

smoothed

HEIGHT (IN CM): 12.7

ORIFICE DIAMETER (IN CM): 26.0

DIAMETER AT BOTTOM OF RIM OR

NECK (IN CM): 26.0

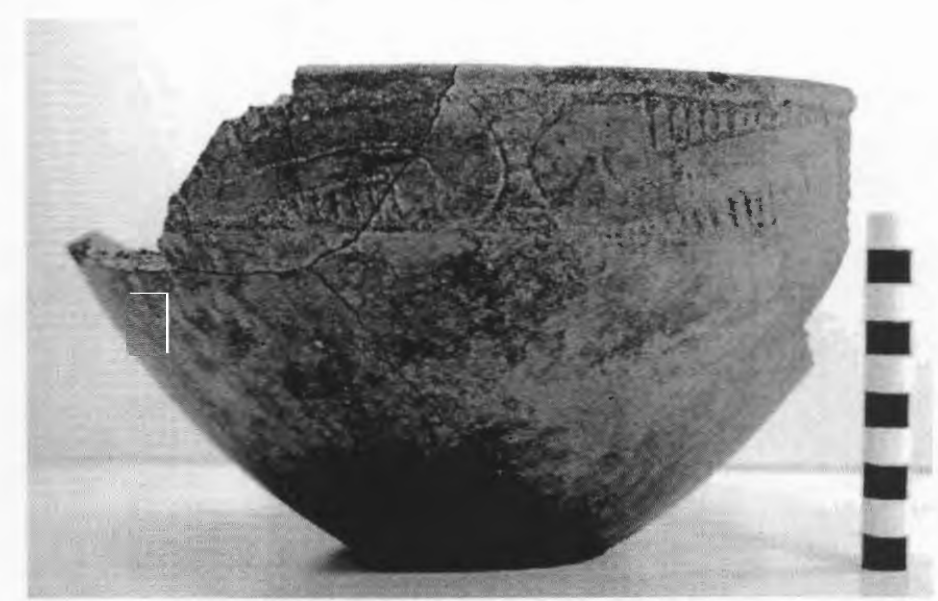

Figure 116. Ripley Engraved, var. Gandy carinated bowl, Henry Williams cemetery, Burial 19, Vessel 2003.08.721.

BASE DIAMETER (IN CM) AND SHAPE OF BASE: 8.9; flat and circular

ESTIMATED VOLUME (IN LITERS): 1.98

DECORATION (INCLUDING MOTIF AND ELEMENTS WHEN APPARENT): The rim panel has an engraved scroll motif repeated an unknown number of times around the vessel (probably four times, but only a portion of the rim is available). The scrolls are divided by hatched brackets, and there are upper and lower hatched scroll fill zones (Figure 116).

PIGMENT USE AND LOCATION ON VESSEL: none

TYPE AND VARIETY [IF KNOWN]: Ripley Engraved, var. Gandy 
VESSEL NO.: 2003.08.960

NON-PLASTICS AND PASTE: grog

VESSEL FORM: Carinated bowl

RIM AND LIP FORM: N/A

CORE COLOR: $F$ (fired in a reducing environment and cooled in the open air)

INTERIOR SURFACE COLOR: yellowish-brown; fire cloud on the base

EXTERIOR SURFACE COLOR: yellowish-brown

WALL THICKNESS (RIM, BODY, AND BASE IN MM): rim, 8.0 mm; body, 7.4 mm

INTERIOR SURFACE TREATMENT: smoothed

EXTERIOR SURFACE TREATMENT: smoothed

HEIGHT (IN CM): N/A

ORIFICE DIAMETER (IN CM): N/A

DIAMETER AT BOTTOM OF RIM OR NECK (IN CM): 22.0

BASE DIAMETER (IN CM) AND SHAPE OF BASE: 9.5; flat and circular

ESTIMATED VOLUME (IN LITERS): N/A

DECORATION (INCLUDING MOTIF AND ELEMENTS WHEN APPARENT): The small portion of the remaining rim has a single horizontal engraved line with excised pendant triangles.

PIGMENT USE AND LOCATION ON VESSEL: none

TYPE AND VARIETY [IF KNOWN]: Ripley Engraved, var. unspecified 


\section{Burial 20}

This burial is in the southern part of the cemetery, a few feet south of Burial 6 and 13 . The burial pit was $1.22 \mathrm{~m}$ deep. Funerary offcrings consisted of four ceramic vessels, of which two can be identified from this burial in the collection: a Ripley Engraved, var. unspecified carinated bowl and a Harleton Appliqued jar.

VESSEL NO.: 2003.08.1973

NON-PLASTICS AND PASTE: grog and hematite

VESSEL FORM: Carinated bowl

RIM AND LIP FORM: Direct rim and rounded, exterior folded lip

CORE COLOR: $F$ (fired in a reducing environment and cooled in the open air)

INTERIOR SURFACE COLOR: yellowish-brown; fire clouds on the rim and body

EXTERIOR SURFACE COLOR: yellowish-brown

WALL THICKNESS (RIM, BODY, AND BASE IN MM): rim, 8.0 mm; body, $7.5 \mathrm{~mm}$; base, $9.7 \mathrm{~mm}$

INTERIOR SURFACE TREATMENT: burnished

EXTERIOR SURFACE TREATMENT: smoothed

HEIGHT (IN CM): N/A

ORIFICE DIAMETER (IN CM): 25.0

DIAMETER AT BOTTOM OF RIM OR NECK (IN CM): 24.9

BASE DIAMETER (IN CM) AND SHAPE OF BASE: 8.5; flat and circular

ESTIMATED VOLUME (IN LITERS): N/A

DECORATION (INCLUDING MOTIF AND ELEMENTS WHEN APPARENT): The rim panel has an engraved horizontal scroll motif; the motifs are separated by open engraved brackets. Above and below the horizontal scrolls are single rows of excised pendant triangles. There is a single horizontal engraved line at the interior carination point.

PIGMENT USE AND LOCATION ON VESSEL: none

TYPE AND VARIETY [1F KNOWN]: Riplcy Engraved, cf. var. Gandy 
VESSEL NO.: 2003.08.1042

NON-PLASTICS AND PASTE: grog

VESSEL FORM: Jar with four rim peaks and four strap handles $(2.2 \times 1.7 \mathrm{~cm}$ in length and width) (Figure 117)

RIM AND LIP FORM: Everted rim and rounded lip

CORE COLOR: $\mathrm{F}$ (fired in a reducing environment and cooled in the open air)

INTERIOR SURFACE COLOR: yellowish-brown

EXTERIOR SURFACE COLOR: yellowish-brown; fire clouds on the rim and body; organic residue on the rim and body

WALL THICKNESS (RIM, BODY, AND BASE IN MM): rim, $5.6 \mathrm{~mm}$; body, $5.1 \mathrm{~mm}$

INTERIOR SURFACE TREATMENT: smoothed

EXTERIOR SURFACE TREATMENT: none

HEIGHT (IN CM): N/A

ORIFICE DIAMETER (IN CM): 16.0

DIAMETER AT BOTTOM OF RIM OR NECK (IN CM): 14.5

BASE DIAMETER (IN CM) AND SHAPE OF BASE: N/A

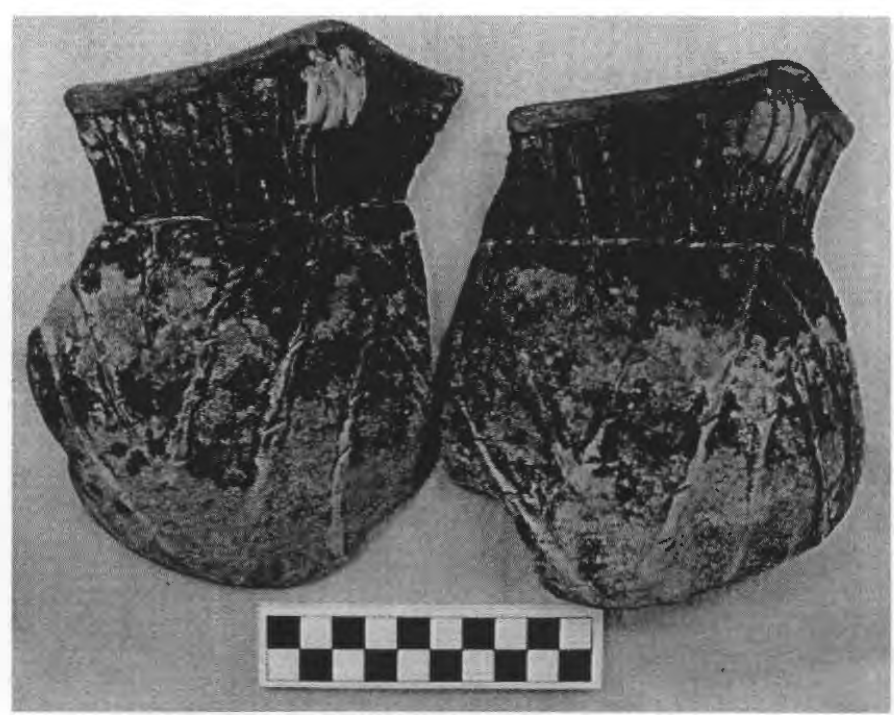

Figure 117. Harleton Appliqued jar, Henry Williams cemetery, Burial 20, Vessel 2003.08.1042.

ESTIMATED VOLUME (IN LITERS): N/A

DECORATION (INCLUDING MOTIF AND ELEMENTS WHEN APPARENT): The rim has broad vertical incised lines, as do each of the four strap handles. The strap handles are set underneath each of the four rim peaks. The vessel body has four upper and lower appliqued fillet chevrons (Figure 117).

PIGMENT USE AND LOCATION ON VESSEL: none

TYPE AND VARIETY [IF KNOWN]: Harleton Appliqued

\section{Burial 21}

Burial 21 is in the western part of the cemetery, southeast of Burials 8 and 9 . The burial pit was 1.02 $m$ in depth, and had three ceramic vessels placed with the deceased as funerary offerings. 


\section{Burial 22}

Burial 22 is a few feet east-northeast of Burial 21 in the western part of the cemetery. The burial pit was $46 \mathrm{~cm}$ bs, and Jones (n.d.) suggested that bones found in one of the vessels may have come from an infant. Funerary offerings consisted of four ceramic vessels, all of which can be identified in the collection. These vessels include a Harleton Appliqued jar, and three Ripley Engraved (cf. var. Gandy, var. Gandy, and var. unspecified) carinated bowls.

VESSEL NO.: 2003.08.957

NON-PLASTICS AND PASTE: grog

VESSEL FORM: Jar

RIM AND LIP FORM: N/A

CORE COLOR: F (fired in a reducing environment and cooled in the open air)

INTERIOR SURFACE COLOR: reddish-brown

EXTERIOR SURFACE COLOR: yellowish-brown; fire clouds on the body

WALL THICKNESS (RIM, BODY, AND BASE

IN MM): rim, $5.6 \mathrm{~mm}$; body, $6.5 \mathrm{~mm}$

INTERIOR SURFACE TREATMENT: smoothed

EXTERIOR SURFACE TREATMENT: none

HEIGHT (IN CM): N/A

ORIFICE DIAMETER (IN CM): N/A

DIAMETER AT BOTTOM OF RIM OR NECK (IN CM): N/A

BASE DIAMETER (IN CM) AND SHAPE OF BASE: N/A

ESTIMATED VOLUME (IN LITERS): N/A

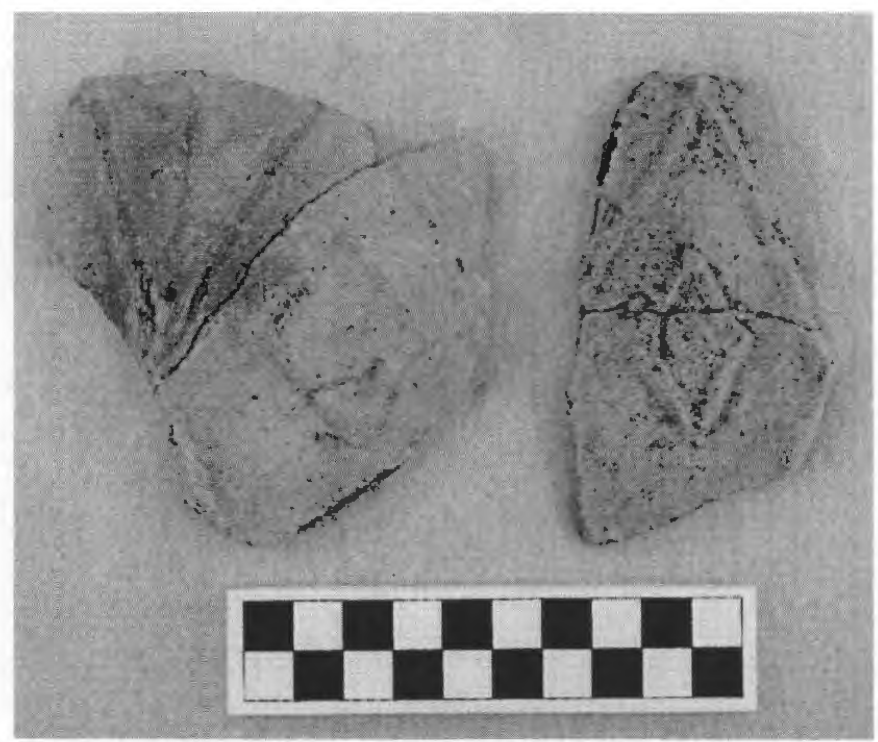

Figure 118. Harleton Appliqued jar, Henry Williams cemetery, Burial 22, Vessel 2003.08.957.

DECORATION (INCLUDING MOTIF AND ELEMENTS WHEN APPARENT): The rim is decorated with horizontal rows of tool punctations. The vessel body has an unknown number of appliqued fillet nested diamonds separated by triangular areas with a single vertical appliqued fillet down the center of the triangles (Figure 118). 
VESSEL NO.: 2003.08.1048

NON-PLASTICS AND PASTE: grog

VESSEL FORM: Carinated bowl

RIM AND LIP FORM: Direct rim and a rounded, exterior folded lip

CORE COLOR: $\mathrm{F}$ (fired in a reducing environment and cooled in the open air)

INTERIOR SURFACE COLOR: yellowish-brown; fire clouds on the rim and body; organic residue on the rim

EXTERIOR SURFACE COLOR: dark yellowish-brown; fire clouds on the body; thick organic residue on the rim and body

WALL THICKNESS (RIM, BODY, AND BASE IN MM): rim, $6.2 \mathrm{~mm}$; body, $6.5 \mathrm{~mm}$

INTERIOR SURFACE TREATMENT: smoothed on the rim

EXTERIOR SURFACE TREATMENT: smoothed

HEIGHT (IN CM): 11.0

ORIFICE DIAMETER (IN CM): 27.5

DIAMETER AT BOTTOM OF RIM OR NECK

(IN CM): 27.1

BASE DIAMETER (IN CM) AND SHAPE OF BASE: 8.2; flat and circular base

ESTIMATED VOLUME (IN LITERS): 1.8

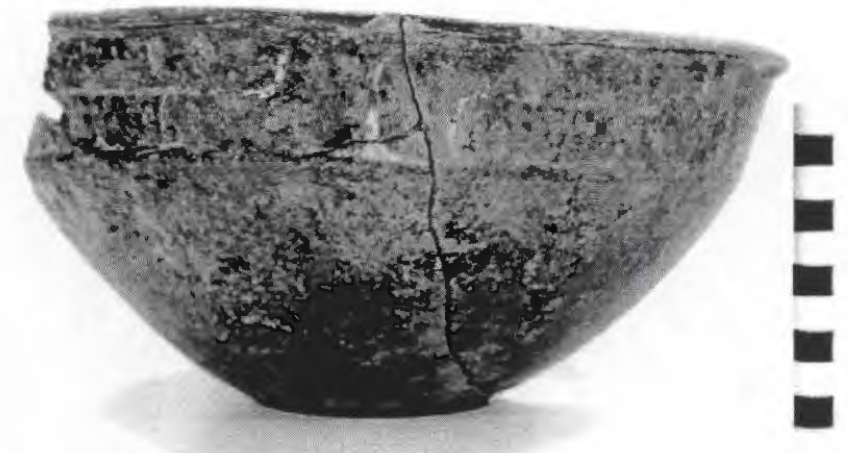

Figure 119. Ripley Engraved, cf. var. Gandy carinated bowl, Henry Williams cemetery, Burial 22, Vessel 2003.08.1048.

DECORATION (INCLUDING MOTIF AND ELEMENTS WHEN APPARENT): The rim panel has an engraved scroll motif repeated four times around the vessel. The scrolls are divided by open brackets. Above and below each of the scrolls are single rows of excised pendant triangles (Figure 119). There is a single horizontal engraved line at the interior carination.

PIGMENT USE AND LOCATION ON VESSEL: white pigment in the engraved lines TYPE AND VARIETY [IF KNOWN]: Ripley Engraved, cf. var. Gandy 
VESSEL NO.: 2003.08.1044

NON-PLASTICS AND PASTE: grog, hematite, and bone

VESSEL FORM: Carinated bowl

RIM AND LIP FORM: Direct rim and a rounded lip

CORE COLOR: $\mathrm{F}$ (fired in a reducing environment and cooled in the open air)

INTERIOR SURFACE COLOR: yellowish-brown; fire cloud on the base; organic residue on the rim

EXTERIOR SURFACE COLOR: yellowish-brown; fire clouds on the body; organic residue on the rim/lip and body

WALL THICKNESS (RIM, BODY, AND BASE IN MM): base, 12.9 mm

INTERIOR SURFACE TREATMENT:

smoothed on the rim

EXTERIOR SURFACE TREATMENT:

smoothed

HEIGHT (IN CM): 10.0

ORIFICE DIAMETER (IN CM): 23.0

DIAMETER AT BOTTOM OF RIM OR

NECK (IN CM): 23.0

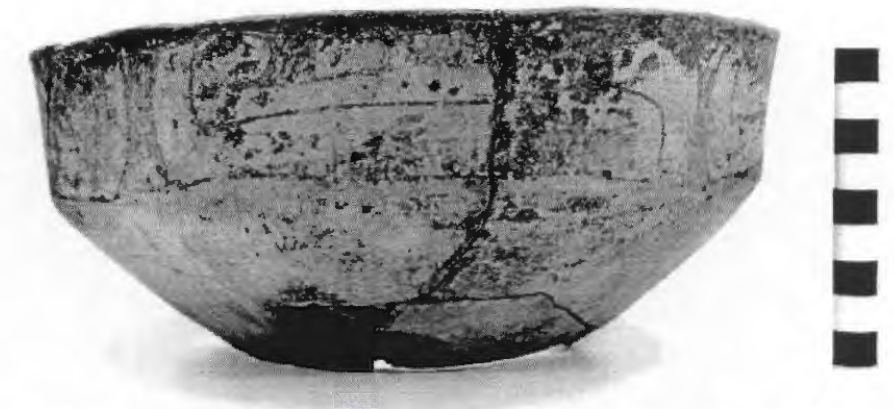

Figure 120. Ripley Engraved, var. Gandy carinated bowl, Henry Williams cemetery, Burial 22, Vessel 2003.08.1044.

BASE DIAMETER (IN CM) AND SHAPE OF BASE: 9.0; flat and circular

ESTIMATED VOLUME (IN LITERS): 1.38

DECORATION (INCLUDING MOTIF AND ELEMENTS WHEN APPARENT): The rim panel has an engraved scroll motif repeated four times around the vessel. The scrolls are divided by excised brackets (one of which has two internal excised pendant triangles on its lower end), and the upper scroll fill zones include excised columns and vertical lines (Figure 120).

PIGMENT USE AND LOCATION ON VESSEL: none

TYPE AND VARIETY [IF KNOWN]: Ripley Engraved, var. Gandy 
VESSEL NO.: 2003.08.1045

NON-PLASTICS AND PASTE: grog

VESSEL FORM: Carinated bowl

RIM AND LIP FORM: Direct rim and rounded, exterior folded lip

CORE COLOR: B (fired and cooled in reducing environment)

INTERIOR SURFACE COLOR: black; fire cloud on the body

EXTERIOR SURFACE COLOR: black

WALL THICKNESS (RIM, BODY, AND BASE IN $\mathrm{MM}$ ): rim, $5.9 \mathrm{~mm}$; body, $4.8 \mathrm{~mm}$; base, $8.2 \mathrm{~mm}$

INTERIOR SURFACE TREATMENT: smoothed EXTERIOR SURFACE TREATMENT: burnished

HEIGHT (IN CM): 12.5

ORIFICE DIAMETER (IN CM): 28.0

DIAMETER AT BOTTOM OF RIM OR NECK (IN CM): 28.0

BASE DIAMETER (IN CM) AND SHAPE OF BASE: N/A

ESTIMATED VOLUME (IN LITERS): 2.1

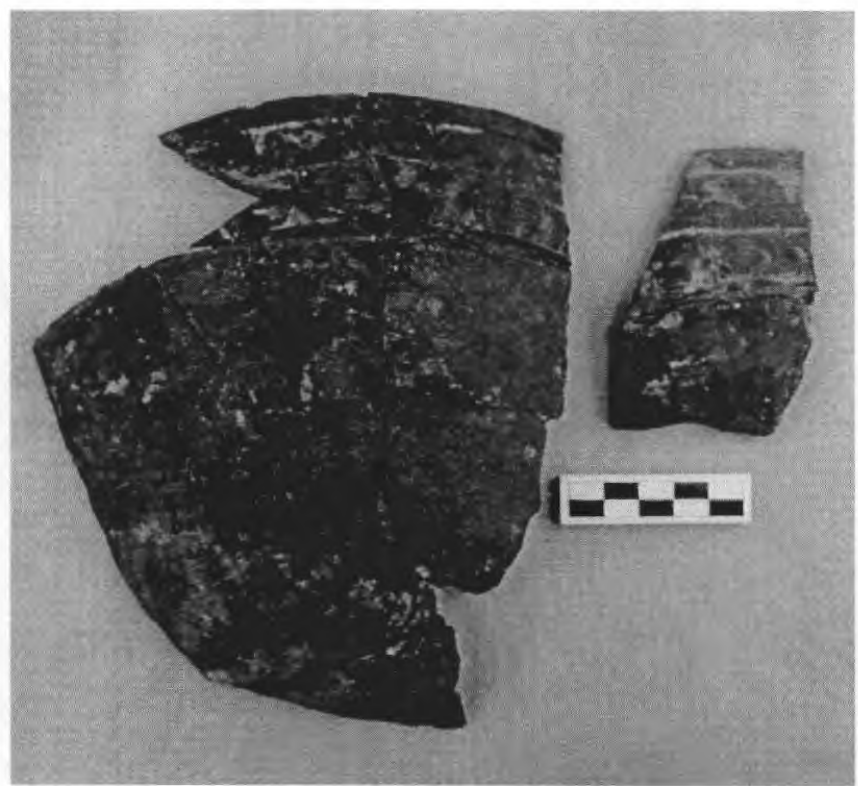

Figure 121. Ripley Engraved, var. unspecified carinated bowl, Henry Williams cemetery, Burial 22, Vessel 2003.08.1045.

DECORATION (INCLUDING MOTIF AND ELEMENTS WHEN APPARENT): The rim has a portion of a horizontal engraved scroll and upper and lower excised pendant triangles (Figure 12I). There is a single horizontal engraved line at the interior carination.

PIGMENT USE AND LOCATION ON VESSEL: none

TYPE AND VARIETY [IF KNOWN]: Ripley Engraved, var. unspecified

\section{Burial 23}

This burial is in the western part of the cemetery. The burial pit was relatively shallow $(46 \mathrm{~cm})$, and four ceramic vessels were placed in the grave as funerary offerings. 


\section{Burial 24}

Burial 24 is a few fcct southeast of Burial 23, and in the vicinity of Burials 25-27 (see Figure 108). The burial pit was $51 \mathrm{~cm}$ in depth, and contained several funerary offerings, including eight triangular arrow points and five ccramic vessels.

\section{Burial 25}

Burial 25 was in a shallow pit ( $15 \mathrm{~cm}$ bs). Funerary offerings consistcd of three ceramic vessels.

\section{Burial 26}

This burial was in a shallow and eroded area, with the burial pit extending only to $15 \mathrm{~cm}$ bs. Funerary offerings included an unknown number of broken ceramic vessels.

\section{Burial 27}

Burial 27 is in the southern part of the cemetery. It had a shallow pit (30 $\mathrm{cm} \mathrm{bs),} \mathrm{and} \mathrm{there} \mathrm{were} \mathrm{four}$ ceramic vessels placed in the grave as funerary offerings. Three of the vessels from this burial are in the collections, and they are all engraved compound bowls. One is from an unidentified type, while the other two are Ripley Engraved (var. Cash and var. Galt) vessels.

VESSEL NO:: 2003.08 .1080

NON-PLASTICS AND PASTE: grog and sandy paste

VESSEL FORM: Compound bowl

RIM AND LIP FORM: Everted rim and rounded, exterior folded lip

CORE COLOR: $\mathrm{G}$ (fircd in a reducing environment and cooled in the open air)

INTERIOR SURFACE COLOR: dark grayish-brown

EXTERIOR SURFACE COLOR: yellowish-brown

WALL THICKNESS (RIM, BODY, AND BASE IN MM): upper panel rim, 6.4 mm; lower panel rim, 6.3 $\mathrm{mm}$; body, $7.5 \mathrm{~mm}$; base, $13.4 \mathrm{~mm}$

INTERIOR SURFACE TREATMENT: smoothed

EXTERIOR SURFACE TREATMENT: smoothed

HEIGHT (IN CM): N/A 
ORIFICE DIAMETER (IN CM): 34.0

DIAMETER AT BOTTOM OF RIM OR NECK (IN CM): 32.9

BASE DIAMETER (IN CM) AND SHAPE OF BASE: 9.3; flat and circular

FSTIMATED VOLUME (IN LITERS): N/A

DECORATION (INCLUDING MOTIF AND ELEMENTS WHEN APPARENT): The upper rim panel is decorated with two widely-spaced horizontal engraved lines. The lower rim panel is plain.

PIGMENT USE AND LOCATION ON VESSEL: none

TYPE AND VARIETY [IF KNOWN]: Unidentified fine ware

VESSEL NO.: 2003.08.1079

NON-PLASTICS AND PASTE: grog, bone, and hematite

VESSEL FORM: Compound bowI

RIM AND LIP FORM: Everted rim and rounded lip

CORE COLOR: $\mathrm{G}$ (fired in a reducing environment and cooled in the open air)

INTERIOR SURFACE COLOR: dark grayish-brown

EXTERIOR SURFACE COLOR: yellowish-brown; fire clouds on the rim and body

WALL THICKNESS (RIM, BODY, AND BASE IN MM): upper rim panel, $10.5 \mathrm{~mm}$; Iower rim panel, $10.2 \mathrm{~mm}$

INTERIOR SURFACE TREATMENT: smoothed

EXTERIOR SURFACE TREATMENT: smoothed

HEIGHT (IN CM): N/A; upper and lower rim panel height is $13.2 \mathrm{~cm}$

ORIFICE DIAMETER (IN CM): 33,0

DIAMETER AT BOTTOM OF RIM OR NECK (IN CM): 35.0

BASE DIAMETER (IN CM) AND SHAPE OF BASE: N/A

ESTIMATED VOLUME (IN LITERS): N/A 
DECORATION (INCLUDING MOTIF AND ELEMENTS WHEN APPARENT): The upper rim panel has three widely-spaced horizontal engraved lines. The lower rim panel has an engraved circle and nested triangle motif repeated around the vessel. The nested triangles (two) have a small central dot, and upper scroll fill zones with excised brackets, curvilinear zones, and triangles. The circle element has a central diamond with a negative oval, and upper scroll fill zones with excised brackets, curvilinear zones, and triangles (Figure 122).

PIGMENT USE AND LOCATION ON VESSEL: white pigment in the engraved lines

TYPE AND VARIETY [IF KNOWN]: Ripley Engraved, var. Cash

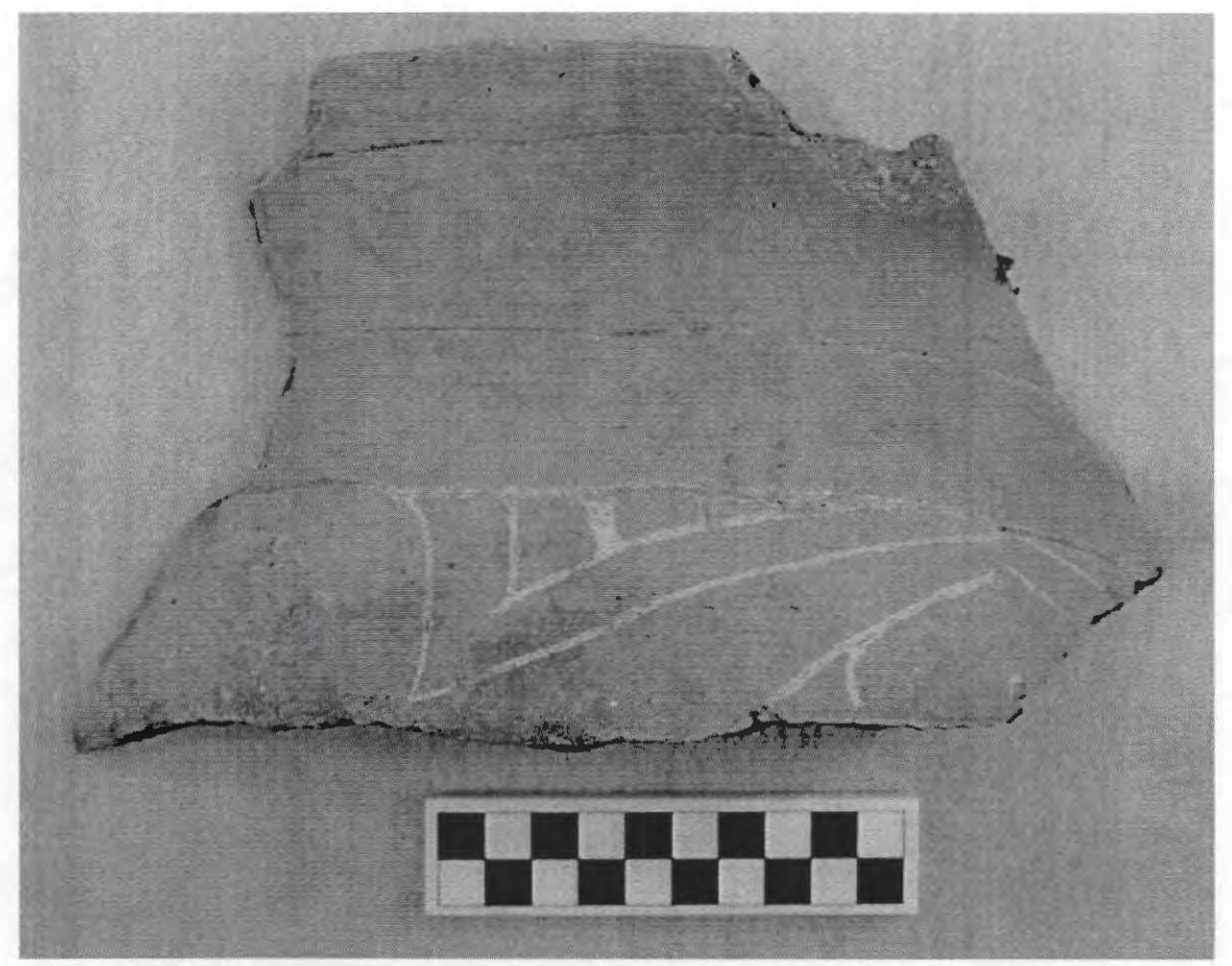

Figure 122. Ripley Engraved, var. Cash compound bowl, Henry Williams cemetery, Burial 27, Vessel 2003.08.1079. 
VESSEL NO.: 2003.08.1078

NON-PLASTICS AND PASTE: grog

VESSEL FORM: Compound bowl

RIM AND LIP FORM: Everted rim and rounded, exterior folded lip

CORE COLOR: B (fired and cooled in a reducing environment)

INTERIOR SURFACE COLOR: dark grayish-brown

EXTERIOR SURFACE COLOR: dark grayish-brown

WALL THICKNESS (RIM, BODY, AND BASE IN

MM): body, $7.3 \mathrm{~mm}$

INTERIOR SURFACE TREATMENT: smoothed

EXTERIOR SURFACE TREATMENT: smoothed

HEIGHT (IN CM): N/A

ORIFICE DIAMETER (IN CM): N/A

DIAMETER AT BOTTOM OF RIM OR NECK (IN CM): N/A

BASE DIAMETER (IN CM) AND SHAPE OF BASE: N/A

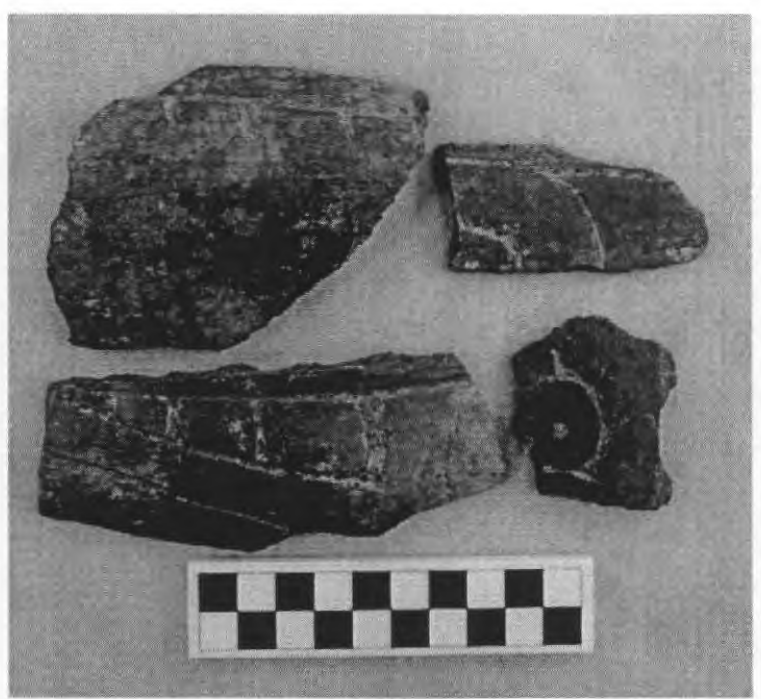

Figure 123. Ripley Engraved, var. Galt compound bowl, Henry Williams cemetery, Burial 27, Vessel 2003.08.1078.

ESTIMATED VOLUME (IN LITERS): N/A

DECORATION (INCLUDING MOTIF AND ELEMENTS WHEN APPARENT): The upper rim panel has widely-spaced horizontal engraved lines. The lower rim panel has an engraved scroll and circle motif repeated four times around the vessel. The circles have a smaller central circle with a dot and exterior tick marks or rays. The upper and lower scroll fill zones have excised brackets and vertical excised lines (Figure 123).

PIGMENT USE AND LOCATION ON VESSEL: white pigment in the engraved lines

TYPE AND VARIETY [IF KNOWN]: Ripley Engraved, var. Galt 


\section{Burial 28}

This burial is one of several (Burials 1, 18,28-30, 36, and 37) in the Henry Williams cemetery situated at the edge of the Gum Creek floodplain (see Figure 108). These burials are in shallow pits; Burial 28 extended to only $36 \mathrm{~cm}$ bs. Funerary offerings consisted of five ceramic vessels.

\section{Burial 29}

Burial 29 is a few feet west of Burial 28 . The burial pit extended to $36 \mathrm{~cm}$ bs. The funerary offerings with this individual included four ceramic vessels.

\section{Burial 30}

Burial 30 is a few fect north of both Burials 28 and 29 . The burial pit was only $30 \mathrm{~cm}$ bs. Funerary offerings consisted of two ceramic vessels and five triangular arrow points. The two vessels are identified in the collection: one is a Ripley Engraved, var. Gandy carinated bowl, while the other is a unique conjoined vessel (carinated bowls and a bottle body) with both Ripley Engraved and Wilder Engraved decorative motifs.

VESSEL NO:: 2003.08.958

NON-PLASTICS AND PASTE: grog

VESSEL FORM: Carinated bowI

RIM AND LIP FORM: Inverted rim and rounded lip

CORE COLOR: $G$ (fired in a reducing environment and cooled in the open air)

INTERIOR SURFACE COLOR: dark grayish-brown; fire clouds on the rim and base

EXTERIOR SURFACE COLOR: yellowish-brown

WALLTHICKNESS (RIM, BODY, AND BASE IN MM): rim, $6.6 \mathrm{~mm}$; body, $7.4 \mathrm{~mm}$; base, $10.4 \mathrm{~mm}$

INTERIOR SURFACE TREATMENT: none

EXTERIOR SURFACE TREATMENT: smoothed

HEIGHT (IN CM): 20.0

ORIFICE DIAMETER (IN CM): 18.0

DIAMETER AT BOTTOM OF RIM OR NECK (IN CM): 20.2

BASE DIAMETER (IN CM) AND SHAPE OF BASE: 7.8; flat and circular

ESTIMATED VOLUME (IN LITERS): 3.2 
DECORATION (INCLUDING MOTIF AND ELEMENTS WHEN APPARENT): The rim panel has an engraved scroll motif repeated four times around the vessel. The scrolls are divided by open brackets. The scroll fill zones consist of either one upper or one lower triangular-shaped engraved area (Figure 124).

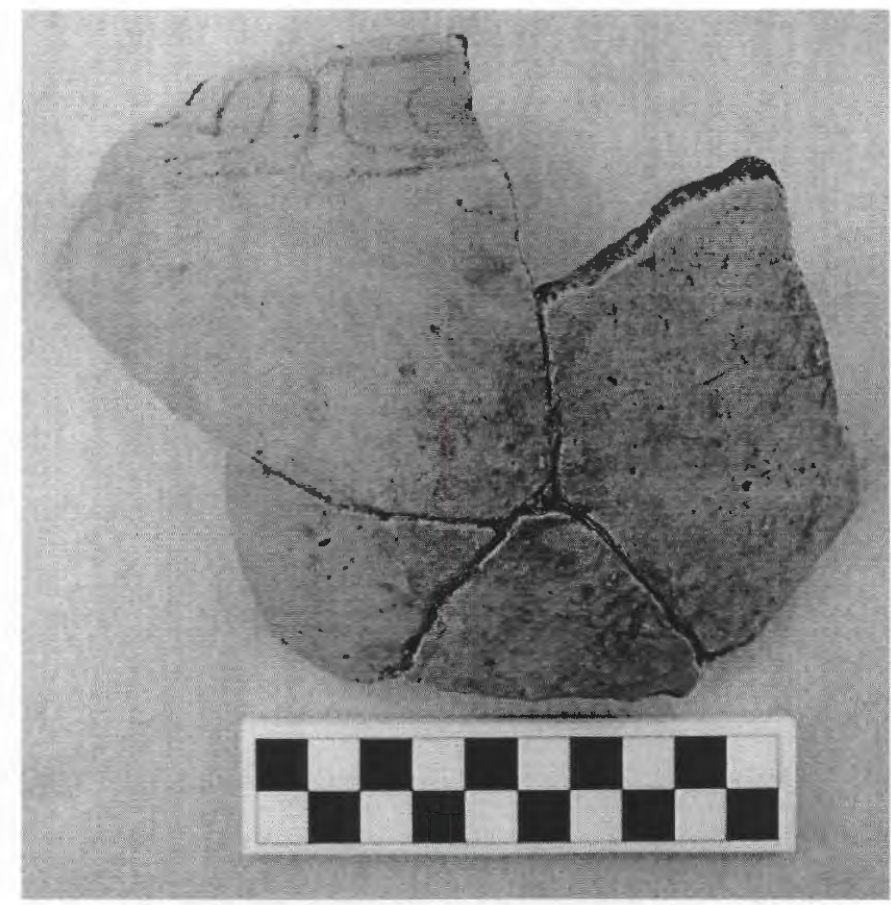

Figure 124. Ripley Engraved, var. Gandy carinated bowl, Henry Williams cemetery, Burial 30, Vessel 2003.08.958.

PIGMENT USE AND LOCATION ON VESSEL: none

TYPEAND VARIETY [IF KNOWN]: Ripley Engraved, var. Gandy

VESSEL NO.: 2003.08.0278

NON-PLASTICS AND PASTE: grog

VESSEL FORM: Conjoined carinated bowls and bottle body (Figure 125)

RIM AND LIP FORM: Direct rim and a rounded, exterior folded lip; scalloped Redwine mode lip (see Walters 2010)

CORE COLOR: $\mathrm{G}$ (fired in a reducing environment and cooled in the open air)

INTERIOR SURFACE COLOR: grayish-brown

EXTERIOR SURFACE COLOR: yellowish-brown 
WALL THICKNESS (RIM, BODY, AND BASE IN MM): rim, $8.1 \mathrm{~mm}$

INTERIOR SURFACE TREATMENT: smoothed

EXTERIOR SURFACE TREATMENT: smoothed

HEIGHT (IN CM): 21.0

ORIFICE DIAMETER (IN CM): 21.2

DIAMETER AT BOTTOM OF RIM OR NECK (IN CM): 21.0

BASE DIAMETER (IN CM) AND SHAPE OF BASE: 7.5; flat and circular

ESTIMATED VOLUME (IN LITERS): 4.0

DECORATION (INCLUDING MOTIF AND ELEMENTS WHEN APPARENT): The lowermost portion of the conjoined vessel has a Wilder Engraved, var. unspecified bottle motif of encircling scrolls that do not meet at the center of the motif. Each scroll arm begins from the apex of large upper and lower pendant triangles. The scrolls have wider excised areas where the two scrolls pass each other (Figure 125).

Above the bottle portion of the vessel is a Ripley Engraved, var. unspecified carinated bowl engraved motif repeated around the vessel. The motif consists of stacked horizontal scrolls that end in squat negative S-shaped elements; the scrolls are divided by two sets of negative S-shaped elements (as seen on var. Gandy vessels) (see Figure 125).

The top portion of the conjoined vessel has a Ripley Engraved, var. McKinney carinated bowl motif. The motif has two alternating central engraved circles and diamonds (both with inner central diamonds), with the diamond element the central part of a scroll element with upper and lower excised columns. Above and below the scrolls are single rows of excised pendant triangles (see Figure 125).

PIGMENT USE AND LOCATION ON VESSEL: red pigment in the engraved lines in all three conjoined vessel sections.

TYPE AND VARIETY [IF KNOWN]: Ripley Engraved and Wilder Engraved fusion

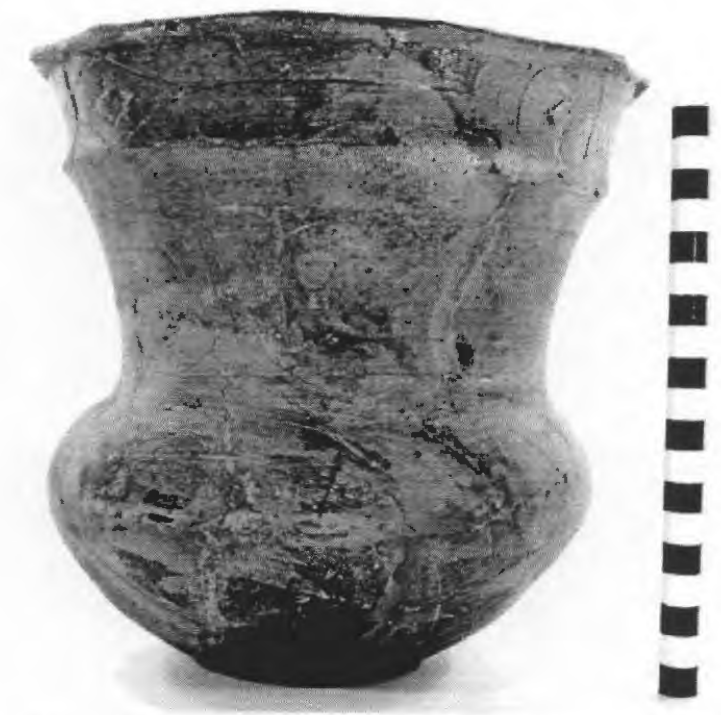

Figure 125. Conjoined Ripley EngravedWilder Engraved carinated bowls and bottle, Henry Williams cemetery, Burial 30, Vessel 2003.08.278. 


\section{Burial 31}

Burial 31 is located along the northernmost row in the Henry Williams cemetery, with Burials 14,5 , $33,32,31,10$, and 37 proceeding from west to east (see Figure 108). The burial pit was shallow (36 cm bs), and had four funerary offerings, all ceramic vessels.

\section{Burial 32}

Burial 32 is between Burials 31 and 33 in the northernmost part of the cemetery. The burial pit was the deepest $(1.37 \mathrm{~m})$ of any of the burials in the cemetery. Funerary offerings included 13 triangular arrow points and three ceramic vessels. The two vessels in the collection that can be identified as coming from Burial 32 are a very large Ripley Engraved, var. Galt compound bowl and a very large Ripley Engraved, cf. var. Gandy carinated bowl.

VESSEL NO.: 2003.08.1964

NON-PLASTICS AND PASTE: grog

VESSEL FORM: Compound bowl

RIM AND LIP FORM: Everted rim and rounded lip

CORE COLOR: $\mathrm{F}$ (fired in a reducing environment and cooled in the open air)

INTERIOR SURFACE COLOR: yellowish-brown

EXTERIOR SURFACE COLOR: yellowish-brown; fire clouds on the rim and body

WALL THICKNESS (RIM, BODY, AND BASE IN MM): rim, 7.1 mm; body, $7.3 \mathrm{~mm}$

INTERIOR SURFACE TREATMENT: smoothed

EXTERIOR SURFACE TREATMENT: smoothed

HEIGHT (IN CM): N/A; upper and lower rim panel height is $11.0 \mathrm{~cm}$

ORIFICE DIAMETER (IN CM): 33.0

DIAMETER AT BOTTOM OF RIM OR NECK (IN CM): 32.0

BASE DIAMETER (IN CM) AND SHAPE OF BASE: N/A

ESTIMATED VOLUME (IN LITERS): N/A 
DECORATION (INCLUDING MOTIF AND ELEMENTS WHEN APPARENT): The upper rim panel has three widely-spaced horizontal engraved lines. The lower rim panel is decorated with an engraved scroll and circle motif repeated four times around the vessel. The central circles have an inner diamond element with a negative oval (Figure 126a-b). The upper and lower scroll fill zones consist of triangular-shaped elements.

PIGMENT USE AND LOCATION ON VESSEL: none

TYPE AND VARIETY [IF KNOWN]: Ripley Engraved, var. Galt
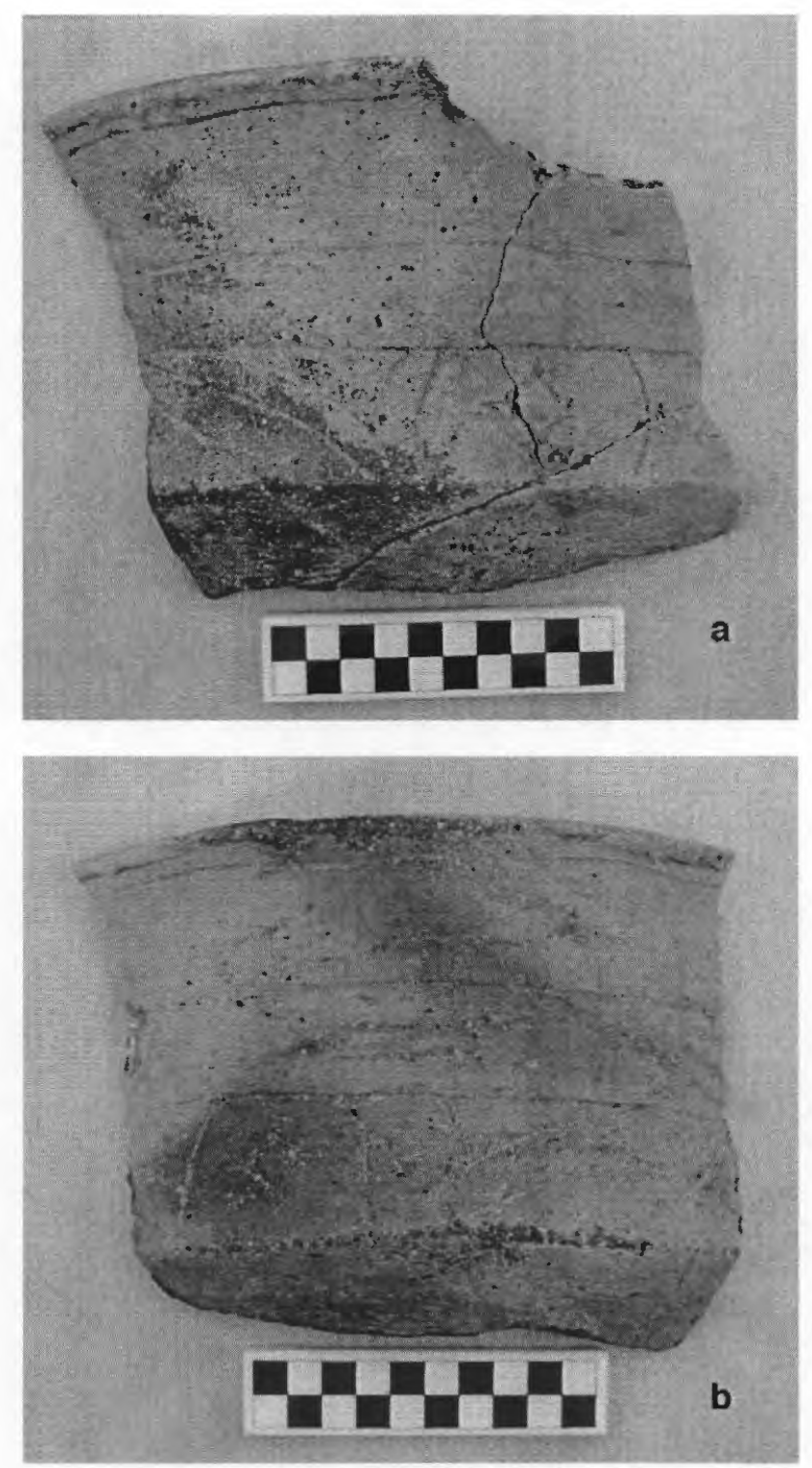

Figure 126. Ripley Engraved, var. Galt compound bowl, Henry Williams cemetery, Burial 32, Vessel 2003.08.1964: a-b, circle element and scroll fill zone. 
VESSEL NO.: 2003.08.1965

NON-PLASTICS AND PASTE: grog and hematite

VESSEL FORM: Carinated bowl

RIM AND LIP FORM: Direct rim and rounded, exterior folded lip

CORE COLOR: $\mathrm{F}$ (fired in a reducing environment and cooled in the open air)

INTERIOR SURFACE COLOR: yellowish-brown; fire clouds on the rim, body, and base

EXTERIOR SURFACE COLOR: yellowish-brown; fire clouds on the rim, body, and base

WALL THICKNESS (RIM, BODY, AND BASE IN MM): body, $7.0 \mathrm{~mm}$; base, $5.9 \mathrm{~mm}$

INTERIOR SURFACE TREATMENT: smoothed

EXTERIOR SURFACE TREATMENT: smoothed

HEIGHT (IN CM): 21.5

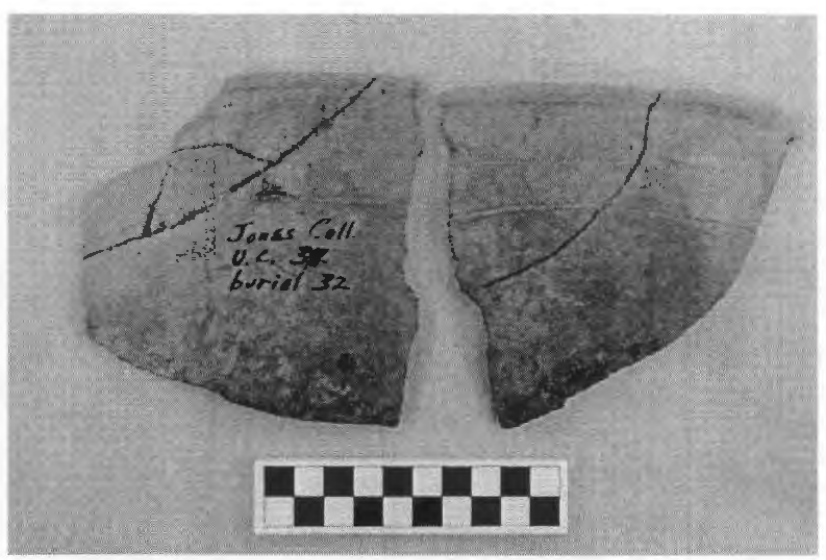

Figure 127. Ripley Engraved, cf. var. Gandy carinated bowl, Henry Williams cemetery, Burial 32, Vessel 2003.08.1965.

ORIFICE DIAMETER (IN CM): 30.0

DIAMETER AT BOTTOM OF RIM OR NECK (IN CM): 29.8

BASE DIAMETER (IN CM) AND SHAPE OF BASE: 6.5; flat and circular

ESTIMATED VOLUME (IN LITERS): 5.8

DECORATION (INCLUDING MOTIF AND ELEMENTS WHEN APPARENT): The rim panel has an engraved scroll motif repeated four times around the vessel. The scrolls are divided by brackets with excised central areas. Above and below each scroll are single rows of small excised pendant triangles (Figure 127).

PIGMENT USE AND LOCATION ON VESSEL: white pigment in engraved lines TYPE AND VARIETY [IF KNOWN]: Ripley Engraved, cf. var. Gandy 


\section{Burial 33}

This burial is in the northern row of burials at the cemetery. The burial pit was $61 \mathrm{~cm}$ in dcpth, and funerary offerings included two ceramic vessels, one being a very large jar.

\section{Burial 34}

Burial 34 is in the central part of the cemetery, on the terrace landform, and overlooking the Gum Creek floodplain (see Figure 108). Jones (n.d.) notes that the burial pit was deep and had an unknown number of broken ccramic vessels.

\section{Burial 35}

Burial 35 was a few feet northwest of Burial 34 in the central part of the cemetery. The burial pit was shallow and the area had been eroded. Funerary offerings consisted of two ceramic vessels.

\section{Burial 36}

Jones (n.d.) did not provide any information about Burial 36, other than to plot it in the northeastem part of the cemetery, just below the alluvial terrace landform (see Figure 108). The one vessel from the burial in the collection is a Pease Brushed-Incised jar.

VESSEL NO.: 2003.08.1040

NON-PLASTICS AND PASTE: grog and bone

VESSEL FORM: Jar

RIM AND LIP FORM: Everted rim and rounded lip

CORE COLOR: $F$ (fired in a reducing environment and cooled in the open air)

INTERIOR SURFACE COLOR: yellowish-brown; fire clouds on the rim and body; organic residue on the rim and body

EXTERIOR SURFACE COLOR: yellowish-brown; fire cloud on the lower body and base; organic residue on the rim and body

WALL THICKNESS (RIM, BODY, AND BASE IN MM): rim, 6.5 mm; body, $7.5 \mathrm{~mm}$

INTERIOR SURFACE TREATMENT: smoothed

EXTERIOR SURFACE TREATMENT: none

HEIGHT (IN CM): 15.3 
ORIFICE DIAMETER (IN CM): 15.0

DIAMETER AT BOTTOM OF RIM OR NECK (IN CM): 14.4

BASE DIAMETER (IN CM) AND SHAPE OF BASE: 7.1; flat and circular

ESTIMATED VOLUME (IN LITERS): 1.4

DECORATION (INCLUDING MOTIF AND ELEMENTS WHEN APPARENT): The rim is decorated with four equally-spaced rows of tool punctations. The vessel body has four vertical appliqued fillets that extend from the rim-body juncture to $2.0 \mathrm{~cm}$ above the base. Each panel between the fillets has vertical brushing marks (Figure 128).

PIGMENT USE AND LOCATION ON VESSEL: none

TYPE AND VARIETY [IF KNOWN]: Pease Brushed-Incised

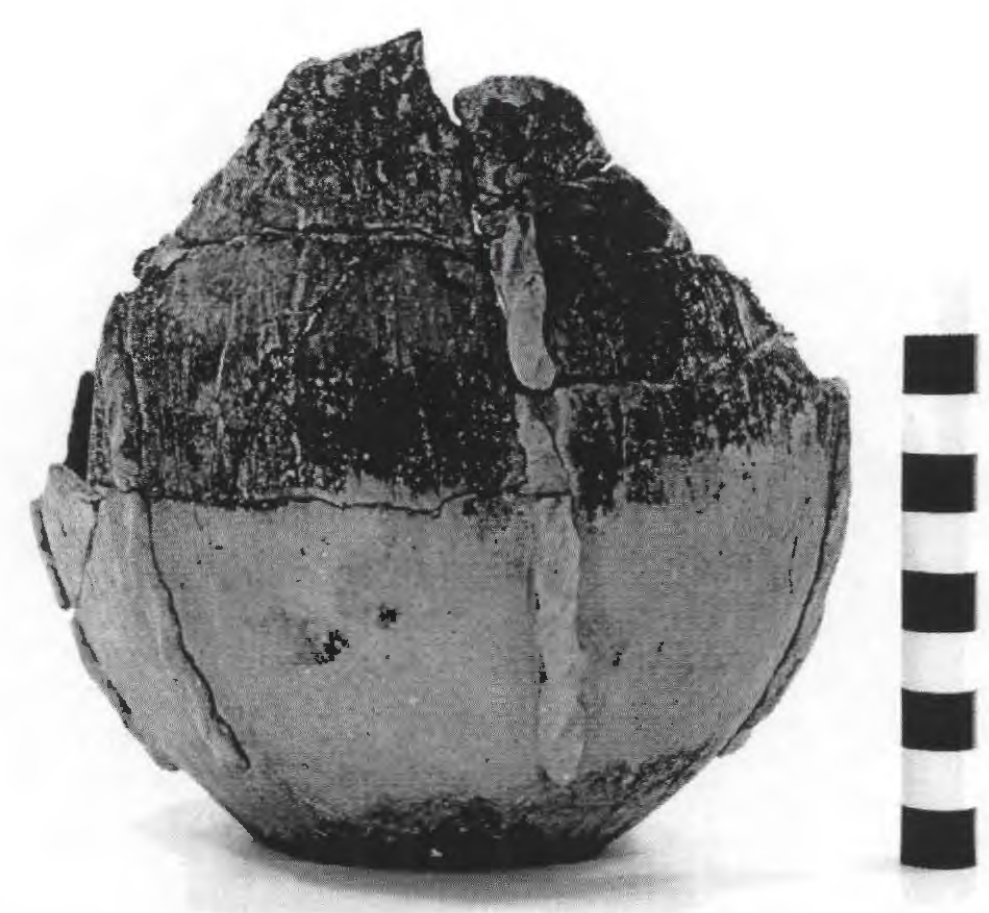

Figure 128. Pease Brushed-Incised jar, Henry Williams cemetery, Burial 36, Vessel 2003.08.1040.

\section{Burial 37}

The only information available on Burial 37 at the Henry Williams cemetery is its plotting on the cemetery map (see Figure 108). This burial is in the northeastern corner of the cemetery, at the eastern end of the north row of burials. 


\section{Vessels from Unknown Burial Contexts at the Henry Williams Site}

VESSEL NO.: 2003.08.1303

NON-PLASTICS AND PASTE: grog

VESSEL FORM: Jar

RIM AND LIP FORM: Everted rim and rounded lip

CORE COLOR: $\mathrm{H}$ (fired in a reducing environment and cooled in the open air)

INTERIOR SURFACE COLOR: dark reddish-brown; fire clouds on rim, body, and base

EXTERIOR SURFACE COLOR: dark grayish-brown

WALL THICKNESS (RIM, BODY, AND BASE IN

MM): rim, $7.3 \mathrm{~mm}$; body, $7.1 \mathrm{~mm}$; base, $12.0 \mathrm{~mm}$

INTERIOR SURFACE TREATMENT: smoothed

EXTERIOR SURFACE TREATMENT: none

HEIGHT (IN CM): 15.5

ORIFICE DIAMETER (IN CM): 14.4

DIAMETER AT BOTTOM OF RIM OR NECK (IN

CM): 15.0

BASE DIAMETER (IN CM) AND SHAPE OF BASE: 8.0; flat and circular

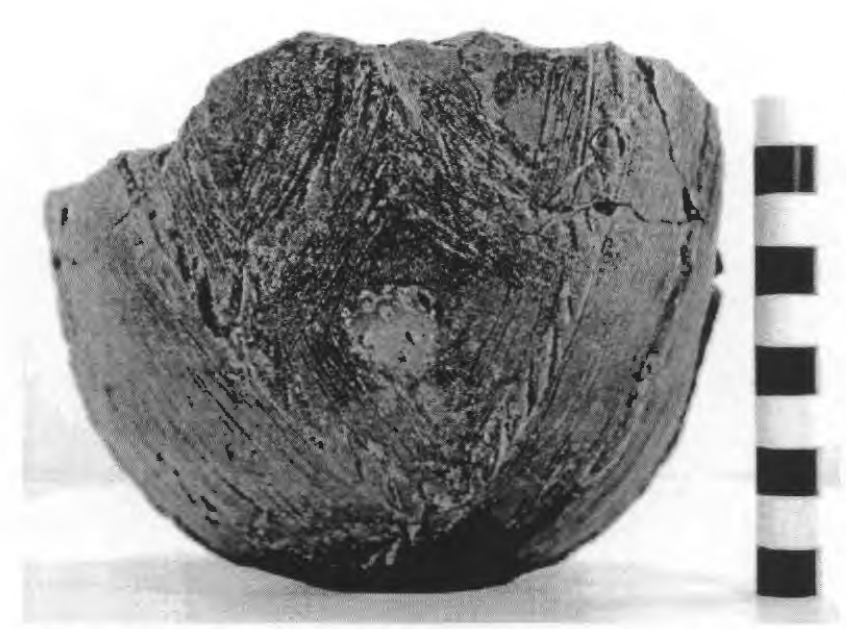

Figure 129. Harleton Appliqued jar, Henry Williams cemetery, Vessel 2003.08.1303.

\section{ESTIMATED VOLUME (IN LITERS): 1.3}

DECORATION (INCLUDING MOTIF AND ELEMENTS WHEN APPARENT): The rim has diagonal opposed incised lines between two rows of tool punctations: one row under the lip and the other at the rimbody juncture. The vessel body is decorated with curvilinear appliqued fillets and nested appliqued fillet diamonds repeated two times on the vessel. Each nested diamond fillet also has a central appliqued node. The area in between the fillets has curvilinear and diamond-shaped incised lines (Figure 129).

PIGMENT USE AND LOCATION ON VESSEL: none

TYPE AND VARIETY [IF KNOWN]: Harleton Appliqued 
VESSEL NO.: 2003.08.1304

NON-PLASTICS AND PASTE: bone

VESSEL FORM: Bowl

RIM AND LIP FORM: Everted rim and rounded lip

CORE COLOR: B (fired and cooled in a reducing environment)

INTERIOR SURFACE COLOR: dark grayish-brown

EXTERIOR SURFACE COLOR: dark grayish-brown

WALL THICKNESS (RIM, BODY, AND BASE IN MM): rim, $7.1 \mathrm{~mm}$

INTERIOR SURFACE TREATMENT: smoothed

EXTERIOR SURFACE TREATMENT: smoothed

HEIGHT (IN CM): 4.2

ORIFICE DIAMETER (IN CM): 9.5

DIAMETER AT BOTTOM OF RIM OR NECK (IN CM): N/A

BASE DIAMETER (IN CM) AND SHAPE OF BASE: 5.8; flat and circular

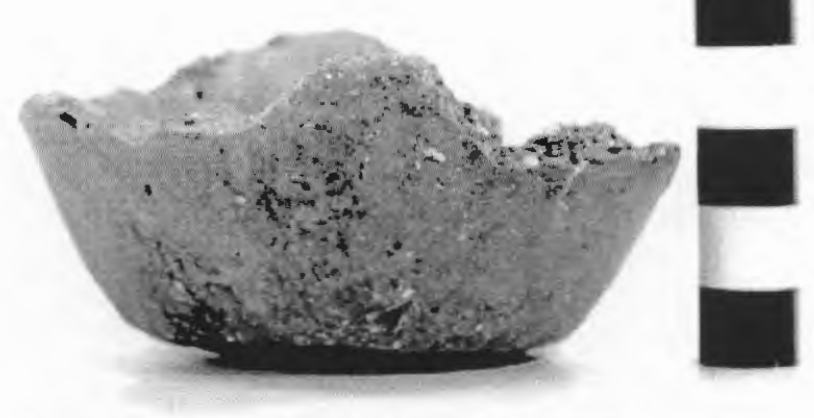

Figure 130. Plain bowl, Henry Williams cemetery, Vessel 2003.08.1304.

ESTIMATED VOLUME (IN LITERS): 0.16

DECORATION (INCLUDING MOTIF AND ELEMENTS WHEN APPARENT): Plain (Figure I30)

PIGMENT USE AND LOCATION ON VESSEL: none

TYPE AND VARIETY [IF KNOWN]: Unidentified plain ware 
VESSEL NO.: 2003.08.1306

NON-PLASTICS AND PASTE: grog and bone

VESSEL FORM: Compound bowl with four rim peaks

RIM AND LIP FORM: Everted rim and rounded lip

CORE COLOR: $\mathrm{G}$ (fired in a reducing environment and cooled in the open air)

INTERIOR SURFACE COLOR: grayish-brown

EXTERIOR SURFACE COLOR: yellowish-brown

WALL THICKNESS (RIM, BODY, AND BASE IN MM): rim, 5.6 mm; body, $5.0 \mathrm{~mm}$

INTERIOR SURFACE TREATMENT: smoothed on the rim

EXTERIOR SURFACE TREATMENT: smoothed

HEIGHT (IN CM): $7.0 \mathrm{~cm}+$

ORIFICE DIAMETER (IN CM): 10.0

DIAMETER AT BOTTOM OF RIM OR NECK (IN CM): 9.4

BASE DIAMETER (IN CM) AND SHAPE OF BASE: N/A

ESTIMATED VOLUME (IN LITERS): 0.56+

DECORATION (INCLUDING MOTIF AND ELEMENTS WHEN APPARENT): The upper rim panel is plain, while the lower rim panel has an engraved motif. This consists of engraved rectangles that alternate with a large horizontal hatched zone.

PIGMENT USE AND LOCATION ON VESSEL: none

TYPE AND VARIETY [IF KNOWN]: Unidentified fine ware 
VESSEL NO.: 2003.08.1307

NON-PLASTICS AND PASTE: grog

VESSEL FORM: Bowl

RIM AND LIP FORM: Direct rim and rounded lip

CORE COLOR: $F$ (fired in a reducing environment and cooled in the open air)

INTERIOR SURFACE COLOR: yellowish-brown

EXTERIOR SURFACE COLOR: yellowish-brown

WALL THICKNESS (RIM, BODY, AND BASE IN MM): rim, 6.0 mm; body, 7.6 mm; base, I0.7 mm

INTERIOR SURFACE TREATMENT: smoothed

EXTERIOR SURFACE TREATMENT: smoothed

HEIGHT (IN CM): 7.7

ORIFICE DIAMETER (IN CM): 12.0

DIAMETER AT BOTTOM OF RIM OR NECK (IN CM): N/A

BASE DIAMETER (IN CM) AND SHAPE OF BASE: N/A

ESTIMATED VOLUME (IN LITERS): 0.37

DECORATION (INCLUDING MOTIF AND ELEMENTS WHEN APPARENT): Plain

PIGMENT USE AND LOCATION ON VESSEL: none

TYPE AND VARIETY [IF KNOWN]: Unidentified plain ware 
VESSEL NO.: 2003.08.1302

NON-PLASTICS AND PASTE: grog-sandy paste

VESSEL FORM: Carinated bowl

RIM AND LIP FORM: Direct rim and rounded, exterior folded lip

CORE COLOR: $\mathrm{G}$ (fired in a reducing environment and cooled in the open air)

INTERIOR SURFACE COLOR: dark grayish-brown

EXTERIOR SURFACE COLOR: dark yellowish-brown

WALL THICKNESS (RIM, BODY, AND BASE IN MM): body, $6.5 \mathrm{~mm}$; base, $9.1 \mathrm{~mm}$

INTERIOR SURFACE TREATMENT: smoothed

EXTERIOR SURFACE TREATMENT: smoothed

HEIGHT (IN CM): N/A

ORIFICE DIAMETER (IN CM): 19.0

DIAMETER AT BOTTOM OF RIM OR NECK (IN CM): 18.8

BASE DIAMETER (IN CM) AND SHAPE OF BASE: 7.9; flat and circular

ESTIMATED VOLUME (IN LITERS): N/A

DECORATION (INCLUDING MOTIF AND ELEMENTS WHEN APPARENT): The rim panel has an engraved pendant triangle motif repeated around the vessel. The central elements in the motif are circles (with an inner diamond and spurs) and diamonds (with an inner diamond). The diamond elements are nested within a horizontal scroll. A bove and below each scroll are single rows of excised pendant triangles.

PIGMENT USE AND LOCATION ON VESSEL: red pigment in the engraved lines

TYPE AND VARIETY [IF KNOWN]: Ripley Engraved, var. McKinney 
VESSEL NO.: 2003.08.1155

NON-PLASTICS AND PASTE: grog and bone

VESSEL FORM: Compound bowl with four rim peaks (Figure 131)

RIM AND LIP FORM: Everted rim and rounded, exterior folded lip

CORE COLOR: $\mathrm{F}$ (fired in a reducing environment and cooled in the open air)

INTERIOR SURFACE COLOR: yellowish-brown; fire cloud on the base

EXTERIOR SURFACE COLOR: yellowish-brown; fire clouds on the rim, body, and base

WALL THICKNESS (RIM, BODY, AND BASE IN $\mathrm{MM}$ ): rim, $5.4 \mathrm{~mm}$; body, $5.5 \mathrm{~mm}$; base, $6.4 \mathrm{~mm}$

INTERIOR SURFACE TREATMENT: smoothed

EXTERIOR SURFACE TREATMENT: smoothed

HEIGHT (IN CM): ca. 12.5

ORIFICE DIAMETER (IN CM): 18.5

DIAMETER AT BOTTOM OF RIM OR NECK (IN CM): 16.0

BASE DIAMETER (IN CM) AND SHAPE OF BASE: 6.0 ; flat and circular

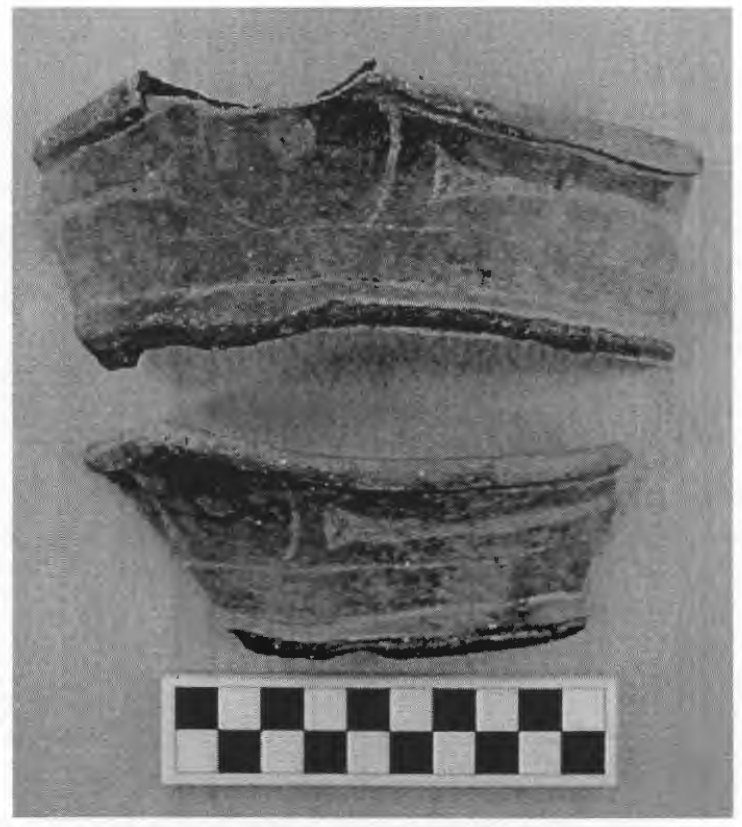

Figure 131. Ripley Engraved, var. unspecified compound bowl, Henry Williams cemetery, Vessel 2003.08.1155.

ESTIMATED VOLUME (IN LITERS): ca. 1.85

DECORATION (INCLUDING MOTIFAND ELEMENTS WHEN APPARENT): The upper rim has engraved circles under each of the rim peaks; the circles have a central inner excised circle. Separating each of these circles are horizontal excised brackets (Figure 131). The lower rim panel is plain.

PIGMENT USE AND LOCATION ON VESSEL: white pigment in engraved lines TYPE AND VARIETY [IF KNOWN]: Ripley Engraved, var. unspecified 
VESSEL NO.: 2003.08.938

NON-PLASTICS AND PASTE: grog

VESSEL FORM: Carinated bowl

RIM AND LIP FORM: Direct rim and rounded, exterior folded lip

CORE COLOR: B (fired and cooled in a reducing environment)

INTERIOR SURFACE COLOR: dark grayish-brown

EXTERIOR SURFACE COLOR: dark grayish-brown

WALL THICKNESS (RIM, BODY, AND BASE IN MM): rim, $7.9 \mathrm{~mm}$; body, $7.3 \mathrm{~mm}$

INTERIOR SURFACE TREATMENT: smoothed

EXTERIOR SURFACE TREATMENT: smoothed

HEIGHT (IN CM): 19.1+

ORIFICE DIAMETER (IN CM): 28.0

DIAMETER AT BOTTOM OF RIM OR NECK

(IN CM): 26.5

BASE DIAMETER (IN CM) AND SHAPE OF

BASE: N/A

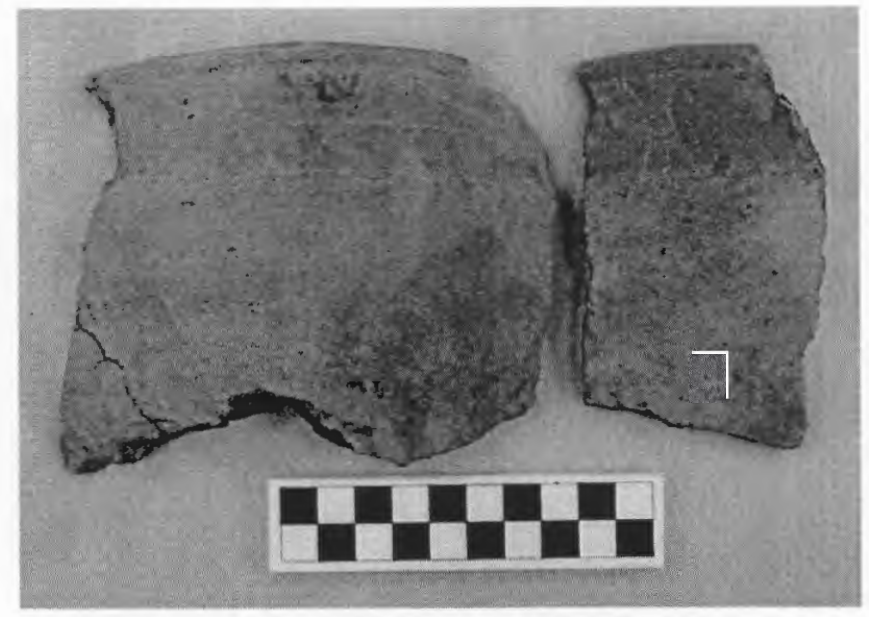

Figure 132. Ripley Engraved, cf. var. Gandy carinated bowl, Henry Williams cemetery, Vessel

ESTIMATED VOLUME (IN LITERS): $4.8+$ 2003.08.938.

DECORATION (INCLUDING MOTIF AND ELEMENTS WHEN APPARENT): The rim panel has an engraved scroll motif repeated four times around the vessel. The scrolls are divided by vertical brackets with hatched central areas. Above and below each scroll are single rows of excised pendant triangles (Figure 132).

PIGMENT USE AND LOCATION ON VESSEL: none TYPE AND VARIETY [IF KNOWN]: Ripley Engraved, cf. var. Gandy 
VESSEL NO.: 2003.08.833

NON-PLASTICS AND PASTE: grog

VESSEL FORM: Carinated bowl

RIM AND LIP FORM: Direct rim and a rounded, exterior folded lip

CORE COLOR: $\mathrm{G}$ (fired in a reducing environment and cooled in the open air)

INTERIOR SURFACE COLOR: dark grayish-brown

EXTERIOR SURFACE COLOR: dark yellowishbrown; fire clouds on the rim and body

WALL THICKNESS (RIM, BODY, AND BASE IN MM): body, $7.9 \mathrm{~mm}$; base, $9.0 \mathrm{~mm}$

INTERIOR SURFACE TREATMENT: smoothed

EXTERIOR SURFACE TREATMENT: smoothed

HEIGHT (IN CM): 11.4

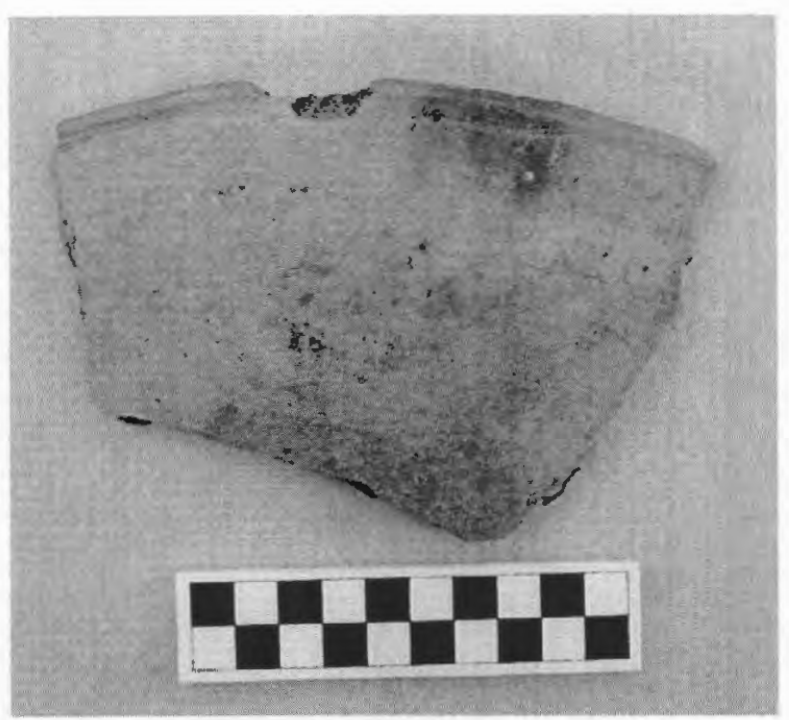

Figure 133. Ripley Engraved, cf. var. Gandy carinated bowl, Henry Williams cemetery, Vessel 2003.08.833.

ORIFICE DIAMETER (IN CM): 24.0

DIAMETER AT BOTTOM OF RIM OR NECK (IN CM): 23.6

BASE DIAMETER (IN CM) AND SHAPE OF BASE: 8.8; flat and circular

ESTIMATED VOLUME (IN LITERS): 1.6

DECORATION (INCLUDING MOTIF AND ELEMENTS WHEN APPARENT): The rim panel has an engraved scroll motif repeated four times around the vessel. The scrolls are divided by vertical brackets with horizontal hatched lines in their central area. Above and below each scroll are single rows of small excised pendant triangles (Figure I33).

PIGMENT USE AND LOCATION ON VESSEL: none

TYPE AND VARIETY [IF KNOWN]: Ripley Engraved, cf. var. Gandy 
VESSEL NO.: 2003.08.1300

NON-PLASTICS AND PASTE: bone and grog

VESSEL FORM: Carinated bowl

RIM AND LIP FORM: Direct rim and a rounded, exterior folded lip; Redwine mode lip (see Walters 2010)

CORE COLOR: $\mathrm{F}$ (fired in a reducing environment and cooled in the open air)

INTERIOR SURFACE COLOR: reddish-brown; fire clouds on the body

EXTERIOR SURFACE COLOR: yellowish-brown; fire clouds on the body

WALL THICKNESS (RIM, BODY, AND BASE IN MM): body, $7.1 \mathrm{~mm}$; base, $10.5 \mathrm{~mm}$

INTERIOR SURFACE TREATMENT: smoothed

EXTERIOR SURFACE TREATMENT: smoothed

HEIGHT (IN CM): N/A

ORIFICE DIAMETER (IN CM): 30.0

DIAMETER AT BOTTOM OF RIM OR NECK (IN CM): 29.6

BASE DIAMETER (IN CM) AND SHAPE OF BASE: 10.0; flat and circular

ESTIMATED VOLUME (IN LITERS): N/A

DECORATION (INCLUDING MOTIF AND ELEMENTS WHEN APPARENT): The rim panel has an engraved scroll motif repeated four times around the vessel. The scrolls are separated by cross-hatched vertical brackets or backward negative $\mathrm{S}$-shaped zones. There are narrow excised bands above and below each of the scrolls (Figure 134).

PIGMENT USE AND

LOCATION ON VESSEL: none

TYPE AND VARIETY [IF

KNOWN]: Ripley Engraved, var. Gandy

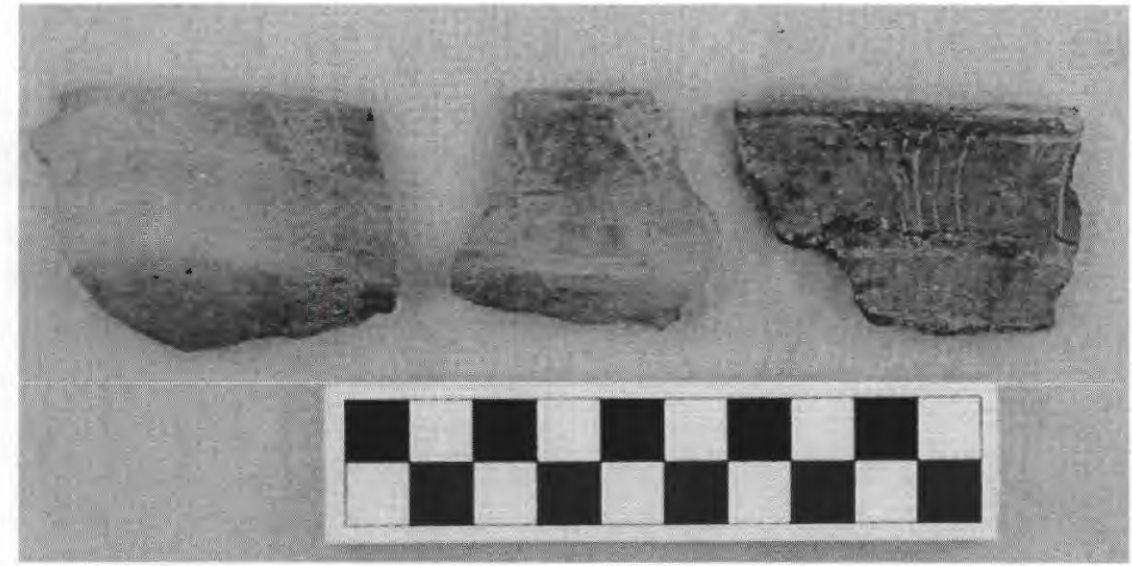

Figure 134. Ripley Engraved, var. Gandy carinated bowl, Henry Williams cemetery, Vessel 2003.08.1300. 
VESSEL NO.: 2003.08.1305

NON-PLASTICS AND PASTE: bone and grog

VESSEL FORM: Jar

RIM AND LIP FORM: N/A

CORE COLOR: $\mathrm{G}$ (fired in a reducing environment and cooled in the open air)

INTERIOR SURFACE COLOR: dark grayish-brown

EXTERIOR SURFACE COLOR: yellowish-brown; fire clouds on the body

WALL THICKNESS (RIM, BODY, AND BASE IN MM): body, $7.6 \mathrm{~mm}$

INTERIOR SURFACE TREATMENT:

smoothed

EXTERIOR SURFACE TREATMENT: none

HEIGHT (IN CM): N/A

ORIFICE DIAMETER (IN CM): N/A

DIAMETER AT BOTTOM OF RIM OR NECK (IN CM): N/A

BASE DIAMETER (IN CM) AND SHAPE OF BASE: N/A

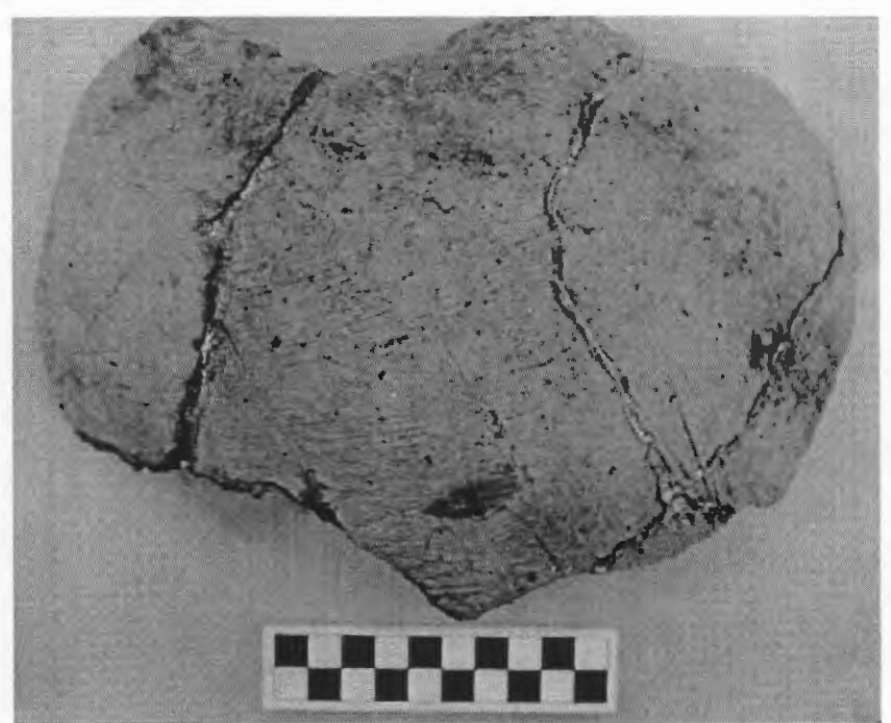

Figure 135. Brushed-Incised jar sherds, Henry Williams cemetery, Vessel 2003.08.1305.

ESTIMATED VOLUME (IN LITERS): N/A

DECORATION (INCLUDING MOTIF AND ELEMENTS WHEN APPARENT): The vessel body has horizontal and overlapping brushing marks, along with a series of overlying vertical incised lines (Figure 135).

PIGMENT USE AND LOCATION ON VESSEL: none

TYPE AND VARIETY [IF KNOWN]: Unidentified utility ware 
VESSEL NO.: 2003.08.1158

NON-PLASTICS AND PASTE: grog

VESSEL FORM: Compound bowl with four rim peaks

RIM AND LIP FORM: Everted rim and rounded lip

CORE COLOR: $\mathrm{F}$ (fired in a reducing environment and cooled in the open air)

INTERIOR SURFACE COLOR: reddish-brown; fire clouds on the rim, body, and base

EXTERIOR SURFACE COLOR: reddish-brown; fire clouds on the body and base

WALL THICKNESS (RIM, BODY, AND BASE IN MM): rim, 5.3 mm; body, $6.3 \mathrm{~mm}$; base, $7.8 \mathrm{~mm}$

INTERIOR SURFACE TREATMENT: smoothed

EXTERIOR SURFACE TREATMENT: smoothed

HEIGHT (IN CM): 12.0

ORIFICE DIAMETER (IN CM): 16.0

DIAMETER AT BOTTOM OF RIM OR NECK (IN CM): 16.4

BASE DIAMETER (IN CM) AND SHAPE OF BASE: 5.6; flat and circular

ESTIMATED VOLUME (IN LITERS): I.5

DECORATION (INCLUDING MOTIF AND ELEMENTS WHEN APPARENT): The upper rim panel is plain. The lower rim panel has vertical engraved brackets and large excised triangles, but the entire motif is undefined.

PIGMENT USE AND LOCATION ON VESSEL: none

TYPE AND VARIETY [IF KNOWN]: Unidentified fine ware 
VESSEL NO.: 2003.08.939

NON-PLASTICS AND PASTE: grog

VESSEL FORM: Carinated bowl

RIM AND LIP FORM: Inverted rim and rounded, exterior folded lip

CORE COLOR: B (fired and cooled in a reducing environment)

INTERIOR SURFACE COLOR: dark grayish-brown

EXTERIOR SURFACE COLOR: dark grayish-brown; fire clouds on the rim

WALL THICKNESS (RIM, BODY, AND BASE IN MM): rim, $7.1 \mathrm{~mm}$; body, $6.8 \mathrm{~mm}$

INTERIOR SURFACE TREATMENT: smoothed

EXTERIOR SURFACE TREATMENT: smoothed

HEIGHT (IN CM): 8.2

ORIFICE DIAMETER (IN CM): 15.0

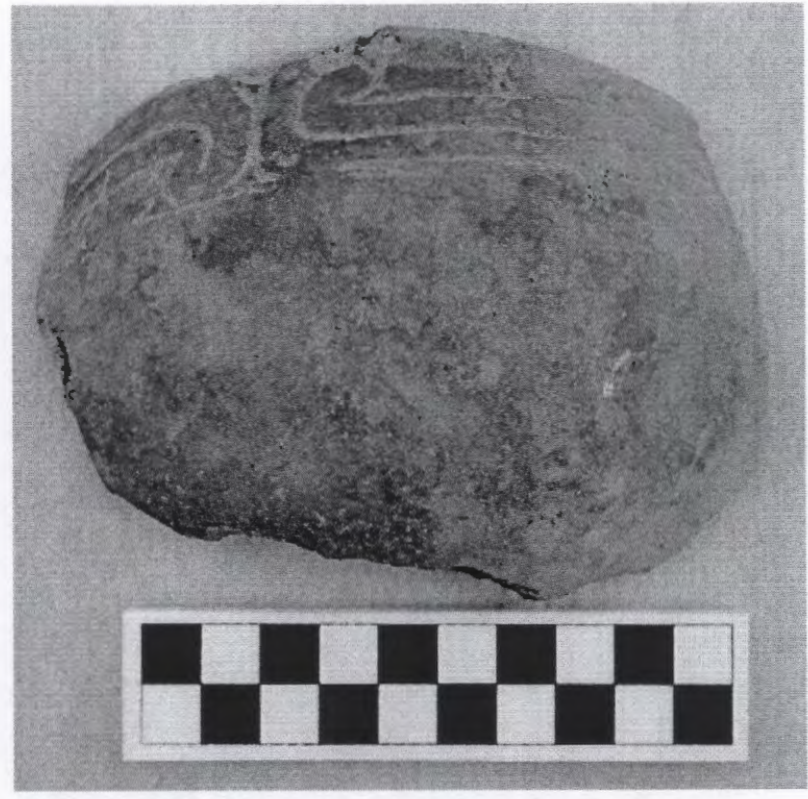

Figure 136. Ripley Engraved, var. Gandy carinated bowl, Henry Williams cemetery, Vessel 2003.08.939.

DIAMETER AT BOTTOM OF RIM OR NECK (IN CM): 15.0

BASE DIAMETER (IN CM) AND SHAPE OF BASE: N/A

ESTIMATED VOLUME (IN LITERS): 0.74

DECORATION (INCLUDING MOTIF AND ELEMENTS WHEN APPARENT): The rim panel has an engraved scroll motif repeated four times around the vessel. The scrolls are divided by vertical engraved brackets. The upper and lower scroll fill zones have cross-hatched and bracket elements (Figure 136).

PIGMENT USE AND LOCATION ON VESSEL: red pigment in engraved lines

TYPE AND VARIETY [IF KNOWN]: Ripley Engraved, var. Gandy 
VESSEL NO.: 2003.08.0940

NON-PLASTICS AND PASTE: grog

VESSEL FORM: Bottle

RIM AND LIP FORM: N/A

CORE COLOR: B (fired and cooled in a reducing environment)

INTERIOR SURFACE COLOR: dark grayishbrown

EXTERIOR SURFACE COLOR: dark grayishbrown

WALL THICKNESS (RIM, BODY, AND BASE IN MM): body, $5.9 \mathrm{~mm}$

INTERIOR SURFACE TREATMENT: none

EXTERIOR SURFACE TREATMENT: smoothed

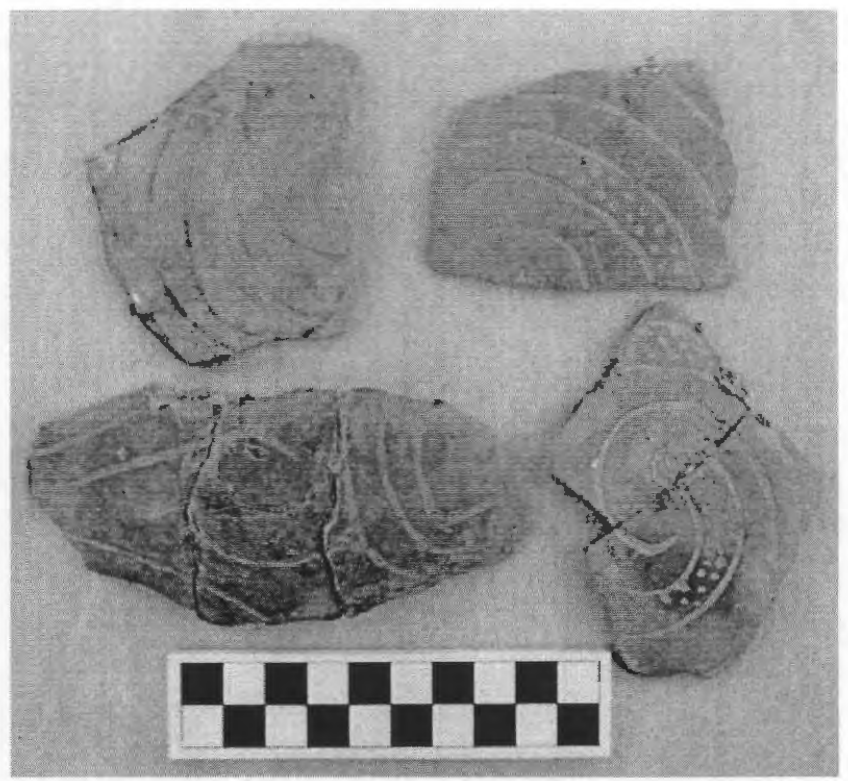

Figure 137. Engraved-punctated bottle, Henry Williams cemetery, Vessel 2003.08.940.

HEIGHT (IN CM): N/A

ORIFICE DIAMETER (IN CM): N/A

DIAMETER AT BOTTOM OF RIM OR NECK (IN CM): N/A

BASE DIAMETER (IN CM) AND SHAPE OF BASE: N/A

ESTIMATED VOLUME (IN LITERS): N/A

DECORATION (INCLUDING MOTIF AND ELEMENTS WHEN APPARENT): The vessel body has two different engraved panels, each repeated twice on the body. The first has a hooked arm motif, with one of the hooked arms represented by a curvilinear zone filled with tool punctations. The other panel has engraved concentric circles with a central and inner engraved oval or a dashed line (Figure 137).

PIGMENT USE AND LOCATION ON VESSEL: none

TYPE AND VARIETY [IF KNOWN]: Unidentified fine ware 
VESSEL NO.: 2003.08.1301

NON-PLASTICS AND PASTE: grog

VESSEL FORM: Carinated bowl

RIM AND LIP FORM: Direct rim and rounded, exterior folded lip

CORE COLOR: $\mathrm{G}$ (fired in a reducing environment and cooled in the open air)

INTERIOR SURFACE COLOR: dark grayish-brown

EXTERIOR SURFACE COLOR: yellowish-brown; fire clouds on the rim and body

WALL THICKNESS (RIM, BODY, AND BASE IN MM): rim, $6.3 \mathrm{~mm}$; body, $7.7 \mathrm{~mm}$; base, $8.7 \mathrm{~mm}$

INTERIOR SURFACE TREATMENT: smoothed

EXTERIOR SURFACE TREATMENT: burnished

HEIGHT (IN CM): 7.0

ORIFICE DIAMETER (IN CM): 18.0

DIAMETER AT BOTTOM OF RIM OR NECK (IN CM): 18.0

\section{BASE DIAMETER (IN CM) AND SHAPE OF BASE: N/A}

ESTIMATED VOLUME (IN LITERS): 0.76

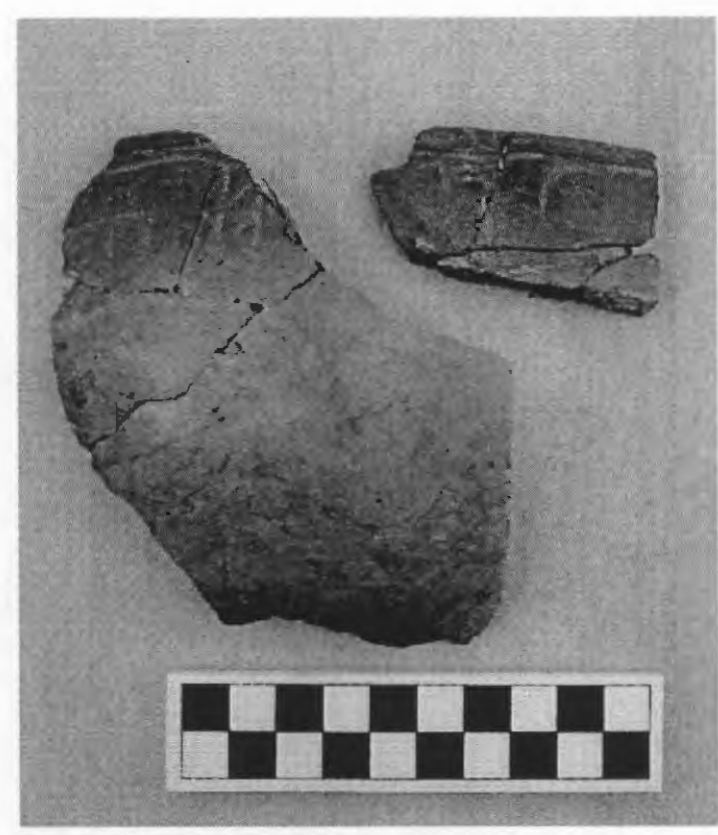

Figure 138. Ripley Engraved, var. Gandy carinated bowl, Henry Williams cemetery, Vessel 2003.08.1301.

DECORATION (INCLUDING MOTIF AND ELEMENTS WHEN APPARENT): The rim panel has an engraved scroll motif repeated four times around the vessel. The scrolls are divided by vertical engraved brackets with a negative S-shaped element within the brackets. The upper and lower scroll fill zones have excised triangles and brackets, as well as negative ovals (Figure 138).

PIGMENT USE AND LOCATION ON VESSEL: red pigment in engraved lines

TYPE AND VARIETY [IF KNOWN]: Ripley Engraved, var. Gandy 
VESSEL NO:: 2003.08.1157

NON-PLASTICS AND PASTE: grog and sandy paste

VESSEL FORM: Jar with short rim (Figure 139)

RIM AND LIP FORM: Everted rim and rounded lip

CORE COLOR: $\mathrm{G}$ (fired in a reducing environment and cooled in the open air)

INTERIOR SURFACE COLOR: grayish-brown; fire clouds on the rim, body, and base

EXTERIOR SURFACE COLOR: yellowish-brown; fire clouds on the rim, body, and base

WALL THICKNESS (RIM, BODY, AND BASE IN MM): rim, $7.8 \mathrm{~mm}$; body, $7.6 \mathrm{~mm}$; base, $10.9 \mathrm{~mm}$

INTERIOR SURFACE TREATMENT: smoothed

EXTERIOR SURFACE TREATMENT: none

HEIGHT (IN CM): 20.0

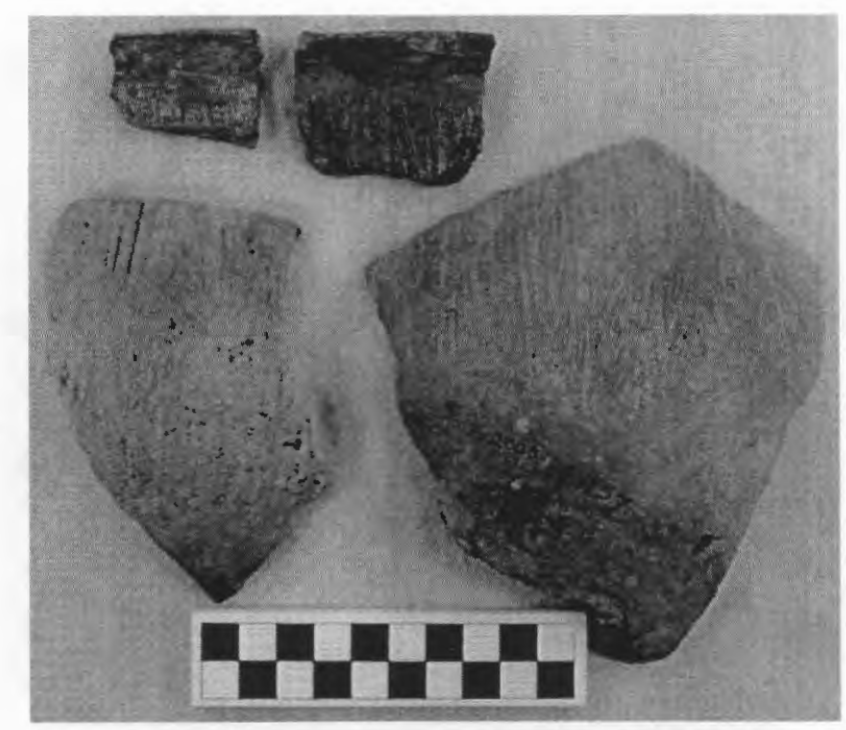

ORIFICE DIAMETER (IN CM): 16.0

Figure 139. Karnack Brushed-Incised jar sherds, Henry Williams cemetery, Vessel 2003.08.1157.

DIAMETER AT BOTTOM OF RIM OR NECK (IN CM): 15.5

BASE DIAMETER (IN CM) AND SHAPE OF BASE: 6.5 ; flat and circular

ESTIMATED VOLUME (IN LITERS): 2.9

DECORATION (INCLUDING MOTIF AND ELEMENTS WHEN APPARENT): The short rim is plain, and the vessel body has vertical brushing and incised marks that extend from the rim-body juncture to 5.0 $\mathrm{cm}$ above the base (Figure 139).

PIGMENT USE AND LOCATION ON VESSEL: none

TYPE AND VARIETY [IF KNOWN]: Karnack Brushed-Incised 
VESSEL NO.: 2003.08.1154

NON-PLASTICS AND PASTE: grog

VESSEL FORM: Compound bowl

RIM AND LIP FORM: Everted rim and a rounded, exterior folded lip

CORE COLOR: $\mathrm{F}$ (fired in a reducing environment and cooled in the open air)

INTERIOR SURFACE COLOR: yellowish-brown

EXTERIOR SURFACE COLOR: yellowish-brown; fire cloud on the rim and body

WALL THICKNESS (RIM, BODY, AND

BASE IN MM): rim, $5.6 \mathrm{~mm}$; body, $6.3 \mathrm{~mm}$

INTERIOR SURFACE TREATMENT:

smoothed

EXTERIOR SURFACE TREATMENT:

smoothed

HEIGHT (IN CM): 9.0

ORIFICE DIAMETER (IN CM): 18.0

DIAMETER AT BOTTOM OF RIM OR

NECK (IN CM): 16.0

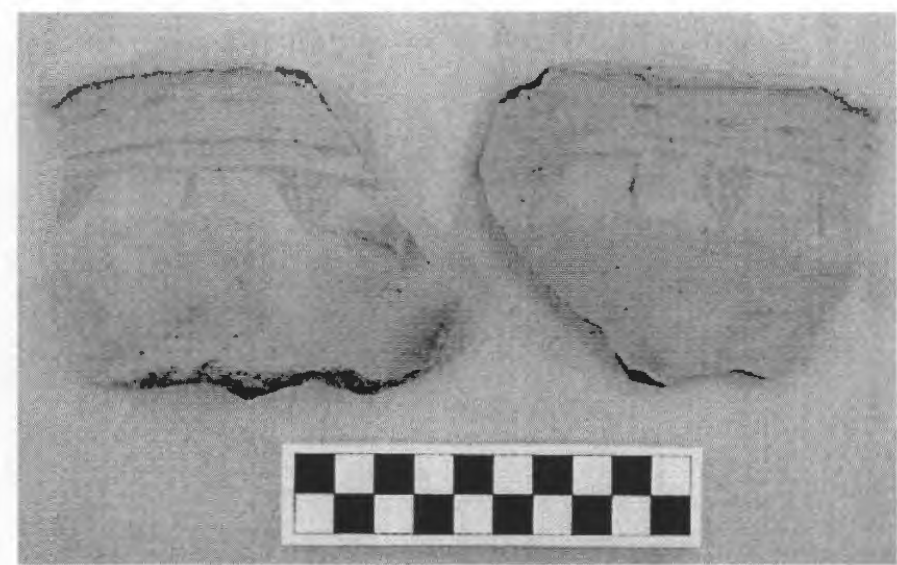

Figure 140. Turner Engraved, var. unspecified compound bowl, Henry Williams cemetery, Vessel 2003.08.1154.

BASE DIAMETER (IN CM) AND SHAPE OF BASE: N/A

ESTIMATED VOLUME (IN LITERS): 1.3

DECORATION (INCLUDING MOTIFAND ELEMENTS WHEN APPARENT): The upper rim panel has two closely-spaced horizontal engraved lines as well as a row of horizontal tool punctations under the vessel lip. The lower rim panel has eight large excised pendant triangles, each divided from the other by single vertical engraved lines (Figure 140).

PIGMENT USE AND LOCATION ON VESSEL: none

TYPE AND VARIETY [IF KNOWN]: Turner Engraved, var. unspecified 
VESSEL NO.: 2003.08 .955

NON-PLASTICS AND PASTE: bone and grog

VESSEL FORM: Carinated bowl

RIM AND LIP FORM: Direct rim and rounded, exterior folded lip

CORE COLOR: $\mathrm{G}$ (fired in a reducing environment and cooled in the open air)

INTERIOR SURFACE COLOR: dark grayishbrown

EXTERIOR SURFACE COLOR: reddish-brown; fire clouds on the body and base

WALL THICKNESS (RIM, BODY, AND BASE IN MM): rim, $7.3 \mathrm{~mm}$; body, $8.6 \mathrm{~mm}$; base, $12.4 \mathrm{~mm}$

INTERIOR SURFACE TREATMENT: smoothed

EXTERIOR SURFACE TREATMENT: smoothed

HEIGHT (IN CM): 15.0

ORIFICE DIAMETER (IN CM): 30.0

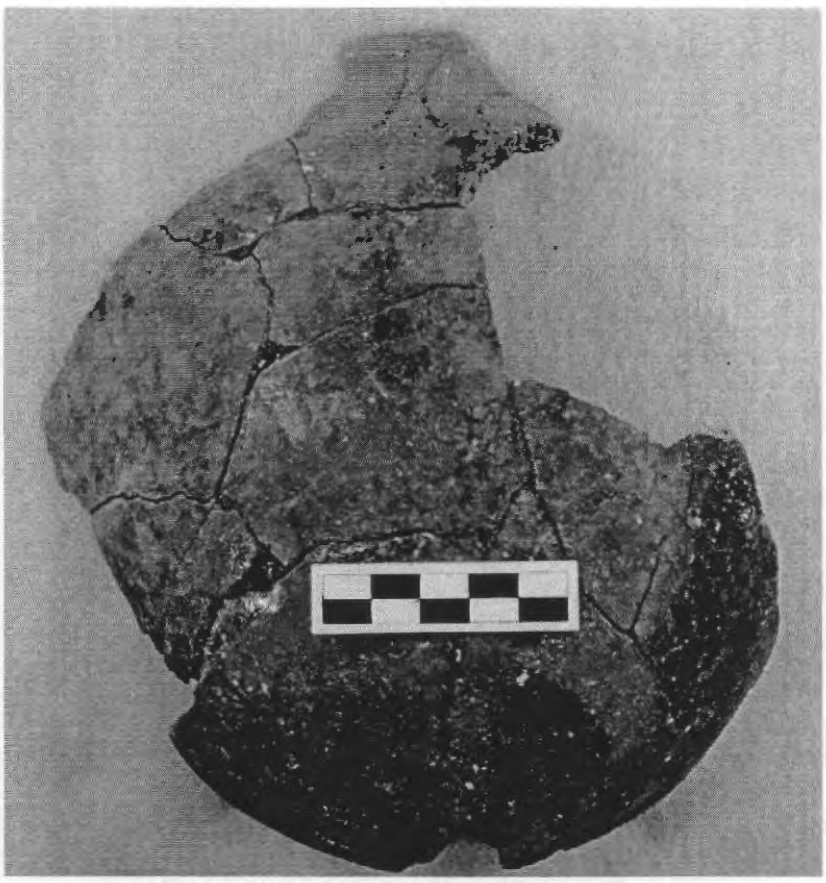

Figure 141. Ripley Engraved, cf. var. Gandy carinated bowl, Henry Williams cemetery, Vessel 2003.08.955.

DIAMETER AT BOTTOM OF RIM OR NECK (IN CM): 29.8

BASE DIAMETER (IN CM) AND SHAPE OF BASE: 7.0; flat and circular

ESTIMATED VOLUME (IN LITERS): 4.1

DECORATION (INCLUDING MOTIF AND ELEMENTS WHEN APPARENT): The rim panel has an engraved scroll motif repeated four times around the vessel. The scrolls are divided by vertical engraved brackets with a single inner slanted line. Above and below each of the scrolls are single rows of small excised pendant triangles (Figure 141).

PIGMENT USEAND LOCATION ON VESSEL: white pigment in engraved lines

TYPE AND VARIETY [IF KNOWN]: Ripley Engraved, cf. var. Gandy 
VESSEL NO.: 2003.08.0952

NON-PLASTICS AND PASTE: bone and grog

VESSEL FORM: Jar

RIM AND LIP FORM: Everted rim and rounded lip

CORE COLOR: G (fired in a reducing environment and cooled in the open air)

INTERIOR SURFACE COLOR: dark yellowish-brown; fire clouds on the rim and body

EXTERIOR SURFACE COLOR: yellowish-brown; fire clouds on the rim, body, and base

WALL THICKNESS (RIM, BODY, AND BASE IN MM): rim, 6.9 mm; body, $6.3 \mathrm{~mm}$; base, $9.7 \mathrm{~mm}$

INTERIOR SURFACE TREATMENT: smoothed

EXTERIOR SURFACE TREATMENT: none

HEIGHT (IN CM): 18.0

ORIFICE DIAMETER (IN CM): 13.2

DIAMETER AT BOTTOM OF RIM OR NECK (IN CM): 11.7

BASE DIAMETER (IN CM) AND SHAPE OF BASE: N/A

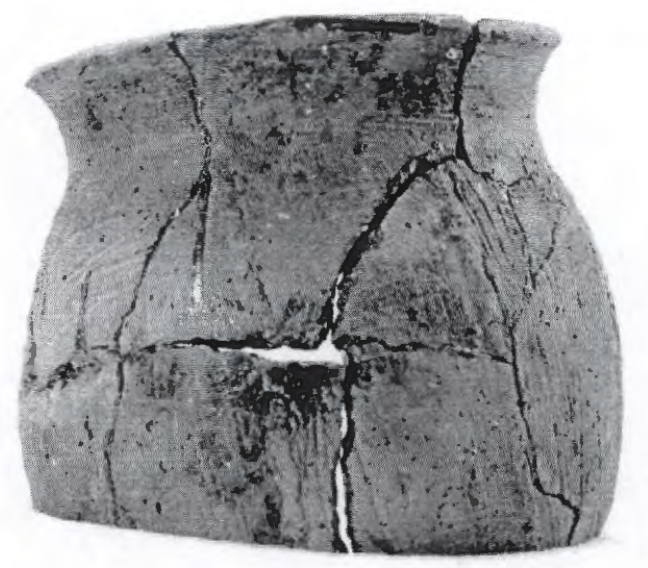

ESTIMATED VOLUME (IN LITERS): 2.I

DECORATION (INCLUDING MOTIF AND

ELEMENTS WHEN APPARENT): The rim is decorated

Figure 142. Pease Brushed-Incised jar, Henry Williams cemetery, Vessel 2003.08.952. with horizontal brushing marks. The vessel body is divided into panels by eight vertical appliqued fillets that extend from the rim-body juncture to within 2.0 $\mathrm{cm}$ of the base. The panels are filled with overlapping brushing marks (Figure 142).

PIGMENT USE AND LOCATION ON VESSEL: none

TYPE AND VARIETY [IF KNOWN]: Pease Brushed-Incised 
VESSEL NO.: 2003.08.0035

NON-PLASTICS AND PASTE: grog

VESSEL FORM: Carinated bowl, miniature

RIM AND LIP FORM: Direct rim and rounded lip

CORE COLOR: $\mathrm{F}$ (fired in a reducing environment and cooled in the open air)

INTERIOR SURFACE COLOR: reddish-brown

EXTERIOR SURFACE COLOR: reddish-brown; fire clouds on the body and base

WALL THICKNESS (RIM, BODY, AND

BASE IN MM): rim, $3.8 \mathrm{~mm}$

INTERIOR SURFACE TREATMENT:

smoothed

EXTERIOR SURFACE TREATMENT:

smoothed

HEIGHT (IN CM): 4.0

ORIFICE DIAMETER (IN CM): 7.9

DIAMETER AT BOTTOM OF RIM OR

NECK (IN CM): 7.0

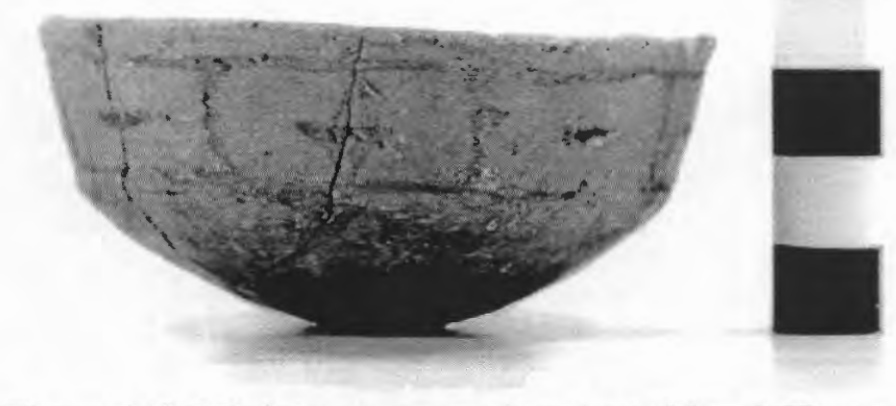

Figure 143. Miniature engraved carinated bowl, Henry Williams cemetery, Vessel 2003.08.0035.

BASE DIAMETER (IN CM) AND SHAPE OF BASE: 3.0; circular and rounded

ESTIMATED VOLUME (IN LITERS): 0.19

DECORATION (INCLUDING MOTIF AND ELEMENTS WHEN APPARENT): The rim panel has eight zones created by engraved vertical brackets. Within each of the zones is a single horizontal engraved dash (Figure 143).

PIGMENT USE AND LOCATION ON VESSEL: red pigment in engraved lines TYPE AND VARIETY [IF KNOWN]: Unidentified fine ware 
VESSEL NO.: 2003.08.0950

NON-PLASTICS AND PASTE: grog and bone

VESSEL FORM: Compound bowl with four rim peaks (Figure 144)

RIM AND LIP FORM: Everted rim and rounded lip

CORE COLOR: B (fired and cooled in a reducing environment)

INTERIOR SURFACE COLOR: dark grayish-brown; fire clouds on the rim

EXTERIOR SURFACE COLOR: dark grayish-brown; fire clouds on the rim and base

WALL THICKNESS (RIM, BODY, AND BASE IN MM): rim, $5.3 \mathrm{~mm}$; body, $6.0 \mathrm{~mm}$; base, $9.7 \mathrm{~mm}$

INTERIOR SURFACE TREATMENT: smoothed on the rim

EXTERIOR SURFACE TREATMENT:

smoothed

HEIGHT (IN CM): 9.6

ORIFICE DIAMETER (IN CM): 16.0

DIAMETER AT BOTTOM OF RIM OR NECK

(IN CM): 15.5

BASE DIAMETER (IN CM) AND SHAPE OF

BASE: 8.0; flat and circular

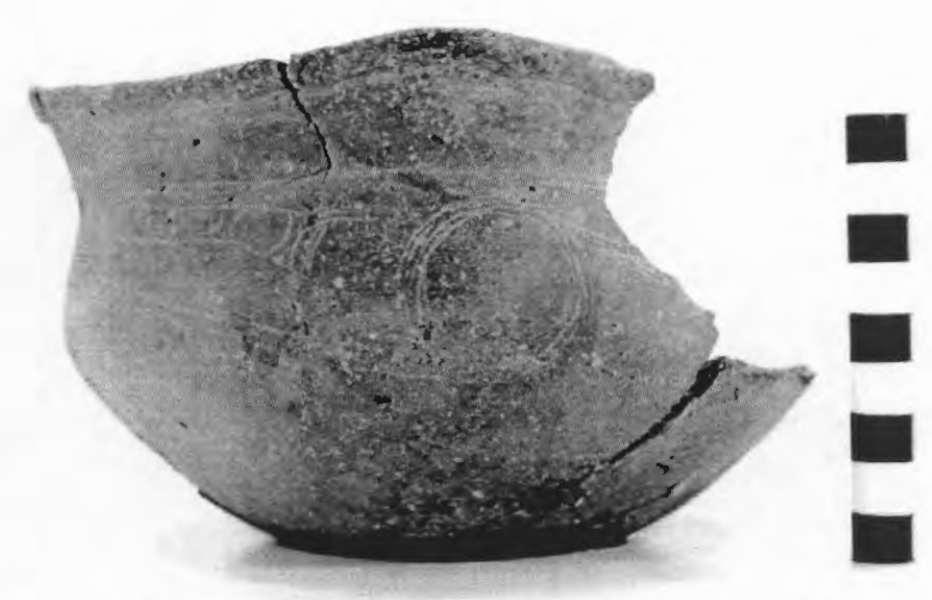

Figure 144. Ripley Engraved, var. Galt compound bowl, Henry Williams cemetery, Vessel 2003.08.950.

\section{ESTIMATED VOLUME (IN LITERS): 1.2}

DECORATION (INCLUDING MOTIF AND ELEMENTS WHEN APPARENT): The upper rim panel is plain, except for an engraved line under the lip, but the lower rim panel has an engraved scroll and circle motif that is repeated four times around the vessel. Each of the circle elements, comprised of multiple closely-spaced circular lines, is centered under the rim peaks. The upper and lower scroll fill zones are triangular areas with hatched brackets and ovals (Figure 144).

PIGMENT USE AND LOCATION ON VESSEL: none

TYPE AND VARIETY [IF KNOWN]: Ripley Engraved, var. Galt 
VESSEL NO.: 2003.08.0951

NON-PLASTICS AND PASTE: bone and grog

VESSEL FORM: Bottle

RIM AND LIP FORM: N/A

CORE COLOR: B (fired and cooled in a reducing environment)

INTERIOR SURFACE COLOR: grayish-brown; fire cloud on the base

EXTERIOR SURFACE COLOR: grayish-brown; fire clouds on the body and base; organic residue on the lower body

WALL THICKNESS (RIM, BODY, AND BASE IN

MM): body, $5.8 \mathrm{~mm}$; base, $10.9 \mathrm{~mm}$

INTERIOR SURFACE TREATMENT: none

EXTERIOR SURFACE TREATMENT: smoothed

HEIGHT (IN CM): N/A

ORIFICE DIAMETER (IN CM): N/A

DIAMETER AT BOTTOM OF RIM OR NECK (IN CM): N/A

BASE DIAMETER (IN CM) AND SHAPE OF

BASE: 6.6; flat and circular

ESTIMATED VOLUME (IN LITERS): N/A

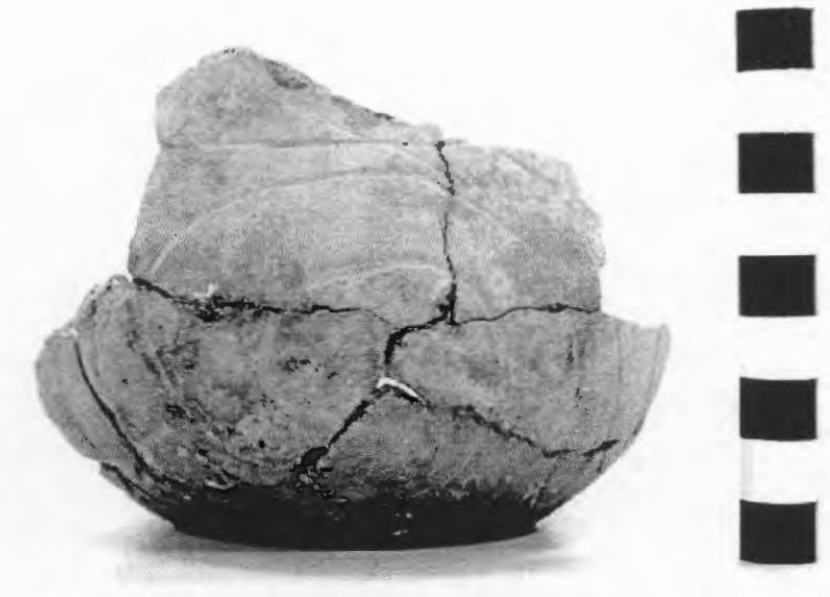

Figure 145. Wilder Engraved, var. unspecified bottle, Henry Williams cemetery, Vessel 2003.08.0951.

DECORATION (INCLUDING MOTIF AND ELEMENTS WHEN APPARENT): The vessel body has encircling scrolls that originate from upper and lower open pendant triangles. Unlike many Wilder Engraved bottles, there is no central circle where the scroll arms meet, nor are the scroll arms wider (with excised or cross-hatched areas) where they pass each other (Figure 145).

PIGMENT USE AND LOCATION ON VESSEL: red pigment in engraved lines

TYPE AND VARIETY [IF KNOWN]: Wilder Engraved, var. unspecified 
VESSEL NO.: 2003.08.971

NON-PLASTICS AND PASTE: grog

VESSEL FORM: Carinated bowl

RIM AND LIP FORM: Direct rim and rounded, exterior folded lip

CORE COLOR: $\mathrm{F}$ (fired in a reducing environment and cooled in the open air)

INTERIOR SURFACE COLOR: yellowish-brown; fire clouds on the rim, body, and base

EXTERIOR SURFACE COLOR: yellowish-brown; fire clouds on the rim, body, and base

WALL THICKNESS (RIM, BODY, AND BASE IN MM): rim, $7.2 \mathrm{~mm}$; body, $7.1 \mathrm{~mm}$

INTERIOR SURFACE TREATMENT: smoothed

EXTERIOR SURFACE TREATMENT: smoothed

HEIGHT (IN CM): 13.2

ORIFICE DIAMETER (IN CM): 29.2

DIAMETER AT BOTTOM OF RIM OR NECK (IN CM): 27.3

BASE DIAMETER (IN CM) AND SHAPE OF

BASE: 8.8 ; flat and circular

ESTIMATED VOLUME (IN LITERS): 3.5

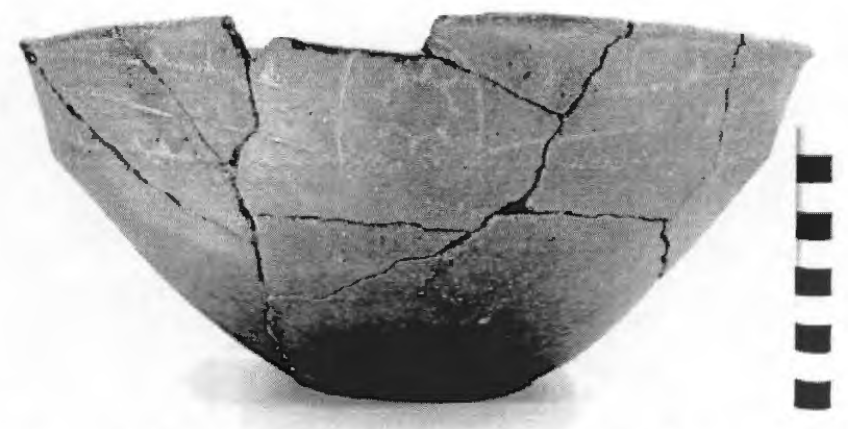

Figure 146. Ripley Engraved, cf. var. Cash carinated bowl, Henry Williams cemetery, Vessel 2003.08.971.

DECORATION (INCLUDING MOTIF AND ELEMENTS WHEN APPARENT): The rim panel has an engraved semi-circle and nested triangle motif repeated twice around the vessel. The semi-circles each have an inner small circle with triangular rays, while the nested triangles consist of slanting scroll linesone with small excised pendant triangles-and a central excised triangle with a negative oval and an inner engraved dash. Scroll fill zones above the nested triangles have small excised pendant triangles and single short vertical line dividers (Figure 146).

PIGMENT USE AND LOCATION ON VESSEL: none

TYPE AND VARIETY [IF KNOWN]: Ripley Engraved, cf. var. Cash 
VESSEL NO.: 2003.08.953

NON-PLASTICS AND PASTE: grog

VESSEL FORM: Carinated bowl

RIM AND LIP FORM: Inverted rim and rounded, exterior folded lip

CORE COLOR: F (fired in a reducing environment and cooled in the open air)

INTERIOR SURFACE COLOR: reddish-brown; fire clouds on the body and base

EXTERIOR SURFACE COLOR: reddish-brown; fire clouds on the body and base

WALL THICKNESS (RIM, BODY, AND BASE IN MM): rim, $9.1 \mathrm{~mm}$; body, $9.7 \mathrm{~mm}$; base, $12.5 \mathrm{~mm}$

INTERIOR SURFACE TREATMENT: smoothed

EXTERIOR SURFACE TREATMENT: smoothed

HEIGHT (IN CM): 13.0

ORIFICE DIAMETER (IN CM): 26.0

DIAMETER AT BOTTOM OF RIM OR NECK

(IN CM): 28.0

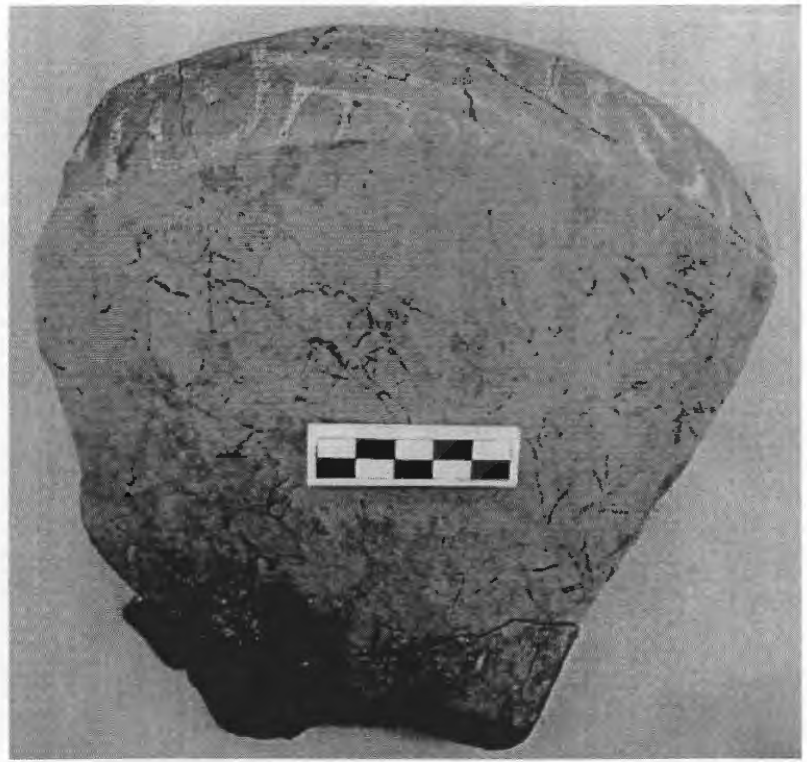

Figure 147. Taylor Engraved carinated bowl, Henry Williams cemetery, Vessel 2003.08.953.

BASE DIAMETER (IN CM) AND SHAPE OF BASE: 8.7; flat and circular

ESTIMATED VOLUME (IN LITERS): 2.0

DECORATION (INCLUDING MOTIF AND ELEMENTS WHEN APPARENT): The rim panel has an engraved slanting scroll motif that is repeated four times around the vessel; the scrolls end in a hooked arms element. The upper and lower scroll fill zones have excised vertical brackets and negative ovals (Figure 147).

PIGMENT USE AND LOCATION ON VESSEL: white pigment in engraved lines

TYPE AND VARIETY [IF KNOWN]: Taylor Engraved 
VESSEL NO.: 2003.08.954

NON-PLASTICS AND PASTE: grog

VESSEL FORM: Bowl

RIM AND LIP FORM: N/A

CORE COLOR: B (fired and cooled in a reducing environment)

INTERIOR SURFACE COLOR: grayish-brown

EXTERIOR SURFACE COLOR: dark grayish-brown

WALL THICKNESS (RIM, BODY, AND BASE IN MM): body, $6.1 \mathrm{~mm}$; base, $10.3 \mathrm{~mm}$

INTERIOR SURFACE TREATMENT: smoothed

EXTERIOR SURFACE TREATMENT: smoothed

HEIGHT (IN CM): N/A

ORIFICE DIAMETER (IN CM): N/A

DIAMETER AT BOTTOM OF RIM OR NECK (IN CM): N/A

BASE DIAMETER (IN CM) AND SHAPE OF BASE: 7.2; flat and circular

ESTIMATED VOLUME (IN LITERS): N/A

DECORATION (INCLUDING MOTIF AND ELEMENTS WHEN APPARENT): The vessel has

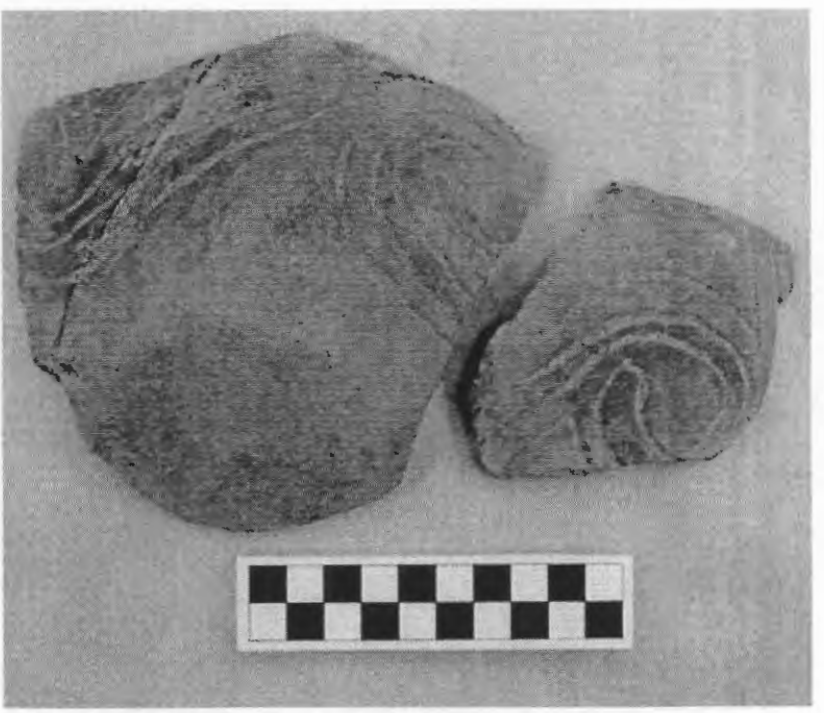

Figure 148. Taylor Engraved bowl, Henry Williams cemetery, Vessel 2003.08.954. engraved scrolls, repeated four times around the vessel, that end in hooked arm elements (Figure 148).

PIGMENT USE AND LOCATION ON VESSEL: none TYPE AND VARIETY [IF KNOWN]: Taylor Engraved 


\section{Pipes}

There are several elbow pipe sherds in the Henry Williams collection, but their burial provenience is unknown. The first pipe sherd (2003.08.1158) is a stem from a grayish-brown grog-tempered pipe with a flat lip. The stem hole diameter is $13.2 \mathrm{~mm}$, while the exterior stem diameter is $23.6 \mathrm{~mm}$; the stem is 8.1 mm thick.

A second grog-tempered elbow pipe stem sherd (2003.08.1902) has a flat lip, and is undecorated. The stem is $16.0 \mathrm{~mm}$ in length from the lip to the opening at the bowl-stem juncture (Figure 149a). The stem hole diameter is $10.8 \mathrm{~mm}$, and the exterior stem diameter is $21.0 \mathrm{~mm}$. The stem is only $5.1 \mathrm{~mm}$ in thickness.

The third grog-tempered elbow pipe sherd (2003.08.1902) is part of a plain bowl (Figure 149b). The bowl height is $21.0+\mathrm{mm}$, and has a $30.0 \mathrm{~mm}$ orifice diameter.

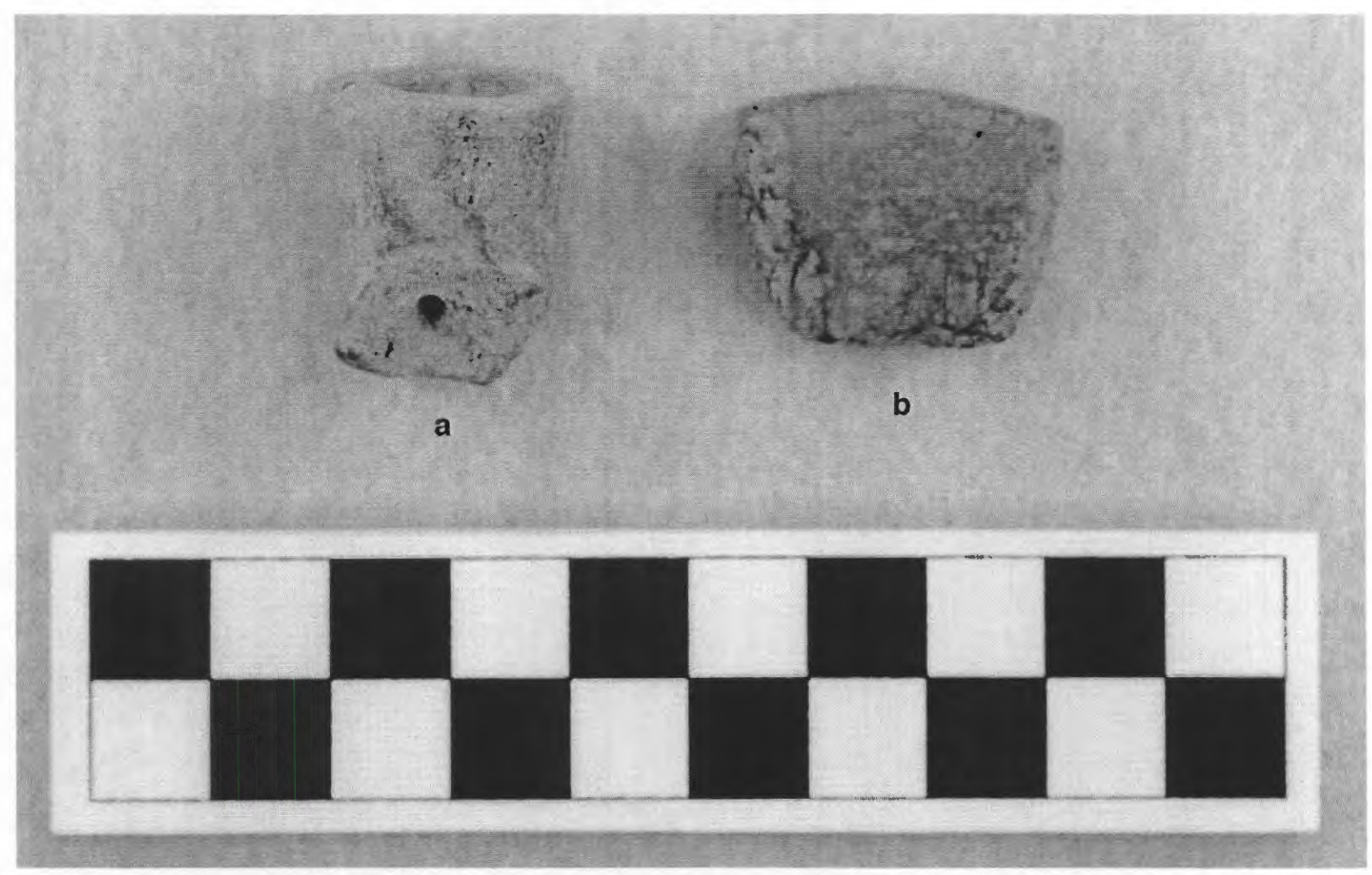

Figure 149. Elbow pipe sherds from the Henry Williams cemetery: a, stem sherd; b, plain bowl sherd.

\section{Arrow Points}

There are six Talco arrow points (2003.08.1888) in the Henry Williams site collection. Their burial provenience is not known (Table 5). 
Table 5. Arrow points from the Henry Williams site.

\begin{tabular}{llcccccl}
\hline Type & $\begin{array}{l}\text { Raw } \\
\text { Material }\end{array}$ & $\begin{array}{c}\mathrm{L} \\
(\mathrm{mm})\end{array}$ & $\begin{array}{c}\mathrm{W} \\
(\mathrm{mm})\end{array}$ & $\begin{array}{c}\text { Th } \\
(\mathrm{mm})\end{array}$ & $\begin{array}{c}\text { SW } \\
(\mathrm{mm})\end{array}$ & Serrated & Chipping \\
\hline Talco & QTZ-NHT & 37.5 & 13.0 & 3.7 & - & + & bifacial \\
Talco & QTZ-HT & 33.0 & 12.0 & 3.2 & - & - & bifacial \\
Talco & QTZ-HT & 36.4 & 14.1 & 2.9 & - & - & bifacial \\
Talco & QTZ-NHT & 33.0 & 12.7 & 2.8 & - & - & bifacial \\
Talco & QTZ-NHT & 33.0 & 14.8 & 2.8 & - & - & bifacial \\
Talco & QTZ-NHT & 37.0 & 12.0 & 2.8 & - & - & bifacial \\
\hline
\end{tabular}

QTZ=quartzite; NHT=non-heat-treated; HT=heat-treated

The Talco points have been bifacially shaped from local fine-grained quartzite flakes; $33 \%$ have been heat-treated. Only one of the points has serrated blades (Figure 150a). The Talco points range from 33.0$37.5 \mathrm{~mm}$ in length, 12.0-14.8 $\mathrm{mm}$ in width, and 2.8-3.7 $\mathrm{mm}$ in thickness (Figure 150a-f).

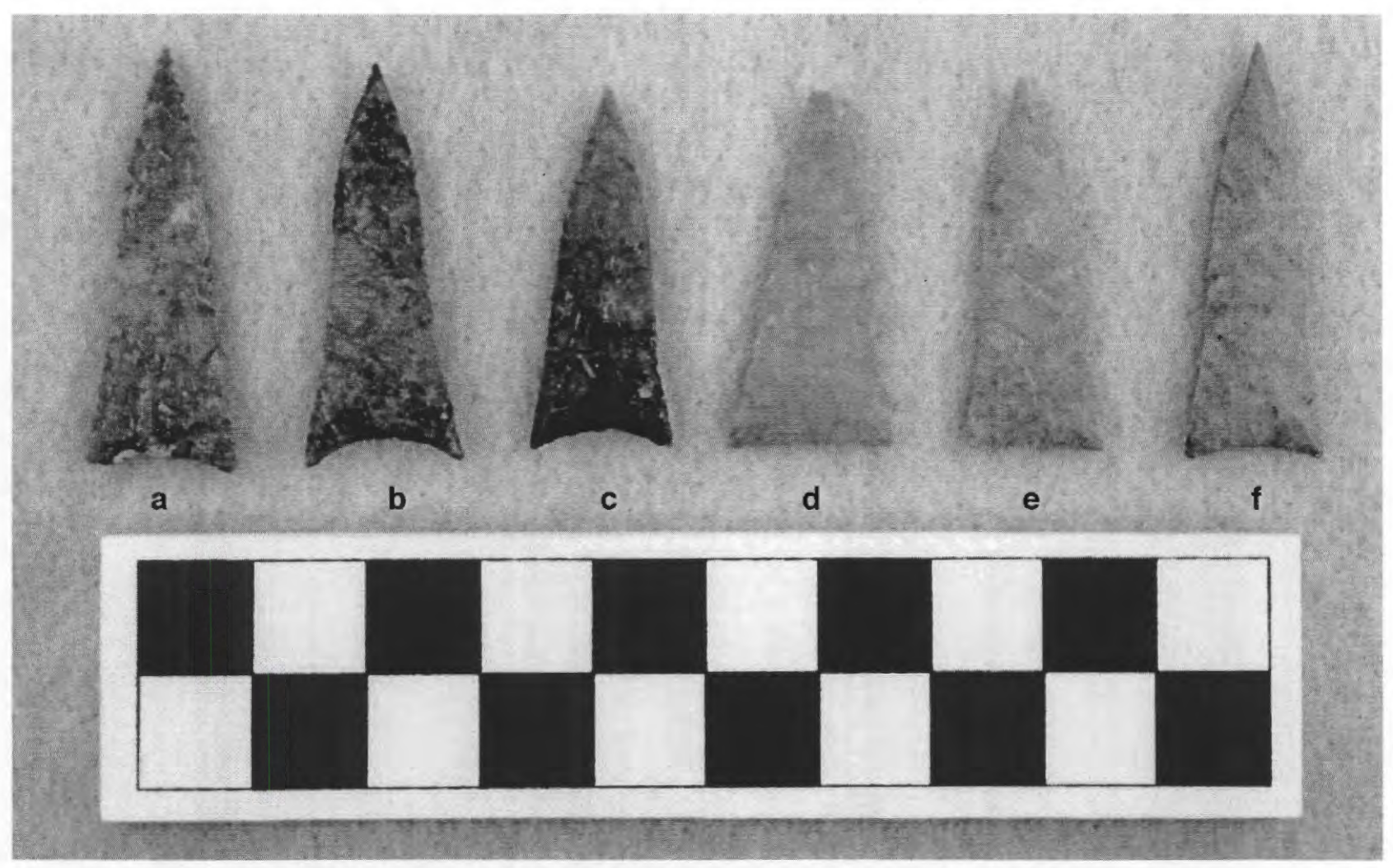

Figure 150. Talco arrow points from the Henry Williams cemetery.

\section{Stone Bead}

A single cylindrical jasper stone bead is in the collection, but its provenience is unknown. The bead, $90.0 \mathrm{~mm}$ in length and $12.8 \mathrm{~mm}$ in width, has been drilled and polished (Figure 151). The diameter of the drilled hole ranges from $4.0-4.5 \mathrm{~mm}$ from one end of the bead to the other. 


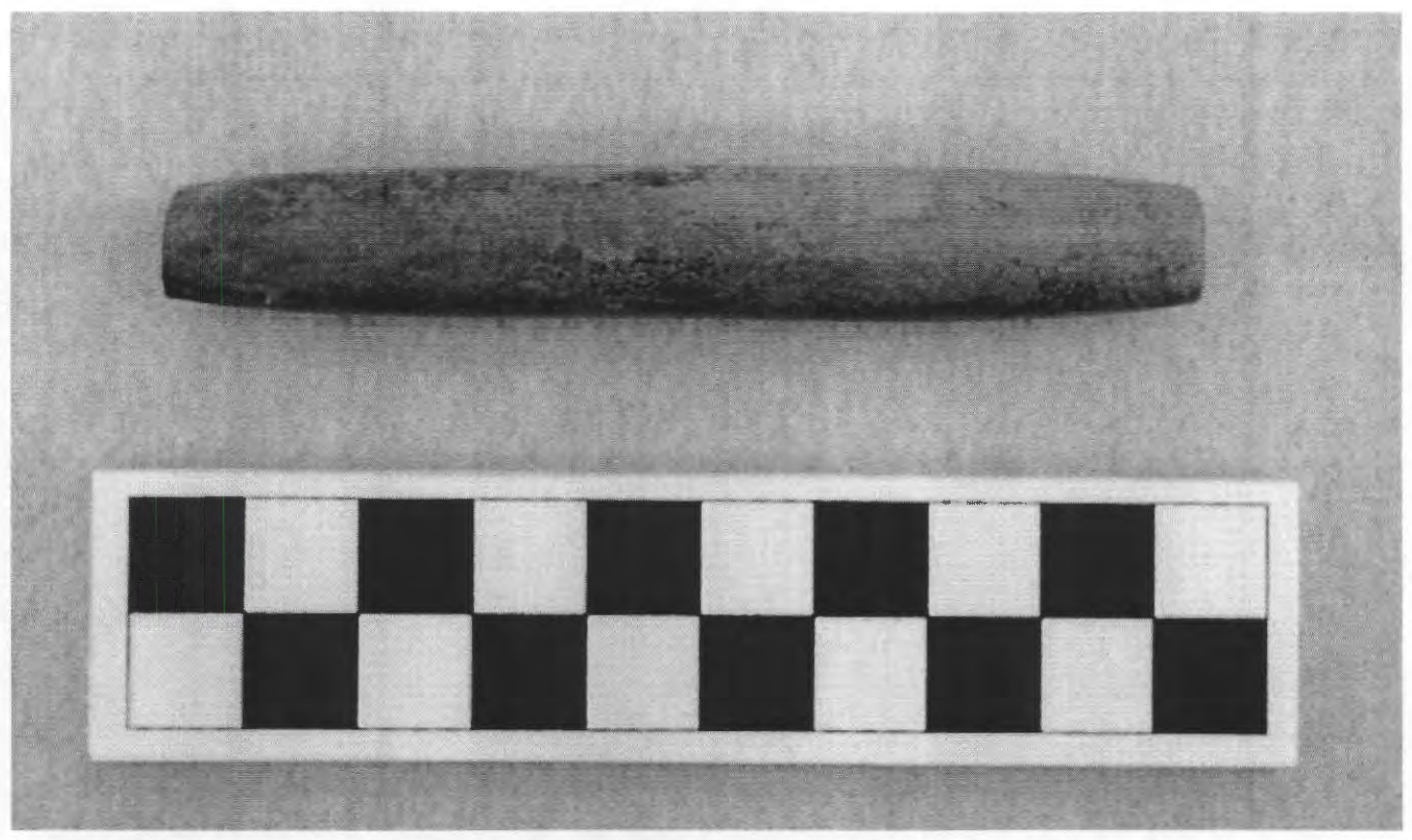

Figure 151. Jasper stone bead, Henry Williams cemetery.

\section{P. Starr Site (41UR319)}

A total of seven Late Caddo period burials were excavated by Buddy Calvin Jones in an old cotton field, a toe slope landform (300-310 feet amsl) situated above the Gum Creek floodplain at the I. P. Starr site (Figure 152). The burials are in two rough north-south rows. The burial excavation started in December 1954 (Jones n.d.), but it is not known when they were completed. It is also not known if the cemetery area was completely investigated, or if the seven burials represent only a sample of the interments present there.

The burials had different kinds of funerary offerings, including ceramic vessels, arrow points, celts, and clay pigment masses (Table 6). Vessels were present in each of the burials where information is available, while arrow points and celts were only included as funerary offerings in one or two burials. Green and red clay pigment were placed in two of the burials, one of which had five chert pebbles.

Table 6. Funerary Offerings in Burials 1-6 at the I. P. Starr site. No information is available on Burial 7.

\begin{tabular}{lccclc}
\hline Burial No. & Ceramic Vessels & Arrow points & Celts & Pigment & Other \\
\hline 1 & 10 & - & 1 & - & - \\
2 & 5 & - & - & - & - \\
3 & 3 & - & 1 & - & - \\
4 & 7 & - & - & green, red & $5 *$ \\
5 & 2 & 9 & - & - & - \\
6 & 5 & 9 & 2 & green & - \\
\hline Totals & 32 & & green, red & 5 \\
\hline
\end{tabular}

*described as "round flint stones" by Jones (n.d.); possible polishing stones 


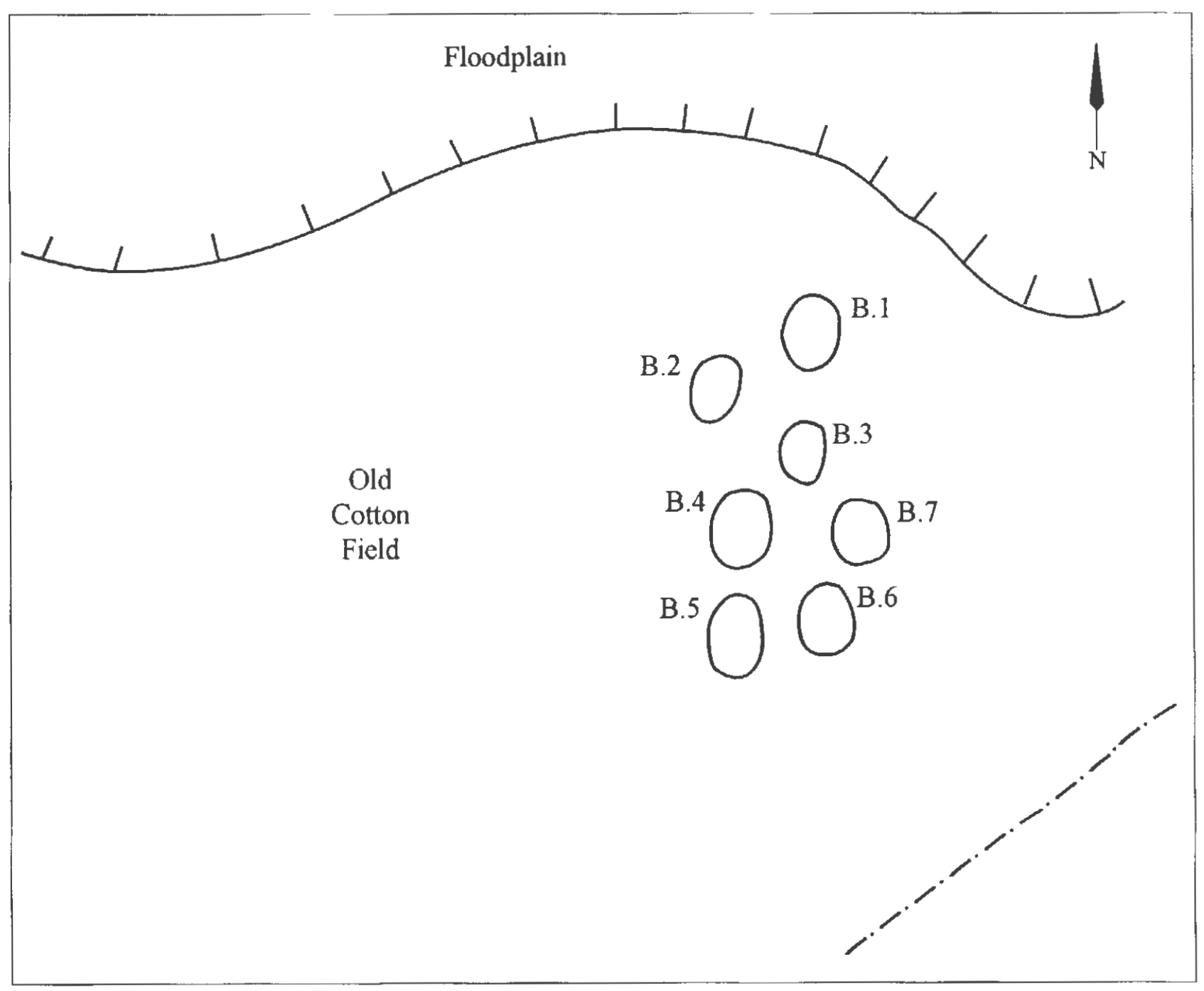

Figure 152. Map of the I.P. Starr site cemetery.

\section{Burial 1}

Burial 1 at the I. P. Starr site is the northernmost burial in the eastern row (see Figure 152). The burial depth was only $30 \mathrm{~cm}$ bs. Jones ( $\mathrm{n} . \mathrm{d}$.) indicated that funerary offerings included 10 ceramic vessels and a single celt (see Table 6).

\section{Burial 2}

This burial is the northernmost burial in the western row of burials at the cemetery (see Figure 152). The burial pit was $36 \mathrm{~cm}$ bs, and there were five ceramic vessels placed as funerary offerings in the grave.

\section{Burial 3}

Burial 3 is in the eastern row in the cemetery. According to Jones (n.d.), the burial pit was excavated to $0.81 \mathrm{~m}$ bs, and had three ceramic vessel funerary offerings along with a gray celt. 


\section{Burial 4}

This particular burial in the western row had been excavated to $0.61 \mathrm{~m}$ bs. There were considerable amounts of red and green pigments in the grave itself and in the vessels found in it. There were seven ceramic vessels in Burial 4, along with "round flint stones" and human skull fragments.

Only one of the vessels in Burial 4 has been identified in the Buddy Jones collection. That was a medium-sized Bullard Brushed jar.

VESSEL NO.: Burial 4, UC 39; 2003.08.1047

NON-PLASTICS AND PASTE: grog

VESSEL FORM: Jar

RIM AND LIP FORM: Everted rim and a rounded lip

CORE COLOR: B (fired and cooled in a reducing environment)

INTERIOR SURFACE COLOR: dark grayish-brown

EXTERIOR SURFACE COLOR: grayish-brown

WALL THICKNESS (RIM, BODY, AND BASE IN MM): rim, $6.7 \mathrm{~mm}$; body, $6.4 \mathrm{~mm}$; base, $8.7 \mathrm{~mm}$

INTERIOR SURFACE TREATMENT:

smoothed

EXTERIOR SURFACE TREATMENT: none

HEIGHT (IN CM): 16.4

ORIFICE DIAMETER (IN CM): 18.0

DIAMETER AT BOTTOM OF RIM OR

NECK (IN CM): 17.5

BASE DIAMETER (IN CM) AND SHAPE

OF BASE: 6.1

ESTIMATED VOLUME (IN LITERS): 2.7

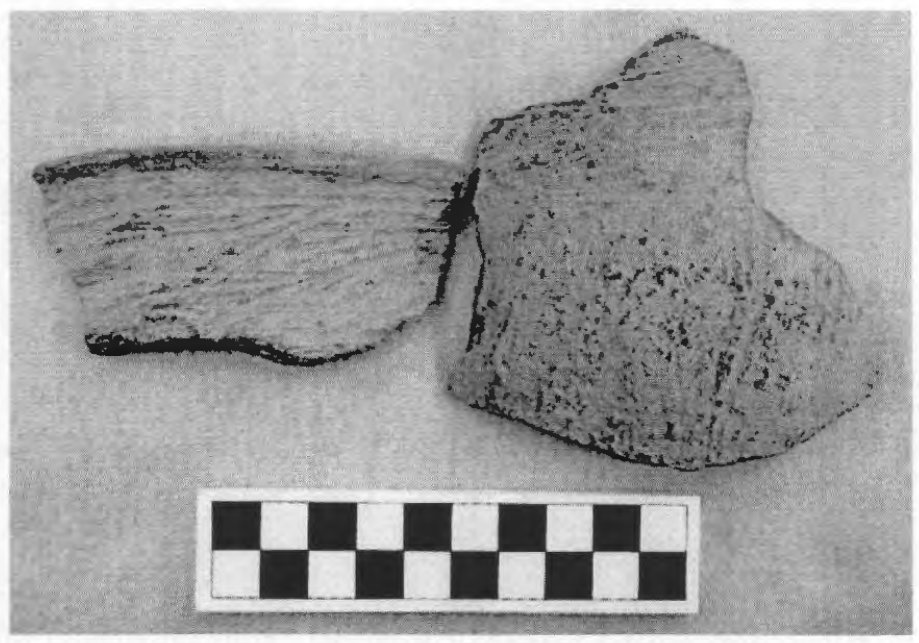

Figure 153. Bullard Brushed jar sherds, I. P. Starr cemetery, Burial 4, Vessel 2003.08.1047.

DECORATION (INCLUDING MOTIF AND ELEMENTS WHEN APPARENT): The rim is decorated with horizontal brushed marks and incised lines. The vessel body has vertical brushed marks that extend from the rim-body juncture to the base (Figure 153).

PIGMENT USE AND LOCATION ON VESSEL: none

TYPE AND VARIETY [IF KNOWN]: Bullard Brushed 


\section{Burial 5}

Burial 5 was a few feet south of Burial 4 in the western row of burials. The burial pit was deep (0.96 $\mathrm{m})$, and there were two large ceramic vessels placed in the grave. One of these vessels has been identified in the Jones collection, a very large cf. Taylor Engraved compound bowl.

VESSEL NO.: Burial 5, UC 39; 2003.08.1956

NON-PLASTICS AND PASTE: grog

VESSEL FORM: Compound bowl

RIM AND LIP FORM: Everted rim and a rounded, exterior folded lip

CORE COLOR: F (fired in a reducing environment and cooled in the open air)

INTERIOR SURFACE COLOR: reddish-brown; fire clouds on the rim, body, and base

EXTERIOR SURFACE COLOR: reddish-brown; fire clouds on the lower body and base

WALL THICKNESS (RIM, BODY, AND BASE IN MM): rim, $8.7 \mathrm{~mm}$; body, $8.8 \mathrm{~mm}$; base, $9.2 \mathrm{~mm}$

INTERIOR SURFACE TREATMENT: smoothed

EXTERIOR SURFACE TREATMENT: upper panel is burnished

HEIGHT (IN CM): 29.0

ORIFICE DIAMETER (IN CM): 37.0

DIAMETER AT BOTTOM OF RIM OR NECK (IN CM): N/A

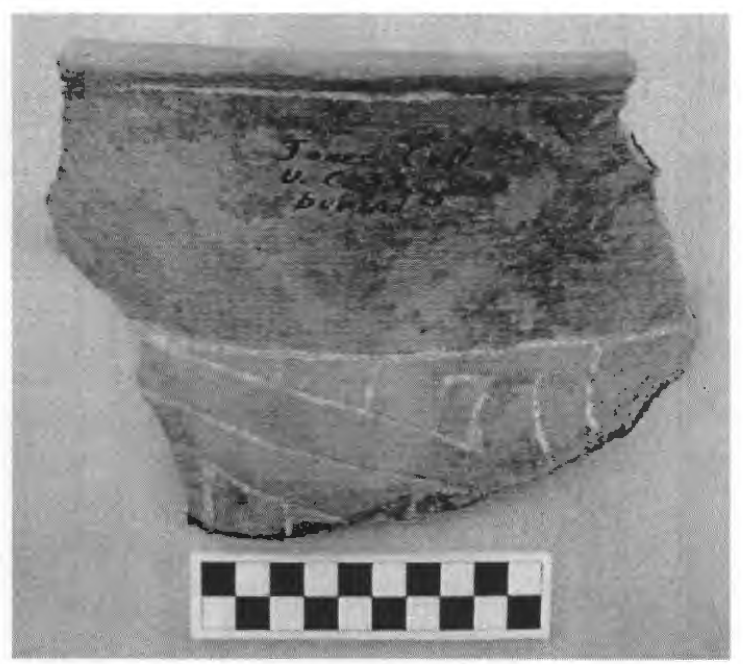

Figure 154. cf. Taylor Engraved compound bowl, I. P. Starr cemetery, Burial 5, Vessel 2003.08.1956.

BASE DIAMETER (IN CM) AND SHAPE OF BASE: N/A

ESTIMATED VOLUME (IN LITERS): 8.6

DECORATION (INCLUDING MOTIF AND ELEMENTS WHEN APPARENT): The upper rim panel has two widely-spaced horizontal engraved lines. The lower panel has an engraved scroll motif, upper and lower hooked arm elements, and excised brackets with negative-S-shaped elements. The upper and lower scroll fill zones have negative ovals, at least one of which has a dash or spur within it (Figure I54).

PIGMENT USE AND LOCATION ON VESSEL: white pigment in the engraved lines 


\section{Burial 6}

Burial 6 is the southernmost burial in the eastern burial row at the I. P. Starr cemetery (see Figure 152). The burial pit was $0.61 \mathrm{~m}$ bs. Funerary offerings in the burial included five ceramic vessels-one at the foot of the grave and the other four in the head area-and nine arrow points, along with green clay pigment. None of the vessels from Burial 6 have been identified in the Buddy Jones collection at the Gregg County Historical Museum.

A total of nine arrow points (2003.08.1886 and 2003.08.1889) were among the funerary offerings in Burial 6 at the I. P. Starr site; they were found in a cache/quiver at the foot of the grave. They include one Maud, two Perdiz, two Talco, three Washita points, and one side-notched arrow point with a flat base (Table 7 and Figure 155a-b). The latter is similar to side-notched arrow points documented at the Titus phaseaffiliated Alex Justiss site (4 1TT13) in the Big Cypress Creek basin (Bcll 1981; Rogers et al. 2003). Bell (1981:63) suggests these are side-notched Talco arrow points. The stylistic diversity of the arrow points in Burial 6 suggests several knappers contributed points for offerings in the grave, and also indicates that these several stylistically distinct Late Caddo arrow point types were in contemporaneous use.

Table 7. Arrow points from Burial 6 at the I. P. Starr site.

\begin{tabular}{|c|c|c|c|c|c|c|c|}
\hline Type & Raw Material & $\begin{array}{c}\mathrm{L} \\
(\mathrm{mm})\end{array}$ & $\begin{array}{c}\mathrm{W} \\
(\mathrm{mm})\end{array}$ & $\begin{array}{c}\text { Th } \\
(\mathrm{mm})\end{array}$ & $\begin{array}{c}\mathrm{SW} \\
(\mathrm{mm})\end{array}$ & Serrated & Chipping \\
\hline Perdiz & QT7.-HT & 30.9 & 24.9 & 4.0 & 6.2 & + & bifacial \\
\hline Perdiz & QTZ & 39.0 & 16.3 & 3.4 & 3.9 & Resharpened & bifacial \\
\hline Maud & w QTZ & 22.9 & 15.3 & 3.6 & - & - & bifacial \\
\hline Talco & QTZ-HT & 44.0 & 17.9 & 3.8 & - & - & bifacial \\
\hline Talco & QTZ-HT & 35.1 & 11.0 & 3.0 & - & - & bifacial \\
\hline Side-notched & QTZ & 33.4 & 15.5 & 2.8 & - & - & bifacial \\
\hline Washita & QTZ-HT & 37.7 & 20.9 & 3.3 & - & - & bifacial \\
\hline Washita & QTZ & 39.0 & 20.5 & 3.3 & - & - & bifacial \\
\hline Washita & light gray chert & 42.0 & 19.0 & 2.5 & - & - & bifacial \\
\hline
\end{tabular}

QTZ=quartzite; HT=heat-treated

Almost $90 \%$ of the arrow points are made from a local quartzite, and $50 \%$ of the quartzite points were heat-treated to facilitate knapping of the tough material. The other point, one of the Washita points. was madc from a non-local light gray chert. All of the points were bifacially chipped, but only the two Perdiz points were serrated or resharpened (see Figure 155a-b), suggesting they have been used before they werc placed in the grave.

\section{Burial 7}

Burial 7 was situated in the eastern burial row, just north of Burial 6 (see Figure 152). No other information is available about this burial feature at the I. P. Starr site. 

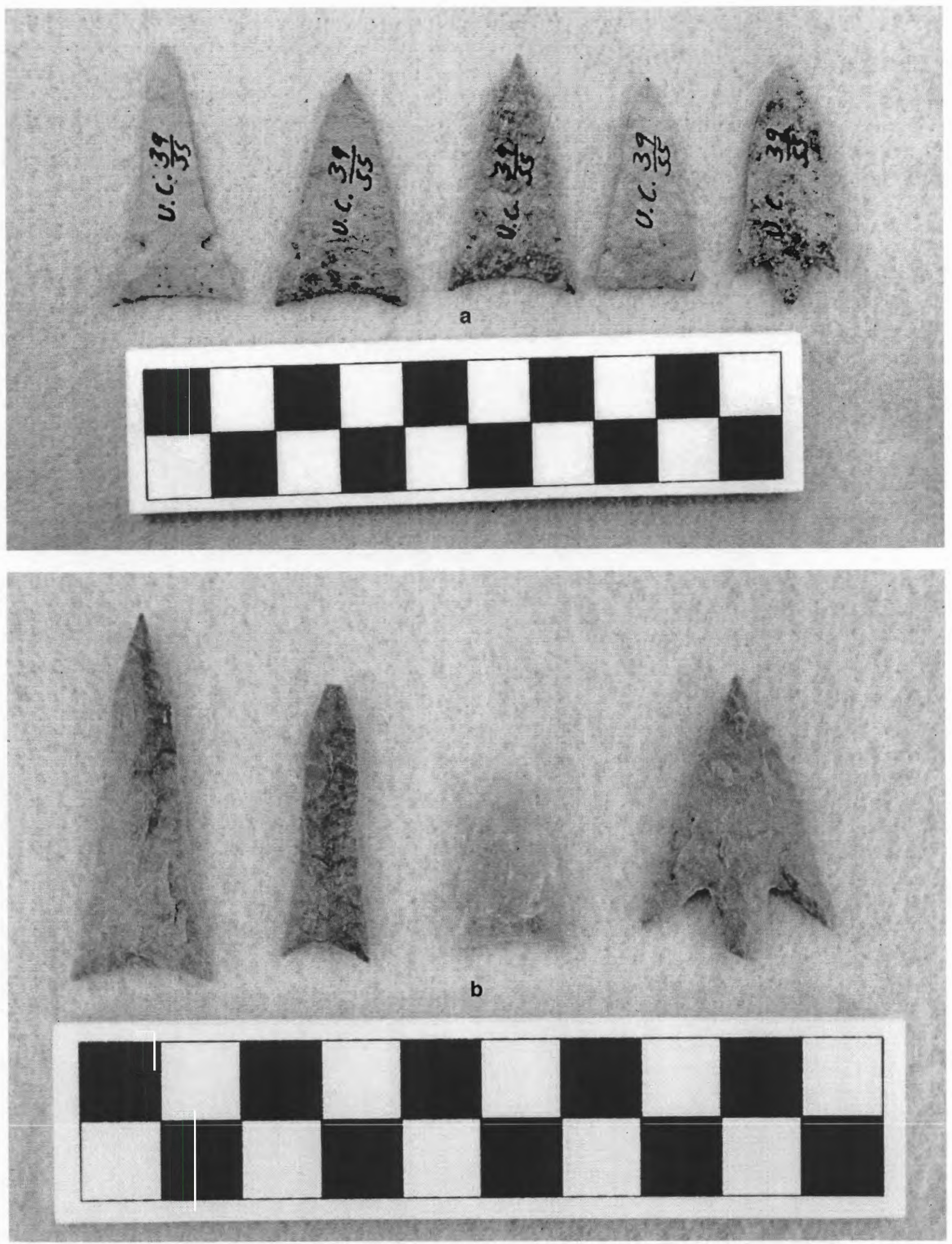

Figure 155. Arrow points from Burial 6 at the I. P. Starr cemetery: a, Washita, side-notched, and Perdiz; b, Talco, Maud, and Perdiz points. 


\section{Vessels from Uncertain Burial Contexts}

Since Burial 1 and 2 were reported by Jones (n.d.) to each have had five vessels as funerary offerings suggests that Vessels 2-5 described below may be from Burial 1, while Vessels 7-9 may be from Burial 2. There is no documentation in the Gregg County Historical Museum collections to confirm this, however. Thus, all the vessels in this portion of the I. P. Starr site discussion must be considered to have come from an uncertain burial context.

VESSEL NO.: M-2, Vessel 2; 2003.08.582

NON-PLASTICS AND PASTE: grog

VESSEL FORM: Compound bowl

RIM AND LIP FORM: Everted rim and rounded lip

CORE COLOR: $\mathrm{G}$ (fired in a reducing environment and cooled in the open air)

INTERIOR SURFACE COLOR: grayish-brown

EXTERIOR SURFACE COLOR: reddish-brown

WALL THICKNESS (RIM, BODY, AND BASE IN MM): rim, $9.4 \mathrm{~mm}$

INTERIOR SURFACE TREATMENT: smoothed

EXTERIOR SURFACE TREATMENT: smoothed

HEIGHT (IN CM): 32.5

ORIFICE DIAMETER (IN CM): 36.7

DIAMETER AT BOTTOM OF RIM OR NECK (IN CM): 32.5

BASE DIAMETER (IN CM) AND SHAPE OF BASE: 8.9

ESTIMATED VOLUME (IN LITERS): 9.5

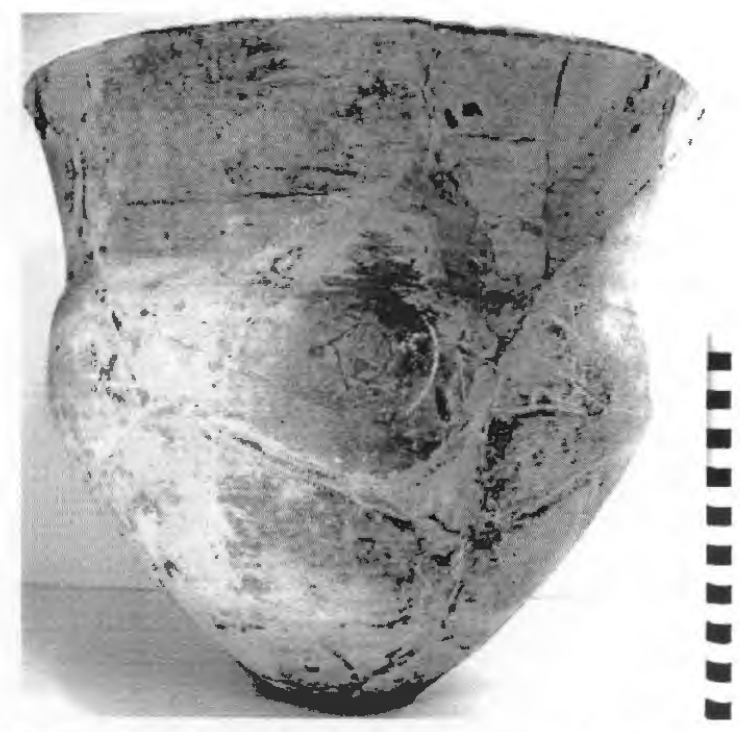

Figure 156. Ripley Engraved, var. Cash compound bowl, I. P. Starr cemetery, Vessel 2003.08.582.

DECORATION (INCLUDING MOTIF AND ELEMENTS WHEN APPARENT): The upper rim panel has two widely-spaced horizontal engraved lines. The narrower lower rim panel has a circle and nested triangle motif repeated four times around the vessel. The central circles have a circle in a circle element, and the smaller circle has short curved lines radiating from it. The central circles alternate with large triangles (Figure 156). Within the large triangles are two excised corners and two short vertical engraved lines. Opposite the nested triangles are smaller but elongated triangular-shaped areas with one excised corner and two vertical engraved lines within them.

PIGMENT USE AND LOCATION ON VESSEL: red pigment in the engraved lines 
VESSEL NO.: Vessel 3; 2003.08.11

NON-PLASTICS AND PASTE: grog

VESSEL FORM: Compound bowl

RIM AND LIP FORM: Everted rim and rounded, exterior folded lip

CORE COLOR: $\mathrm{G}$ (fired in a reducing environment and cooled in the open air)

INTERIOR SURFACE COLOR: dark grayish-brown

EXTERIOR SURFACE COLOR: reddish-brown; fire clouds on the rim, body, and base

WALL THICKNESS (RIM, BODY, AND BASE IN MM): rim, $6.6 \mathrm{~mm}$

INTERIOR SURFACE TREATMENT: smoothed

EXTERIOR SURFACE TREATMENT: smoothed

HEIGHT (IN CM): 24.2

ORIFICE DIAMETER (IN CM): 34.5

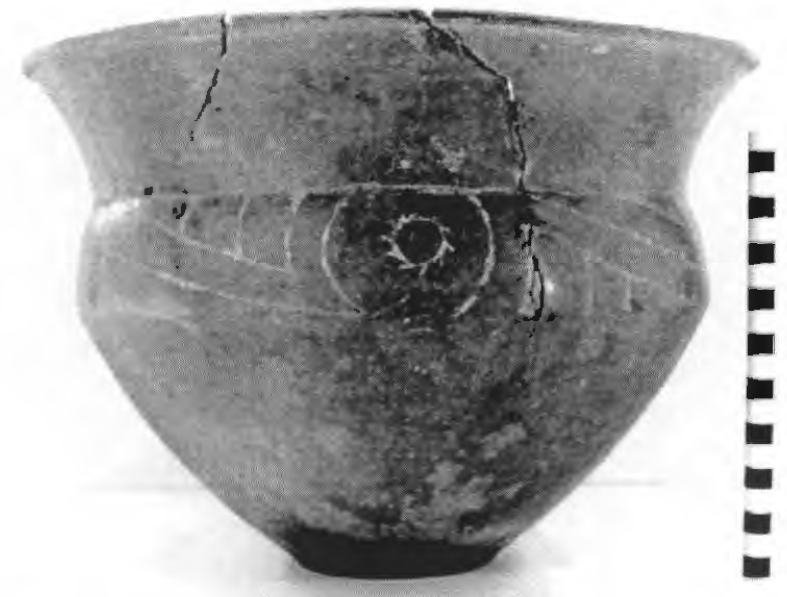

Figure 157. Ripley Engraved, var. Galt compound bowl, Vessel 3.

DIAMETER AT BOTTOM OF RIM OR NECK (IN CM): 29.0

BASE DIAMETER (IN CM) AND SHAPE OF BASE: 10.0; circular and flat

ESTIMATED VOLUME (IN LITERS): 6.7

DECORATION (INCLUDING MOTIF AND ELEMENTS WHEN APPARENT): The upper rim panel is plain, but the lower rim panel has an engraved scroll and circle motif repeated four times around the vessel. The central circles each have a smaller inner circle with short curved lines or spurs radiating from them. The scroll is defined by a single slanting line, with upper and lower scroll fill zones comprised of negative ovals, excised brackets, and excised triangles (Figure 157).

PIGMENT USE AND LOCATION ON VESSEL: white pigment in the engraved lines

TYPE AND VARIETY [IF KNOWN]: Ripley Engraved, var. Galt 
VESSEL NO.: Vessel 4; 2003.08.433

NON-PLASTICS AND PASTE: grog

VESSEL FORM: Carinated bowl

RIM AND LIP FORM: Direct rim and a rounded, exterior folded lip

CORE COLOR: $\mathrm{G}$ (fired in a reducing environment and cooled in the open air)

INTERIOR SURFACE COLOR: grayish-brown

EXTERIOR SURFACE COLOR: reddish-brown; fire clouds on the rim and body

WALL THICKNESS (RIM, BODY, AND

BASE IN MM): rim, $6.5 \mathrm{~mm}$

INTERIOR SURFACE TREATMENT:

smoothed

EXTERIOR SURFACE TREATMENT:

burnished

HEIGHT (IN CM): 8.0

ORIFICE DIAMETER (IN CM): 17.6

DIAMETER AT BOTTOM OF RIM OR

NECK (IN CM): 17.0

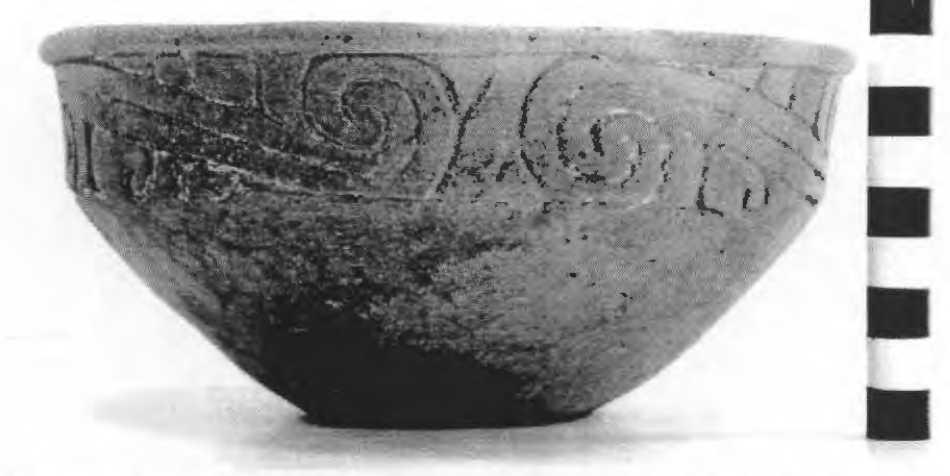

Figure 158. Taylor Engraved carinated bowl, I. P. Starr cemetery, Vessel 4.

BASE DIAMETER (IN CM) AND SHAPE OF BASE: 6.4; circular and flat

ESTIMATED VOLUME (IN LITERS): 0.84

DECORATION (INCLUDING MOTIF AND ELEMENTS WHEN APPARENT): The rim panel has a scroll and hooked arm motif (at either end of the scroll) that is repeated four times around the vessel. The scrolls are divided by open brackets with one short spur element on both sides of the bracket. The upper and lower scroll fill zones have excised brackets, curvilinear lines, and a single hooked arm element (Figure 158).

PIGMENT USE AND LOCATION ON VESSEL: white pigment in engraved lines

TYPE AND VARIETY [IF KNOWN]: Taylor Engraved 
VESSEL NO.: Vessel 5; 2003.08.475

NON-PLASTICS AND PASTE: grog; sandy paste

VESSEL FORM: Carinated bowl

RIM AND LIP FORM: Direct rim and a rounded, exterior folded lip

CORE COLOR: $\mathrm{G}$ (fired in a reducing environment and cooled in the open air)

INTERIOR SURFACE COLOR: very dark grayish-brown

EXTERIOR SURFACE COLOR: reddishbrown; fire clouds on the body and base

WALL THICKNESS (RIM, BODY, AND

BASE IN MM): rim, $5.1 \mathrm{~mm}$

INTERIOR SURFACE TREATMENT:

smoothed

EXTERIOR SURFACE TREATMENT:

burnished

HEIGHT (IN CM): 6.5

ORIFICE DIAMETER (IN CM): I2.4

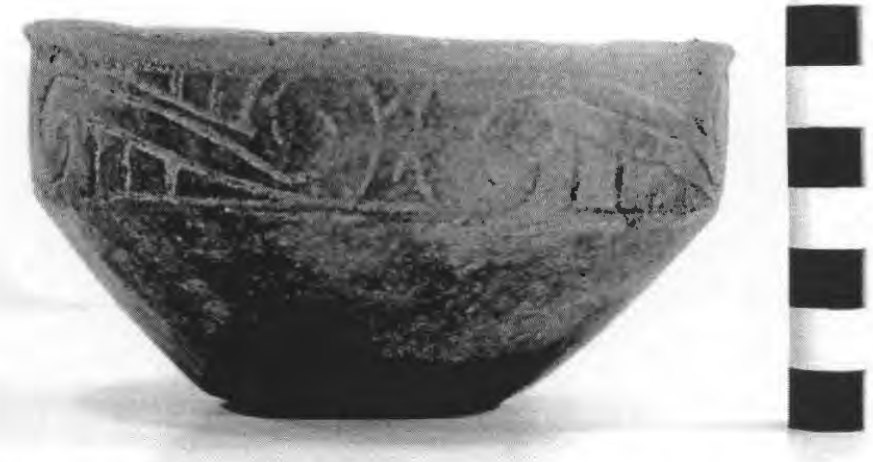

Figure 159. Taylor Engraved carinated bowl, I. P. Starr cemetery, Vessel 5.

DIAMETER AT BOTTOM OF RIM OR NECK (IN CM): I2.2

BASE DIAMETER (IN CM) AND SHAPE OF BASE: 5.5 ; circular and flat

ESTIMATED VOLUME (IN LITERS): 0.48

DECORATION (INCLUDING MOTIF AND ELEMENTS WHEN APPARENT): The rim panel has a scroll and hooked arm motif (at either end of the scroll) that is repeated four times around the vessel. The scrolls are divided by open brackets with one short spur element on both sides of the bracket. The upper and lower scroll fill zones have excised brackets and curvilinear lines (Figure 159).

PIGMENT USE AND LOCATION ON VESSEL: red pigment in the engraved lines

TYPEAND VARIETY [IF KNOWN]: Taylor Engraved 
VESSEL NO.: Vessel 7; 2003.08.762

NON-PLASTICS AND PASTE: grog

VESSEL FORM: Bottle with a short neck

RIM AND LIP FORM: Everted rim and a rounded lip

CORE COLOR: B (fired and cooled in a reducing environment)

INTERIOR SURFACE COLOR: black

EXTERIOR SURFACE COLOR: black

WALL THICKNESS (RIM, BODY, AND BASE IN MM): rim, 5.6 $\mathrm{mm}$

INTERIOR SURFACE TREATMENT: none

EXTERIOR SURFACE TREATMENT: burnished

HEIGHT (IN CM): 14.8

ORIFICE DIAMETER (IN CM): 4.3

DIAMETER AT BOTTOM OF RIM OR NECK (IN CM): 5.9; maximum body diameter is $12.1 \mathrm{~cm}$

BASE DIAMETER (IN CM) AND SHAPE OF BASE: 6.0

ESTIMATED VOLUME (IN LITERS): 0.36

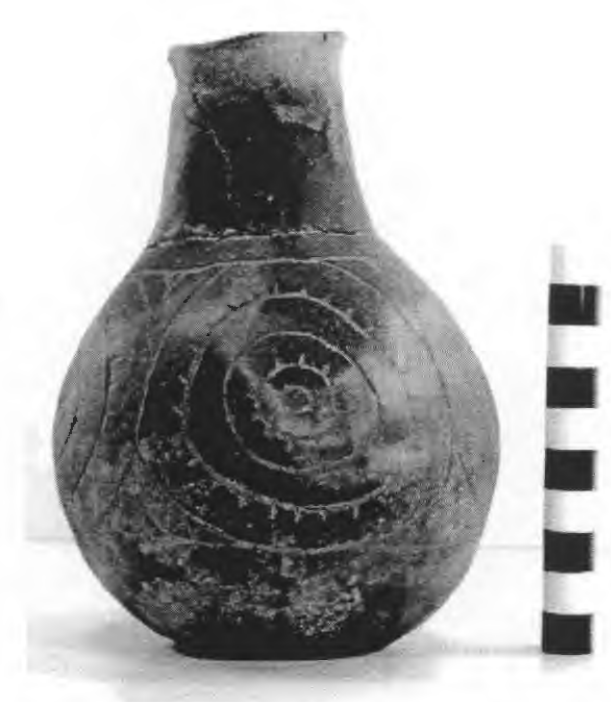

Figure 160. Engraved bottle, I. P. Starr cemetery, Vessel 7.

DECORATION (INCLUDING MOTIF AND ELEMENTS WHEN APPARENT): The vessel body has four panels decorated with a circular engraved motif. The motif consists of five concentric engraved circles, two of which have tick marks on them. Each panel is defined by single upper and lower horizontal engraved lines as well as large pendant triangle-shaped brackets. Each of these has a small excised triangle within it, either open or hatched (Figure 160).

PIGMENT USE AND LOCATION ON VESSEL: red pigment in the engraved lines

TYPE AND VARIETY [IF KNOWN]: Unidentified fine ware 
VESSEL NO.: Vessel 8; 2003.08.479

NON-PLASTICS AND PASTE: grog

VESSEL FORM: Carinated bowl

RIM AND LIP FORM: Direct rim and rounded, exterior folded lip

CORE COLOR: $\mathrm{G}$ (fired in a reducing environment and cooled in the open air)

INTERIOR SURFACE COLOR: dark grayish-brown

EXTERIOR SURFACE COLOR: reddish-brown; fire clouds on the rim, body, and base

WALL THICKNESS (RIM, BODY, AND BASE IN $\mathrm{MM})$ : rim, $8.6 \mathrm{~mm}$

INTERIOR SURFACE TREATMENT: smoothed

EXTERIOR SURFACE TREATMENT: smoothed

HEIGHT (IN CM): 15.3

ORIFICE DIAMETER (IN CM): 23.2

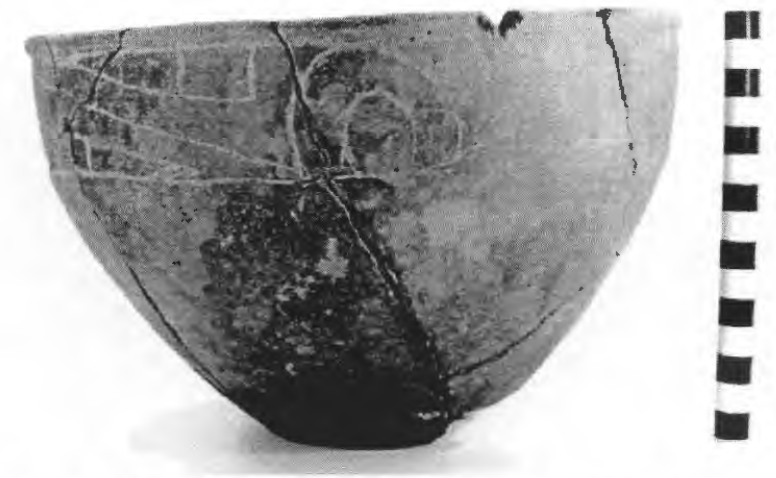

Figure 161. Ripley Engraved, var. Caldwell carinated bowl, I. P. Starr cemetery, Vessel 8.

DIAMETER AT BOTTOM OF RIM OR NECK (IN CM): 22.5

BASE DIAMETER (IN CM) AND SHAPE OF BASE: 8.5; flat and circular

ESTIMATED VOLUME (IN LITERS): 3.2

DECORATION (INCLUDING MOTIF AND ELEMENTS WHEN APPARENT): The rim panel has an engraved semi-circle and scroll motif repeated four times around the vessel. The engraved semi-circles have a smaller inner circle with spurs or tick marks. The slanting scroll line that connects the semi-circles has upper and lower fill zones with excised triangles and brackets, as well as short vertical engraved lines (Figure 161).

PIGMENT USE AND LOCATION ON VESSEL: none

TYPE AND VARIETY [IF KNOWN]: Ripley Engraved, var. Caldwell 
VESSEL NO:: Vessel 9; 2003.08.878

NON-PLASTICS AND PASTE: grog

VESSEL FORM: Jar

RIM AND LIP FORM: Everted rim and rounded, exterior folded lip

CORE COLOR: N/A

INTERIOR SURFACE COLOR: N/A

EXTERIOR SURFACE COLOR: N/A

WALLTHICKNESS (RIM, BODY, AND BASE IN MM):

rim, $6.4 \mathrm{~mm}$

INTERIOR SURFACE TREATMENT: N/A

EXTERIOR SURFACE TREATMENT: N/A

HEIGHT (IN CM): 17.5

ORIFICE DIAMETER (IN CM): 17.3

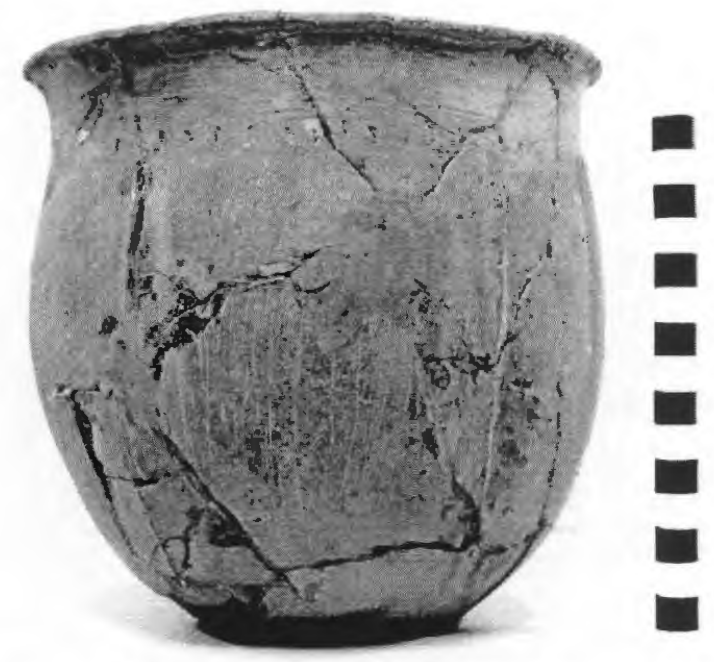

Figure 162. Pease Brushed-Incised jar, I. P. Starr cemetery, Vessel 9.

DIAMETER AT BOTTOM OF RIM OR NECK (IN CM): 16.7

BASE DIAMETER (IN CM) AND SHAPE OF BASE: 8.5; circular and flat

ESTIMATED VOLUME (IN LITERS): 2.7

DECORATION (INCLUDING MOTIF AND ELEMENTS WHEN APPARENT): The rim has horizontal brushing marks. The vessel body is divided into four panels by vertical appliqued ridges; the area between the appliqued ridges is filled with vertical brushing marks (Figure 162).

PIGMENT USE AND LOCATION ON VESSEL: none

TYPE AND VARIETY [IF KNOWN]: Pease Brushed-Incised 
VESSEL NO.: UC 39; 2003.08.1049

NON-PLASTICS AND PASTE: grog

VESSEL FORM: Carinated bowl

RIM AND LIP FORM: Direct rim and a rounded, exterior folded lip

CORE COLOR: G (fired in a reducing environment and cooled in the open air)

INTERIOR SURFACE COLOR: grayish-brown

EXTERIOR SURFACE COLOR: brown; fire clouds on the rim

WALL THICKNESS (RIM, BODY, AND BASE IN MM): body, $8.3 \mathrm{~mm}$; base, $8.8 \mathrm{~mm}$

INTERIOR SURFACE TREATMENT: smoothed

EXTERIOR SURFACE TREATMENT: burnished

HEIGHT (IN CM): N/A; rim panel is $5.0 \mathrm{~cm}$ in height

ORIFICE DIAMETER (IN CM): 19.0

DIAMETER AT BOTTOM OF RIM OR NECK (IN CM): 18.7

BASE DIAMETER (IN CM) AND SHAPE OF BASE: N/A

ESTIMATED VOLUME (IN LITERS): N/A

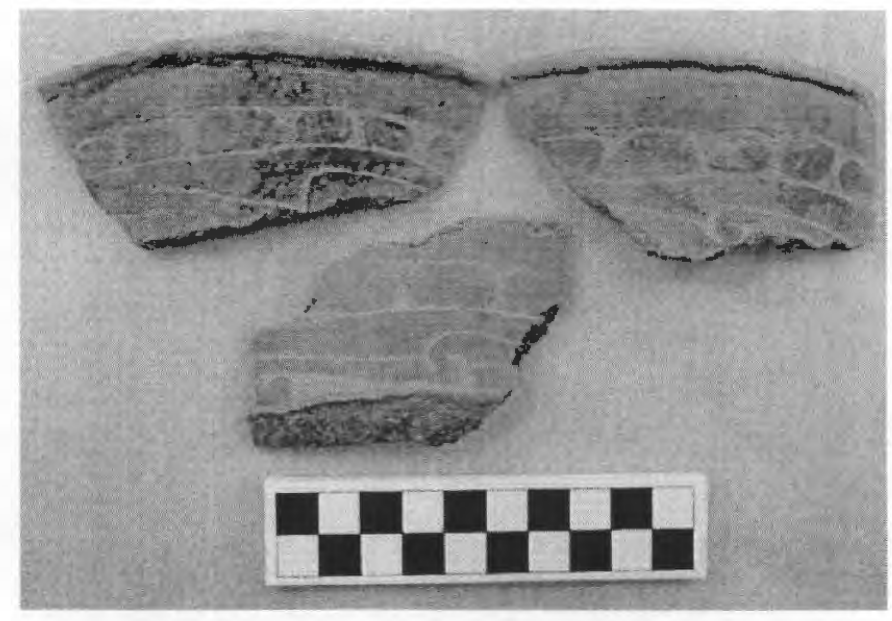

Figure 163. cf. Hodges Engraved carinated bowl, I. P. Starr cemetery, Vessel 2003.08.1049.

DECORATION (INCLUDING MOTIF AND ELEMENTS WHEN APPARENT): The rim panel has a curvilinear scroll line with very distinctive upper and lower scroll fill zones. The upper fill zone is comprised of a series of negative ovals defined by excised brackets and vertical excised lines with upper and lower attached excised pendant triangles. The lower fill zone consists of elongated triangular-shaped excised areas with negative ovals (Figure 163).

PIGMENT USE AND LOCATION ON VESSEL: white pigment in the engraved lines

TYPE AND VARIETY [IF KNOWN]: cf. Hodges Engraved 
VESSEL NO.: UC 39; 2003. 08.1048

NON-PLASTICS AND PASTE: grog

VESSEL FORM: Carinated bowl

RIM AND LIP FORM: Direct rim and a rounded, exterior folded lip

CORE COLOR: B (fired and cooled in a reducing environment)

INTERIOR SURFACE COLOR: grayish-brown

EXTERIOR SURFACE COLOR: grayish-brown

WALL THICKNESS (RIM, BODY, AND BASE IN MM): rim, $8.1 \mathrm{~mm}$; body, $8.0 \mathrm{~mm}$; base, 9.5 $\mathrm{mm}$

INTERIOR SURFACE TREATMENT: none

EXTERIOR SURFACE TREATMENT:

smoothed

HEIGHT (IN CM): 5.8

ORIFICE DIAMETER (IN CM): 13.0

DIAMETER AT BOTTOM OF RIM OR NECK

(IN CM): 12.8

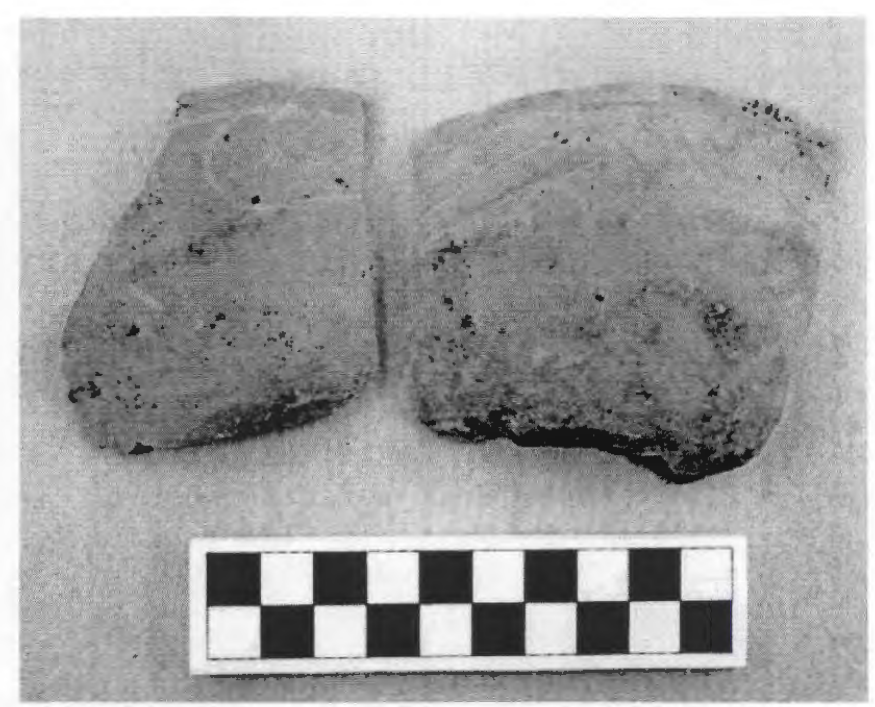

Figure 164. Ripley Engraved, var. Gandy carinated bowl, I. P. Starr cemetery, Vessel 2003.08.1048.

BASE DIAMETER (IN CM) AND SHAPE OF BASE: 5.3

ESTIMATED VOLUME (IN LITERS): 0.45

DECORATION (INCLUDING MOTIF AND ELEMENTS WHEN APPARENT): The rim panel has an engraved scroll motif that is repeated three times around the vessel. The scrolls are divided by negative S-shaped brackets with spurs. The scroll fill zones are filled with excised brackets, negative ovals, and short vertical excised lines (Figure 164).

PIGMENT USE AND LOCATION ON VESSEL: none

TYPE AND VARIETY [IF KNOWN]: Ripley Engraved, var. Gandy 


\section{Herbert Taft Site (41UR320)}

The Taft site cemetery was excavated by Buddy Calvin Jones in October 1958. The cemetery was situated on a toe slope landform (320 fcet amsl) above an old channel of Gum Creek (Figurc 165). Jones (n.d.) described the cemetery as covering only 0.25 acres, and a map he prepared showed four burial features. His notes also indicate that he only excavated three burials at the site, but that his work at the site was unfinished. Since there are ceramic vessels and other funerary offerings from six burials in the Herbert Taft site collections, presumably he returned to the site at a later date and excavated several more burials; the locations on these burials is unknown.

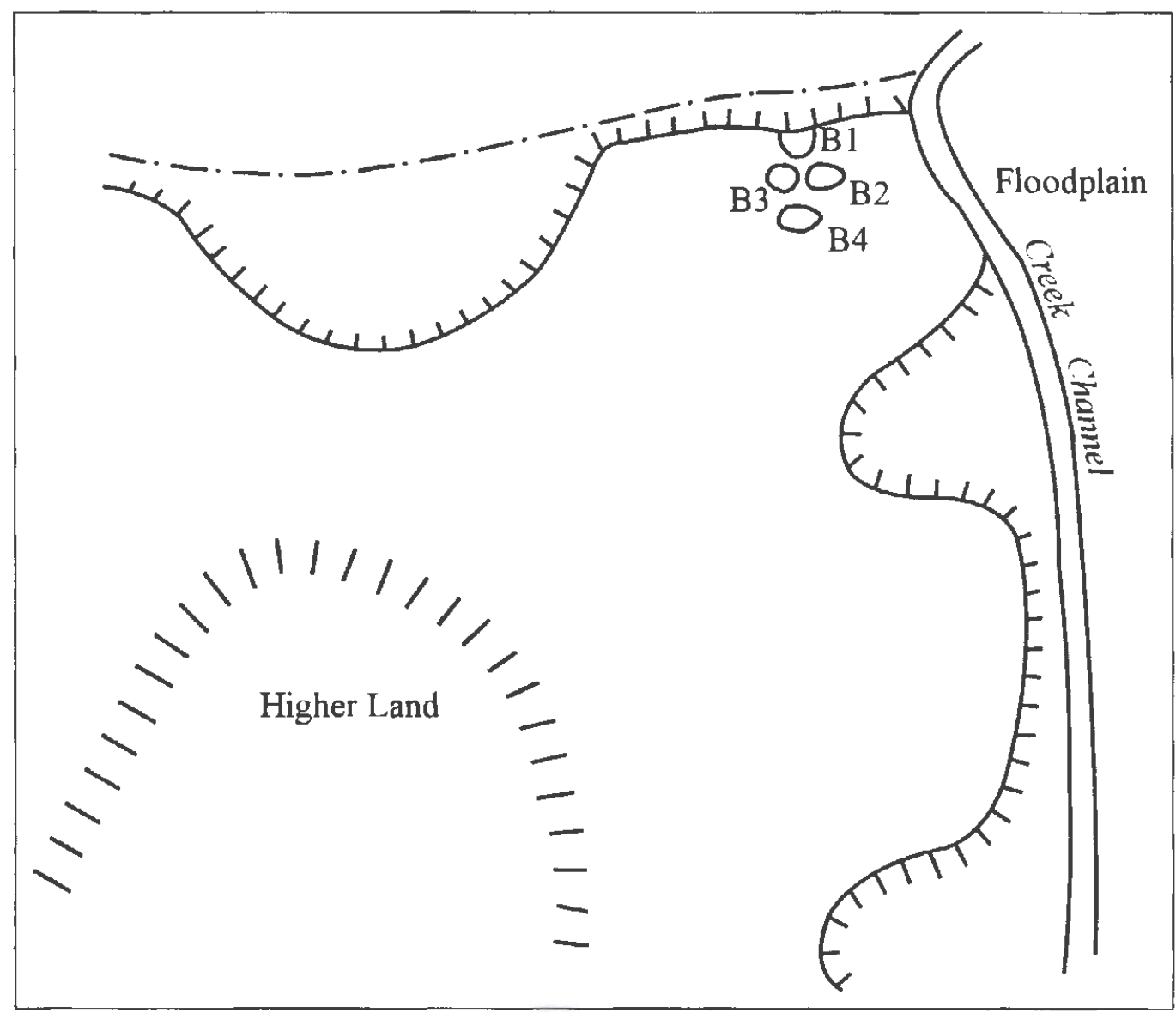

Figure 165. Map of the Herbert Taft site cemetery. 


\section{Burial 1}

Burial 1 was the northernmost burial in the cemetery, and it may have been eroded in the past (see Figure 165). Jones (n.d.) indicated that the burial was in an east-west-oriented pit, with the head facing generally to the west (Figure 166). The burial had a number of funerary offerings, including several ceramic vessels by the head and feet, a ceramic elbow pipe by the left arm, and two large chipped Galt bifaces placed by the left side of the head.

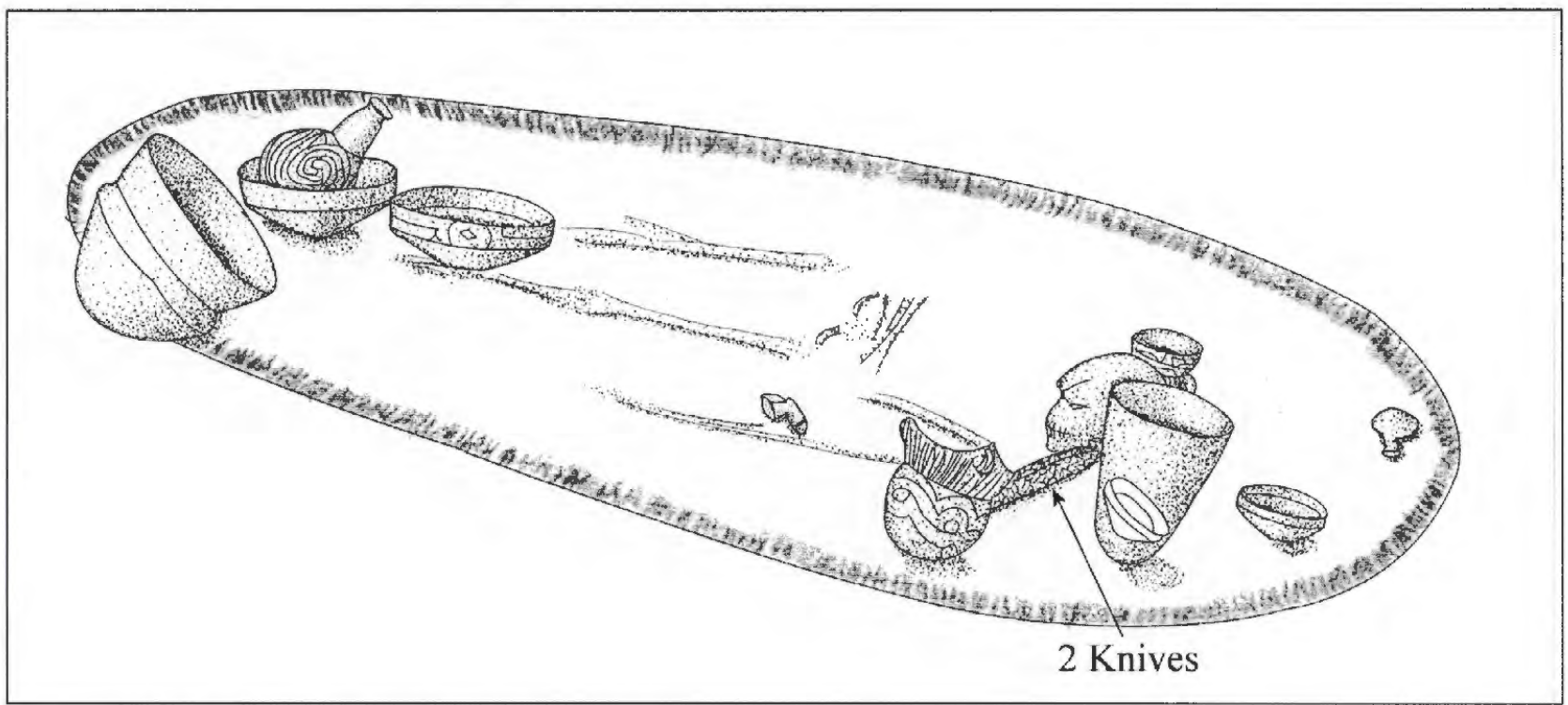

Figure 166. Burial 1 at the Herbert Taft site.

The nine vessels from Burial 1 in the collections include a plain bottle (the engraved-punctated bottle shown in Figure 166 is missing) above the head, one Harleton Appliqued jar by the left shoulder, a redslipped Simms Engraved deep bowl by the left side of the head, one Ripley Engraved, cf, var. Carpenter compound bowl in the foot area, a Taylor Engraved conjoined carinated bowl-bowl by the right side of the head, and four carinated bowls. These include three Ripley Engraved, var. McKinney vessels and one Ripley Engraved, cf. var. Pilgrims vessel.

VESSEL NO.: Burial 1, Vessel 1; 2003.08.924

NON-PLASTICS AND PASTE: grog; sandy paste

VESSEL FORM: Deep bowl

RIM AND LIP FORM: Inverted rim and rounded lip; the lip is notched (Figure 167)

CORE COLOR: F (fired in a reducing environment and cooled in the open air)

INTERIOR SURFACE COLOR: red

EXTERIOR SURFACE COLOR: red 
WALL THICKNESS (RIM, BODY, AND BASE IN MM): rim, 5.4 mm; body, $5.7 \mathrm{~mm}$

INTERIOR SURFACE TREATMENT: smoothed

EXTERIOR SURFACE TREATMENT: smoothed

HEIGHT (IN CM): 21.6

ORIFICE DIAMETER (IN CM): 20.0

DIAMETER AT BOTTOM OF RIM OR NECK (IN CM): 22.7

BASE DIAMETER (IN CM) AND SHAPE OF BASE: 9.4; circular and flat

ESTIMATED VOLUME (IN LITERS): 3.5

DECORATION (INCLUDING MOTIF AND ELEMENTS WHEN APPARENT): The narrow rim has sets (from 6-16 lines) of vertical engraved lines divided by single vertical engraved lines. The interior and exterior vessel surfaces have a red slip (Figure 167).

PIGMENT USE AND LOCATION ON VESSEL: none

TYPE AND VARIETY [IF KNOWN]: Simms Engraved

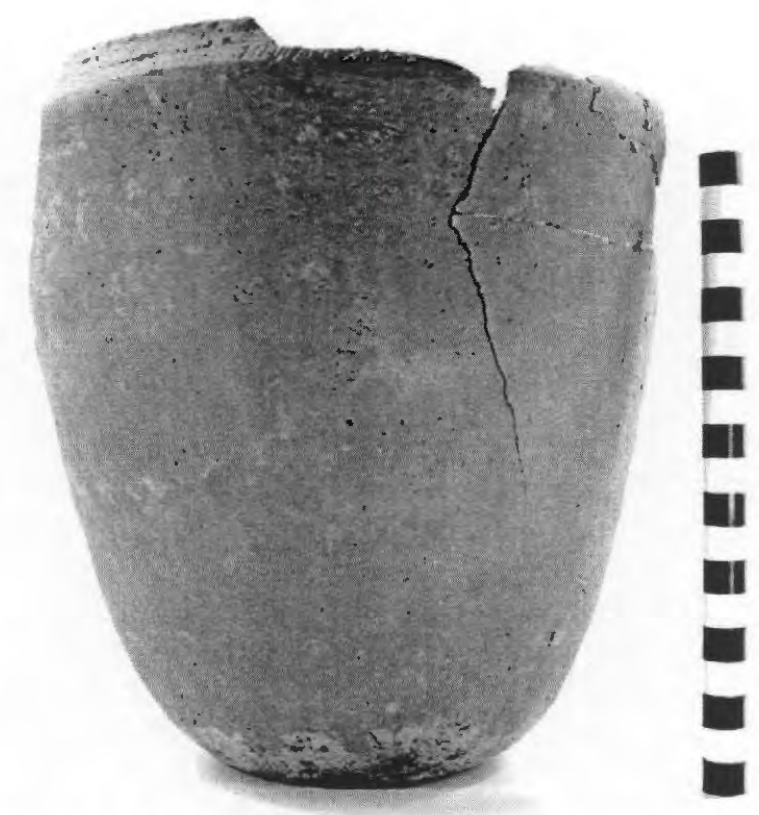

Figure 167. Red-slipped Simms Engraved deep bowl, Herbert Taft cemetery, Burial 1, Vessel 1. 
VESSEL NO.: Burial 1, Vessel 2; 2003.08.803

NON-PLASTICS AND PASTE: grog; sandy paste

VESSEL FORM: Carinated bowl

RIM AND LIP FORM: Direct rim and a rounded, exterior folded lip

CORE COLOR: B (fired and cooled in a reducing environment)

INTERIOR SURFACE COLOR: dark grayish-brown

EXTERIOR SURFACE COLOR: grayish-brown; fire clouds on the rim and body

WALL THICKNESS (RIM, BODY, AND BASE IN MM): rim, $6.3 \mathrm{~mm}$

INTERIOR SURFACE TREATMENT: smoothed

EXTERIOR SURFACE TREATMENT:

burnished

HEIGHT (IN CM): 6.3

ORIFICE DIAMETER (IN CM): 15.8

DIAMETER AT BOTTOM OF RIM OR

NECK (IN CM): 14.4

BASE DIAMETER (IN CM) AND SHAPE OF

BASE: 6.2; circular and flat

ESTIMATED VOLUME (IN LITERS): 0.60

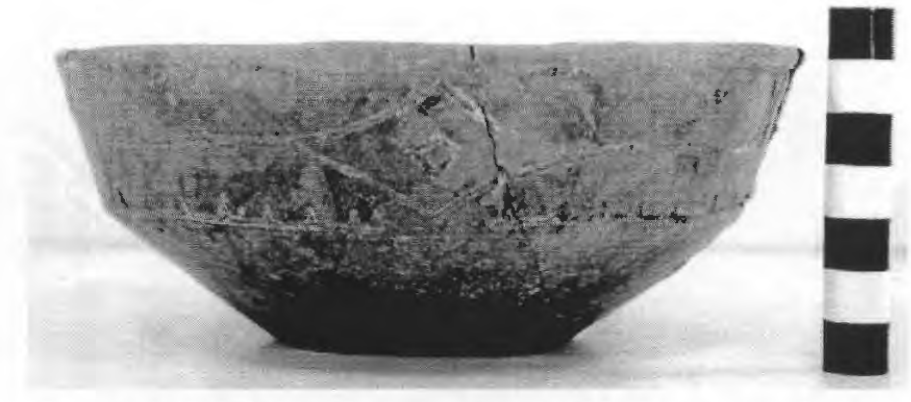

Figure 168. Ripley Engraved, var. McKinney carinated bowl, Herbert Taft cemetery, Burial 1, Vessel 2.

DECORATION (INCLUDING MOTIF AND ELEMENTS WHEN APPARENT): The rim panel has two alternating sets of engraved central circles and nested diamonds; both have an inner engraved diamond. The nested diamond element is at the center of a horizontal scroll with upper and lower brackets; a rectangular area at the center of each brackets has been excised. Above and below the scrolls are tick marks pendant from upper and lower horizontal engraved rim panel lines (Figure 168).

PIGMENT USE AND LOCATION ON VESSEL: white pigment in engraved lines

TYPE AND VARIETY [IF KNOWN]: Ripley Engraved, var. McKinney 
VESSEL NO.: Burial 1, Vessel 3; 2003.08.1811

NON-PLASTICS AND PASTE: grog and hematite; sandy paste

VESSEL FORM: Bottle with a short neck

RIM AND LIP FORM: Everted rim and a rounded, flared, lip

CORE COLOR: K (sooted, smudged, or refired)

INTERIOR SURFACE COLOR: dark grayish-brown

EXTERIOR SURFACE COLOR: yellowish-brown; fire clouds on the body and base

WALL THICKNESS (RIM, BODY, AND BASE IN MM): rim, $3.4 \mathrm{~mm}$

INTERIOR SURFACE TREATMENT: none

EXTERIOR SURFACE TREATMENT: smoothed

HEIGHT (IN CM): 8.0

ORIFICE DIAMETER (IN CM): 4.1

DIAMETER AT BOTTOM OF RIM OR NECK (IN

$\mathrm{CM}$ ): 3.6 ; maximum body diameter is $7.4 \mathrm{~cm}$

BASE DIAMETER (IN CM) AND SHAPE OF BASE:

5.0 ; circular and flat

ESTIMATED VOLUME (IN LITERS): 0.16

DECORATION (INCLUDING MOTIF AND

ELEMENTS WHEN APPARENT): Plain (Figure 169)

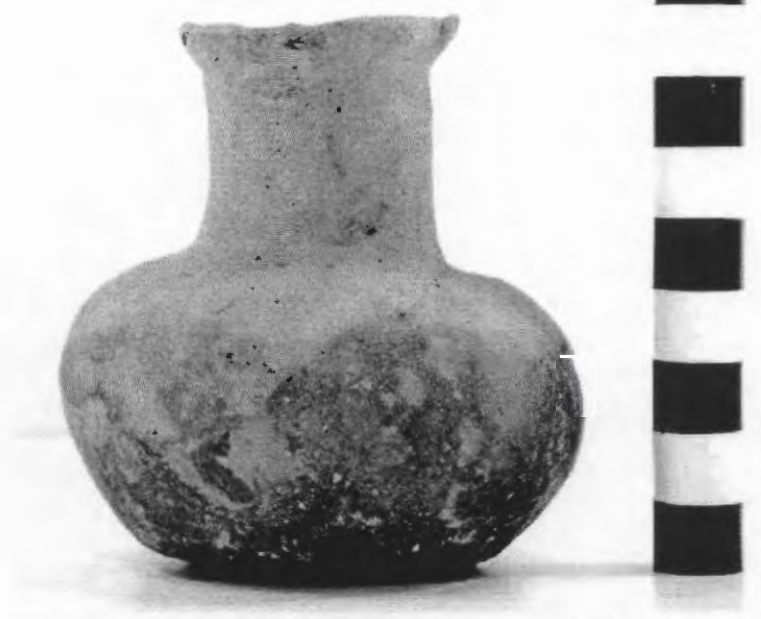

Figure 169. Plain bottle, Herbert Taft cemetery, Burial 1, Vessel 3.

PIGMENT USE AND LOCATION ON VESSEL: none

TYPE AND VARIETY [IF KNOWN]: Unidentified plain ware 
VESSEL NO.: Burial 1, Vessel 4; 2003.08.114

NON-PLASTICS AND PASTE: grog and bone; sandy paste

VESSEL FORM: Jar with four rim peaks and four strap handles (Figure 170)

RIM AND LIP FORM: Everted rim and rounded lip

CORE COLOR: B (fired and cooled in a reducing environment)

INTERIOR SURFACE COLOR: grayish-brown

EXTERIOR SURFACE COLOR: grayish-brown; thick organic residue and resin staining on the rim and body

WALL THICKNESS (RIM, BODY, AND BASE IN MM): rim, $4.7 \mathrm{~mm}$

INTERIOR SURFACE TREATMENT: smoothed

EXTERIOR SURFACE TREATMENT: none

HEIGHT (IN CM): 15.9

ORIFICE DIAMETER (IN CM): 17.6

DIAMETER AT BOTTOM OF RIM OR NECK (IN CM): 14.5

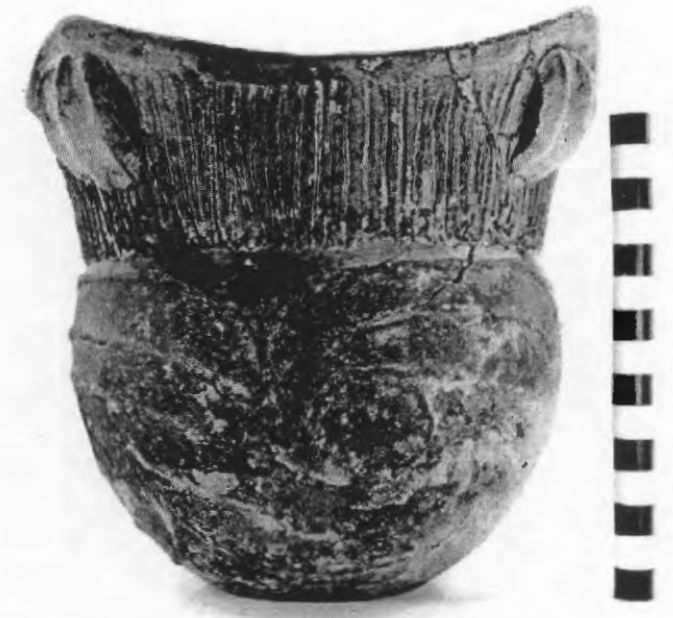

Figure 170. Harleton Appliqued jar, Herbert Taft cemetery, Burial 1, Vessel 4.

BASE DIAMETER (IN CM) AND SHAPE OF BASE: 7.3; circular and flat

ESTIMATED VOLUME (IN LITERS): 1.7

DECORATION (INCLUDING MOTIF AND ELEMENTS WHEN APPARENT): The rim is decorated with a continuous series of closely spaced and deep vertical incised lines. The vessel body has an appliqued fillet circle and scroll motif repeated four times around the body. The upper and lower scroll elements are two sets of curvilinear appliqued fillets (Figure 170).

The strap handles are decorated with three vertical pinched ridges.

PIGMENT USE AND LOCATION ON VESSEL: none

TYPE AND VARIETY [IF KNOWN]: Harleton Appliqued 
VESSEL NO.: Burial 1, Vessel 5; 2003.08.64

NON-PLASTICS AND PASTE: grog

VESSEL FORM: Conjoined carinated bowl and bowl (Figure 171), with two sets of two suspension holes near the carinated bowl rim

RIM AND LIP FORM: Direct rim and a rounded, exterior folded lip

CORE COLOR: $F$ (fired in a reducing environment and cooled in the open air)

INTERIOR SURFACE COLOR: red

EXTERIOR SURFACE COLOR: red; fire clouds on the base

WALL THICKNESS (RIM, BODY, AND BASE IN

MM): rim, $4.1 \mathrm{~mm}$

INTERIOR SURFACE TREATMENT: smoothed

EXTERIOR SURFACE TREATMENT: smoothed

HEIGHT (IN CM): 10.0

ORIFICE DIAMETER (IN CM): 11.7

DIAMETER AT BOTTOM OF RIM OR NECK (IN CM): 12.I

BASE DIAMETER (IN CM) AND SHAPE OF BASE:

5.7 ; circular and rounded

ESTIMATED VOLUME (IN LITERS): 0.70

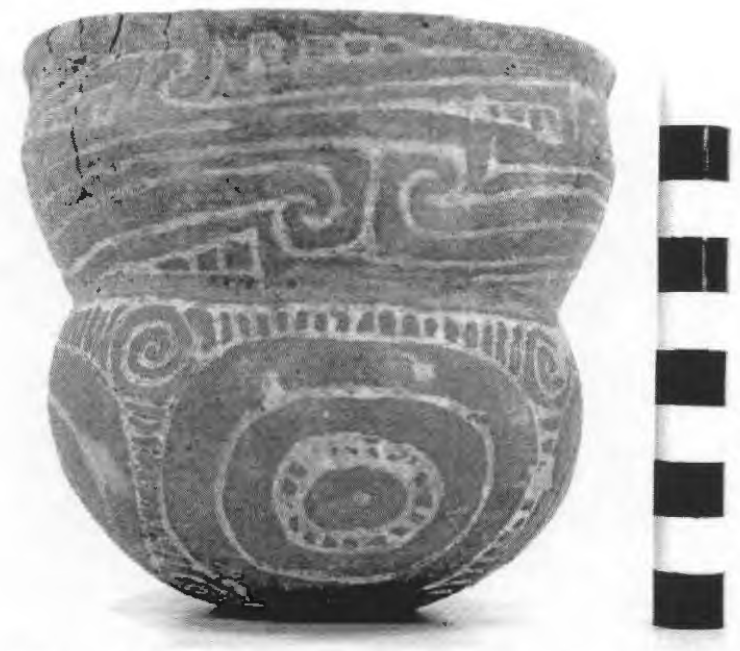

Figure 171. Taylor Engraved conjoined vessel, Herbert Taft cemetery, Burial 1, Vessel 5.

DECORATION (INCLUDING MOTIF AND ELEMENTS WHEN APPARENT): The vessel has a red slip on both interior and exterior surfaces. The carinated bowl portion of the conjoined vessel has two stacks of engraved scrolls that are both repeated four times around the vessel. The scrolls end in hooked arms, and are divided from each other by a single vertical engraved line. The upper and lower scroll fill zones for both scroll stacks are elongated triangles filled with vertical engraved lines (Figure 171).

The decoration on the lower part of the conjoined vessel (the bowl) has four sets of concentric circles that are repeated four times around the vessel. Each set of concentric circles has a inner central dot and a circular hatched zone. The concentric circles have wide brackets around all four sides, and the brackets are filled with both vertical and horizontal hatched lines as well as hooked arm elements at the top and bottom of the brackets (Figure 171).

PIGMENT USE AND LOCATION ON VESSEL: none

TYPE AND VARIETY [IF KNOWN]: Taylor Engraved 
VESSEL NO.: Burial 1, Vessel 6; 2003.08.470

NON-PLASTICS AND PASTE: grog and hematite; sandy paste

VESSEL FORM: Carinated bowl

RIM AND LIP FORM: Direct rim and a rounded, exterior folded lip

CORE COLOR: B (fired and cooled in a reducing environment)

INTERIOR SURFACE COLOR: dark grayish-brown

EXTERIOR SURFACE COLOR: grayish-brown; fire clouds on the rim and body

WALLTHICKNESS (RIM, BODY, AND BASE IN MM): rim, 4.9 mm

INTERIOR SURFACE TREATMENT: smoothed

EXTERIOR SURFACE TREATMENT: smoothed

HEIGHT (IN CM): 7.8

ORIFICE DIAMETER (IN CM): 15.6

DIAMETER AT BOTTOM OF RIM OR NECK

(IN CM): 15.3

BASE DIAMETER (IN CM) AND SHAPE OF

BASE: 5.4 ; circular and flat

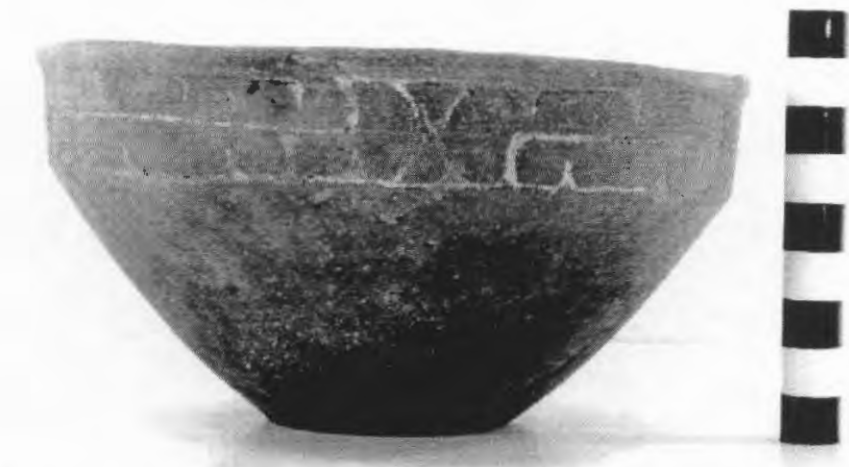

Figure 172. Ripley Engraved, cf. var. Gandy carinated

ESTIMATED VOLUME (IN LITERS): 0.73 bowl, Herbert Taft cemetery, Burial 1, Vessel 6.

DECORATION (INCLUDING MOTIF AND ELEMENTS WHEN APPARENT): The rim panel is decorated with a horizontal scroll motif that is repeated four times around the vessel. Each scroll ends in upper and lower excised brackets, and the scrolls themselves are divided from each other by open brackets. Above and below each scroll motif are small pendant triangles or tick marks.

PIGMENT USE AND LOCATION ON VESSEL: white pigment in the engraved lines TYPE AND VARIETY [IF KNOWN]: Ripley Engraved, cf. var. Gandy 
VESSEL NO.: Burial 1, Vessel 7; 2003.08.566

NON-PLASTICS AND PASTE: grog and hematite; fine sandy paste

VESSEL FORM: Carinated bowl

RIM AND LIP FORM: Direct rim and a rounded, exterior folded lip

CORE COLOR: G (fired in a reducing environment and cooled in the open air)

INTERIOR SURFACE COLOR: grayish-brown

EXTERIOR SURFACE COLOR: yellowish-brown; fire clouds on the rim, body and base

WALL THICKNESS (RIM, BODY, AND BASE IN MM): rim, $7.3 \mathrm{~mm}$

INTERIOR SURFACE TREATMENT: smoothed

EXTERIOR SURFACE TREATMENT:

smoothed

HEIGHT (IN CM): 12.9

ORIFICE DIAMETER (IN CM): 27.2

DIAMETER AT BOTTOM OF RIM OR

NECK (IN CM): 26.0

BASE DIAMETER (IN CM) AND SHAPE

OF BASE: 8.9 ; circular and flat

ESTIMATED VOLUME (IN LITERS): 2.1

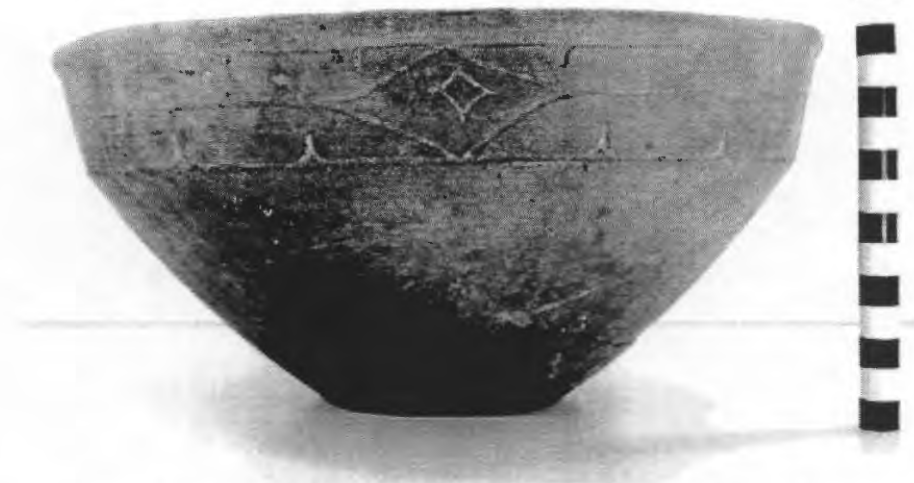

Figure 173. Ripley Engraved, var. McKinney carinated bowl, Herbert Taft cemetery, Burial 1, Vessel 7.

DECORATION (INCLUDING MOTIF AND ELEMENTS WHEN APPARENT): The rim panel has alternating central circles and nested diamond engraved elements repeated four times around the vessel. Both the circles and nested diamonds have a smaller inner diamond element; the diamond element within the circle has four rays or spurs at the corners. The nested diamond element is at the center of a horizontal scroll that ends with upper and lower brackets (Figure 173). Above and below each of the scrolls are excised pendant triangles.

PIGMENT USE AND LOCATION ON VESSEL: white pigment in the engraved lines TYPE AND VARIETY [IF KNOWN]: Ripley Engraved, var. McKinney 
VESSEL NO.: Burial 1, Vessel 8; 2003.08.629

NON-PLASTICS AND PASTE: grog and hematite; sandy paste

VESSEL FORM: Carinated bowl

RIM AND LIP FORM: Direct rim and a rounded, exterior folded lip

CORE COLOR: $\mathrm{F}$ (fired in a reducing environment and cooled in the open air)

INTERIOR SURFACE COLOR: yellowish-brown

EXTERIOR SURFACE COLOR: yellowish-brown; fire clouds on the rim, body, and base; organic residue on the rim/lip

WALL THICKNESS (RIM, BODY, AND BASE IN MM): rim, 5.4 mm

INTERIOR SURFACE TREATMENT: smoothed

EXTERIOR SURFACE TREATMENT:

smoothed

HEIGHT (IN CM): 12.4

ORIFICE DIAMETER (IN CM): 24.6

DIAMETER AT BOTTOM OF RIM OR NECK (IN CM): 22.8

BASE DIAMETER (IN CM) AND SHAPE OF

BASE: 7.6; circular and flat

ESTIMATED VOLUME (IN LITERS): 1.8

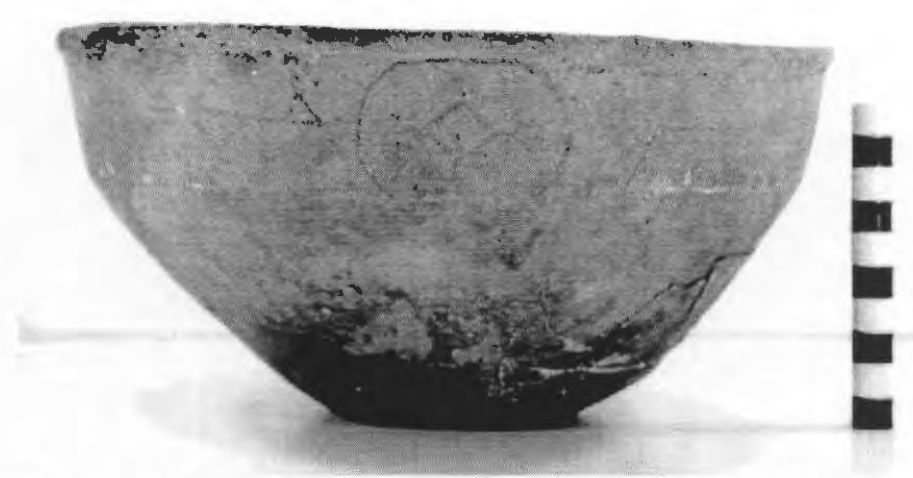

Figure 174. Ripley Engraved, var. McKinney carinated bowl, Herbert Taft cemetery, Burial 1, Vessel 8.

DECORATION (INCLUDING MOTIF AND ELEMENTS WHEN APPARENT): The rim panel has alternating central circles and nested diamond engraved elements repeated twice each around the vessel. Both the cireles and nested diamonds have a smaller inner diamond element; the diamond element within the circle and the nested diamond have four short rays or spurs at the corners. The nested diamond element is at the center of a horizontal scroll that ends with upper and lower open engraved brackets. Above and below each of the scrolls are small excised pendant triangles (Figure 174).

PIGMENT USEAND LOCATION ON VESSEL: white pigment in the engraved lines TYPE AND VARIETY [IF KNOWN]: Ripley Engraved, var. McKinney 
VESSEL NO.: Burial 1, Vessel 10; 2003.08.1427

NON-PLASTICS AND PASTE: grog and bone

VESSEL FORM: Compound bowl

RIM AND LIP FORM: Direct rim and a rounded, exterior folded lip

CORE COLOR: $F$ (fired in a reducing environment and cooled in the open air)

INTERIOR SURFACE COLOR: yellowish-brown

EXTERIOR SURFACE COLOR: yellowish-brown; fire clouds on the rim panels

WALL THICKNESS (RIM, BODY, AND BASE IN MM): rim, $7.0 \mathrm{~mm}$; body, $6.8 \mathrm{~mm}$; base, $11.9 \mathrm{~mm}$

INTERIOR SURFACE TREATMENT:

smoothed

EXTERIOR SURFACE TREATMENT:

smoothed

HEIGHT (IN CM): ca. 22.0

ORIFICE DIAMETER (IN CM): 34.0

DIAMETER AT BOTTOM OF RIM OR NECK

(IN CM): 33.8

BASE DIAMETER (IN CM) AND SHAPE OF

BASE: 8.0 ; circular and flat

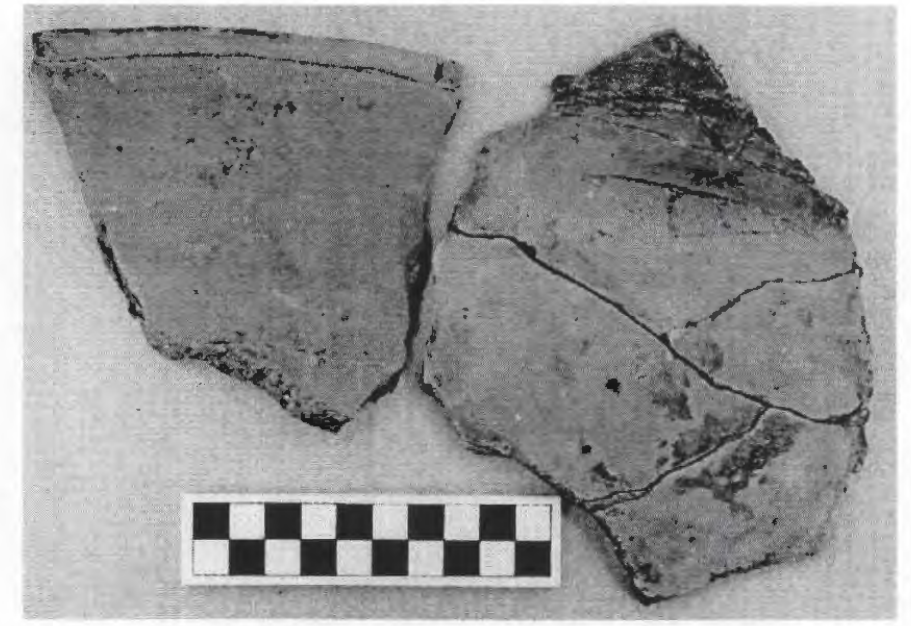

Figure 175. Ripley Engraved, var. Carpenter compound bowl sherds, Herbert Taft cemetery, Burial 1 , Vessel 10.

ESTIMATED VOLUME (IN LITERS): 6.0

DECORATION (INCLUDING MOTIF AND ELEMENTS WHEN APPARENT): The upper rim panel has two widely-spaced horizontal engraved lines; the upper line has a row of excised pendant triangles or tick marks. The lower rim panel has an engraved continuous scroll motif probably repeated four times around the vessel. The upper and lower scroll fill zones are elongated triangular areas with negative ovals and excised corners; one of the upper zone negative ovals has a central dot within it (Figure 175).

There is also a single horizontal engraved line on the interior vessel surface at the carination.

PIGMENT USE AND LOCATION ON VESSEL: none

TYPE AND VARIETY [IF KNOWN]: Ripley Engraved, var. Carpenter 
A single plain long-stemmed elbow pipe (2003.08.306) with a rounded distal end was among the Burial 1 funerary offerings, placed near the left arm (see Figure 166). The pipe, which is bone-tempered, is 42.0 $\mathrm{mm}$ in height and the stem length is $66.0 \mathrm{~mm}$ (Figure 176). The bowl has a broad orifice $(29.0 \mathrm{~mm})$ with relatively thick walls $(6.6 \mathrm{~mm})$. The stem is $14.0 \mathrm{~mm}$ in diameter and the stem hole diameter is $5.4 \mathrm{~mm}$.

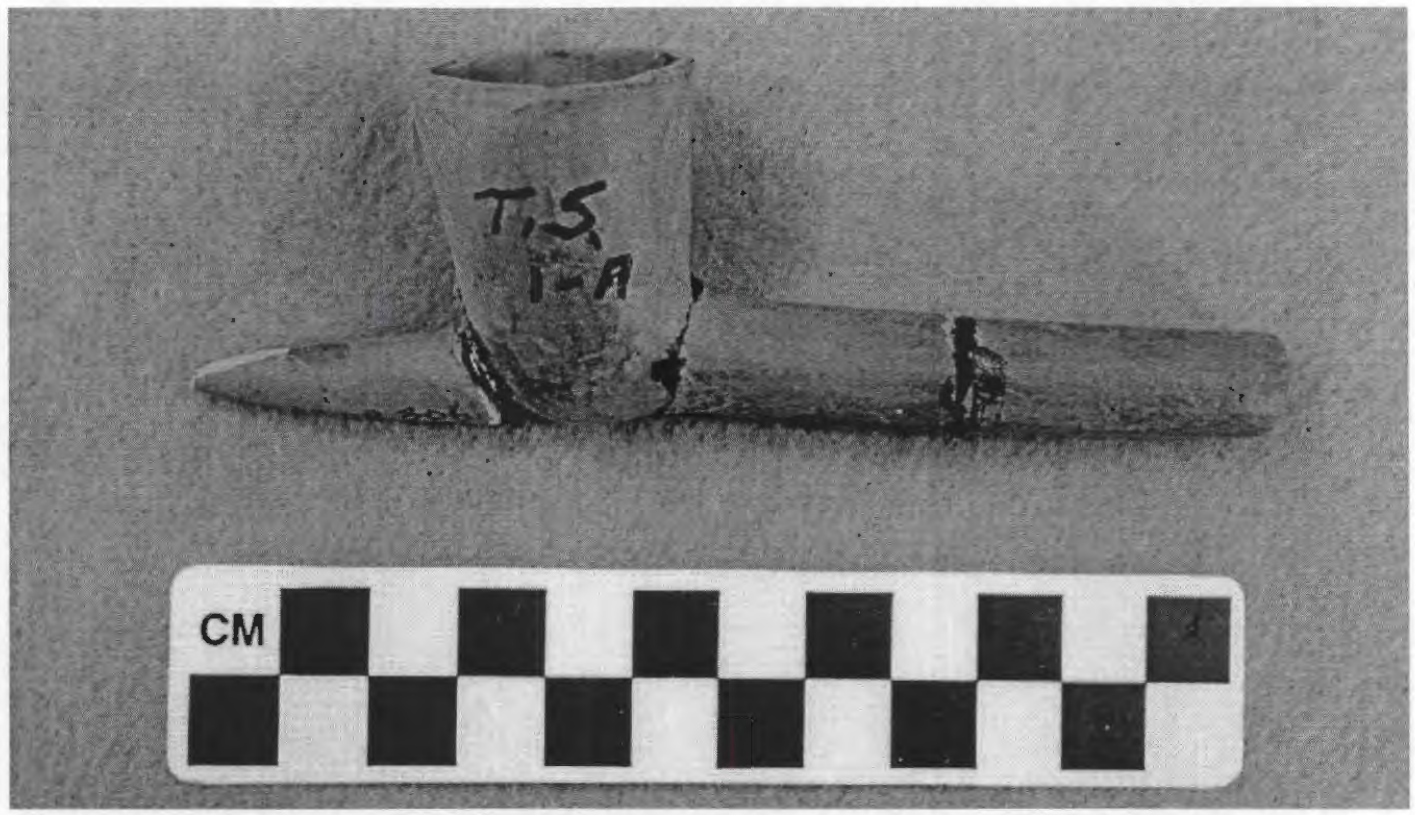

Figure 176. Long-stemmed elbow pipe from Burial 1 at the Herbert Taft cemetery.

\section{Burial 2}

Burial 2 was just south of Burial 1 in the cemetery (see Figure 165). The burial had been excavated into a red-gray clay, and the pit was oriented east-west, with the head of the deceased at the eastem end of the grave, facing west (Figure 177). During the excavations, a Talco point was found outside of the burial pit.

Eight ceramic vessels were placed in the burial to accompany the deceased. This included a large jar by the right shoulder, three vessels in what would have been the waist area, two vessels by the right leg, one by the left leg, and a compound bowl by the left foot. Seven of the vessels from this burial have been identified in the Jones collection. The one jar is a Bullard Brushed vessel, while the bottle is of an unidentified engraved type. The two compound bowls include a Turner Engraved, var. Turner vessel and an unidentified engraved vessel that may be stylistically related to Tumer Engraved. The three carinated bowls are Ripley Engraved, var. Carpenter, Ripley Engraved, var. Caldwell, and Ripley Engraved, cf. var. Gandy.

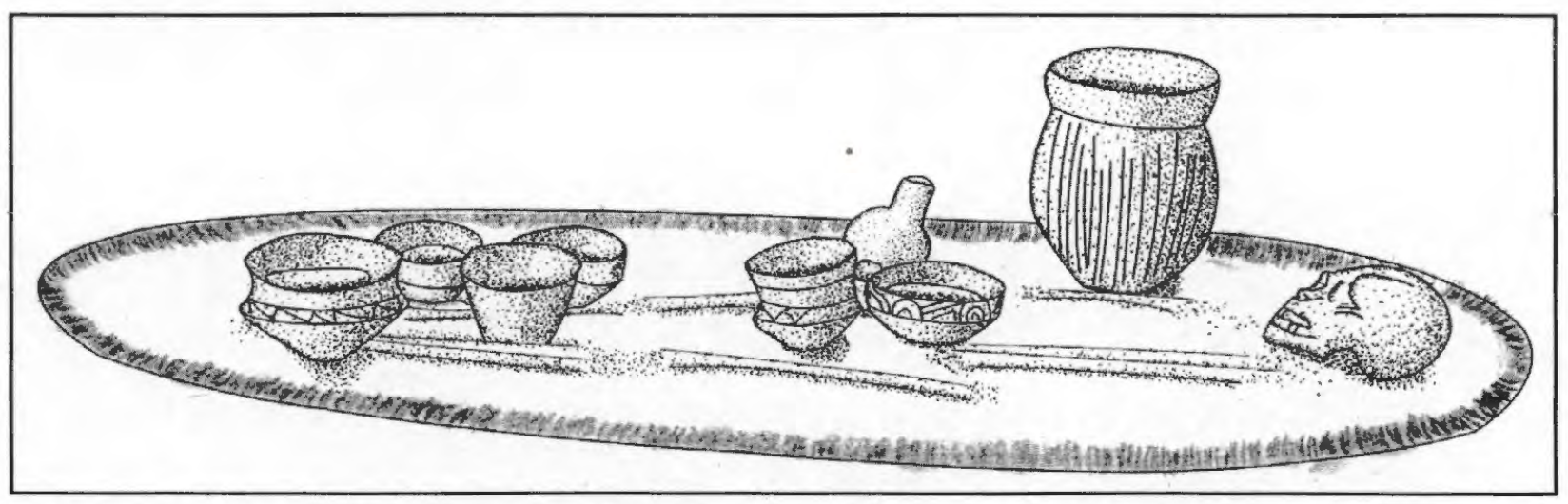

Figure 177. Burial 2 at the Herbert Taft site. 
VESSEL NO.: Burial 2, Vessel 11; 2003.08.758

NON-PLASTICS AND PASTE: grog

VESSEL FORM: Bottle with a short neck

RIM AND LIP FORM: Direct rim and a flat lip

CORE COLOR: G (fired in a reducing environment and cooled in the open air)

INTERIOR SURFACE COLOR: dark grayish-brown

EXTERIOR SURFACE COLOR: reddish-brown; fire clouds on the neck and body

WALL THICKNESS (RIM, BODY, AND BASE IN MM): $\operatorname{rim}, 7.0 \mathrm{~mm}$

INTERIOR SURFACE TREATMENT: none

EXTERIOR SURFACE TREATMENT: none

HEIGHT (IN CM): 14.9

ORIFICE DIAMETER (IN CM): 4.3

Figure 178. Engraved bottle, Herbert Taft

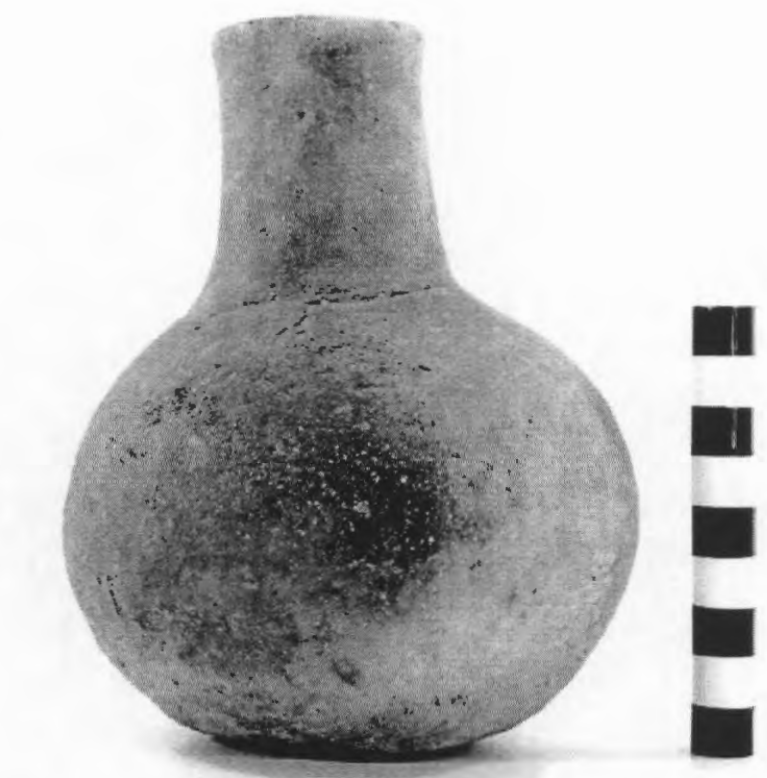
cemetery, Burial 2, Vessel 11.

DIAMETER AT BOTTOM OF RIM OR NECK (IN CM): 5.6

BASE DIAMETER (IN CM) AND SHAPE OF BASE: 5.6; circular and flat

ESTIMATED VOLUME (IN LITERS): 0.34

DECORATION (INCLUDING MOTIF AND ELEMENTS WHEN APPARENT): There is a single horizontal engraved line at the juncture of the neck and body (Figure 178).

PIGMENT USE AND LOCATION ON VESSEL: none

TYPE AND VARIETY [IF KNOWN]: Unidentified fine ware 
VESSEL NO:: Burial 2, Vessel 12; 2003.08.831

NON-PLASTICS AND PASTE: grog, hematite, and organics

VESSEL FORM: Carinated bowl

RIM AND LIP FORM: Direct rim and a rounded, exterior folded lip

CORE COLOR: $\mathrm{F}$ (fired in a reducing environment and cooled in the open air)

INTERIOR SURFACE COLOR:

yellowish-brown

EXTERIOR SURFACE COLOR:

yellowish-brown; fire clouds on the body and base

WALL THICKNESS (RIM, BODY, AND BASE IN MM): rim, $6.5 \mathrm{~mm}$; body, 6.8

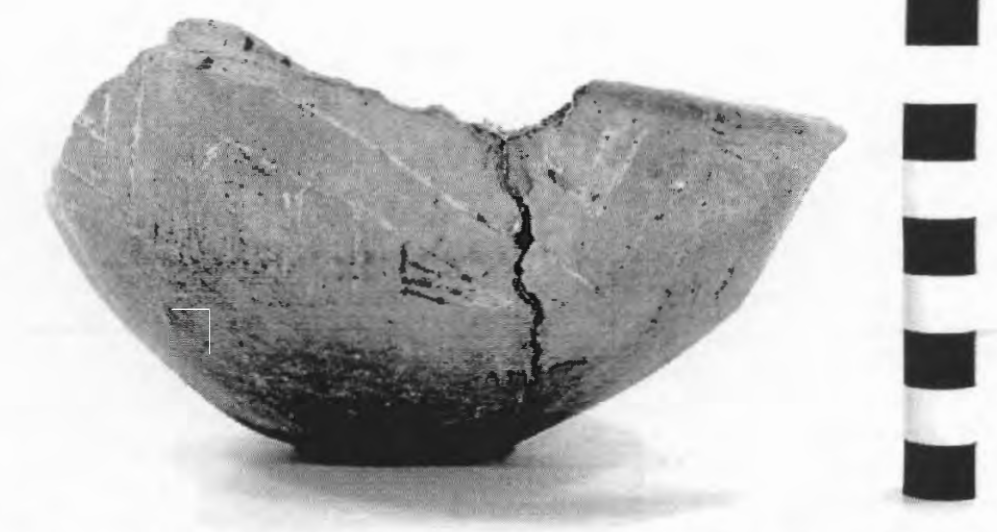
$\mathrm{mm}$; base, $9.4 \mathrm{~mm}$

Figure 179. Ripley Engraved, var. Carpenter carinated bowl, Herbert Taft cemetery, Burial 2, Vessel 12.

INTERIOR SURFACE TREATMENT: smoothed

EXTERIOR SURFACE TREATMENT: smoothed

HEIGHT (IN CM): 7.0

ORIFICE DIAMETER (IN CM): 16.0

DIAMETER AT BOTTOM OF RIM OR NECK (IN CM): 14.6

BASE DIAMETER (IN CM) AND SHAPE OF BASE: 5.0

ESTIMATED VOLUME (IN LITERS): 0.67

DECORATION (INCLUDING MOTIF AND ELEMENTS WHEN APPARENT): The rim panel has an engraved continuous scroll motif that is repeated four times around the vessel. The upper and lower scroll zones have excised triangles and vertical engraved/excised lines, while the lower fill zones have semi-circle elements with an inner dot or dash (Figure 179).

PIGMENT USE AND LOCATION ON VESSEL: white pigment in the engraved lines

TYPE AND VARIETY [IF KNOWN]: Ripley Engraved, var. Carpenter 
VESSEL NO.: Burial 2, Vessel 13; 2003.08.0077

NON-PLASTICS AND PASTE: bone

VESSEL FORM: Compound bowl

RIM AND LIP FORM: Everted rim and a rounded, exterior folded lip

CORE COLOR: $\mathrm{F}$ (fired in a reducing environment and cooled in the open air)

INTERIOR SURFACE COLOR: reddish-brown; fire clouds on the rim, body, and base

EXTERIOR SURFACE COLOR: reddish-brown; fire clouds on the rim, body, and base

WALL THICKNESS (RIM, BODY, AND BASE IN MM): rim, 6.4 mm

INTERIOR SURFACE TREATMENT:

smoothed

EXTERIOR SURFACE TREATMENT:

burnished

HEIGHT (IN CM): 9.3

ORIFICE DIAMETER (IN CM): 15.4

DIAMETER AT BOTTOM OF RIM OR NECK (IN CM): 14.5

BASE DIAMETER (IN CM) AND SHAPE OF BASE: 6.5

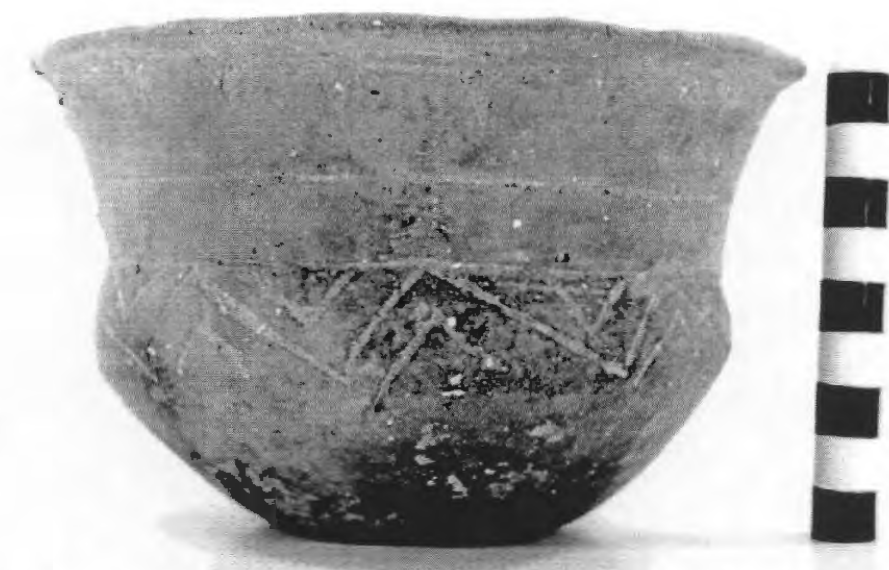

Figure 180. Engraved compound bowl, Herbert Taft cemetery, Burial 2, Vessel 13.

ESTIMATED VOLUME (IN LITERS): 1.15

DECORATION (INCLUDING MOTIF AND ELEMENTS WHEN APPARENT): The upper rim panel has three widely-spaced horizontal engraved lines. The uppermost line has a series of excised pendant triangles. The lower rim panel has a series of 10 upper and lower alternating triangles. Each of these large triangles have a smaller inner triangle element (Figure 180).

PIGMENT USE AND LOCATION ON VESSEL: none

TYPE AND VARIETY [IF KNOWN]: Unidentified fine ware, possibly Turner Engraved 
VESSEL NO.: Burial 2, Vessel 14; 2003.08.1837

NON-PLASTICS AND PASTE: grog and bone

VESSEL FORM: Carinated bowl

RIM AND LIP FORM: Direct rim and a rounded, exterior folded lip

CORE COLOR: B (fired and cooled in a reducing environment)

INTERIOR SURFACE COLOR: dark grayish-brown

EXTERIOR SURFACE COLOR: dark grayish-brown; fire clouds on the body

WALL THICKNESS (RIM, BODY, AND BASE IN MM): rim, $6.0 \mathrm{~mm}$

INTERIOR SURFACE TREATMENT: smoothed

EXTERIOR SURFACE TREATMENT:

burnished

HEIGHT (IN CM): 7.8

ORIFICE DIAMETER (IN CM): 16.1

DIAMETER AT BOTTOM OF RIM OR NECK (IN CM): 15.5

\section{BASE DIAMETER (IN CM) AND SHAPE OF BASE: 7.2}

ESTIMATED VOLUME (IN LITERS): 0.75

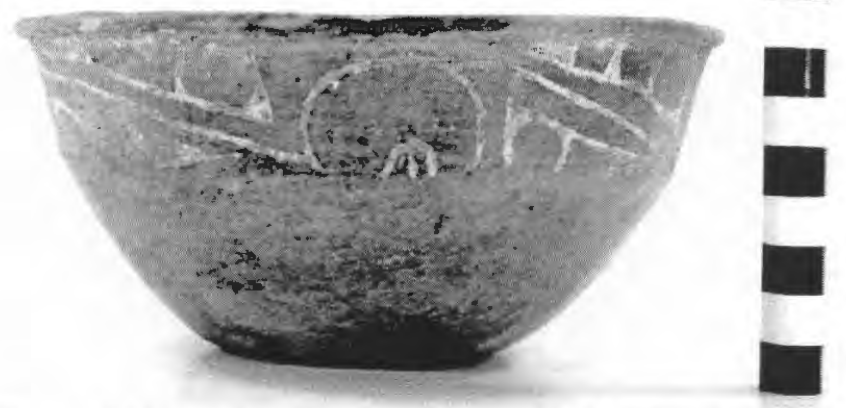

Figure 181. Ripley Engraved, var. Caldwell carinated bowl, Herbert Taft cemetery, Burial 2, Vessel 14.

DECORATION (INCLUDING MOTIF AND ELEMENTS WHEN APPARENT): The rim panel has an engraved semi-circle and scroll motif that is repeated four times around the vessel. Each semi-circle has a small inner semi-circle, and that semi-circle has a small dashed line within it. The upper and lower scroll fill zones have excised triangles, short vertical engraved lines, and negative oval-shaped elements (Figure 181).

PIGMENT USE AND LOCATION ON VESSEL: white pigment in the engraved lines

TYPE AND VARIETY [IF KNOWN]: Ripley Engraved, var. Caldwell 
VESSEL NO.: Burial 2, Vessel 15; 2003.08.374

NON-PLASTICS AND PASTE: grog

VESSEL FORM: Jar

RIM AND LIP FORM: Everted rim and rounded lip

CORE COLOR: G (fired in a reducing environment and cooled in the open air)

INTERIOR SURFACE COLOR: dark grayish-brown

EXTERIOR SURFACE COLOR: yellowish-brown; fire clouds on the rim, body, and base

WALL THICKNESS (RIM, BODY, AND

BASE IN MM): rim, $7.5 \mathrm{~mm}$

INTERIOR SURFACE TREATMENT: smoothed

EXTERIOR SURFACE TREATMENT: none

HEIGHT (IN CM): 10.5

ORIFICE DIAMETER (IN CM): 14.4

DIAMETER AT BOTTOM OF RIM OR NECK

(IN CM): 13.0

BASE DIAMETER (IN CM) AND SHAPE OF

BASE: 5.9; circular and flat

ESTIMATED VOLUME (IN LITERS): 0.91

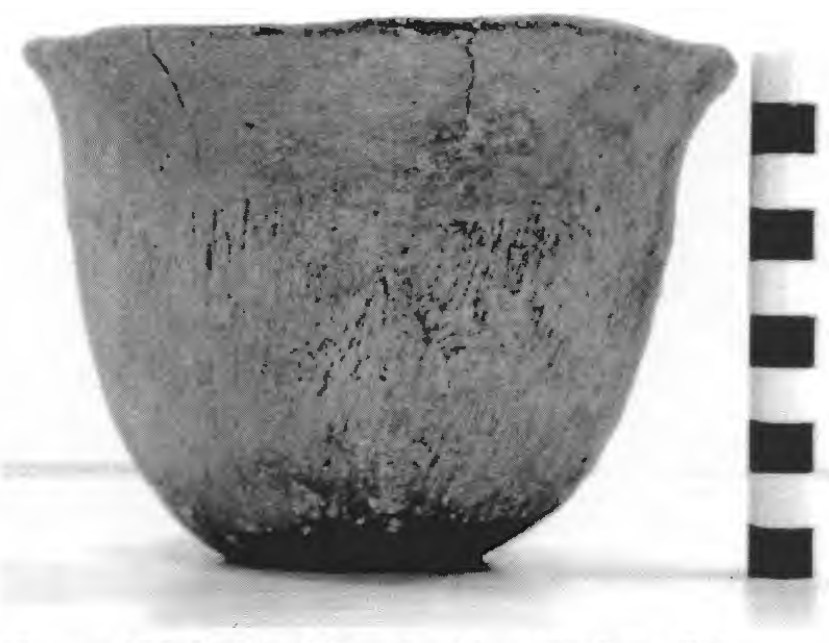

Figure 182. Bullard Brushed jar, Herbert Taft cemetery, Burial 2, Vessel 15.

DECORATION (INCLUDING MOTIF AND ELEMENTS WHEN APPARENT): The rim is decorated with diagonal brushing marks that have been partially smoothed over. The vessel body has vertical brushing marks that extend from the rim-body juncture to the vessel base (Figure 182).

PIGMENT USE AND LOCATION ON VESSEL: none

TYPE AND VARIETY [IF KNOWN]: Bullard Brushed 
VESSEL NO.: Burial 2, Vessel 16; 2003.08.388

NON-PLASTICS AND PASTE: grog; sandy paste

VESSEL FORM: Compound bowl

RIM AND LIP FORM: Direct rim and rounded, exterior folded lip

CORE COLOR: F (fired in a reducing environment and cooled in the open air)

INTERIOR SURFACE COLOR: yellowish-brown; fire clouds on the rim, body, and base

EXTERIOR SURFACE COLOR: yellowish-brown; fire clouds on the rim, body, and base

WALL THICKNESS (RIM, BODY, AND BASE IN MM): rim, 7.9 mm

INTERIOR SURFACE TREATMENT: smoothed

EXTERIOR SURFACE TREATMENT:

burnished

HEIGHT (IN CM): 9.5

ORIFICE DIAMETER (IN CM): 16.8

DIAMETER AT BOTTOM OF RIM OR NECK (IN CM): 17.1

BASE DIAMETER (IN CM) AND SHAPE OF BASE: 7.5; circular and flat

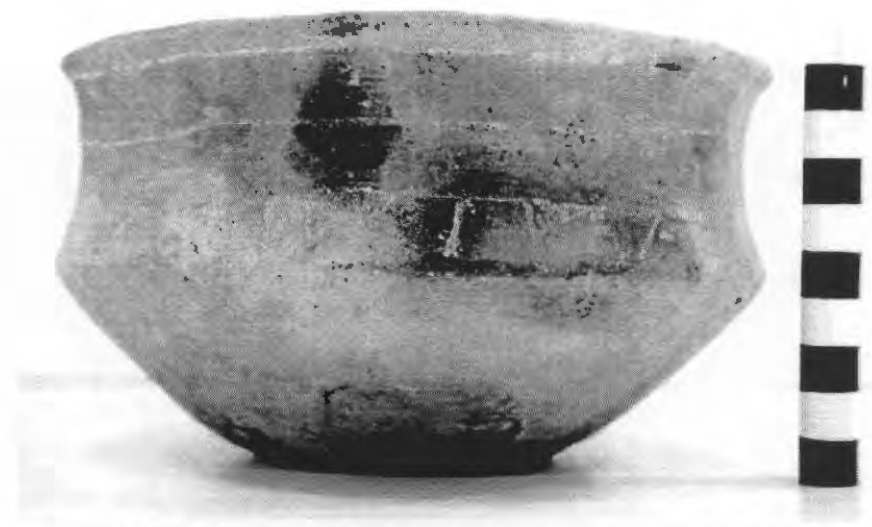

Figure 183. Turner Engraved, var. Turner compound bowl, Herbert Taft cemetery, Burial 2, Vessel 16.

ESTIMATED VOLUME (IN LITERS): 1.3

DECORATION (INCLUDING MOTIF AND ELEMENTS WHEN APPARENT): The upper rim panel has three widely-spaced horizontal engraved lines. The lower rim panel is six upper and six lower large excised pendant triangles. The excised triangles are divided by alternating short vertical or diagonal engraved lines (Figure 183).

PIGMENT USE AND LOCATION ON VESSEL: none

TYPE AND VARIETY [IF KNOWN]: Turner Engraved, var. Turner 
VESSEL NO.: Burial 2, Vessel 17; 2003.08.1821

NON-PLASTICS AND PASTE: grog

VESSEL FORM: Carinated bowl

RIM AND LIP FORM: Direct rim and a flat lip

CORE COLOR: B (fired and cooled in a reducing environment)

INTERIOR SURFACE COLOR: dark grayish-brown; organic residue on the rim

EXTERIOR SURFACE COLOR: dark grayish-brown; organic residue on the rim and body

WALL THICKNESS (RIM, BODY, AND BASE IN MM): rim, 7.1 mm

INTERIOR SURFACE TREATMENT: smoothed

EXTERIOR SURFACE TREATMENT:

smoothed

HEIGHT (IN CM): 7.3

ORIFICE DIAMETER (IN CM): 17.4

DIAMETER AT BOTTOM OF RIM OR NECK (IN CM): 17.0

BASE DIAMETER (IN CM) AND SHAPE OF BASE: 8.0

ESTIMATED VOLUME (IN LITERS): 0.76

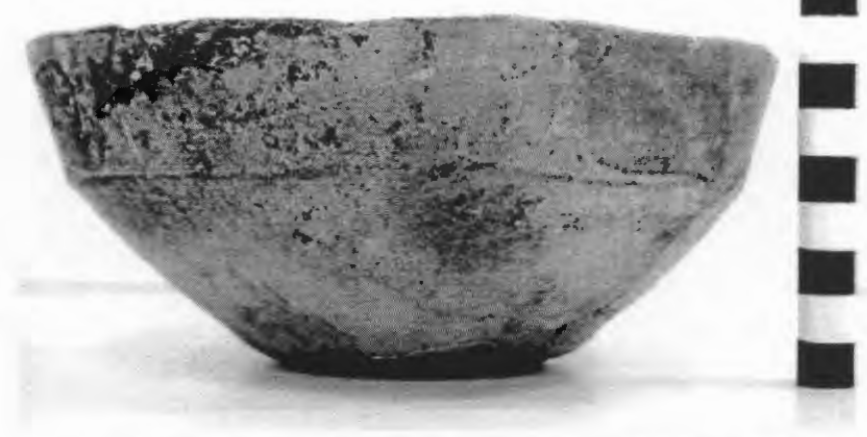

Figure 184. Ripley Engraved, var. Gandy carinated bowl, Herbert Taft cemetery, Burial 2, Vessel 17.

DECORATION (INCLUDING MOTIF AND ELEMENTS WHEN APPARENT): The rim panel has an engraved scroll motif repeated four times around the vessel. The scrolls are divided by engraved brackets; the central portion of each bracket has a rectangular excised area. The upper and lower scroll fill zones have excised triangles and brackets as well as short vertical lines (Figure 184).

There is also a single horizontal engraved line on the interior vessel surface at the carination.

PIGMENT USE AND LOCATION ON VESSEL: none

TYPE AND VARIETY [IF KNOWN]: Ripley Engraved, var. Gandy 


\section{Burial 3}

Burial 3 was situated just to the west of Burial 2 (see Figure 165). No other information is available about this feature other than the vessels identified from it in the Jones collection. These 11 vessels include four jars - Wilder Engraved, var. Wilder $(n=2)$ and Cass Appliqued $(n=2)$, a Wilder Engraved, var. unspecified bottle, two compound bowls (Turner Engraved, var. Horton and Ripley Engraved, var. Caldwell), and four carinated bowls. The carinated bowls are identified as Taylor Engraved, Ripley Engraved, cf. var. Gandy, and Ripley Engraved, var. Galt $(\mathrm{n}=2)$.

VESSEL NO.: Burial 3, Vessel 19; 2003.08.554

NON-PLASTICS AND PASTE: grog and bone

VESSEL FORM: Miniature jar with four rim peaks and opposed suspension holes (Figure 185)

RIM AND LIP FORM: Direct rim and a rounded, exterior folded lip

CORE COLOR: $\mathrm{G}$ (fired in a reducing environment and cooled in the open air)

INTERIOR SURFACE COLOR: reddish-brown to dark gray

EXTERIOR SURFACE COLOR: reddish-brown

WALL THICKNESS (RIM, BODY, AND BASE IN MM): rim, $3.8 \mathrm{~mm}$

INTERIOR SURFACE TREATMENT: none

EXTERIOR SURFACE TREATMENT: none

HEIGHT (IN CM): 5.7

ORIFICE DIAMETER (IN CM): 7.5

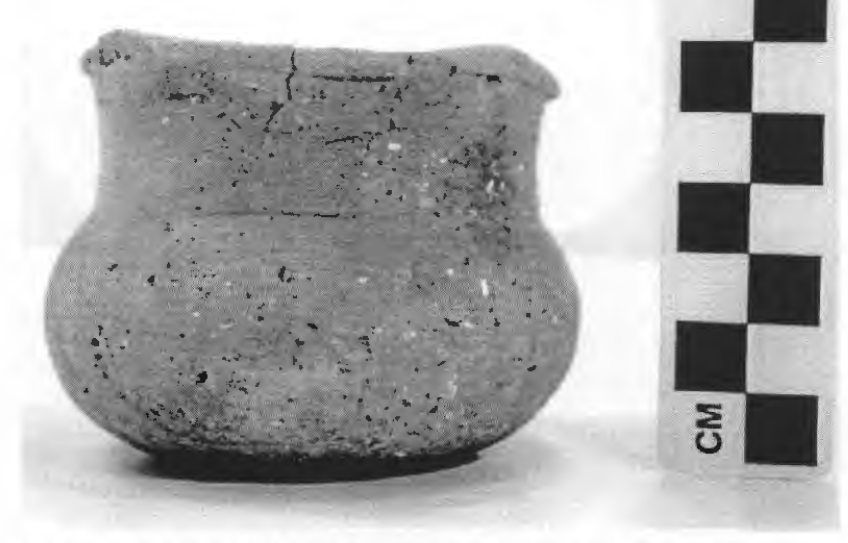

Figure 185. Wilder Engraved, var. Wilder jar, Herbert Taft cemetery, Burial 3, Vessel 19.

DIAMETER AT BOTTOM OF RIM OR NECK (IN CM): 6.3

BASE DIAMETER (IN CM) AND SHAPE OF BASE: 5.6; circular and flat

ESTIMATED VOLUME (IN LITERS): 0.26

DECORATION (INCLUDING MOTIF AND ELEMENTS WHEN APPARENT): The rim has three regularly-spaced horizontal engraved lines. The vessel body has an engraved scroll motif that is repeated four times around the body. Each scroll has an upper and lower arm, and they encircle each other before meeting at a small open circle. The scroll arms originate from upper and lower open triangle elements pendant from the rim and the vessel base (Figure 185). 
VESSEL NO.: Burial 3, Vessel 20; 2003.08.1050

NON-PLASTICS AND PASTE: grog

VESSEL FORM: Bottle

RIM AND LIP FORM: Direct rim and a flat, exterior folded lip

CORE COLOR: A (fired and cooled in an oxidizing environment)

INTERIOR SURFACE COLOR: reddish-brown

EXTERIOR SURFACE COLOR: reddish-brown; fire clouds on the neck, body, and base

WALL THICKNESS (RIM, BODY, AND BASE IN MM): rim, $5.0 \mathrm{~mm}$

INTERIOR SURFACE TREATMENT: none

EXTERIOR SURFACE TREATMENT: none

HEIGHT (IN CM): 8.0

ORIFICE DIAMETER (IN CM): 3.0

DIAMETER AT BOTTOM OF RIM OR NECK
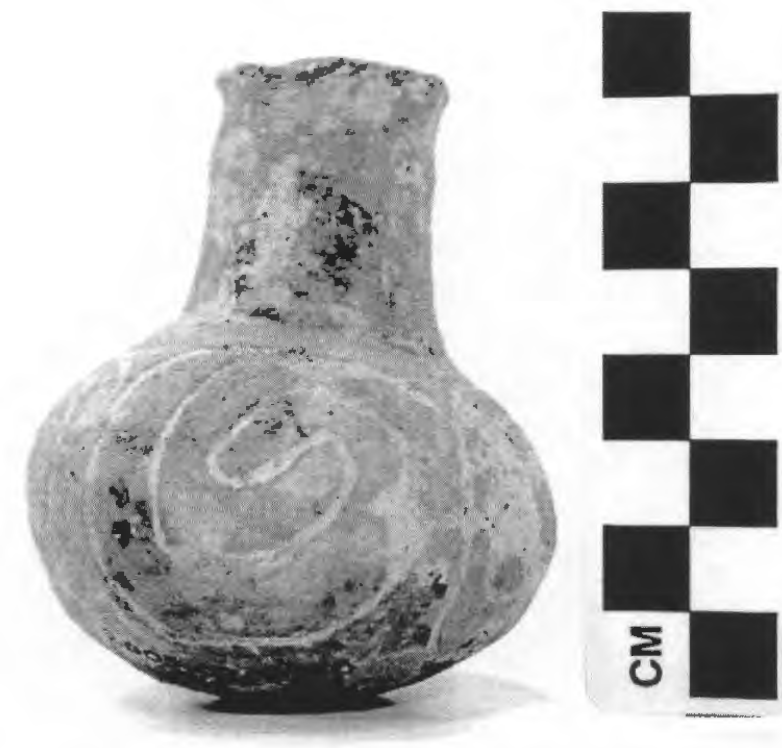

Figure 186. Wilder Engraved, var. unspecified bottle, Herbert Taft cemetery, Burial 3, Vessel 20. (IN CM): $3.5 ; 6.4 \mathrm{~cm}$ maximum body diameter

BASE DIAMETER (IN CM) AND SHAPE OF BASE: 3.9; circular and rounded ESTIMATED VOLUME (IN LITERS): 0.12

DECORATION (INCLUDING MOTIF AND ELEMENTS WHEN APPARENT): The vessel body has two different engraved scroll motifs, each repeated two times around the body. The first has upper and lower arms that encircle each other, but meet in the central part of the motif; there is no small circle where the scroll arms meet (Figure 186). The second scroll motif also has two arms that encircle each other, but the arms form a hooked arm element, and do not meet.

PIGMENT USE AND LOCATION ON VESSEL: none

TYPE AND VARIETY [IF KNOWN]: Wilder Engraved, var. unspecified 
VESSEL NO.: Burial 3, Vessel 21; 2003.08.1774

NON-PLASTICS AND PASTE: N/A [reconstructed]

VESSEL FORM: Carinated bowl

RIM AND LIP FORM: Direct rim and a rounded, exterior folded lip

CORE COLOR: N/A

INTERIOR SURFACE COLOR: N/A

EXTERIOR SURFACE COLOR: N/A

WALL THICKNESS (RIM, BODY, AND BASE IN

MM): rim, $5.9 \mathrm{~mm}$

INTERIOR SURFACE TREATMENT: N/A

EXTERIOR SURFACE TREATMENT: N/A

HEIGHT (IN CM): 6.8

ORIFICE DIAMETER (IN CM): 13.7

DIAMETER AT BOTTOM OF RIM OR NECK (IN CM): 13.8

BASE DIAMETER (IN CM) AND SHAPE OF

BASE: 4.9 ; circular and rounded

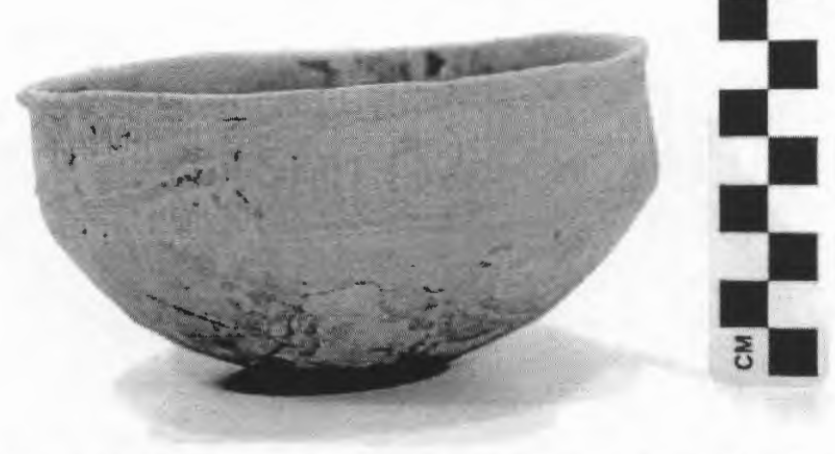

Figure 187. Taylor Engraved carinated bowl, Herbert Taft cemetery, Burial 3, Vessel 21.

ESTIMATED VOLUME (IN LITERS): 0.56

DECORATION (INCLUDING MOTIF AND ELEMENTS WHEN APPARENT): The rim panel has an engraved scroll and hooked arm motif that is repeated four times around the vessel. The upper and lower scroll fill zones have short curvilinear engraved lines (Figure 187).

PIGMENT USE AND LOCATION ON VESSEL: none

TYPE AND VARIETY [IF KNOWN]: Taylor Engraved 
VESSEL NO.: Burial 3, Vessel 22; 2003.08.983

NON-PLASTICS AND PASTE: N/A [reconstructed]

VESSEL FORM: Carinated bowl

RIM AND LIP FORM: Direct rim and a rounded, exterior folded lip

CORE COLOR: N/A

INTERIOR SURFACE COLOR: N/A

EXTERIOR SURFACE COLOR: N/A

WALL THICKNESS (RIM, BODY, AND BASE

IN MM): rim, $6.2 \mathrm{~mm}$

INTERIOR SURFACE TREATMENT: N/A

EXTERIOR SURFACE TREATMENT: N/A

HEIGHT (IN CM): 12.0

ORIFICE DIAMETER (IN CM): 25.4

Figure 188. Ripley Engraved, cf. var. Gandy carinated

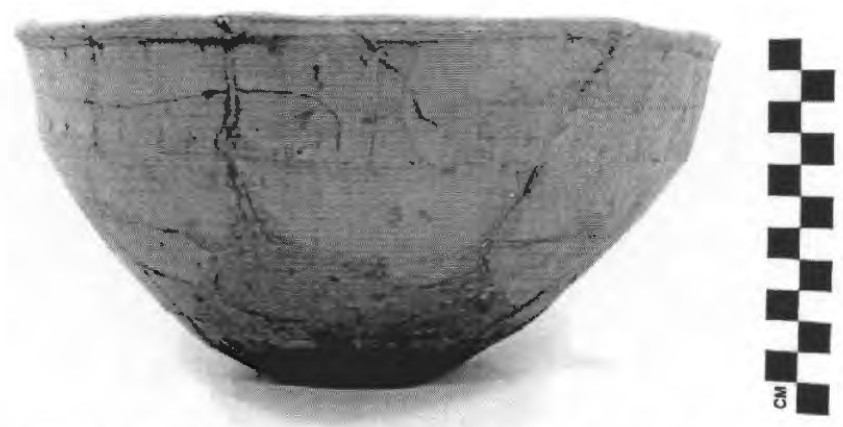

bowl, Herbert Taft cemetery, Burial 3, Vessel 22.

DIAMETER AT BOTTOM OF RIM OR NECK (IN CM): 24.9

BASE DIAMETER (IN CM) AND SHAPE OF BASE: 8.0; circular and flat

ESTIMATED VOLUME (IN LITERS): 1.8

DECORATION (INCLUDING MOTIF AND ELEMENTS WHEN APPARENT): The rim panel has an engraved scroll motif repeated four times around the vessel. The scrolls are separated by vertical brackets with hatched lines. Above and below each of the scrolls are small excised tick marks/pendant triangles (Figure 188).

PIGMENT USE AND LOCATION ON VESSEL: none

TYPE AND VARIETY [IF KNOWN]: Ripley Engraved, cf. var. Gandy 
VESSEL NO.: Burial 3, Vessel 23; 2003.08.244

NON-PLASTICS AND PASTE: grog; sandy paste

VESSEL FORM: Jar

RIM AND LIP FORM: Direct rim and rounded, exterior folded lip

CORE COLOR: N/A

INTERIOR SURFACE COLOR: dark grayish-brown

EXTERIOR SURFACE COLOR: yellowish-brown to dark grayish-brown; fire clouds on the rim and body

WALL THICKNESS (RIM, BODY, AND BASE IN MM): rim, $6.5 \mathrm{~mm}$

INTERIOR SURFACE TREATMENT: smoothed

EXTERIOR SURFACE TREATMENT: smoothed

HEIGHT (IN CM): 19.4

ORIFICE DIAMETER (IN CM): 17.7

DIAMETER AT BOTTOM OF RIM OR NECK (IN CM): 16.6

BASE DIAMETER (IN CM) AND SHAPE OF BASE: 6.6 ; circular and flat

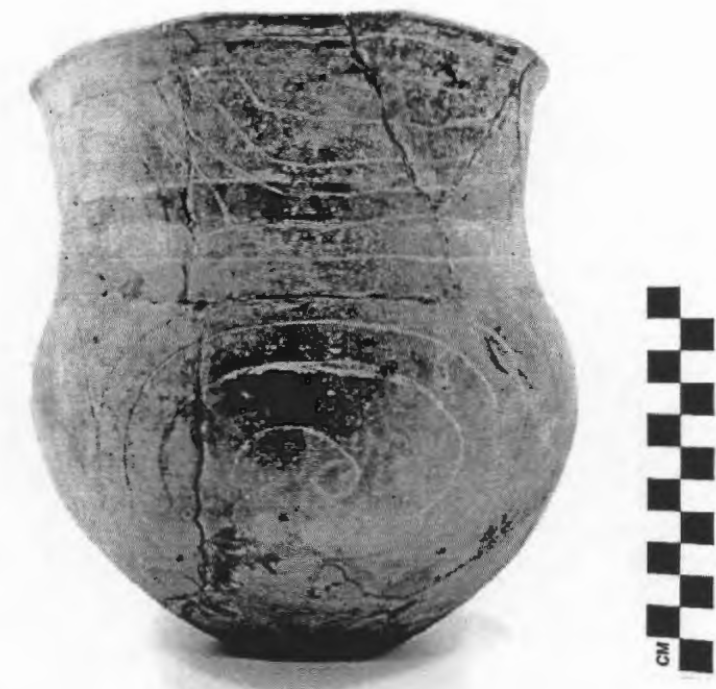

Figure 189. Wilder Engraved, var. Wilder jar, Herbert Taft cemetery, Burial 3, Vessel 23.

\section{ESTIMATED VOLUME (IN LITERS): 3.1}

DECORATION (INCLUDING MOTIF AND ELEMENTS WHEN APPARENT): The rim has an engraved curvilinear scroll motif repeated four times around the vessel. The vessel body has an engraved spiral motif with a small circle at its center. The spirals are divided by upper and lower open triangles at the top and bottom of the body (Figure 189).

PIGMENT USE AND LOCATION ON VESSEL: none

TYPE AND VARIETY [IF KNOWN]: Wilder Engraved, var. Wilder 
VESSEL NO.: Burial 3, Vessel 24; 2003.08.628

NON-PLASTICS AND PASTE: N/A [reconstructed]

VESSEL FORM: Compound bowl with four rim peaks (Figure 190)

RIM AND LIP FORM: Everted rim and a rounded, exterior folded lip

CORE COLOR: N/A

INTERIOR SURFACE COLOR: N/A

EXTERIOR SURFACE COLOR: N/A

WALL THICKNESS (RIM, BODY, AND BASE IN MM): rim, $6.2 \mathrm{~mm}$

INTERIOR SURFACE TREATMENT: N/A

EXTERIOR SURFACE TREATMENT: N/A

HEIGHT (IN CM): $11.0 ; 11.7 \mathrm{~cm}$ at the rim peaks

ORIFICE DIAMETER (IN CM): 26.4

DIAMETER AT BOTTOM OF RIM OR NECK (IN CM): 21.0

BASE DIAMETER (IN CM) AND SHAPE OF BASE: 7.8

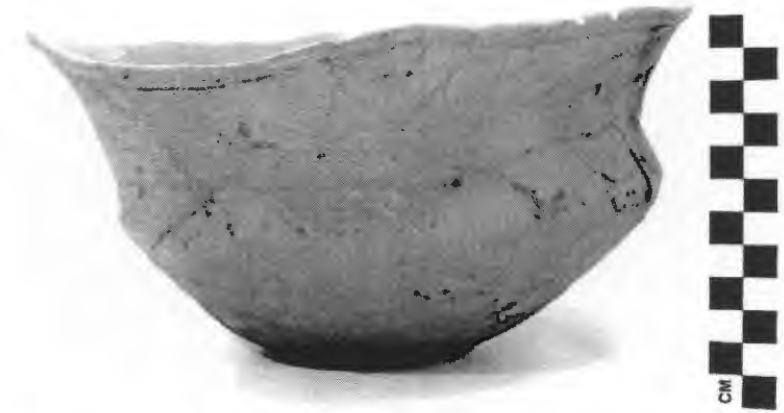

Figure 190. Turner Engraved, var. Horton compound bowl, Herbert Taft cemetery, Burial 3, Vessel 24.

ESTIMATED VOLUME (IN LITERS): 2.3

DECORATION (INCLUDING MOTIF AND ELEMENTS WHEN APPARENT): The upper rim panel has engraved triangles that begin at, and are under, each of the rim peaks as well as four sets of scrolls on either side of the triangles. The upper rim panel is also defined by two widely-spaced horizontal engraved lines below the scrolls (Figure 190).

The lower rim panel has a series of short diagonal engraved lines around the rim (Figure 190).

PIGMENT USE AND LOCATION ON VESSEL: none

TYPE AND VARIETY [IF KNOWN]: Turner Engraved, var. Horton 
VESSEL NO.: Burial 3, Vessel 25; 2003.08.1777

NON-PLASTICS AND PASTE: grog and bone

VESSEL FORM: Carinated bowl [reconstructed]

RIM AND LIP FORM: Direct rim and a rounded lip

CORE COLOR: N/A

INTERIOR SURFACE COLOR: N/A

EXTERIOR SURFACE COLOR: N/A

WALL THICKNESS (RIM, BODY, AND BASE IN MM): rim, $6.0 \mathrm{~mm}$

INTERIOR SURFACE TREATMENT: N/A

EXTERIOR SURFACE TREATMENT: N/A

HEIGHT (IN CM): 10.5

ORIFICE DIAMETER (IN CM): 20.1

DIAMETER AT BOTTOM OF RIM OR NECK (IN CM): 20.0

BASE DIAMETER (IN CM) AND SHAPE OF BASE: 8.0

ESTIMATED VOLUME (IN LITERS): I.3

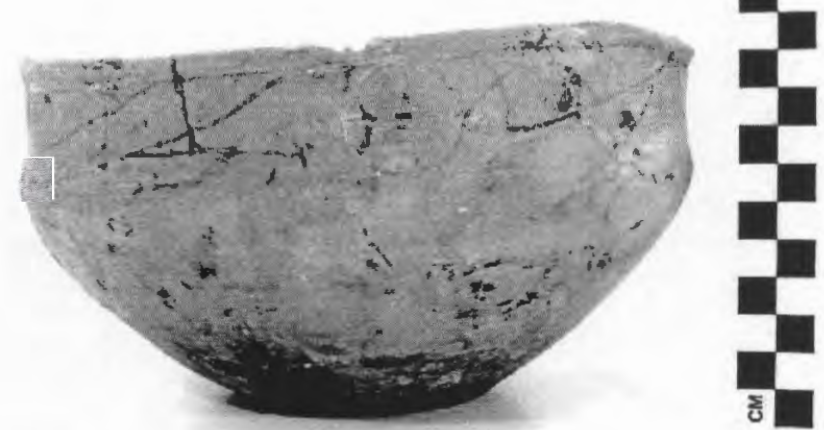

Figure 191. Ripley Engraved, var. Galt carinated bowl, Herbert Taft cemetery, Burial 3, Vessel 25.

DECORATION (INCLUDING MOTIF AND ELEMENTS WHEN APPARENT): The rim panel has an engraved scroll and circle motif repeated four times around the vessel. Each circle has crossed horizontal and vertical engraved lines within it (Figure 191).

PIGMENT USE AND LOCATION ON VESSEL: none

TYPE AND VARIETY [IF KNOWN]: Ripley Engraved, var, Galt 
VESSEL NO.: Burial 3, Vessel 26; 2003.08.532

NON-PLASTICS AND PASTE: grog

VESSEL FORM: Compound bowl

RIM AND LIP FORM: Everted rim and a rounded lip

CORE COLOR: A (fired and cooled in an oxidizing environment)

INTERIOR SURFACE COLOR: brown

EXTERIOR SURFACE COLOR: reddish-brown to brown; fire clouds on the body and base

WALL THICKNESS (RIM, BODY, AND BASE IN $\mathrm{MM}$ ): rim, $6.0 \mathrm{~mm}$

INTERIOR SURFACE TREATMENT: burnished

EXTERIOR SURFACE TREATMENT: burnished

HEIGHT (IN CM): 21.6

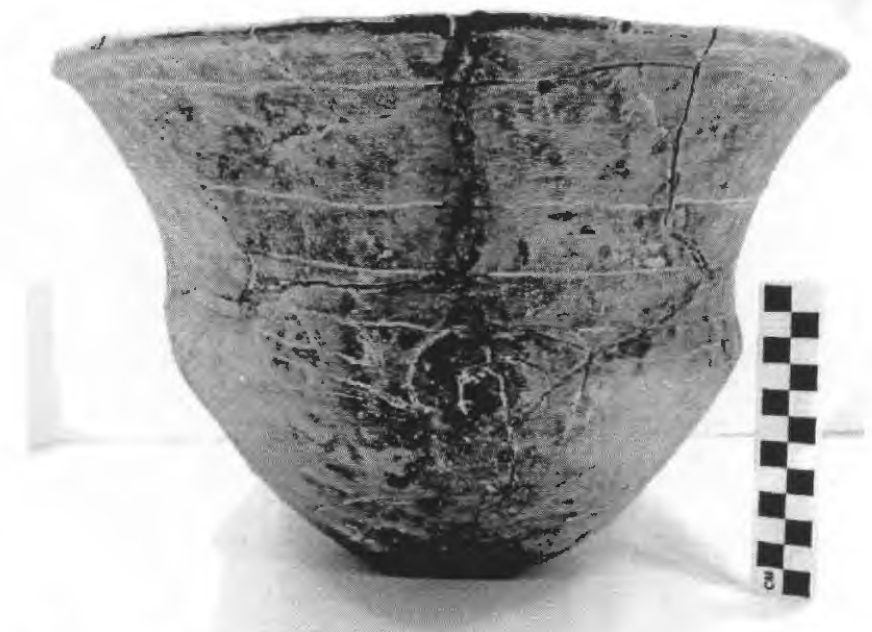

Figure 192. Ripley Engraved, var. Caldwell compound bowl, Herbert Taft cemetery, Burial 3,

ORIFICE DIAMETER (IN CM): 31.0 Vessel 26.

DIAMETER AT BOTTOM OF RIM OR NECK (IN CM): 23.8

BASE DIAMETER (IN CM) AND SHAPE OF BASE: 9.0

ESTIMATED VOLUME (IN LITERS): 5.4

DECORATION (INCLUDING MOTIF AND ELEMENTS WHEN APPARENT): The upper rim panel has four widely-spaced horizontal engraved lines. The lower rim panel has an engraved scroll and semi-circle motif that is repeated four times around the vessel. The upper and lower scroll fill elements have diagonal to curvilinear engraved lines (Figure 192).

PIGMENT USE AND LOCATION ON VESSEL: none

TYPE AND VARIETY [IF KNOWN]: Ripley Engraved, var. Caldwell 
VESSEL NO.: Burial 3, Vessel 27; 2003.08.1754

NON-PLASTICS AND PASTE: grog; sandy paste

VESSEL FORM: Carinated bowl

RIM AND LIP FORM: Direct rim and a rounded lip

CORE COLOR: $\mathrm{H}$ (fired in a reducing environment and cooled in the open air)

INTERIOR SURFACE COLOR: reddish-brown; fire clouds on the body

EXTERIOR SURFACE COLOR: dark grayish-brown; fire clouds on the body and base

WALL THICKNESS (RIM, BODY, AND BASE IN MM): rim, 5.1 mm

INTERIOR SURFACE TREATMENT: smoothed

EXTERIOR SURFACE TREATMENT:

burnished

HEIGHT (IN CM): I3.0

ORIFICE DIAMETER (IN CM): 25.3

DIAMETER AT BOTTOM OF RIM OR NECK

(IN CM): 22.9

BASE DIAMETER (IN CM) AND SHAPE OF BASE: 7.4

ESTIMATED VOLUME (IN LITERS): 2.0

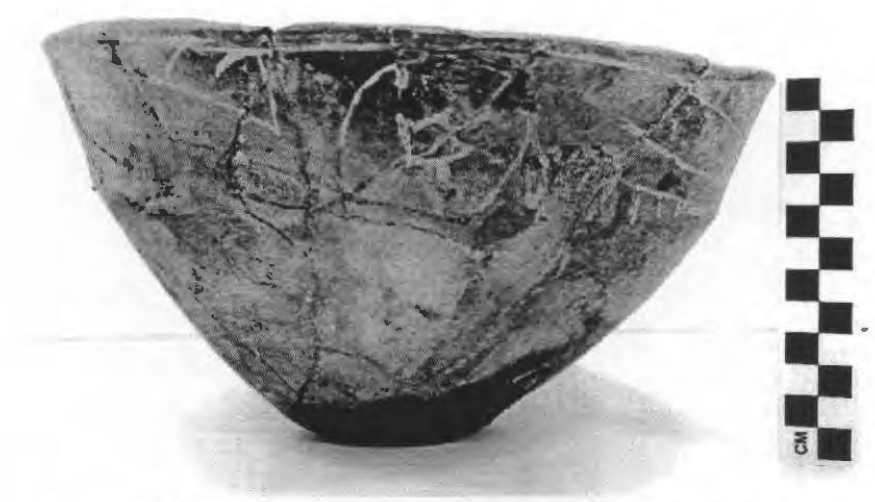

Figure 193. Ripley Engraved, var. Galt carinated bowl, Herbert Taft cemetery, Burial 3, Vessel 27.

DECORATION (INCLUDING MOTIF AND ELEMENTS WHEN APPARENT): The rim panel has an engraved scroll and circle motif that is repeated four times around the vessel. Each of the central circles have a smaller inner negative circle with spurs or excised tick marks (Figure 193).

PIGMENT USE AND LOCATION ON VESSEL: none

TYPE AND VARIETY [IF KNOWN]: Ripley Engraved, var. Galt 
VESSEL NO.: Burial 3, Vessel 29; 2003.08.381

NON-PLASTICS AND PASTE: grog; sandy paste

VESSEL FORM: Jar

RIM AND LIP FORM: Everted rim and rounded lip

CORE COLOR: B (fired and cooled in a reducing environment)

INTERIOR SURFACE COLOR: black; organic residue on the rim and body

EXTERIOR SURFACE COLOR: black; organic residue on the body

WALL THICKNESS (RIM, BODY, AND BASE IN

$\mathrm{MM})$ : rim, $6.2 \mathrm{~mm}$

INTERIOR SURFACE TREATMENT: smoothed

EXTERIOR SURFACE TREATMENT: none

HEIGHT (IN CM): I5.2

ORIFICE DIAMETER (IN CM): 16.5

DIAMETER AT BOTTOM OF RIM OR NECK (IN CM): 12.8

\section{BASE DIAMETER (IN CM) AND SHAPE OF}

BASE: 7.3; circular and flat

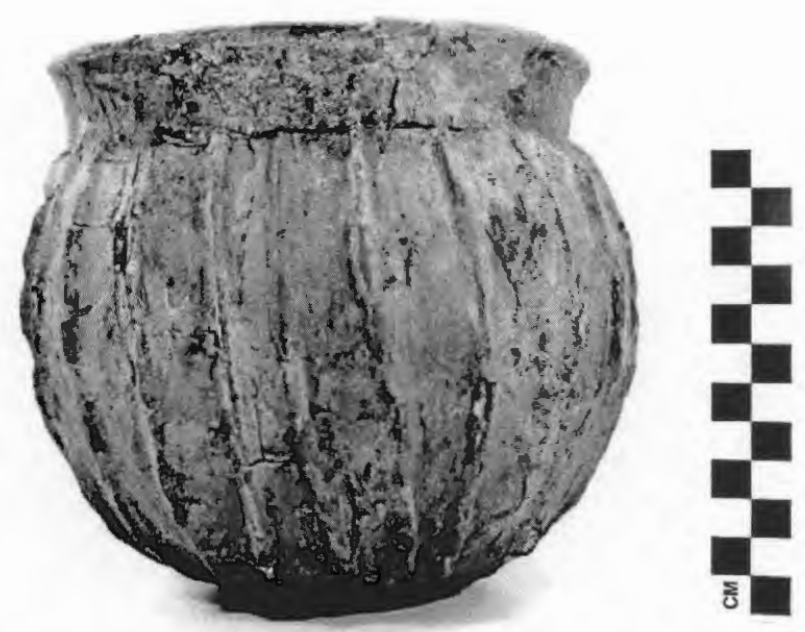

ESTIMATED VOLUME (IN LITERS): 1.5

Figure 194. Cass Appliqued jar, Herbert Taft cemetery, Burial 3, Vessel 29.

DECORATION (INCLUDING MOTIF AND ELEMENTS WHEN APPARENT): The rim has four horizontal rows of tool punctations. The vessel body has a continuous series of 23 vertical appliqued ridges that extend from the rim-body juncture to near the vessel base (Figure 194).

PIGMENT USE AND LOCATION ON VESSEL: none

TYPE AND VARIETY [IF KNOWN]: Cass Appliqued 
VESSEL NO.: Burial 3, Vessel 30; 2003.08.790

NON-PLASTICS AND PASTE: N/A [reconstructed]

VESSEL FORM: Jar

RIM AND LIP FORM: Everted rim and a rounded lip

CORE COLOR: N/A

INTERIOR SURFACE COLOR: N/A

EXTERIOR SURFACE COLOR: N/A

WALL THICKNESS (RIM, BODY, AND BASE

IN MM): rim, $4.9 \mathrm{~mm}$

INTERIOR SURFACE TREATMENT: N/A

EXTERIOR SURFACE TREATMENT: N/A

HEIGHT (IN CM): 11.8

ORIFICE DIAMETER (IN CM): 13.3

DIAMETER AT BOTTOM OF RIM OR NECK

(IN CM): 11.3

BASE DIAMETER (IN CM) AND SHAPE OF

BASE: 6.4 ; circular and flat

ESTIMATED VOLUME (IN LITERS): 0.94
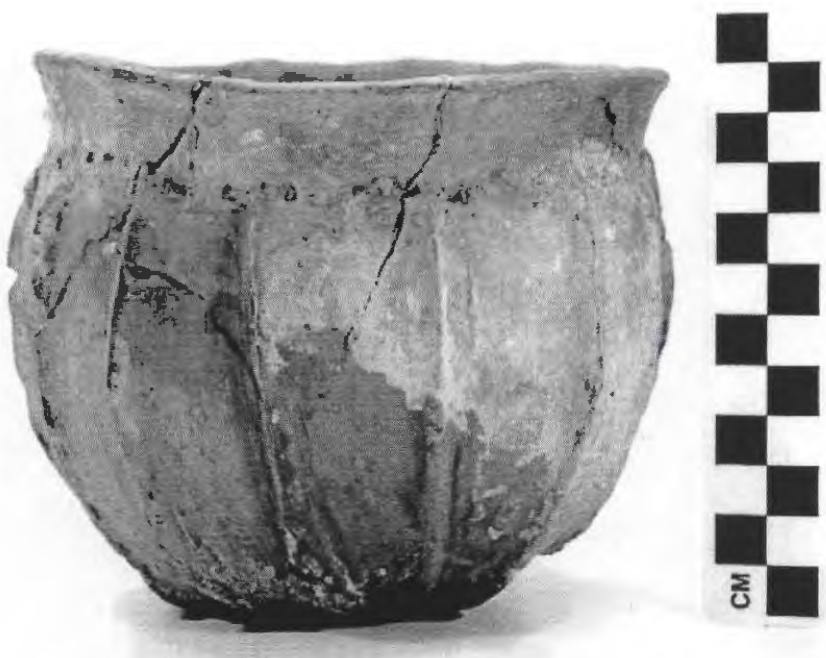

Figure 195. Cass Appliqued jar, Herbert Taft cemetery, Burial 3, Vessel 30.

DECORATION (INCLUDING MOTIF AND ELEMENTS WHEN APPARENT): The rim has a single row of tool punctations at the rim-body juncture. The vessel body has 16 vertical appliqued ridges that extend from the rim-body juncture to near the vessel base (Figure 195).

PIGMENT USE AND LOCATION ON VESSEL: none

TYPE AND VARIETY [IF KNOWN]: Cass Appliqued

\section{Burial 4}

Burial 4 was just south of Burials 2 and 3 in the cemetery (see Figure 165). Like Burial 3 (and Burials 5 and 6), there is no information available about the burial feature except the ceramic vessels identified from it in the Jones collection. These include a plain bowl; a Turner Engraved, var. Turner compound bowl, and two carinated bowls: Taylor Engraved and Ripley Engraved, var. McKinney. 
VESSEL NO.: Burial 4, Vessel 32; 2003.08.47

NON-PLASTICS AND PASTE: sandy paste

VESSEL FORM: Carinated bowl

RIM AND LIP FORM: Direct rim and a rounded, exterior folded lip

CORE COLOR: $\mathrm{G}$ (fired in a reducing environment and cooled in the open air)

INTERIOR SURFACE COLOR: reddish-brown to dark grayish-brown

EXTERIOR SURFACE COLOR: reddishbrown; fire clouds on the rim and body

WALL THICKNESS (RIM, BODY, AND

BASE IN MM): rim, $5.2 \mathrm{~mm}$

INTERIOR SURFACE TREATMENT:

burnished

EXTERIOR SURFACE TREATMENT:

burnished

HEIGHT (IN CM): 4.5

ORIFICE DIAMETER (IN CM): 7.6

DIAMETER AT BOTTOM OF RIM OR

NECK (IN CM): 7.4

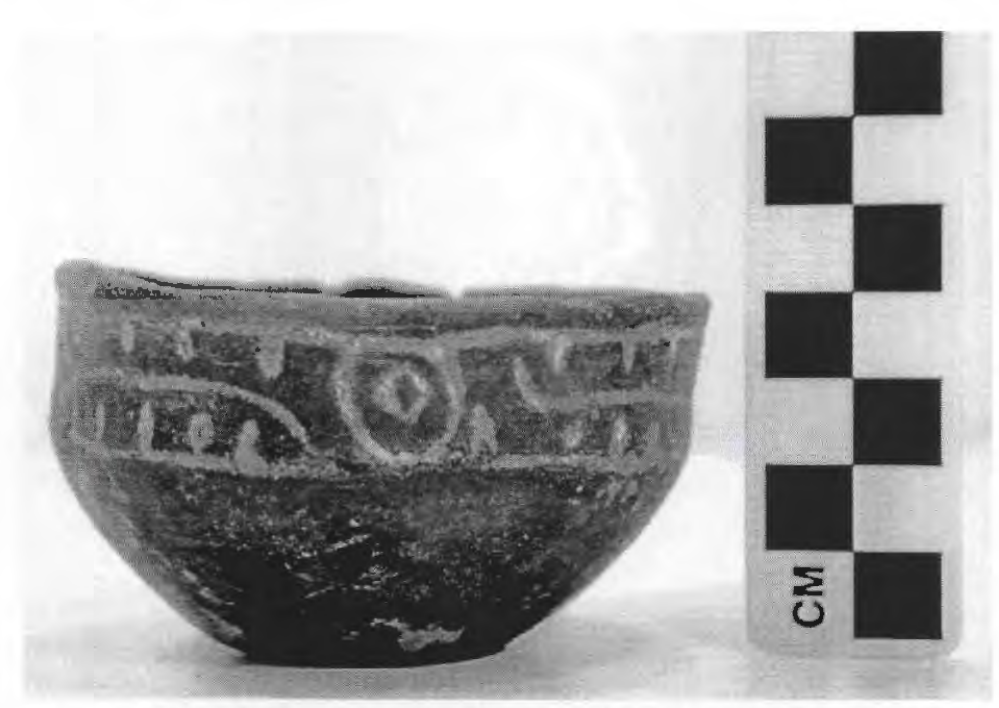

Figure 196. Ripley Engraved, var. McKinney carinated bowl, Herbert Taft cemetery, Burial 4, Vessel 32.

BASE DIAMETER (IN CM) AND SHAPE OF BASE: 4.0; circular and flat

ESTIMATED VOLUME (IN LITERS): 0.21

DECORATION (INCLUDING MOTIF AND ELEMENTS WHEN APPARENT): The rim panel has two alternating central elements, each repeated two times around the vessel: a circle within a circle and a circle within a diamond. The diamond element is the central element in a horizontal scroll. Above and below the scrolls are excised pendant triangles (Figure 196).

PIGMENT USE AND LOCATION ON VESSEL: white pigment in the engraved lines TYPE AND VARIETY [IF KNOWN]: Ripley Engraved, var. McKinney 
VESSEL NO.: Burial 4, Vessel 33; 2003.08.639

NON-PLASTICS AND PASTE: grog

VESSEL FORM: Compound bowl

RIM AND LIP FORM: Everted rim and a rounded, exterior folded lip

CORE COLOR: B (fired and cooled in a reducing environment)

INTERIOR SURFACE COLOR: dark grayish-brown to black

EXTERIOR SURFACE COLOR: dark grayish-brown to black; fire clouds on the rim and body

WALL THICKNESS (RIM, BODY, AND BASE

IN MM): rim, $6.6 \mathrm{~mm}$

INTERIOR SURFACE TREATMENT: burnished

EXTERIOR SURFACE TREATMENT: burnished

HEIGHT (IN CM): 12.3

ORIFICE DIAMETER (IN CM): 20.9

DIAMETER AT BOTTOM OF RIM OR NECK

(IN CM): 17.0

BASE DIAMETER (IN CM) AND SHAPE OF

BASE: 8.3; circular and flat

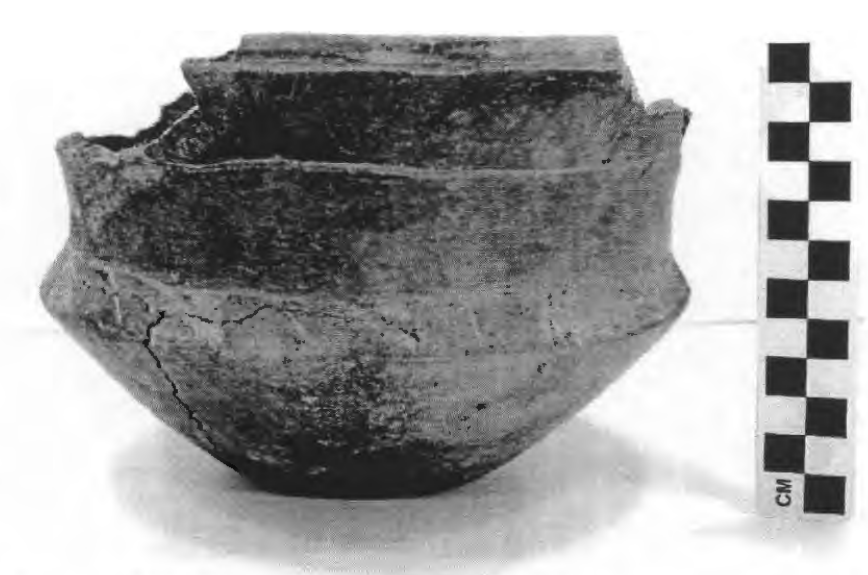

Figure 197. Turner Engraved, var. Turner compound bowl, Herbert Taft cemetery, Burial 4, Vessel 33.

\section{ESTIMATED VOLUME (IN LITERS): 2.1}

DECORATION (INCLUDING MOTIF AND ELEMENTS WHEN APPARENT): The upper rim panel has three widely-spaced horizontal engraved lines. The lower rim panel has a series of 10 large excised triangles and one excised semi-circle. These elements are divided by short alternating vertical and diagonal engraved lines (Figure 197).

PIGMENT USE AND LOCATION ON VESSEL: white pigment in the engraved lines

TYPE AND VARIETY [IF KNOWN]: Turner Engraved, var. Turner 
VESSEL NO.: Burial 4, Vessel 34; 2003.08.1517

NON-PLASTICS AND PASTE: grog

VESSEL FORM: Bowl

RIM AND LIP FORM: N/A

CORE COLOR: $\mathrm{G}$ (fired in a reducing environment and cooled in the open air)

INTERIOR SURFACE COLOR: dark grayish-brown

EXTERIOR SURFACE COLOR: yellowish-brown

WALL THICKNESS (RIM, BODY, AND BASE IN MM): body, $5.2 \mathrm{~mm}$; base, $6.3 \mathrm{~mm}$

INTERIOR SURFACE TREATMENT: none

EXTERIOR SURFACE TREATMENT: smoothed

HEIGHT (IN CM); N/A

ORIFICE DIAMETER (IN CM): N/A

DIAMETER AT BOTTOM OF RIM OR NECK (IN CM): N/A

BASE DIAMETER (IN CM) AND SHAPE OF BASE: 7.9; circular and flat

ESTIMATED VOLUME (IN LITERS): N/A

DECORATION (INCLUDING MOTIF AND ELEMENTS WHEN APPARENT): Plain

PIGMENT USE AND LOCATION ON VESSEL: none

TYPE AND VARIETY [IF KNOWN]: Unidentified plain ware 
VESSEL NO.: Burial 4, UC 41; 2003.08.956

NON-PLASTICS AND PASTE: grog and hematite

VESSEL FORM: Carinated bowl

RIM AND LIP FORM: Direct rim and a rounded, exterior folded lip

CORE COLOR: $\mathrm{F}$ (fired in a reducing environment and cooled in the open air)

INTERIOR SURFACE COLOR: grayish-brown

EXTERIOR SURFACE COLOR: yellowish-brown

WALL THICKNESS (RIM, BODY, AND BASE IN MM): rim, $9.5 \mathrm{~mm}$; body, $8.8 \mathrm{~mm}$; base, 10.1 $\mathrm{mm}$

INTERIOR SURFACE TREATMENT: none

EXTERIOR SURFACE TREATMENT:

burnished

HEIGHT (IN CM): N/A

ORIFICE DIAMETER (IN CM): 27.0

DIAMETER AT BOTTOM OF RIM OR NECK (IN CM): 26.8

\section{BASE DIAMETER (IN CM) AND SHAPE OF BASE: N/A}

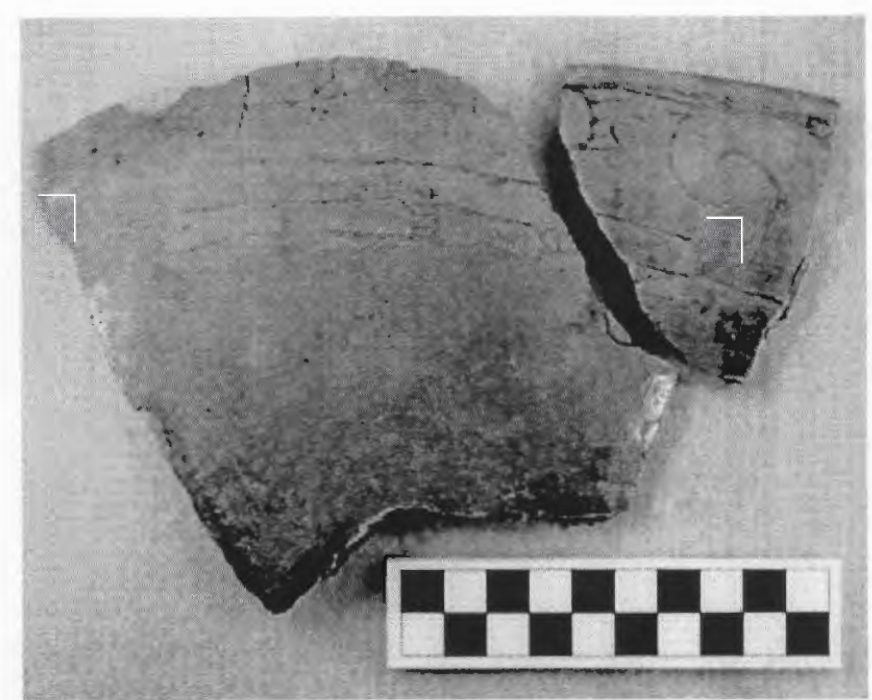

Figure 198. Taylor Engraved carinated bowl, Herbert Taft cemetery, Burial 4, Vessel 2003.08.956.

ESTIMATED VOLUME (IN LITERS): N/A

DECORATION (INCLUDING MOTIF AND ELEMENTS WHEN APPARENT): The rim panel has an engraved scroll that ends at a hooked arm element. The upper and lower scroll zones have hatched brackets and triangles (Figure 198). There is also a single horizontal engraved line on the interior vessel surface at the carination.

PIGMENT USE AND LOCATION ON VESSEL: none

TYPE AND VARIETY [IF KNOWN]: Taylor Engraved

\section{Burial 5}

The location of Burial 5 was not plotted by Jones (n.d.) on his cemetery map. Vessels in the Jones collection from this burial feature consist of two Ripley Engraved, var. McKinney carinated bowls. 
VESSEL NO.: Burial 5, Vessel 35; 2003.08.1242

NON-PLASTICS AND PASTE: grog

VESSEL FORM: Carinated bowl

RIM AND LIP FORM: Direct rim and a rounded, exterior folded lip

CORE COLOR: B (fired and cooled in a reducing environment)

INTERIOR SURFACE COLOR: grayish-brown

EXTERIOR SURFACE COLOR: grayish-brown

WALL THICKNESS (RIM, BODY, AND BASE IN MM): rim, $5.1 \mathrm{~mm}$; body, $5.9 \mathrm{~mm}$; base, 9.7 $\mathrm{mm}$

INTERIOR SURFACE TREATMENT: smoothed EXTERIOR SURFACE TREATMENT: smoothed HEIGHT (IN CM): 8.7 ORIFICE DIAMETER (IN CM): 18.6

Figure 199. Ripley Engraved, var. McKinney carinated bowl, Herbert Taft cemetery, Burial 5,

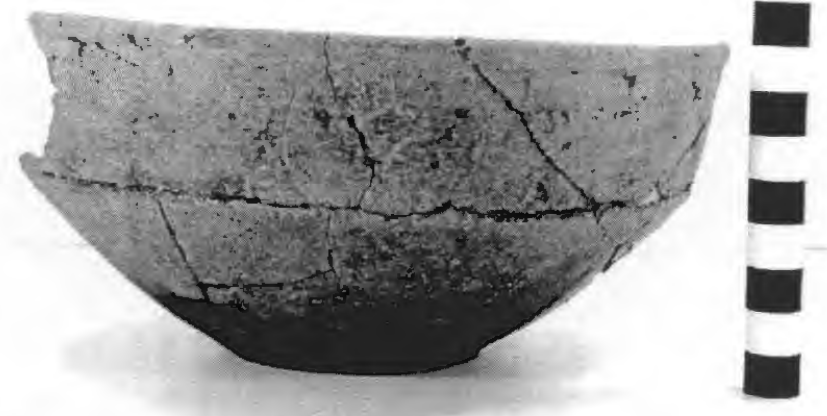
Vessel 35 .

DIAMETER AT BOTTOM OF RIM OR NECK (IN CM): 17.0

BASE DIAMETER (IN CM) AND SHAPE OF BASE: 7.2; circular and flat

ESTIMATED VOLUME (IN LITERS): 0.97

DECORATION (INCLUDING MOTIF AND ELEMENTS WHEN APPARENT): The rim panel has four diamond in a circle elements between short horizontal scrolls that end with an upper engraved bracket element. Above and below the scrolls are excised pendant triangles (Figure 199).

PIGMENT USE AND LOCATION ON VESSEL: none

TYPE AND VARIETY [IF KNOWN]: Ripley Engraved, var. McKinney 
VESSEL NO.: Burial 5, UC 41; 2003.08.962

NON-PLASTICS AND PASTE: grog and hematite; fine sandy paste

VESSEL FORM: Carinated bowl

RIM AND LIP FORM: Direct rim and a rounded, exterior folded lip

CORE COLOR: C (incompletely oxidized during firing)

INTERIOR SURFACE COLOR: yellowish-brown; fire clouds

EXTERIOR SURFACE COLOR: yellowish-brown; fire clouds on the rim and body

WALL THICKNESS (RIM, BODY, AND BASE IN MM): rim, $7.1 \mathrm{~mm}$; body, $6.8 \mathrm{~mm}$; base, $7.5 \mathrm{~mm}$

INTERIOR SURFACE TREATMENT: smoothed

EXTERIOR SURFACE TREATMENT: smoothed

HEIGHT (IN CM): 14.8

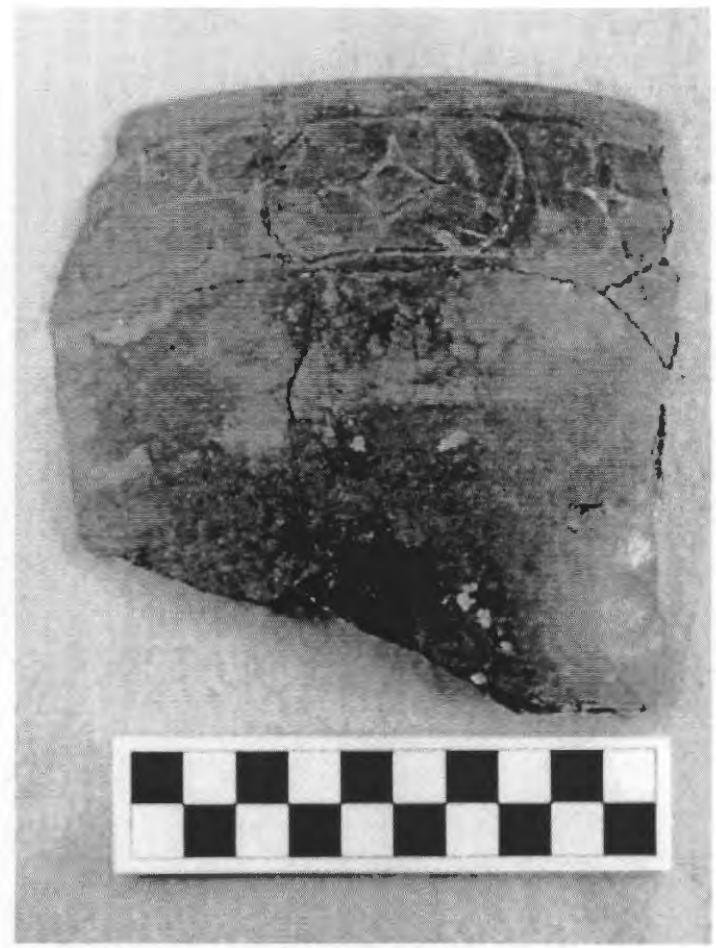

Figure 200. Ripley Engraved, var. McKinney carinated bowl, Herbert Taft cemetery, Burial 5, Vessel 2003.08.962.

ORIFICE DIAMETER (IN CM): 26.0

DIAMETER AT BOTTOM OF RIM OR NECK (IN CM): 25.5

BASE DIAMETER (IN CM) AND SHAPE OF BASE: 8.8; circular and flat

ESTIMATED VOLUME (IN LITERS): 3.5

DECORATION (INCLUDING MOTIF AND ELEMENTS WHEN APPARENT): The rim panel has four diamond in a circle elements between short horizontal scrolls that end with upper and lower engraved bracket elements. Above and below the scrolls are excised pendant triangles (Figure 200).

PIGMENT USE AND LOCATION ON VESSEL: none

TYPE AND VARIETY [IF KNOWN]: Ripley Engraved, var. McKinney 
A single Talco arrow point had apparently been placed in Burial 5. The point is made from a nonlocal gray novaculite, and is $28.6 \mathrm{~mm}$ in length (with the tip missing), $14.3 \mathrm{~mm}$ in width at the base, and $3.0 \mathrm{~mm}$ in thickness (Figure 201).

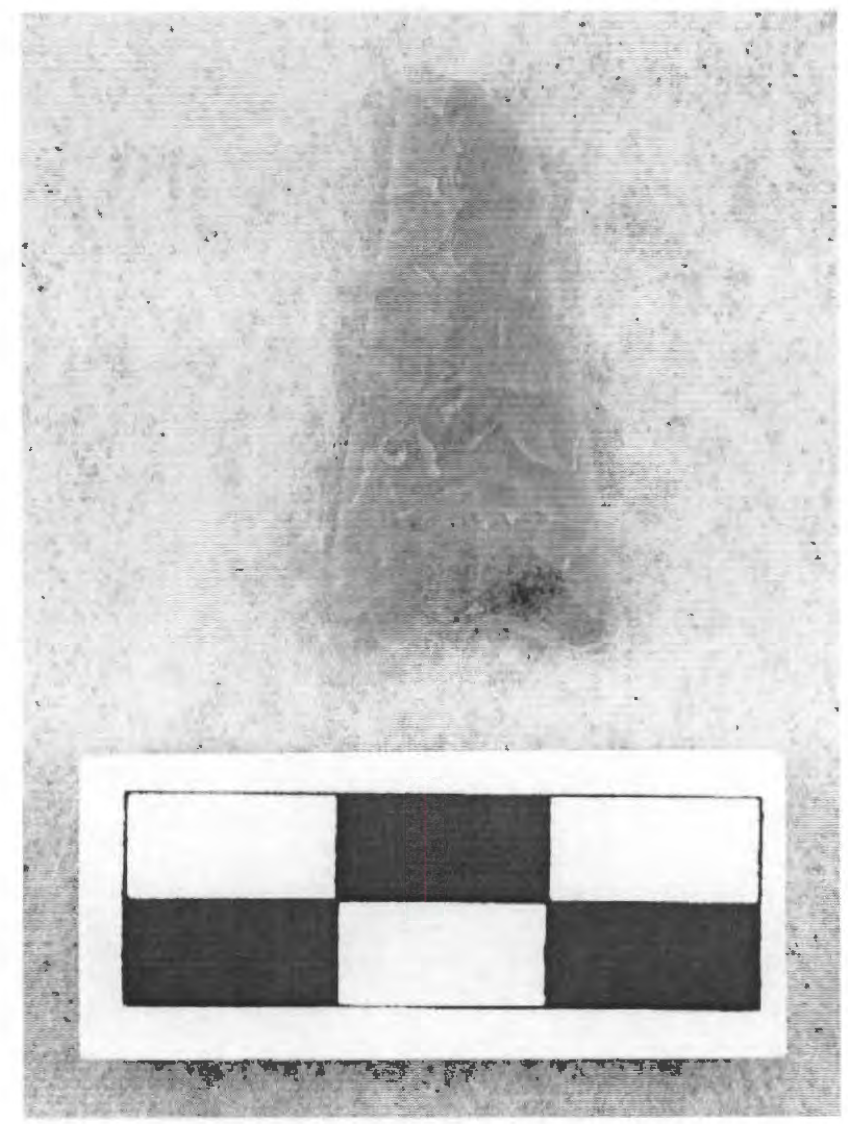

Figure 201. Talco point from Burial 5 at the Herbert Taft cemetery.

\section{Burial 6}

The location of Burial 6 in the Herbert Taft cemetery is unknown. Eight vessels in the Jones collection have been identified with this burial. They include a Bailey Engraved bottle, a cf. Taylor Engraved conjoined vessel, a Taylor Engraved deep bowl, and five carinated bowls. There are two Taylor Engraved carinated bowls, a Ripley Engraved, var. McKinney carinated bowl, and two Simms Engraved carinated bowls; both are late (ca. A.D. 1500-1700) hubcap variety forms (see Perttula 1992:Table 11). 
VESSEL NO:: Burial 6, Vessel 37; 2003.08.109

NON-PLASTICS AND PASTE: grog, bone, and hematite

VESSEL FORM: Bottle with a short neck

RIM AND LIP FORM: Everted rim and a rounded lip

CORE COLOR: $\mathrm{F}$ (fired in a reducing environment and cooled in the open air)

INTERIOR SURFACE COLOR: light grayish-brown

EXTERIOR SURFACE COLOR: grayish-brown; fire clouds on the rim, body, and base

WALL THICKNESS (RIM, BODY, AND BASE IN MM): rim, $4.5 \mathrm{~mm}$

INTERIOR SURFACE TREATMENT: none

EXTERIOR SURFACE TREATMENT: smoothed

HEIGHT (IN CM): 12.4

ORIFICE DIAMETER (IN CM): 4.2

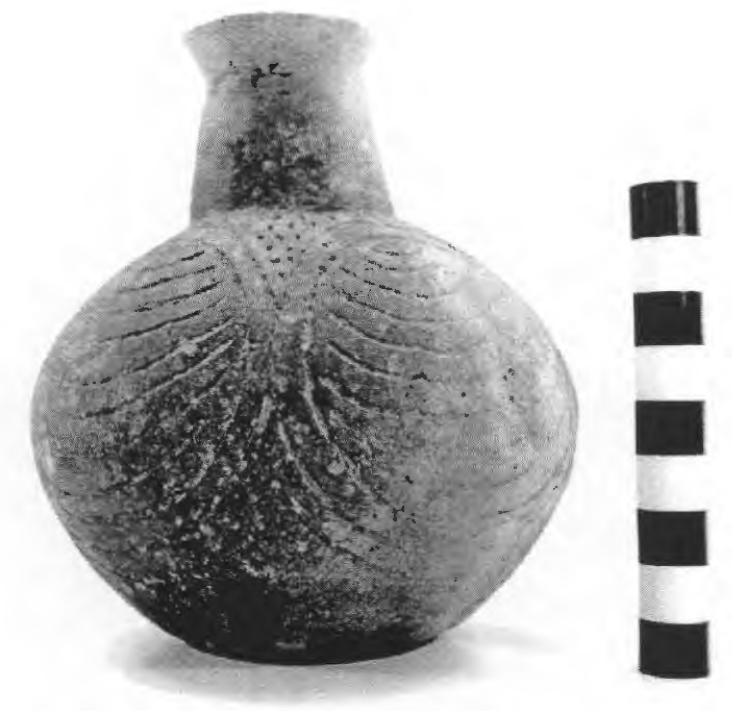

Figure 202. Bailey Engraved bottle, Herbert Taft cemetery, Burial 6, Vessel 37.

DIAMETER AT BOTTOM OF RIM OR NECK (IN CM): 4.3; maximum body diameter is $11.2 \mathrm{~cm}$

BASE DIAMETER (IN CM) AND SHAPE OF BASE: 5.9; circular and flat

ESTIMATED VOLUME (IN LITERS): 0.29

DECORATION (INCLUDING MOTIF AND ELEMENTS WHEN APPARENT): The vessel body has four series of curvilinear engraved arcs, with 11 arcing lines for each set. Above each of the sets of engraved arcs, and below the base of the bottle neck, are triangular zones filled with small tool punctations (Figure 202).

PIGMENT USE AND LOCATION ON VESSEL: none

TYPE AND VARIETY [IF KNOWN]: Bailey Engraved 
VESSEL NO.: Burial 6, Vessel 38; 2003.08.228

NON-PLASTICS AND PASTE: grog; fine sandy paste

VESSEL FORM: Carinated bowl

RIM AND LIP FORM: Direct rim and rounded, exterior folded lip

CORE COLOR: F (fired in a reducing environment and cooled in the open air)

INTERIOR SURFACE COLOR: yellowish-brown

EXTERIOR SURFACE COLOR: yellowish-brown; fire clouds on the rim, body, and base

WALL THICKNESS (RIM, BODY, AND BASE IN MM): rim, $6.2 \mathrm{~mm}$

INTERIOR SURFACE TREATMENT: smoothed

EXTERIOR SURFACE TREATMENT: smoothed

HEIGHT (IN CM): 6.5

ORIFICE DIAMETER (IN CM): I4.0

DIAMETER AT BOTTOM OF RIM OR NECK (IN CM): 14.0

BASE DIAMETER (IN CM) AND SHAPE OF

BASE: 6.0 ; circular and rounded

ESTIMATED VOLUME (IN LITERS): 0.55

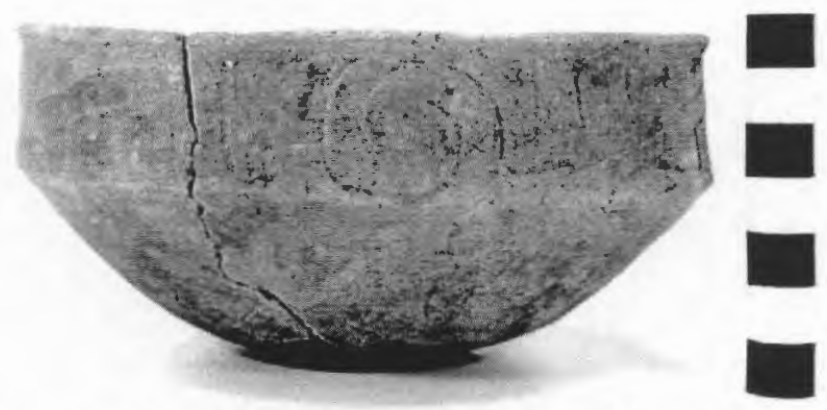

Figure 203. Taylor Engraved carinated bowl, Herbert Taft cemetery, Burial 6, Vessel 38.

DECORATION (INCLUDING MOTIF AND ELEMENTS WHEN APPARENT): The rim panel has an engraved scroll motif that is repeated four times around the vessel. Each scroll ends with a hooked arm element. The upper and lower scroll fill zones are triangular-shaped with vertical or diagonal engraved lines (Figure 203).

PIGMENT USE AND LOCATION ON VESSEL: none TYPE AND VARIETY [IF KNOWN]: Taylor Engraved 
VESSEL NO.: Burial 6, Vessel 39; 2003.08.1833

NON-PLASTICS AND PASTE: grog

VESSEL FORM: Carinated bowl

RIM AND LIP FORM: Direct rim and a rounded lip; the lip is notched

CORE COLOR: $\mathrm{H}$ (fired in a reducing environment and cooled in the open air)

INTERIOR SURFACE COLOR: dark reddish-brown

EXTERIOR SURFACE COLOR: grayishbrown; fire clouds on the rim

WALL THICKNESS (RIM, BODY, AND

BASE IN MM): rim, $4.5 \mathrm{~mm}$

INTERIOR SURFACE TREATMENT:

smoothed

EXTERIOR SURFACE TREATMENT:

smoothed

HEIGHT (IN CM): 5.6

ORIFICE DIAMETER (IN CM): 14.4

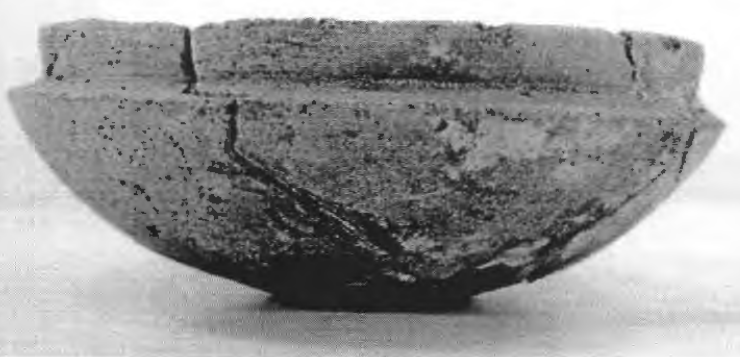

Figure 204. Simms Engraved carinated bowl, hubcap variety, Herbert Taft cemetery, Burial 6, Vessel 39.

DIAMETER AT BOTTOM OF RIM OR NECK (IN CM): 15.4

BASE DIAMETER (IN CM) AND SHAPE OF BASE: 6.0; circular and rounded

ESTIMATED VOLUME (IN LITERS): 0.48

DECORATION (INCLUDING MOTIF AND ELEMENTS WHEN APPARENT): The rim has two widelyspaced horizontal engraved lines. There are a series of short vertical engraved lines perpendicular to the lower horizontal engraved line (Figure 204).

PIGMENT USE AND LOCATION ON VESSEL: none

TYPE AND VARIETY [IF KNOWN]: Simms Engraved, hubcap variety 
VESSEL NO.: Burial 6, Vessel 40; 2003.08.108

NON-PLASTICS AND PASTE: grog

VESSEL FORM: Conjoined vessels (Bowl) with two sets of four opposed suspension holes (Figure 205)

RIM AND LIP FORM: Direct rim and a rounded, exterior folded lip. There is a rim collar where the two vessels have been conjoined.

CORE COLOR: $\mathrm{F}$ (fired in a reducing environment and cooled in the open air)

INTERIOR SURFACE COLOR: red

EXTERIOR SURFACE COLOR: red

WALL THICKNESS (RIM, BODY, AND

BASE IN MM): rim, $4.1 \mathrm{~mm}$

INTERIOR SURFACE TREATMENT:

smoothed

EXTERIOR SURFACE TREATMENT:

smoothed

HEIGHT (IN CM): 11.5

ORIFICE DIAMETER (IN CM): 11.9

DIAMETER AT BOTTOM OF RIM OR

NECK (IN CM): 10.5

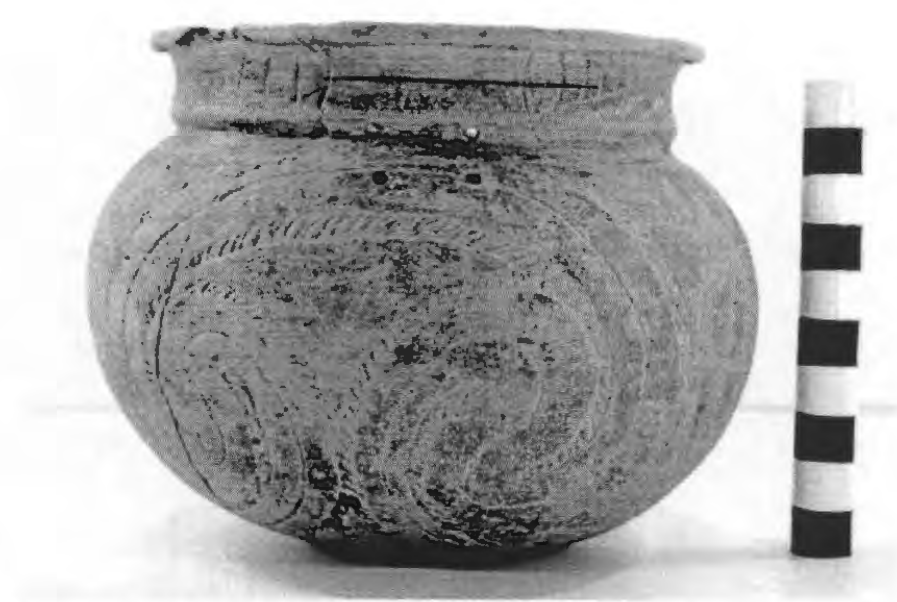

Figure 205. cf. Taylor Engraved conjoined vessel, Herbert Taft cemetery, Burial 6, Vessel 40.

BASE DIAMETER (IN CM) AND SHAPE OF BASE: 9.0; circular and rounded

ESTIMATED VOLUME (IN LITERS): 0.55

DECORATION (INCLUDING MOTIF AND ELEMENTS WHEN APPARENT): The vessel is red-slipped on both interior and exterior surfaces. The upper conjoined vessel (a carinated bowl rim) has a slanted scroll motif with tick marks that are divided by two sets of two or three vertical engraved lines. The upper and lower scroll fill zones have curvilinear engraved lines (Figure 205).

The lower part of the conjoined vessels has three scrolls with hooked arm elements. The scrolls consist of both single line and narrow hatched zones that partially encircle each other, but do not meet, and these are partially encompassed by a semi-circular hatched zone. There are free-standing open triangles within the scrolls, as well as three sets of upper and lower triangles that serve to divide each scroll from each other (Figure 205).

PIGMENT USE AND LOCATION ON VESSEL: none

TYPE AND VARIETY [IF KNOWN]: cf. Taylor Engraved 
VESSEL NO.: Burial 6, Vessel 41; 2003.08.370

NON-PLASTICS AND PASTE: grog and possible leached shell

VESSEL FORM: Carinated bowl, hubcap variety (Figure 206)

RIM AND LIP FORM: Inverted rim and a flat lip; notched lip

CORE COLOR: B (fired and cooled in a reducing environment)

INTERIOR SURFACE COLOR: dark grayish-brown

EXTERIOR SURFACE COLOR: dark grayish-brown

WALL THICKNESS (RIM, BODY, AND BASE IN MM): rim, $4.5 \mathrm{~mm}$

INTERIOR SURFACE TREATMENT: smoothed

EXTERIOR SURFACE TREATMENT:

smoothed

HEIGHT (IN CM): 7.2

ORIFICE DIAMETER (IN CM): 18.4

DIAMETER AT BOTTOM OF RIM OR NECK

(IN CM): 20.5

BASE DIAMETER (IN CM) AND SHAPE OF

BASE: 7.0 ; circular and rounded

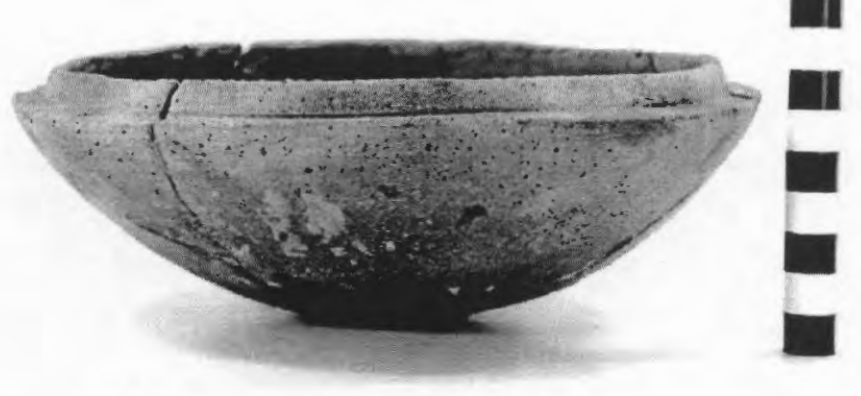

Figure 206. Simms Engraved, hubcap variety, Herbert Taft cemetery, Burial 6, Vessel 41.

ESTIMATED VOLUME (IN LITERS): 0.79

DECORATION (INCLUDING MOTIF AND ELEMENTS WHEN APPARENT): The narrow and flat part of the rim is engraved with four sets of vertical engraved lines. Between each of the sets on the lower part of the rim are a continuous series of tick marks (Figure 206).

PIGMENT USE AND LOCATION ON VESSEL: none

TYPE AND VARIETY [IF KNOWN]: Simms Engraved 
VESSEL NO.: Burial 6, Vessel 42; 2003.08.600

NON-PLASTICS AND PASTE: grog and organics

VESSEL FORM: Carinated bowl

RIM AND LIP FORM: Inverted rim and a rounded, exterior folded lip

CORE COLOR: N/A [reconstructed]

INTERIOR SURFACE COLOR: N/A

EXTERIOR SURFACE COLOR: dark grayish-brown

WALL THICKNESS (RIM, BODY, AND BASE IN MM): rim, $5.3 \mathrm{~mm}$

INTERIOR SURFACE TREATMENT: N/A

EXTERIOR SURFACE TREATMENT: N/A

HEIGHT (IN CM): 8.8

ORIFICE DIAMETER (IN CM): 15.0

DIAMETER AT BOTTOM OF RIM OR NECK (IN

CM): 17.2

BASE DIAMETER (IN CM) AND SHAPE OF

BASE: 5.0; circular and rounded

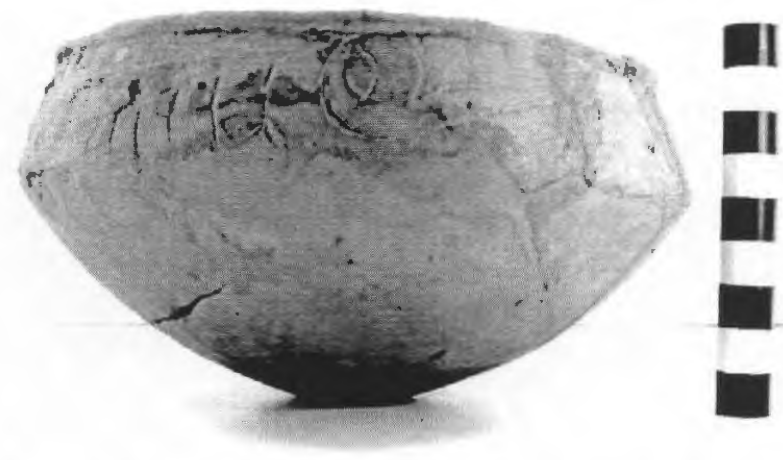

Figure 207. Taylor Engraved carinated bowl,

ESTIMATED VOLUME (IN LITERS): 0.79 Herbert Taft cemetery, Burial 6, Vessel 42.

DECORATION (INCLUDING MOTIF AND ELEMENTS WHEN APPARENT): The rim panel has an engraved scroll with hooked arm motif that is repeated four times around the vessel. The upper and lower scroll fill zones have curvilinear engraved lines (Figure 207).

PIGMENT USE AND LOCATION ON VESSEL: none

TYPE AND VARIETY [IF KNOWN]: Taylor Engraved 
VESSEL NO.: Burial 6, Vessel 43; 2003.08.1823

NON-PLASTICS AND PASTE: grog and hematite

VESSEL FORM: Carinated bowl

RIM AND LIP FORM: Direct rim and a rounded, exterior folded lip

CORE COLOR: A (fired and cooled in an oxidizing environment)

INTERIOR SURFACE COLOR: yellowish-brown

EXTERIOR SURFACE COLOR: yellowish-brown; fire clouds on body and base

WALL THICKNESS (RIM, BODY, AND BASE IN MM): rim, $6.6 \mathrm{~mm}$

INTERIOR SURFACE TREATMENT: smoothed

EXTERIOR SURFACE TREATMENT: smoothed

HEIGHT (IN CM): 16.0

ORIFICE DIAMETER (IN CM): 26.2

DIAMETER AT BOTTOM OF RIM OR NECK

(IN CM): 25.7

BASE DIAMETER (IN CM) AND SHAPE OF

BASE: 9.5 ; circular and flat

ESTIMATED VOLUME (IN LITERS): 3.8

Figure 208. Ripley Engraved, var. McKinney

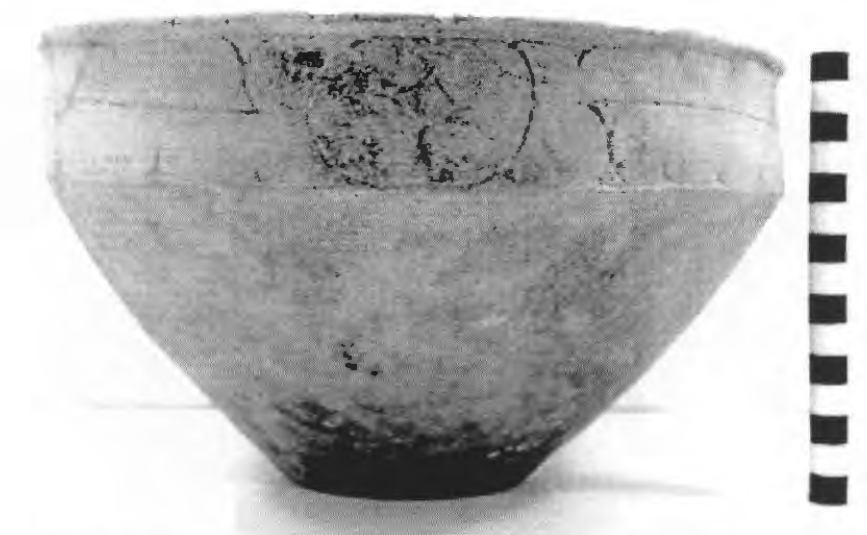

carinated bowl, Herbert Taft cemetery, Burial 6, Vessel 43.

DECORATION (INCLUDING MOTIF AND ELEMENTS WHEN APPARENT): The rim panel has an engraved diamond in circle element that is repeated four times around the vessel. Between the circles are horizontal scrolls with upper and lower brackets as well as upper and lower excised pendant triangles (Figure 208).

PIGMENT USE AND LOCATION ON VESSEL: none

TYPE AND VARIETY [IF KNOWN]: Ripley Engraved, var. McKinney 
VESSEL NO.: Burial 6, Vessel 44; 2003.08.240

NON-PLASTICS AND PASTE: grog; sandy paste

VESSEL FORM: Deep bowl

RIM AND LIP FORM: Everted rim and a rounded lip

CORE COLOR: $\mathrm{G}$ (fired in a reducing environment and cooled in the open air)

INTERIOR SURFACE COLOR: dark grayish-brown to black

EXTERIOR SURFACE COLOR: red; fire clouds on the rim, body, and base

WALL THICKNESS (RIM, BODY, AND BASE IN MM):

rim, $6.2 \mathrm{~mm}$; body, $6.2 \mathrm{~mm}$

INTERIOR SURFACE TREATMENT: smoothed

EXTERIOR SURFACE TREATMENT: smoothed

HEIGHT (IN CM): 22.4

ORIFICE DIAMETER (IN CM): 24.2

DIAMETER AT BOTTOM OF RIM OR NECK (IN CM): 19.0

BASE DIAMETER (IN CM) AND SHAPE OF BASE: 10.4; circular and flat

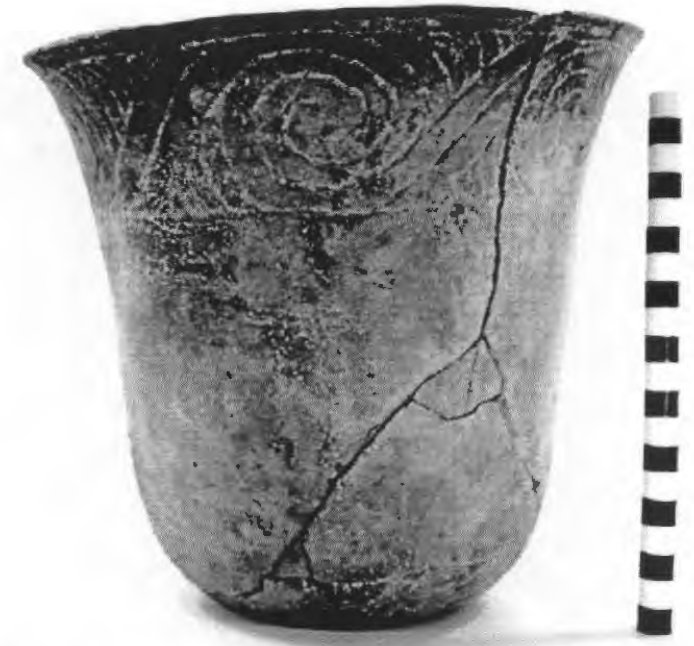

Figure 209. Taylor Engraved deep bowl, Herbert Taft cemetery, Burial 6, Vessel 44.

ESTIMATED VOLUME (IN LITERS): 4.3

DECORATION (INCLUDING MOTIF AND ELEMENTS WHEN APPARENT): The vessel exterior surface has a red slip. The upper part of the deep bowl has a slanting engraved scroll with a hooked arm end that is repeated six times around the vessel. The upper and lower scroll fill zones have curvilinear engraved lines (Figure 209).

PIGMENT USE AND LOCATION ON VESSEL: white pigment in the engraved lines

TYPE AND VARIETY [IF KNOWN]: Taylor Engraved 


\section{Elbow Pipes from Unknown Burial Contexts}

There are two plain ceramic elbow pipes from unknown burials at the Taft site. Based on Jones (n.d.), these pipes came from an unnumbered burial on higher land south of the Taft site cemetery at the base of the toe slope (see Figure 165). The pipes were placed in a burial along with three ceramic vessels and "flint" knives, probably large chipped Galt bifaces.

The first pipe (2003.08.122), grog-tempered, has a broad $(43.9 \mathrm{~mm}$ in height and $42.4 \mathrm{~mm}$ in orifice diameter) bowl and a short stem $(60.0 \mathrm{~mm})$ with a slight distal knob (Figure 210a). The stem's hole diameter is $14.0 \mathrm{~mm}$, while the diameter of the stem itself is $23.2 \mathrm{~mm}$.
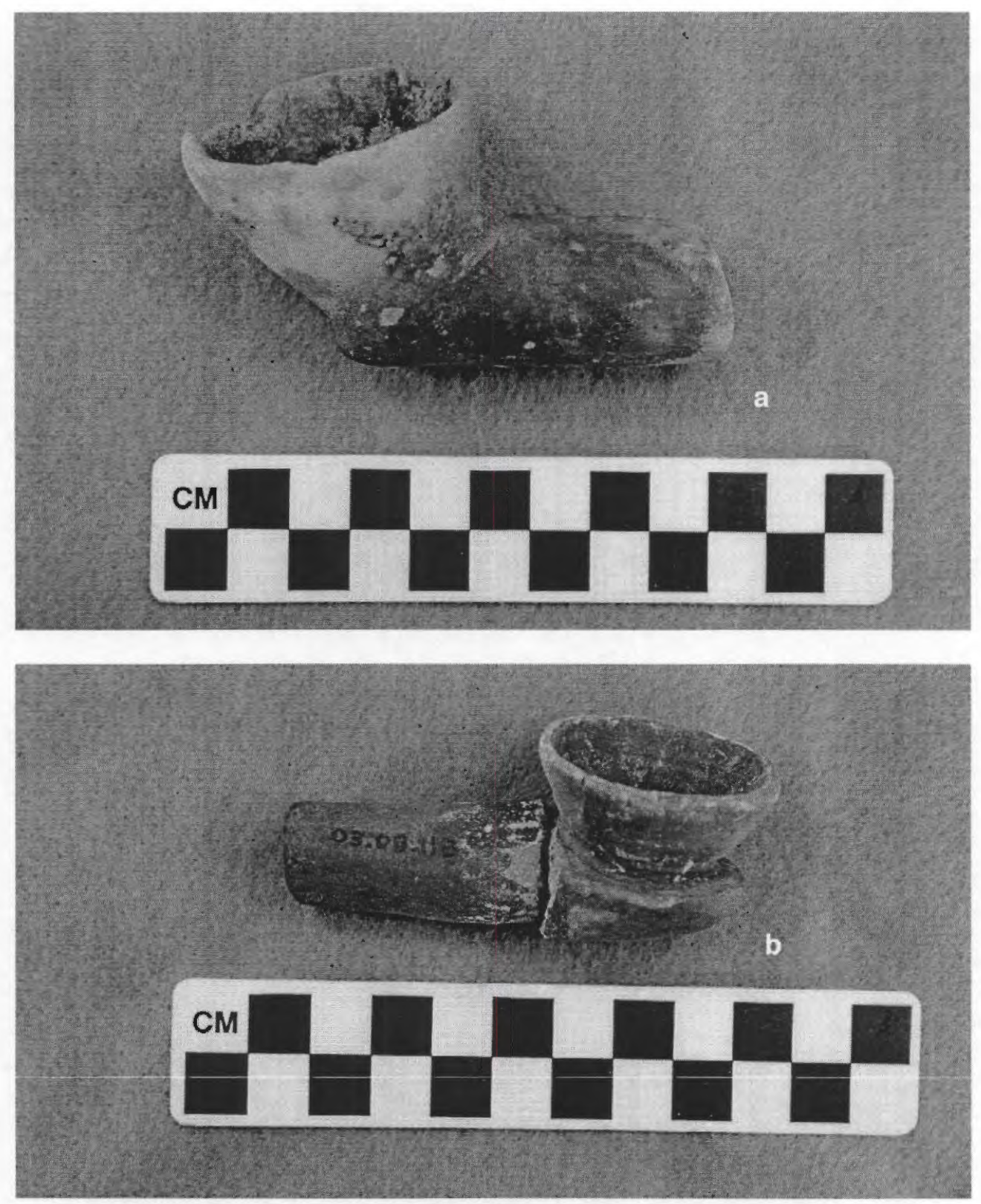

Figure 210. Elbow pipes from the Herbert Taft cemetery: a, 2003.08.122; b, 2003.08.118. 
The second elbow pipe is bone-tempered, and also has a distal knob on its stem, albeit more prominent (Figure 210b). The bowl, $14.0 \mathrm{~cm}$ in height, sits on the flat stem platform; its orifice diameter is 37.0 $\mathrm{mm}$. The stem is $75.0 \mathrm{~mm}$ in length, $16.0 \mathrm{~mm}$ in diameter, and has a stem hole diameter of only $6.3 \mathrm{~mm}$.

\section{Frank Smith Site (41UR326)}

Buddy Calvin Jones excavated the Caddo cemetery at the Frank Smith site in 1955-1956 and 1959. He excavated a total of 16 burials during that time, all apparently oriented east-west and in five east-west rows (Figure 211).

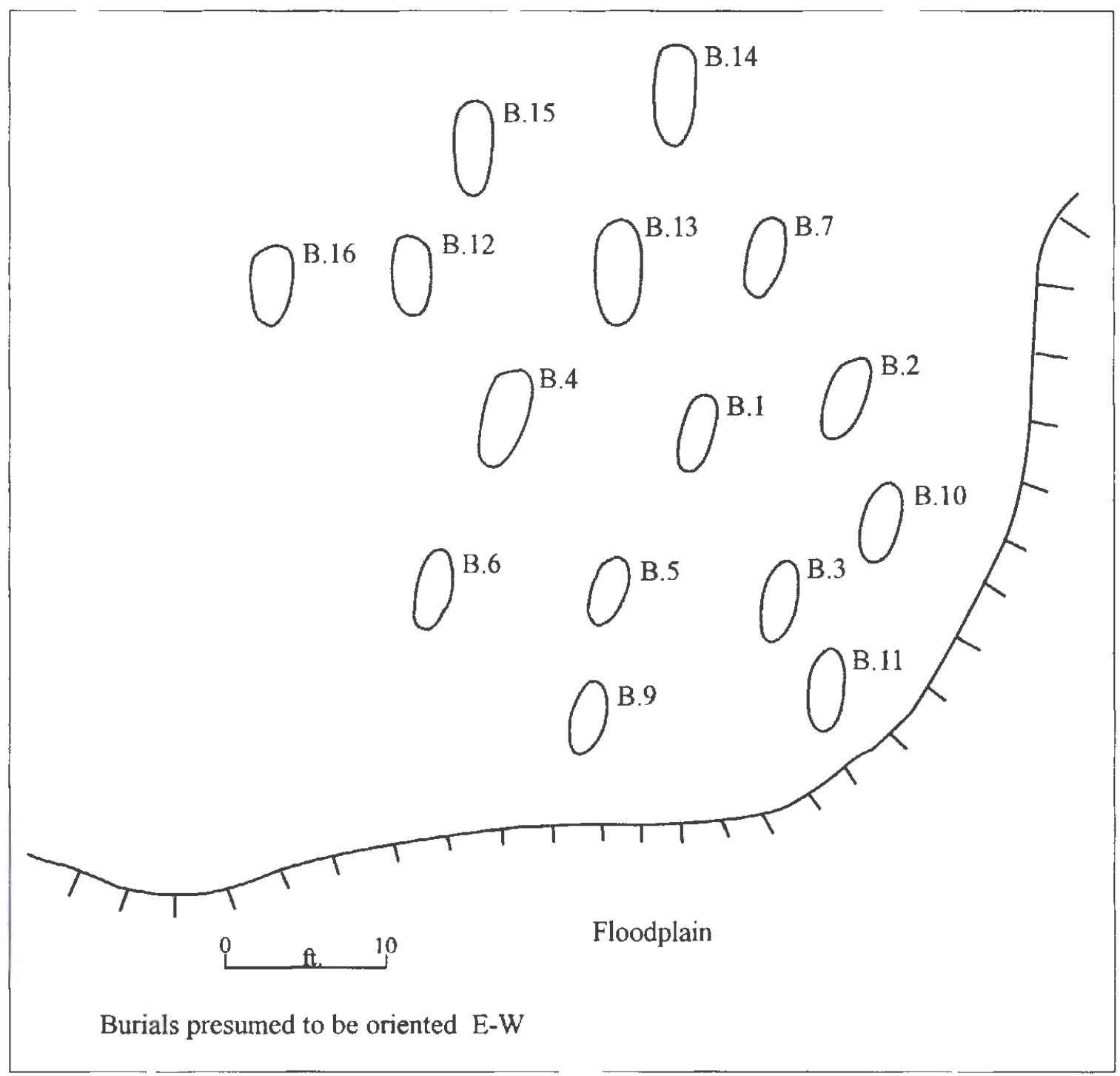

Figure 211. Plan map of the Caddo cemetery at the Frank Smith site.

The site was in an old cotton field, on a low terrace (250-260 feet amsl) overlooking the Clear Creek and Little Cypress Creek floodplains to the east and northeast. The confluence of Clear Creek and Little Cypress Creek lies about $\mathrm{I} \mathrm{km}$ to the east, and the Frank Smith Refinery site is ca. $1.5 \mathrm{~km}$ east of the Frank Smith cemetery (see Figure 1). 


\section{Burial 1}

Burial 1 was in the center of the cemetery (see Figure 211). The bottom of the burial pit was $1.02 \mathrm{~m}$ in depth. Three ceramic vessels had been placed with the deceased: a Karnack Brushed-Incised jar, a cf. Bullard Brushed jar, and a Ripley Engraved, var. McKinney carinated bowl.

VESSEL NO.: Burial 1, Vessel 1,2003.08.0442

NON-PLASTICS AND PASTE: grog

VESSEL FORM: Carinated bowl

RIM AND LIP FORM: direct rim and a rounded, exterior folded lip

CORE COLOR: $\mathrm{F}$ (fired in a reducing environment and cooled in the open air)

INTERIOR SURFACE COLOR: reddish-brown; fire clouds on the lower body and base

EXTERIOR SURFACE COLOR: reddishbrown; fire clouds on rim, body, and base

WALL THICKNESS (RIM, BODY, AND BASE IN MM): rim, $6.2 \mathrm{~mm}$

INTERIOR SURFACE TREATMENT: smoothed

EXTERIOR SURFACE TREATMENT: smoothed

HEIGHT (IN CM): 13.3

ORIFICE DIAMETER (IN CM): 25.8

Figure 212. Ripley Engraved, var. McKinney carinated bowl, Frank Smith cemetery, Burial 1,

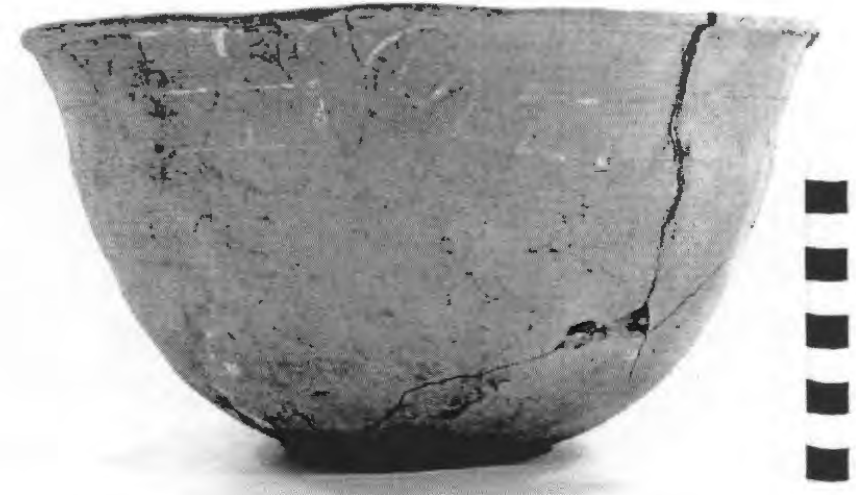
Vessel 1.

DIAMETER AT BOTTOM OF RIM OR NECK (IN CM): 22.5

BASE DIAMETER (IN CM) AND SHAPE OF BASE: 8.2; circular and flat

ESTIMATED VOLUME (IN LITERS): 3.1

DECORATION (INCLUDING MOTIF AND ELEMENTS WHEN APPARENT): The rim panel has a pendant triangle motif that is repeated four times around the vessel. The motif is comprised of four diamond in circle elements that are divided from each other by a horizontal scroll line. Above and below each scroll line are sets of five excised pendant triangles (Figure 212).

PIGMENT USE AND LOCATION ON VESSEL: white pigment in engraved lines 
VESSEL NO.: Burial 1, Vessel 2, 2003.08.412

NON-PLASTICS AND PASTE: grog

VESSEL FORM: Jar

RIM AND LIP FORM: Everted rim and rounded, exterior folded lip

CORE COLOR: $\mathrm{F}$ (fired in a reducing environment and cooled in the open air)

INTERIOR SURFACE COLOR: reddish-brown; fire clouds on the rim and body

EXTERIOR SURFACE COLOR: yellowish-brown; fire clouds on the rim, body, and base

WALLTHICKNESS (RIM, BODY, AND BASE IN

MM): rim, $6.2 \mathrm{~mm}$

INTERIOR SURFACE TREATMENT: burnished on the rim

EXTERIOR SURFACE TREATMENT: burnished on the lower $2.0 \mathrm{~cm}$ of the vessel body

HEIGHT (IN CM): 13.I

ORIFICE DIAMETER (IN CM): 15.6

DIAMETER AT BOTTOM OF RIM OR NECK (IN CM): 14.0

BASE DIAMETER (IN CM) AND SHAPE OF BASE: 6.3; circular and flat

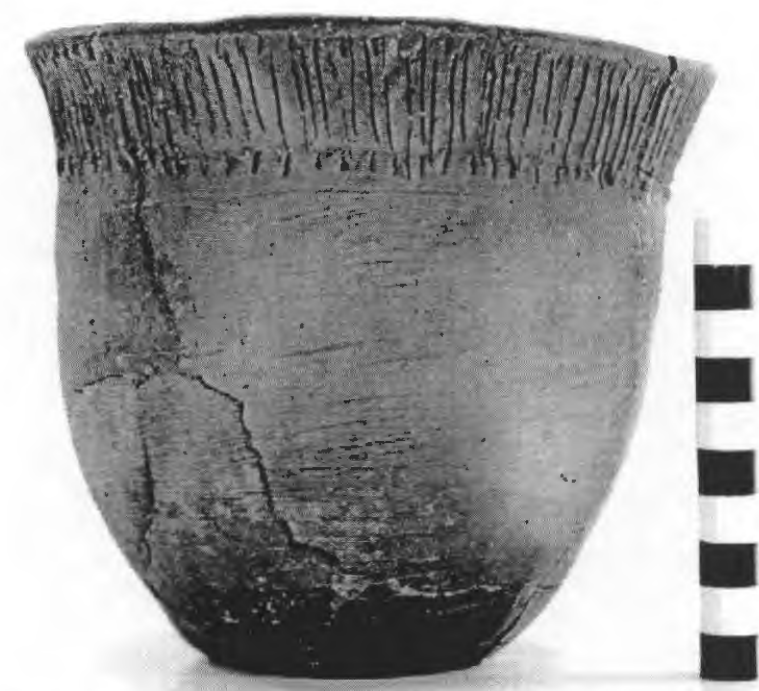

Figure 213. Karnack Brushed-Incised jar, Frank Smith cemetery, Burial 1, Vessel 2.

ESTIMATED VOLUME (IN LITERS): 1.2

DECORATION (INCLUDING MOTIF AND ELEMENTS WHEN APPARENT): The rim has two rows of tool punctations, one under the vessel lip and the other at the rim-body juncture. Between these two rims are a continuous series of short vertical incised lines. The vessel body has horizontal and overlapping brushing marks that extend to within $2.0 \mathrm{~cm}$ of the base (Figure 213).

PIGMENT USE AND LOCATION ON VESSEL: none

TYPE AND VARIETY [IF KNOWN]: Karnack Brushed-Incised 
VESSEL NO.: Burial 1, Vessel 3, M-5, 2003.08.827

NON-PLASTICS AND PASTE: grog

VESSEL FORM: Jar with four rim peaks (Figure 214)

RIM AND LIP FORM: Everted rim and a rounded, exterior folded lip

CORE COLOR: $F$ (fired in a reducing environment and cooled in the open air)

INTERIOR SURFACE COLOR: yellowishbrown; fire clouds on the rim and base

EXTERIOR SURFACE COLOR: yellowishbrown; fire clouds on the rim, body, and base; organic residue on the rim and body

WALL THICKNESS (RIM, BODY, AND BASE IN MM): rim, $6.6 \mathrm{~mm}$; body, $6.4 \mathrm{~mm}$; base, $13.4 \mathrm{~mm}$

INTERIOR SURFACE TREATMENT: smoothed

EXTERIOR SURFACE TREATMENT: none

HEIGHT (IN CM): 16.5

ORIFICE DIAMETER (IN CM): 16.0

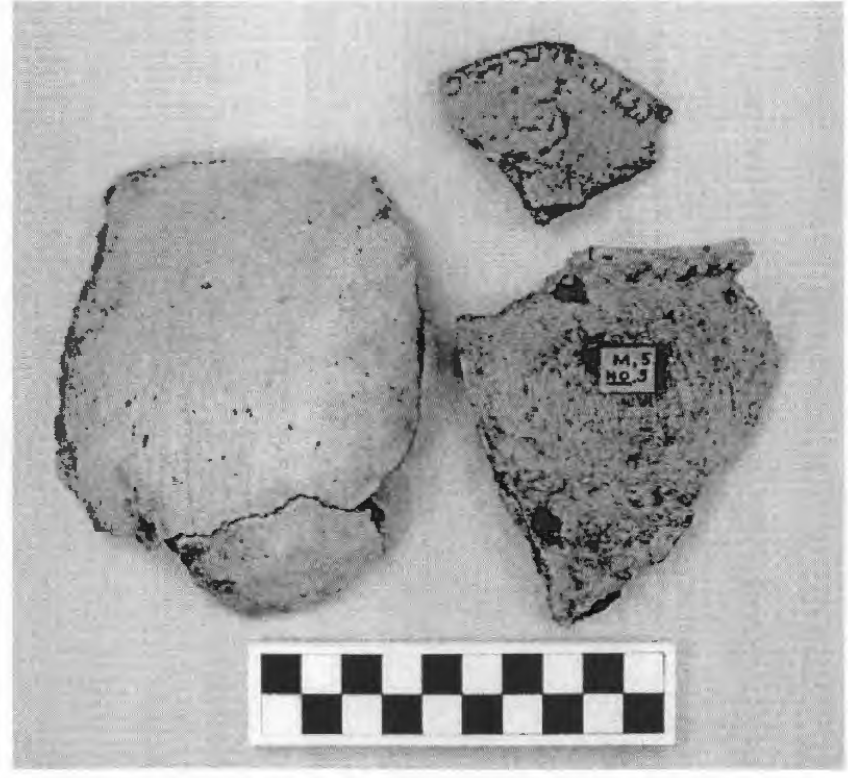

Figure 214. cf. Bullard Brushed jar sherds, Frank Smith cemetery, Burial 1, Vessel 3.

DIAMETER AT BOTTOM OF RIM OR NECK (IN CM): N/A

BASE DIAMETER (IN CM) AND SHAPE OF BASE: 8.0

ESTIMATED VOLUME (IN LITERS): 2.4

DECORATION (INCLUDING MOTIF AND ELEMENTS WHEN APPARENT): The rim has single rows of tool punctations, one under the lip and on the rim peaks and the other at the rim-body juncture. Under the rim peaks are sets of two appliqued nodes. The space between the punctations and the appliqued nodes is filled with vertical brushing marks. The vessel body has horizontal brushing marks (Figure 214).

PIGMENT USE AND LOCATION ON VESSEL: none

TYPE AND VARIETY [IF KNOWN]: cf. Bullard Brushed

\section{Burial 2}

Burial 2 was in the eastern part of the Frank Smith cemetery, in the middle east-west row. According to Jones (n.d.), the burial pit was $0.81 \mathrm{~m}$ in depth. Associated funerary offerings included a ceramic pipe, a celt, a polishing stone, and a pair of ear spools; no ceramic vessels were apparently placed in the grave of the deceased. 


\section{Burial 3}

This burial is in one of the southern burial rows at the cemetery (see Figure 211). The burial pit reached to $0.89 \mathrm{~m}$ bs, and there were six ceramic vessels placed in the grave, along with a ceramic pipe and one arrow point (type unknown). The five vessels identified from this burial in the Jones collection include a Ripley Engraved, var. unspecified bottle, Bullard Brushed and Harleton Appliqued jars, and two carinated bowls: cf. Taylor Engraved and cf. Turner Engraved.

VESSEL NO.: Burial 3, Vessel 5; 2003.08.485

NON-PLASTICS AND PASTE: grog and sandy paste

VESSEL FORM: Jar

RIM AND LIP FORM: Direct rim and a rounded, exterior folded lip

CORE COLOR: $\mathrm{F}$ (fired in a reducing environment and cooled in the open air)

INTERIOR SURFACE COLOR: reddish-brown; fire clouds on the rim and body

EXTERIOR SURFACE COLOR: reddish-brown; fire clouds on the base

WALL THICKNESS (RIM, BODY, AND BASE IN $\mathrm{MM})$ : rim, $8.2 \mathrm{~mm}$

INTERIOR SURFACE TREATMENT: smoothed

EXTERIOR SURFACE TREATMENT: none

HEIGHT (IN CM): 13.5

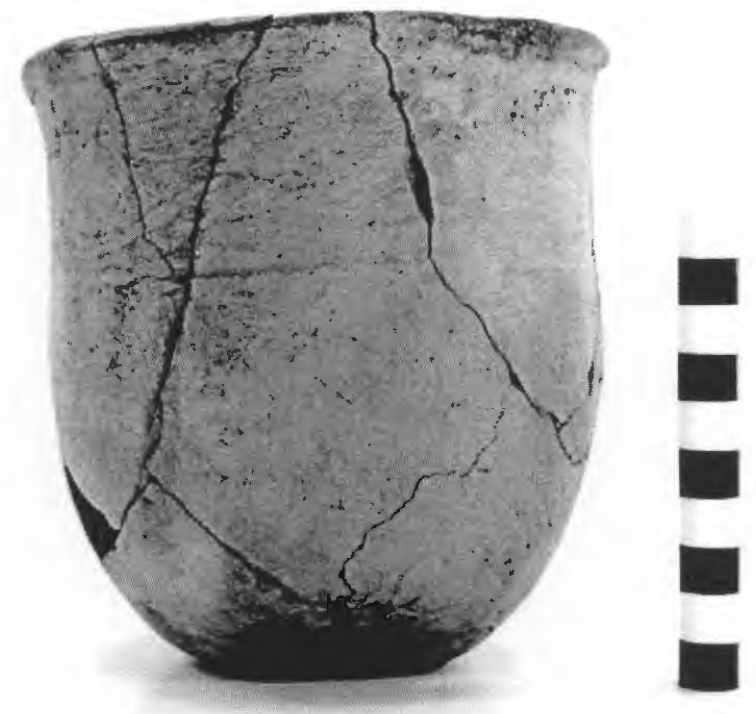

Figure 215. Bullard Brushed jar, Frank Smith cemetery, Burial 3, Vessel 5.

ORIFICE DIAMETER (IN CM): 13.2

DIAMETER AT BOTTOM OF RIM OR NECK (IN CM): 11.4

BASE DIAMETER (IN CM) AND SHAPE OF BASE: 6.6

ESTIMATED VOLUME (IN LITERS): $1 . \mathrm{I}$

DECORATION (INCLUDING MOTIF AND ELEMENTS WHEN APPARENT): The vessel is brushed on the rim and body. The brushing on the rim is horizontal in orientation, and horizontal, diagonal, and overlapping on the vessel body (Figure 215).

PIGMENT USE AND LOCATION ON VESSEL: none

TYPE AND VARIETY [IF KNOWN]: Bullard Brushed 
VESSEL NO.: Burial 3, Vessel 6, M-5; 2003.08.193

NON-PLASTICS AND PASTE: grog and bone

VESSEL FORM: Bottle with a flaring neck

RIM AND LIP FORM: Everted rim and a rounded lip

CORE COLOR: A (fired and cooled in an oxidizing environment)

INTERIOR SURFACE COLOR: light yellowish-brown; fire clouds on the lip

EXTERIOR SURFACE COLOR: light yellowish-brown; fire clouds on the rim, body, and base

WALL THICKNESS (RIM, BODY, AND BASE IN MM): rim, $4.9 \mathrm{~mm}$

INTERIOR SURFACE TREATMENT: none

EXTERIOR SURFACE TREATMENT: burnished

HEIGHT (IN CM): 14.1

ORIFICE DIAMETER (IN CM): 4.6

DIAMETER AT BOTTOM OF RIM OR NECK (IN CM): 4.3; $8.5 \mathrm{~cm}$ maximum body diameter

BASE DIAMETER (IN CM) AND SHAPE OF BASE: 5.9

ESTIMATED VOLUME (IN LITERS): 0.33

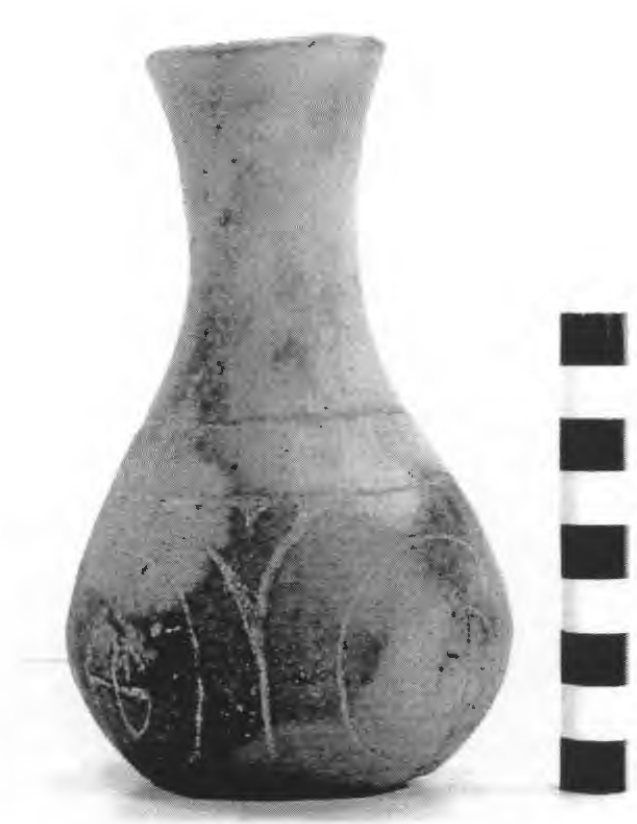

Figure 216. Ripley Engraved, var. unspecified bottle, Frank Smith cemetery, Burial 3, Vessel 6.

DECORATION (INCLUDING MOTIF AND ELEMENTS WHEN APPARENT): The vessel body has an engraved motif repeated four times around the vessel. The top of the motif is defined by two horizontal engraved lines, and the motif is in a panel defined by vertical engraved lines and large triangles at either end of the panel; the triangles are either open or have smaller excised or open triangles or oval-shaped areas within them (Figure 216).

The primary element in the motif is a large circle with a smaller circle within it. The smaller circle has an excised swastika within it (Figure 216).

PIGMENT USE AND LOCATION ON VESSEL: red pigment in engraved lines

TYPE AND VARIETY [IF KNOWN]: Ripley Engraved, var. unspecified 
VESSEL NO.: Burial 3, Vessel 7; 2003.08.1831

NON-PLASTICS AND PASTE: bone and grog

VESSEL FORM: Carinated bowl

RIM AND LIP FORM: Direct rim and a rounded lip

CORE COLOR: F (fired in a reducing environment and cooled in the open air)

INTERIOR SURFACE COLOR: reddish-brown

EXTERIOR SURFACE COLOR: red; fire clouds on the body and base

WALL THICKNESS (RIM, BODY, AND BASE IN MM): rim, $5.5 \mathrm{~mm}$

INTERIOR SURFACE TREATMENT: smoothed

EXTERIOR SURFACE TREATMENT: burnished

HEIGHT (IN CM): 7.1

ORIFICE DIAMETER (IN CM): 14.3

DIAMETER AT BOTTOM OF RIM OR NECK (IN CM): 14.3

BASE DIAMETER (IN CM) AND SHAPE OF

BASE: 5.0; circular and flat

ESTIMATED VOLUME (IN LITERS): 0.6I

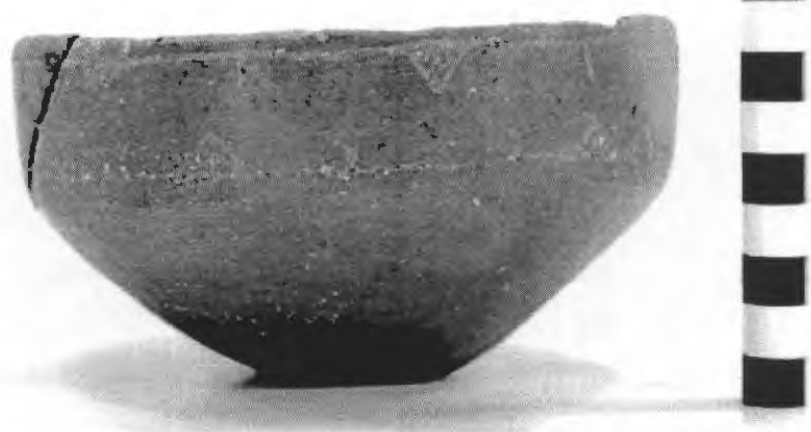

Figure 217. Red-slipped engraved carinated bowl, Frank Smith cemetery, Burial 3, Vessel 7.

DECORATION (INCLUDING MOTIF AND ELEMENTS WHEN APPARENT): The vesseI has an exterior red slip. The rim panel has seven upper and lower excised pendant triangles, and each are divided from the other by upper and lower sets of seven short vertical engraved lines (Figure 217).

PIGMENT USE AND LOCATION ON VESSEL: none

TYPE AND VARIETY [IF KNOWN]: Unidentified fine ware, possibly an unspecified variety of Turner Engraved 
VESSEL NO:: Burial 3, Vessel 8, M-5; 2003.08.1957

NON-PLASTICS AND PASTE: grog and hematite

VESSEL FORM: Jar

RIM AND LIP FORM: Everted rim and a rounded, exterior folded lip

CORE COLOR: F (fired in a reducing environment and cooled in the open air)

INTERIOR SURFACE COLOR: yellowish-brown; fire clouds on the rim, body, and base

EXTERIOR SURFACE COLOR: yellowish-brown; fire clouds on the rim and body; organic residue on the rim

WALL THICKNESS (RIM, BODY, AND BASE IN MM): rim, $6.2 \mathrm{~mm}$; body, $7.4 \mathrm{~mm}$

INTERIOR SURFACE TREATMENT: smoothed

EXTERIOR SURFACE TREATMENT: none

HEIGHT (IN CM): 30.0

ORIFICE DIAMETER (IN CM): 26.0

DIAMETER AT BOTTOM OF RIM OR NECK (IN CM): 23.5

BASE DIAMETER (IN CM) AND SHAPE OF BASE: N/A

ESTIMATED VOLUME (IN LITERS): 10.1

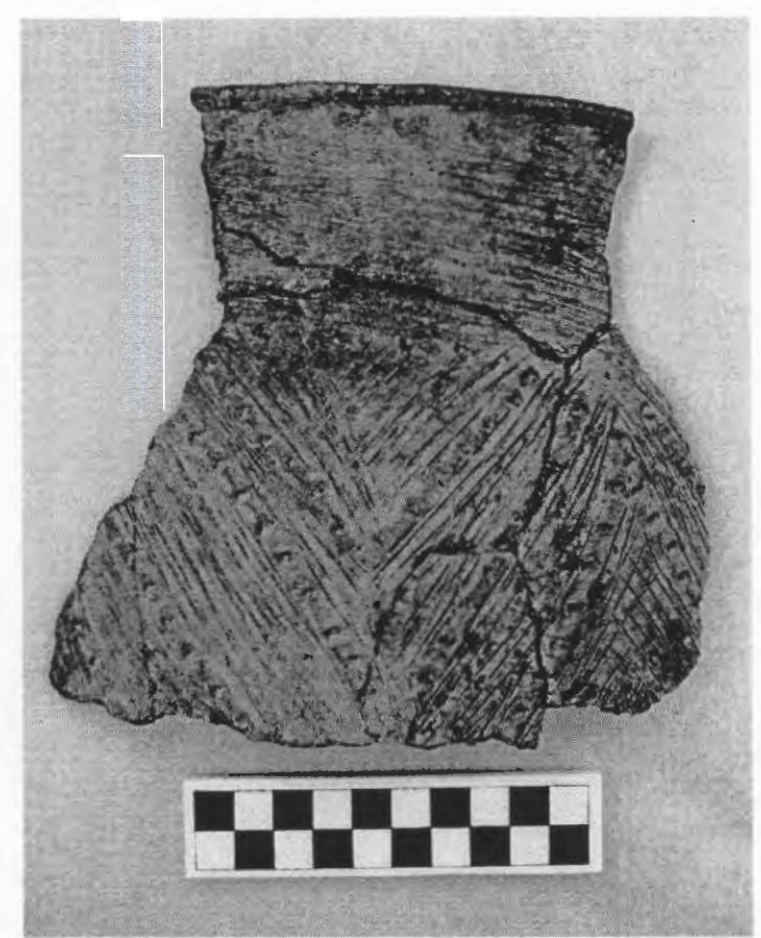

Figure 218. Harleton Appliqued jar, Frank Smith cemetery, Burial 3, Vessel 8.

DECORATION (INCLUDING MOTIF AND ELEMENTS WHEN APPARENT): The rim is horizontally brushed, with upper and lower rows of tool punctations that have been pushed through the brushing; these are just below the lip and at the rim-body juncture. The vessel body has a nested diamond appliqued fillet motif repeated four times around the vessel. At the center of the innermost nested diamond is a small circular appliqued node with four punctations on it. The nested diamonds are also filled with brushing marks that follow the orientation of the nested diamonds (Figure 218).

The nested diamonds are separated from each other by upper and lower appliqued fillet triangles. The appliqued triangles are also filled with near vertical brushing marks (Figure 218). In the case of one appliqued triangle, only the outermost part has near-vertical brushing marks; the remainder of the appliqued triangle is open or undecorated. 
VESSEL NO.: Burial 3, Vessel 61; 2003.08.698

NON-PLASTICS AND PASTE: grog and hematite; sandy paste

VESSEL FORM: Carinated bowl

RIM AND LIP FORM: Inverted rim and a rounded, exterior folded lip

CORE COLOR: $\mathrm{F}$ (fired in a reducing environment and cooled in the open air)

INTERIOR SURFACE COLOR: light reddish-brown; fire clouds on the body and base

EXTERIOR SURFACE COLOR: light reddishbrown; fire clouds on the body

WALL THICKNESS (RIM, BODY, AND BASE IN MM): rim, $5.6 \mathrm{~mm}$

INTERIOR SURFACE TREATMENT: none

EXTERIOR SURFACE TREATMENT:

smoothed

HEIGHT (IN CM): 9.1

ORIFICE DIAMETER (IN CM): 14.5

Figure 219. cf. Taylor Engraved carinated bowl,

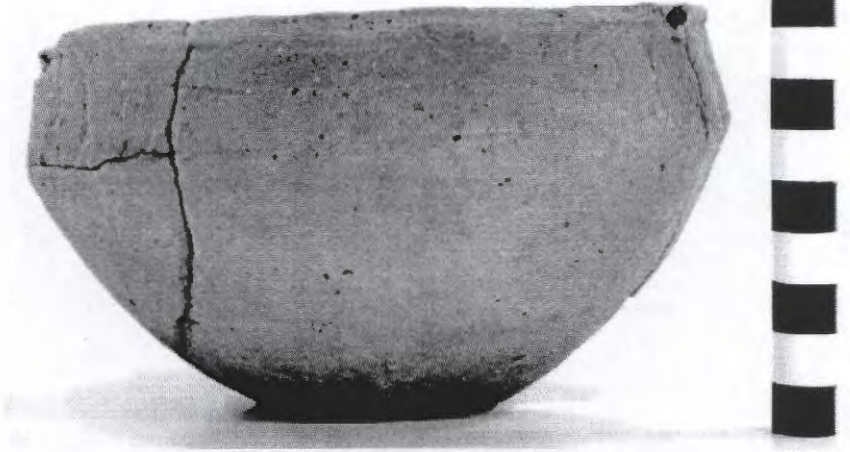

Frank Smith cemetery, Burial 3, Vessel 61.

DIAMETER AT BOTTOM OF RIM OR NECK (IN CM): 15.6

BASE DIAMETER (IN CM) AND SHAPE OF BASE: 6.2; circular and flat

ESTIMATED VOLUME (IN LITERS): 0.79

DECORATION (INCLUDING MOTIF AND ELEMENTS WHEN APPARENT): The rim panel has four sets of engraved scrolls with either hooked arms or an S-shaped element in the scroll line. Each scroll is separated from the other by X-shaped engraved brackets that extend from the top to the bottom of the rim panel (Figure 219). There is a single horizontal engraved line at the top of the panel, and just under the vessel lip.

PIGMENT USE AND LOCATION ON VESSEL: none

TYPE AND VARIETY [IF KNOWN]: cf. Taylor Engraved

\section{Burial 4}

Burial 4 was situated in the western part of the cemetery, in the middle east-west row. The burial pit depth was $0.86 \mathrm{~m}$, and funerary offerings consisted of four ceramic vessels, all identified in the Jones collection. The vessels included a cf. Taylor Engraved bottle, a plain jar, and two carinated bowls: Ripley Engraved, var. McKinney and Ripley Engraved, cf. var. McKinney. 
VESSEL NO.: Burial 4, Vessel 57; 2003.08.237

NON-PLASTICS AND PASTE: grog and hematite

VESSEL FORM: Carinated bowl

RIM AND LIP FORM: Direct rim and rounded, exterior folded lip

CORE COLOR: $\mathrm{F}$ (fired in a reducing environment and cooled in the open air)

INTERIOR SURFACE COLOR: yellowish-brown; fire clouds on the base

EXTERIOR SURFACE COLOR: yellowish-

brown; fire clouds on the rim, body, and base

WALL THICKNESS (RIM, BODY, AND BASE

IN MM): rim, $5.6 \mathrm{~mm}$

INTERIOR SURFACE TREATMENT: smoothed

EXTERIOR SURFACE TREATMENT: smoothed

HEIGHT (IN CM): 7.7

ORIFICE DIAMETER (IN CM): 16.7

DIAMETER AT BOTTOM OF RIM OR NECK

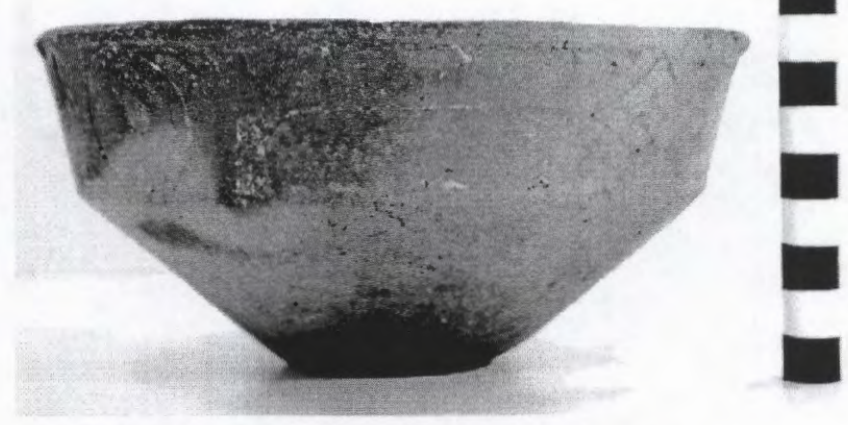

Figure 220. Ripley Engraved, var. McKinney carinated bowl, Frank Smith cemetery, Burial 4, Vessel 57.

(IN CM): 15.3

BASE DIAMETER (IN CM) AND SHAPE OF BASE: 5.4; circular and flat

ESTIMATED VOLUME (IN LITERS): 0.77

DECORATION (INCLUDING MOTIF AND ELEMENTS WHEN APPARENT): The rim panel has an engraved motif that features two central circles with excised dots, two nested diamond elements, and a horizontal and vertical scroll line. Above and below the scroll lines are small pendant triangles and horizontal dash marks. The diamonds have a negative circle at its center that has been defined by excising (Figure 220).

PIGMENT USE AND LOCATION ON VESSEL: white pigment in engraved lines TYPE AND VARIETY [IF KNOWN]: Ripley Engraved, var. McKinney 
VESSEL NO.: Burial 4, Vessel 58; 2003.08.347

NON-PLASTICS AND PASTE: grog

VESSEL FORM: Bottle

RIM AND LIP FORM: Everted rim and a rounded lip

CORE COLOR: $\mathrm{F}$ (fired in a reducing environment and cooled in the open air)

INTERIOR SURFACE COLOR: reddish-brown

EXTERIOR SURFACE COLOR: reddish-brown; fire clouds on lower neck, body, and base

WALL THICKNESS (RIM, BODY, AND BASE IN MM): rim, $4.8 \mathrm{~mm}$

INTERIOR SURFACE TREATMENT: none

EXTERIOR SURFACE TREATMENT: smoothed

HEIGHT (IN CM): 20.7

ORIFICE DIAMETER (IN CM): 4.5

DIAMETER AT BOTTOM OF RIM OR NECK (IN CM): 5.3 ; maximum body diameter of $14.7 \mathrm{~cm}$

BASE DIAMETER (IN CM) AND SHAPE OF BASE: 5.5; circular and rounded

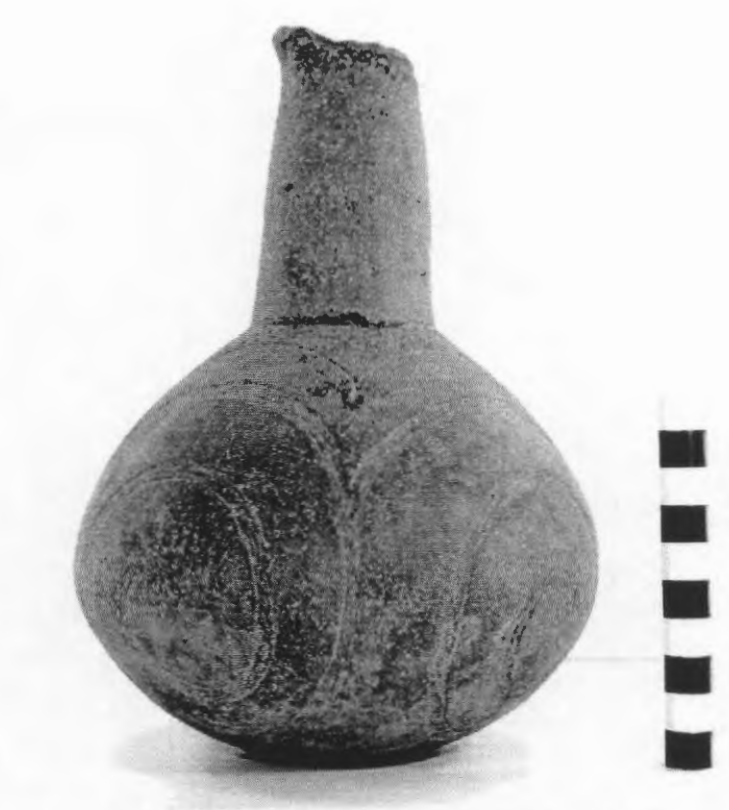

Figure 221. cf. Taylor Engraved bottle, ESTIMATED VOLUME (IN LITERS): 0.46 Frank Smith cemetery, Burial 4, Vessel 58.

DECORATION (INCLUDING MOTIF AND ELEMENTS WHEN APPARENT): The vessel body has an engraved continuous spiral and scroll motif that is repeated four times around the vessel. The spirals and scrolls are comprised of narrow hatched zones (Figure 221). Above the spiral-scroll motifs is an engraved band at the top of the vessel body that is filled with small tool punctations. From above, the band forms a square.

PIGMENT USE AND LOCATION ON VESSEL: red pigment in engraved line TYPE AND VARIETY [IF KNOWN]: cf. Taylor Engraved 
VESSEL NO.: Burial 4, Vessel 59; 2003.08.345

NON-PLASTICS AND PASTE: grog and bone

VESSEL FORM: Jar

RIM AND LIP FORM: Everted rim and a rounded, exterior folded lip

CORE COLOR: $\mathrm{F}$ (fired in a reducing environment and cooled in the open air)

INTERIOR SURFACE COLOR: yellowish-brown; fire clouds on the rim and body

EXTERIOR SURFACE COLOR: yellowish-brown; fire clouds on the rim, body, and base; organic residue on the upper body

WALL THICKNESS (RIM, BODY, AND BASE IN MM): $\operatorname{rim}, 7.1 \mathrm{~mm}$

INTERIOR SURFACE TREATMENT: smoothed

EXTERIOR SURFACE TREATMENT: smoothed

HEIGHT (IN CM): 14.0

ORIFICE DIAMETER (IN CM): 13.1

DIAMETER AT BOTTOM OF RIM OR NECK (IN CM): 11.3

BASE DIAMETER (IN CM) AND SHAPE OF BASE: 6.6; circular and flat

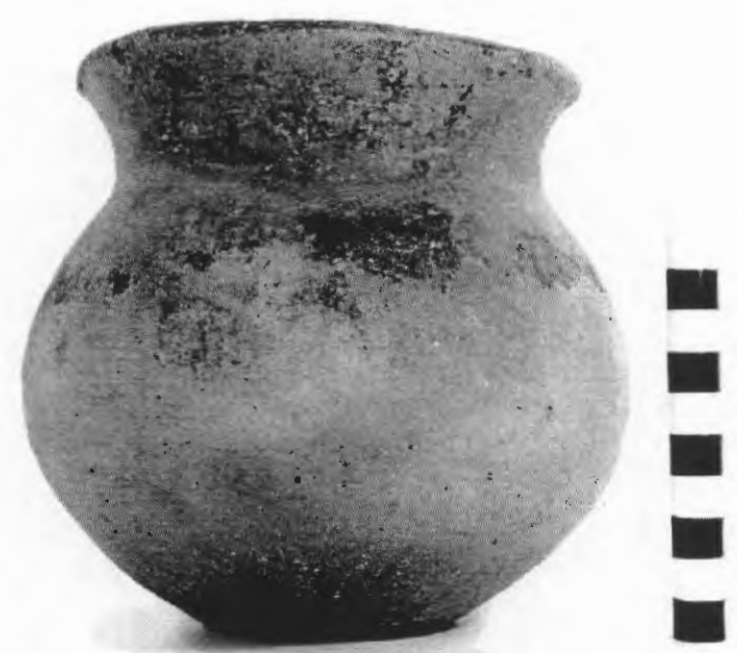

Figure 222. Plain jar, Frank Smith cemetery, Burial 4, Vessel 59.

ESTIMATED VOLUME (IN LITERS): 1.1

DECORATION (INCLUDING MOTIF AND ELEMENTS WHEN APPARENT): Plain (Figure 222)

PIGMENT USE AND LOCATION ON VESSEL: none

TYPE AND VARIETY [IF KNOWN]: Unidentified plain ware 
VESSEL NO.: Burial 4, Vessel 60; 2003.08.1416

NON-PLASTICS AND PASTE: grog

VESSEL FORM: Carinated bowl

RIM AND LIP FORM: Direct rim and a rounded, exterior folded lip

CORE COLOR: $\mathrm{F}$ (fired in a reducing environment and cooled in the open air)

INTERIOR SURFACE COLOR: yellowish-brown; fire clouds on the lower body and base

EXTERIOR SURFACE COLOR: yellowish-brown; fire clouds on the Iower body and base

WALL THICKNESS (RIM, BODY, AND BASE IN MM): rim, $8.6 \mathrm{~mm}$; body, $7.8 \mathrm{~mm}$; base, $7.0 \mathrm{~mm}$

INTERIOR SURFACE TREATMENT: smoothed

EXTERIOR SURFACE TREATMENT: smoothed

HEIGHT (IN CM): 16.5

ORIFICE DIAMETER (IN CM): 29.5

DIAMETER AT BOTTOM OF RIM OR NECK

(IN CM): 28.5

BASE DIAMETER (IN CM) AND SHAPE OF

BASE: N/A

ESTIMATED VOLUME (IN LITERS): 4.4

DECORATION (INCLUDING MOTIF AND

ELEMENTS WHEN APPARENT): The rim panel

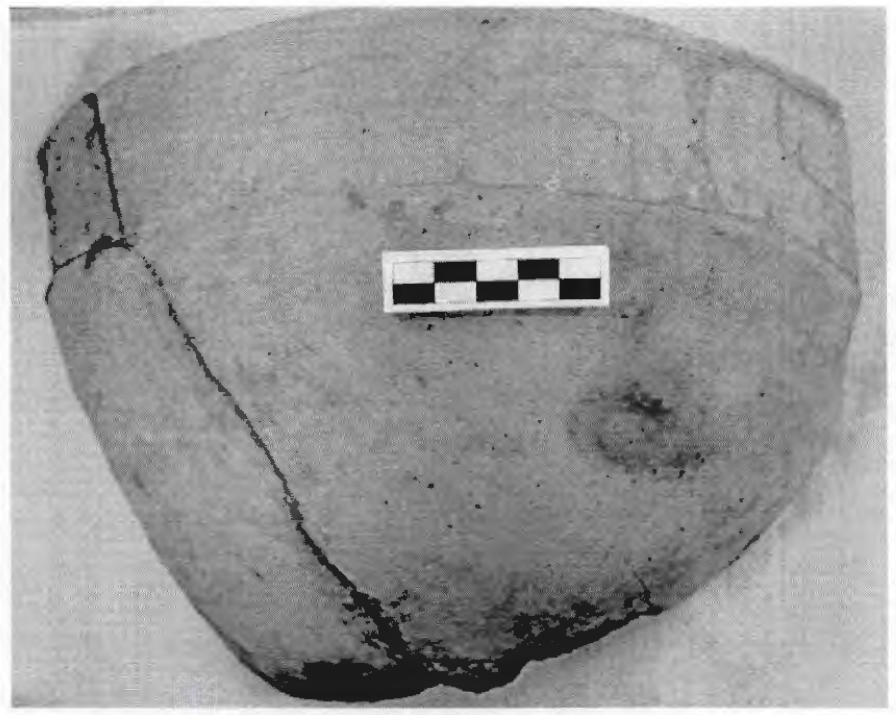

Figure 223. Ripley Engraved, cf. var. Gandy carinated bowl, Frank Smith cemetery, Burial 4, Vessel 60. has a vertical-horizontal scroll motif repeated four times around the vessel. The scrolls are divided from each other by four cross-hatched and excised brackets. Above and below each of the scrolls are open and excised pendant triangles (Figure 223).

PIGMENT USE AND LOCATION ON VESSEL: white pigment in engraved lines

TYPE AND VARIETY [IF KNOWN]: Ripley Engraved, cf. var. Gandy

\section{Burial 5}

This burial was in one of the southern burial rows; the burial pit reached to $0.84 \mathrm{~m}$ bs. According to Jones (n.d.), Burial 5 's funerary offerings included six ceramic vessels. However, there are eight vessels in the Jones collection that are identified as coming from Burial 5 at the Frank Smith cemetery. These vessels include a Taylor Engraved bottle, three jars (cf. Killough Pinched, Taylor Engraved, and Harleton Appliqued), and four carinated bowls: Ripley Engraved, var. unspecified, Ripley Engraved, var. McKinney, Ripley Engraved, var. Galt, and Womack Engraved, var. Gum Creek. 
VESSEL NO.: Burial 5, Vessel 10; 2003.08.1000

NON-PLASTICS AND PASTE: grog

VESSEL FORM: Jar

RIM AND LIP FORM: Everted rim and a rounded lip

CORE COLOR: $\mathrm{F}$ (fired in a reducing environment and cooled in the open air)

INTERIOR SURFACE COLOR: yellowish-brown; fire cloud on the base; green clay pigment stains on the base

EXTERIOR SURFACE COLOR: yellowish-brown; fire clouds on the rim, body, and base; organic residue on the rim and body

WALL THICKNESS (RIM, BODY, AND

BASE IN MM): rim, $5.5 \mathrm{~mm}$

INTERIOR SURFACE TREATMENT:

smoothed

EXTERIOR SURFACE TREATMENT:

smoothed on the rim

HEIGHT (IN CM): 7.7

ORIFICE DIAMETER (IN CM): 9.9

DIAMETER AT BOTTOM OF RIM OR NECK (IN CM): 8.9

BASE DIAMETER (IN CM) AND SHAPE OF

BASE: 5.3; circular and flat

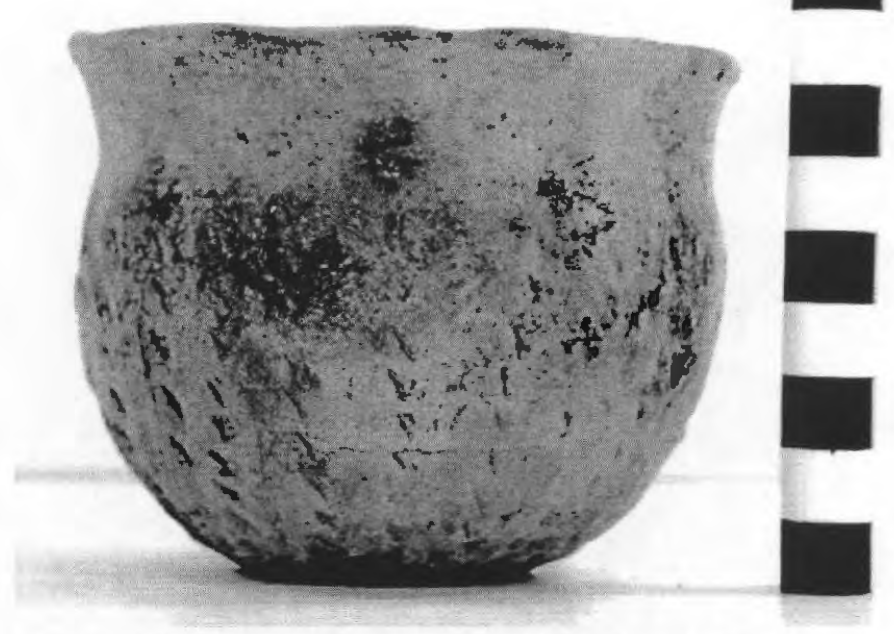

Figure 224. cf. Killough Pinched jar, Frank Smith cemetery, Burial 5, Vessel 10.

ESTIMATED VOLUME (IN LITERS): 0.46

DECORATION (INCLUDING MOTIF AND ELEMENTS WHEN APPARENT): The vessel rim is plain. The vessel body has continuous vertical rows of pinched ridges that cover the entire body from the rimbody juncture to the vessel base (Figure 224).

PIGMENT USE AND LOCATION ON VESSEL: none

TYPE AND VARIETY [IF KNOWN]: cf. Killough Pinched 
VESSEL NO.: Burial 5, Vessel 11; 2003.08.90

NON-PLASTICS AND PASTE: grog

VESSEL FORM: Jar

RIM AND LIP FORM: Everted rim and a rounded, exterior folded lip

CORE COLOR: $\mathrm{F}$ (fired in a reducing environment and cooled in the open air)

INTERIOR SURFACE COLOR: red

EXTERIOR SURFACE COLOR: red

WALL THICKNESS (RIM, BODY, AND

BASE IN MM): rim, $5.2 \mathrm{~mm}$

INTERIOR SURFACE TREATMENT:

smoothed

EXTERIOR SURFACE TREATMENT:

smoothed

HEIGHT (IN CM): 12.0

ORIFICE DIAMETER (IN CM): 16.8

DIAMETER AT BOTTOM OF RIM OR

NECK (IN CM): 14.3

BASE DIAMETER (IN CM) AND SHAPE OF

BASE: 9.5; circular and flat

ESTIMATED VOLUME (IN LITERS): 1.2

Figure 225. Taylor Engraved jar, Frank Smith

cemetery, Burial 5, Vessel 11.

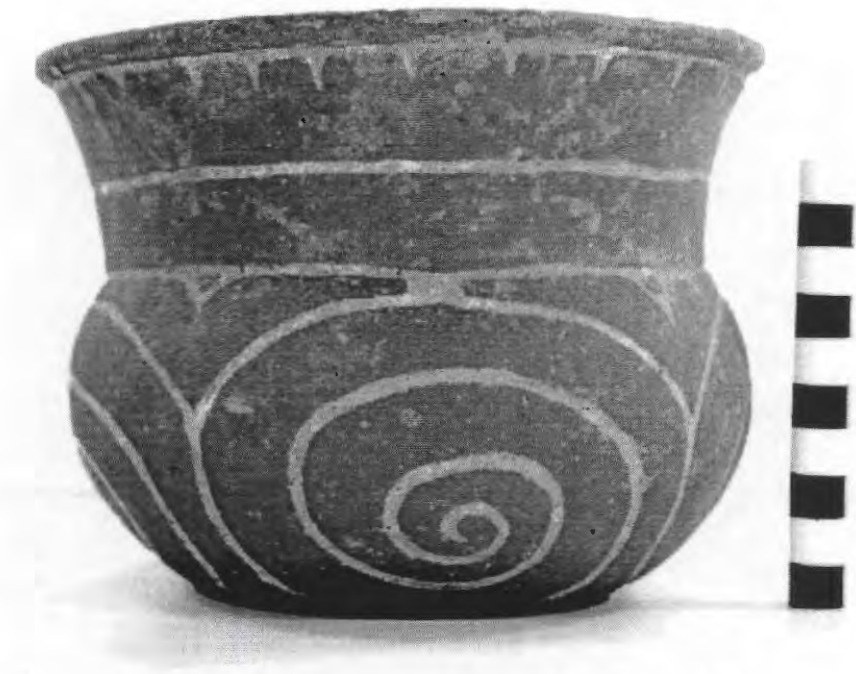

DECORATION (INCLUDING MOTIF AND ELEMENTS WHEN APPARENT): The vessel has a red slip on both interior and exterior surfaces. The rim has three widely-spaced horizontal engraved lines, the uppermost line (under the lip) with small excised pendant triangles (Figure 225).

The vessel body has an engraved spiral and hooked arm motif that is repeated four times around the vessel. Above each spiral motif is a small attached excised rectangle, pendant from a horizontal engraved line at the rim-body juncture. Between each excised rectangle is a large excised triangle, apex pointing towards the base, with a negative oval within it (Figure 225).

PIGMENT USE AND LOCATION ON VESSEL: white pigment in engraved lines 
VESSEL NO:: Burial 5, Vessel 12; 2003.08.1845

NON-PLASTICS AND PASTE: grog and bone

VESSEL FORM: Carinated bowl

RIM AND LIP FORM: Direct rim and a rounded, exterior folded lip

CORE COLOR: $\mathrm{F}$ (fired in a reducing environment and cooled in the open air)

INTERIOR SURFACE COLOR: yellowish-brown; fire clouds on the rim, body, and base

EXTERIOR SURFACE COLOR: yellowish-brown; fire clouds on the rim, body, and base

WALL THICKNESS (RIM, BODY, AND BASE IN

MM): rim, $6.8 \mathrm{~mm}$

INTERIOR SURFACE TREATMENT: smoothed

EXTERIOR SURFACE TREATMENT: smoothed

HEIGHT (IN CM): 6.8

ORIFICE DIAMETER (IN CM): 11.6

DIAMETER AT BOTTOM OF RIM OR NECK (IN

CM): 11.0

BASE DIAMETER (IN CM) AND SHAPE OF

BASE: 4.5; circular and flat

ESTIMATED VOLUME (IN LITERS): 0.47

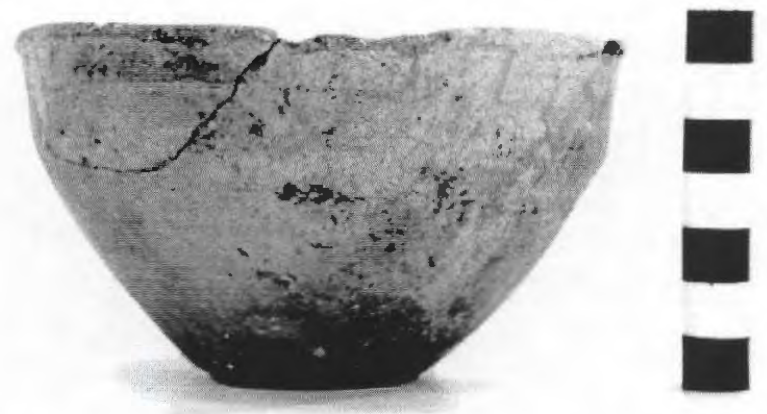

Figure 226. Ripley Engraved, var. unspecified carinated bowl, Frank Smith cemetery, Burial 5, Vessel 12.

DECORATION (INCLUDING MOTIF AND ELEMENTS WHEN APPARENT): The rim panel has four single horizontal scroll lines divided by sets of three vertical engraved lines. Each scroll portion also has five upper and lower excised pendant triangles (Figure 226). There is also an interior horizontal engraved line at the vessel carination.

PIGMENT USE AND LOCATION ON VESSEL: none

TYPE AND VARIETY [IF KNOWN]: Ripley Engraved, var. unspecified 
VESSEL NO.: Burial 5, Vessel 13; 2003.08.293

NON-PLASTICS AND PASTE: grog

VESSEL FORM: Jar with four rim peaks and four strap handles $(3.1 \mathrm{~cm}$ in length, $1.7 \mathrm{~cm}$ in width, and 0.7 $\mathrm{cm}$ in thickness) (Figure 227)

RIM AND LIP FORM: Direct rim and a rounded, exterior folded lip

CORE COLOR: B (fired and cooled in a reducing environment)

INTERIOR SURFACE COLOR: grayish-brown; fire clouds on the rim, body, and base

EXTERIOR SURFACE COLOR: grayish-brown; fire clouds on the rim and body

WALL THICKNESS (RIM, BODY, AND BASE IN MM): rim, $5.3 \mathrm{~mm}$

INTERIOR SURFACE TREATMENT: smoothed

EXTERIOR SURFACE TREATMENT: none

HEIGHT (IN CM): $14.6 \mathrm{~cm}$ between rim peaks; 15.1

$\mathrm{cm}$ at rim peaks

ORIFICE DIAMETER (IN CM): 15.7

DIAMETER AT BOTTOM OF RIM OR NECK (IN

CM): 13.7

BASE DIAMETER (IN CM) AND SHAPE OF

BASE: 6.4 ; circular and flat

ESTIMATED VOLUME (IN LITERS): 1.4

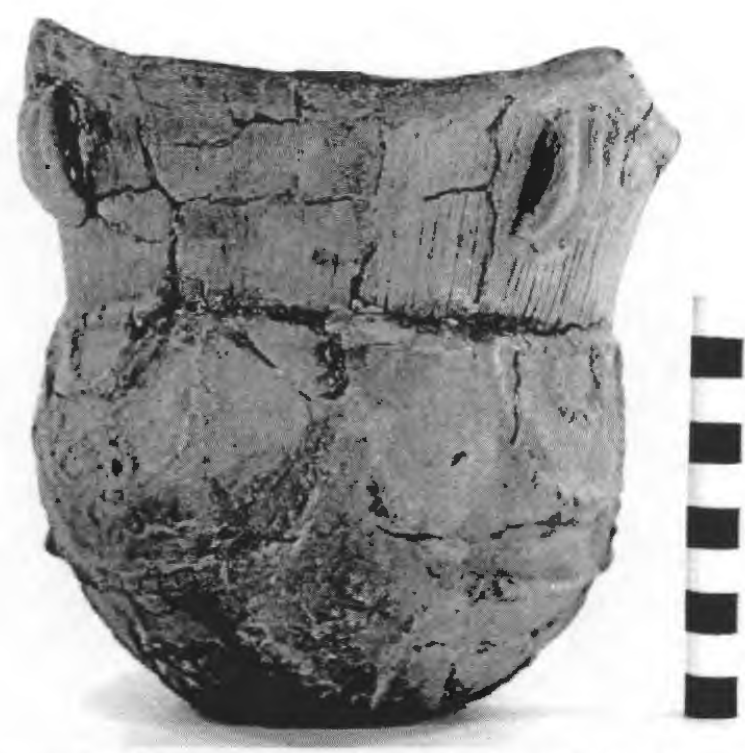

Figure 227. Harleton Appliqued jar, Frank Smith cemetery, Burial 5, Vessel 13.

DECORATION (INCLUDING MOTIF AND ELEMENTS WHEN APPARENT): The rim has a continuous series of vertical incised lines, as well as a row of tool punctations under the lip; the punctations follow the lip and rim peaks (Figure 227).

The vessel body has an appliqued fillet motif, repeated four times around the vessel, defined by a single horizontal appliqued fillet at the rim-body juncture. The main element in the motif is an appliqued diamond with a central appliqued node; the diamonds are connected by a simple appliqued scroll (Figure 227). On either side of the scroll and appliqued diamonds are semi-circular appliqued fillets, two concentric fillets above the diamonds and scroll line, and single semi-circles below the diamonds and scroll line.

The four strap handles are located under the rim peaks. They are decorated with three vertical appliqued ridges. 
VESSEL NO.: Burial 5, Vessel 13A, M5; 2003.08.349

NON-PLASTICS AND PASTE: grog

VESSEL FORM: Carinated bowl

RIM AND LIP FORM: Direct rim and a rounded, exterior folded lip

CORE COLOR: $\mathrm{G}$ (fired in a reducing environment and cooled in the open air)

INTERIOR SURFACE COLOR: grayish-brown; fire clouds on the lower body and base

EXTERIOR SURFACE COLOR: yellowish-brown; fire clouds on the body and base

WALL THICKNESS (RIM, BODY, AND BASE IN MM): rim, $8.1 \mathrm{~mm}$

INTERIOR SURFACE TREATMENT: smoothed

EXTERIOR SURFACE TREATMENT: smoothed

HEIGHT (IN CM): 9.7

ORIFICE DIAMETER (IN CM): 18.9

DIAMETER AT BOTTOM OF RIM OR NECK (IN CM): 18.7

BASE DIAMETER (IN CM) AND SHAPE OF BASE: 7.5

ESTIMATED VOLUME (IN LITERS): 1.1

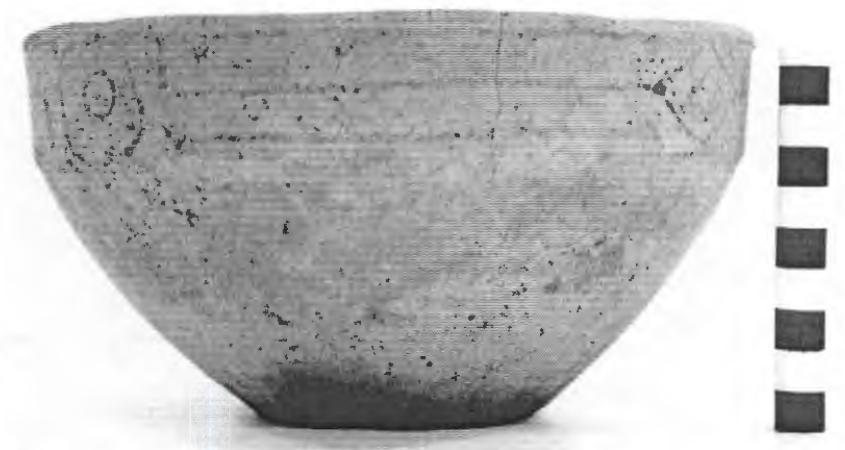

Figure 228. Ripley Engraved, var. McKinney carinated bowl, Frank Smith cemetery, Burial 5, Vessel 13A.

DECORATION (INCLUDING MOTIF AND ELEMENTS WHEN APPARENT): The rim panel has an engraved motif that features two sets each of central circles and nested diamond elements. These elements are either next to or encompassed in horizontal and vertical scroll lines and upper and lower excised pendant triangles (Figure 228).

PIGMENT USE AND LOCATION ON VESSEL: none TYPE AND VARIETY [IF KNOWN]: Ripley Engraved, var. McKinney 
VESSEL NO.: Burial 5, Vessel 14A; 2003.08.780

NON-PLASTICS AND PASTE: grog

VESSEL FORM: Carinated bowl

RIM AND LIP FORM: Inverted rim and rounded, exterior folded lip

CORE COLOR: $\mathrm{F}$ (fired in a reducing environment and cooled in the open air)

INTERIOR SURFACE COLOR: yellowish-brown; fire clouds on the lower body and base

EXTERIOR SURFACE COLOR: yellowish-brown; fire clouds on the rim, body, and base

WALL THICKNESS (RIM, BODY, AND BASE IN MM): rim, $5.5 \mathrm{~mm}$

INTERIOR SURFACE TREATMENT: smoothed

EXTERIOR SURFACE TREATMENT: smoothed

HEIGHT (IN CM): 11.1

ORIFICE DIAMETER (IN CM): 18.9

DIAMETER AT BOTTOM OF RIM OR NECK

(IN CM): 20.0

BASE DIAMETER (IN CM) AND SHAPE OF

BASE: 7.1 ; circular and flat

ESTIMATED VOLUME (IN LITERS): 1.3

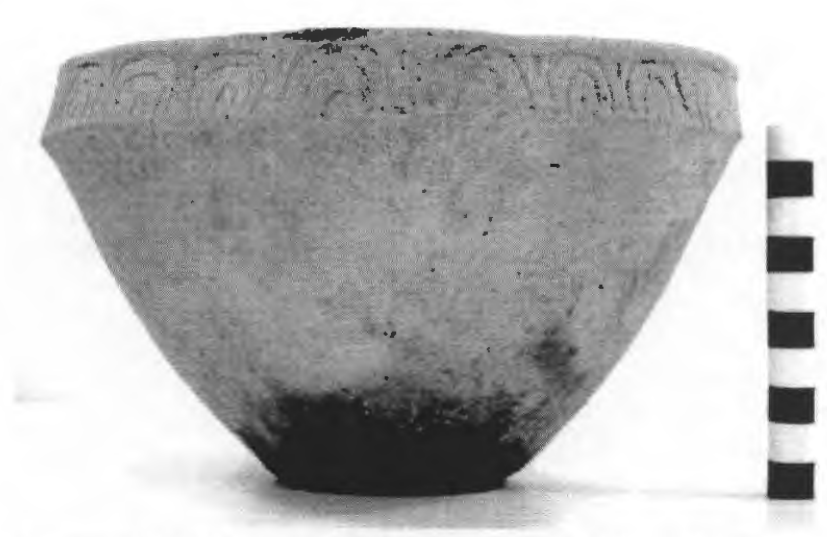

Figure 229. Womack Engraved, var. Gum Creek carinated bowl, Frank Smith cemetery, Burial 5, Vessel 14A.

DECORATION (INCLUDING MOTIF AND ELEMENTS WHEN APPARENT): The rim panel has a total of 21 concentric semi-circle elements. Seventeen have two concentric semi-circles and a short dashed line within the inner semi-circle. Another three have two concentric semi-circles but no dashed lines, and one has three concentric semi-circles and no inner dashed line. There are also 12 small excised triangles along the top part of the rim paneI, as well as six vertical engraved lines that divide several of the concentric semicircles (Figure 229).

PIGMENT USE AND LOCATION ON VESSEL: none

TYPEAND VARIETY [IF KNOWN]: Womack Engraved, var. Gum Creek 
VESSEL NO.: Burial 5, Vessel 14B; 2003.08.864

NON-PLASTICS AND PASTE: grog and bone

VESSEL FORM: Carinated bowl

RIM AND LIP FORM: Everted rim and rounded, exterior folded lip

CORE COLOR: $\mathrm{F}$ (fired in a reducing environment and cooled in the open air)

INTERIOR SURFACE COLOR: yellowish-brown; fire clouds on the rim, body, and base

EXTERIOR SURFACE COLOR: yellowish-brown; fire clouds on the rim and body; organic residue on the rim

WALL THICKNESS (RIM, BODY,AND BASE IN MM): rim, 7.8 mm

INTERIOR SURFACE TREATMENT: smoothed

EXTERIOR SURFACE TREATMENT:

smoothed

HEIGHT (IN CM): 14.6

ORIFICE DIAMETER (IN CM): 28.8

DIAMETER AT BOTTOM OF RIM OR

NECK (IN CM): 28.0

BASE DIAMETER (IN CM) AND SHAPE OF BASE:

9.4; circular and flat

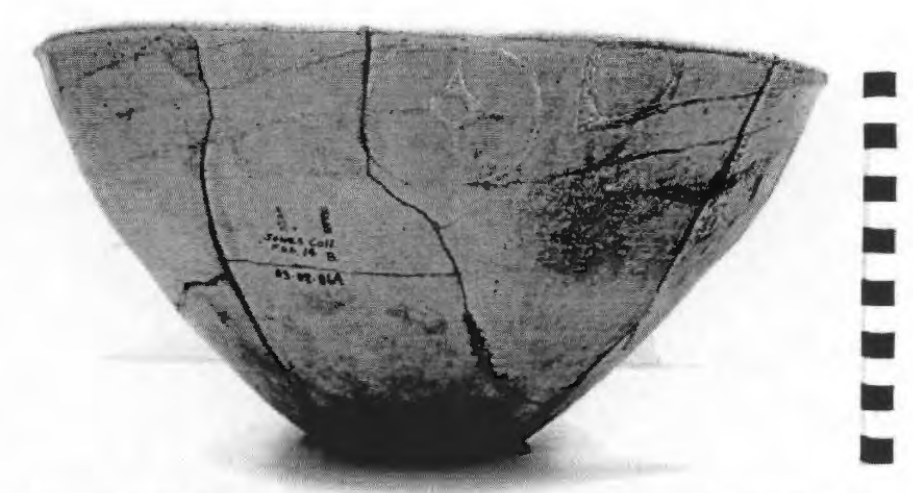

Figure 230. Ripley Engraved, var. Galt carinated bowl, ESTIMATED VOLUME (IN LITERS): 3.8 Frank Smith cemetery, Burial 5, Vessel 14B.

DECORATION (INCLUDING MOTIF AND ELEMENTS WHEN APPARENT): The rim panel has an engraved scroll and circle motif repeated four times around the vessel. The eircles have an inner circle with exeised rays or diamonds. The upper and lower scroll fill elements include hatched zones with negative ovals (Figure 230).

PIGMENT USE AND LOCATION ON VESSEL: white pigment in the engraved lines TYPE AND VARIETY [IF KNOWN]: Ripley Engraved, var. Galt 
VESSEL NO.: Burial 5, Vessel 15; 2003.08.196

NON-PLASTICS AND PASTE: grog and bone; sandy paste

VESSEL FORM: Bottle with a straight neck

RIM AND LIP FORM: Direct rim and a rounded, exterior folded lip

CORE COLOR: $\mathrm{F}$ (fired in a reducing environment and cooled in the open air)

INTERIOR SURFACE COLOR: reddish-brown

EXTERIOR SURFACE COLOR: yellowish-brown; fire clouds on the neck, body, and base

WALL THICKNESS (RIM, BODY, AND BASE IN MM): rim, $6.2 \mathrm{~mm}$

INTERIOR SURFACE TREATMENT: none

EXTERIOR SURFACE TREATMENT: smoothed

HEIGHT (IN CM): 15.8

ORIFICE DIAMETER (IN CM): 3.6

DIAMETER AT BOTTOM OF RIM OR NECK (IN CM):

$5.0 ; 11.0 \mathrm{~cm}$ maximum body diameter

BASE DIAMETER (IN CM) AND SHAPE OF BASE: 5.5; circular and rounded

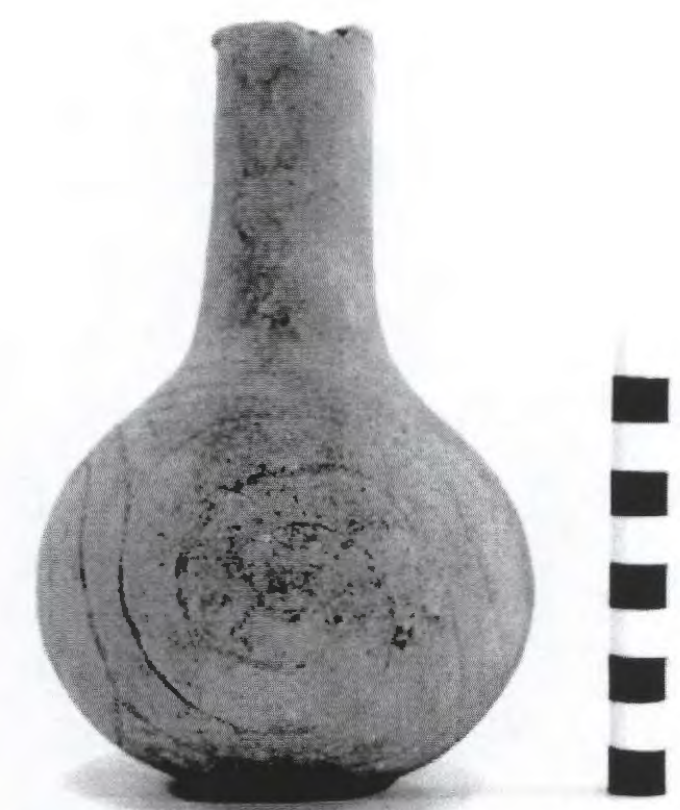

Figure 231. Wilder Engraved, var. unspecified bottle, Frank Smith cemetery, Burial 5, Vessel 15.

ESTIMATED VOLUME (IN LITERS): 0.35

DECORATION (INCLUDING MOTIF AND ELEMENTS WHEN APPARENT): The vessel body has a motif of engraved continuous spirals that end in hooked arms. This motif is repeated four times around the vessel, beginning at upper and lower large engraved triangles. Above each of the spirals are four alternating sets of engraved dashes and open triangles (Figure 231).

PIGMENT USE AND LOCATION ON VESSEL: red pigment in engraved lines

TYPE AND VARIETY [IF KNOWN]: Wilder Engraved, var. unspecified

\section{Burial 6}

Burial 6 was ca. $10 \mathrm{ft}$. west of Burial 5 , at the end of one of the east-west burial rows (see Figure 211). The burial pit reached to $0.94 \mathrm{~m}$ bs, and Jones (n.d.) reported that it had six ceramic vessels as funerary offerings. Four of these vessels have been identified in the Jones collection. They include a Harleton Appliqued jar, a Turner Engraved, var. Horton compound bowl, a Ripley Engraved, var. McKinney carinated bowl, and a Ripley Engraved, cf. var. McKinney carinated bowl. 
VESSEL NO.: Burial 6, Vessel 16; 2003.08.1830

NON-PLASTICS AND PASTE: bone

VESSEL FORM: Carinated bowl

RIM AND LIP FORM: Direct rim and a rounded, exterior folded lip

CORE COLOR: A (fired and cooled in an oxidizing environment)

INTERIOR SURFACE COLOR: light grayish-brown

EXTERIOR SURFACE COLOR: light grayish-brown; fire clouds on the base

WALL THICKNESS (RIM, BODY, AND BASE IN MM): rim, $5.6 \mathrm{~mm}$

INTERIOR SURFACE TREATMENT: none

EXTERIOR SURFACE TREATMENT: smoothed

HEIGHT (IN CM): 7.3

ORIFICE DIAMETER (IN CM): 17.6

DIAMETER AT BOTTOM OF RIM OR NECK (IN CM): 17.1

\section{BASE DIAMETER (IN CM) AND SHAPE OF} BASE: 7.0; circular and flat

ESTIMATED VOLUME (IN LITERS): 0.77

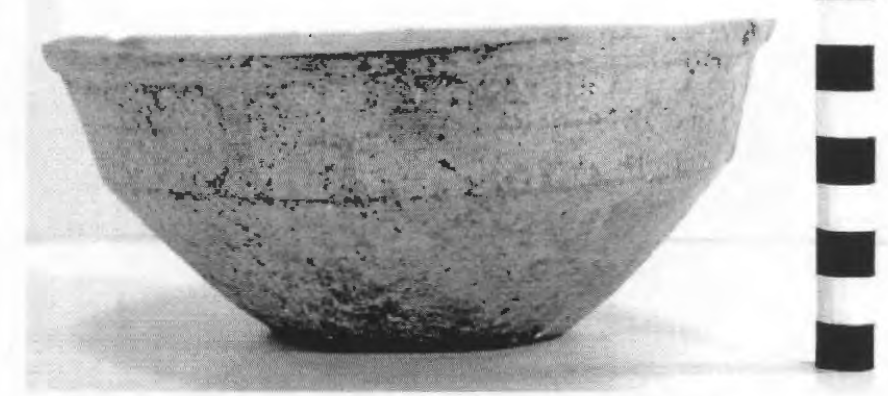

Figure 232. Ripley Engraved, cf. var. McKinney carinated bowl, Frank Smith cemetery, Burial 6, Vessel 16.

DECORATION (INCLUDING MOTIF AND ELEMENTS WHEN APPARENT): The rim panel has an engraved motif that features alternating circles (with an inner diamond) and hatched brackets. Between these central elements are horizontal interlocking scrolls with upper and lower excised brackets and upper and lower excised pendant triangles (Figure 232).

PIGMENT USE AND LOCATION ON VESSEL: none

TYPE AND VARIETY [IF KNOWN]: Ripley Engraved, cf. var. McKinney 
VESSEL NO.: Burial 6, Vessel 17; 2003.08.920

NON-PLASTICS AND PASTE: grog

VESSEL FORM: Carinated bowl

RIM AND LIP FORM: Direct rim and rounded, exterior folded lip

CORE COLOR: $\mathrm{G}$ (fired in a reducing environment and cooled in the open air)

INTERIOR SURFACE COLOR: grayish-brown

EXTERIOR SURFACE COLOR: dark yellowish-brown; fire clouds on the rim, body, and base

WALL THICKNESS (RIM, BODY, AND BASE IN MM): rim, $8.8 \mathrm{~mm}$; body, $7.9 \mathrm{~mm}$; base, $10.5 \mathrm{~mm}$

INTERIOR SURFACE TREATMENT: smoothed

EXTERIOR SURFACE TREATMENT:

smoothed

HEIGHT (IN CM): 15.3

ORIFICE DIAMETER (IN CM): 28.0

DIAMETER AT BOTTOM OF RIM OR NECK

(IN CM): 27.9

BASE DIAMETER (IN CM) AND SHAPE OF BASE: 8.5 ; circular and flat

ESTIMATED VOLUME (IN LITERS): 3.9

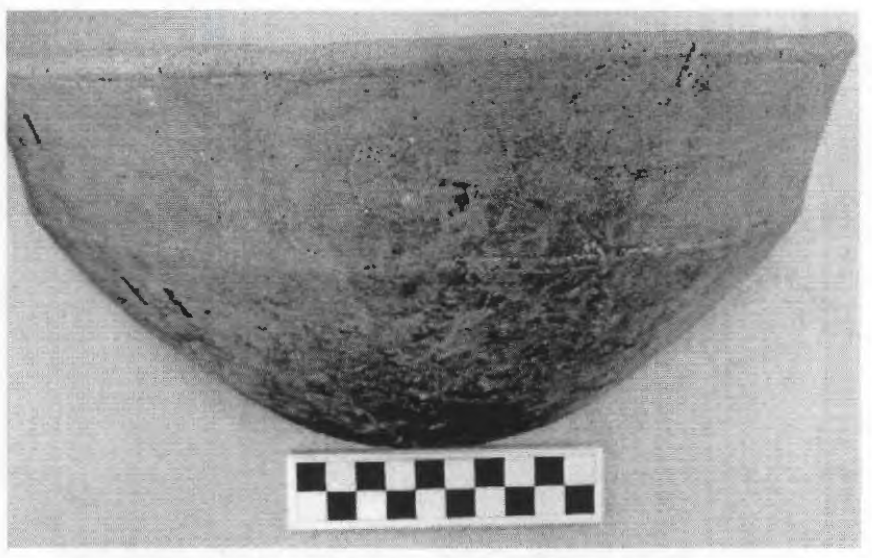

Figure 233. Ripley Engraved, var. McKinney carinated bowl, Frank Smith cemetery, Burial 6, Vessel 17.

DECORATION (INCLUDING MOTIF AND ELEMENTS WHEN APPARENT): The rim panel has an engraved motif that features two alternating circles (with an inner circle and cross element) and nested diamonds (with a smaller diamond within). The nested diamond elements occur with a continuous scroll element that ends on either side of the central circles. Above and below each of the scrolls are small excised pendant triangles (Figure 233).

PIGMENT USE AND LOCATION ON VESSEL: none

TYPE AND VARIETY [IF KNOWN]: Ripley Engraved, var. McKinney 
VESSEL NO.: Burial 6, Vessel 19; 2003.08.782

NON-PLASTICS AND PASTE: grog

VESSEL FORM: Compound bowl with four rim peaks (Figure 234)

RIM AND LIP FORM: Everted rim and rounded lip

CORE COLOR: G (fired in a reducing environment and cooled in the open air)

INTERIOR SURFACE COLOR: grayish-brown

EXTERIOR SURFACE COLOR: yellowish-brown; fire clouds on the rim, body, and base; organic residue on the rim

WALL THICKNESS (RIM, BODY, AND BASE

IN MM): rim, $5.6 \mathrm{~mm}$

INTERIOR SURFACE TREATMENT: smoothed

EXTERIOR SURFACE TREATMENT: smoothed

HEIGHT (IN CM): 6.8

ORIFICE DIAMETER (IN CM): 11.7

DIAMETER AT BOTTOM OF RIM OR NECK (IN CM): 10.5

\section{BASE DIAMETER (IN CM) AND SHAPE OF BASE: 7.0}

ESTIMATED VOLUME (IN LITERS): 0.63

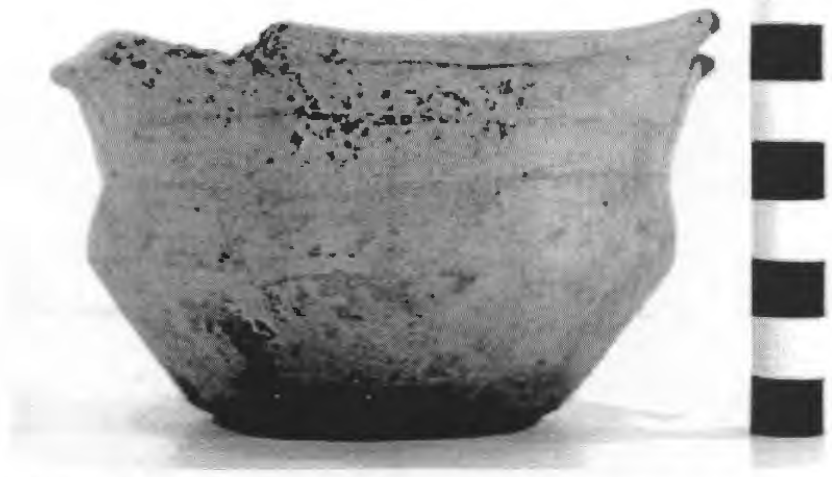

Figure 234. Turner Engraved, var. Horton compound bowl, Frank Smith cemetery, Burial 6, Vessel 19.

DECORATION (INCLUDING MOTIF AND ELEMENTS WHEN APPARENT): The upper rim panel is decorated with two widely-spaced horizontal engraved lines. The rim peaks have two small excised or hatched semi-circular elements that are separated by a single short vertical engraved line (Figure 234).

The lower rim panel has a series of eight large excised pendant triangles. These pendant triangles are separated from one another by a series of short diagonal dash marks (Figure 234).

PIGMENT USE AND LOCATION ON VESSEL: none

TYPE AND VARIETY [IF KNOWN]: Turner Engraved, var. Horton 
VESSEL NO.: Burial 6, Vessel 20; 2003.08.375

NON-PLASTICS AND PASTE: grog and hematite

VESSEL FORM: Jar

RIM AND LIP FORM: Everted rim and a rounded, exterior folded lip

CORE COLOR: $\mathrm{G}$ (fired in a reducing environment and cooled in the open air)

INTERIOR SURFACE COLOR: dark grayish-brown; organic residue on the rim

EXTERIOR SURFACE COLOR: yellowish-brown; fire clouds on the rim, body, and base

WALL THICKNESS (RIM, BODY, AND BASE IN MM): rim, $6.7 \mathrm{~mm}$

INTERIOR SURFACE TREATMENT: smoothed

EXTERIOR SURFACE TREATMENT: none

HEIGHT (IN CM): 14.0

ORIFICE DIAMETER (IN CM): 12.3

DIAMETER AT BOTTOM OF RIM OR NECK (IN CM): 9.4

BASE DIAMETER (IN CM) AND SHAPE OF BASE: 7.7; circular and flat

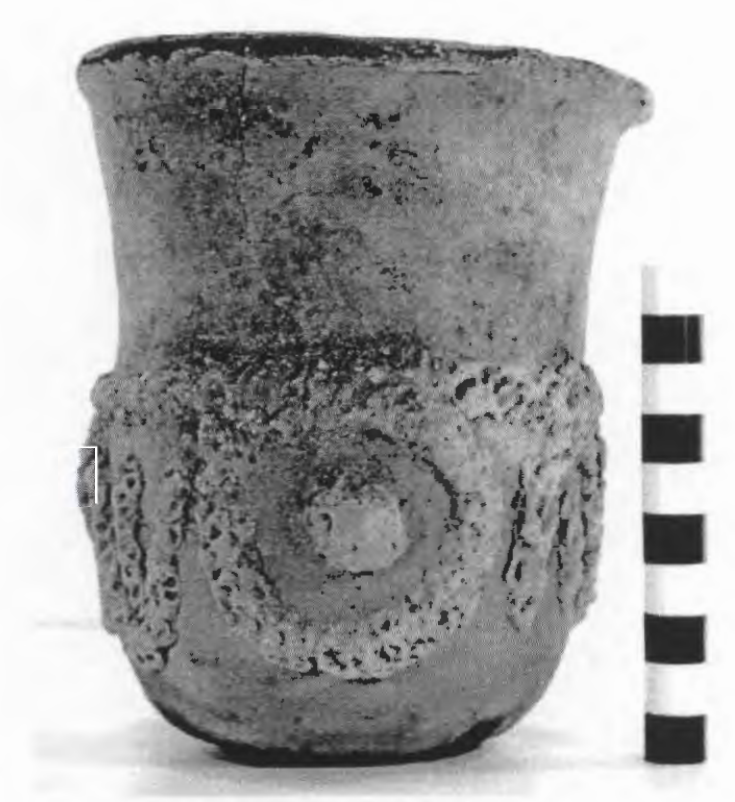

Figure 235. Harleton Appliqued jar, Frank Smith cemetery, Burial 6, Vessel 20.

ESTIMATED VOLUME (IN LITERS): 1.03

DECORATION (INCLUDING MOTIF AND ELEMENTS WHEN APPARENT): The rim is plain, but the vessel body has alternating sets of three semi-circular or circular appliqued fillet elements. Inside each of the appliqued semi-circles or circles are either single appliqued nodes or a linear appliqued fillet element (Figure 235).

PIGMENT USE AND LOCATION ON VESSEL: none

TYPE AND VARIETY [IF KNOWN]: Harleton Appliqued 


\section{Burial 7}

Burial 7 was at the eastern end of one of the northern burial rows in the cemetery, a few feet north of Burials 1 and 2 . The burial pit reached $0.96 \mathrm{~m}$ bs, and six ceramic vessels were reported by Jones (n.d.) to have been placed in the grave as funerary offerings. However, there are seven ceramic vessels in the Jones collection that are identified as being recovered in Burial 7. These include three jars (cf. Karnack Brushed-Incised, Harleton Appliqued, and Maydelle Incised), a compound bowl with hybrid Ripley Engraved, var. Galt-Turner Engraved, var. unspecified design motifs, and three carinated bowls: Ripley Engraved, cf. var. Gandy, Ripley Engraved, cf. var. Carpenter, and Ripley Engraved, var. McKinney.

VESSEL NO:: Burial 7, Vessel 22; 2003.08.785

NON-PLASTICS AND PASTE: grog; sandy paste

VESSEL FORM: Carinated bowl

RIM AND LIP FORM: Direct rim and a rounded, exterior folded lip

CORE COLOR: $\mathrm{F}$ (fired in a reducing environment and cooled in the open air)

INTERIOR SURFACE COLOR: reddish-brown; fire clouds on the rim, body, and base

EXTERIOR SURFACE COLOR: reddish-brown; fire clouding on the rim, body, and base

WALL THICKNESS (RIM, BODY, AND BASE IN MM): rim, $6.7 \mathrm{~mm}$

INTERIOR SURFACE TREATMENT: smoothed

EXTERIOR SURFACE TREATMENT: burnished

HEIGHT (IN CM): 14.3

ORIFICE DIAMETER (IN CM): 25.3

DIAMETER AT BOTTOM OF RIM OR NECK (IN CM): 25.1

BASE DIAMETER (IN CM) AND SHAPE OF BASE:

8.6; circular and flat

ESTIMATED VOLUME (IN LITERS): 3.3

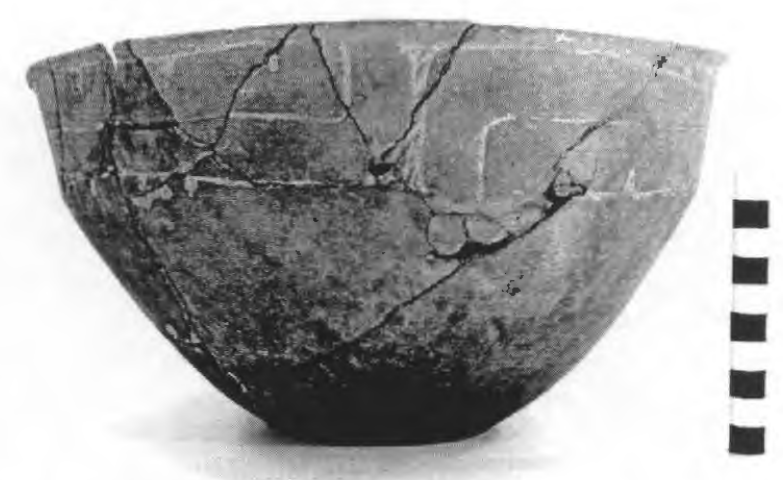

Figure 236. Ripley Engraved, cf. var. Gandy carinated bowl, Frank Smith cemetery, Burial 7, Vessel 22.

DECORATION (INCLUDING MOTIF AND ELEMENTS WHEN APPARENT): The rim panel has an engraved scroll motif repeated four times around the vessel. Above and below each scroll are small excised pendant triangles. The scrolls are divided by excised bracket elements (Figure 236).

There is also a horizontal engraved line at the carination on the vessel interior surface. 
VESSEL NO.: Burial 7, Vessel 23; 2003.08.267

NON-PLASTICS AND PASTE: grog

VESSEL FORM: Carinated bowl

RIM AND LIP FORM: Direct rim and a rounded, exterior folded lip

CORE COLOR: B (fired and cooled in a reducing environment)

INTERIOR SURFACE COLOR: dark grayish-brown

EXTERIOR SURFACE COLOR: grayish-brown; fire clouding on rim, body, and base

WALL THICKNESS (RIM, BODY, AND BASE IN MM): rim, 6.9 mm

INTERIOR SURFACE TREATMENT: smoothed

EXTERIOR SURFACE TREATMENT:

smoothed

HEIGHT (IN CM): 7.5

ORIFICE DIAMETER (IN CM): 14.6

DIAMETER AT BOTTOM OF RIM OR NECK

(IN CM): 14.7

BASE DIAMETER (IN CM) AND SHAPE OF

BASE: 7.5; circular and flat

ESTIMATED VOLUME (IN LITERS): 0.66

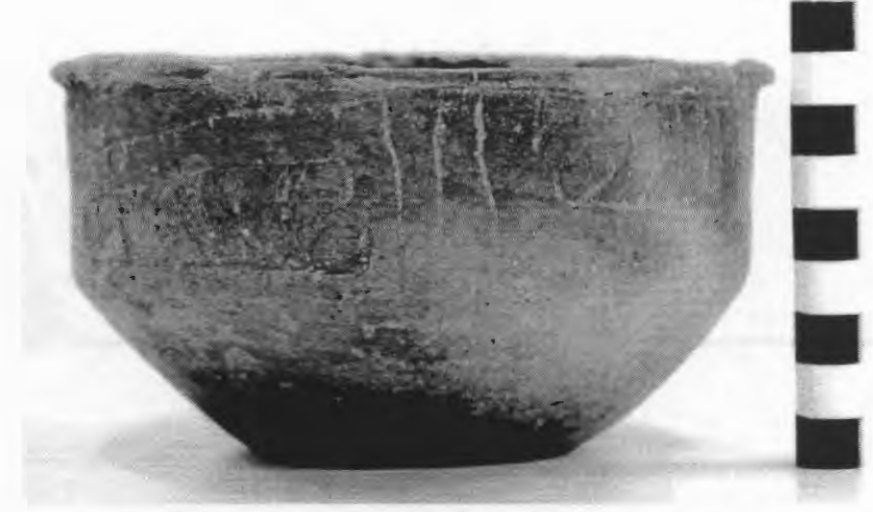

Figure 237. Ripley Engraved, cf. var. Carpenter carinated bowl, Frank Smith cemetery, Burial 7, Vessel 23.

DECORATION (INCLUDING MOTIFAND ELEMENTS WHEN APPARENT): The rim panel has a continuous scroll motif repeated four times around the vessel. The central scroll lines have small excised tick marks. The upper and lower scroll zones have alternating curvilinear hatched zones and curvilinear engraved lines, and there is a hooked arm element at the beginning of each scroll fill zone; underneath the hooked arm on each scroll fill zone is a single small excised triangle (Figure 237).

There is also a single horizontal engraved line at the carination point on the interior vessel surface.

PIGMENT USE AND LOCATION ON VESSEL: none

TYPE AND VARIETY [IF KNOWN]: Ripley Engraved, cf. var. Carpenter 
VESSEL NO.: Burial 7, Vessel 24; 2003.08.273

NON-PLASTICS AND PASTE: grog

VESSEL FORM: Jar with a collared rim (Figure 238)

RIM AND LIP FORM: Everted rim and rounded lip

CORE COLOR: $\mathrm{G}$ (fired in a reducing environment and cooled in the open air)

INTERIOR SURFACE COLOR: dark grayish-brown; fire clouding on the base

EXTERIOR SURFACE COLOR: yellowish-brown; fire clouds on the rim, body, and base

WALL THICKNESS (RIM, BODY, AND BASE IN

$\mathrm{MM})$ : rim, $6.2 \mathrm{~mm}$

INTERIOR SURFACE TREATMENT: smoothed

EXTERIOR SURFACE TREATMENT: none

HEIGHT (IN CM): 11.8

ORIFICE DIAMETER (IN CM): II.5

DIAMETER AT BOTTOM OF RIM OR NECK (IN

CM): 9.9

BASE DIAMETER (IN CM) AND SHAPE OF

BASE: 6.5

ESTIMATED VOLUME (IN LITERS): 0.81

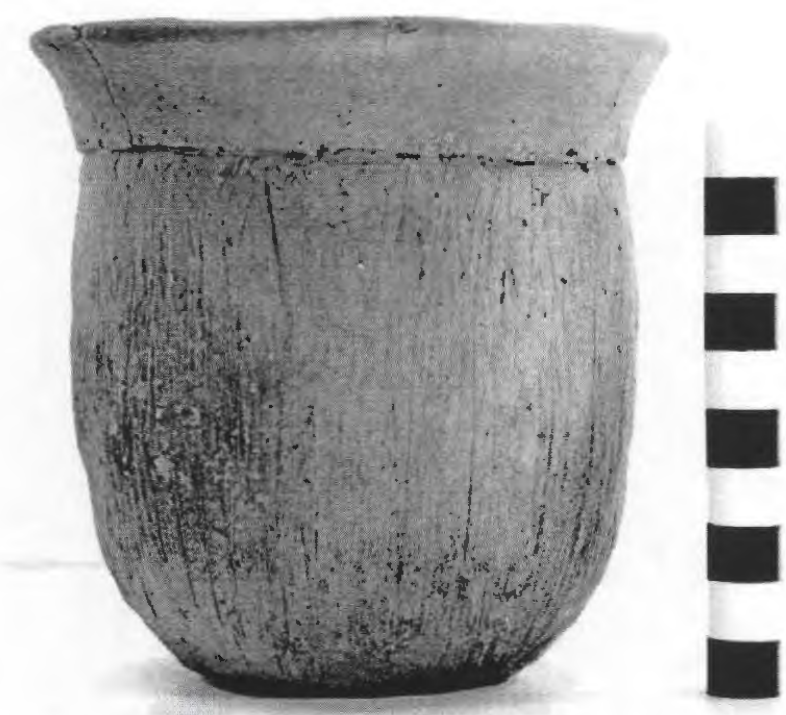

Figure 238. cf. Karnack Brushed-Incised jar, Frank Smith cemetery, Burial 7, Vessel 24.

DECORATION (INCLUDING MOTIF AND ELEMENTS WHEN APPARENT): There is a single broad horizontal incised line at the rim-body juncture. The vessel body has vertical brushing marks that extend to the base (Figure 238).

PIGMENT USE AND LOCATION ON VESSEL: none

TYPE AND VARIETY [IF KNOWN]: cf. Karnack Brushed-Incised 
VESSEL NO.: Burial 7, Vessel 25; 2003.08.1747

NON-PLASTICS AND PASTE: grog and bone

VESSEL FORM: Jar with four rim peaks and strap handles (36 x $25 \mathrm{~mm}$ in length and width) (Figure 239)

RIM AND LIP FORM: Direct rim and a rounded lip

CORE COLOR: B (fired and cooled in a reducing environment)

INTERIOR SURFACE COLOR: black

EXTERIOR SURFACE COLOR: black

WALL THICKNESS (RIM, BODY, AND BASE IN MM): rim, $7.1 \mathrm{~mm}$

INTERIOR SURFACE TREATMENT: none

EXTERIOR SURFACE TREATMENT: none

HEIGHT (IN CM): 14.5

ORIFICE DIAMETER (IN CM): 16.5

DIAMETER AT BOTTOM OF RIM OR NECK (IN CM): 16.3

BASE DIAMETER (IN CM) AND SHAPE OF BASE: 8.3

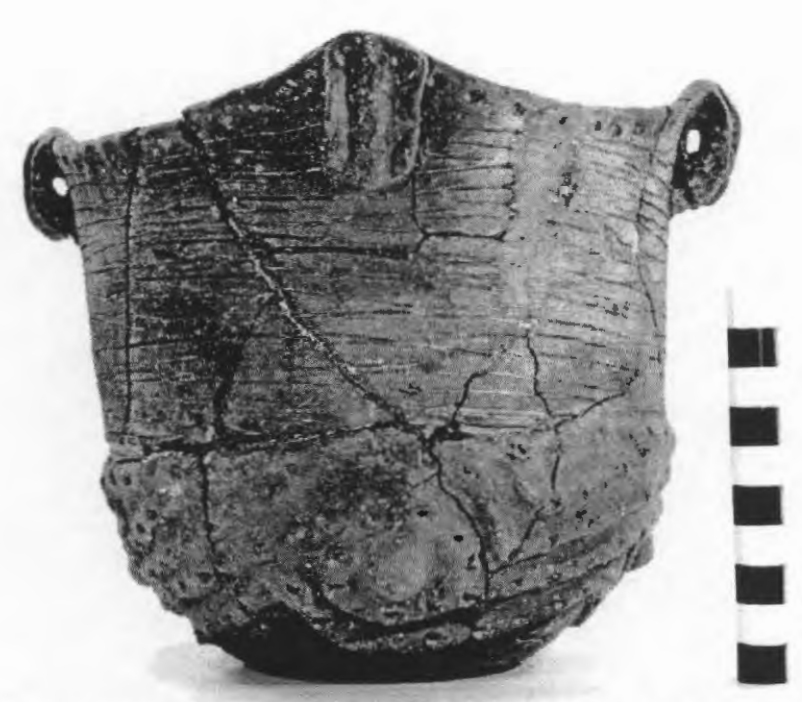

Figure 239. Harleton Appliqued jar, Frank Smith cemetery, Burial 7, Vessel 25.

ESTIMATED VOLUME (IN LITERS): 1.4

DECORATION (INCLUDING MOTIF AND ELEMENTS WHEN APPARENT): The rim has a single row of tool punctations under the lip as well as a series of closely-spaced horizontal incised lines. The vessel body has a scroll and circle motif in appliqued fillets that is repeated four times around the vessel. There is a large appliqued node inside each of the four circles, and there are also appliqued fillet chevrons above and below each of the scrolls (Figure 239).

PIGMENT USE AND LOCATION ON VESSEL: none

TYPE AND VARIETY [IF KNOWN]: Harleton Appliqued 
VESSEL NO.: Burial 7, Vessel 26; 2003.08.88

NON-PLASTICS AND PASTE: grog; sandy paste

VESSEL FORM: Carinated bowl

RIM AND LIP FORM: Direct rim and a rounded, exterior folded lip

CORE COLOR: $F$ (fired in a reducing environment and cooled in the open air)

INTERIOR SURFACE COLOR: red

EXTERIOR SURFACE COLOR: red

WALL THICKNESS (RIM, BODY, AND BASE IN MM): rim, 5.6 mm

INTERIOR SURFACE TREATMENT: smoothed

EXTERIOR SURFACE TREATMENT:

smoothed

HEIGHT (IN CM): 7.0

ORIFICE DIAMETER (IN CM): 15.5

DIAMETER AT BOTTOM OF RIM OR

NECK (IN CM): 13.0

BASE DIAMETER (IN CM) AND SHAPE OF

BASE: 5.0 ; circular and flat

ESTIMATED VOLUME (IN LITERS): 0.65

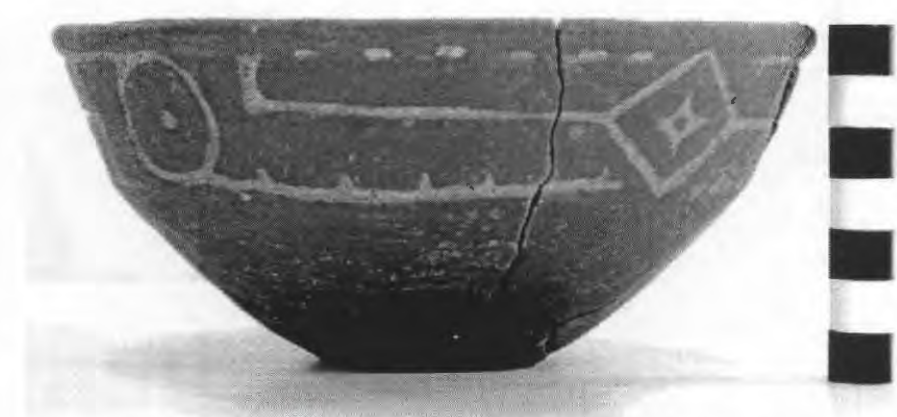

Figure 240. Ripley Engraved, var. McKinney carinated bowl, Frank Smith cemetery, Burial 7, Vessel 26.

DECORATION (INCLUDING MOTIF AND ELEMENTS WHEN APPARENT): The vessel has a red slip on both interior and exterior surfaces. The rim panel features two central engraved circles (each with a central excised dot) that alternate with two engraved nested diamonds (each with a smaller engraved diamond within). The nested diamond element is in a central place in a horizontal scroll, and above and below the scroll line are excised pendant triangles and oval-shaped excised dashes. The scrolls end at upper and lower excised brackets (Figure 240).

There is also a horizontal engraved line at the carination on the interior vessel surface.

PIGMENT USE AND LOCATION ON VESSEL: none

TYPE AND VARIETY [IF KNOWN]: Ripley Engraved, var. McKinney 
VESSEL NO.: Burial 7, Vessel 27; 2003.08.232

NON-PLASTICS AND PASTE: grog

VESSEL FORM: Compound bowl with four rim peaks (Figure 241)

RIM AND LIP FORM: Everted rim and rounded lip

CORE COLOR: $\mathrm{F}$ (fired in a reducing environment and cooled in the open air)

INTERIOR SURFACE COLOR: red

EXTERIOR SURFACE COLOR: red

WALL THICKNESS (RIM, BODY, AND BASE IN MM): rim, $6.0 \mathrm{~mm}$

INTERIOR SURFACE TREATMENT: smoothed

EXTERIOR SURFACE TREATMENT:

smoothed

HEIGHT (IN CM): 7.5

ORIFICE DIAMETER (IN CM): 14.4

DIAMETER AT BOTTOM OF RIM OR NECK

(IN CM): 12.1

BASE DIAMETER (IN CM) AND SHAPE OF

BASE: 5.0; circular and flat

ESTIMATED VOLUME (IN LITERS): 0.86

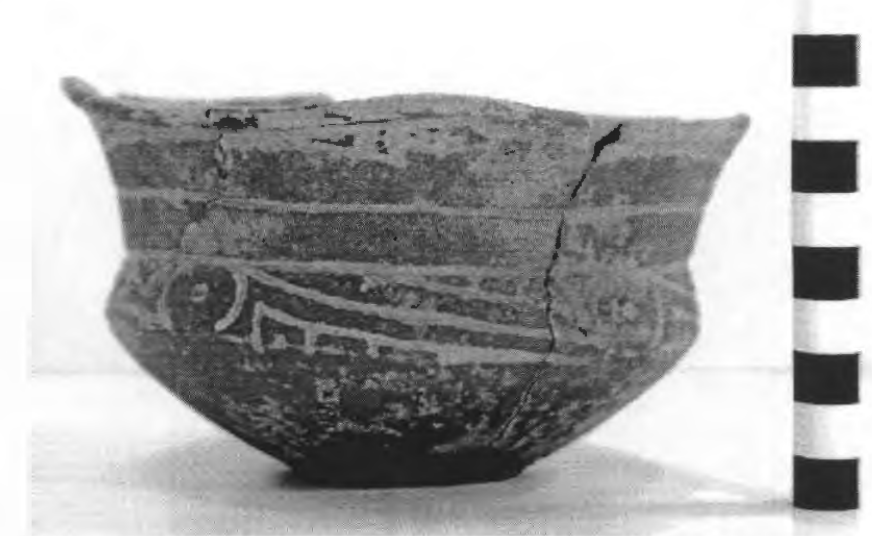

Figure 241. Ripley Engraved, var. Galt and Turner Engraved, var. unspecified hybrid compound bowl, Frank Smith cemetery, Burial 7, Vessel 27.

DECORATION (INCLUDING MOTIF AND ELEMENTS WHEN APPARENT): The vessel has a red slip on both interior and exterior vessel surfaces. The upper rim panel has three widely-spaced horizontal engraved lines. The rim peaks have a centrally placed engraved circle with a central excised dot and scroll fill elements (Figure 241).

The lower rim panel has an engraved scroll and circle motif that is repeated four times around the vessel. The central circles - as on the rim peaks - each have a small central excised dot. The scroll fill elements have curvilinear engraved lines and oval-shaped areas, one of which in each of the lower scroll fill zones has an excised dot or small excised triangle in it (Figure 241).

PIGMENT USE AND LOCATION ON VESSEL: none

TYPE AND VARIETY [IF KNOWN]: Ripley Engraved, var. Galt and Turner Engraved, var. unspecified hybrid 
VESSEL NO.: Burial 7, Vessel M-5-27; 2003.08.186

NON-PLASTICS AND PASTE: grog

VESSEL FORM: Miniature jar

RIM AND LIP FORM: Direct rim and a rounded lip

CORE COLOR: $\mathrm{F}$ (fired in a reducing environment and cooled in the open air)

INTERIOR SURFACE COLOR: reddish-brown; fire clouds on the base

EXTERIOR SURFACE COLOR: reddish-brown; fire clouding on the rim, body, and base

WALL THICKNESS (RIM, BODY, AND BASE IN

MM): rim, $6.4 \mathrm{~mm}$

INTERIOR SURFACE TREATMENT: none

EXTERIOR SURFACE TREATMENT: none

HEIGHT (IN CM): 5.3

ORIFICE DIAMETER (IN CM): 5.9

DIAMETER AT BOTTOM OF RIM OR NECK (IN CM): 5.9

BASE DIAMETER (IN CM) AND SHAPE OF BASE: 5.4 ; circular and flat

ESTIMATED VOLUME (IN LITERS): 0.19

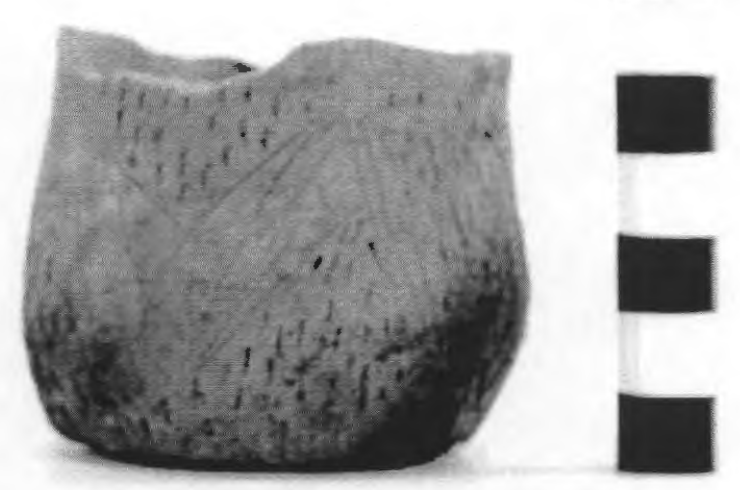

Figure 242. Maydelle Incised jar, Frank Smith cemetery, Burial 7, Vessel M-5-27.

DECORATION (INCLUDING MOTIF AND ELEMENTS WHEN APPARENT): The vessel has an incised-punctated motif that extends from the rim to near the vessel base. It consists of a series of four incised chevrons that have created triangular-shaped areas filled with tool punctations. Below the bottom of the incised chevrons are randomly placed tool punctations (Figure 242).

PIGMENT USE AND LOCATION ON VESSEL: none

TYPE AND VARIETY [IF KNOWN]: Maydelle Incised

\section{Burial 8}

The location of Burial 8 within the Frank Smith cemetery is unknown, but a draft map prepared by Jones (n.d.) in 1955 suggests it was a few feet east or northeast of Burial 7 at the eastern end of one of the northern burial rows (see Figure 211). The burial pit extended to $0.99 \mathrm{~m}$ bs, and funerary offerings consisted of seven ceramic vessels, all identified in the Jones collection. 
The vessels in Burial 8 include a Bailey Engraved bottle and a second bottle with an unidentified engraved motif, an incised-punctated jar, and four carinated bowls. The carinated bowls include Ripley Engraved, var. McKinney, Ripley Engraved, var. Cash $(\mathrm{n}=2)$, and Ripley Engraved, var. unspecified.

VESSEL NO.: Burial 8, Vessel 28; 2003.08.1793

NON-PLASTICS AND PASTE: grog

VESSEL FORM: carinated bowl

RIM AND LIP FORM: Direct rim and a rounded, exterior folded lip

CORE COLOR: $\mathrm{F}$ (fired in a reducing environment and cooled in the open air)

INTERIOR SURFACE COLOR: yellowish-brown; fire clouding on the base

EXTERIOR SURFACE COLOR: yellowishbrown; fire clouding on the body and base

WALL THICKNESS (RIM, BODY, AND BASE IN MM): rim, $6.7 \mathrm{~mm}$

INTERIOR SURFACE TREATMENT: smoothed EXTERIOR SURFACE TREATMENT: smoothed HEIGHT (IN CM): 15.6

ORIFICE DIAMETER (IN CM): 30.2

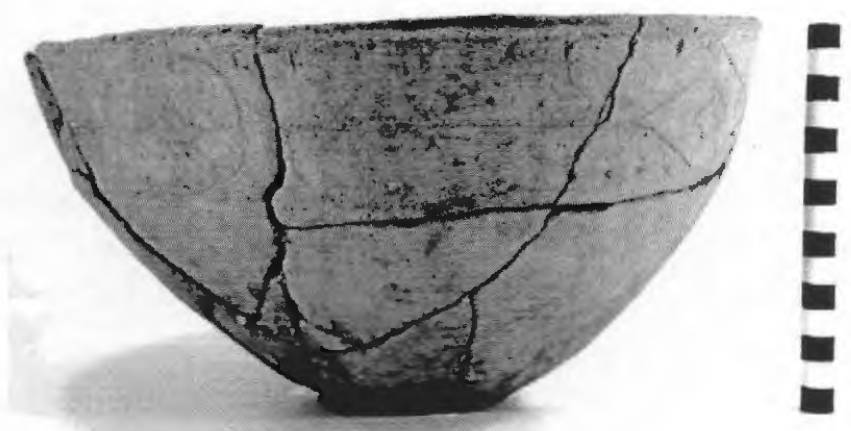

Figure 243. Ripley Engraved, var. McKinney carinated bowl, Frank Smith cemetery, Burial 8, Vessel 28.

DIAMETER AT BOTTOM OF RIM OR NECK (IN CM): 28.3

BASE DIAMETER (IN CM) AND SHAPE OF BASE: 8.0; flat and circular

\section{ESTIMATED VOLUME (IN LITERS): 4.2}

DECORATION (INCLUDING MOTIF AND ELEMENTS WHEN APPARENT): The rim panel has two central engraved circles (with a diamond within the circle; there is a single punctation within the diamond) that alternate with two nested diamonds; there is a smaller diamond within it, and this smaller diamond has a single punctate at its center. The diamonds are at the center of a horizontal scroll with upper and lower excised brackets. Above and below the scrolls and the nested diamonds are alternating series of both small pendant triangles and punctated dashes (Figure 243).

PIGMENT USE AND LOCATION ON VESSEL: white pigment in the engraved lines 
VESSEL NO.: Burial 8, Vessel 28; 2003.08.1839

NON-PLASTICS AND PASTE: grog; sandy paste

VESSEL FORM: Bottle

RIM AND LIP FORM: Everted rim and a rounded lip

CORE COLOR: $\mathrm{G}$ (fired in a reducing environment and cooled in the open air)

INTERIOR SURFACE COLOR: grayish-brown

EXTERIOR SURFACE COLOR: yellowish-brown; fire clouding on the rim and body

WALL THICKNESS (RIM, BODY, AND BASE IN MM): neck, $6.3 \mathrm{~mm}$

INTERIOR SURFACE TREATMENT: none

EXTERIOR SURFACE TREATMENT: smoothed

HEIGHT (IN CM): 14.7

ORIFICE DIAMETER (IN CM): 5.1

DIAMETER AT BOTTOM OF RIM OR NECK (IN CM): $5.0 ; 12.5 \mathrm{~cm}$ maximum body diameter

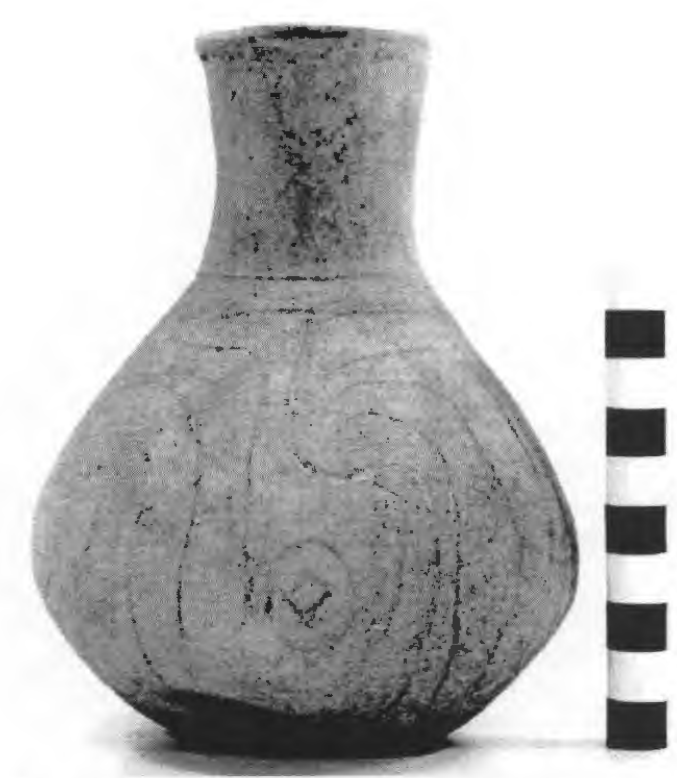

Figure 244. Engraved bottle, Frank Smith cemetery, Burial 8, Vessel 2003.08.1839.

BASE DIAMETER (IN CM) AND SHAPE OF BASE: 7.0

ESTIMATED VOLUME (IN LITERS): 0.41

DECORATION (INCLUDING MOTIF AND ELEMENTS WHEN APPARENT): The vessel has four repeating panels of engraved elements that suggest a fusion of Ripley Engraved and Taylor Engraved motifs. The elements include meandering scrolls, a single hooked arm, as well as an engraved circle with an open diamond element within it (Figure 244). The panel is defined by single upper and lower horizontal engraved lines.

PIGMENT USE AND LOCATION ON VESSEL: none

TYPE AND VARIETY [IF KNOWN]: Unidentified fine ware 
VESSEL NO.: Burial 8, Vessel 30; 2003.08.274

NON-PLASTICS AND PASTE: grog

VESSEL FORM: Carinated bowl

RIM AND LIP FORM: Direct rim and a rounded, exterior folded lip

CORE COLOR: F (fired in a reducing environment and cooled in the open air)

INTERIOR SURFACE COLOR: yellowish-brown; fire clouds on the lower body and base

EXTERIOR SURFACE COLOR: yellowish-brown; fire clouds on the rim, body, and base

WALL THICKNESS (RIM, BODY, AND BASE IN MM): rim, 6.9 mm

INTERIOR SURFACE TREATMENT: smoothed

EXTERIOR SURFACE TREATMENT:

smoothed

HEIGHT (IN CM): I1.0

ORIFICE DIAMETER (IN CM): 22.1

DIAMETER AT BOTTOM OF RIM OR NECK

(IN CM): 22.0

BASE DIAMETER (IN CM) AND SHAPE OF

BASE: 8.0 ; circular and flat

ESTIMATED VOLUME (IN LITERS): 1.5

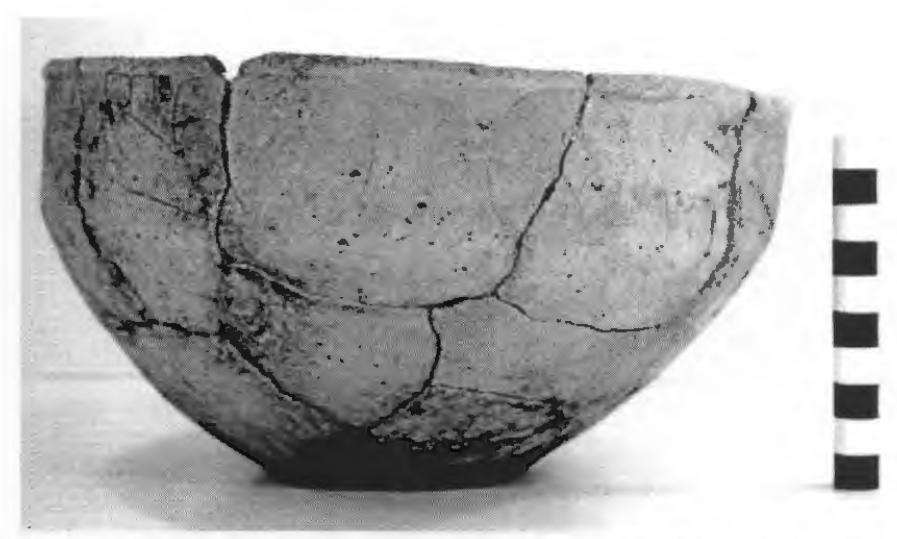

Figure 245. Ripley Engraved, cf. var. Cash carinated bowl, Frank Smith cemetery, Burial 8, Vessel 30.

DECORATION (INCLUDING MOTIF AND ELEMENTS WHEN APPARENT): The rim panel has an engraved circle and nested triangle motif repeated three times around the vessel. There is an extra fourth engraved circle on the rim panel, separated from the others by a vertical excised bracket (Figure 245). Each of the circles have a nested diamond element within, and the nested triangles alternate with the circles. The nested triangles have oval-shaped elements within, defined by small excised triangles within the larger nested triangle, and the ovals have a single distinctive spur element within them. Other elements include triangular-shaped zones with vertical engraved lines and a small excised triangle.

PIGMENT USE AND LOCATION ON VESSEL: none

TYPE AND VARIETY [IF KNOWN]: Ripley Engraved, cf. var. Cash 
VESSEL NO:: Burial 8, Vessel 31; 2003.08.755

NON-PLASTICS AND PASTE: bone and hematite

VESSEL FORM: Jar

RIM AND LIP FORM: Everted rim and rounded lip

CORE COLOR: G (fired in a reducing environment and cooled in the open air)

INTERIOR SURFACE COLOR: dark grayish-brown

EXTERIOR SURFACE COLOR: yellowish-brown; fire clouds on the rim, body, and base; organic residue on the upper body

WALL THICKNESS (RIM, BODY, AND BASE IN MM): rim, $10.1 \mathrm{~mm}$

INTERIOR SURFACE TREATMENT: smoothed

EXTERIOR SURFACE TREATMENT: none

HEIGHT (IN CM): 24.4

ORIFICE DIAMETER (IN CM): 26.9

DIAMETER AT BOTTOM OF RIM OR NECK (IN CM): 24.8

BASE DIAMETER (IN CM) AND SHAPE OF BASE: 8.0; circular and flat

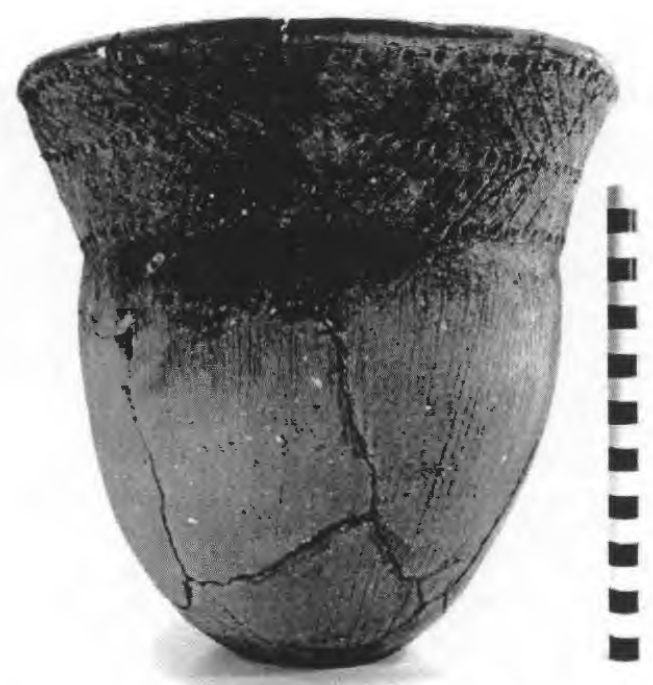

Figure 246. Brushed-punctated-incised jar, Frank Smith cemetery, Burial 8, ESTIMATED VOLUME (IN LITERS): 8.5 Vessel 31.

DECORATION (INCLUDING MOTIF AND ELEMENTS WHEN APPARENT): The rim has three horizontal rows of tool punctations, one under the lip, a second mid-way down the rim, and the third row at the rim-body juncture. Between these tool punctated rows are separate left to right pitched, and right to left pitched, sets of diagonal incised lines. The vessel body has vertical brushing marks (Figure 246).

PIGMENT USE AND LOCATION ON VESSEL: none

TYPE AND VARIETY [IF KNOWN]: Unidentified utility ware 
VESSEL NO.: Burial 8, Vessel 32; 2003.08.190

NON-PLASTICS AND PASTE: grog

VESSEL FORM: miniature carinated bowl (Figure 247)

RIM AND LIP FORM: Direct rim and a rounded, exterior folded lip

CORE COLOR: B (fired and cooled in a reducing environment)

INTERIOR SURFACE COLOR: black

EXTERIOR SURFACE COLOR: black; fire cloud on the lip

WALL THICKNESS (RIM, BODY, AND BASE IN MM): rim, $5.9 \mathrm{~mm}$

INTERIOR SURFACE TREATMENT: smoothed

EXTERIOR SURFACE TREATMENT: smoothed

HEIGHT (IN CM): 3.5

ORIFICE DIAMETER (IN CM): 7.8

DIAMETER AT BOTTOM OF RIM OR NECK (IN CM): 6.2

BASE DIAMETER (IN CM) AND SHAPE OF BASE: 3.7 ; circular and flat

ESTIMATED VOLUME (IN LITERS): 0.16

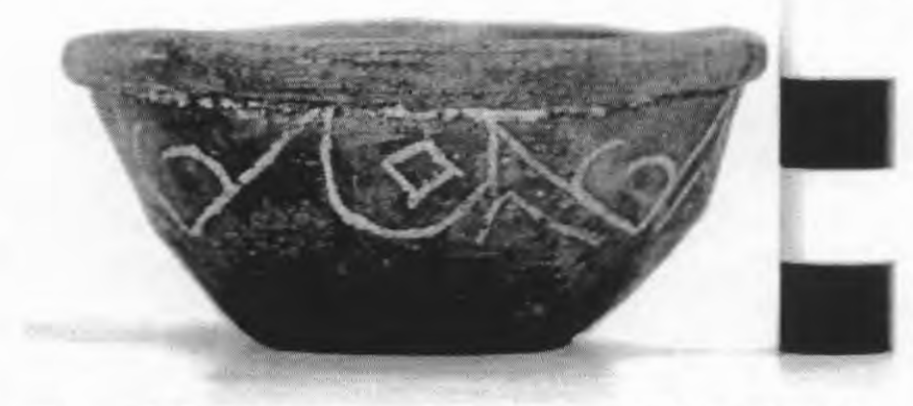

Figure 247. Ripley Engraved, cf. var. Cash carinated bowl, Frank Smith cemetery, Burial 8, Vessel 32.

DECORATION (INCLUDING MOTIF AND ELEMENTS WHEN APPARENT): The rim panel has an engraved circle and nested triangle motif repeated three times around the vessel; there is an extra nested triangle in the motif. The engraved circles have a small diamond element within, while the nested triangles have curvilinear and nearly hooked engraved lines within them; three of them also have a small triangularshaped area pendant from the rim (Figure 247).

There is a single horizontal engraved line on the interior vessel surface at the carination.

PIGMENT USE AND LOCATION ON VESSEL: both red and white pigments in engraved lines on the exterior surface; the red pigment appears to have been placed over the white pigment. Both white and red pigments have been rubbed in the interior horizontal engraved line.

TYPE AND VARIETY [IF KNOWN]: Ripley Engraved, cf. var. Cash 
VESSEL NO.: Burial 8, Vessel 33; 2003.08.17

NON-PLASTICS AND PASTE: grog

VESSEL FORM: Bottle with a flaring neck

RIM AND LIP FORM: Everted rim and rounded lip

CORE COLOR: N/A

INTERIOR SURFACE COLOR: N/A

EXTERIOR SURFACE COLOR: dark grayish-brown; fire clouding on the neck

WALL THICKNESS (RIM, BODY, AND BASE IN $\mathrm{MM})$ : rim, $3.9 \mathrm{~mm}$

INTERIOR SURFACE TREATMENT: none

EXTERIOR SURFACE TREATMENT: smoothed

HEIGHT (IN CM): 12.3

ORIFICE DIAMETER (IN CM): 4.5

DIAMETER AT BOTTOM OF RIM OR NECK (IN $\mathrm{CM})$ : 4.3 ; maximum body diameter of $9.0 \mathrm{~cm}$

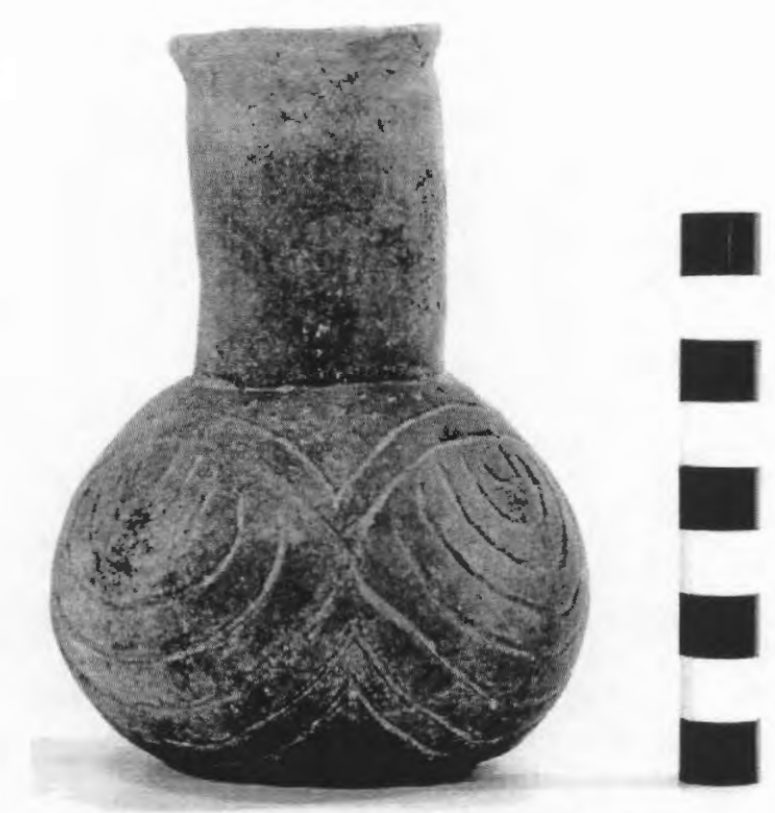

Figure 248. Bailey Engraved bottle, Frank Smith cemetery, Burial 8, Vessel 33.

BASE DIAMETER (IN CM) AND SHAPE OF BASE: 6.0; circular and flat

ESTIMATED VOLUME (IN LITERS): 0.30

DECORATION (INCLUDING MOTIF AND ELEMENTS WHEN APPARENT): The vessel body has four sets of concentric engraved arcs, with seven engraved lines in each set. Above the engraved arcs is a band filled with tool punctations (Figure 248); from above, the band forms a square around the bottle neck.

PIGMENT USE AND LOCATION ON VESSEL: red pigment in engraved lines

TYPE AND VARIETY [IF KNOWN]: Bailey Engraved 
VESSEL NO:: Burial 8, Vessel 34; 2003.08.403

NON-PLASTICS AND PASTE: grog

VESSEL FORM: Carinated bowl

RIM AND LIP FORM: Everted rim and a rounded, exterior folded lip

CORE COLOR: $\mathrm{F}$ (fired in a reducing environment and cooled in the open air)

INTERIOR SURFACE COLOR: reddish-brown; fire clouds on the rim and body; green glauconitic clay pigment stains

EXTERIOR SURFACE COLOR: reddish-brown;

fire clouds on the rim, body, and base

WALL THICKNESS (RIM, BODY, AND BASE IN MM): rim, $7.0 \mathrm{~mm}$

INTERIOR SURFACE TREATMENT: smoothed EXTERIOR SURFACE TREATMENT: burnished

HEIGHT (IN CM): 4.8

ORIFICE DIAMETER (IN CM): 13.0

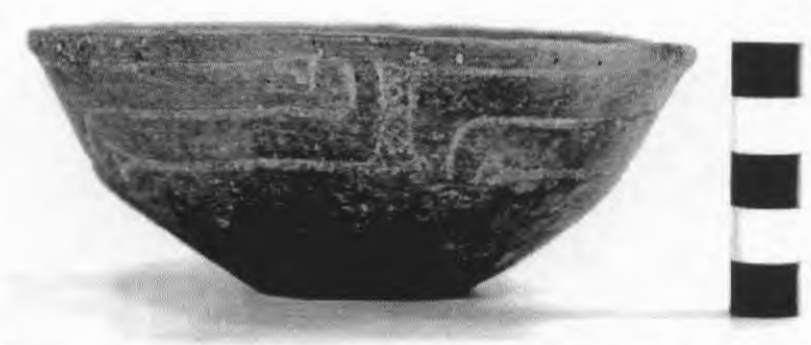

Figure 249. Ripley Engraved, cf. var. Gandy carinated bowl, Frank Smith cemetery, Burial 8, Vessel 34.

DIAMETER AT BOTTOM OF RIM OR NECK (IN CM): 10.4

BASE DIAMETER (IN CM) AND SHAPE OF BASE: 4.2; circular and flat

ESTIMATED VOLUME (IN LITERS): 0.37

DECORATION (INCLUDING MOTIF AND ELEMENTS WHEN APPARENT): The rim panel has an engraved scroll motif repeated four times around the vessel. The scrolls are divided from each other by excised brackets. Above and below each scroll is a single large and open pendant triangle (Figure 249).

There is a horizontal engraved line on the vessel interior surface at the carination.

PIGMENT USE AND LOCATION ON VESSEL: white pigment in engraved lines TYPE AND VARIETY [IF KNOWN]: Ripley Engraved, cf. var. Gandy 


\section{Burial 9}

Burial 9 was in the southernmost burial row in the cemetery, a few feet south of Burial 5 (see Figure 211). Five ceramic vessels had been placed with the deceased in the grave, which extended to $0.76 \mathrm{~m}$ bs. The vessels include a Harleton Appliqued jar and four carinated bowls: Taylor Engraved, Ripley Engraved, var. unspecified, and Ripley Engraved, var. Caldwell or an unspecified variety of Womack Engraved.

In addition to the ceramic vessels, a tubular engraved ceramic pipe is identified in the Jones collection as coming from Burial 9 at the Frank Smith cemetery.

VESSEL NO.: Burial 9, Vessel 35; 2003.08.444

NON-PLASTICS AND PASTE: grog and hematite; sandy paste

VESSEL FORM: Jar with four rim peaks; four star-shaped appliqued lugs under each of the rim peaks (Figure 250)

RIM AND LIP FORM: Everted rim and a rounded lip

CORE COLOR: $\mathrm{F}$ (fired in a reducing environment and cooled in the open air)

INTERIOR SURFACE COLOR: yellowish-brown; fire clouds on the base; organic residue on the rim and body

EXTERIOR SURFACE COLOR: yellowish-brown; fire clouds on the body and base; organic residue on the rim and body

WALL THICKNESS (RIM, BODY, AND BASE IN MM): rim, 6.9 mm

INTERIOR SURFACE TREATMENT: smoothed

EXTERIOR SURFACE TREATMENT: none

HEIGHT (IN CM): 19.1

ORIFICE DIAMETER (1N CM): 16.9

DIAMETER AT BOTTOM OF RIM OR NECK (IN CM): 16.2

BASE DIAMETER (IN CM) AND SHAPE OF BASE: 9.0

ESTIMATED VOLUME (IN LITERS): 2.9 
DECORATION (INCLUDING MOTIF AND ELEMENTS WHEN APPARENT): The rim has a continuous series of vertical incised lines around the vessel. The body has an appliqued fillet scroll and circle motif repeated four times around the vessel; the appliqued circle element has a smaller appliqued circle within it as well as a small appliqued node at the center of the smaller circle (Figure 250). The rim-body juncture has a single horizontal appliqued fillet, and there are appliqued triangle elements both above and below the appliqued scrolls.

PIGMENT USE AND LOCATION ON VESSEL: none

TYPE AND VARIETY [IF KNOWN]: Harleton Appliqued

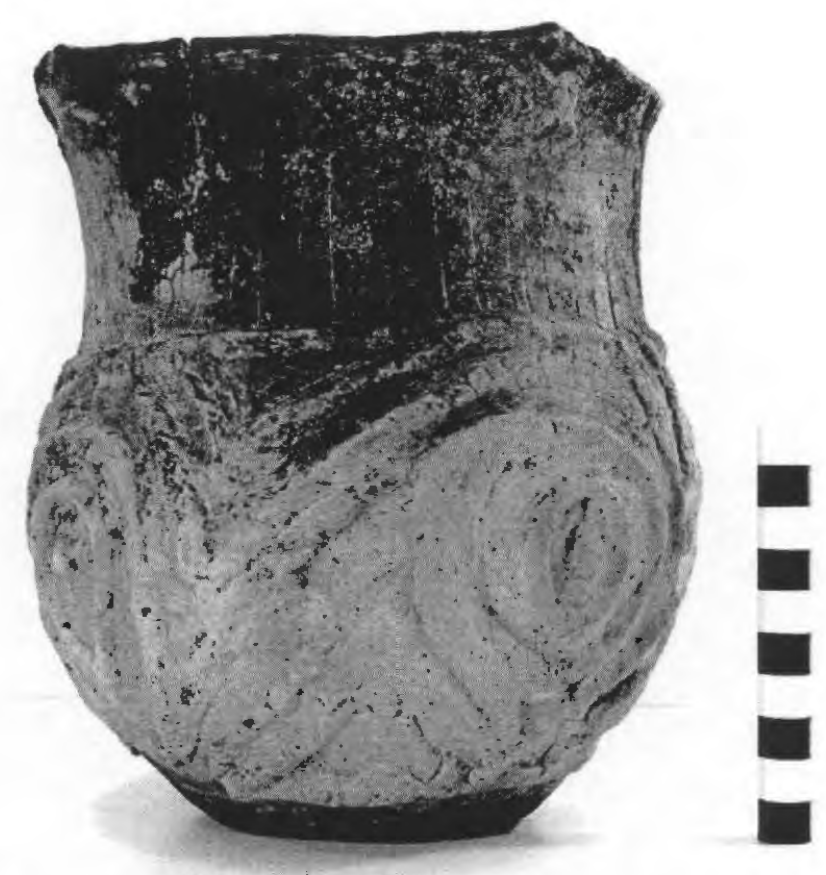

Figure 250. Harleton Appliqued jar, Frank Smith cemetery, Burial 9, Vessel 35.

VESSEL NO.: Burial 9, Vessel 36; 2003.08.1844

NON-PLASTICS AND PASTE: grog, hematite, and bone

VESSEL FORM: Carinated bowl

RIM AND LIP FORM: Inverted rim and a rounded, exterior folded lip

CORE COLOR: $\mathrm{G}$ (fired in a reducing environment and cooled in the open air)

INTERIOR SURFACE COLOR: grayish-brown 
EXTERIOR SURFACE COLOR: dark yellowish-brown; fire clouds on the rim, body, and base

WALL THICKNESS (RIM, BODY, AND BASE IN MM): rim, 6.4 mm

INTERIOR SURFACE TREATMENT: smoothed on the rim

EXTERIOR SURFACE TREATMENT: smoothed

HEIGHT (IN CM): 6.8

ORIFICE DIAMETER (IN CM): 11.0

DIAMETER AT BOTTOM OF RIM OR NECK (IN CM): 13.4

BASE DIAMETER (IN CM) AND SHAPE OF BASE: 5.2

ESTIMATED VOLUME (IN LITERS): 0.45

DECORATION (INCLUDING MOTIF AND ELEMENTS WHEN APPARENT): The rim panel has a scroll motif repeated four times around the vessel. Each scroll is divided from the other by engraved brackets composed of four arcing lines. The elongated and triangular-shaped scroll fill zones are composed of a series of short curvilinear lines, with a short spur at one end. The end of the scroll hooks around that spur (Figure 251).

There is also a single horizontal engraved line on the interior surface at the carination.

PIGMENT USE AND LOCATION ON VESSEL: none

TYPE AND VARIETY [IF KNOWN]: Ripley Engraved, var. unspecified or Taylor Engraved

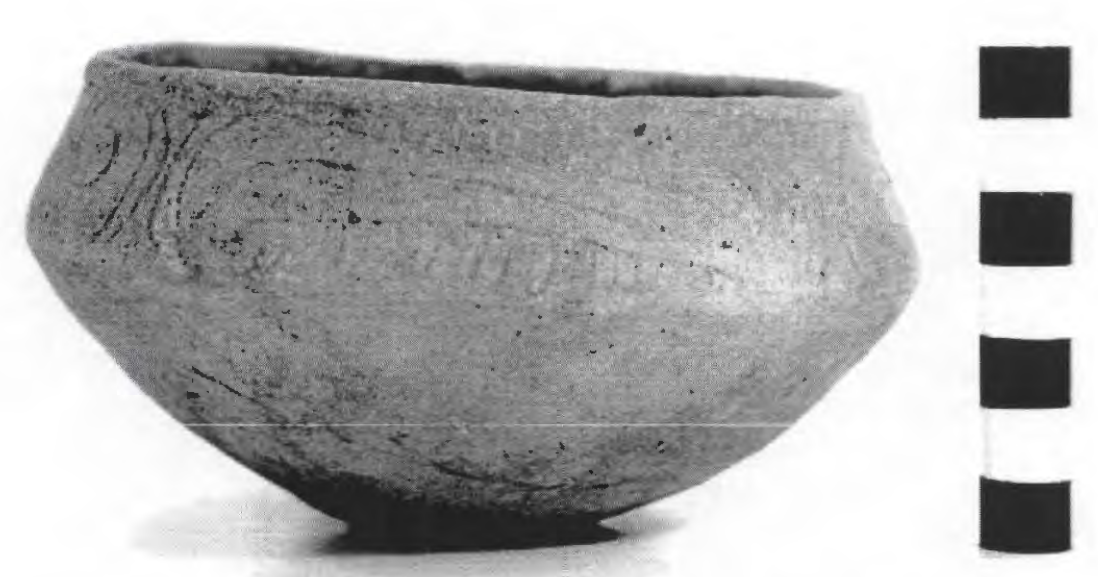

Figure 251. Ripley Engraved, var. unspecified or Taylor Engraved carinated bowl, Frank Smith cemetery, Burial 9, Vessel 36. 
VESSEL NO.: Burial 9, Vessel 37; 2003.08.0441

NON-PLASTICS AND PASTE: grog and hematite

VESSEL FORM: Carinated bowl

RIM AND LIP FORM: Direct rim and rounded lip

CORE COLOR: A (fired and cooled in an oxidizing environment)

INTERIOR SURFACE COLOR: dark yellowish-brown; organic residue on the rim

EXTERIOR SURFACE COLOR: yellowish-brown; organic residue on rim, lip, and vessel body

WALL THICKNESS (RIM, BODY, AND BASE IN MM): rim, $8.1 \mathrm{~mm}$

INTERIOR SURFACE TREATMENT: none

EXTERIOR SURFACE TREATMENT:

smoothed

HEIGHT (IN CM): 11.3

ORIFICE DIAMETER (IN CM): 23.5

DIAMETER AT BOTTOM OF RIM OR

NECK (IN CM): 22.4

BASE DIAMETER (IN CM) AND SHAPE

OF BASE: 7.1; circular and flat

ESTIMATED VOLUME (IN LITERS): 1.6

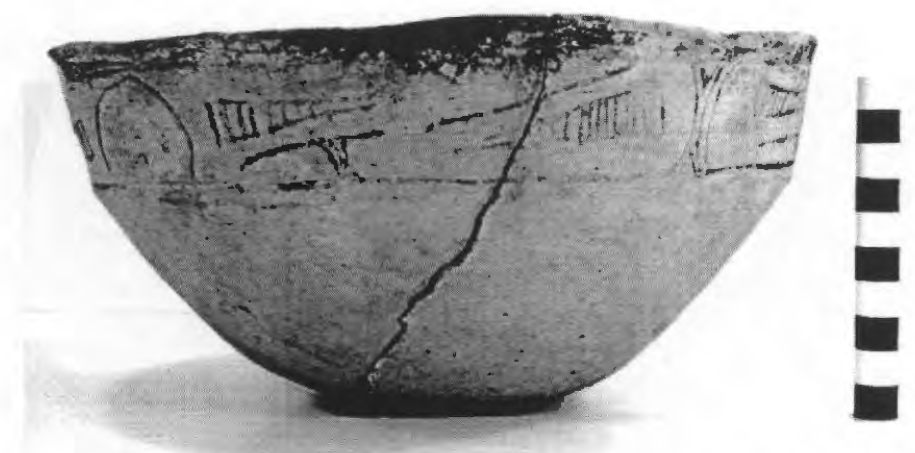

Figure 252. Ripley Engraved, var. unspecified carinated bowl, Frank Smith cemetery, Burial 9, Vessel 37.

DECORATION (INCLUDING MOTIF AND ELEMENTS WHEN APPARENT): The rim panel is comprised of four diagonal scrolls that are divided by two engraved vertical brackets or engraved semicircles. The upper and lower scroll fill zones are elongated triangular-shaped zones filled with vertical engraved lines (Figure 252).

PIGMENT USE AND LOCATION ON VESSEL: red pigment in the engraved lines

TYPE AND VARIETY [IF KNOWN]: Ripley Engraved, var. unspecified 
VESSEL NO.: Burial 9, Vessel 38; 2003.08.1204

NON-PLASTICS AND PASTE: grog

VESSEL FORM: Carinated bowl

RIM AND LIP FORM: Inverted rim and rounded, exterior folded lip

CORE COLOR: $\mathrm{G}$ (fired in a reducing environment and cooled in the open air)

INTERIOR SURFACE COLOR: dark grayish-brown

EXTERIOR SURFACE COLOR: yellowish-brown; fire clouds on the rim and base

WALL THICKNESS (RIM, BODY, AND BASE IN MM): rim, $5.6 \mathrm{~mm}$

INTERIOR SURFACE TREATMENT: none

EXTERIOR SURFACE TREATMENT: smoothed

HEIGHT (IN CM): 4.9

ORIFICE DIAMETER (IN CM): 6.0

DIAMETER AT BOTTOM OF RIM OR NECK (IN CM): 6.7

BASE DIAMETER (IN CM) AND SHAPE OF

BASE: 4.0 ; circular and rounded

ESTIMATED VOLUME (IN LITERS): 0.18

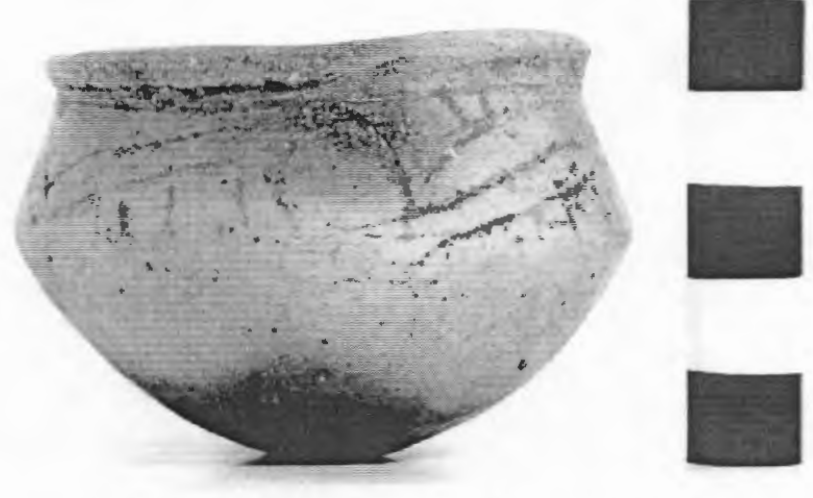

Figure 253. Ripley Engraved, var. unspecified carinated bowl, Frank Smith cemetery, Burial 9, Vessel 37.

DECORATION (INCLUDING MOTIF AND ELEMENTS WHEN APPARENT): The rim panel is defined by a scroll and semi-circle motif repeated three times around the vessel; another central element is a set of two vertical engraved lines. One of the semi-circles is open, while the other two have a smaller semi-circle within (Figure 253).

PIGMENT USE AND LOCATION ON VESSEL: red pigment in engraved lines

TYPE AND VARIETY [IF KNOWN]: Ripley Engraved, cf. var. Caldwell or undefined variety of Womack Engraved 
VESSEL NO.: Burial 9, Vessel 39; 2003.08.1826

NON-PLASTICS AND PASTE: grog

VESSEL FORM: Carinated bowl

RIM AND LIP FORM: Direct rim and a rounded, exterior folded lip

CORE COLOR: $\mathrm{G}$ (fired in a reducing environment and cooled in the open air)

INTERIOR SURFACE COLOR: grayish-brown; fire clouds on the rim; organic residue on the rim

EXTERIOR SURFACE COLOR: yellowish-brown; fire clouds on the body and base; thick organic residue (resin) on the rim and body

WALL THICKNESS (RIM, BODY, AND BASE IN MM): rim, 5.9 mm

INTERIOR SURFACE TREATMENT: smoothed on the rim

EXTERIOR SURFACE TREATMENT: burnished

HEIGHT (IN CM): 13.4

ORIFICE DIAMETER (IN CM): 25.7

DIAMETER AT BOTTOM OF RIM OR NECK (IN CM): 26.0

BASE DIAMETER (IN CM) AND SHAPE OF

BASE: 5.5 ; circular and rounded

ESTIMATED VOLUME (IN LITERS): 3.1

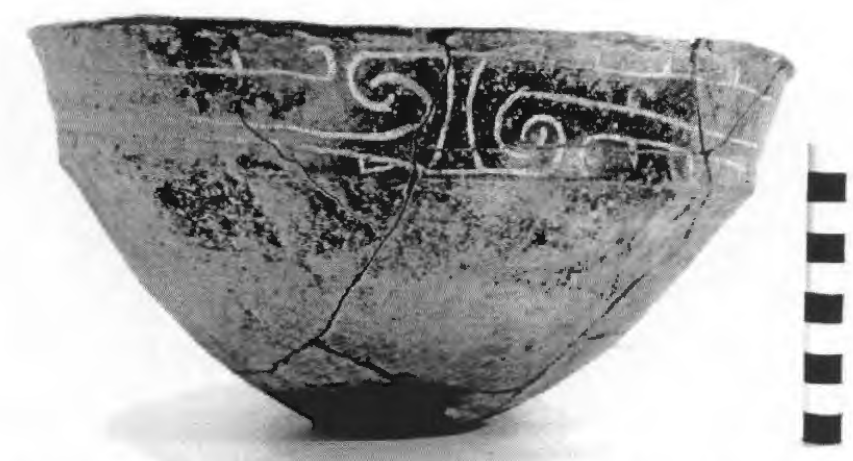

Figure 254. Taylor Engraved carinated bowl, Frank Smith cemetery, Burial 9, Vessel 39.

DECORATION (INCLUDING MOTIF AND ELEMENTS WHEN APPARENT): The rim panel has an engraved slanting scroll with upper and lower hooked arms that is repeated four times around the vessel. The hooked arm elements are next to vertical bracket dividers. Upper and lower scroll fill zones are marked by engraved lines with small excised pendant triangles or tick marks (Figure 254).

PIGMENT USE AND LOCATION ON VESSEL: none

TYPE AND VARIETY [IF KNOWN]: Taylor Engraved 
In addition to the ceramic vessels in Burial 9, a single ceramic tubular pipe was also placed in the grave as a funerary offering. The pipe, $52 \mathrm{~mm}$ in height and between $23-29 \mathrm{~mm}$ wide, has a bowl orifice diameter of $29 \mathrm{~mm}$ and a stem orifice diameter of $19 \mathrm{~mm}$ (Figure 255a). The stem opening has been placed midway along the side of the pipe, not the end as in Late Caddo elbow pipes (Figure 255b).
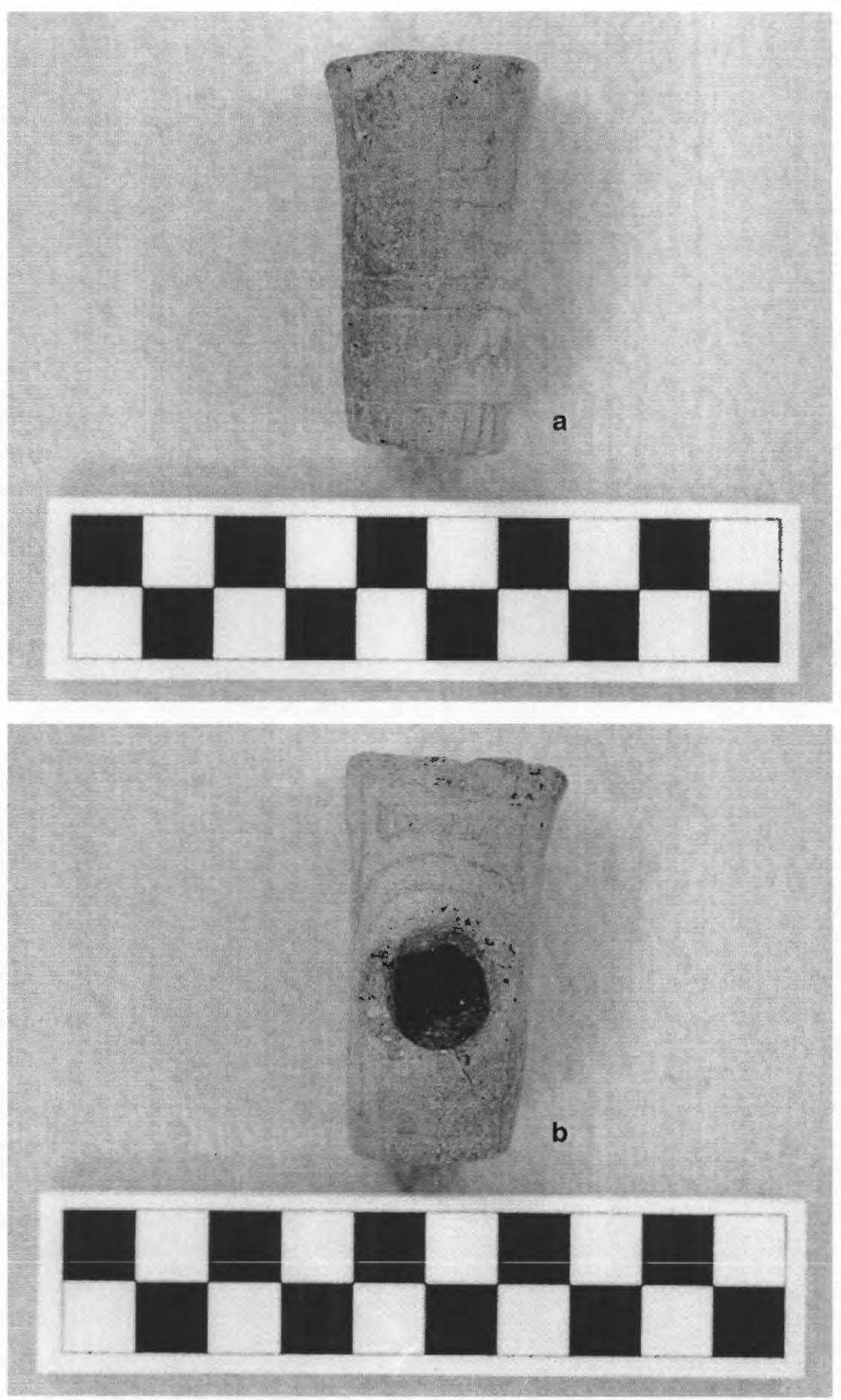

Figure 255. Tubular pipe from Burial 9 at the Frank Smith cemetery: a, side view; b, top down view. 
This tubular pipe is elaborately decorated on all sides, and a red pigment has been rubbed in the engraved lines. On either side of the stem hole, there are rectangular engraved elements filled with short vertical lines. The upper part on the other sides has three concentric engraved semi-circles divided by a vertical panel with small pendant triangles; the semi-circles have tick marks on them. This motif is divided from a second motif by two horizontal engraved lines. This lower motif is comprised of two separate horizontal elements bisected by a single vertical engraved line. The first horizontal element has a series of small triangles, some open, others excised, and two with even smaller triangles within them. The lowermost and second horizontal engraved element has a series of short and regularly-spaced vertical engraved lines, three of which have a single triangular tick mark (Figure 255a-b).

\section{Burial 10}

Burial 10 was in the southeastern part of the cemetery, a few feet northeast of Burial 3 (see Figure 211). The burial pit extended to $0.79 \mathrm{~m}$ bs. A drawing by Jones (n.d.) of Burial 10 showed eight ceramic vessels placed along what would have been the right side of the body from the head to the feet (Figure 256), but the Jones collection has 11 vessels identified with a Burial 10 provenience.

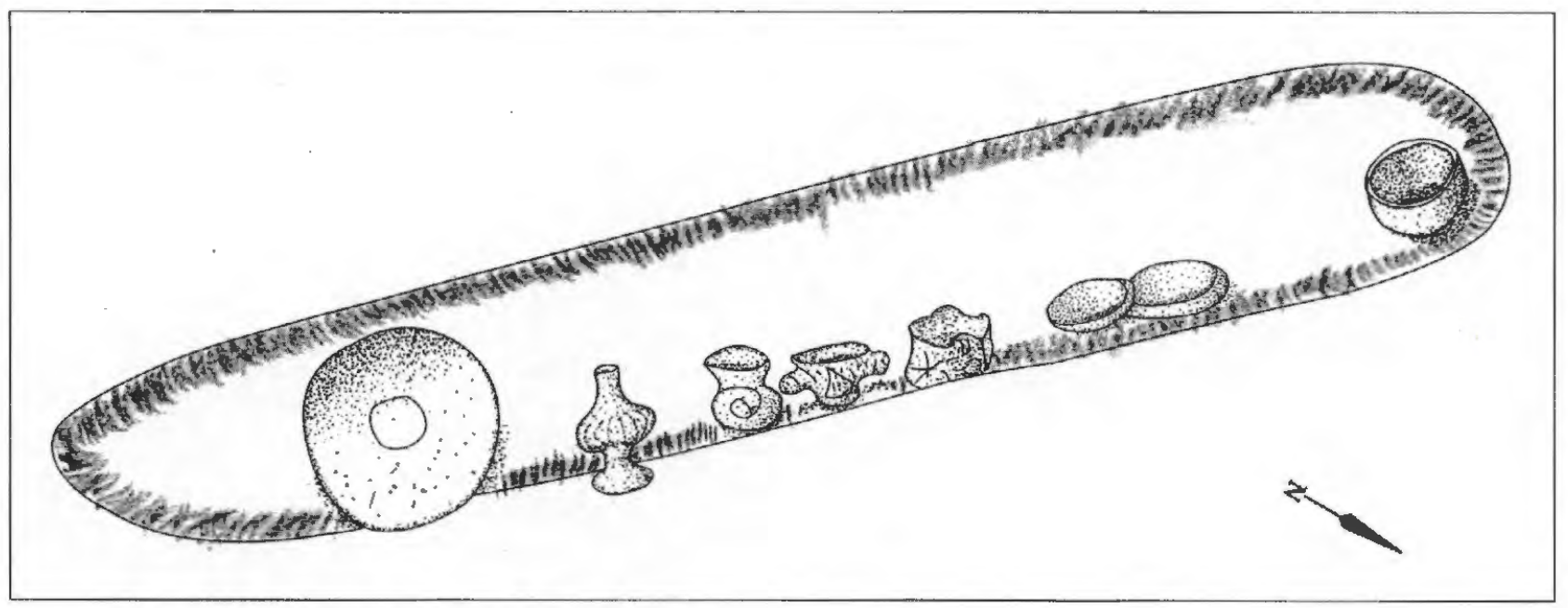

Figure 256. Burial 10 at the Frank Smith site.

The ceramic vessels in the collection from Burial 10 are the most eclectic of the ceramic vessel funerary offerings from the cemetery, with different decorative motifs present along with otherwise rare vessel forms. They include two engraved bottles, one with a pedestal base; three jars (Harleton Appliqued, a brushed-punctated vessel, and an engraved jar); an engraved compound bowl; and five carinated bowls. These are represented by Ripley Engraved, var. McKinney, Ripley Engraved, var. unspecified, a plain vessel, an engraved vessel of unknown type, and a pinched-noded rattle vessel (see Suhm and Jelks 1962:Plate 26). 
VESSEL NO.: Burial 10, Vessel 40; 2003.08.71

NON-PLASTICS AND PASTE: grog

VESSEL FORM: Jar with four rim peaks and four lug handles (25.1 x $12.4 \mathrm{~mm}$ in length and width) under the rim peaks (Figure 257)

RIM AND LIP FORM: Direct rim and a rounded lip

CORE COLOR: $\mathrm{F}$ (fired in a reducing environment and cooled in the open air)

INTERIOR SURFACE COLOR: yellowish-brown; fire clouding on the rim and upper body

EXTERIOR SURFACE COLOR: dark yellowish-brown; fire clouding on the base; a thick organic residue on the rim and body

WALL THICKNESS (RIM, BODY, AND BASE IN MM): rim, $5.9 \mathrm{~mm}$

INTERIOR SURFACE TREATMENT: smoothed

EXTERIOR SURFACE TREATMENT: none

HEIGHT (IN CM): 13.5

ORIFICE DIAMETER (IN CM): 12.3

DIAMETER AT BOTTOM OF RIM OR NECK (IN CM): 11.6

BASE DIAMETER (IN CM) AND SHAPE OF BASE: 4.9; circular and flat

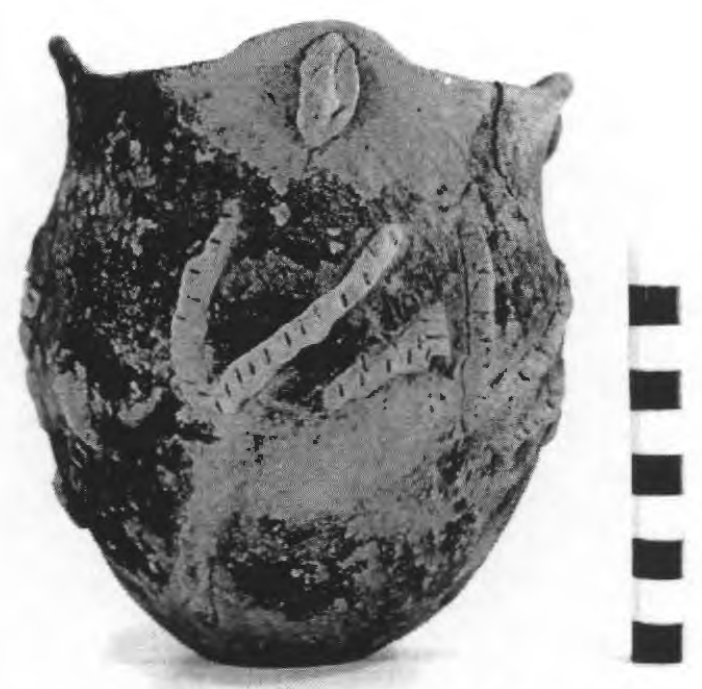

Figure 257. Harleton Appliqued jar, Frank Smith cemetery, Burial 10, Vessel 40.

ESTIMATED VOLUME (IN LITERS): 1.0

DECORATION (INCLUDING MOTIF AND ELEMENTS WHEN APPARENT): The rim is roughened, but otherwise undecorated. The lug handles are decorated with three vertical pinched ridges. The vessel body has an appliqued fillet scroll and circle motif repeated four times around the vessel (Figure 257).

PIGMENT USE AND LOCATION ON VESSEL: none

TYPE AND VARIETY [IF KNOWN]: Harleton Appliqued 
VESSEL NO.: Burial 10, Vessel $41 ; 2003.08 .192$

NON-PLASTICS AND PASTE: grog

VESSEL FORM: Carinated bowl

RIM AND LIP FORM: Direct rim and rounded, exterior folded lip

CORE COLOR: $\mathrm{F}$ (fired in a reducing environment and cooled in the open air)

INTERIOR SURFACE COLOR: red; fire clouds on the base

EXTERIOR SURFACE COLOR: red; fire clouds on the base

WALL THICKNESS (RIM, BODY, AND BASE IN MM): rim, 6.9 mm

INTERIOR SURFACE TREATMENT: smoothed

EXTERIOR SURFACE TREATMENT: smoothed

HEIGHT (IN CM): 7.8

ORIFICE DIAMETER (IN CM): 16.3

DIAMETER AT BOTTOM OF RIM OR NECK (IN CM): 13.3

BASE DIAMETER (IN CM) AND SHAPE OF BASE: 6.8 ; circular and flat

ESTIMATED VOLUME (IN LITERS): 0.76

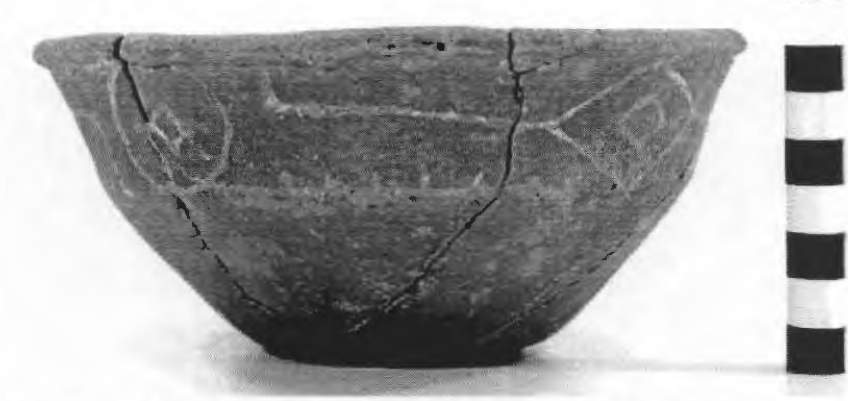

Figure 258. Ripley Engraved, var. McKinney carinated bowl, Frank Smith cemetery, Burial 10, Vessel 41.

DECORATION (INCLUDING MOTIF AND ELEMENTS WHEN APPARENT): The vessel has a red slip on both interior and exterior vessel surfaces. The engraved motif on the rim panel features two alternating central circles and two nested diamonds. The central circles have a small diamond and negative circle element within them, while the nested diamonds have a small diamond within them. The nested diamonds are at the center of a horizontal scroll with upper and lower excised brackets. Above and below each scroll are single rows of small excised pendant triangles and engraved dashes (Figure 258).

There is a single horizontal engraved line on the interior vessel surface at the carination.

PIGMENT USE AND LOCATION ON VESSEL: white pigment in engraved lines

TYPE AND VARIETY [IF KNOWN]: Ripley Engraved, var. McKinney 
VESSEL NO.: Burial 10, Vessel 42; 2003.08.62

NON-PLASTICS AND PASTE: grog

VESSEL FORM: Carinated bowl with four body nodes/rattles and two opposing suspension holes (Figure 259)

RIM AND LIP FORM: Inverted rim and rounded lip

CORE COLOR: $\mathrm{F}$ (fired in a reducing environment and cooled in the open air)

INTERIOR SURFACE COLOR: yellowish-brown; stained with reddish-brown and gray clay pigment

EXTERIOR SURFACE COLOR: yellowish-brown; fire clouds on the rim, body, and base

WALL THICKNESS (RIM, BODY, AND BASE IN MM): rim, 5.0 mm

INTERIOR SURFACE TREATMENT: smoothed

EXTERIOR SURFACE TREATMENT: none

HEIGHT (IN CM): 6.2

ORIFICE DIAMETER (IN CM): 11.2

DIAMETER AT BOTTOM OF RIM OR

NECK (IN CM): 12.0

BASE DIAMETER (IN CM) AND SHAPE

OF BASE: 4.5 ; circular and flat

ESTIMATED VOLUME (IN LITERS): 0.42

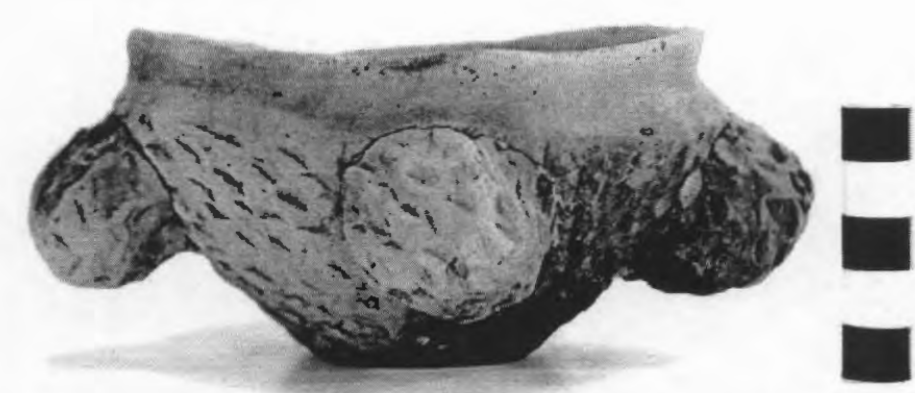

Figure 259. Pinched rattle carinated bowl, Frank Smith cemetery, Burial 10, Vessel 42.

DECORATION (INCLUDING MOTIF AND ELEMENTS WHEN APPARENT): The narrow rim is plain, but has two opposed suspension holes $(4.5 \mathrm{~mm}$ in diameter). The vessel body has vertical pinched rows covering the entire vessel exterior surface, and there are four large (39 $\mathrm{mm}$ in diameter) nodes on the upper body. These nodes are also covered with a pinched decoration (Figure 259).

PIGMENT USE AND LOCATION ON VESSEL: none

TYPE AND VARIETY [IF KNOWN]: Unidentified utility ware 
VESSEL NO.: Burial 10, Vessel 43; 2003.08.112

NON-PLASTICS AND PASTE: grog

VESSEL FORM: Jar with two opposed suspension holes (3.1 $\mathrm{mm}$ in diameter)

RIM AND LIP FORM: Everted rim and a rounded lip

CORE COLOR: $\mathrm{G}$ (fired in a reducing environment and cooled in the open air)

INTERIOR SURFACE COLOR: dark grayish-brown

EXTERIOR SURFACE COLOR: reddish-brown;

fire clouds on the rim, body, and base

WALL THICKNESS (RIM, BODY, AND BASE IN

MM): rim, $5.4 \mathrm{~mm}$

INTERIOR SURFACE TREATMENT: smoothed on the rim

EXTERIOR SURFACE TREATMENT: smoothed

HEIGHT (IN CM): 9.5

ORIFICE DIAMETER (IN CM): 10.6

DIAMETER AT BOTTOM OF RIM OR NECK (IN CM): 8.4

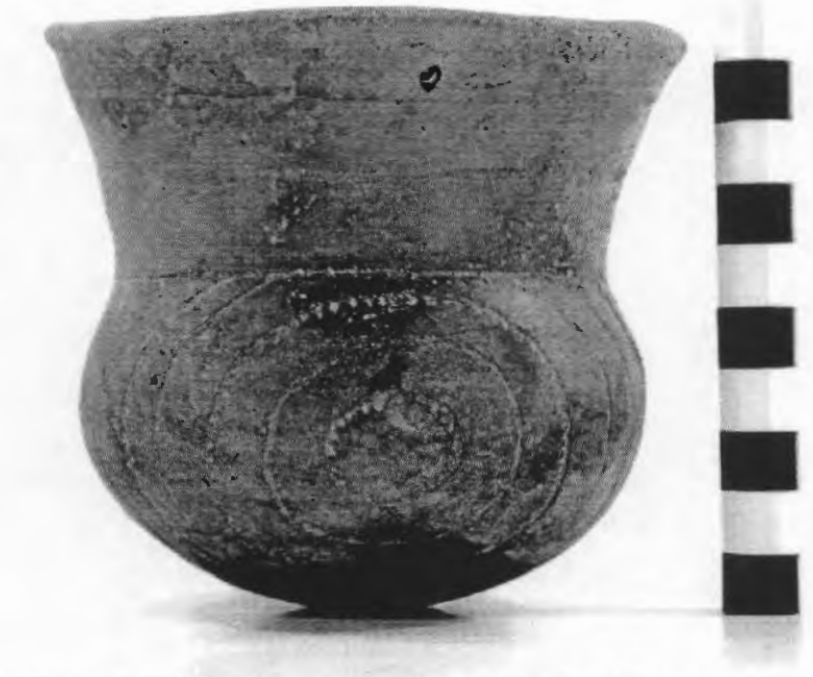

Figure 260. Engraved jar, Frank Smith cemetery, Burial 10, Vessel 43.

BASE DIAMETER (IN CM) AND SHAPE OF BASE: 5.8; circular and rounded

ESTIMATED VOLUME (IN LITERS): 0.60

DECORATION (INCLUDING MOTIF AND ELEMENTS WHEN APPARENT): The rim has three broadly-spaced horizontal engraved lines; the suspension holes have been drilled just above or through the uppermost line. The vessel body has three sets of four concentric engraved circles, and two of these circles have tick marks on them. The concentric circles are separated by four engraved brackets with tick marks, and two of the brackets have a small open triangle within them that is pendant from the horizontal engraved line at the rim-body juncture (Figure 260).

PIGMENT USE AND LOCATION ON VESSEL: red pigment in the engraved lines

TYPE AND VARIETY [IF KNOWN]: Unidentified fine ware 
VESSEL NO.: Burial 10, Vessel 44; 2003.08.65

NON-PLASTICS AND PASTE: grog

VESSEL FORM: Bottle on a pedestal $(3.2 \mathrm{~cm}$ in height; $2.5 \mathrm{~cm}$ in diameter, and $4.6 \mathrm{~cm}$ in diameter at the base); it has a flaring neck (Figure 261)

RIM AND LIP FORM: Everted rim and a rounded lip

CORE COLOR: $\mathrm{G}$ (fired in a reducing environment and cooled in the open air)

INTERIOR SURFACE COLOR: dark grayish-brown

EXTERIOR SURFACE COLOR: yellowish-brown; fire clouds on the body and neck

WALL THICKNESS (RIM, BODY, AND BASE IN MM): rim, $4.5 \mathrm{~mm}$

INTERIOR SURFACE TREATMENT: none

EXTERIOR SURFACE TREATMENT: smoothed

HEIGHT (IN CM): 12.8

ORIFICE DIAMETER (IN CM): 3.8

DIAMETER AT BOTTOM OF RIM OR NECK (IN CM):

5.0 ; maximum body diameter is $8.4 \mathrm{~cm}$

BASE DIAMETER (IN CM) AND SHAPE OF BASE: 4.6; flat and circular

ESTIMATED VOLUME (IN LITERS): 0.24

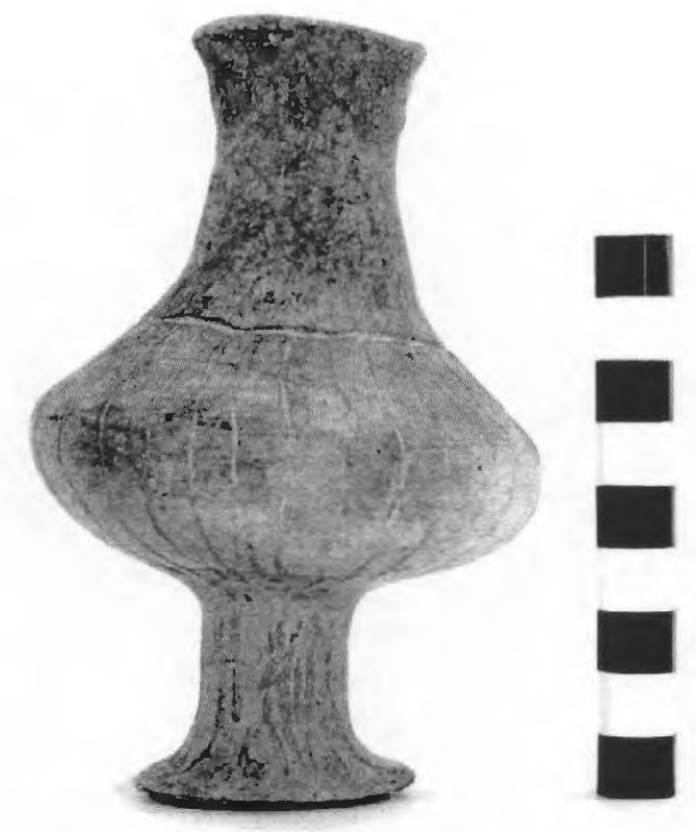

Figure 261. Pedestalled engraved bottle, Frank Smith cemetery, Burial 10, Vessel 44.

DECORATION (INCLUDING MOTIF AND ELEMENTS WHEN APPARENT): The vessel body has a continuous series of vertical to opposed engraved lines around the vessel; there is also a single horizontal engraved line near the top of the body that defines the series of vertical to opposed engraved lines (Figure 261). The pedestal is decorated with vertical engraved lines.

PIGMENT USE AND LOCATION ON VESSEL: red pigment in engraved lines

TYPE AND VARIETY [IF KNOWN]: Unidentified fine ware 
VESSEL NO.: Burial 10, Vessel 45; 2003.08 .1353

NON-PLASTICS AND PASTE: grog

VESSEL FORM: Compound bowl

RIM AND LIP FORM: Everted rim and a rounded, exterior folded lip

CORE COLOR: $\mathrm{F}$ (fired in a reducing environment and cooled in the open air)

INTERIOR SURFACE COLOR: yellowish-brown; fire cloud on the rim

EXTERIOR SURFACE COLOR: yellowish-brown; fire clouds on the rim, lower body, and base

WALL THICKNESS (RIM, BODY, AND BASE IN MM): rim, 6.7 mm

INTERIOR SURFACE TREATMENT: smoothed

EXTERIOR SURFACE TREATMENT: smoothed

HEIGHT (IN CM): 12.5

ORIFICE DIAMETER (IN CM): 28.0

DIAMETER AT BOTTOM OF RIM OR NECK (IN CM): 23.5

BASE DIAMETER (IN CM) AND SHAPE OF BASE:

6.7 ; circular and flat

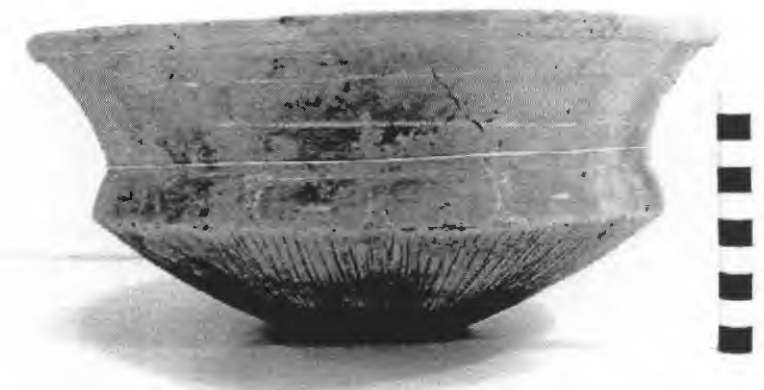

Figure 262. Engraved-incised compound bowl, ESTIMATED VOLUME (IN LITERS): 2.8 Frank Smith cemetery, Burial 10, Vessel 45.

DECORATION (INCLUDING MOTIF AND ELEMENTS WHEN APPARENT): the upper rim panel has four widely-spaced horizontal engraved lines. The narrow lower rim panel has a series of 15 excised brackets, and every other bracket is separated from another by excised dash marks. The vessel body is decorated with closely-spaced vertical incised lines (Figure 262).

PIGMENT USE AND LOCATION ON VESSEL: white pigment in engraved lines on upper and lower rim panels

TYPE AND VARIETY [IF KNOWN]: Unidentified fine ware 
VESSEL NO.: Burial 10, Vessel 46; 2003.08 .718

NON-PLASTICS AND PASTE: grog

VESSEL FORM: Carinated bowl

RIM AND LIP FORM: Direct rim and a rounded, exterior folded lip

CORE COLOR: $\mathrm{F}$ (fired in a reducing environment and cooled in the open air)

INTERIOR SURFACE COLOR: reddish-brown; fire clouds on the base

EXTERIOR SURFACE COLOR: reddish-brown; fire clouds on the rim and body

WALL THICKNESS (RIM, BODY, AND BASE IN MM): rim, $5.1 \mathrm{~mm}$; base, $9.2 \mathrm{~mm}$

INTERIOR SURFACE TREATMENT: smoothed

EXTERIOR SURFACE TREATMENT:

smoothed

HEIGHT (IN CM): 10.8

ORIFICE DIAMETER (IN CM): 19.3

DIAMETER AT BOTTOM OF RIM OR NECK (IN CM): 19.1

BASE DIAMETER (IN CM) AND SHAPE OF BASE: 6.2 ; circular and flat

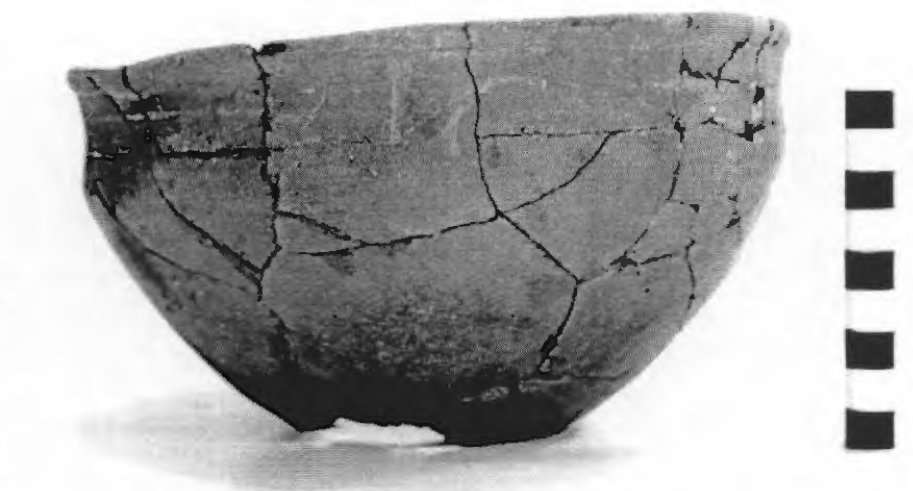

Figure 263. Ripley Engraved, cf. var. Gandy carinated ESTIMATED VOLUME (IN LITERS): 1.3 bowl, Frank Smith cemetery, Burial 10, Vessel 46.

DECORATION (INCLUDING MOTIF AND ELEMENTS WHEN APPARENT): The rim panel has an engraved scroll motif repeated four times around the vessel. The scrolls are separated by narrow vertical excised zones (Figure 263).

PIGMENT USE AND LOCATION ON VESSEL: none

TYPE AND VARIETY [IF KNOWN]: Ripley Engraved, cf. var. Gandy 
VESSEL NO.: Burial 10, Vessel 47; 2003.08.1770

NON-PLASTICS AND PASTE: grog

VESSEL FORM: Carinated bowl

RIM AND LIP FORM: Inverted rim and a rounded, exterior folded lip

CORE COLOR: $\mathrm{G}$ (fired in a reducing environment and cooled in the open air)

INTERIOR SURFACE COLOR: grayish-brown; fire clouds on the rim and base

EXTERIOR SURFACE COLOR: yellowish-brown; fire clouds on the rim and body; organic residue on the body

WALL THICKNESS (RIM, BODY, AND BASE IN MM): rim, $7.1 \mathrm{~mm}$

INTERIOR SURFACE TREATMENT: smoothed

EXTERIOR SURFACE TREATMENT: smoothed

HEIGHT (IN CM): 13.7

ORIFICE DIAMETER (IN CM): 22.0

DIAMETER AT BOTTOM OF RIM OR NECK

(IN CM): 21.5

BASE DIAMETER (IN CM) AND SHAPE OF

BASE: 8.0 ; circular and flat

ESTIMATED VOLUME (IN LITERS): 2.7

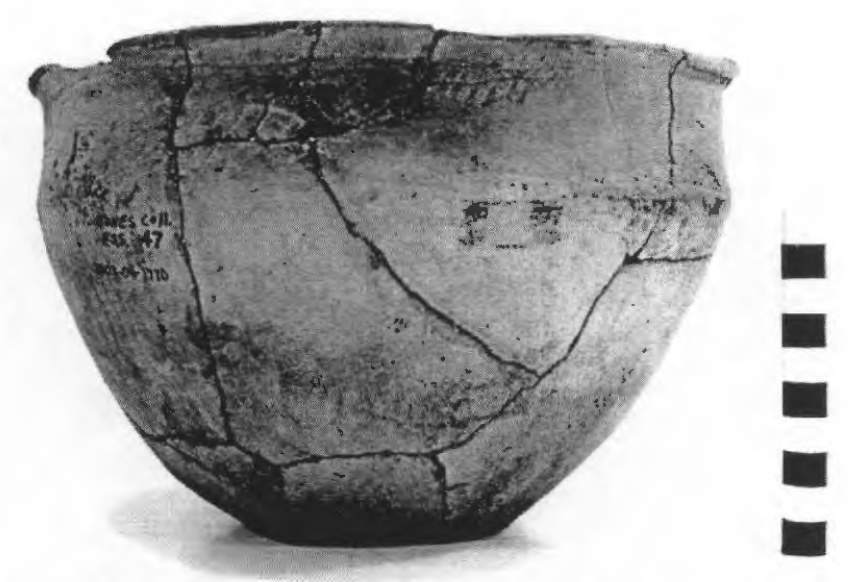

Figure 264. Engraved carinated bowl, Frank Smith cemetery, Burial 10, Vessel 47.

DECORATION (INCLUDING MOTIF AND ELEMENTS WHEN APPARENT): The rim has six upper and four lower engraved semi-circles, either open, hatched, or cross-hatched, around the vessel, along with one oval-shaped area that is partially filled with hatched lines (Figure 264). In addition, there is a large cross-hatched bracket divider at one end of the semi-circles, and a single slanted scroll line and a small open circle at the other end.

PIGMENT USE AND LOCATION ON VESSEL: none

TYPE AND VARIETY [IF KNOWN]: Unidentified fine ware 
VESSEL NO.: Burial 10, M-5 Vessel 47; 2003.08.1016

NON-PLASTICS AND PASTE: grog

VESSEL FORM: Jar

RIM AND LIP FORM: Everted rim and rounded lip

CORE COLOR: $F$ (fired in a reducing environment and cooled in the open air)

INTERIOR SURFACE COLOR: reddish-brown; fire clouds on the rim and body

EXTERIOR SURFACE COLOR: reddish-brown; fire clouds on the rim and body

WALL THICKNESS (RIM, BODY, AND BASE IN MM): rim, $9.1 \mathrm{~mm}$; body, $7.9 \mathrm{~mm}$; base, $10.5 \mathrm{~mm}$

INTERIOR SURFACE TREATMENT: smoothed

EXTERIOR SURFACE TREATMENT: none

HEIGHT (IN CM): 3I.5+

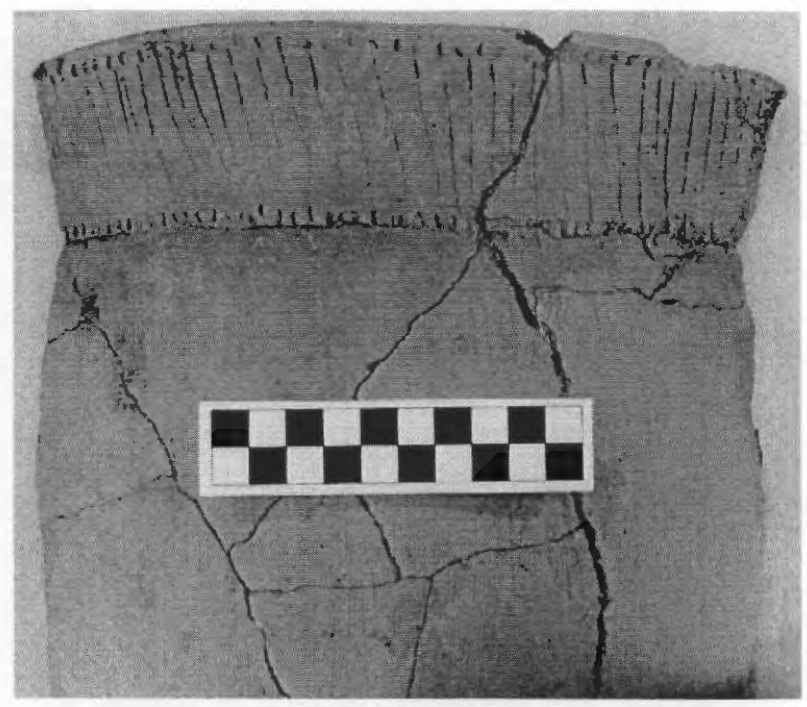

Figure 265. Karnack Brushed-Incised jar, Frank Smith cemetery, Burial 10, Vessel 2003.08.1016.

ORIFICE DIAMETER (IN CM): 27.0

DIAMETER AT BOTTOM OF RIM OR NECK (IN CM): 25.9

BASE DIAMETER (IN CM) AND SHAPE OF BASE: N/A

ESTIMATED VOLUME (IN LITERS): $11.1+$

DECORATION (INCLUDING MOTIF AND ELEMENTS WHEN APPARENT): The rim has two rows of tool punctations, one under the vessel lip and the other at the rim-body juncture. The remainder of the rim is decorated with a continuous series of vertical incised lines. The vessel body has vertical brushing marks (Figure 265).

PIGMENT USE AND LOCATION ON VESSEL: none

TYPE AND VARIETY [IF KNOWN]: Karnack Brushed-Incised 
VESSEL NO.: Burial 10, Vessel 48; 2003.08.720

NON-PLASTICS AND PASTE: grog

VESSEL FORM: Carinated bowl

RIM AND LIP FORM: Direct rim and a rounded, exterior folded lip

CORE COLOR: $\mathrm{G}$ (fired in a reducing environment and cooled in the open air)

INTERIOR SURFACE COLOR: dark grayish-brown

EXTERIOR SURFACE COLOR: yellowish-brown; fire clouds on the rim, body, and base

WALL THICKNESS (RIM, BODY, AND BASE IN MM): rim, $8.5 \mathrm{~mm}$

INTERIOR SURFACE TREATMENT: smoothed

EXTERIOR SURFACE TREATMENT:

smoothed

HEIGHT (IN CM): 13.4

ORIFICE DIAMETER (IN CM): 29.8

DIAMETER AT BOTTOM OF RIM OR

NECK (IN CM): 25.0

BASE DIAMETER (IN CM) AND SHAPE OF

BASE: 7.5

Figure 266. Plain carinated bowl, Frank Smith

ESTIMATED VOLUME (IN LITERS): 3.6 cemetery, Burial 10, Vessel 48.

DECORATION (INCLUDING MOTIF AND ELEMENTS WHEN APPARENT): Plain (Figure 266)

PIGMENT USE AND LOCATION ON VESSEL: none

TYPE AND VARIETY [IF KNOWN]: Unidentified plain ware 
VESSEL NO.: Burial 10, Vessel 50; 2003.08.280

NON-PLASTICS AND PASTE: bone and grog

VESSEL FORM: Bottle with a straight neck and a carinated body

RIM AND LIP FORM: Direct rim and a rounded lip

CORE COLOR: G (fired in a reducing environment and cooled in the open air)

INTERIOR SURFACE COLOR: dark grayish-brown

EXTERIOR SURFACE COLOR: yellowish-brown; fire clouds on the neck and body

WALL THICKNESS (RIM, BODY, AND BASE IN MM): rim, $6.7 \mathrm{~mm}$

INTERIOR SURFACE TREATMENT: none

EXTERIOR SURFACE TREATMENT: smoothed on the neck

HEIGHT (IN CM): 19.5

ORIFICE DIAMETER (IN CM): 5.5

DIAMETER AT BOTTOM OF RIM OR NECK (IN CM):

5.4 ; maximum body diameter is $15.1 \mathrm{~cm}$

BASE DIAMETER (IN CM) AND SHAPE OF BASE:

8.1 ; flat and circular

ESTIMATED VOLUME (IN LITERS): 0.63

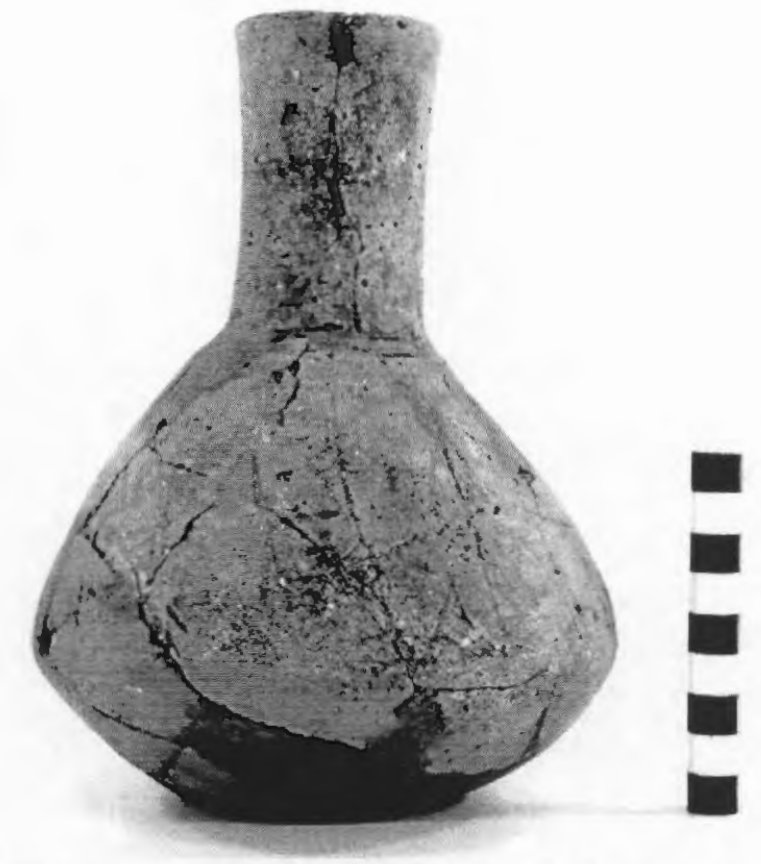

Figure 267. Engraved bottle, Frank Smith cemetery, Burial 10, Vessel 50.

DECORATION (INCLUDING MOTIF AND ELEMENTS WHEN APPARENT): The vessel body above the carination point has eight vertical engraved columns filled with large hatched pendant triangles. Between each vertical column, at the carination point, are eight large hatched pendant triangles (Figure 267).

PIGMENT USE AND LOCATION ON VESSEL: none

TYPE AND VARIETY [IF KNOWN]: Unidentified fine ware

\section{Burial 11}

Burial 11 was in the southernmost burial row in the cemetery, a few feet south-southeast of Burial 3 (see Figure 211). The burial pit was $0.81 \mathrm{~m}$ in depth, and five ceramic vessels had been placed in the grave as funerary offerings for the deceased. 
Four of the vessels from Burial 11 at the Frank Smith cemetery have been identified in the Jones collection. They consist of a Cass Appliqued jar, a Wilder Engraved, var. Wilder bottle, and two Ripley Engraved, var. unspecified carinated bowls.

VESSEL NO.: Burial 11, Vessel 52; 2003.08.1741

NON-PLASTICS AND PASTE: grog, hematite, and organics

VESSEL FORM: Carinated bowl

RIM AND LIP FORM: Direct rim and a rounded, exterior folded lip

CORE COLOR: $\mathrm{F}$ (fired in a reducing environment and cooled in the open air)

INTERIOR SURFACE COLOR: yellowish-brown

EXTERIOR SURFACE COLOR: yellowish-brown

WALL THICKNESS (RIM, BODY, AND BASE IN MM): rim, $8.6 \mathrm{~mm}$; body, $8.0 \mathrm{~mm}$; base, 12.5 $\mathrm{mm}$

INTERIOR SURFACE TREATMENT: smoothed on the rim

EXTERIOR SURFACE TREATMENT: smoothed

HEIGHT (IN CM): 13.2

ORIFICE DIAMETER (IN CM): 28.0

DIAMETER AT BOTTOM OF RIM OR NECK (IN CM): 27.6

BASE DIAMETER (IN CM) AND SHAPE OF BASE: 7.5

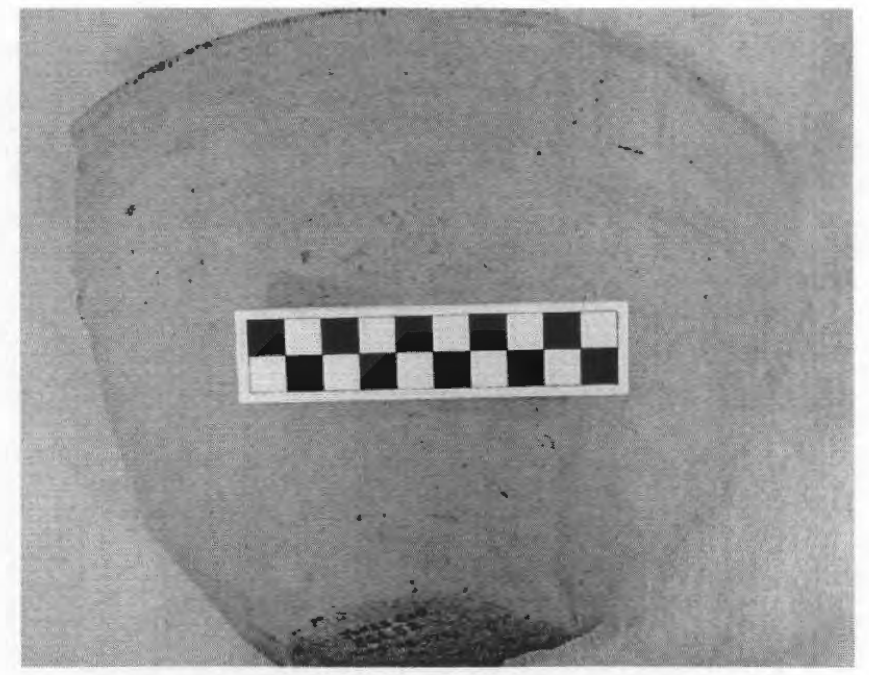

Figure 268. Ripley Engraved, var. unspecified carinated bowl, Frank Smith cemetery, Burial 11, Vessel 52.

ESTIMATED VOLUME (IN LITERS): 3.3

DECORATION (INCLUDING MOTIF AND ELEMENTS WHEN APPARENT): The rim panel has a simple horizontal scroll motif repeated four times around the vessel. The scrolls are divided by excised brackets.

PIGMENT USE AND LOCATION ON VESSEL: none

TYPE AND VARIETY [IF KNOWN]: Ripley Engraved, var. unspecified 
VESSEL NO.: Burial 11, Vessel 54; 2003.08.1809

NON-PLASTICS AND PASTE: grog and hematite

VESSEL FORM: Bottle with a flaring neck

RIM AND LIP FORM: Everted rim and rounded lip

CORE COLOR: $F$ (fired in a reducing environment and cooled in the open air)

INTERIOR SURFACE COLOR: reddish-brown

EXTERIOR SURFACE COLOR: reddish-brown; fire clouds on the neck, body, and base

WALL THICKNESS (RIM, BODY, AND BASE IN MM): rim, $4.7 \mathrm{~mm}$

INTERIOR SURFACE TREATMENT: none

EXTERIOR SURFACE TREATMENT: smoothed

HEIGHT (IN CM): 23.2

ORIFICE DIAMETER (IN CM): 5.1

DIAMETER AT BOTTOM OF RIM OR NECK (IN CM): 5.8

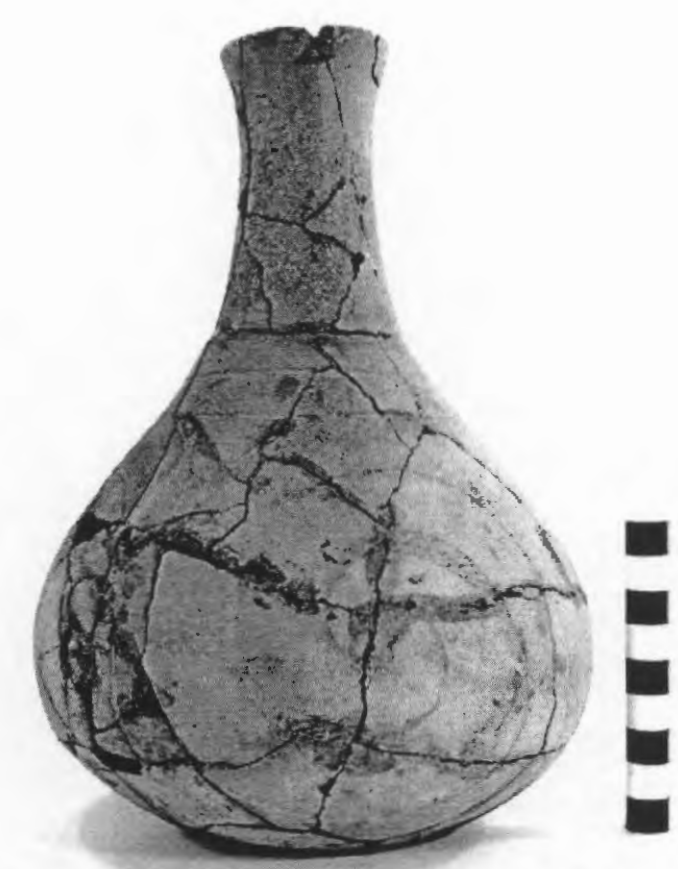

Figure 269. Wilder Engraved, var. Wilder bottle, Frank Smith cemetery, Burial 11, Vessel 54.

BASE DIAMETER (IN CM) AND SHAPE OF BASE: 9.0 ; circular and flat

ESTIMATED VOLUME (IN LITERS): 0.84

DECORATION (INCLUDING MOTIF AND ELEMENTS WHEN APPARENT): The top of the vessel body has three widely-spaced horizontal lines that define the top of the decorated panel; there is another horizontal engraved line at the base of the vessel. The primary motif is scrolls repeated four times around the vessel. The scrolls have two arms that begin at the apex of upper and lower triangles (that have hatched or cross-hatched corners), and the arms circle around each other before meeting at a small hatched circle. There are wider cross-hatched areas on both scrolls where they cross over the small central circle (Figure 269).

PIGMENT USE AND LOCATION ON VESSEL: none

TYPE AND VARIETY [IF KNOWN]: Wilder Engraved, var. Wilder 
VESSEL NO.: Burial 11, Vessel 55; 2003.08.1748

NON-PLASTICS AND PASTE: grog and bone

VESSEL FORM: Jar with a short rim

RIM AND LIP FORM: Everted rim and a rounded lip

CORE COLOR: B (fired and cooled in a reducing environment)

INTERIOR SURFACE COLOR: very dark grayish-brown

EXTERIOR SURFACE COLOR: very dark grayish-brown; fire clouds on the body

WALL THICKNESS (RIM, BODY, AND BASE

IN MM): rim, $5.3 \mathrm{~mm}$

INTERIOR SURFACE TREATMENT: smoothed

EXTERIOR SURFACE TREATMENT: none

HEIGHT (IN CM): 10.0

ORIFICE DIAMETER (IN CM): 10.6

DIAMETER AT BOTTOM OF RIM OR NECK (IN CM): 9.3

BASE DIAMETER (IN CM) AND SHAPE OF BASE: 6.0

ESTIMATED VOLUME (IN LITERS): 0.64

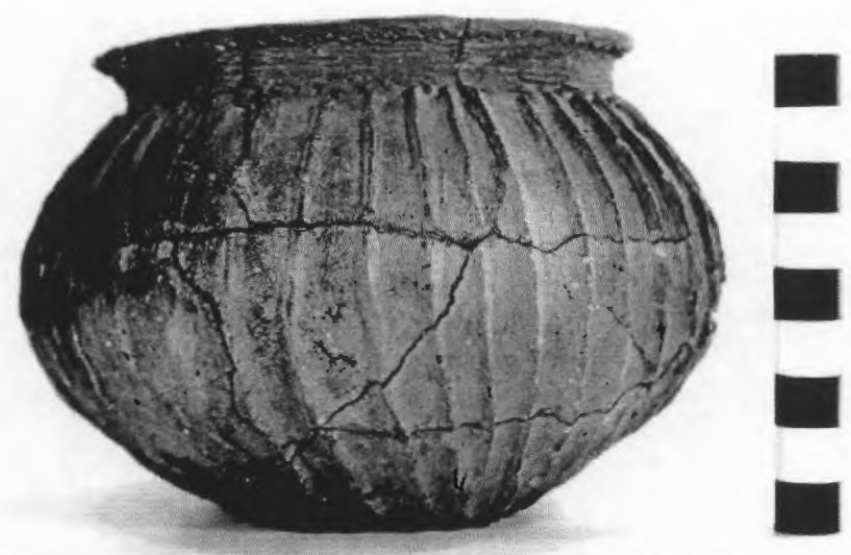

Figure 270. Cass Appliqued jar, Frank Smith cemetery, Burial 11, Vessel 55.

DECORATION (INCLUDING MOTIF AND ELEMENTS WHEN APPARENT): The rim has horizontal brushing marks as well as a row of tool punctates under the lip and a second row at the rim-body juncture. The vessel body is covered with vertical appliqued ridges $(n=39)$ that extend from the rim-body juncture to the vessel base (Figure 270).

PIGMENT USE AND LOCATION ON VESSEL: none

TYPE AND VARIETY [IF KNOWN]: Cass Appliqued 
VESSEL NO.: Burial 11, Vessel 56; 2003.08.1822

NON-PLASTICS AND PASTE: grog and bone

VESSEL FORM: Carinated bowl

RIM AND LIP FORM: Direct rim and a rounded, exterior folded lip

CORE COLOR: $\mathrm{G}$ (fired in a reducing environment and cooled in the open air)

INTERIOR SURFACE COLOR: dark grayish-brown

EXTERIOR SURFACE COLOR: dark yellowish-brown; fire clouds on rim, body, and base

WALL THICKNESS (RIM, BODY, AND BASE IN MM): rim, 6.5 mm

INTERIOR SURFACE TREATMENT: smoothed

EXTERIOR SURFACE TREATMENT: smoothed

HEIGHT (IN CM): 7.5

ORIFICE DIAMETER (IN CM): 16.2

DIAMETER AT BOTTOM OF RIM OR NECK (IN CM): I5.8

BASE DIAMETER (IN CM) AND SHAPE OF

BASE: 6.0

ESTIMATED VOLUME (IN LITERS): 0.73

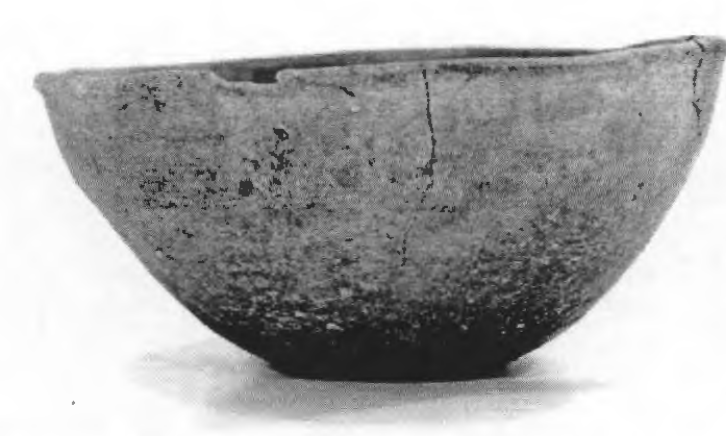

Figure 271. Ripley Engraved, var. unspecified carinated bowl, Frank Smith cemetery, Burial 11, Vessel 56.

DECORATION (INCLUDING MOTIF AND ELEMENTS WHEN APPARENT): The rim panel has stacks of horizontal engraved lines (sometimes with small pendant triangles) repeated four times around the vessel. The stacks of engraved lines are separated by sets of two vertical engraved lines that end in upper and lower open triangles (Figure 27I).

PIGMENT USE AND LOCATION ON VESSEL: none

TYPE AND VARIETY [IF KNOWN]: Ripley Engraved, var. unspecified

\section{Burial 12}

Burial 12 was in one of the northern burial rows, a few feet northwest of Burial 4 (see Figure 211). The burial pit was $0.79 \mathrm{~m}$ in depth, and Jones (n.d.) indicated that there were four ceramic vessels placed in the grave. However, there are seven ceramic vessels in the Jones collection that have a Burial 12 provenience. These include a Maydelle Incised jar, three compound bowls (cf. Womack Engraved, var. Gum Creek or Turner Engraved, var. unspecified, Turner Engraved, var. Horton, and Ripley Engraved, 
var. Caldwell), and three carinated bowls: Ripley Engraved, cf. var. McKinney, an engraved vessel of unknown type, and a plain carinated bowl.

VESSEL NO.: Burial 12, Vessel 63;2003.08.1423

NON-PLASTICS AND PASTE: grog, bone, and hematite

VESSEL FORM: Carinated bowl

RIM AND LIP FORM: Direct rim and a rounded, exterior folded lip

CORE COLOR: C (incompletely oxidized during firing)

INTERIOR SURFACE COLOR: dark yellowish-brown; fire clouds on the rim and base; organic residue on the body

EXTERIOR SURFACE COLOR: dark yellowishbrown; fire clouds on the body

WALL THICKNESS (RIM, BODY, AND BASE IN MM): rim, $6.5 \mathrm{~mm}$

INTERIOR SURFACE TREATMENT: smoothed

EXTERIOR SURFACE TREATMENT:

smoothed

HEIGHT (IN CM): I4.2

ORIFICE DIAMETER (IN CM): 31.6

Figure 272. Ripley Engraved, cf. var. McKinney

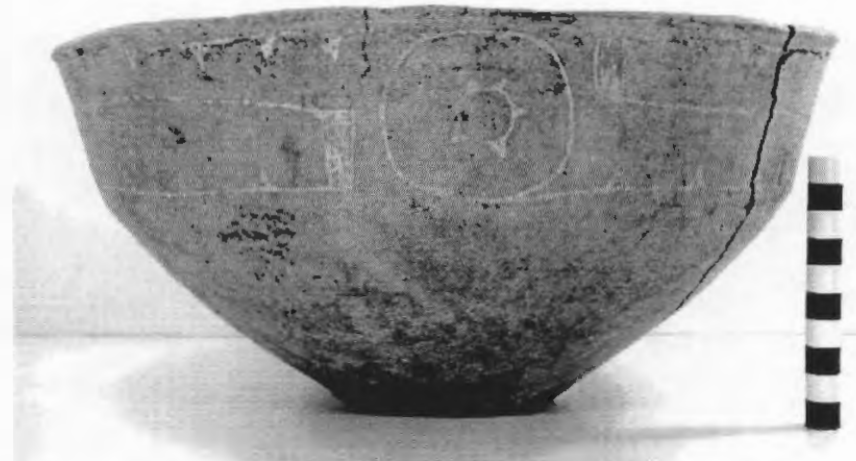

carinated bowl, Frank Smith cemetery, Burial 12, Vessel 63.

DIAMETER AT BOTTOM OF RIM OR NECK (IN CM): 31.0

BASE DIAMETER (IN CM) AND SHAPE OF BASE: 8.4; circular and flat

ESTIMATED VOLUME (IN LITERS): 4.0

DECORATION (INCLUDING MOTIF AND ELEMENTS WHEN APPARENT): The rim panel has a central circle that is repeated four times around the vessel. The circle has a smaller circle within it that has excised pendant triangles on it. The central circles are bracketed by horizontal scrolls with cross-hatched columns at either end. Above and below the scrolls (but not the central circles) are excised pendant triangles (Figure 272).

There is also a single horizontal engraved line on the interior vessel surface at the carination.

PIGMENT USE AND LOCATION ON VESSEL: none

TYPE AND VARIETY [IF KNOWN]: Ripley Engraved, cf. var. McKinney 
VESSEL NO.: Burial 12, Vessel 64; 2003.08.786

NON-PLASTICS AND PASTE: N/A [reconstructed\}

VESSEL FORM: Compound bowl

RIM AND LIP FORM: Everted rim and a rounded lip

CORE COLOR: N/A

INTERIOR SURFACE COLOR: N/A

EXTERIOR SURFACE COLOR: N/A

WALL THICKNESS (RIM, BODY, AND BASE IN $\mathrm{MM})$ : rim, $7.6 \mathrm{~mm}$

INTERIOR SURFACE TREATMENT: N/A

EXTERIOR SURFACE TREATMENT: N/A

HEIGHT (IN CM): 16.5

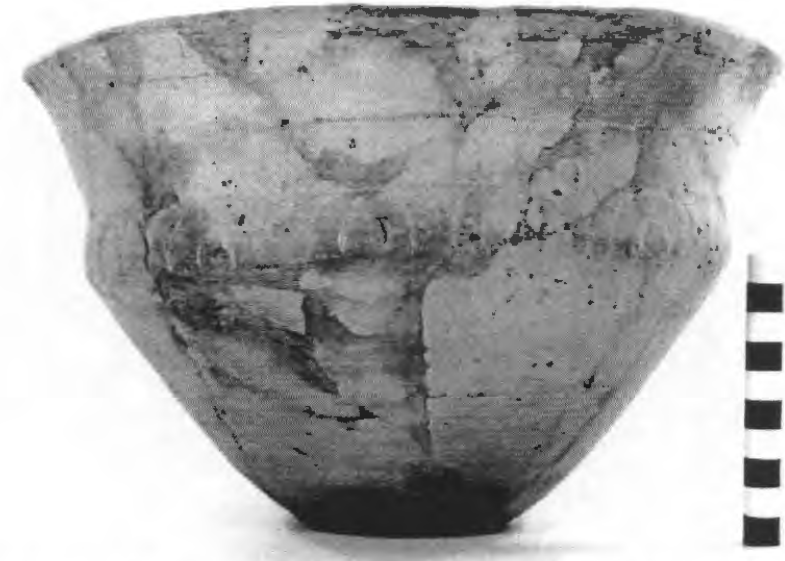

Figure 273. cf. Womack Engraved, var. Gum Creek or Turner Engraved, var. unspecified compound bowl, Frank Smith cemetery, Burial 12, Vessel 64.

ORIFICE DIAMETER (IN CM): 27.6

DIAMETER AT BOTTOM OF RIM OR NECK (IN CM): 24.5

BASE DIAMETER (IN CM) AND SHAPE OF BASE: 8.4 ; circular and flat

ESTIMATED VOLUME (IN LITERS): 3.6

DECORATION (INCLUDING MOTIF AND ELEMENTS WHEN APPARENT): The upper rim panel has four widely-spaced horizontal engraved lines; the uppermost line has small excised pendant triangles. The Iower panel is comprised of 11 engraved semi-circles divided by 11 elongated excised pendant triangles (Figure 273).

PIGMENT USE AND LOCATION ON VESSEL: none

TYPE AND VARIETY [IF KNOWN]: of. Womack Engraved, var. Gum Creek or Turner Engraved, var. unspecified 
VESSEL NO.: Burial 12, Vessel 65; 2003.08.690

NON-PLASTICS AND PASTE: grog and hematite

VESSEL FORM: Jar

RIM AND LIP FORM: Everted rim and rounded lip

CORE COLOR: F (fired in a reducing environment and cooled in the open air)

INTERIOR SURFACE COLOR: reddish-brown; organic residue on the rim and body

EXTERIOR SURFACE COLOR: reddish-brown; fire clouds on the body and base

WALL THICKNESS (RIM, BODY, AND BASE IN MM): rim, $6.3 \mathrm{~mm}$

INTERIOR SURFACE TREATMENT: smoothed

EXTERIOR SURFACE TREATMENT: none

HEIGHT (IN CM): 11.8

ORIFICE DIAMETER (IN CM): 12.1

DIAMETER AT BOTTOM OF RIM OR NECK (IN CM): 9.6

BASE DIAMETER (IN CM) AND SHAPE OF BASE: 8.0 ; circular and flat

ESTIMATED VOLUME (IN LITERS): 0.86

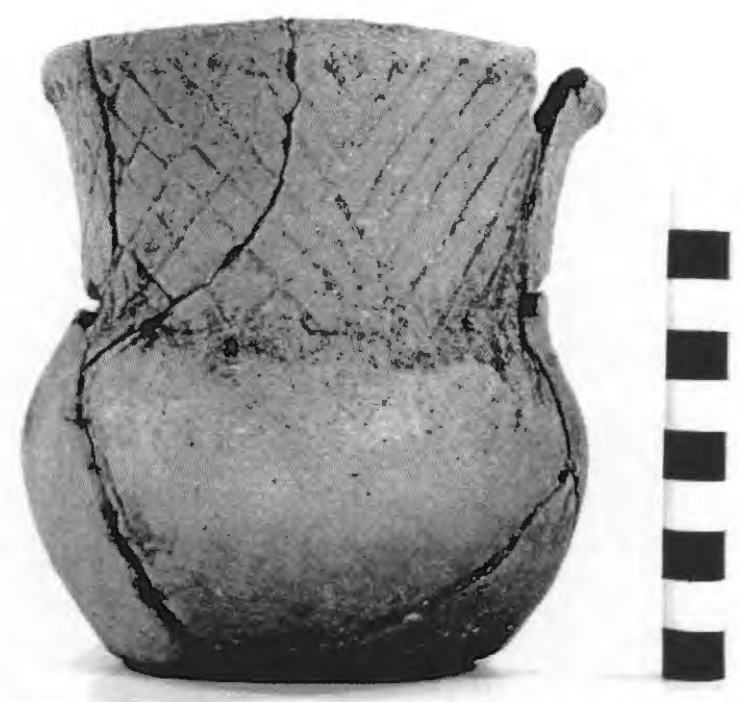

Figure 274. Maydelle Incised jar, Frank Smith cemetery, Burial 12, Vessel 65.

DECORATION (INCLUDING MOTIF AND ELEMENTS WHEN APPARENT): The rim is decorated with cross-hatched and diagonal opposed incised lines. There are also rows of tool punctates under the lip and at the rim-body juncture (Figure 274).

PIGMENT USE AND LOCATION ON VESSEL: none

TYPE AND VARIETY [IF KNOWN]: Maydelle Incised 
VESSEL NO.: Burial 12, Vessel 66; 2003.08.233

NON-PLASTICS AND PASTE: N/A [reconstructed]

VESSEL FORM: Compound bowl with four rim peaks (Figure 275)

RIM AND LIP FORM: Everted rim and a rounded, exterior folded lip

CORE COLOR: N/A

INTERIOR SURFACE COLOR: N/A

EXTERIOR SURFACE COLOR: N/A

WALL THICKNESS (RIM, BODY, AND BASE IN MM): rim, $6.2 \mathrm{~mm}$

INTERIOR SURFACE TREATMENT: N/A

EXTERIOR SURFACE TREATMENT: N/A

HEIGHT (IN CM): 7.0

ORIFICE DIAMETER (IN CM): 18.7

DIAMETER AT BOTTOM OF RIM OR NECK (IN CM): 14.7

BASE DIAMETER (IN CM) AND SHAPE OF BASE: 7.0; circular and flat

ESTIMATED VOLUME (IN LITERS): 1.1

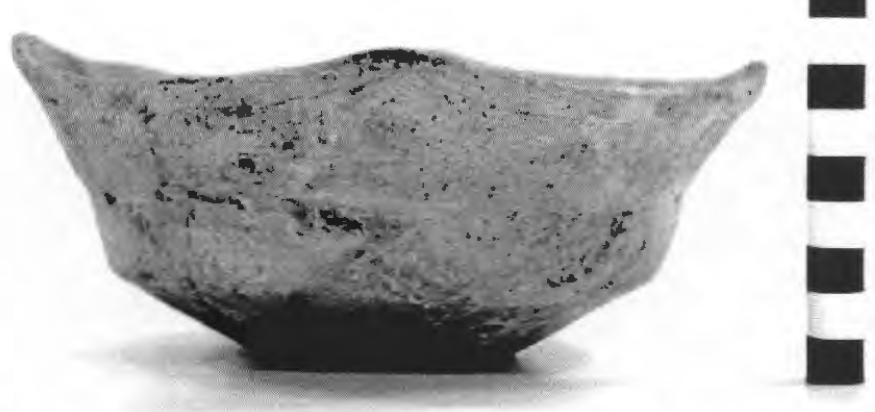

Figure 275. Turner Engraved, var. Horton compound bowl, Frank Smith cemetery, Burial 12, Vessel 66.

DECORATION (INCLUDING MOTIF AND ELEMENTS WHEN APPARENT): The upper rim panel has two broadly-spaced horizontal engraved lines as well as a series of three negative ovals under and adjacent to each rim peak (Figure 275). Two of the negative ovals have a central dot, while the third has a hooked arm element. The lower rim panel has engraved circles repeated four times around the vessel; each circle has a triangular element at its center. The circles are divided by sets of one or two short diagonal engraved lines.

PIGMENT USE AND LOCATION ON VESSEL: none

TYPE AND VARIETY [IF KNOWN]: Turner Engraved, var. Horton 
VESSEL NO.: Burial 12, Vessel 67; 2003.08.187

NON-PLASTICS AND PASTE: grog and bone

VESSEL FORM: Carinated bowl with four rim peaks (Figure 276)

RIM AND LIP FORM: Direct rim and a rounded, exterior folded lip

CORE COLOR: B (fired and cooled in a reducing environment)

INTERIOR SURFACE COLOR: very dark grayish-brown

EXTERIOR SURFACE COLOR: grayish-brown

WALL THICKNESS (RIM, BODY, AND BASE IN MM): rim, $7.0 \mathrm{~mm}$

INTERIOR SURFACE TREATMENT: none

EXTERIOR SURFACE TREATMENT: none

HEIGHT (IN CM): 5.0

ORIFICE DIAMETER (IN CM): 11.5

DIAMETER AT BOTTOM OF RIM OR NECK (IN CM): 9.3

BASE DIAMETER (IN CM) AND SHAPE OF BASE: 5.2; circular and flat

Figure 276. Plain carinated bowl, Frank Smith cemetery, Burial 12, Vessel 67.

ESTIMATED VOLUME (IN LITERS): 0.35

DECORATION (INCLUDING MOTIF AND ELEMENTS WHEN APPARENT): Plain (Figure 276)

PIGMENT USE AND LOCATION ON VESSEL: none

TYPE AND VARIETY [IF KNOWN]: Unidentified plain ware 
VESSEL NO.: Burial 12, Vessel 68; 2003.08.397

NON-PLASTICS AND PASTE: grog and bone

VESSEL FORM: Compound bowl and four rim peaks (Figure 277)

RIM AND LIP FORM: Everted rim and a rounded lip

CORE COLOR: N/A

INTERIOR SURFACE COLOR: N/A

EXTERIOR SURFACE COLOR: N/A

WALL THICKNESS (RIM, BODY, AND BASE IN MM): rim, $5.4 \mathrm{~mm}$

INTERIOR SURFACE TREATMENT: N/A

EXTERIOR SURFACE TREATMENT: N/A

HEIGHT (IN CM): 7.0

ORIFICE DIAMETER (IN CM): 12.5

DIAMETER AT BOTTOM OF RIM OR NECK (IN CM): 10.6

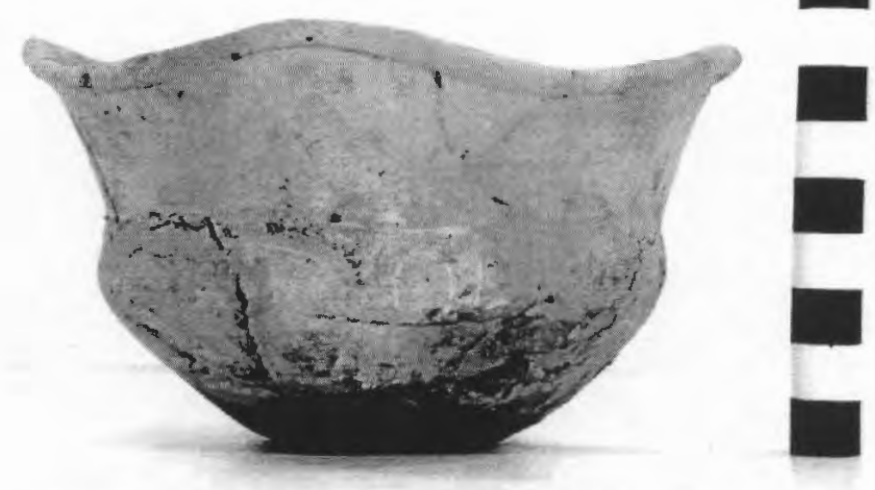

Figure 277. Ripley Engraved, var. Caldwell compound bowl, Frank Smith cemetery, Burial 12, Vessel 68.

BASE DIAMETER (IN CM) AND SHAPE OF BASE: 5.0; circular and flat

ESTIMATED VOLUME (IN LITERS): 0.7

DECORATION (INCLUDING MOTIF AND ELEMENTS WHEN APPARENT): The upper rim panel is undecorated. The lower rim panel has an engraved scroll and semi-circle motif repeated four times around the vessel (Figure 277).

PIGMENT USE AND LOCATION ON VESSEL: none

TYPE AND VARIETY [IF KNOWN]: Ripley Engraved, var. Caldwell

VESSEL NO.: Burial 12, Vessel 69

NON-PLASTICS AND PASTE: grog and bone

VESSEL FORM: Carinated bowl with scalloped lip

RIM AND LIP FORM: Direct rim and a rounded, exterior folded lip 
CORE COLOR: B (fired and cooled in a reducing environment)

INTERIOR SURFACE COLOR: dark grayish-brown

EXTERIOR SURFACE COLOR: grayish-brown

WALL THICKNESS (RIM, BODY, AND BASE IN MM): rim, 5.4 mm; body, $6.5 \mathrm{~mm}$

INTERIOR SURFACE TREATMENT: smoothed

EXTERIOR SURFACE TREATMENT: smoothed

HEIGHT (IN CM): N/A

ORIFICE DIAMETER (IN CM): 13.0

DIAMETER AT BOTTOM OF RIM OR NECK (IN CM): I1.4

BASE DIAMETER (IN CM) AND SHAPE OF BASE: N/A

ESTIMATED VOLUME (IN LITERS): N/A

DECORATION (INCLUDING MOTIF AND ELEMENTS WHEN APPARENT): The rim panel has central engraved semi-circles with triangular-shaped scroll fill zones that have short vertical to curvilinear lines. Radiating from the central circles are three horizontal to diagonal lines that comprise the scroll element (Figure 278).

PIGMENT USE AND LOCATION ON VESSEL: none

TYPE AND VARIETY [IF KNOWN]: Unidentified fine ware

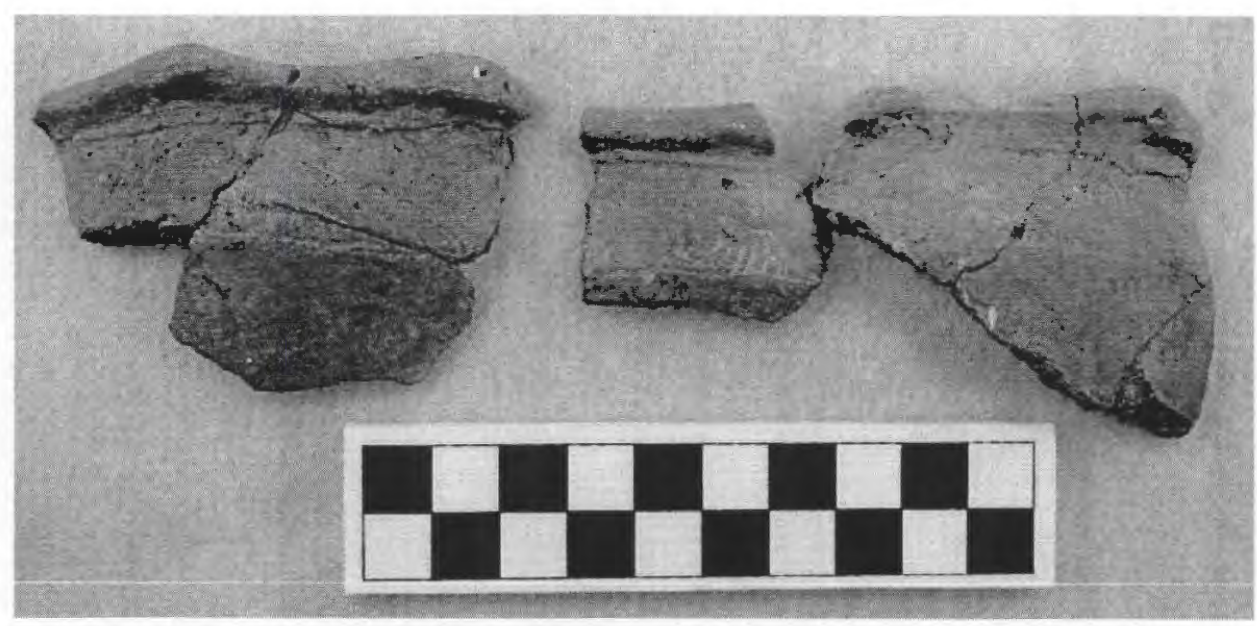

Figure 278. Engraved carinated bowl sherds, Frank Smith cemetery, Burial 12, Vessel 69. 


\section{Burial 13}

Burial 13 was in one of the northern burial rows, between Burials 7 and 12 (see Figure 211). The depth of the burial pit was $0.99 \mathrm{~m}$ bs. Jones (n.d.) indicated that three ceramic vessels had been placed in the grave, but there are only two vessels identified from the burial in the Jones collection. They are a Wilder Engraved, var. unspecified olla and a Wilder Engraved, var. Wilder bottle.

VESSEL NO.: Burial 13, Vessel 71; 2003.08.439

NON-PLASTICS AND PASTE: grog and hematite

VESSEL FORM: Olla

RIM AND LIP FORM: Everted rim and a rounded, exterior folded lip

CORE COLOR: A (fired and cooled in the open air)

INTERIOR SURFACE COLOR: yellowish-brown

EXTERIOR SURFACE COLOR: yellowish-brown; fire clouds on the body and base

WALL THICKNESS (RIM, BODY, AND BASE IN MM): rim, $6.9 \mathrm{~mm}$

INTERIOR SURFACE TREATMENT: smoothed on neck

EXTERIOR SURFACE TREATMENT: smoothed

HEIGHT (IN CM): 27.3

ORIFICE DIAMETER (IN CM): 12.2

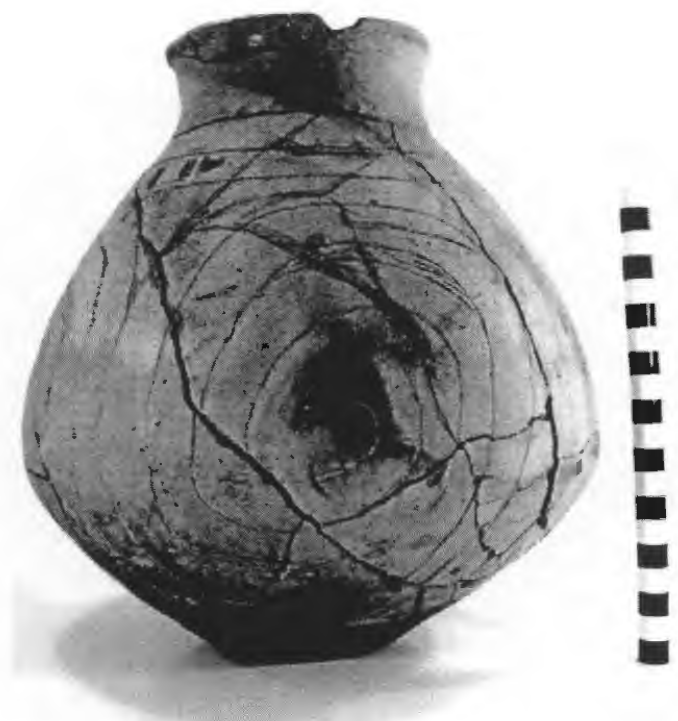

Figure 279. Wilder Engraved, var. unspecified olla, Frank Smith cemetery, Burial 13, Vessel 71.

DIAMETER AT BOTTOM OF RIM OR NECK (IN CM): 12.1

BASE DIAMETER (IN CM) AND SHAPE OF BASE: 9.4; circular and flat

ESTIMATED VOLUME (IN LITERS): 2.1

DECORATION (INCLUDING MOTIF AND ELEMENTS WHEN APPARENT): The vessel has two horizontal engraved lines at the top and bottom of the vessel body. Between are four sets of engraved scrolls that begin and end at upper and lower triangle elements with one hatched corner. The engraved scrolls have upper and lower arms that encircle each other, and end in the center as hooked arms. The scrolls have wider hatched arms where they pass over the central hooked arms (Figure 279).

PIGMENT USE AND LOCATION ON VESSEL: red pigment in the engraved lines 
VESSEL NO.: Burial 13, Vessel 72; 2003.08.66

NON-PLASTICS AND PASTE: grog

VESSEL FORM: Bottle with a flaring neck

RIM AND LIP FORM: Everted rim and a rounded lip

CORE COLOR: $\mathrm{B}$ (fired and cooled in a reducing environment)

INTERIOR SURFACE COLOR: black

EXTERIOR SURFACE COLOR: black

WALL THICKNESS (RIM, BODY, AND BASE IN MM): neck, $5.4 \mathrm{~mm}$

INTERIOR SURFACE TREATMENT: burnished on upper neck

EXTERIOR SURFACE TREATMENT: burnished

HEIGHT (IN CM): 17.4

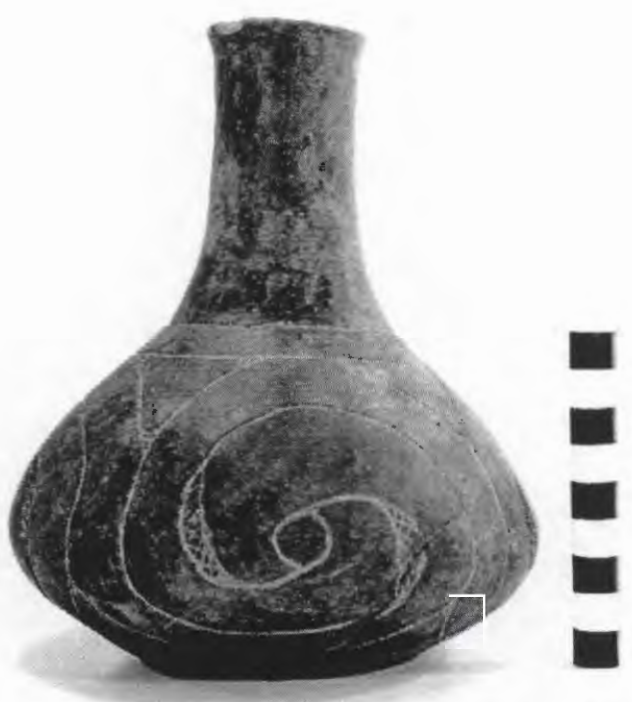

Figure 280. Wilder Engraved, var. Wilder bottle, Frank Smith cemetery, Burial 13, Vessel 72.

ORIFICE DIAMETER (IN CM): 4.6

DIAMETER AT BOTTOM OF RIM OR NECK (IN CM): 6.3

BASE DIAMETER (IN CM) AND SHAPE OF BASE: 8.0; circular and flat

ESTIMATED VOLUME (IN LITERS): 0.56

DECORATION (INCLUDING MOTIF AND ELEMENTS WHEN APPARENT): The vessel body has an engraved scroll motif that is repeated four times around the vessel. Each scroll has upper and lower arms that encircle each other, and meet at a small central circle. There are wider cross-hatched areas on each scroll arm where it passes the small central circle. The scroll arms begin at upper and lower triangle elements with hatched corners (Figure 280).

PIGMENT USEAND LOCATION ON VESSEL: red pigment in engraved lines

TYPE AND VARIETY [IF KNOWN]: Wilder Engraved, var. Wilder 


\section{Burial 14, 15 , and 16}

Burials 14,15 , and 16 at the Frank Smith cemetery were excavated by Jones in October and November 1959. They were located in the two northern burial rows (see Figure 211). Burial 14 was in a pit that was $1.83 \mathrm{~m}$ in length, $0.91 \mathrm{~m}$ in width, and its depth was $0.91 \mathrm{~m}$; no information is available on funerary offerings. Burial 15 was in a $1.68 \mathrm{~m}$ long pit that was $0.86 \mathrm{~m}$ wide, and $1.04 \mathrm{~m}$ in depth. As with Burial 14 , no information is available on the funerary offerings in this burial.

Burial 16 had been placed in a $2.18 \mathrm{~m}$ long pit that was $0.91 \mathrm{~m}$ in width (Figure 281). The depth of the pit ranged from $0.91 \mathrm{~m}$ at the head and $1.14 \mathrm{~m}$ at its feet. Four ceramic vessels were placed in the grave as funerary offerings, including a carinated bowl by the upper left leg, and a jar, bottle, and large carinated bowl by the upper right leg. In the area of the head were pieces of mussel shell, ash, and charcoal, suggesting a fire had been placed on the floor of the burial pit before the deceased was laid in the grave.

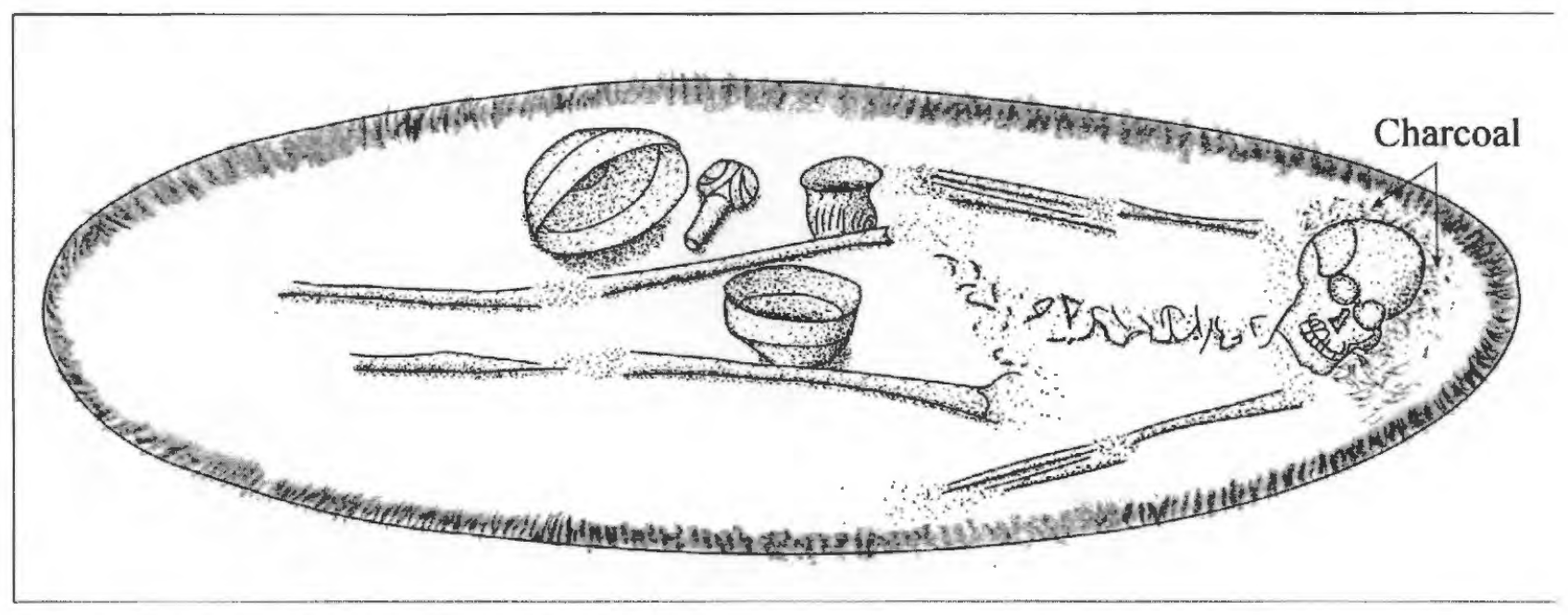

Figure 281. Burial 16 at the Frank Smith cemetery.

\section{Vessels from Unknown Burials}

VESSEL NO.: 12-M-5; 2003.08.670

NON-PLASTICS AND PASTE: grog and bone

VESSEL FORM: Olla

RIM AND LIP FORM: Everted rim and rounded lip

CORE COLOR: G (fired in a reducing environment and cooled in the open air)

INTERIOR SURFACE COLOR: grayish-brown

EXTERIOR SURFACE COLOR: yellowish-brown; fire clouds on the rim and body 
WALL THICKNESS (RIM, BODY, AND BASE IN MM): rim, 6.4 mm

INTERIOR SURFACE TREATMENT: none

EXTERIOR SURFACE TREATMENT: smoothed

HEIGHT (IN CM): 34.4

ORIFICE DIAMETER (IN CM): 10.3

DIAMETER AT BOTTOM OF RIM OR NECK (IN CM): 8.9; $28.6 \mathrm{~cm}$ maximum body diameter

BASE DIAMETER (IN CM) AND SHAPE OF BASE: 9.0; circular and flat

ESTIMATED VOLUME (IN LITERS): 2.5

DECORATION (INCLUDING MOTIF AND ELEMENTS WHEN APPARENT): The rim has crosshatched engraved lines. The vessel body has an engraved scroll motif that is repeated four times around the vessel. Each scroll has upper and lower arms that begin at the apex of large upper and lower pendant triangles, then encircle each other. The scroll arms do not meet. The large pendant triangle elements have cross-hatched corners and a small central triangle within each of them (Figure 282).

PIGMENT USE AND LOCATION ON VESSEL: none

TYPE AND VARIETY [IF KNOWN]: Wilder Engraved, var. unspecified

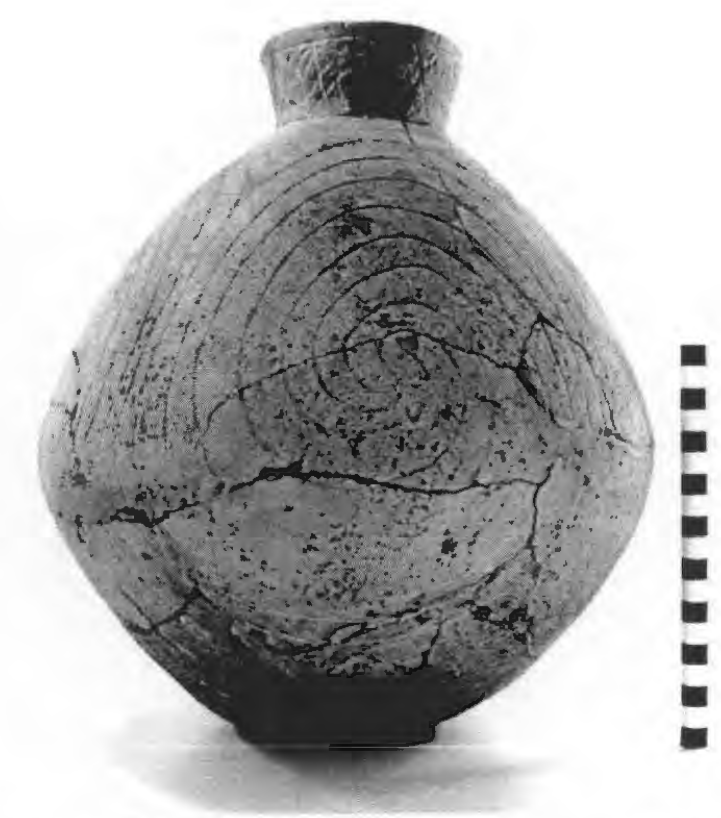

Figure 282. Wilder Engraved, var. unspecified olla, Frank Smith cemetery, Vessel 2003.08.670. 
VESSEL NO.: M-5, A-1; 2003.08.69

NON-PLASTICS AND PASTE: no visible temper; sandy paste

VESSEL FORM: Small bowl with two sets of two suspension holes (Figure 283). From above, the vessel has two $2.5 \mathrm{~cm}$ diameter openings; they are not connected. Neither opening has evidence of fire or charred residues.

RIM AND LIP FORM: Direct rim and rounded lip

CORE COLOR: $\mathrm{G}$ (fired in a reducing environment and cooled in the open air)

INTERIOR SURFACE COLOR: grayish-brown

EXTERIOR SURFACE COLOR: yellowish-brown

WALL THICKNESS (RIM, BODY, AND BASE IN MM): rim, $11.6 \mathrm{~mm}$

INTERIOR SURFACE TREATMENT: none

EXTERIOR SURFACE TREATMENT: none

HEIGHT (IN CM): 5.2

ORIFICE DIAMETER (IN CM): $6.2 \mathrm{~cm}$ in length

DIAMETER AT BOTTOM OF RIM OR NECK

(IN CM): N/A

BASE DIAMETER (IN CM) AND SHAPE OF

BASE: 5.5; circular and flat

ESTIMATED VOLUME (IN LITERS): 0.13

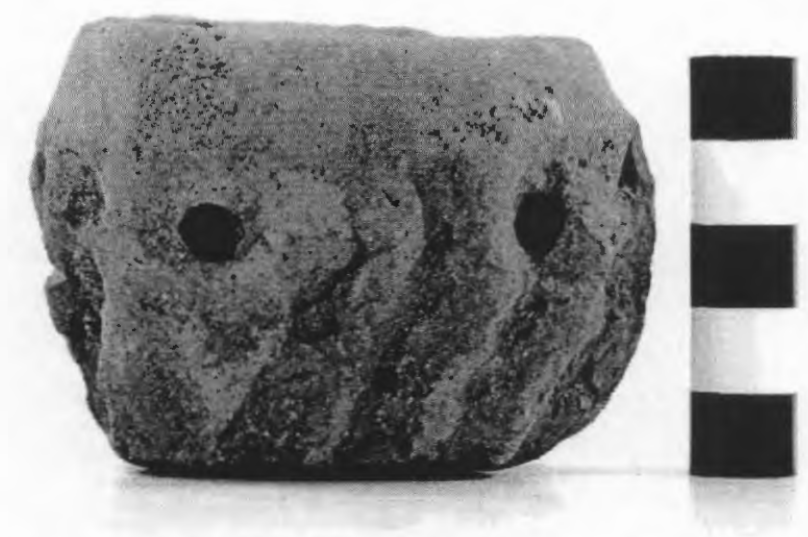

Figure 283. Pinched bowl, Frank Smith cemetery, Vessel 2003.08.69.

DECORATION (INCLUDING MOTIF AND ELEMENTS WHEN APPARENT): The vessel is decorated wit 13 diagonal pinched ridges that cover its entire exterior surface.

PIGMENT USE AND LOCATION ON VESSEL: none

TYPE AND VARIETY [IF KNOWN]: Unidentified utility ware 
VESSEL NO.: Vessel 1-28; 2003.08.490

NON-PLASTICS AND PASTE: grog

VESSEL FORM: Carinated bowl, miniature

RIM AND LIP FORM: Direct rim and rounded lip

CORE COLOR: A (fired and cooled in an oxidizing environment)

INTERIOR SURFACE COLOR: reddish-brown; fire clouds on the rim and body

EXTERIOR SURFACE COLOR: reddish-brown; fire clouds on the rim, body, and base

WALL THICKNESS (RIM, BODY, AND BASE IN MM): rim, $5.0 \mathrm{~mm}$

INTERIOR SURFACE TREATMENT: smoothed

EXTERIOR SURFACE TREATMENT: smoothed

HEIGHT (IN CM): 3.5

ORIFICE DIAMETER (IN CM): 8.5

DIAMETER AT BOTTOM OF RIM OR NECK (IN CM): 7.9

BASE DIAMETER (IN CM) AND SHAPE OF BASE: 4.5; circular and flat

ESTIMATED VOLUME (IN LITERS): 0.18

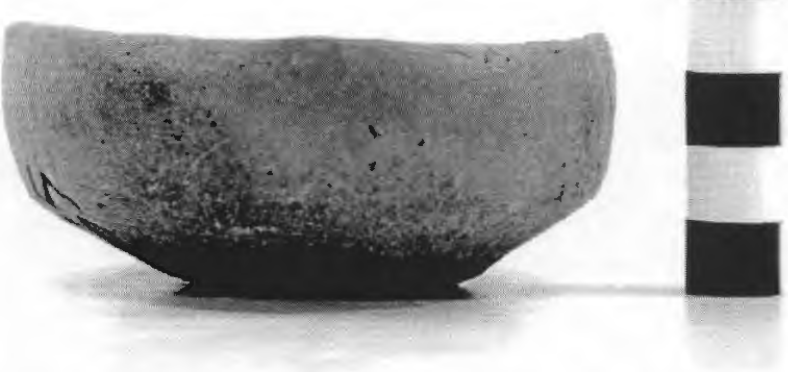

Figure 284. Plain carinated bowl, Frank Smith cemetery, Vessel 2003.08.490.

DECORATION (INCLUDING MOTIF AND ELEMENTS WHEN APPARENT): Plain (Figure 284)

PIGMENT USE AND LOCATION ON VESSEL: none

TYPE AND VARIETY [IF KNOWN]: Unidentified plain ware

\section{Frank Smith Refinery Site (41UR327)}

Apparently Buddy Jones excavated only a single burial at the Frank Smith Refinery site. The site is situated on an alluvial terrace (250-260 feet amsl) of Little Cypress Creek just east of the confluence of Clear Creek and Little Cypress Creek, about I.5 km east of the Frank Smith cemetery (see Figure 1). The one vessel from the site is a Hodges Engraved conjoined vessel. 
VESSEL NO:: UC 6, 2003.08.1791

NON-PLASTICS AND PASTE: grog and hematite

VESSEL FORM: conjoined carinated bowl rim and globular bottle body (Figure 285)

RIM AND LIP FORM: Inverted rim and rounded, exterior folded lip; two sets of four suspension holes

CORE COLOR: $\mathrm{F}$ (fired in a reducing environment and cooled in the open air)

INTERIOR SURFACE COLOR: red

EXTERIOR SURFACE COLOR: red

WALL THICKNESS (RIM, BODY, AND BASE IN

MM): rim, $4.4 \mathrm{~mm}$; body, $3.9 \mathrm{~mm}$

INTERIOR SURFACE TREATMENT: smoothed

EXTERIOR SURFACE TREATMENT: smoothed

HEIGHT (IN CM): I4.4

ORIFICE DIAMETER (IN CM): 10.2

DIAMETER AT BOTTOM OF RIM OR NECK (IN

CM): $11.4 ; 16.1 \mathrm{~cm}$ maximum body diameter

BASE DIAMETER (IN CM) AND SHAPE OF BASE:

5.3 ; circular and rounded

ESTIMATED VOLUME (IN LITERS): 0.88

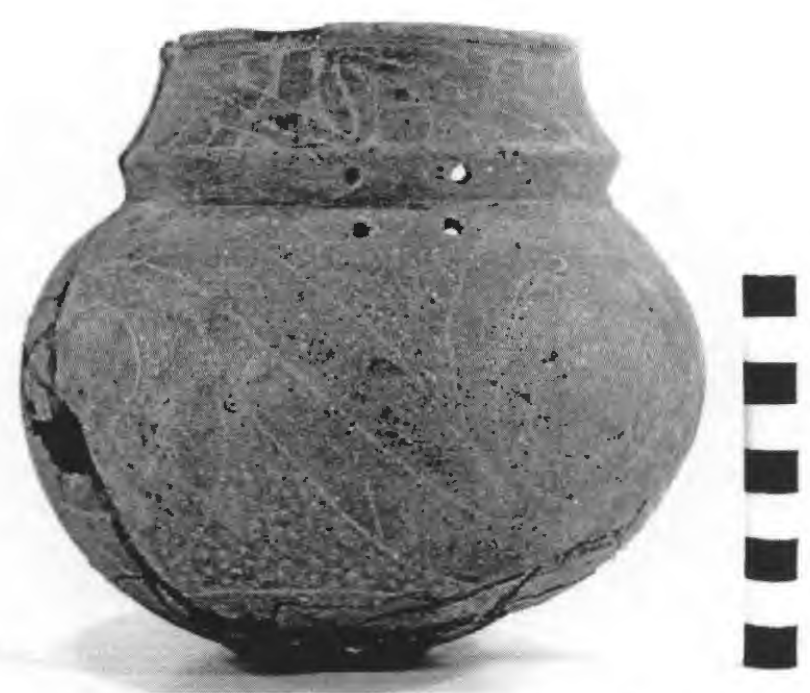

Figure 285. Hodges Engraved conjoined vessel, Frank Smith Refinery burial, Vessel 2003.08.1791.

DECORATION (INCLUDING MOTIF AND ELEMENTS WHEN APPARENT): The vessel has a red slip on both vessel surfaces. The rim of the carinated bowI section has an engraved meandering scroll motif repeated four times around the vessel, with small tick marks on the scroll center line. Upper and lower scroll fill elements include large ovals defined by vertical lines and brackets (Figure 285).

The lower vessel section has two sets of two suspension holes at the upper part of the body. The remainder of the bottle body has four sets of engraved curvilinear meanders and circles. The engraved meanders are filled with small tool punctates. The engraved circles have an outer circle filled with tool punctates, while the inner circle is plain (Figure 285). Webb (1959:Figure 107j) illustrates a very similar decorated Hodges Engraved vessel from Belcher phase contexts (ca. A.D. 1500-1700) at the Belcher site in Northwest Louisiana, and Suhm and Jelks (1962:Plate 38a) document a Hodges Engraved conjoined vessel from the Riley site (41UR2). 


\section{Vessel Comparisons between Funerary Assemblages}

A wide variety of defined ceramic types and varieties are represented in the mortuary vessels from the Gum Creek/Little Cypress Creek cemeteries discussed in this report. Among the fine wares, several varieties of Ripley Engraved and Taylor Engraved are particularly abundant, and other important fine wares include Wilder Engraved bottles, Bailey Engraved bottles, and Turner Engraved compound bowls. In the utility wares, important types include Harleton Appliqued, Bullard Brushed, and Cass Appliqued (Table 8).

Table 8. Fine ware and utility ware types and varieties identified in the Gum Creek/Little Cypress Creek cemetery sites.

\begin{tabular}{llllll}
\hline Types & UR317 & UR318 & UR319 & UR320 & UR326
\end{tabular}

\section{Fine ware types}

Bailey Engraved

Hodges Engraved*

Ripley Engraved, var. Caldwell

Ripley Engraved, ef. var. Carpenter

Ripley Engraved, var. Carpenter

Ripley Engraved, var. Cash

Ripley Engraved, var. Gandy

Ripley Engraved, cf. var. Gandy

Ripley Engraved, var. Galt

Ripley Engraved, var. McKinney

Ripley Engraved, var. Williams

Simms Engraved

Taylor Engraved

Tumer Engraved, var. Horton

Tumer Engraved, var. Turner

Wilder Engraved

Womack Engraved

$\begin{array}{ccccc}4 & - & - & 1 & 1 \\ - & - & 1 & - & - \\ - & - & 1 & 2 & 2 \\ 2 & - & - & 1 & - \\ - & - & - & 1 & - \\ 2 & 1 & 1 & - & - \\ 3 & 6 & 1 & - & - \\ 12 & 10 & - & 3 & - \\ 5 & 3 & 1 & 2 & 1 \\ 7 & 1 & - & 7 & 7 \\ 2 & - & - & - & - \\ - & - & - & 3 & - \\ 11 & 4 & 2 & 7 & 3 \\ - & - & - & 1 & 2 \\ 1 & - & - & 2 & - \\ 3 & 1 & - & 3 & 4 \\ 3 & - & - & - & 1\end{array}$

\section{Utility ware types}

Bullard Brushed

Cass Appliqued

Harleton Appliqued

Karnack Brushed-Incised

La Rue Neck Banded

Maydelle Incised

Mockingbird Punctated

Pease Brushed-Incised

R326

*a second Hodges Engraved vessel is in a burial al the Frank Smith Refinery site (4lUR327)

The most common fine wares are Taylor Engraved carinated bowls, bottles, jars, and deep bowls, Ripley Engraved carinated bowls, cf. var. Gandy (with a stylistic motif on carinated bowls that combines the scroll motif of var. Gandy with the pendant triangle elements of var. McKinney; the cf. var. Gandy vessels warrant a designation as a completely new variety separate from var. Gandy), Ripley Engraved, var. McKinney, Ripley Engraved, var. Galt, and Wilder Engraved bottles, ollas, and jars. Taken together, more than $42 \%$ of all the fine wares in the Gum Creek/Little Cypress Creek cemeteries have been 
assigned to defined varieties of Ripley Engraved. Approximately $14 \%$ of the fine wares are of the Taylor Engraved type, compared to Wilder Engraved vessels that comprise 5.6\% of the mortuary vessels.

Harleton Appliqued jars are the most common utility wares in the mortuary assemblages (see Table 8). It tends to co-occur with both Bullard Brushed and Cass Appliqued jars at the Enis Smith, Herbert Taft, and Frank Smith sites, but with Karnack Brushed-Incised and Pease Brushed-Inciscd at the Henry Williams site.

When do these cemeteries date to in the Late Caddo Titus phase, which spans the period from ca. A.D. 1430-1680, if not a generation later than A.D. 1680? None of these cemeteries have any available radiocarbon or thermoluminescence dates, which hampers definitive chronological estimates. However, one way to possibly establish the temporal age of the cemeteries is through the consideration of the seriation of Ripley Engraved rim motifs, as discussed in Perttula (1992:243-249). This frequency seriation was developed through a co-association of arrow point caches of different types (Perdiz, Bassett, Maud, and Talco) with distinctive Ripley Engraved rim motifs at a number of cemctcries (see Thurmond 1990; Turner 1978), namely the continuous scroll (var. Carpenter), the scroll (var. Gandy), scroll and circle (var. Galt), and the pendant triangle (var. McKimney). Presuming that the Perdiz arrow point was the earliest type used by Titus phase peoples, followed by the Bassett, Maud, and Talco points in later burials, the seriation suggests that the earliest style of Ripley Engraved was the var. Carpenter motif, then next came var. Gandy vessels, followed by var. Galt, and var. McKinney vessels (see Perttula 1992:Table A-2).

Relying on these frequency seriation results from a number of Titus phase cemeteries, as well as the proportions of the different Ripley Engraved carinated bowl and bowl motifs (Table 9) in the Gum Creek/Little Cypress Creek cemeteries, it is possible to suggest on the basis of the available evidence which cemeteries may have been in use in early and/or late Titus phase times. Less common Ripley Engraved varieties may also be placed in this temporal ordering, along with Simms Engraved, Taylor Engraved, and Womack Engraved vessels. Wilder Engraved bottles are present in both early and late Titus phase contexts (Table 10).

Table 9. Relative frequency of fine ware types and varictics in the Gum Creek/Little Cypress Creek cemeteries.

\begin{tabular}{lccccc}
\hline Types & UR317 & UR318 & UR319 & UR320 & UR326 \\
\hline Bailey Engraved & $7.3^{*}$ & - & - & 3.0 & 4.8 \\
Hodgcs Engraved* & - & - & 14.3 & - & - \\
Riplcy Engraved, var. Caldwell & - & - & 14.3 & 6.1 & 9.5 \\
Riplcy Engraved, cf. var. Carpenter & 3.6 & - & - & 3.0 & - \\
Riplcy Engraved, var. Carpenter & - & - & - & 3.0 & - \\
Riplcy Engraved, var. Cash & 3.6 & 3.8 & 14.3 & - & - \\
Riplcy Engraved, var. Gandy & 5.5 & 23.1 & 14.3 & - & - \\
Riplcy Engraved, cf. var. Gandy & 21.8 & 38.5 & - & 9.1 & - \\
Ripley Engraved, var. Galt & 9.1 & 11.5 & 14.3 & 6.1 & 4.8 \\
Ripley Engraved, var. McKinney & 12.7 & 3.8 & - & 21.2 & 33.3 \\
Ripley Engraved, var. Williams & 3.6 & - & - & - & - \\
Simms Engraved & - & - & - & 9.1 & - \\
Taylor Engraved & 20.0 & 15.4 & 28.6 & 21.2 & 14.3 \\
Turner Engraved, var. Horton & - & - & - & 3.0 & 9.5 \\
Turner Engraved, var. Turmer & 1.8 & - & - & 6.1 & - \\
Wilder Engraved & 5.5 & 3.8 & - & 9.1 & 19.1 \\
Womack Engraved & 5.5 & - & - & - & 4.8 \\
\hline Totals & 55 & 26 & 7 & 33 & 21 \\
\hline
\end{tabular}

*percentage 
Table 10. Temporal seriation of fine ware types and varieties.

\begin{tabular}{|c|c|c|c|c|c|c|c|}
\hline $\begin{array}{l}\text { Divisions in Tïtus } \\
\text { phase }\end{array}$ & $\begin{array}{l}\text { Motifs/ } \\
\text { Type }\end{array}$ & $\begin{array}{l}\text { Simms } \\
\text { Eng. }\end{array}$ & $\begin{array}{l}\text { Taylor } \\
\text { Eng. }\end{array}$ & $\begin{array}{c}\text { var. } \\
\text { Caldwell }\end{array}$ & $\begin{array}{c}\text { var. } \\
\text { Williams }\end{array}$ & $\begin{array}{l}\text { var. } \\
\text { Cash }\end{array}$ & $\begin{array}{l}\text { Turner } \\
\text { Eng. }\end{array}$ \\
\hline $\begin{array}{l}\text { Early Titus phase } \\
\text { (ca.A.D. 1430-1550) }\end{array}$ & $\begin{array}{l}\text { var. Carpenter } \\
\text { var. Gandy }\end{array}$ & & & $\mathrm{x}$ & & $x$ & \\
\hline $\begin{array}{l}\text { Late Tilus phase } \\
\text { (ca.A.D. 1550-1680) }\end{array}$ & $\begin{array}{l}\text { cf. var. Gandy } \\
\text { var. Galt } \\
\text { var. McKinney }\end{array}$ & $x$ & $\mathrm{x}$ & $\mathrm{x}$ & $\begin{array}{l}x \\
x\end{array}$ & & $\mathbf{x}$ \\
\hline post-A.D. 1680 & $\begin{array}{l}\text { Womack } \\
\text { Engraved }\end{array}$ & $\mathrm{x}$ & & & & & \\
\hline
\end{tabular}

$\mathrm{x}=$ present

On the basis of Tables 9 and 10, the earlicst Titus phase burials, those predating ca. A.D. 1550, were at the 1. P. Starr, Henry Williams, Enis Smith, and Herbert Taft cemeteries. The proportions of var. Carpenter and var. Gandy vessels at these cemeteries, along with Ripley Engraved, var. Cash vessels, range from 6-28.6\% of the mortuary vesscl assemblages (see Table 9); no early Titus phase variety vessels were identified at the Frank Smith cemetery. The Ripley Engraved, var. Caldwell vessels may have been used during both the early and late Titus phase (see Table 9), although the highest frequencies of this variety occur at the I. P. Starr cemetery, likely the earliest of the Gum Creek/Little Cypress Creek cemeteries. In general, these cemeteries appear to have been used primarily after ca. A.D. 1550-which is supported by the occurrence of Maud and Talco arrow points in burials at several of them-and they have relatively high proportions of var. Galt and var. McKinney vessels. Hubcap variety Simms Engraved carinated vessel from the Herbert Taft site also suggests it also dates to the late Titus phase. Other Ripley Engraved varieties that may have primarily used as funerary offerings during this time include var. Caldwell, var. Williams, and cf. var. Gandy. The proportion of late Titus phase types and varieties ranges from a low of $14.3 \%$ at the I. P. Starr cemctery to $53.8 \%$ at the Henry Williams cemetery. The Frank Smith cemetery only has late Titus phase types and varieties, and may be the latest of the Gum Creek/Little Cypress Creek cemeterics.

It is suspected that inverted rim carinated bowls arc a post-A.D. 1600 ceramic innovation among Titus phase polters and other Caddo groups, becoming relatively frequent in a number of late $17^{\text {th }}$ century Caddo sites in the Sabine, Sulphur, and Big Cypress drainage basins, and such vessels were made into the mid-late $18^{\text {th }}$ century as well (Perttula 2007:141-142). Thus, the latest cemetery usc may be burials at the Enis Smith, Herbert Taft, and Frank Smith sites that include Ripley Engraved, var. McKinney, as well as inverted rim Womack Engraved and Simms Engraved carinated bowls, and the burial at the Frank Smith Refinery site with a Hodges Engraved conjoined vessel. These particular burials may well have been made by Titus phase Caddo peoples after ca. A.D. 1680.

Provisionally, our temporal ordering of the Gum Creek/Little Cypress Creek cemeteries is, from earlicst to latest: I. P. Starr (41UR319), Henry Williams (41UR318), Enis Smith (41UR317), Herber1 Taft (41UR320), and Frank Smith (41UR326). The Frank Smith Refinery burial with a conjoined Hodges Engraved vessel likely dates to the latter part of the Titus phase. The Henry Spencer cemetery was used during both early and late Titus phases as a burial ground, but the absence of Ripley Engraved, var. McKinney in the mortuary vessel assemblage suggests it was primarily used around the same time as the I. P. Starr cemetery (which also has no var. McKinney vessels), and before that of the other Gum Creek/ 
Littlc Cypress Creek cemeteries (Perttula et al. 2012a). Two calibrated radiocarbon dates from the Henry Spencer site was used primarily between A.D. 1450-1530, but later burials in the cemetery may also date to the rest of the $16^{\text {th }}$ century and much of the $17^{\text {th }}$ century.

The mortuary vessels from the Little Cypress Creek cemeteries are dominated by engraved fine wares, as these account for almost $77 \%$ of all the vessels from the sites (Table 11). Utility wares comprise $19 \%$ of the assemblages, and plain wares represent only $4 \%$ of the vessel funerary offerings.

Table 11. Vessel Forms by Ware and Site.

\begin{tabular}{|c|c|c|c|c|c|}
\hline Vessel Form & UR317 & UR3 18 & UR319 & UR320 & IJR326 \\
\hline \multicolumn{6}{|l|}{ Fine Ware } \\
\hline Carinated bowl & 51 & 24 & 5 & 20 & 29 \\
\hline Compound bowl & 5 & 9 & 3 & 6 & 6 \\
\hline Bottle & 9 & 4 & 1 & 3 & 9 \\
\hline $\mathrm{Jar}$ & - & - & - & 2 & 2 \\
\hline Deep Bowl & 1 & - & - & 2 & - \\
\hline Bowl & 1 & - & - & - & - \\
\hline Olla & - & - & - & - & 2 \\
\hline Conjoined & - & 1 & - & 2 & - \\
\hline Subtotal & 67 & 38 & 9 & 35 & 48 \\
\hline \multicolumn{6}{|l|}{ Utility Ware } \\
\hline Jar & 18 & 8 & 2 & 4 & 16 \\
\hline Carinated bowl & - & - & - & - & I \\
\hline Bowl & - & - & - & - & 1 \\
\hline Subtotal & 18 & 8 & 2 & 4 & 18 \\
\hline \multicolumn{6}{|l|}{ Plain Ware } \\
\hline Carinated bowl & - & 1 & - & - & 3 \\
\hline Bowl & 1 & 2 & - & 1 & - \\
\hline Jar & - & - & - & - & 1 \\
\hline Botlle & 1 & - & - & 1 & - \\
\hline Subtotal & 2 & 3 & - & 2 & 4 \\
\hline Totals & 87 & 49 & 11 & 41 & 70 \\
\hline
\end{tabular}

Note: the one vessel from the Frank Smith refinery site (41UR327) is a conjoined fine ware vessel

In the fine wares, the most common ceramic vessel offering was a carinated bowl (65\%), followed by a compound bowl (15\%), and bottles (13\%). Conjoined vessels (found at three of the cemeteries), deep bowls (found in two ccmeteries), a pedestalled bottle (found at one cemetery), and ollas (found only in one cemetery) occur only in the fine wares.

Utility ware vessels in the mortuary assemblages are dominated $(96 \%)$ by jars. There are single examples of wet paste decorated carinated bowls and bowls from the Frank Smith cemetery. The plain wares in burial contexts are a mix of carinated bowls $(n=4)$, bowls $(n=4)$, bottles $(n=2)$, and a jar $(n=1)$. 
The vessels placed as funerary offerings in the graves of deceased Caddo peoples at these Gum Creek/Little Cypress Creek cemeteries were made in a range of sizes. Jars, almost exclusively utility wares that had been cooking and food storage vessels, ranged from very small vessels less than 0.5 liters to volume to very large vessels 14.0 liters in volume (Figure 286). More than $80 \%$ of the jars were less than 3.5 liters in volume, with peaks between 0.5-1.5 and 2.0-3.0 liters. Very large vessels, most likely intended to hold foods for feasts in the afterlife, more than 7.0 liters in volume, comprised $16 \%$ of the jars (see Figure 286).

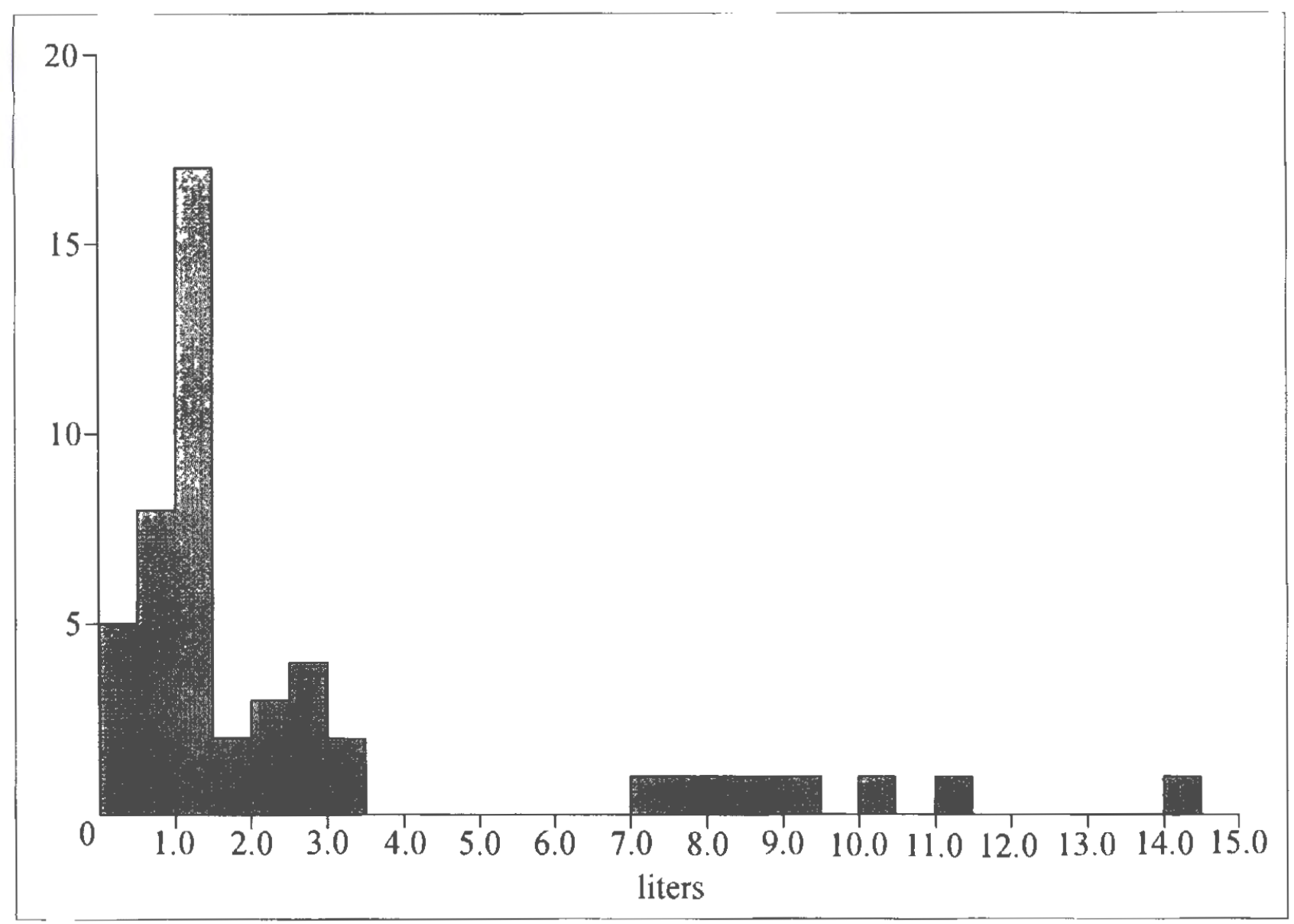

Figure 286. Estimated volumes of jars in the Gum Creek cemeteries.

Carinated bowls occur in three size ranges: 0-1.0 liters, 1.5-2.5 liters, and greater than 3.0 liters (Figure 287). Most of the carinated bowls are of a size that would have been suitable for individual use as food serving vessels, but $18 \%$ ( $>3.0$ liters) - a comparable percentage to that of the jars - were apparently designed for communal use.

Compound bowls have vol umes that range from 0-.5-9.5 liters in volume (Figure 288). These occur in two ranges: $0.5-3.0$ liters (small to medium-sized) and 3.5-9.5 liters (large to very large in size). Forty percent of the compound bowls are large to very large in size. The inordinate frequency of large to very large compound bowls in the Gum Creek/Little Cypress Creek cemeteries points to a regular use of these vessels for use by the deceased in the afterlife for communal food serving. 


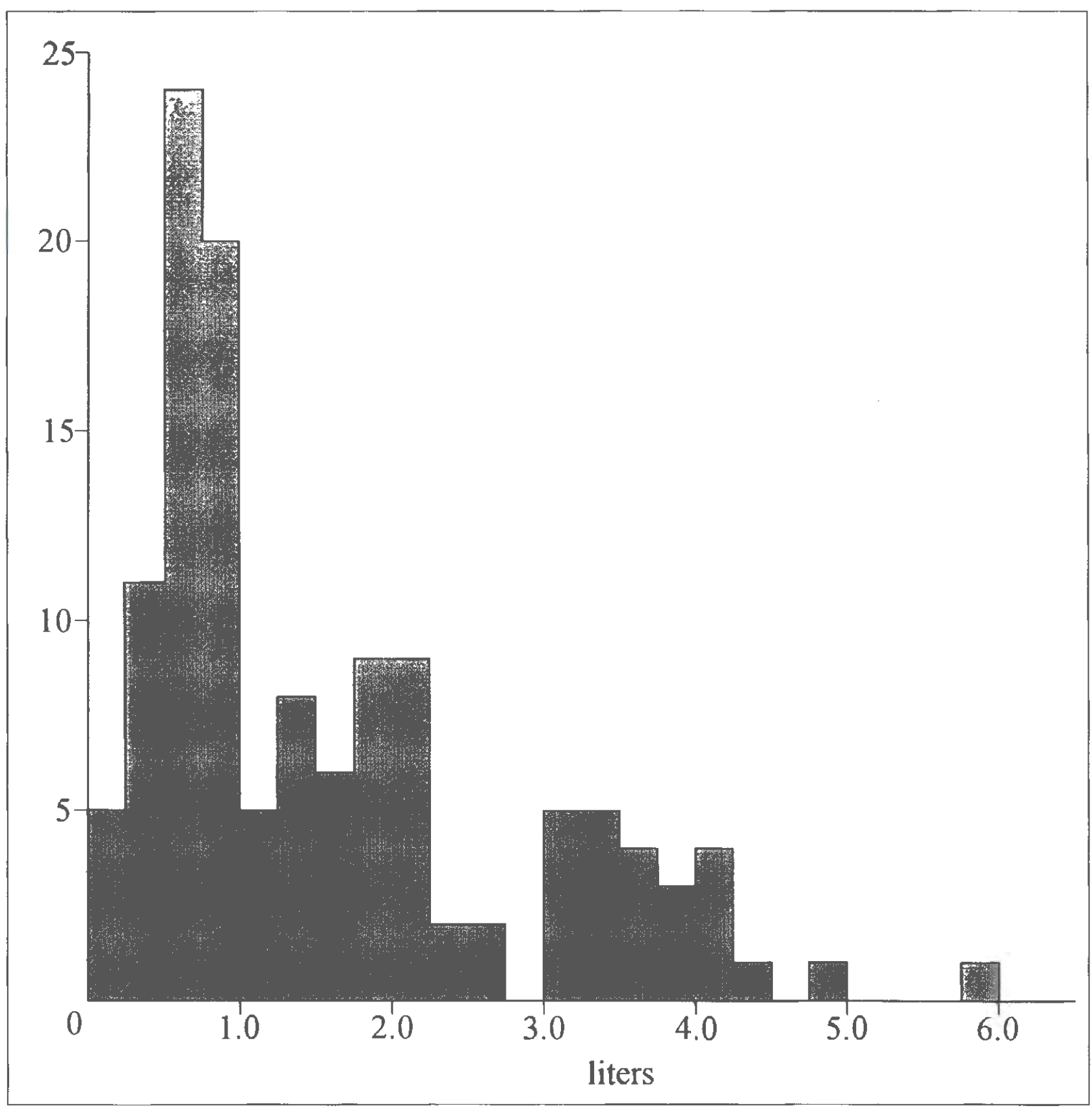

Figure 287. Estimated volumes of carinated bowls in the Gum Creek cemeteries.

The use of red and white clay pigments is a consistent feature of the funerary vessels at these Gum Creek Caddo cemeteries (Table 12). Except in the case of the Frank Smith vessel assemblage, the use of white pigment was preferred to a moderate extent (a 59\%-41\% ratio) to the red pigment; one vessel from the Frank Smith site has had both red and white pigments applied to an engraved decoration. 


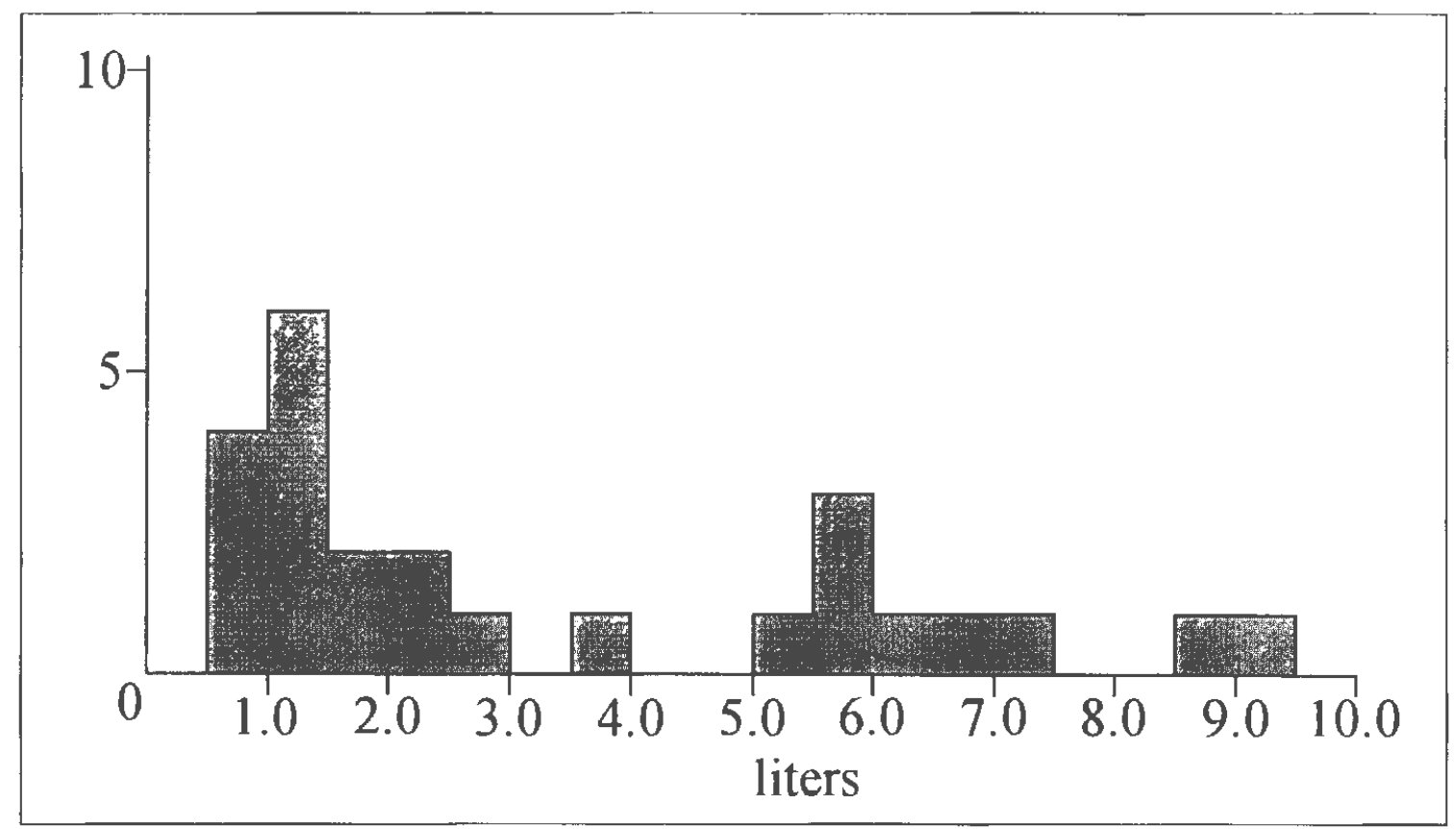

Figure 288. Estimated volumes of compound bowls in the Gum Creek cemeteries.

Table 12. Use of pigments on funerary vessels.

\begin{tabular}{lccc}
\hline Site & Red pigment & White pigment & $\begin{array}{c}\text { Percent of vessels } \\
\text { with pigment }\end{array}$ \\
\hline Enis Smith & 11 & 13 & 27.6 \\
Henry Williams & 6 & 9 & 30.6 \\
I. P. Starr & 3 & 4 & 63.6 \\
Henry Taft & - & 9 & 22.5 \\
Frank Smith & 10 & 8 & 27.1 \\
\hline Totals & 30 & 43 & 28.4 \\
\hline
\end{tabular}

In general, although red pigments are found on almost every fine ware vessel form (i.e., carinated bowl, bottle, olla, compound bowl, jar bowl, and conjoined vessels) the application of a red clay pigment to fine ware vessels is most common in bottles, as $42.3 \%$ of the bottles in these cemeterics have such a pigment. Fifty percent of the engraved ollas $(n=2)$ and bowls $(n=2)$ have a red pigment, compared to only $10.2 \%$ of the carinated bowls and $6.9 \%$ of the compound bowls. The highest proportion of fine ware vessels with white pigments occur in the compound bowls (31.\%) and carinated bowls (25.2\%), and single examples of engraved jars and deep bowls also have a white pigment. The one vessel with both a red and white pigment is an engraved carinated bowl.

At the Henry Spencer cemetery (4IUR315), 14 vessels had red pigment, while 12 had an applied white pigment (Perttula et al. 2012a). By way of comparison, $80 \%$ of the vessels with pigment in Late Caddo Titus phase cemeteries at the Tuck Carpenter (4ICP5), Shelby Mound (41CP71), and Tankersley Creek (41TT18) sites in the Big Cypress Creek basin have a white pigment (Perttula et al. 2012b). 
Other special attributes of the vessels from these Gum Creek sites are listed in Table 13. Most of these special attributes - particularly the use of rim peaks, inverted rims, and slipping of one or both vessel surfaces - are found on the fine wares and/or utility wares, but very rarely on plain ware vessels.

Table 13. Special attributes of the vessels from the cemeteries in the Gum Creek cluster.

\begin{tabular}{lcccc}
\hline Special attribute & FW & $\begin{array}{c}\text { Frequency } \\
\text { UW }\end{array}$ & PW & $\begin{array}{c}\text { Percent Frequency } \\
\text { (all vessels, N=258) }\end{array}$ \\
\hline Rim peaks & 10 & 9 & 1 & 7.8 \\
Inverted rim & 19 & - & - & 7.4 \\
Slipped & 10 & - & - & 3.9 \\
Suspension holes & 5 & 2 & - & 2.7 \\
Miniature vessel & 4 & 1 & 1 & 2.3 \\
Strap handles & - & 5 & - & 1.9 \\
Conjoined vessels & 4 & - & - & 1.6 \\
Lip notched & 3 & - & - & 1.2 \\
Lugs & - & 2 & - & 0.8 \\
Collared rim & - & 2 & - & 0.8 \\
Redwine mode lip & 2 & - & - & 0.8 \\
Scalloped lip & 2 & - & - & 0.8 \\
Rattles & - & 1 & - & 0.4 \\
Pedestal for bottle & 1 & - & - & 0.4 \\
\hline Totals & 60 & 22 & 2 & \\
\hline
\end{tabular}

Inverted rim carinated bowls, rim peaks on compound bowls, and the use of clay slip on certain engraved vessels, are distinctive attributes of the Little Cypress Creek Late Caddo cemetery mortuary assemblages, along with vessels with drilled suspension holes, miniature vessels, and conjoined vessels. The distinctive inverted rim vessels, thought to be present among the latest burials in the cemeteries, account for $9.2 \%$ of the mortuary vessels at the Enis Smith site, $6.1 \%$ of the Henry Williams vessels, $7.5 \%$ of the Henry Taft vessels, and $7.1 \%$ of the Frank Smith vessels. Slipped vessels are present only at the Henry Taft, Frank Smith, and Frank Smith Refinery cemeteries.

Utility wares stand out in the mortuary assemblages because of the use of rim peaks and strap handles (see Table 13) on jars, along with lugs and collared rims.

The mortuary vessels from the cemeteries were tempered with a variety of aplastics, including grog, burned bone, hematite, organics (i.e., pieces of charcoal), and burned mussel shell (Table 14). Except for the vessels from the Herbert Taft site (41UR320), the vast majority of the vessels were made with a clay or silty clay, probably gathered in alluvial settings; at Herbert Taft the vessels placed in the graves were commonly made with a naturally sandy clay. 
Table 14. Use of temper in mortuary vessels.

\begin{tabular}{lccccc}
\hline Temper & UR317 & UR318 & UR319 & UR320 & UR326 \\
\hline grog & $48.3^{*}$ & 61.2 & 90.9 & 29.7 & 51.5 \\
grog-bone & 20.7 & 10.2 & - & 10.8 & 16.2 \\
grog-bone/SP & 1.2 & - & - & 2.7 & 1.5 \\
grog-bone-hernatite & 3.4 & 4.1 & - & 2.7 & 2.9 \\
grog-bone-organics & 1.2 & - & - & - & - \\
grog-hematite & 9.2 & 4.1 & - & 5.4 & 10.3 \\
grog-hematite-organics & - & - & - & 2.7 & 1.5 \\
grog-hematite/SP & 1.2 & - & - & 13.5 & 2.9 \\
grog-organics & 1.2 & - & - & 2.7 & - \\
grog-shell & - & - & - & 2.7 & - \\
grog/SP & 9.2 & 6.1 & 9.1 & 21.6 & 5.9 \\
bone & 1.2 & 2.0 & - & 2.7 & 1.5 \\
bone-grog & 1.2 & 12.2 & - & - & 2.9 \\
bone-hematite & 1.2 & - & - & - & 1.5 \\
none/SP & 1.2 & - & - & 2.7 & 1.5 \\
Summary of temper use & & & & & \\
grog & & & & & 94.6 \\
bone & 96.6 & 98.0 & 100.0 & 94.6 & 95.6 \\
hernatite & 28.7 & 28.6 & - & 19.0 & 26.5 \\
shell & 15.0 & 8.2 & - & 24.3 & 19.1 \\
organics & - & - & - & 2.7 & - \\
SP & 2.3 & - & - & 5.4 & 1.5 \\
\hline No. of vessels & 11.5 & 6.1 & 9.1 & 40.5 & 11.8 \\
\hline
\end{tabular}

* =percentage; $\mathrm{SP}=$ sandy paste

Between 94.6-100\% of the vessels at the five cemeteries have some amount of grog temper added to the clay paste. Bone temper (between 19-28.7\%) was a common additive in vessels-except not at the I. P. Starr cemetery - as was crushed pieces of hematite (8.2-24.3\%). One Simms Engraved vessel from the Herbert Taft site had both grog and burned mussel temper; it was probably made on the Red River since shell-tempered pottery in Northeast Texas tended to have been made in Latc Caddo McCurtain phase sites in this area (see Perttula et al. 2012c).

Few of the vessels had any charred organics in the paste (see Table 14). This suggests that the mortuary vessels had been well-fired before use, fired to a sufficiently high temperature and/or sufficiently long duration that such inclusions were burned away during the firing process.

At four of the five cemetery sites, between $6.1-11.8 \%$ of the vessels were made from a naturally sandy elay (see Table 14). At the Herbert Taft site, however, $40.5 \%$ of the vessels were made from a naturally sandy clay. These vessels also had the lowest proportion of grog use among the cemeteries (albeit only slightly less), the highest proportion of crushed hematite temper, moderate amounts of bone temper, and the largest amount of vessels with charred organics in the paste. Clearly, the potters that produced the vessels placed as funerary offerings in the Herbert Taft burials had different clay-temper recipes for vessel manufacture than was the case at the other four cemetery sites. 
The Henry Spencer (4IUR315) mortuary vessels have clay-temper recipes very similar to four of the Gum Creek/Little Cypress Creek cemetery assemblages, and not to those vessels from the Herbert Taft cemetery. Al Henry Spencer, $96.2 \%$ of the vessels had grog as a temper; $29.5 \%$ also had burned bone tcmper; and $16.4 \%$ had crushed hematite temper. Only a low proportion of the vessels (1.6\%) had organics in the paste, and $9.3 \%$ of the vessels were made with a naturally sandy clay (see Perttula et al. 2012a).

Organic residues - soot, charred plant remains, and a resin pitch-are present in all threc ceramic wares in the funerary assemblages; $23 \%$ of all the vessels at the Little Cypress Creek cemetcries have residues. These organic residues are indicative of vessel use prior to their having being placed as funerary offerings in individual graves. A bout $70 \%$ of the organic residues occur on the exterior vessel surfaces. Approximately $16 \%$ of the fine wares ( $n=31$ vessels) have residues, compared to $50 \%$ of the utility wares $(n=25)$ and $36 \%$ of the plain wares $(n=4)$. 


\section{Summary and Conclusions}

The documentation of funerary offerings in the collections of the Gregg County Historical Museum (Longview, Texas) from six Late Caddo, Titus phase, cemeteries in the Gum Creek/Little Cypress Creek basin in Northeast Texas has provided insights into the native history of Caddo peoples in this locale. These cemetery sites are the Enis Smith (41UR317, 12-15 burials), Henry Williams (41UR318, 37 burials), I. P. Starr (41UR319, seven burials), Herbert Taft (41UR320, six burials), Frank Smith (41UR326, 16 burials), and the Frank Smith Refinery (41UR327, one burial) sites, all excavated by Buddy Calvin Jones in the 1950s. These cemeteries represented the linal resting place of Caddo peoples from settlements and communities in the Gum Creek/Little Cypress Creek area over a period of at least 250 years. There is no evidence in the Jones (n.d.) notes and records that these cemeteries were situated on previously occupied habitation areas, but we suspect that settlements and communities were located nearby.

Other cemeteries in the Gum Creek area include the Henry Spencer (41UR315, 38-42 burials) and Sword (41UR8/208, 47 burials) sites. Perttula et al. (2012a) discuss the varied findings from the Henry Spencer cemetery and earlier Caddo midden deposits from the extensive Buddy Jones excavations there. The Sword site is another Late Caddo, Titus phase cemetery on Gum Creek in the Little Cypress Creck basin. It is the same site as 41 UR8, according to the Texas Historic Sites Atlas, a cemetery excavated by Buddy Jones in 1957, although there is no record of any vessels or other funerary offerings from this site in the Gregg County Historical Museum. Information obtained in the 1990s from looters indicates that a cemetery was present at the sitc that contained 47 burials arranged in north-south rows; the burials themselves were oriented east-west, and covcred a $60 \times 60 \mathrm{~m}$ area. One burial of an important individual, probably an adult male, was found in the middlc of the cemetery; this individual was accompanied by a large number of ceramic vessels (>15) and two large chipped stone Galt bifaces or "swords" that were 45-60 cm in length and made of a black lithic raw material (probably a black novaculite). Other burials had offerings of Talco arrow points, $10-15 \mathrm{~cm}$ long bifacially chipped blades, and Ripley Engraved ceramic vessels, including one Ripley Engraved, var. McKinney carinated bowl. These offerings indicate that the Sword site cemetery was likely used in the latter part of the Titus phase.

These Caddo cemeteries together represent a mortuary population of between 164-171 individuals. A population of 150 individuals, and an annual death rate of $1 \%$ (i.e., 1.5 deaths per year), could have created these cemeteries in 110-120 ycars of continuous use, so the settlements and communities along Gum Creek and Little Cypress Creek that created and maintained these cemeteries may not necessarily have been extensive at any one time over the period of the Titus phase from ca. A.D. 1430-1680. The examination of the types and varieties of ceramic vessels recovered from burials at these cemeteries suggests that their major period of use was between ca. A.D. 1550-1680. The recovery of a post-1680 glass bead from one of the burials at the Henry Spencer site, the reported occurrence of glass beads in one burial at the Enis Smith site (Perttula 2006:22,33), and glass beads and a copper/brass hawk bell from one or more burials at the Henry Williams site (Perttula 2006:87), ${ }^{1}$ also suggest some use of several of the cemeteries after initial contact with Europeans.

The cemeteries reffect long-standing mortuary practices and beliefs of Caddo peoples (see Perttula 2012:388-407). They also reffect a continuity of kin and community, ethnicity and identity, in their

\footnotetext{
'The glass beads and hawk bell purportedly from the Enis Smith and Henry Williams sitcs that were documented in 1999 by Perttula (2006) could not be identified in the present collections from the Gregg County Historical Museum.
} 
location relative to the inhabited and habitable landscape and in their location relative to other dcceased Caddo people. The Titus phase Caddo peoples buried their dead in family cemeteries and community cemeteries (> 70 individuals; no community cemeteries are known in the Little Cypress Creek basin), in extended supine position in rows, with the head of the deceased facing west, towards the House of Death in the sky. The deceased were accompanied by a variety of funerary offerings-among them ceramic vessels to hold food and liquids on the six day journey to the Housc of Death as well as for use in the afterlife, stone tools (i.e., celts and large chipped Galt bifaces), quivers of arrow points (most likely placed in the graves of adult men), clay pipes, clay pigments, as well as perishables such as baskets and wooden implements. In the Gum Creek/Little Cypress Creek cemeteries, ceramic vessels were by far the most common funerary offering.

Ceramic vessels $(n=259)$ placed with the deceased in these Caddo cemeteries occur in a variety of forms and sizes, including carinated bowls, compound bowls, bowls, deep bowls, bottles, ollas, and jars. Vessels range from small-volume forms likely meant for individual use by the deceased in the afterlife to large and very large carinated bowls, compound bowls, and jars likely meant for communal use in feasting.

As is the case in all other Titus phase cemeteries, the vessels placed with the deceased were primarily engraved and/or slipped fine ware vessels, especially carinated bowls. Utility wares are dominated by jars, but they represent less than $20 \%$ of the combined mortuary vessel assemblage. Plain vessels are rare, comprising only $4 \%$ of the vessel offerings. They were primarily tempered with grog, burned bone, or hematite, fired in a low oxygen or reducing environment, and smoothed and/or burnished on one or more vessel surfaces. Among the fine wares, several varieties of Ripley Engraved (especially cf. var. Gandy and var. McKinney) and Taylor Engraved are particularly abundant, and other important fine wares include Wilder Engraved bottles, Bailey Engraved bottles, and Turner Engraved compound bowls. Unique among the fine wares are Hodges Engraved conjoined vessels and inverted rim Womack Engraved, var. Gum Creek carinated bowls at the Enis Smith and Frank Smith cemeteries. Many of the fine ware vessels have also had either a red or white clay pigment applied to the engraved decoration. In the utifity wares, important types include Harleton Appliqued, Bullard Brushed, and Cass Appliqued, but there are a range of other decorated jars in these cemeteries, among them Pease Brushed-Incised, Mockingbird Punctated, and La Rue Neck Banded.

The documented arrow point quivers from these cemeteries primarily include Talco and Maud points made from local lithic raw materials, consistent with their use primarily after ca. A.D. 1550, but one burial at the 1. P. Starr site was accompanied by a quiver with Perdiz, Washita, side-notched, Maud, and Talco arrow points. Finally, the few documented clay pipes in the burials are plain elbow pipes, except for a very distinctive engraved tubular pipe from the Frank Smith cemetery. 


\section{References Cited}

Bell, M.

1981 The Alex Justiss Site: A Caddoan Cemetery in Titus County, Texas. Publications in Archaeology No. 21. Highway Design Division, Texas Department of Highways and Public Transportation, Austin.

Brown, J.A.

1996 The Spiro Ceremonial Center: The Archaeology of Arkansas Valley Caddoan Culture in Eastern Oklahoma. 2 Vols. Memoirs No. 29. Museum of Anthropology, The University of Michigan, Ann Arbor.

Cast, R., T. K. Perttula, B. Gonzalez, and B. Nelson

2006 Documentation of Caddo Ceramic Vessels from 4IWD60, Wood County, Texas. Historic Preservation Program, Caddo Nation of Oklahoma, Binger, Oklahoma.

Ferring, C. R. and T. K. Perttula

1987 Defining the Provenance of Red-Slipped Pottery from Texas and Oklahoma by Petrographic Methods. Journal of Archaeological Science 14:437-456.

Foster, W. C.

2012 Climate and Culture Change in North America AD 900-1600. University of Texas Press, Austin.

Gadus, E. F. and R. C. Fields

1996 Ceramic Vessels from the Pleasure Point Site (41MR63), Marion County, Texas. Technical Reports No. 22. Prewitt and Associates, Inc., Austin.

Gadus, E. F., R. C. Fields, J. K. McWilliams, J. Dockall, and M. C. Wilder

2006 National Register Testing of Seven Prehistoric Sites in the Sabine Mine's Area Q, Harrison County, Texas. Reports of Investigations No. 147. Prewitt \& Associates, Inc., Austin.

Gonzalez, B., R. L. Cast, T. K. Perttula, and B. Nelson

2005 A Rediscovering of Caddo Heritage: The W. T. Scott Collection at the American Museum of Natural History and Other Caddo Collections from Arkansas and Louisiana. Historic Preservation Program, Caddo Nation of Oklahoma, Binger.

Jones, B.C.

n.d. Notes on file at the Gregg County Historical Museum, Longview, Texas.

Perttula, T. K.

1992 "The Caddo Nation": Archaeological \& Ethnohistoric Perspectives. University of Texas Press, Austin.

2006 A Study of the Buddy Calvin Jones Collection from Northeast Texas Caddo Sites. Special Publication No. 6. Friends of Northeast Texas Archaeology, Pittsburg and Austin.

2007 Inverted Rim Engraved Vessels in Protohistoric and Early Historic Caddo Sites in Parts of Northeast Texas. Journal of Northeast Texas Archaeology 26:136-144.

2011 Vessel Documentation, Caddo Sites in Anderson and Cherokee Counties, Texas, in the Upper Neches River Basin. In Archeological Investigations at the Lang Pasture Site (4IAN38) in the Upper Neches River Basin of East Texas, assembled and edited by T. K. Perttula, D. B. Kelley, and R. A. Ricklis, pp. 703-981. Report No. 129. Texas Department of Transportation, Archeological Studies Program, Environmental Affairs Division, Austin. 
2012 The Character of Fifteenth- to Seventeenth-Century Caddo Communities in the Big Cypress Creek Basin of Northeast Texas. In The Archaeology of the Caddo, edited by T. K. Perttula and C. P. Walker, pp. 363-410. University of Nebraska Press, Lincoln.

Perttula, T. K. (editor)

2005 Archeological Investigations at the Pilgrim's Pride Site (41CP304), a Titus Phase Community in the Big Cypress Creek Basin, Camp County, Texas. 2 Vols. Report of Investigations No. 30. Archeological \& Environmental Consultants, LLC, Austin.

Perttula, T. K. and B. Nelson

1998 Titus Phase Mortuary Practices in the Northeast Texas Pineywoods and Post Oak Savanna. In Analysis of the Titus Phase Mortuary Assemblage at the Mockingbird or "Kahbakayammaahin" Site (41TT550), by T. K. Perttula, M. Tate, H. Neff, J. W. Cogswell, M. D. Glascock, E. Skokan, S. Mulholland, R. Rogers, and B. Nelson, pp. 328-401. Document No. 970849. Espey, Huston \& Associates, Inc., Austin.

2007 The Gum Creek Cluster: Protohistoric Caddo Sites in the Little Cypress Creek Basin, ca. 16701720. Journal of Northeast Texas Archaeology 26:128-135.

Perttula, T. K., B. Nelson, M. Walters, R. Cast, and B. Gonzalez

2009a Documentation of Caddo Funerary Objects in the Gilcrease Museum Collections. Historic Preservation Program, Caddo Nation of Oklahoma, Binger.

Perttula, T. K., M. Tate, H. Neff, J. W. Cogswell, M. D. Glascock, E. Skokan, S. Mulholland, R. Rogers, and B. Nelson

1998 Analysis of the Titus Phase Mortuary Assemblage at the Mockingbird Site, Kahbakayammaahin, 41TT550. Document No. 970849 . Espey, Huston \& Associates, Inc., Austin.

Perttula, T. K., M. Walters, and B. Nelson

2010a Caddo Pottery Vessels and Pipes from Sites in the Big Cypress, Sulphur, Neches-Angelina, and Middle Sabine River Basins in the Turner and Johns Collections, Camp, Cass, Cherokee, Harrison, Morris, Titus, and Upshur Counties, Texas and Sabine Parish, Louisiana. Special Publication No. 10. Friends of Northeast Texas Archaeology, Pittsburg and Austin.

2010b Caddo Pottery Vessels and Pipes from the Johns Site (41CPI2) in the Big Cypress Creek Basin in the Turner and Johns Collections, Camp County, Texas. Special Publication No. 11. Friends of Northeast Texas Archaeology, Austin and Pittsburg.

2012a Caddo Archaeology at the Henry Spencer Site (41UR315) in the Little Cypress Creek Basin of East Texas. Friends of Northeast Texas Archaeology, Austin and Pittsburg, in press.

Perttula, T. K., R. Cast, B. Gonzalez, and B. Nelson

2010c The Clements Site (41CS25): A Late $17^{\text {th }}$ to Early $18^{\text {th }}$ Century Nasoni Caddo Settlement and Cemetery. Anthropological Papers No. 92. American Museum of Natural History, New York.

Perttula, T. K., P. S. Marceaux, and B. Nelson

2012b Study of the Margaret Hinton Collection of Pottery Vessels from Northeast Texas Caddo Cemeteries. Special Publication No. 24. Friends of Northeast Texas Archaeology, Austin and Pittsburg, in press.

Perttula, T. K., M. Walters, S. Marceaux, and B. Nelson

2009b Caddo Pottery Vessels and Pipes from Sites in the Middle and Upper Sabine and Upper Neches River Basins, Smith and Wood Counties, Texas. Special Publication No. 7. Friends of Northeast Texas Archaeology, Pittsburg and Austin. 
Perttula, T. K., M. B. Trubitt, and J. S. Girard

2012c The Use of Shell-Tempered Pottery in the Caddo Area of the Southeastern United States. Southeastern Archaeology 30(2):242-267.

Perttula, T. K., M. Walters, B. Nelson, B. Gonzalez, and R. Cast, with a contribution by R. G. Franciscus 2010d Documentation of Associated and Unassociated Funerary Objects in the Stephen F. Austin State University Collections, Nacogdoches, Texas. Historic Preservation Program, Caddo Nation of Oklahoma. Binger, Oklahoma.

Rice, P. M.

1987 Pottery Analysis: A Sourcebook. University of Chicago Press, Chicago.

Rogers, R., M. B. Cliff, T. K. Perttula, G. Rutenberg, S. Victor, P. Dering, and M. Malainey

2003 Excavations at the Alex Justiss Site, 41TT13, Titus County, Texas. Report No. 36. Archeological Studies Program, Texas Department of Transportation, Austin.

Skibo, J. M.

1992 Pottery Function: A Use-Alteration Perspective. Plenum Press, New York.

Suhm, D. A. and E. B. Jelks (editors)

1962 Handbook of Texas Archeology: Type Descriptions. Special Publication No. 1, Texas Archeological Society, and Bulletin No. 4, Texas Memorial Museum, Austin.

Teltser, P. A.

1993 An Analytic Strategy for Studying Assemblage-Scale Ceramic Variation: A Case Study from Southeast Missouri. American Antiquity 58(3):530-543.

Thurmond, J. P.

1990 Archeology of the Cypress Creek Drainage Basin, Northeastern Texas and Northwestern Louisiana. Studies in Archeology 5. Texas Archeological Research Laboratory, The University of Texas at Austin.

Turner, R. L., Jr.

1978 The Tuck Carpenter Site And Its Relation to Other Sites Within the Titus Focus. Bulletin of the Texas Archeological Society 49:1-110.

Walters, M., with contributions by T. Middlebrook and T. K. Perttula

2010 Redwine or Pie-Crust Mode Forms in East Texas Caddo Ceramics and comparisons with SprocketRims of Southwest Arkansas. Caddo Archeology Journal 20:77-128.

Webb, C. H.

1959 The Belcher Mound: A Stratified Caddoan Site in Caddo Parish, Louisiana. Memoirs No. 16. Society for American Archaeology, Salt Lake City.

Wilson, D.

2012 Bioarchaeological Evidence of Subsistence Strategies among the East Texas Caddo. In The Archaeology of the Caddo, edited by T. K. Perttula and C. P. Walker, pp. 86-116. University of Nebraska Press, Lincoln. 